\title{
MĀCĪ̌̌ANĀS
}
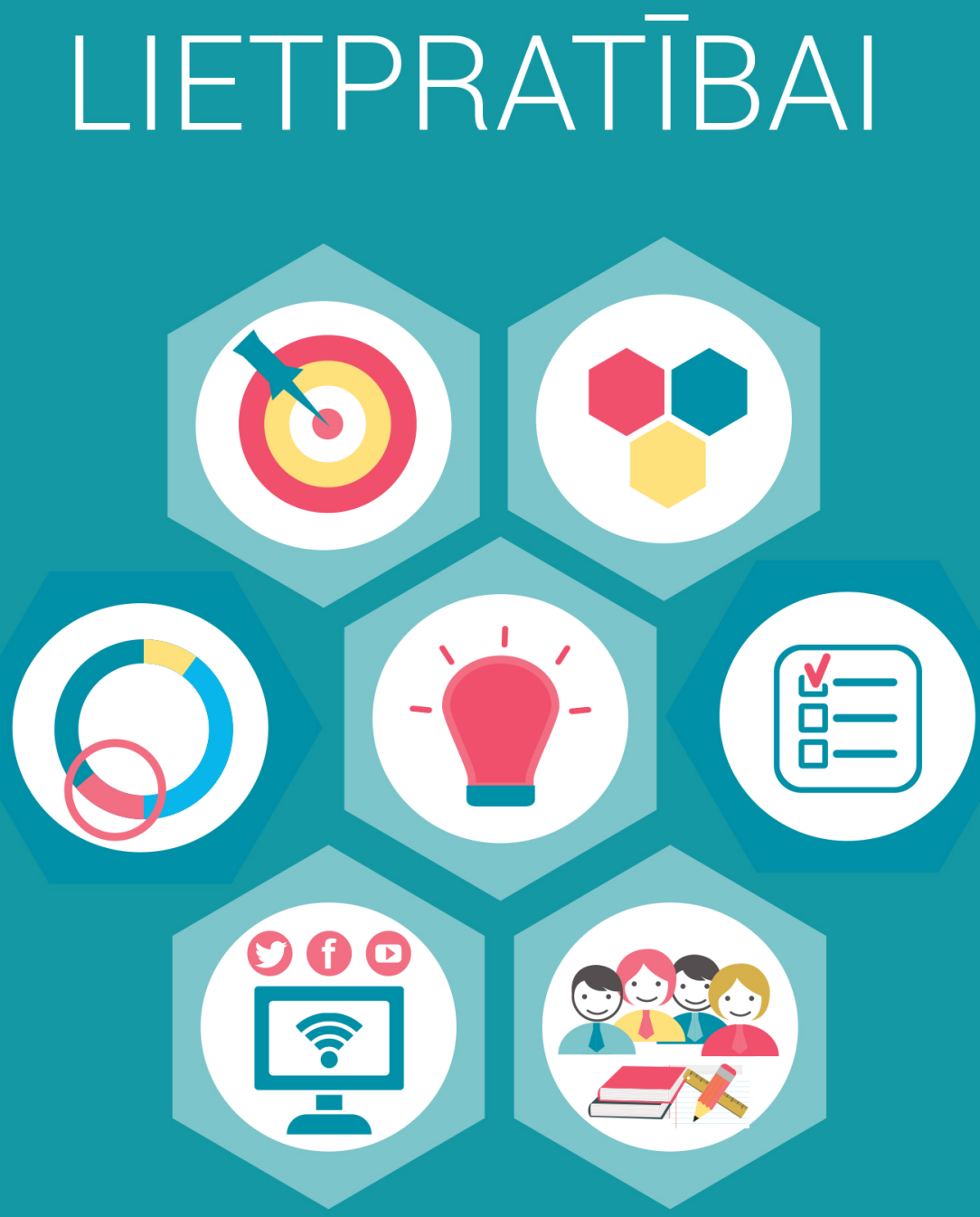

LU Akadēmiskais apgāds 


\section{MĀCĪŠANĀS LIETPRATĪBAI}

LU Akadēmiskais apgāds 


\section{Mācīšanās lietpratībai}

Kolektīva monogrāfija

Zane Oliṇa, Dace Namsone, Ilze France, Līga Čakāne, Pāvels Pestovs, Dace Bērtule, Jel̦ena Volkinšteine, Gunta Lāce, Inese Dudareva, Jāzeps Logins, Anete Butkēviča

Grāmatā atklāta kompetences jēdziena būtība, aplūkota mācī̌anās iedziḷinoties un mācīšanās paradigmas pakāpeniska maiṇa skolu praksē. Atsegtas kompetences kā kompleksa snieguma vērtēšanas iespējas. Analizēts jau esošo valsts līmeņa pārbaudes darbu potenciāls mērīt kompleksu sniegumu, ieviest formatīvo vērtēšanu regulārā skolu praksē. Analizētas skolotājiem nepieciešamās prasmes šādas pieejas īstenošanā, iespēja mērīt skolotāju prasmes mācīšanās vajadzību apzināšanā un būvēt atbilstošu ilgtermiņa praksē balstītu skolotāju mācīšanos un inovāciju pārnesi skolā un starp skolām. Aplūkota digitālās pratības attīstǐšanas nepieciešamība un informācijas tehnologiju iespējas snieguma vērtēšanā. Autori analizē esošo situāciju, salīdzinot to ar citu valstu pieredzi un pētījumu datiem, parāda piemērus, kā šīs pārmaiṇas pakāpeniski ienāk skolu praksē, un apzina turpmāk veicamos soḷus. Grāmata adresēta izglītības pētniekiem, skolu vadītājiem, skolotājiem, studentiem - lasītājiem, kas ir ieinteresēti iedziḷināties valstī izglītības jomā notiekošo pārmaiṇu būtībā.

Apstiprināta Latvijas Universitātes Humanitāro zinātṇu padomes sēdē 2018. gada 27. martā, protokola Nr. 5

Zinātniskā redaktore Dr. paed. Dace Namsone

Recenzenti: $\quad$ Dr. paed. Rudite Koka

Dr. hist. Guntars Catlaks

Dr. mat. Astrida Cirulis

Literārais redaktors Edžus Vējiṇš

Korektors Oskars Lapsiņš

Kolektīvā monogrāfija ir sagatavota valsts pētījumu programmas INOSOCTEREHI projekta "Jauna pedagogiija un kompetences attīstoša mācīšanās" ietvaros laikposmā no 2014. līdz 2018. gadam.

ISBN 978-9934-18-341-6

(C) Latvijas Universitāte, 2018

(C) Autori: Zane Oliņa, Dace Namsone, Ilze France, Inese Dudareva, Līga Čakāne, Pāvels Pestovs, Dace Bērtule, Jāzeps Logins, Jel̦ena Volkinšteine, Gunta Lāce, Anete Butkēviča, 2018

https://doi.org/10.22364/ml.2018 


\section{Saturs}

Priekšvārds ................................................................................................

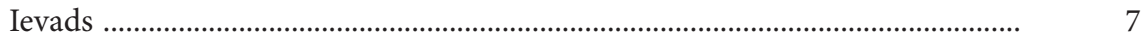

1. nodala

Kompetence kā komplekss skolēna mācīšanās rezultāts

Zane Olina, Dace Namsone, Ilze France

2. nodal̦a

Kas ir mācīšanās iedzilịnoties jeb kādā procesā mācǐšanās

rezultāts var būt kompetence

Dace Namsone, Zane Oliņa

3. nodala

Kā vērtē kompleksu sniegumu

Dace Namsone, Zane Oliṇa

4. nodala

Ko rāda makrolīmeņa vērtēšanas darbu analīze eksaktajos

mācỉbu priekšmetos trīs gadu periodā

Līga Čakāne, Dace Namsone, Pāvels Pestovs, Dace Bērtule

5. nodaļa

Formatīvās vērtēšanas lomas pastiprināšanās, īstenojot mācīšanos iedziḷinoties

\section{Līga Čakāne}

6. nodala

Skolotājam nepieciešamās

kompetences

Dace Namsone, Jel̦ena Volkinšteine, Gunta Lāce

\section{7. nodalı}

Kā novērtēt skolotāju sniegumu un mērķtiecīgi pilnveidot

skolotāju prasmes

Dace Namsone, Līga Čakāne, Jel̦ena Volkinšteine, Anete Butkēviča 


\section{8. nodaḷa}

Informācijas tehnoloǵijas mācišanās iedziḷinoties atbalstam

Inese Dudareva

9. nodala

Informācijas tehnologiijas formatīvajā vērtēšanā

Jāzeps Logins

10. nodaḷa

Inovāciju pārnese skolā un starp skolām

Lìga Čakāne, Anete Butkēviča

Introduction 


\section{Priekšvārds}

Mūsdienu skolu beidzēji strādās profesijās, kuru šobrīd nav, bet daudzas esošās vairs nepastāvēs. Viṇi risinās problēmas, kuras vēl neapzināmies, tāpēc viņu sagatavotībai kritiski svarīgi pievērst uzmanību tam, lai viṇi spētu identificēt problēmas, izvēlēties agrāk nebijušus risinājumus, turpināt attīstīt jaunas prasmes.

Paradigmas maiṇas nepieciešamība izglìtībā ir globāla aktualitāte. Līdz šim pārāk bieži laba izglìtība tikusi traktēta kā zināt daudz, nevis kā izglìitiba, kuras mērḳis ir saprast būtību (jēgu) un spēt zināšanas lietot. ${ }^{1}$ OECD ziņojumā par 21. gadsimta vajadzībām atbilstošu izglīiības rīcībpolitiku² uzsvērts, ka skolēniem būs jāspēj zināšanas lietot reālās dzīves kontekstā, jābūt gataviem uzṇemties atbildību par savu mācīšanos mūža garumā.

Hierarhiski augstākie Latvijas attīstības plānošanas dokumenti - Latvijas ilgtspējīgas attīstības stratēgija 2030 (LIAS, 2030) un Nacionālais attīstības plāns 2014.-2020. gadam (NAP, 2014-202033) pamato kompetenču attīstǐšanas nepieciešamību.

Kolektīvā monogrāfija "Mācǐšanās lietpratībai" ir 11 autoru kopīgs ieguldỉjums, lai skaidrotu kompetences jēdziena būtîbu, teorētiski atsegtu un ar piemēriem parādītu mācišsanās iedziļinoties procesu, kurā ir iespējams attīstīt kompetenci; aplūkotu iespējas, kā kompleksu sniegumu iespējams vērtēt valsts lìmeņa pārbaudes darbos un ikdienas mācību procesā. Balstoties veiktajos pētỉjumos, autori analizē esošo situāciju, salīdzinot to ar citu valstu pieredzi un pētỉjumu datiem, parāda piemērus, kā šìs pārmaiņas pakāpeniski ienāk skolu praksē, un apzina turpmāk veicamos soḷus. Liela uzmanība pievērsta skolotājiem

1 UNESCO IBE. (May 2015). Repositioning and reconceptualizing the curriculum for the effective realization of Sustainable Development Goal Four, for holistic development and sustainable ways of living. Position paper for UNESCO International Bureau of Education (UNESCO IBE) Side Event: "Repositioning Curriculum in Education Quality \& DevelopmentRelevance" for May 21, 2015, Incheon, Republic of Korea. Pieejams: http://www.ibe.unesco. org/sites/default/files/resources/wef_ibe_position_paper_eng.pdf (aplūkots 20.10.2017.).

2 OECD CERI. (2008). $21^{\text {st }}$ Century Learning: Research, Innovation and Policy. Directions from recent OECD analyses. OECD Center for Educational Research and Innovation. Pieejams: http:// www.oecd.org/site/educeri21st/40554299.pdf (aplūkots 20.10.2017.).

3 Latvijas Republikas Saeima. (2012). Latvijas Nacionālais attīstỉbas plāns 2014.-2020. gadam. Pieejams: http://polsis.mk.gov.lv/documents/4247 (aplūkots 16.02.2018.). 
nepieciešamajām kompetencēm, iespējai mērìt skolotāju prasmes mācīšanās vajadzību apzināšanā un veidot atbilstošu ilgtermiņa praksē balstītu skolotāju mācǐšanos un inovāciju pārnesi skolā un starp skolām.

Autori aplūko informāciju tehnologiju ienākšanu skolās, digitālās pratîbas attīstīšanas nepieciešamību gan skolēniem, gan skolotājiem un informācijas tehnolog̣iju iespējas vērtēšanai.

Grāmata adresēta izglīīibas pētniekiem, skolu vadītājiem, skolotājiem, studentiem - lasîtājiem, kuri ir ieinteresēti iedziḷināties valstĩ izglîtības jomā notiekošo pārmaiṇu būtībā.

Kolektīvās monogrāfijas tapšanā izmantoti dati, kas iegūti, vērojot mācību stundas daudzās Latvijas skolās, strādājot ar skolotājiem profesionālās pilnveides nodarbībās, analizējot valsts pārbaudes darbus. Autori ìpaši pateicas skolu vadītājiem un skolotājiem par iespēju ielūkoties mācību stundās, profesionālās pilnveides nodarbībās, pieredzes materiālos. 


\section{levads}

Izglìitibas teorētiḳi, pētnieki, praktiḳi un politiķi piesaka nepieciešamību pēc jaunām prasmēm, zināšanām, vērtībām, ieradumiem skolu mācību saturā, piedāvājot tā saukto 21. gadsimta kompetenču model̦us, lai aprakstītu citādus izglīîibas mērķus, kas ir cieši saistīti ar nozīmīgām izmaiņām ekonomikā un sabiedrības attīstībā.

Kompetence ir indivīda spēja kompleksi lietot zināšanas, prasmes un paust attieksmes, risinot problēmas mainīgās reālās dzīves situācijās, kas atbilst OECD "Izglîtība 2030" definīcijai ${ }^{1}$. Kompetence ir kompleksa, tās attīstǐšana saistās ar pārnesuma veidošanu rīcībai jaunā situācijā, jaunos kontekstos, to nevar reducēt uz kādu atsevišķu prasmi vai izolētu zināšanu kopu.

Pētnieciskajā literatūrā pēdējās desmitgadēs ir sastopami visdažādākie kompetenču struktūras piedāvājumi. Aplūkotajos modeḷos dažādās kombinācijās mijas kompetences nozìmīgākajās cilvēka darbỉbas jomās (tekstpratība, matemātiskā pratība, dabaszinātniskā izpratîba u. c.) ar caurviju (transversālajām) prasmēm (problēmrisināšana, kritiska un radoša domāšana, pašvadìta mācǐšanās, saziņa, sadarbība, digitālā pratība u. c.), kas attiecas uz visām jomām, kurām mācỉbu saturā līdz šim nav pievērsta pietiekama uzmanỉba. Tiek akcentēta vērtībās balstītu ieradumu veidošana.

Analizējot pasaules pieredzi un nākotnes redzējumu (dažādus kompetenču ietvarus) un attīstot tālāk iepriekšējo Latvijas vispārējās izglìtības mācību saturu, radīts ietvars mācỉbu satura izveidei, konceptuāli attīstot virzienu, kas sākts, veidojot šobrīd spēkā esošos mācību satura dokumentus. Lai gan 2006. gada mācību saturu reglamentējošos dokumentos ir formulēti mācišanās aspekti, kas konceptuāli atbilst caurviju kompetencēm, un to attīstî̌sanu paredz valsts izglìtîbas standarti, tomēr mācību stundu vērojumi un skolēnu snieguma analīze rāda, ka daudzās skolās tā nav ikdienas prakse.

Kompetenci kā skolēna mācǐšanās rezultātu nav iespējams sasniegt, kardināli nemainot pieeju mācišanai un skolas darba organizācijai. Tieši mācību pieejai,

1 VISC. (2016). Cẹ̦ā uz kompetenču pieeju mācībām. Pieejams: http://www.izm.gov.lv/images/ izglitiba_visp/Konferences_Tagad/VISC_-_Ce\%C4\%BC\%C4\%81_uz_kompeten\%C4\%8Du_ pieeju_m\%C4\%81c\%C4\%ABb\%C4\%81m.pdf (aplūkots 16.02.2018.). 
ne tikai sasniedzamo rezultātu pārformulēšanai mācību satura dokumentos, būs izšķiroša loma tajā, vai skolēni attīstīs kompetenci.

ASV Zinātṇu akadēmijas Nacionālās pētniecības padomes ziṇojumā (National Research Council, 2012²), kurā izvērtēti prominentākie 21. gadsimta kompetenču model̦i, īpaši izcelta nepieciešamība mācību procesā panākt, ka skolēni mācās iedziļinoties (deeper learning), detalizējot pieeju mācībām, kura pazīmes ir kopīgas citu autoru aplūkotajam mācīšanās procesam (deep learning, visible learning) (Fullan, \& Langworthy, 2014 ${ }^{3}$; Hattie, 2012 $2^{4}$; u. c.).

Mācīšanās iedziļinoties ir process, kura laikā skolēni attīsta spēju vispārināt jeb pārnest iegūtās zināšanas un prasmes uz jaunām, nezināmām situācijām. Pastāv lielāka iespējamība, ka notiks pārnese, ja skolēniem ir izpratne par vispārējiem principiem un pieejām problēmu risināšanai, ja skolēniem ir gan faktologiskas un konceptuālas zināšanas attiecīgajā jomā, gan atbilstošas problēmu risināšanas stratēgijas, ja skolēni spēj atpazìt kā, kad un kāpēc izmantot faktologiskās, konceptuālās un procedurālās zināšanas un prasmes (National Research Council, 2012).

Ziṇojuma autoru ieskatā tāds arī ir 21. gadsimta caurviju prasmju integrācijas mērḳis - sekmēt mācīšanās iedziḷinoties procesus. Tā kā 21. gadsimta prasmju attīstība sekmē padziḷinātu mācību satura apguvi, šādas pieejas mācībām nostiprināšanās varētu samazināt mācību sasniegumu nevienlīdzību skolēnu vidū, tādējādi sagatavojot lielāku skaitu jauniešu sekmīgai dzīvei sabiedrībā un profesionālai darbībai. Šādas pieejas ieviešanai ir vairāki iemesli - gan jau pieminētās objektīvās izmaiņas sabiedrības attīstībā, kad līdzšinējās prasmes vairs nav pietiekamas un skolas beidzējiem jārēķinās ar to, ka mācības būs jāturpina mūža garumā, gan jauna izpratne par efektīvu mācīšanās procesu un faktoriem, kas sekmē pārnesi jeb spēju lietot zināšanas kompleksās, nepazīstamās situācijās.

Mācību procesā, kura laikā skolēns attīsta spēju vispārināt, pārnest jaunās zināšanas un prasmes uz nezināmām situācijām (tostarp reālās dzīves situācijām), mācǐšanās priekšslānā izvirzot procesus, ar kuru palīdzību mēs iegūstam zināšanas ( $k \bar{a}$ mès zinām?), ne tikai uzkrātu noteiktu satura apjomu (ko mēs zinām?). Mācību stundas līmenī tas vispirms nozīmē mērķu izvirzīšanu, atgriezeniskās saites saņemšanu skolēniem, skolēnu pieredzes aktualizēšanu, apzinātu kognitīvo un metakognitīvo paṇēmienu izmantošanu domas (jēgas) konstruēšanai dažādos

2 NRC. (2012). Education for Life and Work: Developing transferable knowledge and skills in the $21^{\text {st }}$ century. In Pellegrino, J. W., \& Hilton, M. L. (eds.). Committee on Defining Deeper Learning and $21^{\text {st }}$ Century Skills, National Research Council (NRC). Pieejams: http://www.nap. edu/catalog.php?record_id=13398 (aplūkots 20.10.2017).

3 Fullan, M., \& Langworthy, M. (2014). A rich seam: How new pedagogies find deep learning. MaRS Discovery District.

4 Hattie, J. (2012). Visible learning for teachers: Maximizing impact on learning. Routledge. 
kontekstos un situācijās, kā arī sadarbību. Tas ir paradigmatiski atšķirīgi no tradicionālās mācǐšanas, t. i., informācijas nodošanas, modeḷa.

Šādā pieejā mācībām process vistiešākajā mērā ietekmē sasniedzamo rezultātu jeb faktiski ir ekvivalents rezultātam. Ideju par to, ka 21. gadsimta kompetenču apguvei mācišanās jeb darǐšana nav atraujama no sasniedzamā rezultāta, uzsver arī Maikls Fulans (Michael Fullan) savā esejā "Izglítība ar plusa zīmi” (Fullan, \& Scott, 20145). Viņš aicina nostiprināt izglitībā vēl nebijušu ideju, ka izglìtota persona ir darītājs - darošs domātājs jeb domājošs darītājs -, kurš mācās, lai darītu, un dara, lai mācītos.

Kompetence (mācīšanās iedzil̦inoties rezultāts) veidojas no dažādu veidu atsevišķu elementu kopuma, demonstrējot to darbībā. Kompetenci mēra kā kompleksu sniegumu, izvēloties atbilstošus uzdevumus, izvirzot snieguma kritērijus un aprakstot tos lïmenos. Ričards Stigins (Richard Stiggins) un autoru kolektīvs $\left(2004^{6}\right)$ uzsver, ka snieguma vērtēšana ir tāda pieeja vērtēšanai, kas balstita uz novērojumiem par skolēna darbību vai radītu produktu un sprieduma izteikšanu par novēroto. Kā atzīst vairāki autori, tas ir vienīgais veids, kā pārliecināties par skolēnu spēju lietot prasmi kontekstā.

Izvirzot skaidrus un konkrētus kritērijus, ir iespējams piedāvāt laba snieguma aprakstu, kas var kalpot kā signāls tālākas attīstības virzienam un palīdzēt identificēt konkrētas darbības jomas, kurās nepieciešami uzlabojumi.

Snieguma vērtēšanas plānošana ietver piemērotu uzdevumu izvēli, kurus veicot skolēniem būs iespēja demonstrēt attiecīgās prasmes un atbilstošu kritēriju izvēli šĩ snieguma novērtēšanai. Nozīmīgs kritērijs uzdevumu atlasei ir sasniegtais rezultāts skolēnam, kuru mērām. Sasniedzamajam rezultātam esot kompleksam, tiek analizēts, no kādām dạ̦ām tas veidojas - zināšanas un izpratne nozarēe, starpdisciplināri jautājumi, prasmes - darbā ar tekstu, pētnieciskas prasmes u. c., reālās dzīves un citu nozaru konteksts (starpdisciplinaritāte), kognitīvās darbības dziḷums; metakognitīvās darbības iespējas.

Lai analizētu, cik dzị̣i domā skolēns, un lai viṇam palīdzētu saprast, kā uzlabot savu rezultātu (pāriet uz nākamo līmeni), un lai spriestu par paša mācību uzdevuma kognitīvo līmeni, var izmantot dažādas taksonomijas. SOLO (Structure of the Observed Learning Outcome) taksonomija (Biggs, \& Collis,

5 Fullan, M., \& Scott, G. (July 2014). New Pedagogies for Deep Learning Whitepaper: Education PLUS. Collaborative Impact SPC, Seattle, Washington. Pieejams: http://www.academia. edu/7999210/Education_Plus (aplūkots 20.10.2017.).

6 Stiggins, R. J., Arter, J. A., Chappuis, J., \& Chappius, S. (2004). Classroom assessment for student learning: Doing it right - using it well. Portland, Oregon: Assessment Training Institute. 
$1982^{7}$ ) ir izziñas rìks, ar kura palīdzību var atspoguḷot un izvērtēt kvalitatīvu virzību no virspusējas uz dziļu mācī̌sanos.

Attīstoties tehnologískajiem risinājumiem un procedūrām, kā vērtējumi tiek saskaņoti starp vairākiem vērtētājiem, snieguma vērtēšanu iespējams sekmīgi îstenot ne tikai ikdienas vērtēšanā klasē, bet arī nacionāla mēroga pārbaudījumos. Vērtěšanas darbi makrolīmenī pārsvarā tiek izmantoti starptautiskajā, nacionālajā vai pašvaldības līmenī. Tradicionāli šāda veida vērtēšana tiek izmantota starptautiskos salīdzinošos pētijumos PISA (Programme for International Student Assessment), PIRLS (Progress in International Reading Literacy Study), TIMSS (Trends in International Mathematics and Science Stud), summatīvajai novērtēšanai, mācību programmu novērtēšanai.

Kā norāda Linda Dārlinga-Hamonda (Linda Darling-Hammond) un Frenks Adamsons (Frank Adamson) (Darling-Hammond, \& Adamson, 2010 ${ }^{8}$ ) - mainoties prasmēm, kas skolēniem jāapgūst 21. gadsimtā, ir jāmainās arī pieejai vērtēšanai, jo svarīgas ir ne tikai zināšanas, bet arī tas, ko skolēns spēj ar tām paveikt. Latvijas situācijā būtiski ir saprast, cik precīzi valsts līmeņa pārbaudes darbi mēra spēkā esošajos (kopš 2006. gada) mācību satura dokumentos noteiktās prioritātes, vai un kā tie mēra kompleksu sniegumu, kā tie atbilst labam makrolīmeņa vērtēšanas instrumentam. Veiktā analīze aptver valsts līmeṇa darbus eksaktajos mācību priekšmetos laikposmā no 2015. līdz 2017. gadam.

Konstatēts, ka zināšanu un izpratnes par procesiem, parādībām dabā, specifisku prasmju apguves mērījumi nedod iespēju iegūt drošu atbildi par skolēna sniegumu katrā no mācību satura laukiem, jo tas notiek fragmentāri. Pārbaudes darbi mēra galvenokārt skolēnu prasmi rīkoties tipveida situācijās. Kopumā trīs gadu periodā 64-92\% visu uzdevumu prasa reproduktīvu skolēna darbību faktu un procedūru atcerēšanos, zināšanu un prasmju lietošanu tipveida uzdevumos, vienkāršu datu kopumu interpretēšanu. Šie dati atsedz pretrunu starp 2006. gada satura dokumentos iestrādāto virzību uz produktīvu skolēnu darbību un to, ko mēra valsts līmeņa pārbaudes darbi.

Saskatāma pozitīva tendence valsts mēroga pārbaudes darbos iekḷaut uzdevumus ar potenciālu mērīt kompleksu sniegumu, bet potenciāls netiek izmantots, iegūstot virspusēju informāciju par skolēnu sniegumu. Darbos sastopami uzdevumi, kuru konteksts ir veiksmīgs un kuri, tos nedaudz pārveidojot, no kognitīvi virspusējiem iegūtu iespēju mērīt daudz augstāka līmeņa kognitīvu skolēna darbību.

7 Biggs, J. B., \& Collis, K. F. (1982). Evaluating the quality of learning: The SOLO taxonomy. New York: Academic.

8 Darling-Hammond, L., \& Adamson, F. (2010). Beyond basic skills: The role of performance assessment in achieving $21^{\text {st }}$ century standards of learning. Stanford, CA. 
Vērtējuma izlikšanai valsts pārbaudes darbos dabaszinātnēs un matemātikā joprojām pārsvarā tiek izmantota pieeja - pareiza/nepareiza atbilde. Tā izmantojama, ja nepieciešams konstatēt faktu zināšanas, bet tā nel̦auj spriest par prasmēm, domāšanas dziḷumu, ko darbi pretendē mērīt. Ja gribam ieviest pieeju mācīties iedziḷinoties, tad valsts līmeņa pārbaudes darbos vajadzētu mērìt arī prasmes, ko var darìt, veidojot snieguma līmeņu aprakstus.

Ir pierādījumi, ka skolotāji veic izmaiņas mācību saturā un metodēs, vadoties tieši no uzdevumiem makrolīmeņa vērtēšanas darbos. Tik liels zema kognitīva līmen̦a uzdevumu pārsvars valsts pārbaudes darbos, kāds tas ir šobrīd, neveicina produktīvu mācību aktivitāšu skaita palielināšanos mācību stundās.

Konstatētais, ka skolēni uzdevumā nespēj izmantot daudzus gadus mācību procesā lietotu algoritmu, ja tas piedāvāts citā kontekstā, iezīmē nepieciešamību mācību procesā konsekventi noskaidrot skolēnu iepriekšējo pieredzi un, balstoties uz to, dažādot uzdevumu kontekstus, tādējādi apzināti mācot skolēniem pārnesuma veidošanu: atpazīt situācijas, paṇēmienus, vairāk izmantot uzdevumus ar atbilžu un risināšanas paņēmienu variativitāti. Skolēnu rezultāti uzrāda arī nepieciešamību pārskatìt, kā notiek prasmju mācīšana, vai tiek veidota stratēgija un strādāts pie pārnesuma no situācijas uz situāciju, no temata uz tematu, no priekšmeta uz priekšmetu, uz dzīvi.

Makrolīmeña darbu analīzē konstatētais aktualizē nepieciešamību sekmēt sadarbỉbu starp skolotājiem skolas mērogā, nepaliekot tikai sarunu un plānošanas līmenī, bet mācību stundās savstarpēji vērojot, kādas stratēgijas katrs izmanto, kā māca tās atpazìt un pārnest. Tas sasaucas ar pašvadītas mācišanās prasmju nepieciešamu ienākšanu skolēna ikdienas pieredzē, kas nav iespējama bez metakognitīvo paņēmienu (strategy) izmantošanas.

Nereti praksē neizmantota iespēja palīdzēt skolēniem uzlabot rezultātu slēpjas formatīvajā vērtēšanā, ko īsteno mikrolīmenī, t. i., mācību stundā. Formatīiās vērtēšanas būtỉba ir iegūt pierādījumus par skolēna sniegumu, tos interpretēt un izmantot, lai pieṇemtu lēmumu par turpmākajiem mācību procesa soḷiem, lai tie būtu pamatotāki, (Black, \& Wiliam, 20079; Black, 2004 ${ }^{10}$ ). Vērtēšanas eksperti (Brownlie et al., 2006 ${ }^{11}$; Pollard et al., $2008^{12}$, u. c.) lieto arī terminus assessment

9 Black, P., \& Wiliam, D. (2007). Large-scale assessment systems: Design principles drawn from international comparisons. Measurement: Interdisciplinary Research and Perspectives, 5(1), pp. 1-53.

${ }^{10}$ Black, P. (2004). The Nature and Value of Formative Assessment for Learning. London.

${ }^{11}$ Brownlie, F., Feniak, C., \& Schnellert, L. (2006). Student Diversity (2 ${ }^{\text {nd }}$ ed.) Markham, ON: Pembroke Publishers.

${ }^{12}$ Pollard, A., Anderson, J., Maddock, M., Swaffield, S., Warin, J., \& Warwick, P. (2008). Reflective teaching: evidence-informed professional practice. ( $3^{\text {rd }}$ ed.) London: Continuum International Publishing Group. 
for learning - vērtēšana, lai mācītos, un vērtēšana kā mācišanās (assessment as learning). Lai notiktu vērtēšana kā mācīšanās, būtiskākais aspekts - skolotāja dota aprakstošā atgriezeniskā saite skolēnam par viņa mācišanos, iesaistot skolēnu savu rezultātu analīzē, turpmāko mācīšanās mērḳu definēšanā.

Veicot formatīvo vērtēšanu, tieši tāpat kā summatīvās vērtēšanas gadījumā, jābūt skaidriem vērtēšanas kritērijiem, jo tas pilnībā nosaka, tieši kādi skolēna snieguma aspekti tiks izvērtēti un kādus secinājumus izdarīsim. Formatīvo vērtēšanu mācību stundā raksturo skolēnu iesaistîšana (Harlen, 2013 ${ }^{13}$ ), gan komunicējot stundas mērķus un veidojot vienotu izpratni par snieguma vērtēšanas kritērijiem; gan procesa cikliskums - skolēna darbība, ar mērķa sasniegšanu saistìtu pierādījumu iegūšana, gan lēmums par nepieciešamajiem nākamajiem soḷiem un to īstenošana, kā arī atbilstošas skolēna darbības.

Formatīvajai vērtēšanai un noderīgai, kvalitatīvai atgriezeniskajai saitei jāsniedz atbildes uz jautājumiem: kas jāiemācās? kas izdodas, kas vēl ne? ko darīt tālāk? Lai varētu uzlabot turpmāko māciššnos, skolēnam nepieciešamas atbildes par savu darbību un skolotajam - par viņa skolēniem. Svarīgi, lai atbildes uz šiem jautājumiem ir pamatotas, tās ir datos un faktos balstittas.

Valsts līmeņa izglīiỉbu reglamentējošos dokumentos nepieciešams skaidri parādìt formatīvās vērtēšanas lomu mācību procesā, uzsverot tās nozīmīgumu gan konkrētā satura mācīšanas aspektā, ìstenojot mācī̌̌anos iedziḷinoties, gan kā būtisku pašvadītas mācišanās elementu.

Formatīvās vērtēšanas efektivitāte ir atkarīga no skolotāju prasmēm, skolotāju un skolu vaditāju izpratnes par šo vērtēšanu, prasmes izmantot dažādus vērtēšanas instrumentus un iegūtos datus. Nepieciešams sekmēt skolotāju profesionālo sadarbību, ieviešot, pārbaudot formatīvās vērtēšanas paṇēmienus, veicot savas darbïbas izpēti ar mērḳi iegūt pierādījumus, kas apliecina vērtēšanas efektivitāti.

Pētnieki (Barber, \& Mourshed, 2007 ${ }^{14}$; Hargreaves, \& Fullan, 2012 ${ }^{15}$; Hattie, $2012^{16}$, u. c.) ir vienisprātis par mācīšanas un skolotāja personības milzīgo ietekmi uz skolēna sasniegto rezultātu. Turpretim vairums skolotāju savu ietekmi uz skolēnu mācī̌anos un viṇu sasniegumu dinamiku novērtē pārāk zemu (Helmke, $\left.2009^{17}\right)$.

${ }^{13}$ Harlen, W. (2013). Assessment and inquiry-based science education: issues in policy and practice. Global Network od Science Academies (IAP) Science Education Programme (SEP).

${ }^{14}$ Barber, M., \& Mourshed, M. (2007). How the world's best-performing schools systems come out on top. McKinsey \& Company.

${ }^{15}$ Hargreaves, A., \& Fullan, M. (2012.) Professional capital: Transforming teaching in every school. Teachers College Press.

${ }^{16}$ Hattie, J. (2012). Visible learning for teachers: Maximizing impact on learning. Routledge.

${ }^{17}$ Helmke, A. (2009). Unterrichtsqualität und Lehrerprofessionalität - Diagnose, Evaluation und Verbesserung des Unterrichts. Seelze: Klett-Kallmeyer in. 
Lai skolēnu mācīšanās rezultāts būtu kompetence, aktualizējas skolotāja prasmes vadìt atbilstošu mācišanos, analizēt un reflektēt, sadarboties. Svarīgi, lai mācību procesā skolotājs prot izvirzìt skolēnam aktuālus mācību mērḳus un dot noderīgu atgriezenisko saiti par to sasniegšanu, prot mācìt skolēnu pašu formulēt mērḳi, sekot virzibai uz to, dot un pien,emt atgriezenisko saiti - veicināt pašvadītu mācīšanos; izvēlēties un prasmīgi lietot mācību paņēmienus, metodes, kas panāk skolēnu iedziḷināšanos un iesaistišanos, izmantot produktīvus uzdevumus, veidot sasaisti ar reālo dzīvi; mācìt jēgpilni izmantot informācijas un komunikāciju tehnolog̣iju (IKT) rīkus; izmanto atbilstošus instrumentus (snieguma līmeņu aprakstus), lai sekotu skolēnu izaugsmei; analizē datus, lai plānotu turpmāko darbību.

Skolēna mācǐšanās rezultāts būs dziḷa izpratne un kompetence, ja skolotāja īstenotās darbības - mācǐšana - būs efektīva. Skolotāja darbības efektivitāti mēra (paši skolotāji, skolu vadītāji, izglìtības pārvaldes u. c.), izmantojot skolotāja snieguma aprakstus līmeņos. Tie ir pieejami literatūrā, tiek izmantoti pētnieciskām vajadzībām, tos var izmantot pašnovērtējumam skolotāju personīgai izaugsmei un profesionālās pilnveides vajadzībām.

Latvijas Universitātes Starpnozaru izglītības inovāciju centra (LU SIIC) veiktie pētijumi (France et al., 2015 ${ }^{18}$; Dudareva et al., 2015 ${ }^{19}$; Volkinsteine et al, $2014^{20}$, u. c. ) par skolotāju prasmēm, savu prasmju un mācǐšanās vajadzību vērtējumu, skolotāju darbībām mācību stundā un skolotāju mācību aktivitātēs liecina, ka skolotājiem nepieciešams profesionāls atbalsts, lai veidotu mācǐšanos, darbinot dziḷu domāšanu, stundās palielinātos produktīvu uzdevumu īpatsvars, uzlabotos skolotāju prasme veidot sarunu, nevis "atprasišanu", būtu jēgpilns IKT lietojums. Saskatāma plaisa starp skolotāja prasmju pašnovērtējumu un ekspertu konstatēto vērotajās mācību stundās. Lai vadītu mācīšanos iedziḷinoties, aktualitāti iegūst skolēnu mācīšanās vadīšana, skolotāju refleksijas un pašnovērtējuma prasmes, kā arī sadarbība.

Nepārtraukta profesionāla mācīšanās sadarbojoties ir atslēgas vārdi, kas 21. gadsimtā raksturo skolotāju profesionālo pilnveidi. Skolotāja karjeras sākumā notiek sagatavošana (pre-service training). Turpmākā skolotāja izaugsme

${ }^{18}$ France, I., Namsone, D., \& Cakane, L. (2015). What Research Shows about Mathematics Teachers' Learning Needs: Experience from Latvia. In SOCIETY, INTEGRATION, EDUCATION (Vol. 2, pp. 45-55). Pieejams: http://dx.doi.org/10.17770/sie2015vol2.457 (aplūkots 14.02.2018.).

${ }^{19}$ Dudareva, I., Namsone, D., \& Čakāne, L. (2015). The development of students' digital competence and physics teacher's professional development needs. Conference of International Research Group on Physics Teaching (GIREP EPEC) 6-10.07.2015. Wroclaw, Poland.

${ }^{20}$ Volkinšteine, J., Namsone, D., \& Čakāne, L. (2014). Latvian chemistry teachers' skills to organize student scientific inquiry. Problem sof Education in the $21^{\text {st }}$ Century, Vol. 59, pp. 86-98. 
un mācīšanās ir nepārtraukts ilgtermiṇa process, kas vispirms atkarīgs no katra paša. Profesionāla mācǐšanās - kā organizēts process; mācǐšanās sadarbojoties process, kas ietver pieredzes apmaiṇu starp kolēgiem, atgriezeniskās saites u. c. atbalsta mehānismus.

Veidojot profesionālās pilnveides programmas un nodarbības, nepieciešams plānot, kādā līmenī vēlamies panākt profesionālās pilnveides ietekmi - dalībnieku apmierinātība, uzlabojumi skolotāju zināšanās, prasmēs, uzskatos, izmaiņas skolotāju praksē vai skolēnu sniegumā (Lipowsky, \& Rzejak, 2012 ${ }^{21}$ ). Katru lìmeni ietekmē atškịīigas profesionālās pilnveides formas.

Efektīvu profesionālo pilnveidi raksturo iespēja ieviest inovatīvu praksi, kurā dalībnieki mācās cits no cita, mācās sadarbojoties un daloties pieredzē, skolotāji jūt kolēguu atbalstu un saṇem atgriezenisko saiti, mācās reflektēt nevis hierarhiski, bet koordinēti, un kurā aktivitātes notiek ilgtermiṇā un regulāri. LU SIIC izstrādātais un ìstenotais modelis savstarpējai stundu vērošanai ietver trīs dimensijas - jaunas pieredzes apguvi, vērojot un analizējot mācību stundas, refleksiju un sadarbību. ${ }^{22}$ Tas tiek īstenots, ilgtermiṇā veicot regulāras aktivitātes skolas vidē. Uzlabotais modelis ir kombinēts. Tas ietver trīs nozīmīgus struktūrelementus: ilgtermiṇa, regulāras kopīgas darbnīcas savstarpējai stundu vērošanai un analīzei, mācīšanas pētīšana starp darbnīcām, radot un izmēgénot stundu piemērus, sadarbība skolas komandā. Modelis ir aprobēts praksē izmēǵinājumskolu grupā un veiksmīgi izmantojams caurviju prasmju (21. gadsimta prasmju) mācīšanas pieredzes uzkrāšanai. Izmēǵinājuma pētījums parāda, ka ir vajadzīgs laiks, lai skolotāji saskatītu atškirīibu un iekḷautu savā praksē ne tikai zinātnes mācību satura, bet arī šo prasmju mācīšanas elementus.

Darbs mācīšanās grupā savas profesionālās prakses izpētei ir mācīšanās, pētot savu praksi, kas norisinās individuāli un sadarbojoties grupā. Skolotāji veic nelielu pētījumu, uzkrājot datus par savu praksi, analizējot šo praksi, pilnveidojot izpratni par notiekošo; interpretē savus secinājumus un pieņem lēmumus turpmākai darbībai; sadarbojas grupā. Gūtā pieredze apstiprina, ka mācīšanās grupā savas profesionālās darbības izpētei palīdz skolotājiem uzlabot viṇu prasmes, kā arī uzlabot skolotāju praksi (Volkinšteine, \& Namsone, 2016 ${ }^{23}$ ). Vērojama

${ }^{21}$ Lipowsky, F., \& Rzejak, D. (2012). Lehrerinnen und Lehrer als Lerner - Wann gelingt der Rollentausch? Merkmale und Wirkungen effektiver Lehrerfortbildungen. Schulpädagogik heute, 5(3), pp. 1-17.

${ }^{22}$ Namsone, D., \& Čakāne, L. (2018). A Collaborative Classroom-Based Teacher Professional Learning Model. In Yeo, J., Teo, T., \& Tang K. S. (eds.). Science Education Research and Practice in Asia-Pacific and Beyond (pp. 177-195). Springer, Singapore. DOI: https://doi. org/10.1007/978-981-10-5149-4_13

${ }^{23}$ Volkinšteine, J., \& Namsone, D. (2016). Science Teachers' learning team for the action research as a way of improving inquiry teaching practice. $9^{\text {th }}$ annual International Conference of Education, Research and Innovation ICERI2016, Spain, Seville, IATED, pp. 3911-3920. 
tendence skolēnu sasniegumiem uzlaboties, mainās skolēnu attieksme pret mācību priekšmetu; palielinās skolēnu interese un vēlme mācīties.

Mācoties skolā, skolēniem jāapgūst zināšanas, prasmes un attieksmes, kas viniem ļautu iesaistīties un pilnveidoties arī digitālajā vidē.

IT rīku un digitālo resursu jēgpilnai lietošanai ir potenciāls atbalstīt un organizēt skolēnu mācīšanos iedziļinoties. ISTE (International Society for Technology in Education, 2016 ${ }^{24}$ ) standarti digitālās kompetences apguvei nosaka, ka skolēnam informāciju tehnolog̣ijas vajadzētu izmantot, lai attīstītu pašvadītas mācīšanās prasmes, kḷūtu par digitālu pilsoni, konstruētu zināšanas, izmantotu dažādas informāciju tehnologiijas, lai identificētu, risinātu un atrisinātu problēmas, radot jaunus, noderīgus vai teorētiskus risinājumus; apgūtu algoritmiskās domāšanas prasmes, komunikācijas un prezentācijas prasmes, kḷūtu par sadarbības partneri, t. i., tās ir neatṇemama visu caurviju prasmju apguves sastāvdala. Tas sasaucas ar literatūrā lietotu jēdzienu Leveraging digital (New Pedagogy for Deep Learning). Ar to saprot digitālo tehnologiju pieejamību un tehnologiju potenciālu nodrošināt personalizētās mācīšanās, komunikācijas un sadarbības iespējas, veikt vērtēšanu reālajā laikā, sniegt tūlītēju atgriezenisko saiti, atrast, apkopot, apstrādāt un prezentēt informāciju, piekḷūt autentiskiem mācību kontekstiem (Fullan, \& Langworthy, 2013 ${ }^{25}$ ).

IT rīku un digitālo resursu jēgpilna lietošana palīdz mācīties efektīvāk. To nodrošina iespējas saṇemt atgriezenisko saiti uzreiz mācību procesā, daudzpusīgi aplūkot problēmu ar digitālo resursu - tekstu, video, attēlu, animāciju, simulāciju, modelēšanas programmatūru - starpniecību, forumos un sociālajās platformās uzdot jautājumus un pamatot savu viedokli, radīt izcilus darbus, saglabājot, pārskatot un pilnveidojot radīto, konstruēt zināšanas vidē, kas ḷauj aktīvi iesaistīties procesā, iegūt nepastarpinātu pieredzi, mācīties no labās prakses piemēriem, papildināt zināšanas jebkurā vietā un laikā. (Abbott, et al., 2009²)

Formatīvā vērtěšana digitāli mācību procesā var būt kā tradicionālās vērtēšanas nozīmīgs papildinājums. Tās veidam, saturam un funkcionalitātei jānodrošina nozīmīga un ticama datu ieguve. Sniegtajai atgriezeniskajai saitei jābūt personalizētai, motivējošai un saistītai ar kognitīvo procesu. Tai ir jābūt pēc iespējas operatīvākai un individualizētai, atbilstošai katra skolēna sniegumam.

${ }^{24}$ ISTE Standards for Students. (2016). Pieejams: https://www.iste.org/standards (aplūkots 16.02.2018.)

${ }^{25}$ Fullan, M., \& Langworthy, M. (2013). Towards a New End: New Pedagogies for Deep Learning. Pieejams: http://npdl.thumbtack.co.nz/wp-content/uploads/2015/08/Towards-a-New-End-NewPedagogies-for-Deep-Learning-Invitation.pdf (aplūkots 16.02.2018.).

${ }^{26}$ Abbott, I., Townsend, A., Johnston-Wilder, S., \& Reynolds, L. (2009). Literature Review: Deep learning with technology in 14 to 19-year-old learners. Coventry (UK): British Educational Communications and Technology Agency (Becta). 
Lai skolotājs attīstu un pilnveidotu skolēnu digitālo kompetenci, jau mācību procesu plānošanā ir jāparedz iespējas veikt IT uzdevumus ar IT rīkiem. Lai saprastu, vai IT rīku potenciāls tiek izmantots mērḳtiecīgi, skolotājs var izvērtēt plānotās un realizētās aktivitātes, izmantojot snieguma aprakstu līmeņos.

Analizējot IT rīku ienākšanu eksakto zinātņu mācību procesā, I. Dudareva konstatē, ka laikā kopš 2006. gada IT ir kḷuvušas par neatṇemamu daudzu skolotāju rīku mācỉbu stundās. Mācību stundu vērojumi uzrāda plaisu starp IT rīku jēgpilnas lietošanas potenciālu un to, kā IT rīki tiek reāli izmantoti mācību procesā. Stundās, kurās tiek izmantoti IT rīki un resursi, skolēni bieži ir pasīvā lomā. IT rīki tiek izmantoti galvenokārt konkrētu uzdevumu veikšanai, nevis zināšanu konstruēšanai. Jaunais izaicinājums ir padarìt IT lietojumu jēgpilnu, noderīgu skolēna kompetenču attīstīšanai.

Lai skolotājs varētu mērḳtiecīgi attīstìt un pilnveidot skolēnu digitālo kompetenci dažādos mācỉbu priekšmetos, vispirms viņam pašam ir jāattīsta un jāpilnveido sava digitālā kompetence. Skolotāju profesionālajai pilnveidei būs ilgtermiņa ietekme, ja tā tiks veidota, balstoties uz skolotāju vajadzībām, organizējot mācǐšanos grupas, sadarbojoties ar kolẹgiem. Skolotājam ir jābūt mācīšanās centrā, lai viņš varētu mainìt savus IT rīku lietošanas paradumus (Daly, Pachler, \& Pelletier, $2009^{27}$ ).

Mācīšanās iedzilinoties pieejas ieviešana, kompleksa snieguma vērtēšana u.c. ir paradigmatiski atšķirīgas no tradicionālās mācǐšanas, t. i., no informācijas nodošanas model̦a. To ieviešanai skolu praksē nepieciešama visu iesaistìto sadarbība inovāciju ieviešanai un pārnesei. Pārmaiņu un inovāciju ienākšana skolās ir dažādu līmeṇu iesaistīto pušu atbildība. Ikvienā skolā to ietekmē katra skolotāja izpratne par pārmaiņu būtỉbu, motivācija un prasmes, skolas vadības izpratne un spēja to plānot un vadìt, būtisks ir skolas dibinātāja atbalsts to ieviešanā.

Lai skolās ienāktu inovācijas un lai notiktu šo inovāciju pārnese starp skolotājiem un starp skolām, ir jāiesaistās gan skolotājiem, gan skolas vadībai. Skola, kura izmanto pārmaiṇu dotās iespējas, lai skolēnu rezultāti uzlabotos, ievēro šādus principus: izvirza un komunicē skaidrus, konkrētus, reālus un izvērtējamus, terminētus mērḳus katram pārmaiṇu īstenošanā iesaistìtajam; skolā ir izveidota struktūra rezultāta konstatēšanai, regulāra atgriezeniskā saite ikvienam iesaistītajam. Mērḳu izvirzišana seko esošās situācijas analīzei, datiem par mācību stundu kvalitāti un skolēnu sniegumu; dati ir daudzpusīgi (mācību procesa vērojumi, aptaujas, skolēnu sniegums). Skolā ir radìta vienota izpratne par pārmaiṇu būtību, visu iesaiste mērḳu definēšanā un sasniegtā izvērtēšanā. Skolā

${ }^{27}$ Daly, C., Pachler, N., \& Pelletier, C. (2009). Continuing Professional Developmentin ICT for Teachers: A literaturereview. BECTA. Pieejams: http://eprints.ioe.ac.uk/3183/1/Daly2009 CPDandICTforteachersprojectreport1.pdf (aplūkots 16.02.2018.). 
veidojas mācišanās kopiena ${ }^{28}$, kurā nodrošināti nepieciešamie apstākḷi pārmaiṇu ieviešanai un pārnesei, tostarp skolotāju sadarbībai plānot un analizēt mācǐšanu un mācīšanos, savstarpējai mācību stundu vērošanai un analīzei. Skolas vadība strādā kā komanda, kas vienoti iet uz mērkiiem, spēj motivēt skolotājus, plāno skolotāju mācīšanos. Tiek sniegts individuāls atbalsts skolotājam, kas pamatojas datu analīzē par viņa prasmēm.

Inovāciju ieviešanā būtisku lomu ieņem skolotāji līderi' ${ }^{29,30}$. Skolas vadība var veicināt skolotāju līderu darbību. Skolas vadībai vajadzētu pamanīt un atbalstīt skolotājus līderus, piesaistot izglìtības ekspertus vajadzību diagnosticēšanai, darbību plānošanai, skolotāju sadarbības modeḷu sākotnējai ieviešanai, plānot laiku un finansiālu atbalstu skolotāju sadarbības nodrošināšanai.

${ }^{28}$ Andrews, D., \& Lewis, M. (2007). Transforming practice from within: The power of the professional learning community. In Stoll, L., \& Louis, K. S. (eds.). Professional learning communities: Divergence, depth and dilemmas. Maidenhead: Open University Press.

${ }^{29}$ Lieberman, A., \& Miller, L. (2004). Teacher leadership. San Francisco: Jossey-Bass.

${ }^{30}$ Namsone, D., Čakāne, L., \& Sarceviča-Kalviške, D. (2016). Teacher Teams and Schools Become Leaders to Disseminate Innovative Practice. SOCIETY. INTEGRATION. EDUCATION. Proceedings of the International Scientific Conference, 2016. Vol. 2 (pp. 208-222). Rezekne: Rezeknes Academy of Technologies. DOI: http://dx.doi.org/10.17770/sie2016vol2.1393 


\title{
Kompetence ${ }^{1}$ kā komplekss skolēna mācǐšanās rezultāts
}

\author{
Zane Olina, Dace Namsone, Ilze France
}

Globalizācijas un informācijas tehnologiju attīstîbas laikmetā skolēniem nepieciešamas tādas prasmes un sagatavotība, ko nespēj piedāvāt tradicionālās, akadēmiskās zinātṇu nozarēs balstìtas izglìtỉbas sistēmas, kurās mācību centrālais fokuss ir noteikta, jau zināma zināšanu apjoma nodošana nākamajām paaudzēm.

Mūsdienu skolu beidzēji veiks darbus, kādu vēl nav, risinās problēmas, kuras vēl neapzināmies. Tāpēc vinuu sagatavotībā kritiski svarīgi pievērst uzmanību tam, lai viṇi spētu saskatīt iespējas un identificēt problēmas, izvēlēties agrāk nebijušus risinājumus, turpināt attīstīt jaunas prasmes mūža garumā. Sekmīgai personiskajai un profesionālajai darbībai īpaši pieprasītas ir sociālās prasmes, spēja kritiski izvērtēt informāciju, izmantot zināšanas, vēlme un prasme mācīties mūža garumā. Vēl vairāk - nostiprinās uzskats par izglīīibas nozīmīgo lomu sabiedrības turpmākajā attīstībā.

Eiropas izglītības rīcỉbpolitikas pamatnostādnes (Pamatprasmes mūǔzizglìtībai - Eiropas paraugkritēriju sistēma, 2006) aktualizē zināšanu sabiedrībai nozīmīgos mūžizglìtîbas un kompetenču jēdzienus. Eiropas Savienības līmeṇa attīstības plānošanas dokumentā Eiropa 2020 Stratēgija gudrai, ilgtspējīgai un integrējošai izaugsmei ${ }^{2}$ izvirzìtas trīs prioritātes, kas savstarpēji pastiprina cita citu: pirmkārt, viedā izaugsme - uz inovācijām balstīta ekonomikas attīstība; otrkārt, ilgtspējīga izaugsme - resursu ziņā efektīvākas, videi nekaitīgākas un konkurētspējīgākas ekonomikas veicināšana; treškārt, integrējoša izaugsme - tādas

1 Tekstā lietots termins "kompetence". Iespējams, ka precīzāks termins latviešu valodā ir "lietpratība". Notiek diskusija.

2 Eiropas Komisija. (2010). EIROPA 2020. Stratēgija gudrai, ilgtspējīgai un integrējošai izaugsmei. Komisijas paziņojums. Pieejams: http://ec.europa.eu/eu2020/pdf/1_LV_ACT_ part1_v1.pdf (aplūkots 20.10.2017.). 
ekonomikas veicināšana, kurā ir augsts nodarbinātỉbas līmenis un kas nodrošina sociālo un teritoriālo kohēziju.

Kompetences attīstišanas nepieciešamību pamato arī Latvijas attīstības plānošanas dokumenti - Latvijas ilgtspējīgas attīstības stratēgija 2030 (LIAS, 2030) un Nacionālais attīstìbas plāns 2014.-2020. gadam (NAP, 2014-202033). Abos šajos dokumentos uzsvērts gan mūsdienu dzīves mainīgums, gan kompetenču nozīmīgums. LIAS 2030 uzsvērta nepieciešamība īstenot paradigmas maiņu izglīīibā. Saskaņā ar LIAS 2030 izglīiībai jābūt kvalitatīvai, visa mūža garumā pieejamai un uz radošumu orientētai. Tas l̦auj reagềt uz globālās konkurences un demogrāfijas izaicinājumiem un ir viens no ekonomikas model̦a maiņas priekšnoteikumiem. NAP 2014-2020 ietverts rīcības virziens "Kompetenču attīstība", kas nosaka, ka cilvēkam ir nepieciešamas daudzveidīgas kompetences, lai viņam būtu iespēja iegūt un strādāt cien̄igu darbu un gādāt par sevi, saviem tuviniekiem un sniegt ieguldījumu valsts attīstībā. Šajā dokumentā uzsvērts, ka ḷoti svarīgi ir attīstīt un pilnveidot kompetences visa mūža garumā, n̦emot vērā mūsdienu mainīgos dzīves un darba apstākḷus, grūtības paredzēt nākotnes vajadzības.

Paradigmas maiṇas nepieciešamība izglìtībā ir globāla aktualitāte. Līdz šim pārāk bieži laba izglîtība tikusi traktēta kā zināt daudz, nevis kā izglìtība, kuras mērḳis ir saprast būtību un spēt zināšanas lietot. ${ }^{4}$ Ekonomiskās sadarbības un attīstîbas organizācijas (OECD) ziņojumā par 21. gadsimta vajadzībām atbilstošu izglīîibas politiku ${ }^{5}$ uzsvērts, ka sekmīgai dzīvei un darbam zināšanu sabiedrībā skolēniem mācībās jāiegūst padziḷināta konceptuāla izpratne par pasauli, nevis virspusēji fakti un procedūras. Viṇu zināšanu bāzei jābūt savstarpēji saistītai un izmantojamai, nevis sadalìtai pēc atsevišķu mācību priekšmetu un kursu principa. Viniiem jāspēj zināšanas lietot reālās dzìves kontekstā, skolu beidzējiem jābūt gataviem uzņemties atbildību par savu mācīšanos mūža garumā. Izglìtības teorētiķi, pētnieki, praktiķi un politiķi piesaka nepieciešamību pēc jaunām prasmēm, zināšanām, vērtībām, ieradumiem, uzskatiem skolu mācību saturā, piedāvājot tā saukto 21. gadsimta prasmju modeḷus kā ilustrāciju citādiem izglìtības mērḳiem

3 Latvijas Republikas Saeima. (2012). Latvijas Nacionālais attīstības plāns 2014.-2020. gadam. Pieejams: http://polsis.mk.gov.lv/documents/4247 (aplūkots 20.10.2017.).

4 UNESCO IBE. (May 2015). Repositioning and reconceptualizing the curriculum for the effective realization of Sustainable Development Goal Four, for holistic development and sustainable ways of living. Position paper for UNESCO International Bureau of Education (UNESCO IBE) Side Event: "Repositioning Curriculum in Education Quality \& DevelopmentRelevance” for May 21, 2015, Incheon, Republic of Korea. Pieejams: http://www.ibe.unesco. org/sites/default/files/resources/wef_ibe_position_paper_eng.pdf (aplūkots 20.10.2017.).

5 OECD CERI. (2008). $21^{\text {st }}$ Century Learning: Research, Innovation and Policy. Directions from recent OECD analyses. OECD Center for Educational Research and Innovation. Pieejams: http://www.oecd.org/site/educeri21st/40554299.pdf (aplūkots 20.10.2017.). 
(Pasaules ekonomikas forums, (World economic forum (WEF')); ATC21S, 20127\% Fullan, \& Scott, 2014; Hewlett Packard, 2013; OECD DeSeCo ${ }^{9}$; Gordon, Arjomand, \& Kearney, 2013; u. c. plānošanas dokumenti $\left.{ }^{10,11}\right)$. Šajos modeḷos dažādās kombinācijās mijas pamatprasmes nozīmīgākajās cilvēka darbības jomās ar transversālām (transversal) jeb caurviju prasmēm, kas attiecas uz visām jomām, kurām mācību saturā līdz šim nav pievērsta pietiekama uzmanība.

Kā atzìmē Roberts Kìgans (Robert Kegan), kompetences jēdziens l̦auj paplašināt mācǐšanās mērḳi - no konkrētu zināšanu apgūšanas uz mācīšanos un domāšanu par to, kā šīs zināšanas tiek iegūtas, kas ir ḷoti svarīgs priekšnoteikums mācīšanās mācīties prasmju apguvei (Kegan, 2002 ${ }^{12}$ ). Brenija Hoskinsa (Bryony Hoskins) un Ulfe Fredriksons (Ulf Fredriksson) uzsver, ka galvenā atškirīìba pieejā mācībām, kuras mērḳis ir attīstìt kompetenci kā kompleksu skolēna mācīšanās rezultātu, no tradicionālās pieejas izglìtības mērḳu un satura noteikšanai ir tā, ka izglìitīā uzsvars vairs netiek likts uz zināšanu nodošanu no iepriekšējās paaudzes nākamajai. Viņi atzīmē, ka šì tradicionālā pieeja vairs neatbilst mūsdienu main̄̄gajam tehnologiju un informācijas laikmetam, kurā nav iespējams zināt, kādas zināšanas būs nepieciešamas pat pēc pieciem vai desmit gadiem, kur nu vēl cilvēka mūža garumā (Hoskins, \& Fredriksson, 2008).

Kompetences attīstǐšana saistīta ar mācǐšanos iedzị̣inoties - procesu, kura laikā skolēns attīsta spēju vispārināt, pārnest jaunās zināšanas un prasmes uz nezināmām situācijām (tostarp dzīves situācijām), priekšplānā izvirzot procesus, ar kuru palīdzību mēs iegūstam zināšanas ( $k \bar{a}$ mès zinām?), ne tikai uzkrātu

6 World Economic Forum (WEF). (2015). New Vision for Education - unlocking the potential of technology. Pieejams: http://www3.weforum.org/docs/WEFUSA_NewVisionforEducation_ Report2015.pdf (aplūkots 20.10.2017.).

7 ATC21S. (2012). Assessment and Teaching of 21st Century Skills (ATC21S) Project. Pieejams: http://www.atc21s.org/ (aplūkots 20.10.2017.).

8 Hewlett Packard. (April 2013). Deeper Learning Competencies. Pieejams: http://www.hewlett. org/uploads/documents/Deeper_Learning_Defined_April_2013.pdf (aplūkots 22.10.2017.).

9 OECD. (2005). The Definition and Selection of Key Competencies. Executive summary. Pieejams: http://www.oecd.org/pisa/35070367.pdf (aplūkots 20.10.2017.).

${ }^{10}$ UNESCO IBE. (May 2015). Repositioning and reconceptualizing the curriculum for the effective realization of Sustainable Development Goal Four, for holistic development and sustainable ways of living. Position paper for UNESCO International Bureau of Education (UNESCO IBE) Side Event: "Repositioning Curriculum in Education Quality \& DevelopmentRelevance" for May 21, 2015, Incheon, Republic of Korea. Pieejams: http://www.ibe.unesco. org/sites/default/files/resources/wef_ibe_position_paper_eng.pdf (aplūkots 20.10.2017.).

${ }^{11}$ NRC. (2012). Education for Life and Work: Developing transferable knowledge and skills in the $21^{\text {st }}$ century. In Pellegrino, J. W., \& Hilton, M. L. (eds.). Committee on Defining Deeper Learning and $21^{\text {st }}$ Century Skills, National Research Council (NRC). Pieejams: http://www.nap. edu/catalog.php?record_id=13398 (aplūkots 20.10.2017.).

${ }^{12}$ Kegan, R. (2002). Mental demands of modern life: Implications for defining competencies. Keynote address DeSeCo Symposium, Geneva, February 11-13, 2002. Pieejams: http://www. portal-stat.admin.ch/deseco/deseco_int02.htm (aplūkots 20.10.2017.). 
noteiktu satura apjomu (ko mēs zinām?). İstenojot metodisku pieeju, kas virza mācīšanos iedziḷinoties, skolotājs dod iespēju skolēnam darbināt augsta līmeņa domāšanas prasmes (analizēt, sintezēt, izvērtēt, risināt problēmas), attīsta skolēnu metakognitīiās prasmes, lai skolēns spētu konstruēt apgūtā jēgu un izmantot pieredzi, risinot kompleksus uzdevumus jaunās situācijās un kontekstā. Skolu praksē nepieciešams nodrošināt, lai katra skolotāja darbs klasē būtu virzīts uz iedzilināšanos un tiktu mainīts veids, kā skolas līmenī tiek plānots un organizēts mācību saturs un vērtēšana.

\section{Kas ir kompetence? Kompetences jēdziena attīstība}

Mūsdienās kompetences jēdziens ir iekḷauts vispārējās izglīîibas reformu plānos visā pasaulē.

Pēdējo četrdesmit gadu laikā tā ieņem arvien lielāku vietu arodizglìtības, augstākās izglīîibas un mūžizglìtības kontekstā un ir cieši saistîta ar darba devēju prasībām labākai izglìtības iestāžu absolventu sagatavotībai darba tirgum. Šìs izpratnes kontekstā darba devēji un ekonomisti uzlūko kompetenci kā sniegumu (performance), kas saistīts ar lielāku darbinieku produktivitāti, efektivitāti un profesionalitāti (Moore, Cheng, \& Dainty, 2002). Centieni formulēt kompetenci kā kompleksu sniegumu, kuru iespējams novērtēt reālā darbībā, un praktisku darba pieredzi pielīdzināt augstskolas diploma saņemšanai, saistīi ar darba tirgū pieaugošo neapmierinātību ar izglìtības iestāžu absolventu sagatavotību. Šãda pieeja izglìtíbai tiek uzskatīta par veidu, kā uzlabot mācišanos ekonomikas sistēmās, kurās nepārtraukti notiek pārmaiņas un kompleksums pieaug un palīdz notikt pārejai uz zināšanās balstītu ekonomiku (Velde, 1999).

Izglìtības satura un pieejas fokuss aizvien vairāk tiek vērsts uz skolēnu ar mērḳi attīstīt dzīvei 21. gadsimtā nozīmīgas pamatkompetences (Baartman, Bastiaens, Kirschner, \& van der Vleuten, 2007, p. 114). Eiropas Savienības izglītîbas politikas dokumentos teikts, ka pamatkompetencēm būtu jāpiemìt visiem cilvēkiem, sekmējot personīgo izaugsmi un attīstību un veicinot sociālo iekḷaušanos un nodarbinātību. ${ }^{13}$ Izglìtība, kas fokusēta uz izolētu zināšanu un prasmju pārnesi, mainās uz tādu, kurā tiek iegūtas kompleksas kompetences. Skolēnu

\footnotetext{
${ }^{13}$ European Parliament and the Council. (December 2006). Recommendation of the European Parliament and of the Council of 18 December 2006 on key competencies for lifelong learning (2006/962/EC). Official Journal of the European Union, L394/10, 30.12.2006. Pieejams: http:// eur-lex.europa.eu/LexUriServ/LexUriServ.do?uri=OJ:L:2006:394:0010:0018:EN:PDF (aplūkots 20.10.2017.).
} 
mācīšanās tiek vadīta tā, lai attīstītu mācīšanās prasmes un informācijas apguvi no dažādajiem mūsdienās pieejamajiem avotiem.

Eiropas Savienības 2006. ${ }^{14}$ un $2018 .{ }^{15}$ gada izglītības pamatnostādnēs kompetence definēta kā kontekstam atbilstoša zināšanu, prasmju un attieksmju kombinācija. Dokumentā dalībvalstis tiek aicinātas nodrošināt, ka katram pilsonim ir pamatprasmes (kompetences jeb competencies ang̣̣u valodā), lai varētu elastīgi pielāgoties mainīgajai pasaulei, kurā viss ir savstarpēji cieši saistīts.

Bronija Hoskinsa (Bryony Hoskins) un Rūta D. Krika (Ruth Deakin Crick) jēdzienu "kompetence" skaidro kā kompleksu zināšanu, prasmju, izpratnes, vērtību, attieksmju un vēlmju kombināciju, kas kalpo par pamatu cilvēka rīcībai pasaulē noteiktā jomā (Hoskins, \& Crick, 2010).

Hoskinsa un Fredriksons (Hoskins, \& Fredriksson, 2008) atzīmē OECD DeSeCo programmas kompetences definīciju, kurā uzsvērts, ka kompetence ir spēja sekmīgi rīkoties kompleksā situācijā, noteiktā kontekstā mobilizējot psihosociālos resursus, kas ietver gan kognitīvos resursus, gan citus indivīda rīcību ietekmējošos faktorus. Šajā definīcijā ar jēdzienu "kompetence" apzīmē indivīda iekšējos - mentālos resursus jeb struktūru, kas tiek iedarbināta, saskaroties ar konkrēto uzdevumu vai situāciju. Izšķir vairākas šîs mentālās struktūras dimensijas - zināšanas, kognitīvās prasmes, praktiskās prasmes, attieksmes, emocijas, ètiskus apsvērumus un vērtības, un motivāciju.

Autori (Hoskins, \& Fredriksson, 2008, p. 1) citē R. Kīganu (Kegan, 2002 ${ }^{16}$ ), kurš uzsver, ka jēdziena "kompetence" lietošana dod iespēju pievērst uzmanību ne tikai ārēji novērojamai rīcībai, demonstrējot konkrētu sniegumu, bet arī indivīda mentālajai kapacitātei, kas nodrošina šo rīcībspēju. Tādējādi, kā atzīmē R. Kīgans, zināšanu apguvi varam uztvert nevis kā procesu, kura gaitā mēs uzkrājam noteiktu satura apjomu (ko mēs zinām?), bet gan priekšplānā izvirzot procesus, ar kuru palīdzību mēs zināšanas iegūstam (kā mēs zinām?).

${ }^{14}$ European Parliament and the Council. (December 2006). Recommendation of the European Parliament and of the Council of 18 December 2006 on key competencies for lifelong learning (2006/962/EC). Official Journal of the European Union, L394/10, 30.12.2006. Pieejams: http:// eur-lex.europa.eu/LexUriServ/LexUriServ.do?uri=OJ:L:2006:394:0010:0018:EN:PDF (aplūkots 20.10.2017.).

${ }^{15}$ European Commission. (2018). Commission Staff Working Document Accompanying the document Proposal for a council Recommendation on Key Competences for Life Long Learning. Brussels, 17.01.2018. Pieejams: https://ec.europa.eu/education/sites/education/files/ swd-recommendation-key-competences-lifelong-learning.pdf (aplūkots 20.03.2018.).

${ }^{16}$ Kegan, R. (2002). Mental demands of modern life: Implications for defining competencies. Keynote address DeSeCo Symposium, Geneva, February 11-13, 2002. Pieejams: http://www. portal-stat.admin.ch/deseco/deseco_int02.htm (aplūkots 20.10.2017.). 
Latvijā kompetences jēdzienu ir aprakstijjuši vairāki pētnieki (Maslo, Tiḷ̣la, 2005 ${ }^{17}$; Garleja, 2006; Blūma, 2004; Rauhvargers, 2008 ${ }^{18}$; Dāvidsone, 2008; Bikse, 2011, u. c.). Piemēram, Andrejs Rauhvargers kompetenci definē kā zināšanu, prasmju un attieksmju kopumu, kas kvalificē noteikta veida vai līmeņa uzdevumu veikšanai (Rauhvargers, $2008^{19}$ ). Tatjana Koḳe kompetenci saista ar zināšanās pamatotu spēju izvēlēties situācijai vai darbībai atbilstošākos līdzekḷus un adekvāti rīkoties (Koḳe, 2003).

Autori šeit un turpmāk jēdzienu kompetence (lietpratība) definē kā indivīda spēju kompleksi lietot zināšanas, prasmes un paust attieksmes, risinot problēmas mainīgās reālās dzīves situācijās, kas atbilst OECD programmas "Izglitīiba 2030" (Education 2030) definīcijai. ${ }^{20}$

Kompetence ir komplekss sasniedzamais rezultāts, nevis atsevišķu zemāka līmeņu prasmju summa. Tas, ka kompetenci nevar reducēt uz kādu konkrētu prasmi vai izolētu zināšanu kopu, ir liels izaicinājums, gan veidojot mācību saturu, gan izvēloties atbilstošu pieeju mācīšanai un vērtēšanai. Šādus mērķus nav iespējams sasniegt, kardināli nemainot pieeju mācišanai un skolas darba organizācijai. Tāpēc lietderīgāk būtu runāt par kompetenci kā mācišanās rezultātu, nevis tikai mācību saturu, jo tieši mācišanas pieejai, nevis tikai sasniedzamo rezultātu pārformulēšanai būs izškirīga loma, vai skolēni attīstīs attiecīgās kompetences.

UNESCO Starptautiskā izglìtības biroja ziņojuma ${ }^{21}$ autori atzīmē, ka problēmu-risināšanas pieeja mācīšanai, projektu metode un līdzīgas metodes jau pēc savas būtības ir piemērotākas kompetences attīstībai atšķirībā no tradicionālajām mācībām noškirtās disciplīnās. Tàs dod iespēju dabiski iesaistìt starpdiciplināras zināšanas un prasmes un mācības padarìt iesaistošas un jēgpilnas. Turklāt, kā uzsver autori, šāds mācīšanās veids labāk atspoguḷo daudzveidīgo un mainīgo pasauli, kurā skolēniem būs jādzìvo.

Skolēns, kas parāda kompetenci savā darbībā, ir kompetents, t. i., vērtējot sniegumu, tiek aplūkots, cik lielā mērā indivīdam piemīt noteikts kompetences

${ }^{17}$ Maslo, I., \& Tiḷı,a, I. (2005). Kompetence kā audzināšanas ideāls un analītiska kategorija. Skolotājs, 2005, Nr. 3.

${ }^{18}$ Rauhvargers, A. (2008). Boloṇas procesa un ES kvalifikāciju ietvarstruktūras - kopējais un atškikirīgais.

19 Turpat.

${ }^{20}$ VISC. (2016). Cel̦ā uz kompetenču pieeju mācībām. Pieejams: http://www.izm.gov.lv/images/ izglitiba_visp/Konferences_Tagad/VISC_-_Ce\%C4\%BC\%C4\%81_uz_kompeten\%C4\%8Du_ pieeju_m\%C4\%81c\%C4\%ABb\%C4\%81m.pdf (aplūkots 20.10.2017.).

${ }^{21}$ UNESCO IBE. (May 2015). Repositioning and reconceptualizing the curriculum for the effective realization of Sustainable Development Goal Four, for holistic development and sustainable ways of living. Position paper for UNESCO International Bureau of Education (UNESCO IBE) Side Event: "Repositioning Curriculum in Education Quality \& DevelopmentRelevance" for May 21, 2015, Incheon, Republic of Korea. Pieejams: http://www.ibe.unesco. org/sites/default/files/resources/wef_ibe_position_paper_eng.pdf (aplūkots 20.10.2017.). 
līmenis. Kompetences demonstrēšanas pamatā ir darbība dotā uzdevuma izpildei, kuru veicot indivīds izmanto iekšējos un ārējos resursus. Kompetenci nav iespējams novērot un novērtēt atrauti no darbïbas. Kompetenci parasti var novērtēt dzīvē nepieciešamu uzdevumu, problēmu risināšanas kontekstā, nevis ar tradicionālajiem testiem kā vispārīgas teorētiskas prasmes. Tāpēc jāmainās arī vērtēšanai, izmantojot snieguma vērtēšanai ierastas formas - portfolio, darbības novērojumus praksē, kompetenču demonstrāciju dažādos kontekstos, lomu spēles, gadijumu izpēti u. tml.

\section{Visbiežāk minētās kompetences, kas nepieciešamas skolas beidzējam 21. gadsimtā}

Izglìtības teorētiķi, pētnieki, praktiķi un politiķi piesaka nepieciešamību pēc jaunām prasmēm, zināšanām, vērtībām, ieradumiem, attieksmēm skolu mācību saturā, piedāvājot tā saukto 21. gadsimta prasmju modeļus kā ilustrāciju citādiem izglitības mērkiiem. Eiropas Savienības $2006 .{ }^{22}$ un $2018 .{ }^{23}$ gada izglitïbas pamatnostādnēs minētas astoņas pamatprasmes ${ }^{24}$ (kompetences, anglu val.: core competencies) ir saziņa dzimtajā valodā, saziṇa svešvalodās, matemātiskās prasmes un pamatprasmes dabaszinātnēs un tehnologijās, digitālā prasme, mācīšanās mācīties, sociālās un pilsoniskās prasmes, pašiniciatīva un uzṇēmējdarbība, kultūras izpratne un izpausme. Tās savstarpēji stiprina cita citu un ir papildinātas ar transversālajām jeb caurviju prasmēm - kritiskā domāšana, problēmu risināšana, jaunrade, iniciatīvas uzṇemšanās, lēmumu pieņemšana. Tās visas ir svarīgas, lai sasniegtu ilgtspējīgas attīstības mērḳus. Šìs kompetences nepieciešamas visiem indivīdiem pašrealizācijai un attīstībai, aktīvai pilsoniskai līdzdalībai, kā arī sociālai iekḷaušanai un nodarbinātîbai.

${ }^{22}$ European Parliament and the Council (December 2006). Recommendation of the European Parliament and of the Council of 18 December 2006 on key competencies for lifelong learning (2006/962/EC). Official Journal of the European Union, L394/10, 30.12.2006. Pieejams: http:// eur-lex.europa.eu/LexUriServ/LexUriServ.do?uri=OJ:L:2006:394:0010:0018:EN:PDF (aplūkots 20.10.2017).

${ }^{23}$ European Commission. (2018). Commission Staff Working Document Accompanying the document Proposal for a council Recommendation on Key Competences for Life Long Learning. Brussels, 17.01.2018. Pieejams: https:/ec.europa.eu/education/sites/education/files/ swd-recommendation-key-competences-lifelong-learning.pdf (aplūkots 20.03.2018.).

${ }^{24}$ Oficiālajā tulkojumā lietotais jēdziens (angl. - key competences). 
Pasaules ekonomikas forumā $\overline{-}^{25}$ apspriestajā modelī (skat. 1. attēlu), kurā līdztekus ierastajām pamata pratībām ${ }^{26}$ tekstpratība, matemātiskā pratība, dabaszinātniskā izpratîba, pilsoniskā pratîba ietvertas caurviju ${ }^{27}$ prasmes - kritiskā domāšana, radošums, saziṇa un sadarbība - un rakstura iezīmes - zinātkāre, pašiniciatīva, mērḳtiecỉba un neatlaidība.

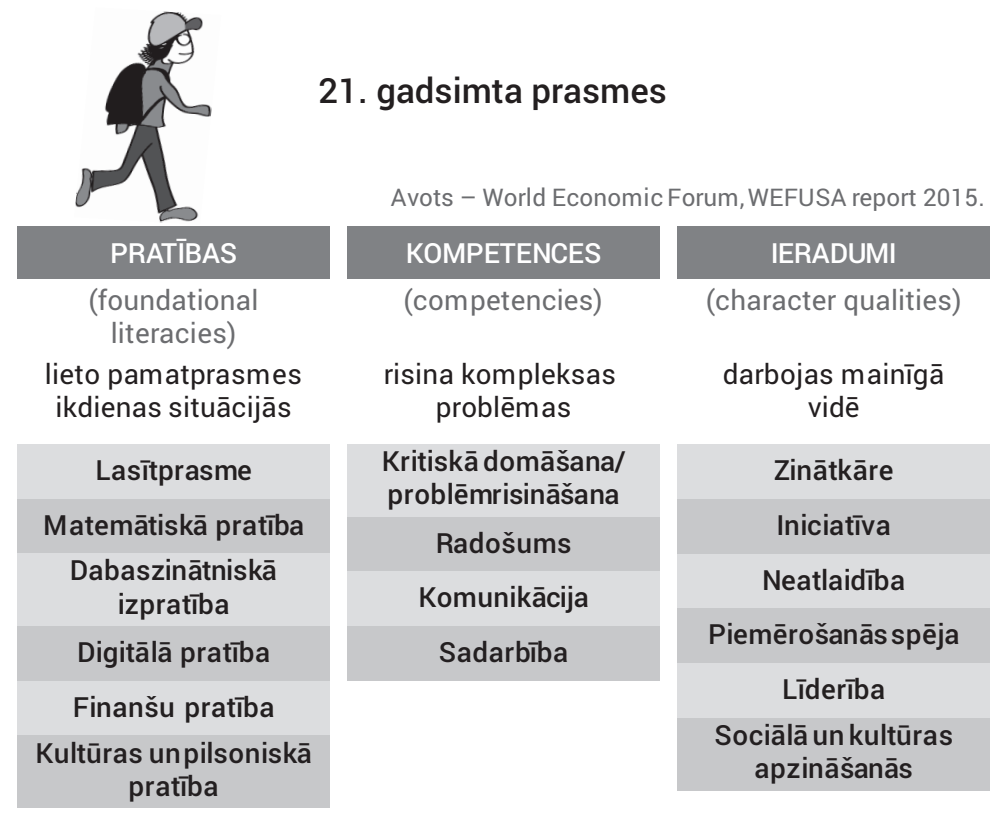

1. attēls. Pasaules ekonomikas foruma 21. gadsimta prasmju modelis (adaptēts pēc WEF, 201528)

${ }^{25}$ World Economic Forum (WEF). (2015). New Vision for Education - unlocking the potential of technology. Pieejams: http://www3.weforum.org/docs/WEFUSA_NewVisionforEducation_ Report2015.pdf (aplūkots 20.10.2017.).

${ }^{26}$ Termins "literacy" lietots kā pratība, izpratîba. Konstatēta problēma ar termina "kompetence" neviennozìmīgu lietojumu latviešu valodā, nereti ar to aizvietojot terminus "pamatprasmes" vai "pratība".

27 Termins "transversal" tekstā lietots kā "caurviju”.

${ }^{28}$ World Economic Forum (WEF). (2015). New Vision for Education - unlocking the potential of technology. Pieejams: http://www3.weforum.org/docs/WEFUSA_NewVisionforEducation_ Report2015.pdf (aplūkots 20.10.2017.). 
Līdzīgus modeḷus piedāvā arī citi avoti (ATC21S, 201229; Fullan, \& Scott, 2014; Hewlett Packard, 2013 ${ }^{30}$ ). Šajos model os dažādās kombinācijās mijas prasmes nozīmīgākajās cilvēka darbības jomās ar caurviju prasmēm, kas attiecas uz visām jomām, bet kurām mācību saturā līdz šim pievērsta vismazākā uzmanība. Maikla Fulana vadỉbā izveidots tā sauktais 6C kompetenču ietvars, kuru veido: personības veidošana, identitāte globālajā pasaulē, kritiskā domāšana un tās attīstỉba, komunikācijas spējas, sadarbošanās prasmes, radošums un iztēle (Fullan, \& Langworthy, 2014).

OECD DeSeCo $o^{31}$ programmā piedāvātas trīs kompetenču kategorijas: interaktīvi izmantot dažādus resursus (zināšanas, zinātniskos resursus, tehniskos līdzekḷus u. c. resursus), darboties patstāvīgi un mērḳtiecīgi, sadarboties ar citiem cilvēkiem. Līdzīgas kategorijas piedāvātas ASV Zinātṇu akadēmijas Nacionālās pētniecības padomes pārskatā par prominentākajiem 21. gadsimta prasmju ietvariem, piedāvājot kognitīvās, "es pats" un "es un citi" kompetenču grupas. ${ }^{32}$

OECD programmā "Izglìtība 2030" turpina attīstìt un paplašināt kompetenču saturiskā ietvara izpratni tā jaunākajos darba dokumentos (skat. 2. un 3. attēlu), skolas beidzējam nozīmīgus sasniedzamos rezultātus raksturojot kā zināšanas, prasmes, rakstura iezīmes un metakognitīvās prasmes.

3. attēlā redzamajā OECD vizualizācijā uzsvērta kompetences kā mācīšanās rezultāta būtība - spēja lietot zināšanas, prasmes un attieksmes koordinētā rīcībā.

${ }^{29}$ ATC21S. (2012). Assessment and Teaching of 21 ${ }^{\text {st }}$ Century Skills (ATC21S) Project. Pieejams: http://www.atc21s.org/ (aplūkots 20.10.2017.).

${ }^{30}$ Hewlett Packard. (April 2013). Deeper Learning Competencies. Pieejams: http://www.hewlett. org/uploads/documents/Deeper_Learning_Defined_April_2013.pdf (aplūkots 22.10.2017.).

${ }^{31}$ OECD. (2005). The Definition and Selection of Key Competencies. Executive summary. Pieejams: http://www.oecd.org/pisa/35070367.pdf (aplūkots 20.10.2017.).

${ }^{32}$ NRC. (2012). Education for Life and Work: Developing transferable knowledge and skills in the $21^{\text {st }}$ century. In Pellegrino, J. W., \& Hilton, M. L. (eds.). Committee on Defining Deeper Learning and $21^{\text {st }}$ Century Skills, National Research Council (NRC). Pieejams: http://www.nap. edu/catalog.php?record_id=13398 (aplūkots 20.10.2017.). 


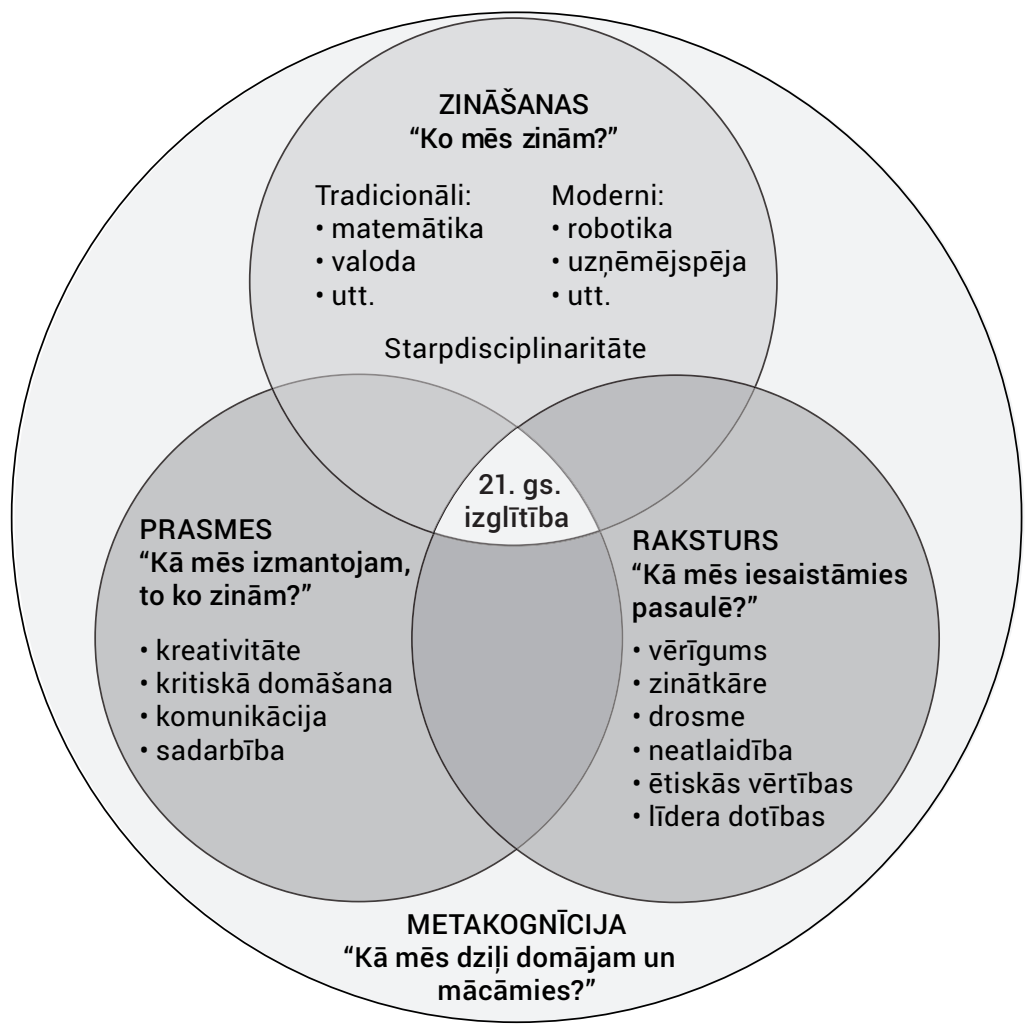

2. attēls. OECD Education 2030 kompetences veidošanās struktūra (adaptēts pēc Fadel, Bailik, \& Trilling, 2015)

Mācību priekšmeta zināšanas

Starpdisciplinārās zināšanas Zināšanas Praktiskās zināšanas

Attieksmes un vērtības

3. attēls. OECD “Izglitīiba 2030" kompetences ietvars (adaptēts pēc OECD, 2016 $6^{33}$ )

${ }^{33}$ OECD. (2016). Global competency for an inclusive world. France: OECD. 
ASV Zinātṇu akadēmijas ziņojumāā ${ }^{34}$ uzsvērts, ka kognitīvajām caurviju prasmēm, kas visvairāk saistītas ar domāšanas un informācijas apstrādes prasmēm, skolā līdz šim pievērsta vislielākā uzmanība. Savukārt "es pats" un "es un citi” caurviju prasmes aptver mācību afektīvo dimensiju, kas visvairāk saistītas ar pašizpēti, emocionālo un sociālo attīstību un rakstura audzināšanu un kurām līdz šim skolu mācību saturā pievērsta mazāka uzmanība. Tieši sociāli emocionālā attīstība, rakstura audzināšana un vērtībizglìīiba ir tie mācību satura aspekti, kuriem arī pievēršama uzmanība 21. gadsimta kontekstā. Šīs kompetences izpelnījušās īpašu ievērību, pateicoties diviem bestselleriem - Paula Tafa (Paul Tough) (Tough, 2013) grāmatai "Kā bērni gūst sekmes: neatlaidība, zinātkāre un apslēptais ieradumu spēks" (How Children Succeed: Grit, Curiosity and the Hidden Power of Character) par to, cik svarīgas īpašības akadēmiskai un profesionālai veiksmei ir mērkstiecība un neatlaidỉba, un Daniela Golmena (Daniel Goleman) (Goleman, 1996) grāmatai "Emocionālā inteligence" (Emotional Intelligence), kas līdztekus tradicionāli visaugstāk novērtētajai intelekta kognitīvajai dimensijai izcel indivīda pašizpratni, spēju apzināt citu cilvēku rīcības motīvus un sekmīgi rỉkoties sociālā vidē. Karolas Dvekas (Carol Dweck; Dweck, 2008) pētījumi liecina, ka indivīdu veiksmes pamatā daudz lielākā mērā, nekā ierasts, ir ticība savām spējām un pūles, kas tiek ieguldītas mērḳa sasniegšanā, nevis dabas dots talants, uzsverot, ka skolēnos svarīgi veidot un nostiprināt pārliecību, ka intelekts ir maināms lielums un skolēnu spēkos ir to ietekmēt. K. Dvekas pētỉjumi rāda, ka skolēni, kuri uzskata, ka viņu intelekts ir maināms (growth mindset), iegulda lielākas pūles un izmanto efektīvākus māciššnās paṇēmienus nekā skolēni, kuri uzskata, ka vinuu intelekts ir fiksēts jeb nemaināms (fixed mindset).

R. D. Roberts, J. E. Martins un G. Olaru par nozīmīgākajām sociāli emocionālajām kompetencēm (Roberts, Martin, \& Olaru, 2015) nosauc piecas kategorijas (Big Five)- ekstraversija (extraversion), laipnība (agreeableness), uzcìtība (conscientiousness), emocionālā stabilitāte (emotional stability) un intelektuālā atvērtība (openness). Šajā ziņojumā uzsvērts: lai gan daudzi skolēni šīs kompetences apgūst, jo viniiem ir paveicies ar labiem skolotājiem, vai arī tāpēc, ka vinini piedalījušies ārpusstundu nodarbībās, skolu darbības centrālais fokuss ir uz kognitīvo prasmju attīstību. Tas nozīmē, ka visdrīzāk visiem skolēniem netiek nodrošinātas iespējas attīstìt šīs kompetences.

Līdztekus rakstura audzināšanai jeb noteiktu ieradumu attīstībai arvien būtiskāku vietu debatēs par izglìtỉbas saturu ieṇem vērtības kā nozīmīgs

\footnotetext{
${ }^{34}$ NRC. (2012). Education for Life and Work: Developing transferable knowledge and skills in the $21^{\text {st }}$ century. In Pellegrino, J. W., \& Hilton, M. L. (eds.). Committee on Defining Deeper Learning and $21^{\text {st }}$ Century Skills, National Research Council (NRC). Pieejams: http://www.nap. edu/catalog.php?record_id=13398 (aplūkots 20.10.2017.).
} 
sasniedzamais rezultāts blakus tradicionālākiem kognitīvajiem mērḳiem. Lielā daḷā valstu spēkā pieņemas diskurss par plašākiem izglìtības mērḳiem pretstatā sagatavotībai darba tirgum kā centrālajam vispārējās izglìtības mērḳim. UNESCO Starptautiskā izglìtības biroja ziņojumā ìpaši uzsvērts, ka izglìiībai ir izškirirošā loma valstu attīstībā, nākotnes sabiedrības veidošanā un ka mācību satura dokumenti zināmā mērā ir kā sociāls kontrakts, kurā formulētas tās vērtỉbas, kas veidos nākotnes sabiedrības pamatu. ${ }^{35}$ Zin,ojuma autori uzsver, ka skolas beidzēju sagatavotîba un kompetence ir kritiski svarīga valstu ekonomiskajai attīstîbai. Tajā pašā laikā mācību procesam jābūt iekḷaujošam, jāpiedāvā vienlīdzīgas iespējas visiem vispusīgai attīstībai, jānostiprina vērtības un izpratne par taisnīgu pasauli un ilgtspējīgu attīstību.

Mācību satura dokumentos vērtỉbu dimensija tiek iekḷauta kā viens no sasniedzamo rezultātu aspektiem vai kā konceptuālais ietvars, kas caurvij visu mācību saturu. Piemēram, Lielbritānijas mācību satura dokumentos (Gordon, Arjomand, \& Kearney, 2013) nosauktas mācību satura pamatvērtības. Tas iekḷauj vērtības, kas saistìtas ar indivīdu pašu, atzīstot, ka ikviens ir unikāla cilvēciska būtne, spējīga uz garīgu, morālu, intelektuālu attīstību; attiecībām ar citiem, kas ir būtiskas paša un citu attīstìbai un izaugsmei un sabiedrības labklājỉbai; $s a-$ biedrības daudzveidību, kur augstu tiek novērtēta patiesība, brīvība, taisnīgums, cilvēktiesības, tiesiskums un kolektīvas pūles kopīga labuma vārdā, un vidi, tostarp dabas un cilvēka veidotu vidi, kas ir dzìvības pamatā un par kuru jārūpējas. Jaunajos Somijas izglitības satura dokumentos uzsvērts, cik svarīgi skaidri noformulēt vērtības, kas kalpo par pamatu gan mācỉbu saturam, gan skolas izglìtības misijai kopumā. Šīs vērtības ir: katra bērna unikalitāte un ikviena tiesības uz kvalitatīvu izglìtību; nepieciešamība piekopt ilgtspējīgu dzīvesveidu; humānisms, kultūra un civilizācija, vienlīdzība un demokrātija; kultūrdaudzveidība kā bagātība (Gordon, Arjomand, \& Kearney, 2013).

KeyCoNet programmas uzdevumā izvērtējot Eiropas Savienības valstu mācību satura dokumentus, autori (Gordon, Arjomand, \& Kearney, 2013, p. 47) secina: lai gan tajos pārstāvēts plašs un daudzveidīgs kompetenču, prasmju, vērtību un tēmu loks, šādi mācību satura aspekti ir mazāk izteikti vai vispār nav iekḷauti:

- pārāk maza uzmanība pievērsta tam, ka skolēniem ir svarīgi apzināties, kā viṇi vislabāk mācās;

${ }^{35}$ UNESCO IBE. (May 2015). Repositioning and reconceptualizing the curriculum for the effective realization of Sustainable Development Goal Four, for holistic development and sustainable ways of living. Position paper for UNESCO International Bureau of Education (UNESCO IBE) Side Event: "Repositioning Curriculum in Education Quality \& DevelopmentRelevance" for May 21, 2015, Incheon, Republic of Korea. Pieejams: http://www.ibe.unesco. org/sites/default/files/resources/wef_ibe_position_paper_eng.pdf (aplūkots 20.10.2017.). 
- nepietiekami tiek domāts par pašizziņu un savas identitātes apzināšanos. Salīdzinoši lielāka uzmanība skolu kontekstā tiek pievērsta tieši intrapersonālajām kompetencēm, indivīda rīcíbas sociālajiem aspektiem;

- tikai dažos gadijumos satura dokumentos iekḷautas vērtỉbas, kas kalpos par pamatu tam, kā jaunieši veidos savstarpējās attiecỉbas un attieksmi pret pasauli;

- nepietiekami izvērsti jautājumi saistībā ar ilgtspējīgu attīstîbu abās nozīmēs - gan attiecībā uz indivīda lomu globālā pasaulē, gan jautājumiem, kas skar planētas izdzīvošanu.

Arī Maikls Fulans īpaši uzsver, ka ir svarīgi saprast, kāda mērķa vārdā kompetences vispār tiek attīstītas. Viņš runā par ètisku uzṇēmējspēju (ethical entrepreneuralism) kā izglìtības centrālo mērḳi, norādot, ka šāds uzstādījums noārda tradicionālo dalījumu starp spēju rīkoties ar rokām un ar galvu, paplašina tradicionālo uzṇēmējspējas jēdzienu no naudas pelnīšanas uz spēju ieraudzīt un risināt kompleksas personīgas un sociālas problēmas gan vietējā, gan globālā mērogā (Fullan, \& Scott, 2014).

\section{Mācību satura un pieejas plānošanas principi kompetenču attīstībā}

Izglìtības psiholoǵijas pètijumi pēdējās desmitgadēs liecina, ka virspusēju, savstarpēji nesaistītu zināšanu un prasmju apguve nav efektīva un pietiekama. UNESCO Starptautiskā izglìtības biroja ziņojumā ${ }^{36}$ teikts, ka skolu mācību programmās pašlaik ir pārāk daudz satura, bet pārāk maz uzmanības tiek veltîts izpratnes dziḷumam. "Līdz šim pārāk bieži laba izglìīiba tikusi traktēta kā zināt daudz, nevis kā izglìtība, kuras mērḳis ir saprast būtību un spēt zināšanas lietot. Pārskatot mācību saturu, kritiski svarīgi ir fokusēties uz dažām centrālajām idejām, samazinot apgūstamo detalizētas informācijas apjomu, kas nepavisam nav tas pats, kas atteikšanās no padziḷinātas izpratnes iegūšanas (no kā daudzi baidās). Ir daudz vērtīgāk saprast būtiskākos jēdzienus, idejas, cēloṇu un seku sakarības nekā izolētus faktus un piemērus. Skolēni pārāk bieži aiz kokiem vairs

${ }^{36}$ UNESCO IBE. (May 2015). Repositioning and reconceptualizing the curriculum for the effective realization of Sustainable Development Goal Four, for holistic development and sustainable ways of living. Position paper for UNESCO International Bureau of Education (UNESCO IBE) Side Event: "Repositioning Curriculum in Education Quality \& DevelopmentRelevance" for May 21, 2015, Incheon, Republic of Korea. Pieejams: http://www.ibe.unesco. $\mathrm{org} /$ sites/default/files/resources/wef_ibe_position_paper_eng.pdf (aplūkots 20.10.2017.). 
neredz mežu, un, pazaudējot šo perspektīvu, izglīiības rezultāts ir bezmērkịga nesaistītu sīkumu krātuve," secina ziṇojuma autori. ${ }^{37}$

Veidojot saturu, kurā kompetence jeb lietpratība ${ }^{38}$ ir kā komplekss skolēna mācīšanās rezultāts, jāatrod līdzsvars starp ierastākām, vieglāk demonstrējamām un tāpēc vieglāk novērtējamām pamatprasmēm cilvēka daudzveidīgās darbības jomās - dabaszinātṇu izpratību, matemātisko pratību, caurviju prasmēm - kritisko domāšanu vai sadarbību un sociāli emocionālām caurviju prasmēm - pašizziņu, pašvadību un vērtīborientāciju. Pēdējās ir grūtāk pamanāmas un īstenojamas atsevišķu mācību priekšmetu ietvarā un prasa kopēju redzējumu un koordinētu rīcību visas skolas mērogā. Atslēga varētu būt UNESCO IBE ${ }^{39}$ piedāvātais redzējums par to, ka mācỉbu saturs ir sabiedrības vērtību atspoguḷojums. Tāpēc, veidojot mācību satura modeli, svarīgi sākt no vīzijas par to, kādu sabiedrību gribam veidot.

Dažas pamatprasmes (komunikācija, tekstpratība) tiek uzlūkotas kā cieši saistìtas ar tradicionālajiem mācību priekšmetiem, un tās tiek īpaši izceltas mācību jomās (core learning areas), piemēram, valodas, māksla, matemātika, dabaszinātnes. Citas pamatprasmes (mācīšanās mācīties, kritiskā domāšana, problēmu risināšana) tiek uzlūkotas kā caurviju prasmes, kas jāattīsta visās jomās un mācību priekšmetos (Amadion, 2013, p. 7). Piemēram, ASV Nākamās paaudzes dabaszinātṇu standartā $\bar{a}^{40}$ kā vienlīdz svarīgas tiek izdalìtas vairākas dimensijas dabaszinātṇu apguvē: daudzdisciplinārie jēdzieni (crosscutting concepts), dabaszinātņu un inženierzinātn̦u prakses (darbības pamatprasmju apguvē; science and engineering practices), jomas pamatidejas (disciplinary core ideas). ASV pamatprasmju ietvaru matemātikā (Core Curriculum) veido šādas sasniedzamo rezultātu kategorijas: izprast problēmas un neatlaidīgi tās risināt; spriest

${ }^{37}$ UNESCO IBE. (May 2015). Repositioning and reconceptualizing the curriculum for the effective realization of Sustainable Development Goal Four, for holistic development and sustainable ways of living. Position paper for UNESCO International Bureau of Education (UNESCO IBE) Side Event: "Repositioning Curriculum in Education Quality \& DevelopmentRelevance" for May 21, 2015, Incheon, Republic of Korea. Pieejams: http://www.ibe.unesco.org/ sites/default/files/resources/wef_ibe_position_paper_eng.pdf (aplūkots 20.10.2017.). 18. lpp.

${ }^{38}$ Lietpratība jeb kompetence ir indivīda spēja kompleksi lietot zināšanas, prasmes un paust attieksmi, risinot problēmas mainīgās reālās dzīves situācijās. "Skola 2030". (2017). Izglītība mūsdienīgai lietpratībai: mācỉbu satura un pieejas apraksts. Pieejams: http://www.izm.gov.lv/ images/aktualitates/2017/Skola2030Dokuments.pdf (aplūkots 25.10.2017.).

${ }^{39}$ UNESCO IBE. (May 2015). Repositioning and reconceptualizing the curriculum for the effective realization of Sustainable Development Goal Four, for holistic development and sustainable ways of living. Position paper for UNESCO International Bureau of Education (UNESCO IBE) Side Event: "Repositioning Curriculum in Education Quality \& DevelopmentRelevance" for May 21, 2015, Incheon, Republic of Korea. Pieejams: http://www.ibe.unesco. org/sites/default/files/resources/wef_ibe_position_paper_eng.pdf (aplūkots 20.10.2017.).

${ }^{40}$ Next generation science standards. Three Dimensional Learning. Pieejams: https://www. nextgenscience.org/three-dimensions (aplūkots 25.10.2017.). 
abstrakti un kvantitatīvi, konstruēt pamatotus argumentus un kritiski izvērtēt citu argumentus, izmantot matemātisko modelēšanu; stratēǵiski lietot atbilstošus rīkus; pievērst uzmanību precizitātei; meklēt un lietot struktūras; meklēt un izpaust regularitāti, atkārtoti argumentējot. Mācību satura dokumenti Austrālijāa ${ }^{41}$ iekḷauj zināšanas, prasmes, uzvedību un noslieces (dispositions). Skolēni attīsta spēju lietot zināšanas un prasmes efektīivi, atbilstoši un ar pārliecību kompleksos un mainīgos apstākḷos. Tas notiek gan skolā, gan ārpus tās. Ang̣̣u valodas un lasītprasmes pamatprasmju ietvars (vēsturē, sociālajās zinībās, dabaszinātnēs un inženierzinātnēs) nosaka, ka skolēni lasa stāstus un literatūru, kā arī kompleksākus tekstus, kas nodrošina faktus un fona zināšanas dabaszinātnēs un sociālajās zinībās. Skolēni tiek mudināti uzdot jautājumus, kas liek viniiem atsaukties uz lasītajiem tekstiem. Šāda pieeja sekmē kritisko domāšanu, problēmu risināšanu un analītiskās spējas, kas ir nepieciešamas augstskolās, nākotnes karjerā un dzīvē kopumā.

Aplūkojot kompetenci kā kompleksu skolēna mācīšanās rezultātu kopumā, nevis tikai kā mācību saturu, šos mērḳus nav iespējams sekmīgi ìstenot, kardināli nemainot pieeju mācǐšanai un skolas darba organizācijai. Tas nozīmē īstenot paradigmas maiṇu gan individuālas mācību stundas līmenī, gan skolas mācību darba organizācijā.

Paradigmas maiņas modelis kā iesaistìtos komponentus ietver - skolēna mācǐšanos, kuras rezultāts ir skolēna kompetence; skolotāja mācīšanas darbu klasē un skolotāju mācišsanos; skolas kā sistēmas lomu. Lai to panāktu, nepieciešamas kompleksas un sistēmiskas izmainas mācību satura dokumentu izveidē, mācību materiālu izveidē, pārbaudes darbu izveidē, skolotāju sagatavošanā un citās jomās.

Mācỉbu satura apguves mērḳis ir indivīda pratības (literacy) veidošanās, kas ietver spēju radīt pārnesumu, t. i., patstāvīgi rīkoties ne tikai viena mācību priekšmetā, bet arī ārpus mācību priekšmeta, risinot problēmas mainīgās dzìves situācijās un kontekstā. Veidojot mācību saturu, tiek aprakstītas indivīda kompetences noteiktā izglìīibas posmā, kas nepieciešamas viṇa sekmīgai darbībai tuvākā un tālākā nākotnē, darba dzīvē. Šādas pieejas pieprasỉjumu lielā mērā nosaka gan mainīgā sociālā realitāte (visās tās dimensijās), gan sabiedrības ekonomiskās attīstỉbas vajadzības un intereses. Tradicionāli Latvijā mācību saturs ir ticis veidots, vadoties no zinātnes nozaru pozīcijām, t. i., noteiktus zinātnes jēdzienus, sakarības un likumus iekḷaujot skolas kursā ne tikai vidusskolā, bet arī pamatskolā, nosakot to apguves apjomu katrā izglìtỉbas posmā. Mācību satura apguves mērḳis tradicionāli ir zinātnisku zināšanu, prasmju apguve un attieksmju veidošanās.

${ }^{41}$ Australian Curriculum. General capabilities. Pieejams: https://www.australiancurriculum.edu. $\mathrm{au} / \mathrm{f}-10$-curriculum/general-capabilities/ (aplūkots 25.10.2017.). 
Indivīda kompetence noteikta izglītības posma beigās ir dažādos mācību priekšmetos apgūtā komplekss rezultāts atškirīibā no pieejas, kur uzsvars ir likts uz jēdzienu un faktu apguvi, zināšanu lietošanu standartsituācijās atsevišķos mācību priekšmetos. Kompetenci kā kompleksu rezultātu raksturo zināšanu funkcionalitāte, integritāte un lietojums praksē, apkārtējās pasaules skaidrošana, prasmju universālums, problēmu risināšana u. c., ne tikai atsevišḳas zinātnes fakti, likumi, jēdzieni, teorijas un prasmes. Mācīšanos iedziḷinoties raksturo darbības (domāšanas, mācīšanās u. c.) paṇēmienu (stratēgiju) apguve, balstīšanās pieredzē un jaunas pieredzes iegūšana, gatavība patstāvīgai turpmāku zināšanu ieguvei atšķirībā no pieejas, kur zināšanas tiek nodotas kā gatavs kaut kā kopums. Nozīmīgi atšksiras skolēnu sasniegtā rezultāta vērtēšana. Skolēna kompetence tiek mērīta kā veselums, aprakstot skolēnu sniegumu līmeņos. Snieguma konstatēšanai atbilstoši konkrētiem kritērijiem tiek veidoti snieguma apraksti, graduējot līmeņos to sniegumu, ko skolēniem jāspēj parādīt (skat. 1. tabulu).

1. tabula. Divu mācību satura apguves pieeju salīdzinājums*

\begin{tabular}{|c|c|c|}
\hline & $\begin{array}{l}\text { "Gatavu" zināšanu } \\
\text { nodošana }\end{array}$ & Mācī̌anās iedziḷinoties \\
\hline Izejas pozīcija & $\begin{array}{l}\text { Zinātne, zinātnes } \\
\text { nozares }\end{array}$ & $\begin{array}{l}\text { Indivīds, indivīda vajadzības attīstībai, } \\
\text { nākotnes karjerai }\end{array}$ \\
\hline Pasūtītājs & Zinātne & Bizness, ekonomika \\
\hline Mērkis & $\begin{array}{l}\text { Zināšanu un specifisku } \\
\text { prasmju apguve } \\
\text { zinātnes nozarēs }\end{array}$ & $\begin{array}{l}\text { Izpratības (pratības) veidošanās - attīstot } \\
\text { spēju rīkoties ārpus vienas nozares } \\
\text { robežām, risinot problēmas daudzveidīgās } \\
\text { situācijās (kontekstā) }\end{array}$ \\
\hline Mācību saturs & $\begin{array}{l}\text { Fakti, likumi, teorijas, } \\
\text { prasmes konkrētā } \\
\text { nozarē }\end{array}$ & Komplekss, starpdisciplinārs, universāls \\
\hline $\begin{array}{l}\text { Uzdevumi mācību } \\
\text { stundā }\end{array}$ & $\begin{array}{l}\text { Atsevišk̦i, } \\
\text { nesaistīti; darbībai } \\
\text { standartsituācijā }\end{array}$ & $\begin{array}{l}\text { Arī kombinēti, darbīibas paṇēmienu } \\
\text { (stratēǵiju apguve), pieredzes iegūšana } \\
\text { rīcībai nezināmā situācijā, daudzveidīgā } \\
\text { kontekstā }\end{array}$ \\
\hline Vērtēšana & $\begin{array}{l}\text { Konkrēta uzdevuma } \\
\text { pareiza/nepareiza izpilde }\end{array}$ & Snieguma vērtēšana \\
\hline
\end{tabular}

* Autoru veidota tabula. 


\section{Kādi ir pašlaik mācību satura plānošanas principi vispārējā izglītībā Latvijā}

Jau 1998. gadā Latvijā Ministru kabineta izdotajā konceptuālajā dokumentā "Valsts pamatizglìtības standarts" (saukts arī par "dzelteno grāmatiṇu”) izvirzīti mācǐšanās aspekti - pašizpausmes un radošais; analītiski kritiskais, vērtējošais, sociālais (sadarbības), saziņas, mācīšanās un praktiskās darbības, kas atbilst caurviju prasmēm. To attīstīšanu paredz arī 2006. gadā apstiprinātais pamatizglìtības standarts $^{42}$, sākot kursu uz nozīmīgu pamatprasmju un sekmīgai dzìvei 21. gadsimtā nepieciešamo caurviju prasmju attīstību. Tajā pašā laikā Latvijā spēkā esošie mācìbu satura dokumenti, kas nosaka konkrētu mācību priekšmetu saturu (mācību priekšmetu standarti, programmas) pārsvarā paredz mācību priekšmetiem specifisku zināšanu un prasmju apguvi. Tajos nav tieši saskatāma vispārējo prasmju mērķtiecīga, saskaņota, pēctecīga apguve un lietošana. Arī mācību stundu vērojumi un skolēnu snieguma analīze rāda, ka tā nav ikdienas prakse visās skolās (Namsone, \& Čakāne, 2015a, 2015b; Sebre, Rubene, Kalnbērziņa, Namsone, \& Kḷave, 2015 ${ }^{43}$ ).

Analizējot mācību priekšmetu standartus ${ }^{44}$ dabaszinātṇu kontekstā (matemātika, fizika, k̦īmija, biolog̣ija, ǵeogrāfija, dabaszinības), redzams, ka tajos jau šobrīd ir iekḷautas noteiktas prasības, kas saistītas ar caurviju prasmēm, piemēram, prasības, kas saistītas ar kritiskās un analītiskās domāšanas prasmju apguvi (novērtēšana, izvērtēšana, analizēšana, secināšana, darbs ar informāciju un sadarbība), piemēram:

- ǵeogrāfija: izvērtē iegūtās informācijas ticamību un derīgumu. Saskata un atzīmē iegūtajā informācijā būtisko, galveno;

- fizika: izskaidro iegūtos rezultātus, salīdzinot tos ar informāciju no dažādiem avotiem, un novērtē to ticamību, analizējot iespējamos kḷūdu cēloṇus, ierobežojumus un ietekmi uz rezultātiem;

${ }^{42}$ Ministru kabinets. (2006). Noteikumi par valsts standartu pamatizglìtībā un pamatizglìtības mācību priekšmetu standartiem. Nr. 68 10. Pieejams: https://m.likumi.lv/doc.php?id=150407 (aplūkots 01.11.2017.).

${ }^{43}$ Sebre, S., Rubene, Z., Kalnbērziņa, V., Namsone, D., \& Kḷave, E. (2015). Kompetenču pieejā balstita pamatizglitibas standarta pamatojums un galvenie principi. VISC darba grupas ziñojums.

${ }^{44}$ Ministru kabinets. (2014). Noteikumi par valsts pamatizglìtibas standartu, pamatizglìtības mācību priekšmetu standartiem un pamatizglìtības programmu paraugiem. Nr. 468. Pieejams: https://likumi.lv/doc.php?id=268342 (aplūkots 01.11.2017.).

Ministru kabinets. (2013). Noteikumi par valsts vispārējās vidējās izglītības standartu, mācību priekšmetu standartiem un izglìīibas programmu paraugiem. Nr. 281. Pieejams: https://likumi.lv/doc.php?id=257229 (aplūkots 01.11.2017.).

VISC. (2017). Mācību priekšmetu programmu paraugi. Pieejams: http://visc.gov.lv/vispizglitiba/saturs/programmas.shtml (aplūkots 01.11.2017.). 
- matemātika: skolēns prot izvēlēties un lietot piemērotus pañēmienus, lai atrisinātu problēmas, izmantojot algebriskus un geometriskus modeḷus.

Tomēr prasību pēctecība dažādos izglītības posmos ne vienmēr ir skaidri saprotama, piemēram:

- matemātikā: 1.-3. klase - skolēni prot uzklausīt citu viedokli; izteikt savu viedokli; 4.-6. klase: uzklausìt un izprast dažādus viedokḷus; 7.-9. klase objektīvi izvērtēt dažādus viedokḷus, pamatot un aizstāvēt savu viedokli; 10.-12. klase - formulēt, argumentēt, pamatot viedokli (tostarp matemātiskas sakarības, faktus, sava darba rezultātus), cienīt citu viedokli;

- ǵeogrāfija: 7.-9. klase - raksturo dabas parādību (vulkāni, zemestrīces) izraisītos postījumus un vērtē to ietekmi uz dabas procesiem un cilvēku dzīvi; 10.-12. klase: analizē un vērtē dabas procesu un parādību radītās sekas cilvēku dzīvē.

Analizējot prasību pēctecību dažādos vecumposmos, var secināt, ka tās ir gandrīz vienādas satura apguvei dažādos priekšmetos dažādos vecuma posmos. Piemēram:

- dabaszinības: 4.-6. klase - skolēni iepazīstina citus ar iegūtajiem rezultātiem, izskaidrojot un pamatojot tos, lietojot dabaszinību terminus;

- ķīmija: 8.-9. klase - skolēni iepazīstina citus ar iegūtajiem rezultātiem (rakstos, mutvārdos vai izmantojot daudzveidīgu mediju tehnologiju), piedalās diskusijās, aizstāv un argumentē savu viedokli, lietojot k,īmijas terminus;

- fizika: 8.-9. klase - skolēni iepazīstina citus ar iegūtajiem rezultātiem (rakstos, mutvārdos vai izmantojot daudzveidīgu mediju tehnologiju), piedalās diskusijās, aizstāv un argumentē savu viedokli, lietojot fizikas terminus un jēdzienus.

Lai gan atsevišķas caurviju prasmes ir iekḷautas, tomēr tās dažādos priekšmetos ir praktiski vienādi formulētas dažādos izglītības posmos, nav ieraugāma pēctecība prasmju attīstībā. Piemēram, 7.-9. klašu posmā fizikā, ķīmijā un bioloǵijā standarta prasības ir vienādas (skat. 2. tabulu).

2. tabula. Standartu prasības k̦īmijā, fizikā un bioloǵijā

\begin{tabular}{|c|c|c|}
\hline K̦īmija & Fizika & Bioloǵija \\
\hline $\begin{array}{l}\text { 8.3. izvēlas nepieciešamos } \\
\text { informācijas avotus un } \\
\text { informācijas iegūšanas } \\
\text { paṇēmienus atbilstoši } \\
\text { veicamajam uzdevumam }\end{array}$ & $\begin{array}{l}\text { 8.3. izvēlas nepieciešamos } \\
\text { informācijas avotus un } \\
\text { informācijas iegūšanas } \\
\text { paṇēmienus atbilstoši } \\
\text { veicamajam uzdevumam }\end{array}$ & $\begin{array}{l}\text { 8.2. izvēlas nepieciešamos } \\
\text { informācijas avotus un } \\
\text { informācijas iegūšanas } \\
\text { paṇēmienus atbilstoši } \\
\text { veicamajam uzdevumam }\end{array}$ \\
\hline
\end{tabular}


Skatoties ilgākā laika distancē, ir ieraugāma Latvijas mācību satura dokumentu evolūcija, kuru ilustrēsim ar matemātikas satura dokumentu analīzi kā piemēru (skat. 3. tabulu). Tabulā ieraugāms, ka 20. gadsimta 90. gadu sākuma dokumentos ir tikai nosaukti atbilstošo nozaru jēdzieni, kas jāiekḷauj saturā (piemērā - naturālie skaiț̣i, decimāldal̦as u. c.), 2004. gadā ir iekḷauts matemātikas lietojums dabas un sabiedrības procesu analīzē, matemātisko modeḷu veidošana un pētî̌sana; 2017. gada dokumentu projektos ${ }^{45}$ ir iekḷauta matemātikai raksturīgās stratēgiijas un spriešana, t. i., skolēna mācību darbība kḷūst par mācību saturu. Mācỉbu satura dokumentu plānošanā arvien vairāk tiek izmantots atpakaliejošās (backward) plānošanas princips, vadoties no sagaidāmā rezultāta skolēnam.

3. tabula. Matemātikas mācību satura 1.-9. klasei struktūras evolūcija. 1992.-2017. gads

\begin{tabular}{|c|c|}
\hline Gads & Satura bloki \\
\hline \multirow[t]{7}{*}{1992} & Aritmētika \\
\hline & $\begin{array}{l}\text { - Naturālie skaitḷi; parastās dalas; decimāldaḷas; racionālie skaiț̣i; reālie skaiț̣i; } \\
\text { lielumi un to mērǐšana. }\end{array}$ \\
\hline & Algebra \\
\hline & $\begin{array}{l}\text { - Algebriskās izteiksmes; vienādojumi un nevienādības; elementārās funkcijas; } \\
\text { statistikas, kombinatorikas un varbūtību teorijas elementi. }\end{array}$ \\
\hline & Geometrija \\
\hline & • G Geometriskās figūras un to īpašības. \\
\hline & - Geometriskie lielumi un to mērīšana. \\
\hline
\end{tabular}

2004 Matemātiskā instrumentārija izveide

- Skaiți un darbības ar tiem; algebriskās izteiksmes un darbības ar tām; ǵeometriskās figūras un to pētīšana.

Matemātikas lietojums dabas un sabiedrības procesu analīzē

- Lielumi un to mērǐšana, sakarības starp tiem; informācijas apstrādes, statistikas un varbūtību teorijas elementi.

Matemātisko modeḷu veidošana un pētīšana ar matemātikai raksturīgām metodēm

- Matemātiskā valoda; matemātisko modeḷu veidošana un analizēšana.

${ }^{45}$ Valsts izglìtibas satura centra projekts “Skola 2030”. Pieejams: www.Skola2030.lv (aplūkots 01.11.2017.). 


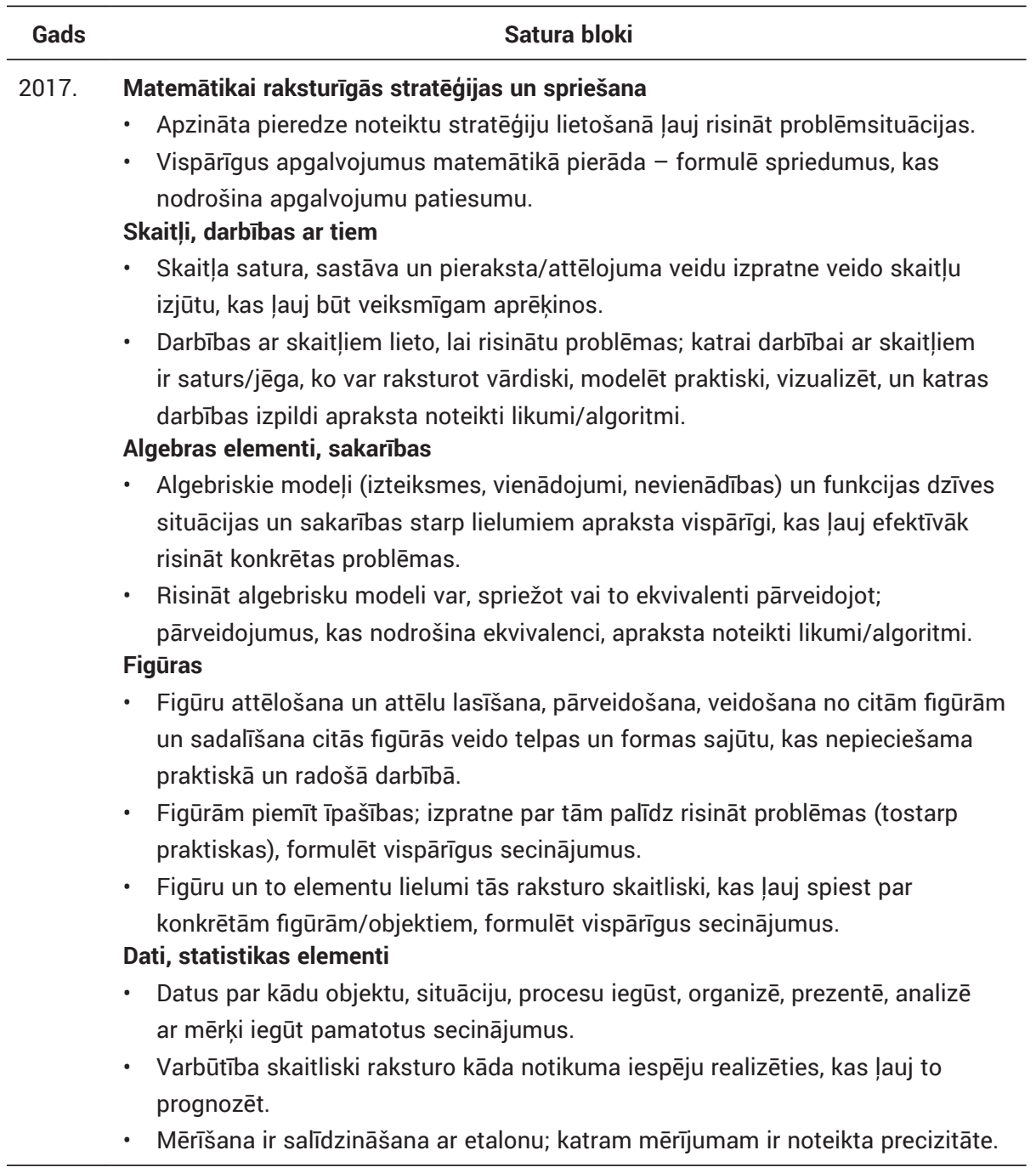

Piemēram, veicot pašreizējo un plānoto Latvijas mācību satura dokumentu analīzi, redzams, ka atsevišķas caurviju prasmes tajos iekḷautas jau tagad. Novērojams arī pakāpenisks progress no fokusa uz atsevišķu prasmju attīstību uz prasībām demonstrēt kompleksu sniegumu, kam nepieciešamas vairāku mācību priekšmetu vai jomu zināšanas un prasmes. Tomēr pašlaik mācību saturā un mācību procesā joprojām vērojama sadrumstalotība, fragmentārisms, dublěšanās, pārāk liels uzsvars tiek likts uz izolētu, pasīvu zināšanu apguvi, mācību saturs tiek nepietiekami saistīts ar reālās dzīves situācijām. Satura izstrādē īpašu uzmanību nepieciešams pievērst sistemātiskai prasmju attīstībai, vienlaikus novēršot dublēšanos un sadrumstalotību gan katrā mācību jomā, gan starp jomām. 


\section{Secinājumi un ieteikumi uz kompetenču attīstību vērsta mācību satura un pieejas plānošanai vispārējā izglītībā Latvijā}

Balstoties uz iepriekš aprakstìto izpratni par kompetenci kā kompleksu skolēna mācīšanās rezultātu, piedāvājam atbilstošu mācību satura modeli vispārējai izglìtībai Latvijā, kas varētu kalpot par pamatu atbilstošu vadlīniju un izglìtības standartu izstrādē (skat. 4. tabulu).

Izmantojot šo modeli, skolēni padzilināti apgūst pamatprasmes nozīmīgās cilvēka darbības jomās, attīstot caurviju prasmes. Šì struktūra palīdz atrast krustpunktus, kas kalpo par pamatu skolēnu sasniedzamo rezultātu, vērtēšanas kritēriju un snieguma līmeņu noteikšanai gan turpmākai satura attīstībai, gan skolotāju ikdienas darbā. Apgūstot mācību saturu, skolēniem tiek attīstīti ieradumi, kas balstās vērtībās.

4. tabula. Mācību satura struktūras trīs dimensijas*

\begin{tabular}{|c|c|c|c|c|c|c|}
\hline Mācību jomas (pratības) & & & Caurvi & asmes & \multirow{8}{*}{ 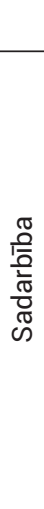 } & \multirow{8}{*}{ 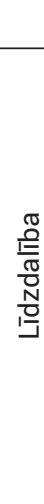 } \\
\hline Valodu & \multirow{7}{*}{ 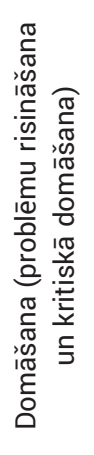 } & \multirow{7}{*}{ 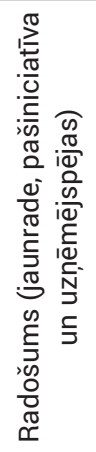 } & \multirow{7}{*}{$\begin{array}{l}\frac{\pi}{0} \\
\frac{1}{\pi} \\
\frac{10}{2} \\
\frac{10}{10} \\
\frac{10}{0} \\
\frac{0}{0}\end{array}$} & \multirow{7}{*}{ 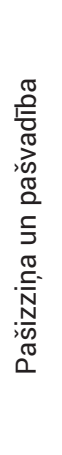 } & & \\
\hline Sociālā un pilsoniskā & & & & & & \\
\hline $\begin{array}{l}\text { Kultūras izpratnes un } \\
\text { pašizpausmes mākslā }\end{array}$ & & & & & & \\
\hline Matemātikas & & & & & & \\
\hline Dabaszinātṇu & & & & & & \\
\hline Tehnoloǵiju & & & & & & \\
\hline Veselības un fiziskās aktivitātes & & & & & & \\
\hline
\end{tabular}

*autoru veidota tabula

Piedāvātā mācību satura modeḷa mērḳis ir veidot skaidru, vienotu, uz nākotni vērstu skatījumu par vispārējās izglìtības mērḳiem, tajā pašā laikā saglabājot un tālāk nostiprinot skolotāju profesionālo autonomiju attiecībā uz šo mērḳu sasniegšanu un vienlaikus uzsverot nepieciešamību pēc regulāras un sistemātiskas skolotāju sadarbības mācību plānošanā un īstenošanā skolas līmenī.

Mācību satura modȩ̣a pamatā ir apraksts par skolēnu, kuram piemìt attiecīgās prasmes. Seko trīs mācību satura dimensijas - vērtîbas, mācību jomas (pamatprasmes) un caurviju prasmes, kuru savstarpējā integrācija to krustpunktos 
tad arī kalpotu par pamatu detalizētu sasniedzamo rezultātu noteikšanai un satura attīstībai. Septiņas mācību jomas šajā modelī ir valodu, sociālā un pilsoniskā, kultūras izpratnes un pašizpausmes māksla, dabaszinātņu, tehnolog̣iju, matemātikas un veselības un fiziskās aktivitātes.

Caurviju prasmes šajā modelī ir domāšana (problēmu risināšana un kritiskā domāšana) un radošums (jaunrade, pašiniciatīva, uzṇēmējspēja); digitālā pratība; pašizziṇa, pašvadība un mācǐšanās mācīties; sadarbỉba; līdzdalība.

Latvijā šādu pieeju mācībām nepieciešams ieviest tādēl, lai:

- uzlabotu pamata prasmju apguvi nozīmīgās indivīda un sabiedrības dzīves jomās, samazinot sadrumstalotību un fragmentārismu mācību saturā;

- nostiprinātu izpratni par izglìtības procesa sasniedzamo rezultātu kā skolēna spēju un vēlmi rīkoties kompleksās dzīves situācijās atškịirīā no izolētu, pasīvu zināšanu apguves izmantošanai nezināmā nākotnē;

- ieviestu tādu pieeju mācišanai, kas dod skolēniem iespēju veikt kompleksus uzdevumus, izmantojot resursus un praktiski darbojoties kontekstos, kas maksimāli pietuvināti reālai dzīvei.

Mācību satura model̦a pamatā ir nozīmīgākie Eiropas Savienības un globālie satura dokumenti, ārvalstu labās prakses piemēri, kā arī līdzšinējā Latvijas pieredze un pieeja mācību satura veidošanā, tostarp:

- Eiropas izglìtības pamatnostādņu astoṇas mūžizglīitibas pamatprasmju jomas jeb kompetences ${ }^{46}$;

- OECD DeSeCo projekta caurviju prasmju klasifikācija ${ }^{47}$;

- ASV Zinātņu akadēmijas Nacionālās pētījumu padomes ziņojums par biežāk izmantotajām 21. gadsimta prasmju kategorijām ${ }^{48}$;

- globālā izglīiības projekta "Jaunā pedagogiija dziḷākām mācībām” (New Pedagogies for Deep Learning) caurviju prasmju ietvars (Fullan, \& Scott, 2014);

- 1998. gadā izstrādātā koncepcija Valsts pamatizglìtỉbas standartam (IZM ISEC $\left.^{49}\right)$.

${ }^{46}$ European Parliament and the Council (December 2006). Recommendation of the European Parliament and of the Council of 18 December 2006 on key competencies for lifelong learning (2006/962/EC). Official Journal of the European Union, L394/10, 30.12.2006. Pieejams: http:// eur-lex.europa.eu/LexUriServ/LexUriServ.do?uri=OJ:L:2006:394:0010:0018:EN:PDF (aplūkots 20.10.2017.).

${ }^{47}$ OECD. (2005). The Definition and Selection of Key Competencies. Executive summary. Pieejams: http://www.oecd.org/pisa/35070367.pdf (aplūkots 20.10.2017.).

${ }^{48}$ NRC. (2012). Education for Life and Work: Developing transferable knowledge and skills in the $21^{\text {st }}$ century. In Pellegrino, J. W., \& Hilton, M. L. (eds.). Committee on Defining Deeper Learning and $21^{\text {st }}$ Century Skills, National Research Council (NRC). Pieejams: http://www.nap. edu/catalog.php?record_id=13398 (aplūkots 20.10.2017).

${ }^{49}$ ISEC. (1998). Valsts pamatizglìtibas standarts. Rìga: ISEC. 
Modelī iekḷautas visas astoṇas Eiropas mūžizglìtíbas kompetences un transversālie jeb caurviju aspekti. Pamatprasmes jaunajā satura modelī veidotas, balstoties uz piecām Eiropas Savienības mūžizglìtîbas kompetencēm. Galvenā atškirīiba pieejā ir tā, ka mācǐšanās mācìties un digitālā kompetence jaunajā modelī ietvertas kā caurviju, nevis pamata prasme, tādējādi uzsverot to transversālo raksturu.

Piedāvātais caurviju prasmju redzējums visciešāk saistās ar Eiropas mūžizglìtības pamatnostādnēs minētajiem transversālajiem aspektiem - kritisko domāšanu, radošumu, pašiniciatīvu, problēmu risināšanu, risku izvērtēšanu, lēmumu pieņemšanu, emocionālo pašregulāciju. Strukturāli piedāvātais caurviju prasmju komplekts visvairāk saskan ar OECD DeSeCo projekta un ASV Zinātņu akadēmijas Nacionālās pētniecības padomes piedāvāto caurviju prasmju koncepciju un dalījumu. Abos model̦os tās iedalītas trīs grupās - kognitīvās/interaktīva resursu izmantošana ${ }^{50,51 ;}$ "es pats"/darboties patstāvīgi un mērķtiecīgi; "es un citi”/sadarboties ar citiem cilvēkiem. Šāds konceptuālais iedalījums arī likts par pamatu caurviju prasmju izvēlei jaunajā modelī. Tajā problēmu risināšanas un kritiskās domāšanas, jaunrades, pašiniciatīvas un uzṇēmējspējas, digitālās caurviju prasmes visvairāk var attiecināt uz kognitīvo jeb domāšanas un tehnisko rìko izmantošanas jomu. Savukārt pašizziñas, pašvadības un mācišanās mācīties caurviju prasmes visvairāk var attiecināt uz "es pats" jeb spēju būt autonomam pasaulē, pieņemot patstāvīgus lēmumus un rūpējoties par sevi. Visbeidzot sadarbïbas un lìdzdalības caurviju prasmes visvairāk attiecas uz "es un citi" jomu, kas sagatavo sadarbībai ar citiem cilvēkiem globālajā pasaulē.

Galvenā atškirīiba mācot iedziḷināties no izolētu zināšanu un prasmju mācīšanas ir tā, ka skolēnam jāprot ne tikai piemērot dotu formulu konkrētam uzdevumam, bet arī atpazīt un definēt problēmu, izvēlēties piemērotāko risināšanas paņēmienu, lietot šo paṇēmienu jaunā, nepazīstamā situācijā, izvērtēt problēmas risināšanas nozīmību un savu motivāciju, atrast nepieciešamos papildu resursus tās risināšanai, izstāstìt citiem par situāciju, sadarboties ar citiem, ja tas nepieciešams, u. tml. Piedāvātā caurviju prasmju komplekta mērḳis ir kalpot par pamatu šādai paplašinātai un padziḷinātai izpratnei par zināšanu, prasmju un attieksmju kopu, kas nepieciešama kompetentai rīcībai jebkurā jomā. Caurviju prasmes kḷūst par skolēna rīkiem, kas palīdz dziḷāk apgūt mācību saturu.

${ }^{50}$ OECD. (2005). The Definition and Selection of Key Competencies. Executive summary. Pieejams: http://www.oecd.org/pisa/35070367.pdf (aplūkots 20.10.2017.).

${ }^{51}$ NRC. (2012). Education for Life and Work: Developing transferable knowledge and skills in the $21^{\text {st }}$ century. In Pellegrino, J. W., \& Hilton, M. L. (eds.). Committee on Defining Deeper Learning and $21^{\text {st }}$ Century Skills, National Research Council (NRC). Pieejams: http://www.nap. edu/catalog.php?record_id=13398 (aplūkots 20.10.2017.). 


\section{Secinājumi}

Mācību pieejas maiṇas nepieciešamība, par centrālo skolas mērḳi izvirzot skolēnu kompetenču attīstîbu sekmīgai dzīvei 21. gadsimtā, ir globāla aktualitāte. Lìdz šim pārāk bieži laba izglìīiba tikusi traktēta kā zināt daudz, nevis kā izglītîba, kuras mērḳis ir saprast būtību un spēt zināšanas lietot. ${ }^{52}$ Izglìtības teorētiḳi, pētnieki, praktiḳi un politiḳi piesaka nepieciešamību pēc jaunām prasmēm, zināšanām, vērtībām, ieradumiem un uzskatiem skolu mācỉbu saturā, piedāvājot tā saukto 21. gadsimta kompetenču modeḷus kā ilustrāciju citādiem izglìtỉbas mērkiem (ATC21S, 201253; Fullan, \& Scott, 2014; Hewlett Packard, 201354; OECD DeSeCo ${ }^{55}$; Gordon, Arjomand, \& Kearney, 2013; u.c. plānošanas dokumenti ${ }^{56,57,58}$ ). Aplūkotie mācību satura dokumenti liecina, ka mācību saturā un mācību procesā joprojām vērojama sadrumstalotība, fragmentārisms, dublēšanās, pārāk liels uzsvars tiek likts uz izolētu, pasīvu zināšanu apguvi, mācību saturs nepietiekami saistīts ar reālās dzīves situācijām. Mācišanās praksē vingrināšanās nereti izpaužas kā darbību atkārtošana identiskās situācijās, kas nedod pieredzi pārnesuma veidošanai, spējai rīkoties nezināmā situācijā, jaunā kontekstā. Mācību process galvenokārt balstîts uzdevumos, kas palīdz attīstīt atsevišḳas/izolētas prasmes, taču nepiedāvā iespējas koordinēti lietot zināšanas, prasmes un

${ }^{52}$ UNESCO IBE. (May 2015). Repositioning and reconceptualizing the curriculum for the effective realization of Sustainable Development Goal Four, for holistic development and sustainable ways of living. Position paper for UNESCO International Bureau of Education (UNESCO IBE) Side Event: "Repositioning Curriculum in Education Quality \& DevelopmentRelevance" for May 21, 2015, Incheon, Republic of Korea. Pieejams: http://www.ibe.unesco. org/sites/default/files/resources/wef_ibe_position_paper_eng.pdf_(aplūkots 20.10.2017.).

${ }^{53}$ ATC21S. (2012). Assessment and Teaching of 21 ${ }^{\text {st }}$ Century Skills (ATC21S) Project. Pieejams: http://www.atc21s.org/ (aplūkots 20.10.2017.).

${ }^{54}$ Hewlett Packard. (April 2013). Deeper Learning Competencies. Pieejams: http://www.hewlett. org/uploads/documents/Deeper_Learning_Defined_April_2013.pdf (aplūkots 22.10.2017.).

${ }^{55}$ OECD. (2005). The Definition and Selection of Key Competencies. Executive summary. Pieejams: http://www.oecd.org/pisa/35070367.pdf (aplūkots 20.10.2017.).

${ }^{56}$ World Economic Forum (WEF). (2015). New Vision for Education - unlocking the potential of technology. Pieejams: http://www3.weforum.org/docs/WEFUSA_NewVisionforEducation_ Report2015.pdf (aplūkots 20.10.2017.).

${ }^{57}$ UNESCO IBE. (May 2015). Repositioning and reconceptualizing the curriculum for the effective realization of Sustainable Development Goal Four, for holistic development and sustainable ways of living. Position paper for UNESCO International Bureau of Education (UNESCO IBE) Side Event: "Repositioning Curriculum in Education Quality \& DevelopmentRelevance" for May 21, 2015, Incheon, Republic of Korea. Pieejams: http://www.ibe.unesco. org/sites/default/files/resources/wef_ibe_position_paper_eng.pdf (aplūkots 20.10.2017.).

${ }^{58}$ NRC. (2012). Education for Life and Work: Developing transferable knowledge and skills in the $21^{\text {st }}$ century. In Pellegrino, J. W., \& Hilton, M. L. (eds.). Committee on Defining Deeper Learning and $21^{\text {st }}$ Century Skills, National Research Council (NRC). Pieejams: http://www.nap. edu/catalog.php?record_id=13398 (aplūkots 20.10.2017.). 
attieksmes apjomīgākos uzdevumos. Mācību satura dokumenti (standarti, programmas) paredz mācỉbu priekšmetiem specifisku zināšanu un prasmju apguvi, bet nav tieši saskatāma vispārējo prasmju mērḳtiecīga, saskaņota, pēctecīga apguve un lietošana. Neraugoties uz to, ka jau 1998. gadā formulēti mācišanās aspekti (kas atbilst caurviju kompetencēm), ka to attīstīšanu paredz izglitïbas standarti, mācību stundu vērojumi un skolēnu snieguma analīze rāda, ka tā nav ikdienas prakse visās skolās (Namsone, \& Čakāne, 2015a, 2015b; Sebre et al., 2015 ${ }^{59}$ ).

Analizējot pasaules pieredzi un nākotnes redzējumu (dažādus kompetenču ietvarus), šajā nodaḷā piedāvāti ieteikumi mācību satura dokumentu pilnveidei. Lìdztekus pamatprasmēm, kuru attīstǐšana notiek nozīmīgās cilvēka darbības jomās (valodas, sociālā un pilsoniskā, kultūras izpratnes un mākslas, matemātikas un datorzinātnes, dabaszinātņu un inženierzinātņu, veselības un fiziskās aktivitātes), akcentējamas vērtības, ieradumi un caurviju prasmes - problēmu risināšana un kritiskā domāšana, jaunrade, pašiniciatīva un uzṇēmējspēja, digitālā un medijpratība, pašvadība, pašizziņa, mācǐšanās mācīties, sadarbība un līdzdalība. Kompetence ir kompleksa, tās attīstǐšana saistās ar pārnesuma veidošanu rīcībai jaunā situācijā, jaunā kontekstā, to nevar reducēt uz kādu atsevišşu prasmi vai izolētu zināšanu kopu. Šādus mērḳus nav iespējams sasniegt, kardināli nemainot pieeju mācǐšanai un skolas darba organizācijai, jo tieši mācī̌anai, ne tikai sasniedzamo rezultātu pārformulēšanai, būs izškirīga loma, vai skolēni attīstīs kompetenci. Tas nozīmē īstenot paradigmu mainu individuālas mācību stundas līmenī.

\section{IZMANTOTĀ LITERATŪRA}

Amadio, M. (2013). A rapid assessment of curricula for general education focusing on crosscurricular themes and generic competences or skills. Background paper for EFA Global Monitoring Report, 14.

Baartman, L. K., Bastiaens, T. J., Kirschner, P. A., \& van der Vleuten, C. P. (2007). Evaluating assessment quality in competence-based education: A qualitative comparison of two frameworks. Educational Research Review, 2(2), pp. 114-129.

Bikse, V. (2011). Uzṇēmējspējas. Rīga: 2011.

Blūma, D. (2004). Skolotāji kā mūžizglītības veicinātāji. Zin. rakstu krāj. 760. sēj. Rīga: LU. 19.-28. lpp.

Dāvidsone, G. (2008). Organizāciju efektivitātes modelis. Organization Development Academy.

Dweck, C. (2008). Mindset: The new psychology of success. Ballantine Books Inc.

Fullan, M., \& Langworthy, M. (2014). A rich seam: How new pedagogies find deep learning. MaRS Discovery District.

${ }^{59}$ Sebre, S., Rubene, Z., Kalnbērziņa, V., Namsone, D., \& Kḷave, E. (2015). Kompetenču pieejā balstita pamatizglitibas standarta pamatojums un galvenie principi. VISC darba grupas ziņojums. 
Fullan, M., \& Scott, G. (July 2014). New Pedagogies for Deep Learning Whitepaper: Education PLUS. Collaborative Impact SPC, Seattle, Washington. Pieejams: http://www.academia. edu/7999210/Education_Plus (aplūkots 20.10.2017.).

Garleja, R. (2006). Cilvēkpotenciāls sociālā vidē. Rīga: RaKa.

Goleman, D. (1996). Emotional Intelligence: Why it can matter more than IQ. Bloomsbury Publishing.

Gordon, J., Arjomand, G., \& Kearney, C. (2013). Key competence development in school education in Europe. Section 2. Key competences in policy. Pieejams: http:// keyconet.eun.org/c/document_library/get_file?uuid=947fdee6-6508-48dc-80568cea02223d1e\&groupId=11028 (aplūkots 20.10.2017.).

Hoskins B., \& Crick, D. R. (2010). Competences for learning to learn and active citizenship: different currencies or two sides of the same coin? European Journal of education, 45(1), Part II, pp. 121-138.

Hoskins, B., \& Fredriksson, U. (2008). Learning to Learn: What is it and how can it be measured? European Commission JRC Scientific and Technical Reports EUR 23432 EN 2008. Pieejams: http://www.jtlearning.com/wp-content/uploads/Learning-to-Learn-whatis-it-and-can-it-be-measured1.pdf (aplūkots 22.10.2017.).

Koķe, T. (2003). Nepārtrauktā izglītība: galvenie uzdevumi un to īstenošana. Nepārtrauktās izglīīibas sociāli pedagoǵiskie aspekti. Rīga: SIA Izglītības soḷi.

Moore, D. R., Cheng, M. I., \& Dainty, A. R. (2002). Competence, competency and competencies: performance assessment in organisations. Work study, 51(6), pp. 314-319.

Namsone, D., \& Čakāne, L. (2015a). What lesson observation data reveal about the changes in teaching science and mathematics. What lesson observation data reveal about the changes in teaching science and mathematics? $11^{\text {th }}$ biannual Conference ESERA 2015. Helsinki, Finland, 31.08.-04.09.2015.

Namsone, D., \& Čakāne, L. (2015b). How the absence of higher PISA scores is connected with science classroom? World Conference of Education Technologies and Research, North Cuprys, 15-17.10.2015.

Rauhvargers, A. (2000). Qualifications: instruments and structures for recognition Proceedings, Council of Europe Workshop on structures and qualifications, Krajanska Gora, 9-10 November 2000, Council of Europe, 2000, pp. 61-87.

Roberts, R. D., Martin, J. E., \& Olaru, G. (January 2015). A Rosetta Stone for Noncognitive Skills: Understanding, assessing, and enhancing noncognitive skills in primary and secondary education. Asia Society. Pieejams: http://asiasociety.org/files/A_Rosetta_Stone_ for_Noncognitive_Skills.pdf (aplūkots 25.10.2017.).

Tough, P. (2013). How Children Succeed: Grit, curiosity and the hidden power of character. Houghton Mifflin.

Velde, C. (1999). An alternative conception of competence: implication for vocational education. Journal of Vocational Education and Training, 51(6). 


\section{Kas ir mācīšanās iedziḷinoties jeb kādā procesā mācīšanās rezultāts var būt kompetence}

Dace Namsone, Zane Oliṇa

\section{Mācīšanās iedzilịnoties pazīmes}

Kompetenču attīstǐšana tieši saistìta ar mācīšanos iedziḷinoties jeb mācību pieeju, ko dažādi autori angḷu valodā dēvē arī par deep learning (dziḷmācīšanās) jeb visible learning (ieraugāma, uzskatāma, redzama mācǐšanās) (Fullan, \& Langworthy, 2014; Hattie, 2012; u. c.) un ir šādas mācību pieejas rezultāts. Hjūleta Fonds (The Hewlett Foundation) definē mācīšanos iedziḷinoties kā "visaptverošu/jumta jēdzienu, kas ietver tās prasmes un zināšanas, kurām būtu jāpiemìt skolēniem veiksmīgu darba gaitu uzsākšanai un pilsoniskās dzīves veidošanai 21. gadsimtä" .

ASV Zinātṇu akadēmijas Nacionālās pētniecības padomes ziṇojumā (National Research Council²), kurā izvērtēti prominentākie 21. gadsimta prasmju modeḷi, īpaši izcelta nepieciešamība mācību procesā panākt, ka skolēni mācās iedziļinoties (deeper learning). Mācīšanās iedziļinoties, kā atzīmē ziṇojuma autori, ir process, kura laikā skolēni attīsta spēju vispārināt jeb pārnest jaunās zināšanas un prasmes uz jaunām, nezināmām situācijām. Ir lielāka iespējamība, ka notiks

1 Hewlett Packard. (April 2013). Deeper Learning Competencies. Pieejams: http://www.hewlett. org/uploads/documents/Deeper_Learning_Defined_April_2013.pdf (aplūkots 22.10.2017.).

2 National Research Council. (2012). Education for Life and Work: Developing Transferable Knowledge and Skills in the $21^{\text {st }}$ Century. Committee on Defining Deeper Learning and $21^{\text {st }}$ Century Skills, J. W. Pellegrino, \& M. L. Hilton, Editors. Board on Testing and Assessment and Board on Science Education, Division of Behavioral and Social Sciences and Education. Washington, DC: The National Academies Press. 
pārnese, ja skolēniem ir izpratne par vispārējiem principiem un pieejām problēmu risināšanā, ja skolēniem ir gan faktolog̣iskas un kontekstuālas zināšanas attiecīgajā jomā, gan atbilstoši problēmu risināšanas paṇēmieni (strategy $\left.y^{3}\right)$, ja skolēni spēj atpazīt kā, kad un kāpēc izmantot faktologiskās (deklaratīvās), kontekstuālās un procedurālās zināšanas un prasmes.

Ziṇojuma autoru ieskatā, tāds arī ir 21. gadsimta caurviju jeb transversālo prasmju (transversal skills) integrācijas mērḳis - sekmēt mācǐšanās iedzilinoties procesus, tādējādi palīdzot skolēniem labāk un pamatīgāk apgūt mācību saturu. Ziņojuma autori norāda, ka šis pieejas izmantošana varētu samazināt mācību sasniegumu nevienlīdzību skolēnu vidū. Tādējādi lielāks skaits jauniešu būtu sagatavots sekmīgai dzīvei sabiedrībā un profesionālai darbībai.

Mācǐšanās iedziḷinoties ir process, kura laikā skolēni attīsta, nostiprina un izmanto augsta līmeņa domāšanas prasmes - analizē, sintezē, izvērtē, risina problēmas, lieto metakognitīvos paṇēmienus, lai konstruētu ilgtermiṇa izpratni. Mācīšanās iedziḷinoties ietver jaunu ideju vērtējošu analīzi, sasaistot tās ar jau esošajām, un šādas mācišanās pieejas mērḳis ir prast risināt problēmas jaunās, nezināmās situācijās (tostarp, reālās dzīves situācijās) un kontekstā jeb spēja pārnest. Šādas mācišanās pieejas priekšplānā izvirzās procesi, ar kuru palīdzību mēs iegūstam zināšanas (kā mēs zinām?), ne tikai uzkrātu noteiktu satura apjomu (ko mēs zinām?). Mācību stundas līmenī tas vispirms nozīmē mērķu izvirzīšanu, atgriezeniskās saites saņemšanu skolēniem, skolēnu pieredzes aktualizēšanu, apzinātu kognitīvo un metakognitīvo paņēmienu darbināšanu domas (jēgas) konstruēšanai dažādā kontekstā un situācijās, kā arī skolēnu sadarbību.

Mācišanās iedziḷinoties pamatmērḳis ir tiekties uz to, lai skolēns iegūtu padziḷinātu un konceptuālu izpratni par kompleksām/sarežğìtām tēmām. Šādu izpratni nav iespējams iegūt, ja skolēns apgūst tikai deklaratīvas zināšanas (faktus), kas ir tikai viena no kompleksa snieguma nepieciešamajām sastāvdal̦ām (Greene, \& Azavedo, 2009). Šai pieejai raksturīga skolēna aktīva intelektuāla iesaiste savas izpratnes veidošanā. Skolēns, iepazīstoties ar jauno informāciju, idejām, tās izvērtē un sasaista ar jau iepriekš iepazītiem jēdzieniem un principiem. Skolēnam rodas izpratne un stabilas zināšanas par jaunajiem jēdzieniem ilgterminnā, kas palīdz tos lietot un risināt problēmas jaunā un nepazīstamā kontekstā. Šādā mācību procesā notiek zināšanu integrācija, sintēze un refleksija (Vos, Meijden, \& Denessen, 2011).

Izmantojot šādu mācību pieeju, process vistiešākajā mērā ietekmē sasniedzamo rezultātu jeb faktiski ir ekvivalents rezultātam. Nevar teorētiski mācīt vērtības, ar tām ir jādzīvo. Nevar teorētiski mācīt par neatlaidību, šĩ

3 Tekstā anĝ̣u valodas termins strategy lietots kā paṇēmiens, lai gan profesionālajā ikdienā ieviešas termins "stratēgijas". 
spēja ir jāattīsta ikdienā, saskaroties ar uzdevumiem un situācijām, kur tā nepieciešama. Nevar teorētiski mācīties par iecietību, tā ir jāpraktizē attiecībās ar skolasbiedriem. Ticỉba intelekta mainīgajai dabai nevar rasties, ja skolēniem nav skaidri kritēriji, pēc kuriem viṇu darbu vērtēs, un izpratnes par to, ar kādām darbībām viṇi var savu sniegumu uzlabot. Jābūt arī reālai iespējai uzlabot savu darbu. Ideju par to, ka 21. gadsimta prasmju apguvei mācīšanās jeb darǐšana nav atraujama no sasniedzamā rezultāta, uzsver arī Maikls Fulans savā esejā "Izglìīiba ar plusa zīmi” (Fullan, \& Scott, 2014). Viņš aicina nostiprināt vēl nebijušu ideju izglìtībā, ka izglìtota persona ir darītājs - darošs domātājs jeb domājošs darītājs, kurš mācās, lai darìtu, un dara, lai mācītos.

Šādas pieejas mācībām īstenošanai ir vairāki iemesli - gan jau pirmajā nodaḷā pieminētās objektīvās izmaiņas sabiedrības attīstībā, kad līdzšinējās prasmes vairs nav pietiekamas un skolas beidzējiem jārēḳinās ar to, ka mācības būs jāturpina mūža garumā, gan arvien pieaugošais zinātnisku pētījumu apjoms par efektīvu mācǐšanās procesu un faktoriem, kas sekmē pārnesi jeb spēju lietot zināšanas kompleksās, nepazīstamās situācijās, pierādījumi, ka mācību pieeja, kurā skolotāja pamatdarbība vērsta uz gatavu zināšanu nodošanu skolēniem, ved pie trauslām, fragmentārām un pasīvām zināšanām, ierobežojot skolēna spēju tās sekmīgi izmantot dzīvē. Šādas zināšanas tiek dēvētas par fragmentārām, inertām, kūtrām, naivām, rituālām pretēji nepieciešamībai gūt dziḷu izpratni, skaidrojot, salīdzinot, sniedzot piemērus, pretstatot un vispārinot (Gardner, \& Perkins, 1988). Mācī̌anās iedzị̣inoties pieeja mācībām nozīmē gan paradigmatiski jaunu izpratni par to, kas ir nozīmīgs sasniedzamais rezultāts mācību procesā - spēja saskatīt problēmu, izvēelēties, izstrādāt un ieviest piemērotu risinājumu, darot to atbildīgi, patstāvīgi, kvalitatīvi u. tml. -, un tāpēc citādu skolotāja un skolēna lomu mācībās, gan noteiktu mācišanas un mācišanās paṇēmienu izmantošanu mācību procesā, piedāvājot iespējas vingrināties šāda integrēta snieguma demonstrēšanai.

ASV Zinātṇu akadēmijas Nacionālās pētniecības padomes ziṇojumāa ${ }^{4}$ uzskaitìtas skolotāja darbības, kas sekmē mācǐšanos iedzililinoties un tādējādi kompetences attīstību: sākt ar skaidri definētu sasniedzamo rezultātu un modeli jeb izpratni par to, kā noritēs mācǐšanās, lai to sasniegtu; izmantot vērtēšanu, lai novērtētu un atbalstītu skolēnu progresu ceḷā uz mērḳi; piedāvāt vairākus, daudzveidīgus piemērus un demonstrācijas apgūstamajiem jēdzieniem un uzdevumiem; rosināt

${ }^{4}$ National Research Council. (2012). Education for Life and Work: Developing Transferable Knowledge and Skills in the $21^{\text {st }}$ Century. Committee on Defining Deeper Learning and $21^{\text {st }}$ Century Skills, J. W. Pellegrino, \& M. L. Hilton, Editors. Board on Testing and Assessment and Board on Science Education, Division of Behavioral and Social Sciences and Education. Washington, DC: The National Academies Press. 
jautājumu uzdošanu un diskusijas; piedāvāt skolēniem izaicinošus, intelektuāli sarežḡitus uzdevumus, nodrošinot atbilstošu atbalstu un pārraudzību; mācīt, izmantojot rūpīgi izvēlētus piemērus un gadījumus; apzināti strādāt pie skolēnu motivācijas palielināšanas; izmantot formatīvo vērtēšanu, lai sniegtu atgriezenisko saiti.

Mācǐšanās iedziḷinoties ir pieeja palīdzēt skolēniem mācīties risināt uzdevumus līdzīgi tam, kā tas notiktu viṇu turpmākajā profesionālajā darbībā (Fullan, \& Langworthy, 2013).

Skolēna mācīšanās dziḷumu lielā mērā nosaka mācīšanas paṇēmieni, kurus izmanto skolotājs. Skolēnu mācǐšanās dziḷums atkarīgs no mācību uzdevumu kompleksuma, kas prasa atbilstošu skolēna sniegumu. Šajā procesā notiek mācību satura un zināšanu integrācija, sintēze un refleksija (Vos, Meijden, \& Denessen, 2011).

Apkopojot varam konstatēt, ka mācīšanās iedziḷinoties (deep, deeper learning) nozìmē:

- padzilịnātu skolēna motivāciju un interesi par mācību uzdevuma saturu;

- fokusēti saprast mācību satura būtību;

- saistīt mācību satura elementus savā starpā;

- sasaistìt jaunas idejas ar iepriekš apgūtajām zināšanām;

- sasaistìt jēdzienu ar ikdienas pieredzi (Chin, \& Brown, 2000; Fullan, \& Scott, 2014; Hattie, 2012).

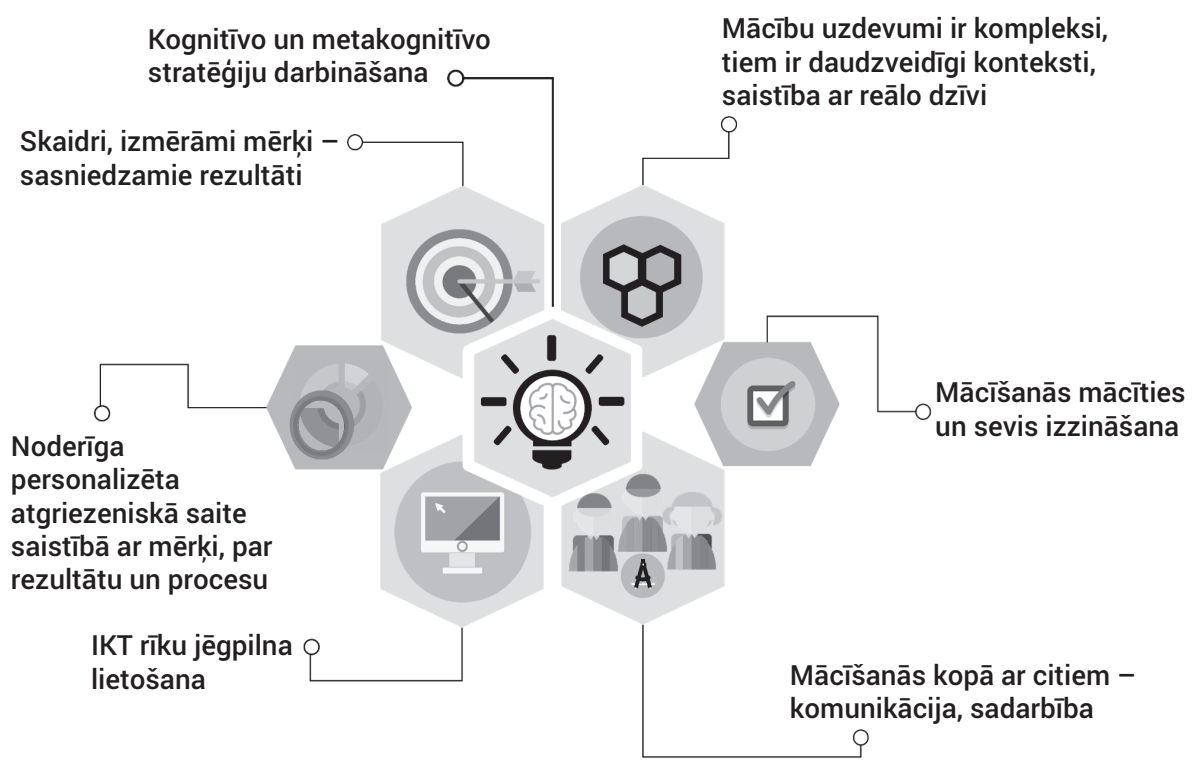

1. attēls. Pazīmes, kas raksturo mācišanos iedziḷinoties (LU SIIC arhīvs) 
1. attēlā apkopotas svarīgākās pazīmes, kas raksturo mācīšanos iedziḷinoties - skaidrs, izmērāms, skolēnam saprotams mērḳis jeb sasniedzamais rezultāts; noderīga, personalizēta, attīstoša atgriezeniskā saite; kognitīvu un metakognitīvu mācīšanās pañēmienu darbināšana kompleksu mācỉbu uzdevumu risināšanā, kas doti daudzveidīgos kontekstos; mācišanās norisinās kopā ar citiem, jēgpilni lietojot informācijas un komunikācijas tehnologijas.

İstenojot šādu pieeju mācībām, jāmainās gan uzskatiem par skolotāja lomu mācību procesā, gan veidam, kā skolas līmenī tiek plānots un organizēts mācību darbs un vērtēšana, gan katra skolotāja darbam klasē.

Tālāk piedāvāsim teorētisko pamatojumu mācišanās iedziḷinoties pieejas iedzīvināšanai no skolēna mācišanās viedokḷa un detalizētāk ar piemēriem raksturosim mācišanas paṇēmienus efektīiākas mācīšanās sekmēšanai.

\section{Mācīšanās iedziḷinoties pieejas teorētiskie aspekti no skolēna mācīšanās viedokla}

Kopš 20. gadsimta 70. gadiem dažādās mācǐšanās teorijās aprakstot mācīšanās procesu no skolēna viedokḷla, izmantoti jēdzieni "virspusēja mācišanās" un "māciššnās iedziḷinoties" (surface learning vs deep learning). Virspusēja mācīšanās saistās ar zema līmeṇa mācǐšanās rezultātu (learning outcomes) jeb trauslām, fragmentētām zināšanām, bet mācīšanās iedziḷinoties - ar augsta līmeņa rezultātu (Marton, \& Säljö, 1984; Biggs, 1987; Entwistle, 2001) jeb patiesu izpratni, spēju vispārināt un pārnest iegūtās zināšanas un prasmes uz jaunām, nepazistamām situācijām.

Virspusēja mācīšanās raksturīga tiem brīžiem mācišsanās procesā, kad skolēns cenšas jaunu informāciju iegaumēt no galvas (Biggs, Kember, \& Leung, 2001). Atsevišķi fakti tiek iegaumēti, norādes un procedūru gaita tiek reproducētas, tās atkārtojot un iegaumējot (rote learning). Skolēni neredz uzdevuma sasaisti ar citiem uzdevumiem, situācijām no reālās dzīves, viṇi to uztver kā pienākumu, kas jāizpilda (Chin, \& Brown, 2000, p. 110). Ja skolēns mācību stundā izmanto virspusējas mācišanās pieeju, skolēns reproducē vai kategorizē informāciju, atdarina vienkāršotas darbības (procedūras) (Smith, \& Colby, 2007, pp. 205-206). Šìs pieejas ietvars nosaka to, ka mācīšanās procesā skolēna iesaistišanās līmenis ir zems, fokuss ir uz iegaumēšanu vai darbïbu veikšanu bez reflektēšanas un mācǐšanās nodoms ir saņemt nepieciešamo sekmīgo atzīmi (Marton, \& Säljö, 1984).

Jebkurai mācišanās pieejai raksturīgi divi elementi: 1) stratēgija - skolēnu darbības; 2) nodoms - kāpēc skolēni veic šis darbības (Marton, \& Säljö, 1984). Tāpēc mācǐšanās iedziḷinoties pieejā svarīgi ir definēt sasniedzamo rezultātu un par to kopīgi diskutēt. Šīs mācīšanās pieeja ietver nodomu izprast un piešḳirt 
nozīmes. Skolēns piešķir uzmanību attiecībām, kas pastāv starp mācību satura elementiem un aspektiem, izvirza hipotēzes vai pieņēmumus par problēmu vai jēdzienu struktūrām. Pieeja arī saistās ar to, ka tiek iegūta patiesa interese par mācǐšanos un izpratni (Marton, \& Säljö, 1984).

No abu pieeju īsās analīzes ir novērojams, ka šīs tiešām ir pieejas, kas ietekmē to, kas mācišanās procesā notiek ar skolēnu. Skolotājs ar izvēlēto mācīšanas metodi var sekmēt vienu vai otru pieeju mācībām no skolēna viedokḷa. Skolotājs fokusējas uz mācǐšanu kā skolēna personīgās izpratnes radīšanu (Entwistle, $2000^{5}$ ). Jebkuru mācīšanās pieeju nevajadzētu uzlūkot kā skolēnam piemītošu nemainīgu, tikai viņam raksturīgu , bet gan kā viņa atbildi un reakciju uz doto (mācǐšanās/mācǐšanas) situāciju (Marton, 1983; Ramsden, 1988). Citiem vārdiem, skolēns attiecīgi reagêe uz to, kā skolotājs organizē mācību darbu stundā. Pētijjumi ir pierādījuši, ka skolotāji savā mācību praksē adaptē vai nu dziļas, vai virspusējas mācīšanas pieeju (Boulton-Lewis, Smith, McCrindle, Burnett, \& Campbell, 2001; Smith, Gordon, Colby, \& Wang, 2005). Tas ir izplatīts novērojums arī augstākajā izglìīibā (Trigwell, Prosser, \& Waterhouse, 1999).

Skolēna mācišanās nereti izpaužas vairākās dimensijās. Atsevišķos kontekstos skolēni var atspoguḷot padzịlinātāku mācišanās pieeju. Skolotāja uzdevums ir ievērot to dimensiju, kurā notiek padziḷināta mācǐšanās pieeja, un izmantot to kā pirmo atskaites punktu, no kura vadīt skolēnu uz padziļinātākiem domāšanas lìmeņiem (Chin, \& Brown, 2000, p. 131). Mācīšanos iedzịlinoties var veicināt, mudinot skolēnus pašiem formulēt jautājumus, skaidrojumus, prognozes un eksperimentēšanu vai pat veidot minimālus teorētiskus skaidrojumus mācību stundās (Chin, \& Brown, 2000, p. 133).

Mācību stundas kontekstā nozīme ir arī tam, kura mācišanās pieeja tiek lietota izteiktāk. Ir vairāki pētỉjumi, kuros mācišanos iedziḷinoties pieeju apskata kontekstā ar informācijas tehnolog̣iju lietošanu. Mācīšanās ar šiem rīkiem var veicināt mācǐšanos iedziḷinoties (Vos, Meijden, \& Denessen, 2011).

Konstruktīvisma (teorija par to, kā prāts rada zināšanas) filozofijas un ar to saistìto mācišanas un mācišanās teoriju kopums visprecīzāk/vistuvāk raksturo un skaidro mācišanās iedziḷinoties pieejas nepieciešamību. Atbilstoši konstruktīisisma teorijai (Piažē, Vigockis, Novaks, Ozbels, Niazs u. c.) apjēgšana norisinās kā jaunu zināšanu, prasmju konstruēšana, nevis vienkārši atcerēšanās (Niaz, 2008). Tā ir iespējama, ja ir skaidrs, kas jāapgūst (sasniedzamais rezultāts jeb mācī̌sanās mērḳis), ja tiek aktualizēts iepriekš apgūtais, tiek veicināta skolēna motivācija; rezultāts ir tad, ja skolēns pašnovērtē apgūto pret plānoto mērḳi. Atbilstoši šai

5 Entwistle, N. (2000). Promoting deep learning through teaching and assessment: Conceptual frameworks and educational contexts. Paper presented at the Teaching and Learning Research Programme Conference, November, in Leicester. 
teorijai skolēnam apgūstamais mācību saturs (zināšanas, izpratne, prasmes u. c.) netiek uzskatīts par statisku, ko otram cilvēkam var nodot kā gatavu kopumu un otrs to atceras, bet gan veidojas individuāli atšksirīga jēga uz tās pieredzes bāzes, kas jau ir izveidojusies. Konstruktīvisma teorija aplūko mācǐšanos no aspekta, kā prāts rada zināšanas, izmantojot jēdzienus (concepts, preconcepts); tā aplūko arī maldīgo priekšstatu (missconceptions) veidošanās risku. Plānojot sasniedzamo rezultātu, vienlaikus ar mācību satura idejām tiek plānota skolēna kognitīva darbiba.

Vēl viena mācīšanās iedziḷinoties pieejai raksturīga pazīme ir uzsvars uz sistemātisku skolēna paša iesaisti savas mācišsanās darbības plānošanā un vadīšanā. Pašvadīta mācišanās (self-direct learning) ir process, kurā skolēns darbina un lieto domāšanas, emocionālo stāvokḷu un uzvedības regulēšanas rīkus, lai sistemātiski orientētu sevi uz personisko mācību mērḳu sasniegšanu (Schunk, \& Zimmerman, 2011, p. 1).

Nozīmīgs mācǐšanās aspekts ir tas, lai ne tikai skolotājam, bet arī skolēnam katrā stundā ir skaidrs mācīšanās mērḳis (sasniedzamais rezultāts) un ko skolēns spēs, stundai beidzoties. Skolēna mērḳis, ko izvirzām, ir daudzdimensionāls. Tam jāatbilst laba mērḳa izvēles kritērijiem - jābūt konkrētam un skaidri saprotamam, izmērāmam, izaicinošam, bet reāli konkrētajiem skolēniem sasniedzamam, tā îstenotājam nozīmīgam (relevant), saistītam ar kopējo saturu un skolas mērḳiem, īstenojamam atvēlētajā laikā. Mērḳu apzināta izvirziššna skolēnam plānojama, sākot no pirmajām skolas dienām.

Pašvadīta mācǐšanās ietver arī mācišanās pārnesuma pašapzināšanu (apzinātas līdzības meklēšanu) jeb metakognitīvu darbību, kas ir izšķiroša, lai skolēns apgūtu mācišanās rīkus apzināti. Atslēgas jautājumi, uz kuriem skolēnam jāatbild, ir:

- vai šeit kaut kas man atgādina kaut ko no iepriekš mācītā?

- kā šì problēma līdzinās tai, kuru risināju senāk (šajā vai citā priekšmetā, ikdienas situācijā, ...)?

Metakognitīvs process ir izglîtības process, kas ietver zināšanas par skolēna spējām (abilities), dotā uzdevuma prasībām un potenciāli efektīvākajiem mācīšanās paṇēmieniem. Tas iekḷauj pašvadību caur plānošanu, prognozēšanu, pārraudzī̌sanu, regulěšanu, vērtēšanu, pārskatǐšanu (O’Toole, 2005). Praktizējoties (vingrinoties) skolēnam tiek mācìts ar metakognitīvajiem rīkiem atpazìt: kur šo jau esmu redzèjis?; ar ko man tas saistās?; ar kädu paņēmienu šis tika risināts fizikā?; kā mēs meklējām teksta jēgu valodā? Vingrināšanās nozīmē aktualizēšanu ar jēgu, apgūto lietojot dažādā kontekstā, nevis "drillěšanu" (vienmuḷu atkārtošanu abstraktās situācijās).

Skaidrs un saprotams sasniedzamais rezultāts skolēnam, attīstoša atgriezeniskā saite, laiks domāt, sistemātiska, akumulēta (accumulated) un veiksmīga 
praktizēšanās, regulāri atkārtojot apgūto; savas izpratnes vai prasmju attīstības regulāra pārraudzība (monitoring) ir svarīgi nosacỉjumi, lai notiktu mācišanās (Hattie, \& Yates, 2013). Atgriezeniskās saites nozīmīgumu uzsver daudzi pētnieki. Džons Hatijs (John Hattie) ietekmes faktoru (effect size; kur vidējā ietekme 0,4) rāda, ka ietekmes faktors "atgriezeniskajai saitei” ir 0.72, "izaicinošu mērķu izvirzǐšanai” 0.56, "metakognitīvajām stratẹgijām" 0.67; "mācīšanās sadarbojoties" 0.59 (Hattie, 2009).

1. tabulā parādīta Latvijas Universitātes Starpnozaru Izglìtības inovāciju centrā (LU SIIC) izveidota darba lapa, kurā apkopotas svarīgākās pazīmes, kas raksturo skolēna mācišanos iedziļinoties. Darbības apkopotas, analizējot teorētisko literatūru un LU SIIC veiktu pētījumu (periodā 2011.-2017.) datus par skolotāju stundu vērojumiem. Tas tālāk pilnveidotas LU SIIC darbā, ìstenojot profesionālo pilnveidi dažādu mācību priekšmetu skolotājiem un skolu vadìtājiem.

Iepriekšêjā sadal̦ā detalizēti apskatijām teorētisko pamatojumu mācišanās iedziļinoties pieejai no skolēna viedokḷa, īpaši uzsverot konstruktīvisma filozofijai un ar to saistītām mācišanas un mācišanās teorijām raksturīgo uzsvaru uz skolēna aktīvo lomu un pašvadītas mācišanās nozīmi patiesas izpratnes, pamatīgu un ilgtermiņa zināšanu konstruēšanā. Uzsvērām, ka no skolēna mācišanās viedokḷa ir svarīgi, ka mācišanās procesā viṇam tiek dota iespēja un laiks pašam skolotāja sistemātiskā vadībā veidot savu izpratni par mācību saturu jeb konstruēt zināšanas. Lai tas notiktu efektīvi, nepieciešams panākt skolēna aktīvu, apzinātu un stratēgisisku iesaisti jeb mācišanos iedzị̣inoties. Tādēl mācišanās skolēnam jāpadara redzama/ieraugāma, t. i., ne tikai skolotājam, bet arī skolēnam jābūt skaidram mācišanās mērḳim un izpratnei par to, kādā ceḷā to ir iespējams sasniegt. Skolēnam nepieciešamas prasmes lietot efektīvus mācišanās paṇēmienus un vēlmi tos izmantot, lai paṇemtu pēc iespējas vairāk no katras mācišanās situācijas.

\section{Mācīšanas iedziḷinoties pazīmes mācību stundas līmenī}

Veidojot mācību stundu, skolotājam svarīgi ņemt vērā faktorus, kas sekmē efektīvu mācǐšanos, izvirzot skaidru sasniedzamo rezultātu, plānojot atgriezenisko saiti, paredzot laiku praktizēties u. c. Sākot mācīšanu, ir svarīgi izvirzìt sasniedzamo rezultātu (ko skolēns gūs mācoties) un saprast, kāpēc tas, ko mēs mācīsimies, skolēnam ir vajadzīgs, ne tikai domājot par mācību saturu, bet arī par veidu, kādā tiks organizēts mācīšanās process. Nozīmīgi skolotājam ir trīs jautājumi: kas ir tas, ko vēlamies sasniegt?; kā varu panākt, lai skolēni to iemācās?; kā zināšu, ka skolēni rezultātu sasnieguši? (Reece, \& Walker, 2007). 
1. tabula. Mācību stundu analīzes lapa "Es kā skolēns stundā mācos" (LU SIIC arhīvs)

Skolēna mācīšanās darbīibas

Ir/nav
Pierādījumi mācību stundā vērotajam

Zinu mērḳi, kas man jāsasniedz, kas jāiemācās

- tas ir par saturu, kas man jāapgūst

- es skaidri saprotu, ko no manis sagaida, kādi ir laba snieguma kritēriji

- tas būs interesanti

- tas man ir izaicinājums, bet es to varēšu

Mācos

Par katru mācību uzdevumu, ko saṇemu:

- skaidrs, kas jādara

- skaidrs, kā jādara

- skaidrs, kāpēc to daru, kā tas saistās kopā

Kā notiek mācīšanās:

- man ir iespēja, laiks domāt

- man ir iespēja praktizēties, vingrināties

- man ir iespēja iesaistīties, jautāt, piedāvāt, izteikties

Metakognitīvais lïmenis:

- man ir jādomā par to, kādā veidā es mācos, kā es domāju, atceros

Sadarbība:

- man ir iespēja darīt kopā ar klasesbiedriem

- skolotājs mani atbalsta

Dažādi mācību rīki, līdzekli:

- es izmantoju IT

- izmantoju piederumus, ierīces

- izmantoju dažādus informācijas avotus

Saprotu, ko iemācījos:

- man ir iespēja pārliecināties, kā man izdodas

- mācos/protu dot atgriezenisko saiti klasesbiedriem

- mācos/protu sañemt atgriezenisko saiti no skolotāja un klasesbiedriem

- par rezultātu (kas sanāca?)

- $\quad$ par veidu, kā mācījos (kā darīju?)

- saprotu, ko darīt turpmāk 
Efektīvām mācībām svarīga ir skolēnam skaidra stundas struktūra. Tieši stratēgiskā skaidrība (teachers clarity) (vai katram klasē sēdošajam ir skaidrs, kas šeit notiek?) ir viens no faktoriem ar augstu ietekmi uz rezultātu (effect size 0,75 salīdzinājumā ar 0,4 vidēji; Hattie, 2009). Efektīvas stundas struktūras izveides plānošana sākas ar atbildēm uz jautājumiem Ko gribu panākt? un Kā zināšu, ka rezultāts ir sasniegts? Pēc tam logiski jāstrukturē skolotāja un skolēnu darbību secība stundā, par atskaites punktu izvirzot plānoto skolēnam sasniedzamo rezultātu (Kà es to panākšu?).

Magdalēna Lamperta (Magdalene Lampert), salīdzinot divas matemātikas stundas, kurās abās ir iespējams apgūt vienu un to pašu matemātikas saturu ar dažādām pieejām - vienā tradicionālā veidā, otrā mācoties iedzilinoties -, raksta: "Balstoties uz maniem novērojumiem klasēs, es aprakstu, kā divi skolotāji savās mācību stundās mācỉja saturu un kādas darbības skolēni veica, lai to apgūtu. Vienā gadījumā fokuss tika likts uz mācīšanos iedziḷinoties, otrajā - ne. Pievēršot uzmanību detal̦ām, kḷūst skaidrs, ka mācīšana iedziḷinoties attiecas uz ko plašāku par šo konkrēto mācību stundu. Šì pieeja pieprasa, lai mēs balstìtu katru saskarsmes elementu starp skolēnu un skolotāju jaunā izpratnē par to, ko nozīmē mācìt un ko nozīmē mācìties" (Lampert, 2015, p. 9; skat. 2. tabulu).

Skolotājs staigā pa klasi un runā veidā, kas iesaista skolēnus nosacīti "publiskā” mācīšanās procesā, uzklausot viṇus un piedāvājot vinu domu gaitu pārējiem skolēniem apspriešanai. Skolotājs kopīgi ar skolēniem konstruē idejas, strādā sadarbojoties, lai radītu un veidotu kopīgu izpratni, piemēram, par matemātiskiem jēdzieniem vai prasmju apguvi latviešu valodā. 
2. tabula. Divu skolotāju redzējumu salīdzinājums (adaptēts pēc Lampert, 2015, p. 19)

\begin{tabular}{|c|c|c|}
\hline & $\begin{array}{l}\text { Skolotājs novēro skolēna } \\
\text { zināšanas netieši }\end{array}$ & $\begin{array}{c}\text { Skolotājs novēro skolēna } \\
\text { zināšanas tieši }\end{array}$ \\
\hline $\begin{array}{l}\text { Skolotājs uzlūko } \\
\text { zināšanas kā } \\
\text { nemainīgas/fiksētas } \\
\text { un meklē saskaṇu starp } \\
\text { skolēna zināšanām un } \\
\text { fiksētajām zināšanām. }\end{array}$ & $\begin{array}{l}\text { Skolotājs izmanto vairāku } \\
\text { atbilžu testus, mājasdarbus, } \\
\text { izdales materiālus u. c., lai } \\
\text { pārbaudītu skolēnu zināšanas. } \\
\text { Skolotājam minimāli } \\
\text { nepieciešamas saskarsmes } \\
\text { spējas un zināšanas, lai } \\
\text { lietotu izpētes paṇēmienus. }\end{array}$ & $\begin{array}{l}\text { Skolotājs izmanto vienkāršus } \\
\text { jautājumus, atbildes vai } \\
\text { formālu atkārtošanu, lai } \\
\text { pārbaudītu skolēnu zināšanas. } \\
\text { Skolotājiem nedaudz } \\
\text { nepieciešamas saskarsmes } \\
\text { spējas; zināšanas un } \\
\text { spēja formulēt atbilstošus } \\
\text { jautājumus un ātri izvērtēt } \\
\text { skolēnu atbildes. }\end{array}$ \\
\hline $\begin{array}{l}\text { Skolotājs uzlūko } \\
\text { zināšanas kā izziṇas } \\
\text { procesa iznākumu } \\
\text { un meklē norādes uz } \\
\text { domāšanu darbībā } \\
\text { (signs of minds at work). }\end{array}$ & $\begin{array}{l}\text { Skolotājs izmanto esejas, } \\
\text { pierakstu veikšanu un līdzīgus } \\
\text { pan̄ēmienus, lai pētītu, ko } \\
\text { skolēni zina un kā viṇi to } \\
\text { māk izklāstīt. Skolotājam } \\
\text { nepieciešamas saskarsmes } \\
\text { spējas un zināšanas, viṇam } \\
\text { nepieciešamas specializēta } \\
\text { satura zināšanas, lai } \\
\text { uzdotu labus jautājumus un } \\
\text { pārdomāti atbildētu uz skolēnu } \\
\text { jautājumiem. }\end{array}$ & $\begin{array}{l}\text { Skolotājs organizē sarunas, } \\
\text { diskusijas, debates, } \\
\text { pagarinātus kolokvijus } \\
\text { un līdzīgas tiešā diskursa } \\
\text { metodes, lai noskaidrotu, } \\
\text { ko skolēni zina. Skolotājam } \\
\text { nepieciešamas zināšanas par } \\
\text { saturu, prasmes sadarbībai ar } \\
\text { skolēniem un spēja savienot } \\
\text { šos elementus. }\end{array}$ \\
\hline
\end{tabular}

Šādas stundas būtiskas sastāvdaḷas ir apgūstamās satura jēgas noskaidrošana, ieraudziššna, kā to dara, paṇēmienu mācīšanās, kā darīt; domāt un sarunāties par to, kā personīgi es to daru. Tālāk dots konkrētas latviešu valodas stundas 4. klasē piemērs, kā skolotāja A. veido šādu stundu. 


\section{4. klase, latviešu valoda, skolotāja $A$.}

Skolotāja saka: "Lai saprastu, kas ir tēma, aicināšu paklausīties un vārdu spēlē atrast, ko šodien mācīsimies." Skolēni dažas sekundes klausās dziesmu "(..) jāj pa celu pasacina". Skolēni reaǵē, ka atpazīst. Skolotāja jautāa, kas ir autors, par ko ir dzejolis. Piebilst, ka šodien loti vēlētos, lai skolēni uzrakstītu pasaciṇu par tēmu, kurā viṇi atklātu fantāzijas lidojumu, un lai pasaka atškirtos no citiem prozas darbiem.

Skolotāja saka: "Lai saprastu, kā pasaka atškiras no citiem darbiem, jāapkopo savas zināšanas." Izdala lapas; uz lapas ir septini jautājumi; jāapvelk viena no trim iespējamām atbildēm. Kādā grupā viens iekrāso pareizo atbildi; citā grupā meitene uzṇemas lasīt visiem priekšā; ir atbilžu varianti; prasa, kuru apvilkt.

"Izlasīsim, kas mums no tā ir sanācis, kas ir pasaka?" Skolēni tiek saukti pa vienam un rosināti lasīt pa teikumam, kas ir pasaka. Skolotāja aicina pateikt vienu konkrētu atškirīibu. Klausās. Jautā, ko pārējie par šo saka. Kā varētu sākties pasaka? Reiz sensenos laikos; aiz kalniem un mežiem..., reiz dzīvoja..., kādu dienu. Pēc sākuma atpazīstam, kas ir pasaka. Vai pasaka ir gabaldarbs? Kas ir svarīgi, lai uzrakstītu pasaku? Kā sauc tās dalas? Kā sauc sākumu? levads? Kādas vēl dal as? Raksta uz tāfeles: ievads, galvenā dala, nobeigums. Uzsver, ka tas ir loti svarīgi. "Ko gribam nobeigumā redzēt?" Kā notikums beidzas. "Kā parasti beidzas?"

Uz tāfeles dažādi vārdi, kas iederas šajās dalāâs. Skolotāja jautā, kurā dalā iederas šie vārdi. Aicina katru grupu piespraust pie tāfeles vienu vārdu. Skolēni iet pa vienam no grupas un piesprauž. Grupas sarunājas par vārdiem. Vārdi: Kā tas sākās; Dzīves gudrība; Tēlu apraksts; Atrisinājums; Virsraksts; Notikumi; Pamācība; Vide; Sarežǵỉjumi un problēmas; Pozitīvs nobeigums.

Skolotāja aicina: "Pavērojam!" Jautā: "Vai ievadā runājam par...?" Apskata vārdus un veido sarunu par piemēriem ar šiem vārdiem. Apstājas pie virsraksta un jautā par virsrakstu. "Padomā, pirms dari; Mūžu dzīvo, mūžu mācies; Dari, ko darīdams, apdomā galu."

“Tu saproti, kas kurā dalā būtu jāraksta? Atveriet aploksnes, tajās ir vārdi, kas ir jāsavirknē ievada teikumā; bīdiet vārdus, līdz sanāk loǵisks teikums. Bīdiet, līdz izmantoti visi vārdi." Skolēni grupās liek teikumu. Skolotāja grupām dod konkrētus ieteikumus: "Jūs varētu likt strīpā, jo tad..." Aicina vienu grupu teikumu nolasīt visiem skali kopā. Vaicā, vai kādam ir citādāk, skolēni lasa.

Teikumi atškiras ar vienu vārdu. Katrs pats padomā, kāds varētu būt virsraksts. Ja ir ideja, pacel roku. Skolotāja uz tāfeles raksta virsrakstus, ko sauc skolēni. "Jautrā princese. Trīs kēniṇi. Atraktīvā princese. Skaistā princese. Dusmīgais karalis". Skolotāja pārjautā un komentē: "Kāpēc gan ne?!"

Skolotāja aicina uzrakstīt, kas pēc šāda ievada varētu notikt turpmāk. "Strādāsim tikai ar turpinājumu!" Skolotāja vēl pieliek klāt divus virsrakstus "Negaidītās pārmaiṇas. Pazaudētā prieka vācelīte";" Varbūt kādam noder." Skolēni individuāli raksta burtnīcās. "Es uzlikšu loti klusu mūziku, vai tas netraucēs?" 
“Uz katra stūra uzlikšu lapiṇu, kas tev var palīdzēt, ja neraisās domas." Uz lapiṇas kontrollapa ar jautājumiem: "Vai visi apkārtējie arī ir tik dzīvespriecīgi? Kas princesi satrauca vai apbēdināja? Ko darīja princese? Kas palīdzēja? Kā tas beidzās?" Skolotāja staigā pa klasi. Ir klusums, notiek darbs.

Rosina turpināt mājās.

Skolotāja jautā: "Kurš gribētu nolasīt?" Aicina klausīties ar domu, vai cilvēks, kurš to ir rakstījis, ir ievērojis šos noteikumus: vai ir notikumi, sarežǵĭjumi, problēmas? Klausies uzmanīgi, vai tev ir savs viedoklis? Elizabete lasa. Skolotāja jautā, vai ir notikums, sarežǵíjums Elizabetes problēmā? Lasa Anna. Skolotāja jautā: "Vai tu, Anna, n̦ēmi vērā, ka bija ievads? Es tev ieteiktu vēlreiz pārdomāt, kā skanēja teikums. Tagad tev ir drīzāk ir jauna, bet skaista pasaka." Annija runā no galvas. Skolotāja komentē: "Domas skrien pa priekšu ātrāk, nekā tu spēj uzrakstīt." (lepriekš aicināja lasìt uzrakstīto.)

Mājas uzdevums uz A4 lapas. "Mēs aiziesim pie 1. klases Labo darbu nedēlā un nolasīsim uzrakstīto viniem priekšā. Tu saṇemsi mazu lapiṇu, un iesāktajiem teikumiem būs jāuzraksta nobeigums; šo lapiṇu es gribēšu atpakal,." "Es šajā stundā sapratu...; Rakstīt pasaku ir svarīgi...; Es pats vēl neprotu..." "No tā atkarīgs, ko mēs darīsim nākamajā stundā." "Vai mēs varētu padalīties: "Es šajā stundā sapratu..."' Lìva: "Jādabū iztēle!" Jautā: "Vai tu dabūji to, kas tev palī́lzēja? Loti labi!" Cits skolēns: "Es šajā stundā sapratu, kā labāk rakstīt." Jautā: "Kas tev palīdzēja?" ledvesma. Aicina pacelt roku, kurš zina, ko rakstīt ievadā, saturā, nobeigumā.

Kā pieeju atškiriība izpaužas konkrētos mācību stundas elementos atkarībā no skolotāja izvēles?

Svarīgi ir nosacījumi mācǐšanās mērķu (skolēniem sasniedzamo rezultātu) izvirzišanai:

- mērḳi ir saskaṇā ar mācǐšanās būtîbas kopainu (piemēram, izglìtības standartu);

- mērḳi fokusējas uz mācišanos (mēs mācāmies, lai...);

- mērḳi ved uz māciššnos iedziḷinoties un transversālo prasmju un prakšu apgūšanu;

- mērķi ir reāli un sasniedzami dotajā laika ietvarā (mācību stundas laikā);

- mērksi ir skolēniem kopīgi un saprotami (formulēti vecumam atbilstošã valodā, izskaidroti, pārrunāti ar skolēniem tā uzstādīšanas sākumposmā - mācību stundas sākumā) (Andrade, \& Heritage, 2017, p. 43).

Pārliecināšanās par sasniegto rezultātu pret plānoto mācību stundā ar tai sekojošu attīstošu atgriezenisko saiti katram skolēnam ir neiztrūkstoša šādas stundas daḷa. Vairums formālo testu (summatīvo mērijumu) kā vērtēšanas pieejas mēra spēju atcerēties kaut ko (Bloom, 1956), kas ir virspusējas mācīšanās pieejas elements. SOLO taksonomija atspoguḷo virzišanos/secību no virspusējas mācīšanās uz mācǐšanos iedzị̣inoties (Biggs, \& Collis, 1982). Tomēr jāṇem vērā: jo kompleksāks mācǐšanās mērḳis, jo sarežgitīāk to nomērìt. Izpratne par kompetencēm kā prasmi tikt galā ar ikdienas dzìves kompleksajiem izaicinājumiem nozīmē, ka vērtēšanas metodēm jābūt attiecīgi uzlabotām, elastīgām un orientētām 
uz procesu (Hughes, Green, \& Greene, 2014, p. 27). Skolēnu iesaistīšana sevis un citu skolēnu vērtēšanā un atgriezeniskās saites sniegšanā un saņemšanā var veicināt mācǐšanos iedzil̦inoties (Boud, \& Feletti, 1998; Falchikov, \& Goldfinch, 2000).

Stundā, kurā notiek mācīšanās iedziḷinoties, atslēga ir uzdevums, kuru skolotājs izvēlas dot skolēnam, kā arī tas, kā tiek veidots mācību process, strādājot ar šo uzdevumu. Vai uzdevums dos iespēju skolēnam iedziḷināties (darboties produktīvi) vai paliks reproduktīvā līmenī (reproduktīvi - atkārtot definīcijas, vienkāršus skaidrojumus, veikt tipveida darbības pēc iepriekš zināma parauga un tml.)? (Petty, 2014). Vairāk par uzdevumu izvēles kritērijiem - 3. nodaḷā.

Salīdzinājumam aplūkosim divas pieejas (skat. 3. tabulu), kā veidot mācīšanos, veicot 2. attēlā redzamo uzdevumu.

3. tabula. Viena uzdevuma divas pieejas tā risināšanā

\begin{tabular}{|c|c|}
\hline Variants A & Variants B \\
\hline $\begin{array}{l}\text { Skolēniem nepieciešams zināt, ka } \\
\text { fosfātus izmanto kā ūdens mīkstinātāju, } \\
\text { jāzina fosfātjona kīmiskā formula, jāzina, } \\
\text { kuri joni nosaka ūdens cietību, un jāprot } \\
\text { uzrakstīt saīsināto jonu vienādojumu. Ja } \\
\text { skolēnam trūkst zināšanu par kādu no } \\
\text { nosauktajiem elementiem, tad viṇš nevar } \\
\text { atrisināt uzdevumu. }\end{array}$ & $\begin{array}{l}\text { Skolēni uzdevuma tekstā atrod, ka ūdens cietību } \\
\text { veido kalcija un magnija joni; attēlā dotajā etiketē ir } \\
\text { atpazīstami fosfātjoni, tekstā ir rakstīts, ka ūdens } \\
\text { cietību samazina, jonus izgulsnējot nešḳistošu } \\
\text { savienojumu veidā. Skolēnam ir pieejama šk̦īības } \\
\text { tabula, kurā ir atrodamas atbilstošo jonu formulas. } \\
\text { Atliek sastādīt prasīto saīsināto jonu vienādojumu. Ja } \\
\text { skolēnam ir izpratne, kā vispār veidojas vienādojums, } \\
\text { tad vin̄š spēj ar šo uzdevumu tikt galā bez specifisku } \\
\text { zināšanu atcerēšanās. }\end{array}$ \\
\hline
\end{tabular}

Variantā A mācīšanās tiek veidota, iegaumējot konkrētus faktus un formulas, variantā B jāiegaumē minimāls nepieciešamās informācijas daudzums (ḳ̂̄misko elementu simboli). Process tiek veidots, attīstot prasmes domāt, izmantot informāciju, kas atrodama uzdevuma tekstā, un lietot specifisku informācijas avotu (šḳīības tabulu). Abos gadījumos iespējams nonākt līdz risinājumam, bet mērķi, izvēloties vienu vai otru pieeju, ir principiāli atšķirīgi: vienā gadījumā process balstās uz iegaumēšanu, otrā - uz informācijas apstrādes prasmju attīstīšanu, spriestspēju u. c. kognitīvajām prasmēm. Salīdzinot mērḳi ìstermiṇā (dažas stundas, temata apguve u. c.) vai ilgtermiṇā (pabeigta skola, sāktas darba gaitas) - kas skolēnam ir noderīgāk, īpaši, ja karjera netiek saistīta ar ķīmiju? Šis piemērs parāda, ka l̦oti bieži noteicošais ir nevis tas, ko mēs mācāmies, bet gan tas, kādu mērḳi gribam sasniegt un kādā veidā ir uzbūvēts mācīšanās process, t. i., kādu pieeju ir izvēlējies skolotājs. 
5. uzdevums (9 punkti)

Katra mājā atrodas desmit dažādu sadzīves k̦īmijas produktu. Viens no tiem ir trauku mazgājamā mašīnā izmantojamās tabletes.

Sastāvs: 30\% - fosfāti, 5-15\% - skābekḷa bāzes balinātājs, < $5 \%$ - polikarboksilāti, nejonu virsmaktīvās vielas, fosfāti, enzīmi (proteāzes), amilāzes.

Ūdens satur dažādus izškīdušos sālus, tostarp kalcija un magnija sāḷs, kas veido ūdens cietību. Trauku mazgājamā mašīnā izmantojamo tablešu sastāvā ir viela, ar kurām novērš vai samazina ūdens cietību. To panāk, kalcija un magnija jonus izgusnējot neškīstošu savienojumu veidā.

5.1. Aplūko attēlu ar tabletes sastāvu un uzraksti kīimisko formulu vielai, kuru var izmantot kā ūdens mīkstinātāju šajās tabletēs!

5.2. Starp ūdenī esošajiem joniem un ūdens mīkstinātāju norisinās ḳīmiskā reakcija. Uzraksti jonu vienādojumu šai daḷai.

2. attēls. Uzdevums kịimijā 12. klasei (VISC, 2016)

Iepriekš aplūkotajā piemērā (skat. 2. attēlu), darot zināmu šo mērḳi skolēniem, tas ietvertu ne tikai konkrēto mācību saturu par cietu ūdeni. Vienā gadījumā skolēniem būtu jāzina, ka viṇi mācās iegaumēt šo saturu, otrā - ka viṇi mācās domāt, lietojot tekstā doto informāciju.

Kā pieeju atšksirīiba izpaužas, veidojot mācību aktivitātes stundā? Piemēram, dabaszinībās mācoties par putnu uzbūvi un funkcijām, skolotājam ir izvēle izmantot modeli ilustrācijai vai dot iespēju skolēniem vingrināties apgūt modelēšanas prasmi (skat. 4. tabulu).

\section{4. tabula Atškirīgas mācīšanas pieeju izvēles}

\begin{tabular}{lr}
\hline Modelis kā ilustrācija & Modelēšana kā skolēna prasme \\
\hline $\begin{array}{l}\text { Skolotājs demonstrē putna } \\
\text { modeli un parāda, kā uzbūve ir } \\
\text { saistīta ar funkcijām. }\end{array}$ & $\begin{array}{r}\text { 1. Skolēni modelē putnu, izmantojot dažādus materiālus } \\
\text { un darba lapu. }\end{array}$ \\
& $\begin{array}{l}\text { 2. Skolēni nosaka, kādas funkcijas veiks un kādā vidē } \\
\text { dzīvos citas grupas izveidots putns. }\end{array}$ \\
\hline Skolēni klausās, pieraksta. & $\begin{array}{l}\text { Skolēni apgūst uzbūvi un funkcijas, radoši modelējot, } \\
\text { izvērtējot, t. i., veicot dzillas domāšanas darbības. }\end{array}$ \\
\hline
\end{tabular}

Otrajā gadījumā (skat. 4. tabulu) skolēni ne tikai iepazīstas ar putnu uzbūvi un funkcijām, bet paši vingrinās modelēt. Iedziḷinās, kā uzbūve ir saistīta ar funkcijām un vidi. Modelēšanas prasmes attīstǐšana pamatojas Gilberta teorētiskajā 
modelī (skat. 3. attēlu), kas liecina, ka atbilstoši izvēlētajam mērḳim vispirms norisinās modelēšana kā prāta darbība, tad kā praktiska darbība, tad radītais modelis tiek izvērtēts un uzlabots, veicot šo ciklu vairākkārt. Alternatīvajā gadījumāa skolēns ir pasīvs skolotāja demonstrētā modeḷa vērotājs (Gilbert, 2004).

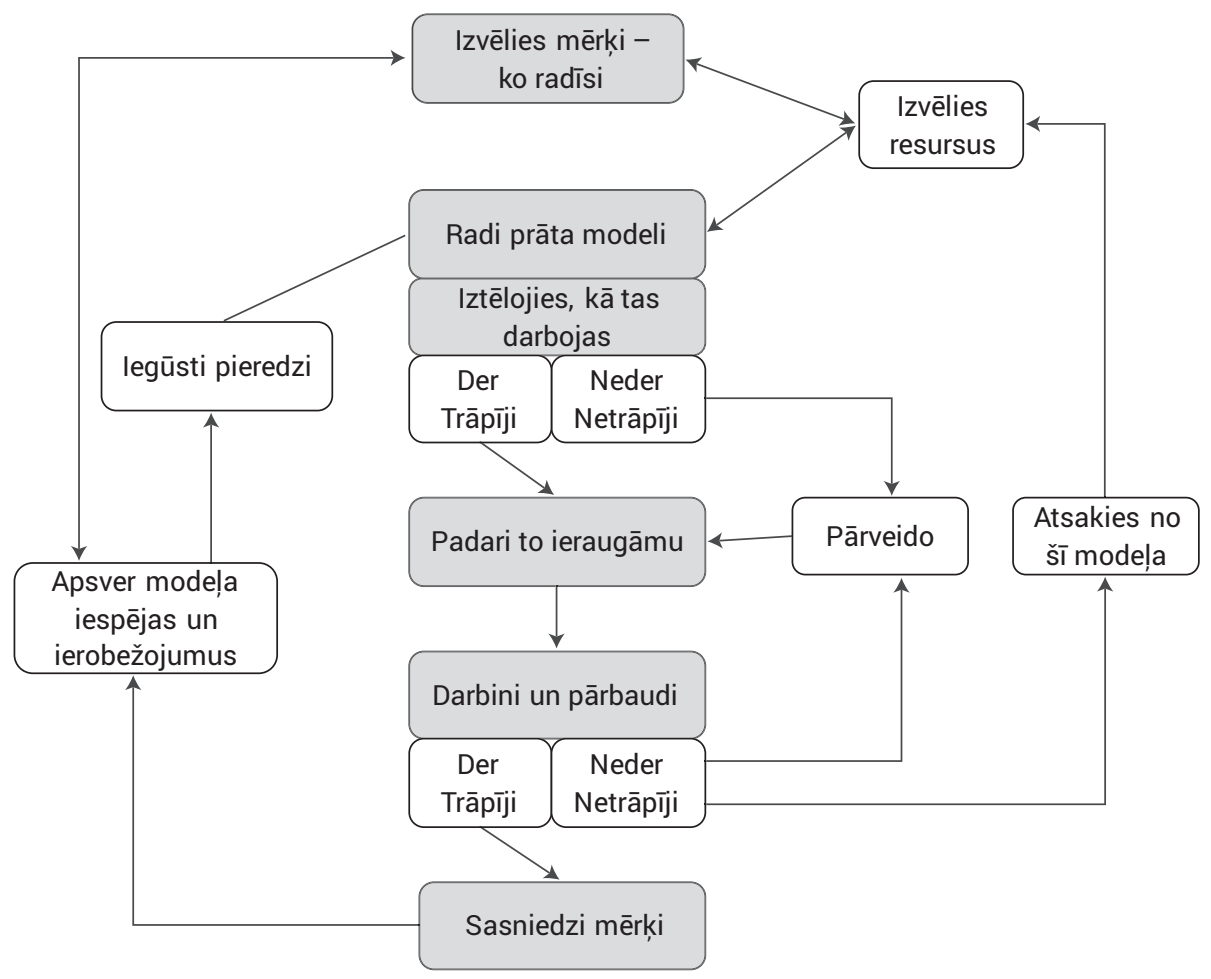

3. attēls. Modelēšana kā skolēna mācīšanās darbība (adaptēts pēc Gilbert, 2004)

Līdzīgas izvēles ir saistītas ar skolēnu pētnieciskās darbïbas (scientific inquiry) organizēšanu klasē u. c. Tikai no skolotāja ir atkarīgs, vai skolēnam ir iespēja apjēgt, kā strādā pētnieks, un gūt šādas mācīšanās pieredzi.

Piemērā aplūkosim skolēna mācīšanos iedziḷinoties fizikas stundā 8. klasē, kur skolotāja V. māca skolēniem eksperimentāli noteikt ķermeņa blīvumu. praktiskajam darbam (vārglāzes, svari, diegi utt.). Skolēni saṇem darba lapas, kurās ir uzdevumi. Skolotāja saka, ka stundas mērkis būs, strādājot pāros, pašiem noteikt doto kermeṇu (arī škidrumu) blīvumu un ka uzmanība tiks pievērsta arī sadarbībai. 
Uzdevumu varianti ir:

1. Noteikt blīvumu:

a) koka klucītim un pienam;

b) koka klucītim un dotajam škidrumam (nezināmam);

c) metāla armatūras stienim un kartupelim;

d) metāla armatūras stienim un ābolam.

2. Secīgi aprakstīt uzdevuma izpildes gaitu, iegūtos mērījumus un parādīt aprēkinu. Skolēni sāk darīt, sarunāties. Daži pāri uzreiz sāk darboties ar piederumiem. Viens n̦em armatūras gabalu, ṇem diegu un sien; cits lej vārglāzēēdeni utt.; citi sarunājas; kāds pāris pieraksta plānu, ko darīs utt. Skolotāja staigā un vēro skolēnus, iesaistās sarunās. Ir redzams, ka ar blīvuma noteikšanu metālam skolēni tiek galā, to ievietojot mērglāzē ar ūdeni. Skolēni dara, tad pieraksta, aprēkina. Atškiras, cik ātri katra grupa tiek uz priekšu. Veicot otro uzdevumu, ir grupa, kas lielu ābolu mēǵina ievietot mazā vārglāzē. Pie cita galda no ābola ir izgriezts ǵeometrisks gabaliṇš (gandrīz kubs). Viens pāris spriež, kā noteiks piena blīvumu. Skolēni ir ielējuši pienu divos traukos; un skolotāja jautā: "Vai tu domā, ka, ielejot divos traukos, piena blīvums atškirsies? Kāpēc tu tā domā?" Skolotāja uzdod jautājumus, cenšas neteikt priekšā. Pēc laika redzams, ka arī tie skolēni, kuri visu ābolu gribēja iedabūt vārglāzē, izgriež gabaliṇu.

Skolotāja dod uzdevumu telpas stūros kopā par darbu secību apspriesties tām grupām, kurām bija līdzīgi uzdevumi. Grupas aktīvi sarunājas; kāds jautā, kā vajadzēja darīt; cits stāsta; skolēni salīdzina rezultātus. Kāds pāris konstatē: "Sapratām, kā jādara", atstāj lielo grupu un dodas pabeigt savu darbu; skolotāja ieklausās sarunā; dod nākamo uzdevumu, lai katrs pāris komentē savu vērtējumu par iegūtajiem rezultātiem un apraksta izmantoto metožu plusus un minnusus.

Kāpēc šì ir mācǐšanās iedziḷinoties? Ir problēma. Otrajā piemērā skolēniem ir radīta jauna situācija (ābols, šķidrums), kad iepriekš redzētais nav pietiekams risinājumam. Nepieciešams salikt kopā visu vinuu rīcībā esošo informāciju, lai izvēlētos paņēmienu, kā darīt. Skolēni sarunājoties, sadarbojoties tiek paši galā plāno, izdomā, kā rīkoties; ja nepieciešams, mēǵina vairākas reizes. Ja iepriekšējais informācijas apjoms ir pietiekams, tad ir risinājums. Ja ir tāda vajadzība, skolēni saṇem atbalstu no klasesbiedriem vai skolotāja. Izpratne par to, kā darìt, veidojas pētnieciskā procesā. Vienlaikus šādas mācību pieejas izvēle dod iespēju skolotājam gūt labāku priekšstatu par skolēnu mācǐšanos. Pāri ir izvēelēti nejauši. Tikai ieklausoties sarunā, kas parāda, kā skolēni konkrētajā grupā domā, skolotājs ierauga, ko īsti skolēni saprot par to, kas ir blīvums un kā to ir iespējams noteikt; skolotājs uzzina radušos maldīgos priekšstatus un var plānot, kā ar tiem strādāt turpmāk. 
Skolotājs U. māca noteikt blīvumu atšķirīgi:

Skolēniem izdalîti dažādu materiālu, bet vienāda (zināma) tilpuma klucīši. Skolotājs aicina tos nosvērt un kopīgā sarunā secina, ka dažādām vielām vienāda tilpuma objektiem ir dažādas masas, tātad kaut kas atškiras pašā vielā. Skolotājs stāsta, ka šis lielums ir blīvums. Skolotājs izstāsta blīvuma definīciju, aicina to pierakstīt kladē, parāda skolēniem blīvuma aprēkināšanas formulu uz tāfeles, aicina to pierakstīt kladē, izskaidro visus lielumus un mērvienības, izrēkina kopīgi vienu piemēru. Izrunā, ka labi cilvēki jau sarēkinājuši vielu blīvumus un apkopojuši tos tabulās. Parāda, kā atrast blīvumu tabulā. ledod katram pārim trīs koka klucīšus vai metāla cilindrus un, mērot un aprēkinot pēc dotās formulas, liek noteikt, no kādas koksnes vai metāla tie izgatavoti. Skolēnam pieejams lineāls un atsperes svari. Skolēni rēkinina, tabulās atrod vistuvāko materiālu.

Kāpēc šì nav mācǐšanās iedziļinoties? Skolēni rīkojas tipveida situācijā - klausās skolotāja teikto, pieraksta definīciju, no tāfeles noraksta paraugu, kā aprēķina blīvumu; vēro paraugu, kā skolotājs atrod blīvumu tabulā; tad ilustrē apgūto praktiski nosaka ķermen̦a blīvumu, mērot masu un tilpumu un aprēķinot to pēc dotas formulas.

5. tabulā apkopotas pazìmes, kas raksturo mācīšanās iedziḷinoties pieejas īstenošanu mācību stundā no skolotāja darbību viedokḷa. Tabula veidota kā praktisks rīks skolotāja darba pašnovērtējumam un refleksijai, vienaudžu savstarpējam vērtējumam, lai attīstītu un nostiprinātu mācī̌sanās iedziḷinoties praksi skolotāju ikdienas darbā. Pazīmes atvasinātas no teorētiskās literatūras apskata un skolotāju stundu vērojumiem periodā no 2011. līdz 2017. gadam un tālāk pilnveidotas LU SIIC darbā, īstenojot pedagogu profesionālo pilnveidi.

Lai notiktu mācǐšanās iedziḷinoties, tiek veikta iepriekšèjā satura aktualizācija. Jaunā satura apjēgšana tiek veidota, paplašinot esošo, iepriekš apgūto pieredzi un dodot iespēju jaunapgūto lietot, darbināt un par to reflektēt. Papildus tiek vingrinātas prasmes, lai panāktu, ka skolēns apzināti var izteikties par to, ko nozīmē novērot, secināt, strukturēt informāciju, izvērtēt savu darbu pret plānoto, un kā to dara. 
5. tabula. Mācību stundu analīzes lapa "Skolotājs stundā vada mācīšanos iedzilinoties" (LU SIIC arhīvs)

\begin{tabular}{lcc}
\hline Skolotājs stundā & Ir/nav & $\begin{array}{c}\text { Pierādījumi mācību } \\
\text { stundā vērotajam }\end{array}$ \\
\hline
\end{tabular}

\section{Sagatavo, lai notiek mācīšanās:}

- komunicē skolēniem sasniedzamo rezultātu

- aktualizē skolēnu pieredzi

- rosina skolēnu interesi

\section{Vada mācišanos}

Izvēlas mācību uzdevumus:

- tie virza uz sasniedzamo rezultātu

- tie ir produktīvi - dod iespēju skolēnam pašam konstruēt zināšanas

- uzdevumu un mācību aktivitāšu secība skaidra, pamatota, savstarpēji saistīta

Komunicē uzdevumus:

- dod skaidrus, saprotamus norādijjumus

- uzdevumam ir atbalsta struktūra, kas palīdz darīt

Veicina, atbalsta mācīšanos:

- iesaista skolēnus

- skolēniem ir pietiekami daudz laika, lai domātu

- diferencē uzdevumus un aktivitātes atbilstoši skolēnu spējām, vajadzībām

Metakognitīvais līmenis:

- māca metakognitīvās stratēǵijas, rosina skolēnus domāt par to, ko un kā dara

\section{Sadarbības organizēšana un mācīšana}

Izmanto un māca skolēnus izmantot dažādus mācību rīkus, līdzeklus:

- IT

- piederumus, ierīces

- dažādus informācijas avotus

Dod atgriezenisko saiti skolēniem

- konstatē rezultātu - iegūst informāciju par sasniegto

- dod skolēniem izmantojamu atgriezenisko saiti, lai uzlabotu mācīšanos

- māca skolēnus dot un saṇemt atgriezenisko saiti 


\section{Secinājumi}

Lai skolēna mācīšanās rezultāts būtu kompetence, kas pēc savas būtības ir kompleksa un ietver gan zināšanas, gan prasmes un attieksmes, kā arī spēju šos atsevišķos elementus integrēt saskan,otā, mērḳtiecīgā un atbildīgā rīcībā, skolotājiem svarīgi īstenot mācī̌sanās iedzilinoties pieeju - plānot un veidot procesu, kura laikā skolēns attīsta spēju vispārināt, pārnest jaunās zināšanas un prasmes uz nezināmām situācijām (tostarp reālās dzīves situācijām), mācǐšanas priekšplānā izvirzot procesus, ar kuru palīdzību mēs iegūstam zināšanas (kā mēs zinām?), ne tikai uzkrātu noteiktu satura apjomu (ko mēs zinām?). Īstenojot metodisko pieeju, kas virza mācīšanos iedzị̣inoties, skolotājs dod iespēju skolēnam attīstīt augsta līmeņa kognitīiās prasmes - analizēt, sintezēt, izvērtēt, risināt problēmas, attīstīt metakognitīvās prasmes, lai skolēns spētu konstruēt apgūtā jēgu un izmantot pieredzi, risinot kompleksus uzdevumus jaunās situācijās un kontekstā.

Novērojumi stundās liecina, ka šie mācī̌sanās iedzilịnoties elementi sastopami atsevišķu skolotāju praksē, taču tie nav pietiekami bieži novērojami sistēmas līmenī. Nepieciešama akcentu maiņa mācī̌anas pieejā:

- no gatavu zināšanu nodošanas un atprasišsanas uz jautāšanu, sarunu, situāciju analīzi, produktīviem uzdevumiem, radot jaunas zināšanas;

- no frontāla procesa uz iesaistišanos un sadarbību;

- no faktologisku zināšanu iegaumēšanas uz zināšanu lietošanu daudzveidīgās situācijās un kontekstā, lai skolēni iegūtu šādas vingrināšanās un pārnesuma veidošanas pieredzi;

- no tikai summatīvās vērtēšanas uz jēgpilnu atgriezenisko saiti par mācīšanās procesu, refleksiju, mācīšanās apzināšanos.

Lai skolēnu mācišanās rezultāts būtu kompetence, skolu praksē nepieciešams:

- katram skolotājam darbu klasē virzìt uz iedziḷināšanos; mainìt veidu, kā skolas līmenī tiek plānots un organizēts mācību saturs un vērtēšana.

\section{IZMANTOTĀ LITERATŪRA}

Andrade, H. L., \& Heritage, M. (2017). Using Formative Assessment to Enhance Learning, Achievement, and Academic Self-Regulation. Routledge.

Biggs, J. (1987). Student approaches to learning and studying. Melbourne: Australian Council for Educational Research.

Biggs, J., Kember, D., \& Leung, Y. (2001). The revised two-factor study process questionnaire: R-SPQ-2F. British Journal of Educational Psychology, 71, pp. 133-149.

Biggs, J. B., \& K. F. Collis. (1982). Evaluating the quality of learning: The SOLO taxonomy. New York: Academic. 
Bloom, B. S. (ed.). (1956). Taxonomy of educational objectives: the classification of educational goal. New York: Longmans Green.

Boud, D., \& Feletti, G. (1998). The challenge of problem-based learning. London: Routledge.

Boulton-Lewis, G. M., Smith, D. J. H., McCrindle, A. R., Burnett, P. C., \& Campbell, K. J. (2001). Secondary teachers' conceptions of teaching and learning. Learning and instruction, 11(1), pp. 35-51.

Chin, C., \& Brown, D. E. (2000). Learning in science: A comparison of deep and surface approaches. Journal of research in science teaching, 37(2), pp. 109-138.

Entwistle, N. (2001). Conceptions, styles and approaches within higher education: Analytic abstractions and everyday experience. In Perspectives on cognitive, learning, and thinking styles, Sternberg, R. \& Zhang, L. F. (eds.). pp. 103-36. Mahwah, NJ: Erlbaum.

Falchikov, N., \& Goldfinch, J. (2000). Student peer assessment in higher education: A meta analysis comparing peer and teacher marks. Review of Educational Research, 70(3), pp. 287-322.

Fullan, M., \& Langworthy, M. (2013). Towards a new end: New pedagogies for deep learning. Seattle, Washington: Collaborative Impact.

Fullan, M., \& Langworthy, M. (2014). A rich seam: How new pedagogies find deep learning. MaRS Discovery District.

Fullan, M., \& Scott, G. (2014). New pedagogies for deep learning. Whitepaper: Education PLUS.

Gardner, H., \& Perkins, D. N. (1988). Art, mind, and education: Reasons from project Zero. Champaign: University of Illinois Press.

Gilbert, J. K. (2004). Models and modelling: Routes to more authentic science education. International Journal of Science and Mathematics Education, 2(2), pp. 115-130.

Greene, J. A., \& Azevedo, R. (2009). A macro-level analysis of SRL processes and their relations to the acquisition of a sophisticated mental model of a complex system. Contemporary Educational Psychology, 34(1), pp. 18-29.

Hattie, J. (2009). Visible Learning. A synthesis of over 800 meta-analysis relating to achievement. Routledge, London and New York (Appendix A).

Hattie, J. (2012). Visible learning for teachers: Maximizing impact on learning. Routledge. Hattie, J., \& Yates, G. C. (2013). Visible learning and the science of how we learn. Routledge. Hughes, S., Green, C., \& Greene, V. (2014). Report on current state of the art in formative and summative assessment in IBE in STM-Part 2. Pieejams: http://assistme.ku.dk/resources/ report_series/ (aplūkots 7.11.2017.).

Lampert, M. (2015). Deeper teaching. Boston, MA: Jobs for the Future. Pieejams: https:// jfforg-prod-prime.s3.amazonaws.com/media/documents/Deeper-Teaching-120315.pdf (aplūkots 07.11.2017.).

Marton, F. (1983). Beyond individual differences. Educational Psychology, 3, pp. 289-303.

Marton, F., \& Säljö, R. (1984). Approaches to learning. In Marton, F., Hounsell, D., \& Entwistle, N. (eds.). The experience of learning. Edinburgh: Scottish Academic Press.

Niaz, M. (2008). Whither constructivism? - A chemistry teachers' perspective. Teaching and Teacher Education, 24(2), pp. 400-416.

O’Toole, M. T. (2005). Miller-Keane Encyclopedia \& Dictionary of Medicine, Nursing \& Allied Health ( $7^{\text {th }}$ Ed.). Philadelphia: WB Saunders.

Petty, G. (2014). Evidence-based teaching. Oxford University Press. 
Ramsden, P. (1988). Context and strategy: Situational influences on learning. In Schmeck, R. R. (ed.). Learning strategies and learning styles, pp. 159-184. New York: Plenum.

Reece, I., \& Walker, S. (2016). Teaching, training and learning: A practical guide $\left(6^{\text {th }}\right.$ ed.). Business Education Publishers Ltd.

Schunk, D. H., \& Zimmerman, B. (eds.). (2011). Handbook of self-regulation of learning and performance. Taylor \& Francis.

Smith, T. W., \& Colby, S. A. (2007). Teaching for deep learning. The Clearing House: A Journal of Educational Strategies, Issues and Ideas, 80(5), pp. 205-210.

Smith, T. W., Gordon, B., Colby, S. A., \& Wang, J. (2005). An examination of the relationship between depth of student learning and National Board Certification status. Office for Research on Teaching, Appalachian State University. Pieejams: http://images3.cersp.com/ blog2/uploadfiles/2006-12/1210107137.pdf (aplūkots 01.11.2017.).

Trigwell, K., Prosser, M., \& Waterhouse, F. (1999). Relations between teachers' approaches to teaching and students' approaches to learning. Higher education, 37(1), pp. 57-70.

Vos, N., van der Meijden, H., \& Denessen, E. (2011). Effects of constructing versus playing an educational game on student motivation and deep learning strategy use. Computers \& Education, 56(1), pp. 127-137. 


\title{
3. nodala \\ Kā vērtē kompleksu sniegumu
}

\author{
Dace Namsone, Zane Olina
}

Izglìtībā vērtēšanu izmanto trīs galvenajiem mērķiem: atbalstīt skolēnu mācǐšanos, sertificēt (izsniegt apliecinājumu) skolēna mācīšanās rezultātus un apmierināt sabiedrības pieprasijumu pēc sistēmas vai iestādes atbildības, iegūstot datus par tās darbïbas kvalitāti. Viens un tas pats uzdevums (testelements ${ }^{1}$ ) var tikt izmantots dažādiem mērḳiem, līdzīgi kā vienam mērḳim var tikt izmantota vērtēšanas procesā iegūta informācija no dažādiem avotiem (Black, \& Wiliam, 2007).

21. gadsimtā no skolēna tiek sagaidīta kompetence jeb lietpratība, ko demonstrē kā kompleksu sniegumu. Pie mums pazīstamākie pètijumi, kuros komplekss sniegums tiek mērīts, ir OECD (The Organisation for Economic Co-operation and Development) PISA (The Programme for International Student Assessment) pētijumi lasītprasmē (lasīšanā) jeb tekstpratībā² dabaszinātnēs, matemātikā ${ }^{3}$.

Kompetence sastāv no zināšanu, prasmju, ieradumu kopuma, ko skolēns demonstrē kā kompleksu sniegumu koordinētā darbībā. Kompleksu sniegumu mēra, izvēloties atbilstošus uzdevumus, izvirzot kritērijus snieguma izvērtēšanai un aprakstot snieguma kvalitātes līmeņus. Kompleksa snieguma vērtēšana, par pamatu ņemot vairākas snieguma dimensijas un izvērtējot snieguma kvalitāti katrā, būtiski atškịiras no tradicionāli izmantotās standartizētās rezultāta vērtēšanas pieejas, kad testu veidā tiek vērtēta rezultāta pareizība, skaitot punktus, izmantojot tikai skalu pareizi/nepareizi jeb 1/0.

1 Vērtēšanas kontekstā par testelementu sauc strukturēta pārbaudes uzdevuma daḷu vai veselu uzdevumu.

2 Pieejamajā literatūrā latviešu valodā termins reading literacy (angl.) tiek tulkots kā lasītprasme, lasǐšanas kompetence vai tekstpratîba, ko var uzskatīt par sinonīmiem.

3 OECD pētījumu rezultāti. Pieejams: https://www.ipi.lu.lv/publikacijas/ (aplūkots 12.02.2018.). 
Kompleksa snieguma mērǐšana, kombinējot dažādus vērtēšanas rīkus, tostarp izmantojot snieguma vērtěšanas pieeju, kḷūst par neatṇemamu sastāvdal̦u, gan vērtējot ikdienas mācību procesā (mikrolīmenī), vērtējot, lai mācìtos (formatīivi), un vērtējot mācīšanās rezultātu (summatīvi), gan makrolīmenī jeb nacionāla (arī starptautiska) mēroga pārbaudes darbos. Šo izmaiṇu pamatā ir nozīmīgas izmainas mācību saturā, ko raksturo nepieciešamība arvien lielāku uzsvaru mācībās likt uz kompleksu prasmju mācǐšanu. Linda Dārlinga-Hamonda un Frenks Adamsons uzsver, ka, mainoties prasmēm, kas skolēniem jāapgūst 21. gadsimtā, ir jāmainās arī pieejai vērtēšanā, jo svarīgas ir ne tikai zināšanas, bet arī tas, ko skolēns spēj ar tām paveikt (Darling-Hammond, \& Adamson, 2010). Nepieciešams paplašināt ikdienā izmantojamos vērtēšanas paṇēmienus ar snieguma vērtēšanu, kas ḷauj precīzāk izvērtēt kompleksu sniegumu. Problēma ar standartizētu testu izmantošanu, kad skolēniem lielākoties jāizvēlas atbildes uz jautājumiem no dotajiem atbilžu variantiem, ir tā, ka tas nostiprina vērtēšanas un tāpēc arī mācišanas fokusu vienīgi uz zemāka kognitīva līmeņa prasmēm, nepietiekami lielu uzmanību pievēršot kompleksam sniegumam, kas svarīgs 21. gadsimtā. Šādus testus gan iespējams relatīvi lēti un vienkārši administrēt, taču tie pēc būtības nav piemēroti, lai novērtētu skolēnu spēju formulēt patstāvīgu viedokli, izvēlēties saviem apgalvojumiem atbilstošus pierādījumus vai demonstrēt citas augstāka līmeņa prasmes. Viṇi uzsver, ka ir apjomìgs skaits pētijumu, kas liecina par centralizēto pārbaudes darbu formas un satura lielo ietekmi uz mācǐšanu. Tāpēc, ka skolās māca to, ko vērtē, standartizētu testu ar ierobežotiem atbilžu variantiem, kas mēra izolētas zemāka līmeņa prasmes, izplatība un nostiprināšanās jo îpaši sašaurinājusi izglitīibas iespējas akadēmiski vājākajiem skolēniem. Turklāt šāda pieeja samazinājusi iespējas akadēmiski spējīgākajiem skolēniem demonstrēt, ko viṇi patiešām var paveikt. Autori citē pētījumus, ka ar šāda veida pārbaudỉjumiem skolotāji arvien mazāk rosina skolēnus veikt eksperimentus, gatavot mutiskas uzstāšanās, rakstìt apjomīgus pārspriedumus un piedāvāt cita veida intelektuāli izaicinošus uzdevumus, kas vienlaikus rosina skolēnu interesi par mācībām. Pètỉjumos daudz aprakstìtā standartizēto testu sistēma un skolotāju vēlme gatavot skolēnus konkrētiem testiem nereti noved pie pavisam cita rezultāta mācību procesā, nekā tiek sagaidīts. Piemēram, matemātikā mācỉbu programmas turpina būt sadrumstalotas, un to sekas ir skolēnu sadrumstalotā matemātiskā pieredze (Pecheone, \& Whittaker 2016, p. 50; Black, \& William, 2007).

Mācību saturā arvien lielāku uzmanību pievēršot dziḷākas izpratnes veidošanai, prasmju attīstišanai, lietojot to starppriekšmetu kontekstā, sniegumu nav iespējams izmērìt skalā pareizi/nepareizi. Gadu desmitiem turpinās centieni izstrādāt pārbaudes darbus konceptuālas, dziḷas matemātiskās izpratnes mērī̌̌anai, tostarp starptautiski - NAEP (The National Assessment of Educational Progress), 
TIMSS (Trends in International Mathematics and Science Study), PISA un dažādu valstu darbos (Wertheim, Holthuis, \& Schultz, 2016).

ASV, līdzīgi kā daudzās valstīs, tiek ieviests jauns mācību saturs, kam vajadzētu sekot arī atbilstošiem vērtēšanas rīkiem. Jaunais saturs paredz, ka "skolēns izprot un var lietot jaunas idejas daudzveidīgā kontekstā, veidojot sasaisti starp dažādiem šo ideju attēlojumiem (Wertheim et al., 2016, p. 86). Tomēr jauni vērtēšanas rīki vēl top Piemēram, dabaszinātnēs skolotājiem, skolu administratoriem u. c. ir pieejami tikai atseviški atbilstoši izmantojami resursi, jo desmitiem gadu ilgi atsevišķi ir tikušas vērtētas skolēnu mācību satura zināšanas un pētnieciskā procesa prasmes (Hannaway, \& Hamilton, 2008; Pellegrino, 2013). Jaunu vērtēšanas instrumentu izstrāde prasa jaunus pētijjumus un laiku, lai tos veiktu. Piemēram, dabaszinātnēs saturā akcentējot skolēna prasmes - spriest par parādībām un procesiem dabā, izmantojot pierādỉjumus, risināt dabaszinātniskas vai inženiertehniskas problēmas, reflektēt par zinātnes procesu u. c., mācīšanās rezultāts tiek aprakstīts kā skolēna darbība, ko viņš spēs veikt, jeb sniegums.

\section{Kas ir snieguma vērtēšana}

Ričards Stigins un autori (Stiggins, Arter, Chappuis, \& Chappius, 2004) atzīmē, ka tikai ar snieguma vērtěšanas palīdzību iespējams adekvāti novērtēt skolēnu prasmes, kuras nepieciešams demonstrēt (performance skills targets). Vienīgais veids, kā noteikt, vai skolēns spēj "prasmīgi izmantot prasmi", ir novērot skolēnu darbošanās procesā un izdarot spriedumu par viņa snieguma līmeni. Tāpat vienīgais paṇēmiens, kā iespējams pārliecināties, vai skolēns spēj radīt kādu produktu, ir snieguma vērtēšana - likt viņam radīt produktu vai demonstrēt sniegumu un tad vērtēt tā kvalitāti. R. Stigins un autori (2004) uzsver, ka snieguma vērtēšana ir tāda pieeja vērtēšanai, kas balstita uz novērojumiem par skolēna darbību vai radītu produktu un sprieduma izteikšanu par novēroto.

Kā atzìmē Džeimss Popams (James Popham) (Popham, 2008), pētnieku viedokḷi par to, kas ir snieguma vērtēšana, atšķiras. Daži uzskata, ka jebkurš vērtēšanas paṇēmiens, kad skolēniem jānoformulē sava oriğināla atbilde, ir snieguma vērtēšanas piemērs. Tātad jebkura situācija, kad skolēnam jāsniedz ìsa atbilde vai jāraksta eseja, ir snieguma vērtēšanas piemērs. Citi uzskata, ka par snieguma vērtēšanu var saukt tikai tādas vērtēšanas formas, kas atbilst vismaz trim kritērijiem:

- sniegums jānovērtē, izmantojot vairāk nekā vienu vērtēšanas kritēriju;

- katram vērtēšanas kritērijam ir jau iepriekš izveidots kvalitātes līmeņu apraksts,

- sniegumu vērtēs parasti kāda persona (atšķirībā no automatizētas vērtējuma izlikšanas), pamatojoties uz savu spriedumu. 
Parasti, izmantojot snieguma vērtēšanu, skolotājs vai cits interesents vai nu novēro skolēna sniegumu tā veikšanas laikā, vai arī izvērtē sniegumu pēc fakta, ja skolēns izveidojis kādu produktu, ko iespējams apskatìt. Tiek norādīts, ka nav iespējams skaidri nodalìt atškirīibu starp snieguma vērtēšanu un citiem vērtēěanas veidiem (Popham, 2008). Galvenā atšķirīiba starp snieguma vērtēšanu un tradicionālajām pārbaudes formām ir pakāpē, kādā snieguma vērtēšanas uzdevums simulē iecerēto sasniedzamo rezultātu.

\section{Snieguma vērtēšanas ideju attīstība}

Snieguma vērtēšana vispārējā izglîtỉbā ir relatīvi jauna parādība. Tā daudz lielākā mērā un sistemātiski tikusi izmantota personālvadībā un pieaugušo izglītībā korporatīvajā vidē, novērtējot darbinieku sagatavotību veikt atbilstošus pienākumus darba vidē un identificējot profesionālās izaugsmes vajadzības.

Snieguma vērtēšana ilgus gadus tiek izmantota tieši pieaugušo izglìtībā, profesijās industrijā, kur ir svarīgi izvērtēt un attīstìt darbinieku kompetences profesionālās situācijās. Lai identificētu darbinieku profesionālās pilnveides vajadzības vai novērtētu viņu piemērotību noteiktu uzdevumu veikšanai vai darbībai noteiktā kontekstā, bieži izmanto tā saukto deficìta analīzi (gap analysis), novērojot darbībā izcilākos, prasmīgākos uzdevuma veicējus, lai iegūtu laba snieguma aprakstu, uz kura pamata tālāk veidot snieguma limennu aprakstus (Popham, 2008).

Snieguma vērtēšana visbiežāk un veiksmīgāk izmantota jomās, kur nepieciešamas tehniskas prasmes, kuras iespējams relatīvi vieglāk aprakstìt, novērot un izvērtēt. Tehnisko prasmju demonstrēšanas gadījumā ir iespējams izvērtēt arī šo darbību galarezultātu - pašu produktu, ne tikai procesu. Tà sauktās cilvēkprasmes (soft skills) jeb sociāli emocionālās prasmes ir grūtāk izvērtēt ar augstu ticamības pakāpi, jo to izpausme daudz lielākā mērā atkarīga no konkrētās situācijas.

Veidojoties arvien lielākai pieredzes bāzei un pārliecỉbai par snieguma vērtēšanas pieeju un paṇēmieniem, šìs vērtēšanas pieejas izmantošana paplašinās. Snieguma vērtēšana ir pamatā visu veidu sertificēšanas sistēmām. Arvien vairāk, tostarp augstākajā izglìīibā, tiek pieļautas un ieviestas pieredzes pielīdzināšanas sistēmas, kas lielā mērā balstās uz pārliecību, ka snieguma vērtēšanā iespējams iegūt ticamu vispārināmu informāciju par bērna, jaunieša vai pieaugušā prasmju līmeni. Snieguma vērtěšanai un šajā procesā izmantotajiem instrumentiem, kas ietver snieguma lìmeņu aprakstus, ir potenciāli liela ietekme uz mācību procesa kvalitāti gan individuāla skolotāja un skolēna līmenī, gan lielāku sistēmu, piemēram, skolu kā institūciju, līmenī. Izvirzot skaidrus un konkrētus kritērijus, ir iespējams piedāvāt laba snieguma aprakstu, kas var kalpot kā signāls turpmākas attīstības virzienam un palīdzēt identificēt konkrētas darbības jomas, kurās nepieciešami uzlabojumi. 


\section{Snieguma vērtēšana makrolīmenī}

Kā raksta Dž. Popams (Popham, 2008), snieguma vērtēšana vispārējā izglītîbā īpašu popularitāti ieguva 20. gadsimta 90. gadu sākumā. Iemesls bija tas, ka daudzi izglìīibā iesaistītie nebija apmierināti ar to, cik adekvāti ierobežotu atbilžu standartizētie testi novērtē skolēnu prasmes veikt uzdevumus reālas dzīves kontekstā. Popams atzīmē, ka daudzi snieguma vērtēšanas aizstāvji vēlētos, lai skolēni saņemtu vērtēšanas uzdevumus, kas arvien vairāk līdzinās situācijām, kuras viniiem būs jāveic reālajā dzīvē, nevis tie izskatītos pēc tipiskiem "skolas uzdevumiem".

Dž. Stigins un autori (2004) uzsver vairākus snieguma vērtēšanas aspektus, kas ir īpaši raksturīgi mūsdienām. Pirmkārt, joprojām pastāv izaicinājums - izmantojot sistemātisku pieeju, padarì šo subjektīvo vērtēšanas formu pēc iespējas objektīvāku. Vislabāk to var panākt, kalibrējot vērtēšanu jeb starp vairākiem vērtētājiem panākot vienādu izpratni par snieguma kvalitāti. Otrkārt, snieguma vērtēšana kḷūst arvien populārāka, vērtējot arī makrolīmenī: attīstot paṇēmienus snieguma sistemātiskai izvērtēšanai, panākot, ka vērtētāji vērtē sniegumu pēc iespējas līdzīgi. Treškārt, snieguma vērtēšana arvien vairāk tiek izmantota ar mērḳi uzlabot mācīšanos (assessment for learning). Kā atzīst Dž. Stigins un autori (2004), paradoksāli, ka mēǵinājumi objektivizēt snieguma vērtēšanu noveduši pie tā, ka skolēni arvien vairāk tiek iesaistīti sava darba novērtēšanā. Prasmīgi izmantojot snieguma vērtēšanu, skolēniem ir iespēja skaidrāk saredzēt sava snieguma kvalitātes līmeņus un izprast kvalitatīva darba raksturiezīmes jeb kritērijus.

Arī L. Dārlinga-Hamonda un F. Adamsons (Darling-Hammond, \& Adamson, 2010) savā ziņojumā raksta, ka šobrīd ir atrasti un attīstìti atbilstoši paṇēmieni, lai panāktu ḷoti augstu sakritību vērtējumos, arī vērtējot makrolīmenī. Autori uzsver, ka pretstatā pašlaik īpaši ASV izplatītajai centralizēto pārbaudes darbu praksei pasaules labākajās izglīiības sistēmās, piemēram, matemātikā un dabaszinātnēs māca mazāku skaitu tematu, taču mācīšanās notiek dzị̄ākā līmenī jeb izziņas pakāpē. Ziņojumā iekḷauts plašs piemēru loks no Singapūras, Austrālijas, Somijas, Lielbritānijas, arī starptautiskā bakalaurāta programmām un atsevišķām ASV pavalstīm, kur arī valsts mēroga pārbaudījumos plaši tiek izmantota snieguma vērtēšana. Skolēnu snieguma vērtēšana nereti tiek īstenota, kombinējot skolotāju vērtējumus ar centralizētām procedūrām un ārējiem vērtētājiem. Autori uzsver, ka, attīstoties tehnologijiām, kvalitatīvas snieguma vērtēšanas īstenošanas izmaksas lielā mērogā samazināsies. Turklāt šìs vērtēšanas pieejas iespējamie ieguvumi ir daudzkārt lielāki, nekā izmantojot tradicionālās vērtēšanas pieejas. Iesaistot skolotājus vērtēšanas procesā kā lēmumu pieņēmējus un dodot skolēniem noderīgāku atgriezenisko saiti par vinu sniegumu, snieguma vērtēšana var pozitīvi ietekmēt mācību saturu un pieeju. Ziņojuma autori lieto analog̣iju 
ar autovadītāja braukšanas pārbaudi, kas jānokārto, lai saṇemtu autovadītāja apliecỉbu. Gatavošanās braukšanas eksāmenam palīdz nākamajam autovadītājam uzlabot savu prasmi. Snieguma vērtēšanas izmantošana izglìtībā palīdz skolotājiem iegūt informāciju par to, ko skolēni spēj paveikt ar to, ko viṇi mācās. Autori apgalvo, ka, rosinot skolēnus izmantot augstākā līmeņa kognitīvās prasmes un skaidrot savu viedokli, snieguma vērtēšanas procesā tiek iegūta daudzpusīgāka informācija par skolēnu stiprajām pusēm un snieguma dimensijām, kurās nepieciešami uzlabojumi.

\section{Snieguma vērtēšana mikrolīmenī}

Grants Vigins (Grant Wiggins) (Wiggins, 2006 ${ }^{4}$ ) uzsver, ka nepieciešams pārskatīt, kādiem mērḳiem izmantojam vērtēšanu vispār. Viṇš aicina uz vērtēšanu raudzīties kā uz līdzekli, kas sniedz iespēju uzlabot mācīšanos, nevis tikai "auditēt faktu uzkrāšanu". Viņš arī piedāvā aizstāt jēdzienu "vērtēšana" ar jēdzienu "atgriezeniskā saite" un rosina domāt par vērtēšanu kā par informāciju, kas nepieciešama, lai uzlabotu sniegumu. G. Vigins aicina daudz lielākā mērā izmantot tā saukto autentisko vērtēšanu (authentic assessment) jeb tādu pieeju vērtēšanai, kas prasa skolēniem demonstrēt sniegumu un radīt produktus, kuri līdzinās uzdevumiem un situācijām, ar ko viṇi saskarsies reālajā dzīvē ar atbilstošām prasībām, iespējām un ierobežojumiem. Autentiska vērtēšana, viņaprāt, nozīmē tādu pieeju vērtēšanai, kurā tiek vērtēta skolēnu spēja "rîkoties", izmantojot attiecīgās jomas prasmes kontekstā, lai nostiprinātu viṇu spēju tās efektīivi pārnest un vispārināt. Viginsa aicinājumu tādējādi varētu attiecināt arī uz kompleksa rezultāta jeb kompetences mērǐšanu.

G. Vigins uzsver, ka jebkura laba vērtēšanas sistēma dara vairāk nekā tikai auditē jeb novērtē sniegumu. Tā ir veidota tā, lai modelētu autentisku sniegumu un radītu iespējas to uzlabot. Viņaprāt, mācišanas mērḳis ir nevis sasniegt labus rezultātus valsts pārbaudes darbos, bet gan apgūt intelektuāli nozīmīgas prasmes. Viņš aicina atgriezties pie vērtēšanas primārā mērḳa - palīdzēt skolēniem labāk mācīties un skolotājiem labāk mācīt, veidojot tādus vērtēšanas uzdevumus, kuru izpildē skolēniem jālieto prasmes, kas būs nepieciešamas reālajā dzīvē. Autors uzsver, ka tikai tad, ja vērtēšanas sistēma būs vērsta uz šāda īsta sniegumu mērišsanu, ir iespējams panākt to, ka skolēnu mācišanās un skolotāju mācǐšana laika gaitā uzlabojas.

4 Wiggins, G. (2006). Healthier testing made easy: The idea of authentic assessment. Edutopia. Pieejams: http://www.edutopia.org/authentic-assessment-grant-wiggins (aplūkots 12.02.2018.). 
G. Vigins ir pārliecināts, ka skolēniem ir tiesības uz viņiem noderīgāku un lietotājam draudzīgāku vērtēšanas sistēmu, jo skolēni ir pelnījuši saṇemt atgriezenisko saiti un iespējas to izmantot kā daļu no ikdienas vērtēšanas sistēmas. Šiem uzdevumiem mācību procesā vajadzētu atkārtoties regulāri tāpat, kā tas notiek vizuālajā mākslā, izpildītājmākslā vai sportā, kur skolēniem ir iespējas arvien uzlabot savu sniegumu. Kad vērtēšana palīdz pareizi ievirzīt mācišanu šādā veidā, skolēna paša vērtējums par savu sniegumu un iespēja atbilstoši reagét, pašam uzlabojot savu darbu (self-adjustment), kḹust par kritiski nozīmīgu mācīšanas un mācīšanās procesa daļu (Wiggins, 2006 ${ }^{5}$ ). Viginsa redzējums par vērtēšanu, izvēloties autentiskus uzdevumus, ar kuru palīdzību pakāpeniski attīstìt skolēnu prasmes, īpaši akcentē nepieciešamību uztvert vērtēšanu kā organisku mācīšanas un mācišanās procesa sastāvdaļu, nevis kā izolētu lēmumu par vienas vai otras vērtēšanas metodes vai instrumenta izvēli.

\section{Uzdevumu izvēle snieguma vērtēšanai}

Snieguma vērtēšanas plānošana ietver piemērotu uzdevumu izvēli, kurus veicot, skolēniem būs iespēja demonstrēt attiecīgās prasmes, un atbilstošu kritēriju izvēli šì snieguma novērtēšanai. Dž. Popams (Popham, 2008) uzsver, ka, tāpat kā jebkurā citā vērtēšanas situācijā, arī snieguma vērtēšanā skolotājam vienmēr svarīgi paturēt prātā snieguma vērtēšanas mērḳi - kādu sasniedzamo rezultātu (prasmi vai kompetenci) skolotājs vēlas novērtēt un kādu lēmumu vai secinājumus par skolēna sniegumu izdarìt.

Nozīmīgs kritērijs uzdevumu atlasē ir skolēna sasniegtais rezultāts - katram uzdevumam varam formulēt sasniedzamo rezultātu, jeb indikatoru. Kompleksa sasniedzamā rezultāta gadījumā tiek analizēts, no kādām dạ̦ām tas veidojas - zināšanas un izpratne nozarē, starpdisciplināri jautājumi, domāšanas, pētnieciskās, teksta apstrādes u. c. prasmes.

Dž. Popams atzimmē, ka snieguma vērtēšanā atbilstoša uzdevuma izvēlei ir īpaši svarīga nozīme, jo atškirinibā no tradicionālās pieejas vērtēšanai skolēni veic mazāku skaitu apjomīgu uzdevumu, tādējādi katram uzdevumam ir daudz lielāks svars. Piemēram, ḳ̄mijas pārbaudes darbā tipiska 50 ierobežotu atbilžu izvēḷu uzdevumu vietā skolēniem varētu būt pašiem jāveic eksperiments, jāveic rezultātu analīze, jāuzraksta secinājumi. Skolotājam jāizdara vērtējums par skolēna sniegumu, pamatojoties uz vienreizēju demonstrējumu, nevis uz skolēna atbildēm uz 50 jautājumiem.

5 Wiggins, G. (2006). Healthier testing made easy: The idea of authentic assessment. Edutopia. Pieejams: http://www.edutopia.org/authentic-assessment-grant-wiggins (aplūkots 12.02.2018.). 
G. Vigins un autoru kolektīvs (Wiggins, Grant, \& McTighe, 2005) salīdzina problēmuzdevuma un tipveida uzdevuma pazīmes - formulējumu, pieeju risinājumam, nosacījumus, risinājumu, panākumu indikatorus. Tiek uzsvērts, ka problēmuzdevuma gadijumā:

- problēmas nosacijumi ir formulēti skaidri, bet nav dotas norādes vai informācija par risināšanas pañēmieniem;

- ir iespējamas vairākas pieejas risinājumam. Problēmas veida noteikšana ir viens no svarīgākajiem atslēgas elementiem. Ir nepieciešamas vairākas log̣iskās kombinācijas ar mēginājumiem un kḷūdām, kḷūdu labojumiem un nākamajiem mēginājumiem;

- nosacijumi ir reāli, autentiski, sarežǧiti, bieži iekḷauj dažādus pretrunīgus un konkurējošus nosacījumus vai lielumus, kas ir saistoši un interesanti auditorijai;

- atbilstošs risinājums ietver vairākus nosacijumus un to izvērtēšanu. Ir iespējamas vairākas pareizas atbildes. Atbildes ir precīzi argumentētas;

- panākumu nodrošināšanai fokuss tiek pārnests no pareizās atbildes uz risinājuma pañēmienu izvēli un to logisku pamatojumu.

Dž. Popams piedāvā šādus kritērijus, kas jāṇem vērā, izvēloties snieguma vērtēšanas uzdevumus (Popham, 2008, p. 179):

- vispārināmība (generalizability). Vai ir liela iespējamība, ka skolēns spēs tikpat sekmīgi paveikt līdzīgus uzdevumus kā doto?

- autentiskums (authenticity). Vai uzdevums ir līdzīgs tiem uzdevumiem, ar kuriem skolēns saskarsies reālajā dzīvē, vai drīzāk tāds, ar kuriem skolēns saskarsies tikai skolā?

- daudzpusīgs fokuss (multiple foci). Vai uzdevums mēra vairākus sasniedzamos rezultātus (multiple instructional outcomes) vai tikai vienu?

- iespēja prasmi iemācīt (teachability). Vai uzdevums ir tāds, ar kura starpniecỉbu skolēns var pilnveidot savu prasmi mācišanas rezultātā?

- taisnīgums (fairness). Vai uzdevums ir taisnīgs attiecībā pret visiem skolēniem, t. i., vai uzdevuma uzstādījumi nav balstīti stereotipiskos pienēèmumos par skolēnu dzimumu, etnisko piederību, sociāli ekonomisko statusu vai tamlīdzīgi?

- praktiskums (feasibility). Vai uzdevumu reāli iespējams paveikt, n̦emot vērā izmaksas, vietu, laiku un nepieciešamo aprīkojumu?

- izvērtējamība (scorability). Vai skolēna sniegumu, ko viņš demonstrēs, atbildot uz uzdevumu, iespējams uzticami (reliably) un precīzi (accurately) izvērtēt?

Dž. Popams atzīst, ka būs situācijas, kurās nederēs visi kritēriji. Taču autors uzsver, ka iespēju robežās uzdevumu izvēelē vajadzētu ņemt vērā visus septiṇus kritērijus. 
Skolēnu izpratni nepieciešams vērtēt, izmantojot multidimensionālu pieeju, rosinot ikvienu mācību satura tematu vērtēt četrās dimensijās: matemātiskā prasme (ietver algoritmus un procedūras); īpašība (aplūko principus); izmantošana un modelēšana (representations, diagrammas, attēli, kas vizuāli atsedz konceptu). Piemēram, 1. attēlā parādīti uzdevumu piemēri reizināšanas izpratnei četrās dimensijās. Ja skolēns prot reizināt, bet nevar vizualizēt šo darbību, ko ir iespējams secināt par izpratni?

No veiktajiem pētījumiem citviet pasaulē (ASV un Singapūrā) par vairāku dimensiju izpratni tiek secināts, ka sasniegumi katrā no četrām dimensijām šajās valstīs ir atšķirīgi. Tas dal̦ēji varētu būt skaidrojams ar dažādiem uzsvariem mācību procesā (Thomson, \& Kaur, 2011; Bleiler, \& Thompson, 2012/2013).

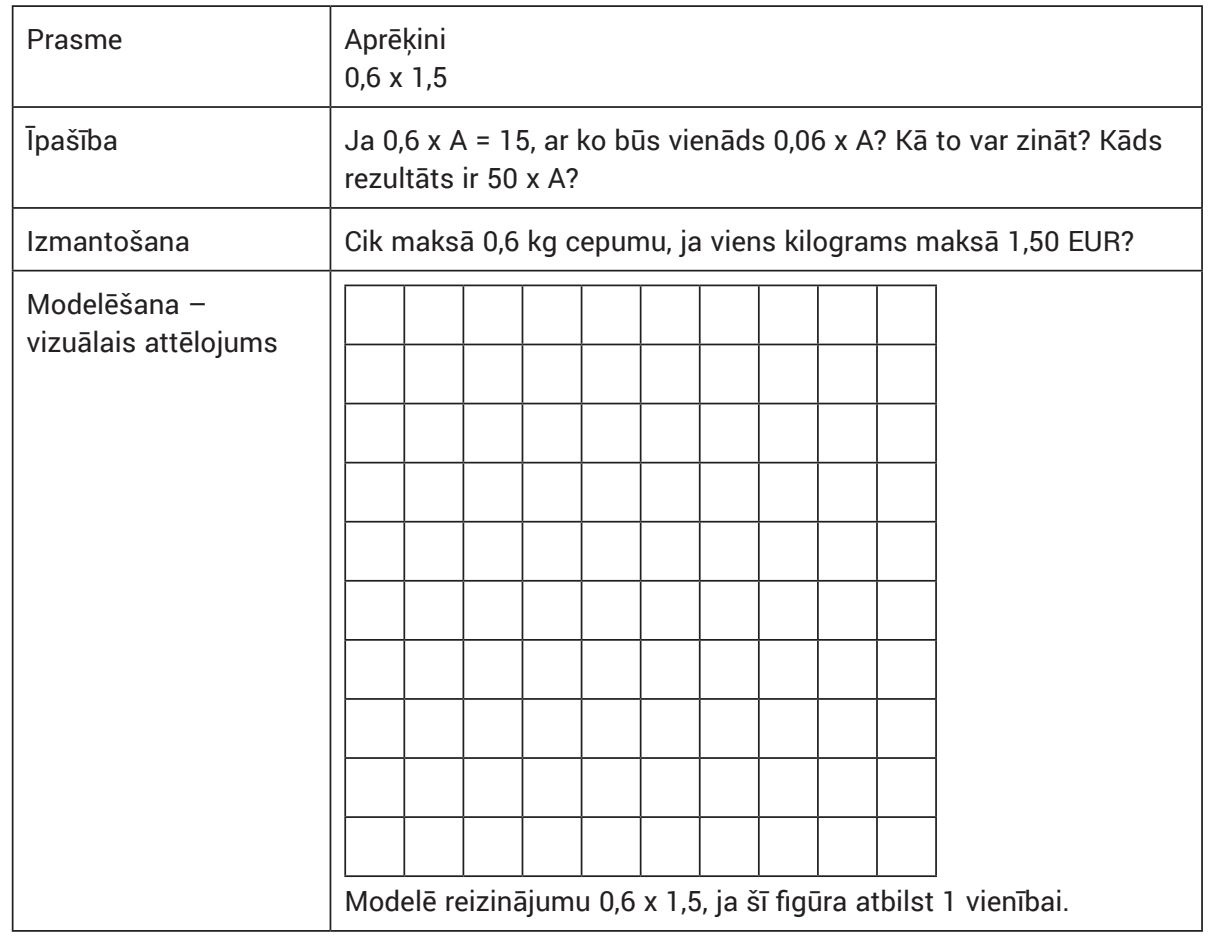

1. attēls. Uzdevumi izpratnes par reizināšanu vērtēšanai četrās dimensijās 
Stenforda (ASV) universitātes pētnieki (Daro, \& Kokka, Wertheim et al., 2016), analizējot dažādus uzdevumus vairākos mācību priekšmetos, izvirza kritērijus uzdevumiem dažādās jomās.

Dabaszinātnēs (Wertheim et al. 2016, p. 88): skolēnu atbildes veids; nozares lielās idejas; prasmes dabaszinātnēs un inženierzinātnēs; starpdisciplinārie jēdzieni; integrācijas pakāpe; cik lielā mērā fokuss ir uz būtisko nozarē; kognitīvā dziḷuma līmenis (zems, vidējs, augsts).

Matemātikā (Daro, \& Kokka, 2016, p. 54):

- pamatidejas un procesi (vai uzdevums mērksē uz skolēnu izpratni un būtiski svarīgiem matemātikas procesiem un idejām);

- vairāki "ieejas punkti" (vai uzdevums piedāvā vizuālus attēlojumus, tehnologiju izmantošanu, vai atbilžu forma nodrošina iespēju skolēniem spriest arī tad, ja viṇi neatceras kādu procedūru);

- daudzveidīgas risināšanas stratēgijas (vai ir daudzveidīgu risinājumu iespējas un vairāk nekā viena pareiza atbilde);

- izsvērta prezentācija (vai uzdevumu veids minimizē grūtỉbas; vai tas ir matemātiski un kontekstuāli (coherrent) skaidrs un skolēniem draudzīgs);

- tehnoloǵiju pastiprināts (piedāvā produktīvu atbalstu spriešanai, nesamazinot disciplināro skaidrību);

- iesaistošs konteksts (jēgpilns un saprātīgs skolēniem ar atškirīgu socioekonomisko, kulturālo un valodisko pieredzi).

Vēsturē tiek vērtēts: kognitīvais kompleksums; uzdevumu izveide - forma, izmantotie avoti, vēstures zināšanu un prasmju integritāte; prasmes - lasīšana, argumentēšana un rakstī̌̌ana; izvirzìtais jautājumu loks testu izveidei (Martin, 2016, pp. 116-117):

- vai izcel nozarē specifiskas zināšanas un prasmes; ja prasa lasīt vai rakstīt, vai vērtēšana fokusējas uz disciplīnas kompetencēm;

- vai uzdevums ietver originālus un definē, kas skolēnam ar tiem jādara; vai prasa zināšanas sasaistīt vai kontekstualizēt?

- vai materiāli ir izvēlēti uzmanīgi un sagatavoti, lai samazinātu satraucošo faktoru ietekmi - spēju lasit, iepriekšējās zināšanas?

- vai ir daudzveidīgi cel̦i atbildes ieguvei; vai ir daudzas pareizas atbildes, vai arī tiek mērīts kaut kas konkrēts?

- vai uzdevuma konstrukcija ir sabalansēta? Vai uzdevums ir veidots, lai maksimalizētu pierādījumus, ka tiek mērīti iecerētie mērḳi? Vai uzdevumā tiek dots atbalsts tām prasmēm, kas vajadzīgas, bet netiek mērītas? 
Apkopojot iepriekš analizēto, konstatējams, ka mūsdienīga uzdevuma pazīmes kompleksa snieguma vērtēšanai ir:

- izpratne nozarē ar fokusu uz būtisko, galveno (Lielo ideju);

- starpdisciplinaritāte un pārnesums (ietverts konteksts, integritāte, situāciju autentiskums);

- prasmes, kas tiek attīstītas (pētnieciskās, tekstpratības u. c.);

- kognitivās darbības dziḷums;

- metakognitīvās darbības iespējas;

- vērtēšanas iespējas - kritēriji (kā tie rāda fokusu, par ko ir uzdevums);

- uzdevuma forma (daudzveidīgu darbību iespējas, kas skolēniem jāveic, lai iegūtu atbildi; variatīvu risinājumu, atbilžu iespējas);

- tehnologiju izmantošanas iespējas;

- uzdevuma tehniskā kvalitāte u. c.

Šajā situācijā ir svarīgi kā atseviškłu kritēriju izcelt arī tekstpratību. Salīdzinājumā ar tipveida uzdevumiem šādi uzdevumi (kompleksi problēmuzdevumi) ir daudzfunkcionāli, tie dod iespēju demonstrēt kompleksu sniegumu plašā spektrā (skat. 1. tabulu).

1. tabula. Tipveida uzdevuma un uzdevuma kompleksa snieguma demonstrēšanai salīdzinājums

\begin{tabular}{|c|c|c|}
\hline Kritēriji & Tipveida uzdevums & Komplekss problēmuzdevums \\
\hline Sasniedzamais rezultāts & $\begin{array}{l}\text { Vērsts uz atsevišḳu prasmi, } \\
\text { sakarību }\end{array}$ & $\begin{array}{l}\text { Komplekss, saistās ar skolēna } \\
\text { pieredzi }\end{array}$ \\
\hline $\begin{array}{l}\text { Uzdevuma situācija } \\
\text { (jēdzieni, likumi, } \\
\text { teorijas, fakti... tekstā + } \\
\text { kontekstā) }\end{array}$ & $\begin{array}{l}\text { Jēdzieni, fakti, likumi un } \\
\text { teorijas šaurā zinātnes } \\
\text { kontekstā; dominējoša } \\
\text { zinātnes temata aktuālais } \\
\text { saturs }\end{array}$ & $\begin{array}{l}\text { lespēja paplašināt - jēdzieni, fakti, } \\
\text { likumi, teorijas + starpdiciplinārs } \\
\text { konteksts; reālās dzīves situācijas, } \\
\text { autentisks }\end{array}$ \\
\hline $\begin{array}{l}\text { Kognitīvais līmenis, } \\
\text { uzdevumu risināšanas } \\
\text { paṇēmieni }\end{array}$ & $\begin{array}{l}\text { Dominējoši zems; risinot } \\
\text { tipveida uzdevumus, atceras } \\
\text { procedūras, izpilda rutīnas } \\
\text { darbības }\end{array}$ & $\begin{array}{l}\text { Daudzveidīgs. } \\
\text { Attīsta prasmes lietot kognitīvos } \\
\text { un metakognitīvos pan̄ēmienus } \\
\text { dažādā dzilımāā, lasītprasmes } \\
\text { paṇēmienus u. c. letver tipveida } \\
\text { un nestandarta darbības; rīcība } \\
\text { jaunā situācijā }\end{array}$ \\
\hline $\begin{array}{l}\text { Risinājumu variantu } \\
\text { iespējamība; atbilžu } \\
\text { variantu iespējas }\end{array}$ & $\begin{array}{l}\text { Dominējoši viens risinājuma } \\
\text { pan̄ēmiens; viena pareizā } \\
\text { atbilde }\end{array}$ & Tiek veicināta variativitāte \\
\hline
\end{tabular}


Kā iespējams raksturot konkrētu uzdevumu (piemēru), izmantojot kritērijus, aplūkots 2. attēla piemērā un 2. tabulā.

16. uzdevums (2 punkti)

Jānis shematiski apkopojis informāciju par vienādiem trijstūriem (sk. attēlu). Attēlā ieskatījās Kārlis un jautāja, ko nozīmē simbols $\Rightarrow$. Jānis paskaidroja, ka simbols $\Rightarrow$ nozīmē "seko" jeb "var secināt".

Kārlis: "Tādā gadījumā viens no secinājumiem ir aplams."

Izvērtē un pamato, vai Kārlim ir taisnība.

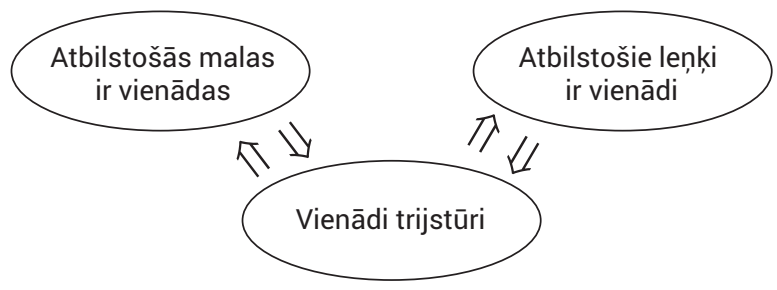

2. attēls. Darba uzdevums matemātikā 8 . klasei (VISC, 2017)

2. tabula. Uzdevuma raksturojums atbilstoši kritērijiem

\begin{tabular}{lc}
\hline \multicolumn{1}{c}{ Izvēlētie kritēriji } & Uzdevuma raksturojums \\
\hline $\begin{array}{l}\text { Izpratne disciplīnā ar fokusu uz būtisko } \\
\text { Starpdisciplinaritāte (pārnesums, integritāte, } \\
\text { autentiskums) }\end{array}$ & $\mathrm{Nav}$ \\
\hline Prasmes, kas tiek mērītas & $\begin{array}{c}\text { Izmantot tekstā dotu informāciju, izvērtēt } \\
\text { apgalvojuma patiesumu }\end{array}$ \\
\hline Kognitīvās darbības dziḷums & Vidējs \\
\hline Metakognitīvā darbība & Nav \\
\hline Atbilžu, risināšanas stratēǵiju variativitāte & Ir \\
\hline Vērtēšanas kritēriji & Snieguma kritēriji \\
\hline
\end{tabular}

\section{Kognitīvās darbības dziḷums un tā mērīšana}

Nozīmīgs jautājums vērtēšanas plānošanai, uzdevumu izvēlei un skolēna snieguma vērtēšanai ir tas, kā vērtēt izpratnes dziḷumu/patiesu izpratni. Viens no 
veidiem, kā iegūt precīzāku izpratnes izvērtējumu, ir piedāvāt uzdevumus, kas prasa arvien lielāku kognitīvās darbības ${ }^{6}$ dziḷumu.

Dažādos valsts mēroga pārbaudes un diagnosticējošos darbos tradicionāli tiek piedāvāts skolēnu izziñas darbības dziḷumu aplūkot trīs līmeņos, par kuriem norādes var atrast pie pārbaudes darba (VISC ${ }^{104}$ ). Vienkāršoti: veicot uzdevumus 1. lìmenī, nepieciešama zema, 2. līmenī - vidēja, 3. līmenī - augsta līmeņa kognitīva darbība.

Šāda pieeja ir sastopama arī vairāku citu makrolīmeņa vērtēšanas darbu struktūrietvaros. Tā kopumā atbilst Stouna klasifikācijai (Стоунс, 1984), tā ir pielīdzināma Blūma taksonomijai (Bloom, Englehart, Furst, Hill, \& Krathwohl, 1956), kas piedāvā skolēnam sasniedzamus rezultātus, kas plaši izplatīiti formālajā izglìtības sistēmā, sagrupēt trīs sfērās - kognitīvajā, afektīvajā un psihomotorajā. Atbilstoši Blūma taksonomijai kognitīvajā sfērā ir seši kognitīvās darbības līmeņi: zināšana (atcerēšanās), saprašana, lietošana, analīze, sintēze un izvērtēšana. Pirmajos līmeņos kognitīvā darbība raksturojama kā zema, pēdējos - kā augsta.

Literatūrā plaši aprakstītas kritiskās domāšanas dimensijas šādās kategorijās: iegaumēšana, domāšana un valoda, deduktīvā argumentēšana, argumentu analīze, racionālā domāšana, kritiskās domāšanas iespējamības un nenoteiktības izvērtēšana, problēmrisināšanas un radošuma prasmes (Halpern, 2014).

Lai vērtētu kognitīvo darbību, dažādu mērī̌sanas instrumentu veidotāji piedāvā struktūrietvarus, aprakstot potenciālo skolēnu sniegumu kompleksi līmeņos. Piemēram, OECD PISA pētijumu struktūrietvars dabaszinātnēs apraksta sešus snieguma līmenuus no zema līdz augstam, parādot raksturīgos atslēgas vārdus darbībām konkrētā līmenī. Piemēram, 3. līmenī, kas pārsvarā apzīmēts kā vidējs, skolēns parāda zinātnisku domāšanu spriestpēju ikdienišķās situācijās, bet 6 . līmenī, kas raksturots kā augsts, skolēns demonstrē augsta līmeņa domāšanu, kā arī modeḷu un abstraktu ideju lietošanu nezināmās, kompleksās situācijās. ${ }^{7}$

Austrālijas pētnieki (Biggs, \& Collis, 1982; Biggs, \& Tang, 2007) ir izveidojuši SOLO (structure of observed learning outcomes) taksonomiju, ar kuras palīdzību var raksturot atškirīibu starp virspusēju un dziḷu mācišanos (skat. 3. attēlu). Tā atspoguḷo, par cik elementiem un dažādām attiecībām starp elementiem skolēnam ir jādomā, lai atrisinātu kādu uzdevumu. SOLO taksonomija ir izziñas rìks, ar kura palīdzību var atspoguḷot un izvērtēt kvalitatīvu virzību no virspusējas uz dziļu māciššnos. Šo taksonomiju var izmantot, lai analizētu, cik dziḷi domā skolēns, lai viņam palīdzētu saprast, kā uzlabot savu rezultātu (pāriet uz nākamo izziṇas darbības līmeni) un spriestu par paša mācību uzdevuma kognitīvo

Kognitīvā darbība un izziņas darbība tekstā lietoti kā sinonīmi.

7 OECD, PISA Latvija. (2015). Starptautiskajā skolēnu novērtēšanas programmā 2015 - pirmie rezultāti un secinājumi. A. Kangro redakcijā. Rīga, Latvijas Universitāte. 
līmeni. SOLO taksonomija tiek plaši izmantota Austrālijā, Jaunzēlandē, Kanādā un Lielbritānijā (Brookhart, 2010) ne tikai kā skolotāja, bet arī kā skolēna rīks. Ar tās palīdzību ir iespējams analizēt un interpretēt mācību līdzekḷu efektivitāti skolēnu izaugsmes sekmēšanā (Smith, \& Colby, 2007).

SOLO taksonomijas izmantošana uzdevumu izvēlē skolēnam rosina pievērst uzmanību domāšanas dziḷumam, nevis satura plašumam. Vēsturiski šì taksonomija attīstijās diagnosticējošiem mērḳiem mācību stundās, lai izvērtētu skolēnu izpratnes dziļumu un konstatētu nepareizus priekšstatus ar mērķi tos mainīt (skat. 3. attēlu).

\section{SKOLĒNA KOGNITĪVĀS DARBĪBAS DZIL̦UMA MËRIIŠANA, IZMANTOJOT SOLO TAKSONOMIJU}

\section{VIRSPUSĒJA MĀCTŠANĀS}

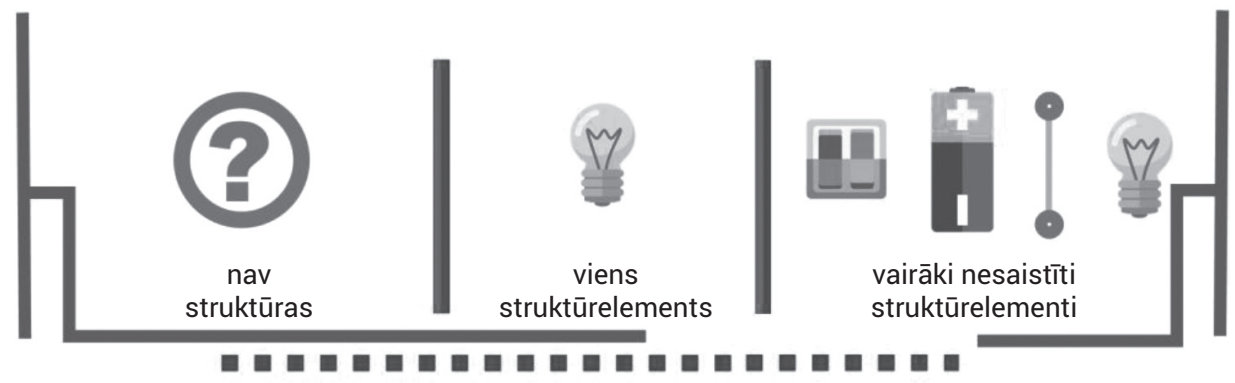

\section{DZIL,A MĀCĪŠANĀS}
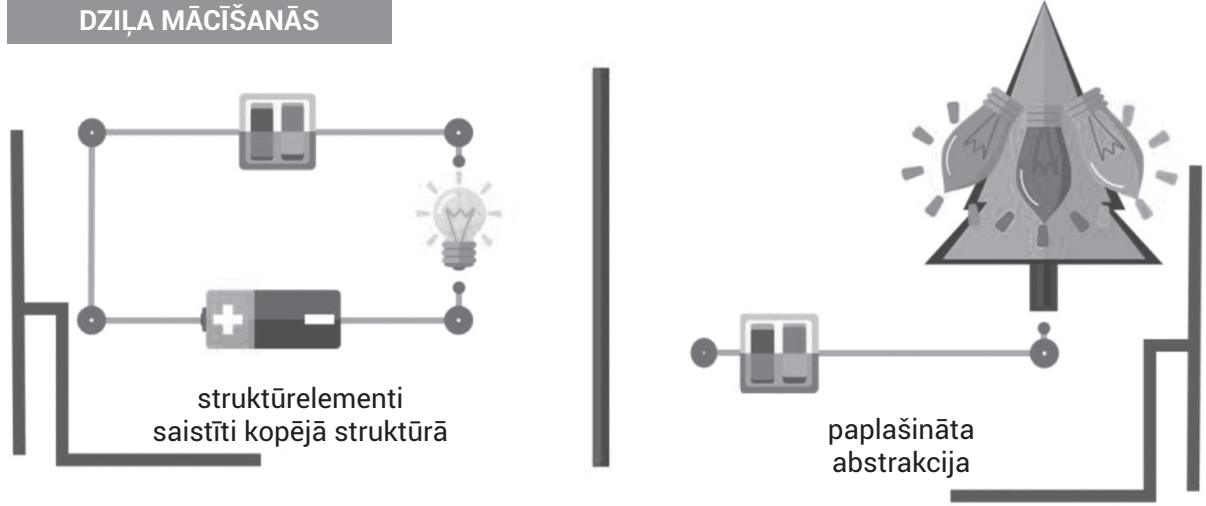

3. attēls. SOLO taksonomijas līmeṇu vizualizācija attēlos (LU SIIC arhīvs)

SOLO taksonomijas pilnveidotā versija (Pannizon, \& Pegg, 2003) dod iespēju gan mācību stundās, gan analizējot skolēnu sniegumu valsts mēroga pārbaudes darbos, precīzāk ieraudzìt, kā skolēns domā. Lai novērtētu izpratnes dziḷu$\mathrm{mu}$, tiek piedāvāts izmantot pilnveidotu SOLO instrumentu, skolēna sniegumu 
aplūkojot divos lokos. Pirmajā lokā skolēna atbildēs dominē sadzīviskā pieredze, otrajā lokā izpratne balstās dabaszinātniskajās likumsakarībās, teorijās un modelı́s; katrs loks ietver trīs līmeņus līdzīgi kā klasiskajā SOLO taksonomijā (Pannzion \& Pegg, 2003).

Analizējot dzị̄āk OECD PISA pētijuma dabaszinātnēs ${ }^{8}$ kognitīvo ietvaru un SOLO taksonomiju, skolēna kognitīvo darbību iespējams raksturot ar divu būtisku stūrakmeņu palīdzību - kompleksumu un pārnesumu jeb spēju risināt uzdevumus jaunā, nezināmā situācijā (kuru veido konteksts); svarīga ir situācijas pazīstamība (jaunums, tālums), t. i., vai situācija ir mācīta, vai skolēns atrodas jaunā situācijā.

Uzdevuma pazīstamības koncepts variē no pilnīgi identiska uzdevuma skolēnam, kas jārisina, līdz piln̄̄gi nezināmai, jaunai situācijai. Piemērā parādīti uzdevumi, kuru būtỉba ir daļas no veselā aprēķināšana, mainot kontekstu un situāciju. Skolēns demonstrē tuvu pārnesumu, kad jaunā uzdevuma izpildē ir nepieciešams relatīvi mazs kognitīvo prasmju kopums, konteksts ir viena mācību priekšmeta saturs un situācija ir ḷoti līdzīga iepriekšējai mācišanās situācijai (uzdevums kreisajā tabulas kolonnā) (skat. 3. tabulu).

3. tabula. Diagnosticējošo darbu uzdevumi dabaszinātnēs

\begin{tabular}{|c|c|}
\hline Pazīstama situācija & Jauna, atšḳirīga situācija \\
\hline \multirow[t]{2}{*}{$\begin{array}{l}\text { Aprēḳini, cik gramu } \mathrm{NaCl} \text { satur } \\
200 \text { g 10\% šḳīduma? }\end{array}$} & $\begin{array}{l}\text { Aprēḳini vajadzīgo kristāliskā nātrija hlorīda masu, lai } \\
\text { pagatavotu } 500 \text { g fizioloǵiskā šk̦īduma - 0,9\% NaCl } \\
\text { škīdumu. Parādi risinājumu! (VISC, 9. kl. DD 2015). }\end{array}$ \\
\hline & $\begin{array}{l}\text { Anna ir ieplānojusi apstrādāt maurinu ar minerālmēslojumu } \\
\text { šḳīdumu. Uz minerālmēslojuma pudeles etiḳetes ir rakstīts, } \\
\text { ka vienu tilpuma daḷu minerālmēslojuma nepieciešams } \\
\text { sajaukt ar } 15 \text { tilpuma daḷām ūdens un vienmērīgi } \\
\text { izsmidzināt. Cik liels ir nepieciešamais minerālmēslojuma } \\
\text { tilpums, ja mauriṇa apstrādei ir nepieciešami } 12 \text { litri } \\
\text { šḳīduma? A } 750 \text { mL B } 800 \mathrm{~mL} \text { C } 1200 \mathrm{~mL} \text { D } 1333 \mathrm{~mL} \text { (VISC, } \\
\text { 9. kl. DD 2017). }\end{array}$ \\
\hline
\end{tabular}

Pretēji - ja skolēnam jādarbojas jaunā un atšḳirīgā situācijā, ir nepieciešams relatīvi liels kognitīvo prasmju kopums un uzdevuma kontekstā ir saredzams vairāku mācību priekšmetu saturs. Šāds uzdevums nav uzskatāms par risināmu pēc apgūtā parauga (lai arī tajā ir rutīnas darbỉbas) un kḷūst par problēmu skolēnam, kuram regulārajā mācību procesā ir tikusi "drillēta" atsevišķu, savstarpēji

8 OECD, PISA Latvija. (2015). Starptautiskajā skolēnu novērtēšanas programmā 2015 - pirmie rezultāti un secinājumi. A. Kangro redakcijā. Rīga, Latvijas Universitāte. 
nesaistitu algoritmu apguve šaurā kontekstā. Mainot kontekstu, tipveida uzdevums var kḷūt par problēmuzdevumu, kuru risinot skolēns veic cita līmeña kognitīvas darbības. Diagnosticējošo darbu rezultātu analīze rāda, ka 9. klašu skolēniem tabulas labajā kolonnā ievietotie uzdevumi rada lielas grūtības.

Augsta līmeña kognitīva darbība ir produktīva, to raksturo skolēna spēja dzị̣i domāt. Uzdevumi jāizvēlas dažāda dziḷuma (augstuma) kognitīiajā līmenī.

Iepriekš minētajam taksonomijām šajos līmeṇos ir kopīgi atslēgas vārdi, kas apraksta skolēna sniegumu, - skaidro, lieto, analizē, izvērtē u. c. Tas dod iespēju tās savstarpēji savietot, izmantot dažādu pētỉjumu vajadzībām. Lai būtu iespējams salīdzināt skolēnu sniegumu pārbaudes darbos un kognitīvo dziḷumu mācību stundās, Latvijas Universitātes Starpnozaru izglīîibas inovāciju centrā (LU SIIC) izveidots "instruments", kā samērot kognitīvo dziḷumu dažādās sistēmās (skat. 4. tabulu).

4. tabula. Kognitīvā dziḷuma salīdzinājums dažādos instrumentos

\begin{tabular}{|c|c|c|c|}
\hline $\begin{array}{c}\text { PISA } \\
\text { snieguma } \\
\text { līmenis }\end{array}$ & $\begin{array}{c}\text { PISA } \\
\text { kognitīvais } \\
\text { līmenis (2015) }\end{array}$ & $\begin{array}{c}\text { Valsts } \\
\text { pārbaudes darbu } \\
\text { kognitīvais } \\
\text { līmenis }\end{array}$ & SOLO taksonomija \\
\hline 5,6 & Augsts & \multirow{2}{*}{ Augsts } & 4 - paplašināta abstrakcija \\
\hline 4,3 & Vidējs & & 3 - vairāki elementi saistīti kopējā struktūrā \\
\hline 2 & \multirow{2}{*}{ Zems } & Vidējs & 2 - vairāki nesaistīti struktūrelementi \\
\hline $1 a$ & & Zems & 1 - viens struktūrelemets \\
\hline $1 b$ & & & 0 - nav struktūras \\
\hline
\end{tabular}

Instruments dod iespēju salīdzināt kognitīvās darbības dziḷumu, veicot uzdevumu mācību stundā vai pildot to pārbaudes darbā.

\section{Metakognitīvā darbība un tās mērīšana}

Lai sekmētu metakognitīvo prasmju apguvi, skolotājam mācību procesā nepieciešams apzināti un regulāri dot iespēju skolēnam pašam darīt, domāt (tostarp domāt skalii), kā viņš mācās; vērot un saprast, kā skolēns domā; sniegt skolēnam jēgpilnu atgriezenisko saiti par viņa mācīšanos; mācìt skolēnu pieņemt atgriezenisko saiti un mācīt sevi novērtēt, uzdodot mērḳtiecīgus jautājumus. Metakognitīvā darbība ir mācǐšanās procesa dal̦a, tās vērtēšana norisinās "meta" līmenī, kā arī vērtējot skolēna sniegumu procesā. 
Visbiežāk sastopamais veids ir skolēna pašnovērtējums, izmantojot kontrollapu (apgalvojums un jautājums ar vērtējumu - ir/nav). Saskaņā ar Šravu (Schraw, 1998) skolēns uzdod sev jautājumus par sava darba plānošanu, uzraudzišanu (monitorēšanu) un izvērtēšanu. Uzdot šādus jautājumus skolotājs māca skolēniem pakāpeniski.

Kūns (Kuhn, 2000) raksta, ka mācību uzdevums būtu palielināt metauzdevuma izpratni un kontroli, nevis uzdevumu izpildes procedūras. Viņš iesaka noteikt norādījumus metakognitīvajai darbībai izpildes, nevis meta līmenī. Šravs (1998) iesaka sniegt skaidrus norādījumus, lai palīdzētu skolēniem uzlabot savas pašregulēšanas spējas. Viņš rekomendē izmantot atgādnes ar ierakstiem par plānošanu, uzraudzību un novērtēšanu, apgalvojot, ka šādas atgādnes palīdz skolēniem būt sistemātiskākiem un stratēǵiskākiem problēmu risināšanā. Līdzīgi Kramarski un Mevarech (2003) nodrošināja skolēnus ar metakognitīvu jautājumu komplektiem, tostarp izpratnes jautājumiem, jautājumiem par izmantotajiem mācī̌sanās pañēmieniem un to saistību. Izpratnes jautājumi tika veidoti, lai mudinātu skolēnus pārdomāt problēmu pirms tās risināšanas. Jautājumi par paņēmieniem tika veidoti, lai iedrošinātu skolēnus domāt par to, kāds paṇēmiens varētu būt piemērotākais konkrētam uzdevumam, un norādīt iemeslu šai izvēlei. Jautājumi, kas rosina meklēt sakarības, tika veidoti, lai mudinātu skolēnus identificēt un atpazìt dzilas struktūras uzdevumu pazīmes, lai vini varētu aktivizēt attiecīgo panēmienu un pamatzināšanas.

Šādi jautājumi tiek pievienoti uzdevumiem ne tikai ikdienas situācijās. To iespējams darīt, vērtējot arī makrolīmenī. Metakognitīvu darbību var pārbaudìt, pārbaudes darbā iekḷaujot atbilstoša rakstura jautājumus, piemēram, Uzraksti, $k \bar{a}$ tu risināji šo uzdevumu! Paskaidro, kā tu tiki lìdz atbildei! Paskaidro, kā tu veidoji spriedumu! Käds bija tavs plāns?

\section{Snieguma līmen,u aprakstu ${ }^{9}$ izveide}

Lai izliktu vērtējumu par skolēna sniegumu, plaši izplatīta prakse ir punktu summēšana par konkrētu darbību izpildi atbilstoši iepriekš izvirzītiem vērtēšanas kritērijiem. Punktu skaitîšana labi strādā, ja ir vienkāršs konkrēts uzdevums ar viennozīmīgu atbildi. Skaitot punktus, parasti tos parāda par uzdevumu kopumā, paskaidrojot, par ko var saņemt mazāk punktu, ja kopā ir, piemēram, 3 punkti. Punktu skaitišana attiecas uz konkrēto uzdevumu. 4. attēlā redzami divi uzdevumi, kurus valsts līmeņa darbā 3. klasei matemātikā piedāvā vērtēt

9 Ar terminu "snieguma līmeṇu apraksts" tiek tulkots angḷu termins rubrics. 
skalā - pareizi/nepareizi. Uzdevuma kreisajā pusē, kur jāizvēlas pareizā atbilde no dotajām, tas darbojas. Vērtējot otra uzdevuma izpildi, par katrā lodziņā pareizi ierakstītu skaitli liekot 1 punktu, netiek iegūta turpmāk izmantojama informācija par skolēna sniegumu.

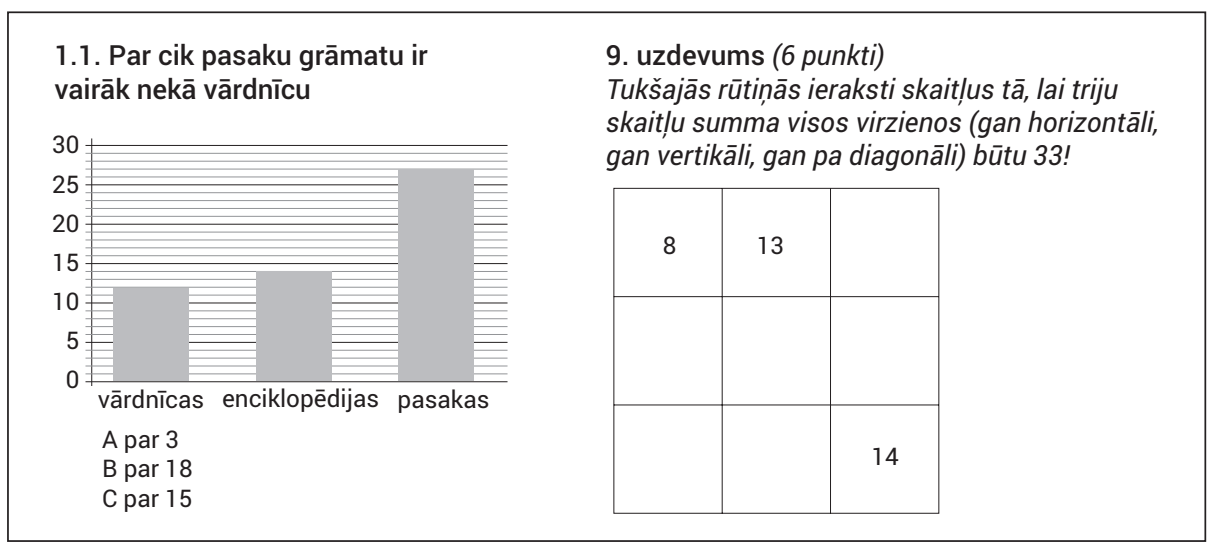

4. attēls. Diagnosticējošā darba uzdevums matemātikā 3. klasei (VISC, 20150)

Piemērs: vērtēšanas kritērijs, pie uzdevuma norādīts punktu skaits, cik par tā izpildi var saṇemt. Piemēram, apskatot 2017. gada 9. klases dabaszinātnes diagnostikas darba 10.1. uzdevumu, skolotājam tiek piedāvāta vērtēšanas kritēriju tabula (skat. 5. tabulu).

5. tabula. Vērtēšanas kritēriju tabula (VISC, 2017 ${ }^{11}$ )

\begin{tabular}{lll}
\hline \multicolumn{1}{c}{ Standarta prasība } & \multicolumn{1}{c}{ Prasme } & \multicolumn{1}{c}{ Kritērijs } \\
\hline $\begin{array}{l}\text { Izskaidro iegūtos datus un } \\
\text { izdara secinājumus }\end{array}$ & $\begin{array}{l}\text { Izskaidro rezultātus un izdara } \\
\text { secinājumus }\end{array}$ & $\begin{array}{l}\text { Interpretē grafikā doto } \\
\text { informāciju, secina }\end{array}$ \\
\hline
\end{tabular}

Šāds kritērijs ir vispārīgs, tas ietver divas nozīmīgas prasmes - interpretēt informāciju un secināt.. Uzdevuma vērtējums pareizi/nepareizi 1/0 pret šādu kritēriju nav pietiekams, lai izdarītu spriedumus par skolēnu prasmi. Šim nolūkam ir nepieciešams precīzāks vērtēšanas instruments - snieguma līmeṇu apraksts (rubrika), veidojot detalizētu snieguma līmeņu aprakstu par katru kritēriju.

${ }^{10}$ VISC. (2015-2018). Mācību priekšmetu metodiskie materiāli. Pieejams: http://visc.gov.lv/ vispizglitiba/eksameni/metmat.shtml (aplūkots 16.02.2018.).

${ }^{11}$ VISC. (2017). Mācību priekšmetu programmu paraugi. Pieejams: http://visc.gov.lv/vispizglitiba/saturs/programmas.shtml (aplūkots 01.11.2017.). 
Dž. Popams (Popham, 2008) un citi autori atzīst, ka snieguma vērtēšana ir laikietilpīga, lai izvēlētos piemērotus uzdevumus snieguma vērtěšanai; izveidotu atbilstošu mehānismu - kritērijus un instrumentus - snieguma novērtēšanai un izvērtētu skolēnu sniegumu, izmantojot šos instrumentus. Tāpēc viņš aicina šo pieeju vērtēšanai izmantot tikai patiesi nozīmīgām prasmēm. Mācību procesā šādas nozīmīgas prasmes būs tikai dažas, tāpēc vajag pārliecināties, ka tās tiešām ir svarīgākās. Piemērā minētās - interpretēt informāciju un secināt - tādas noteikti ir. Ar vērtēšanu, izmantojot snieguma līmeṇu aprakstus un detalizētu uzdevumu analīzi, var iepazīties, 4 . nodaḷas 14 . tabulā.

\section{Vērtēšanas kritēriju identificēšana un snieguma līmeṇa aprakstu veidošana}

Snieguma vērtēšanas gadījumā parasti vērtē kompleksu prasmi (kompetenci), izmantojot vairākus vērtēšanas kritērijus. Saskaņā ar Dž. Popamu (2008) kritērijs ir standarts, uz kuru balstoties iespējams sniegt vērtējumu vai pieņemt lēmumu. Tāpēc kritēriju izvēlei ir būtiska nozīme, jo tā pilnībā nosaka, tieši kādi skolēna snieguma aspekti tiks izvērtēti un kādus secinājumus izdarīsim.

Dž. Popams par snieguma līmeņu aprakstiem (rubrics) sauc vērtēšanas procedūras, ko skolotāji izmanto, lai izvērtētu skolēna sniegumu. Sūzana Brukhārta (Susan Brookhart) (Brookhart, 2013) par rubriku dēvē vienotu kritēriju kopumu skolēna darba novērtēšanai, kas ietver kvalitātes līmeņu aprakstus par katru kritēriju. S. Brukhārta skaidro, ka Meriama Vebstera vārdnīcā anglu valodas jēdziena "rubrika" pirmā nozīme ir "autoritatīvs noteikums" un kā jēdziena ceturtā nozīme minēta "vadlīnijas, kurās uzskaitīti specifiski kritēriji akadēmisku pārspriedumu, projektu vai testu novērtēšanai”.

S. Brukhārta (Brookhart, 2013) uzsver snieguma līmeñu aprakstu pozitīvo iezīmi - rubrikas pašas par sevi ir aprakstošs, nevis vērtējošs instruments. Tās var izmantot, lai novērtētu, taču to galvenais lietojums ir savietot sniegumu ar atbilstošo aprakstu, nevis izdarìt spriedumu jeb vērtēt (judge it). Tāpēc rubrikas ir tik labas, cik rūpīgi izraudzīti un atbilstoši ir tajās iekḷautie kritēriji un cik labi uzrakstīti ir snieguma limeñu apraksti.

Kas ir rubrika, un kā tā veidojas?

Saskaņā ar Dž. Popamu rubrikām ir trīs pazīmes (Popham, 2008):

- vērtēšanas kritēriji, t. i., faktori jeb pazīmes, kas tiks izmantoti, lai novērtētu skolēna snieguma kvalitāti;

- apraksti kvalitatīvām atšķirīibām par katru vērtēšanas kritēriju skolēna sniegumā, lai būtu iespējams izdarìt spriedumus par konkrētām snieguma kvalitātes dimensijām; 
- norāde, vai izmantot holistisku vai analītisku pieeju snieguma vērtēšanā. Rubrikās mēdz norādīt, vai sniegums jāizvērtē, piemērojot visus vērtēšanas kritērijus kopumā/vienotā veselumā, t. i., holistiski, vai arī sniegums jāizvērtē, balstoties uz katru kritēriju atsevišķi, izmantojot analītisko vērtēšanas pieeju. Holistiski vērtējot, rubrikā tiek apvienoti visi kritēriji, izveidojot vienotu līmeṇu aprakstu. Tādas ir arī OECD PISA izmantotās. ${ }^{12}$

Gan Dž. Popams (2008), gan S. Brukhārta (2013) atzīst, ka mācību procesā vērtīgāk gan skolēnam, gan skolotājam ir izmantot analītisko pieeju vērtēšanā. Holistisko pieeju piemērot ir ātrāk, un to vislabāk izmantot summatīvās vērtēšanas gadījumā, kad skolēni nesaņem detalizētu atgriezenisko saiti par sniegumu (piemēram, vidusskolas beigšanas eksāmena gadījumā). Taču mīnuss rezultātu apkopošanas holistiskajai pieejai ir tas, ka šāda pieeja nepietiekami skaidri komunicē skolēniem, īpaši vājākiem, kā uzlabot sniegumu. Analītiska pieeja rubriku lietošanā dod daudz lielākas iespējas precīzāk izvērtēt katru snieguma aspektu un sniegt skolēniem noderīgu atgriezenisko saiti, kā arī izvērtēt, kur mācību procesā nepieciešami uzlabojumi.

Analīiski vērtējot, rubriku veido atbilstoši izvirzìtajam fokusam, pakāpeniski atsedzot konkrētās prasmes dimensijas (konkrētajā piemērā - kāda informācija jāmeklē, kādā tekstā, situācija skolēnam mācìta vai jauna, lasī̌sanas stratēgija) un izveidojot katram lìmenim precīzu aprakstu. Vertheima un citu autoru (2016) aplūkotā analītiskā rubrika attēlota 5. tabulā.

5. tabula. Analītiskās rubrikas piemērs (adaptēts no Wertheim, 2016)

\begin{tabular}{|c|c|c|c|c|}
\hline & Nav sasniegts & Tuvojas iecerēm & Sasniedz ieceres & Sekmīgs \\
\hline $\begin{array}{l}\text { Novērtējuma } \\
\text { elementi }\end{array}$ & 1 & 2 & 3 & 4 \\
\hline Fokuss & $\begin{array}{l}\text { Mēǵinājumi } \\
\text { pievērst } \\
\text { uzmanību } \\
\text { situācijai, bet } \\
\text { zaudē uzmanību } \\
\text { no uzdevuma }\end{array}$ & $\begin{array}{l}\text { Situācijā } \\
\text { atbilstoši norāda } \\
\text { un izveido } \\
\text { pozīciju, bet } \\
\text { uzmanība nav } \\
\text { vienmērīga }\end{array}$ & $\begin{array}{l}\text { Situācijā atbilstoši } \\
\text { norāda un } \\
\text { saglabā skaidru, } \\
\text { vienmērīgu fokusu. } \\
\text { Nodrošina vispārēji } \\
\text { pārliecinošu } \\
\text { nostāju }\end{array}$ & $\begin{array}{l}\text { Izvērtē visus } \\
\text { situācijas } \\
\text { aspektus. Stingra } \\
\text { pārliecība un } \\
\text { pārliecinoša } \\
\text { nostāja }\end{array}$ \\
\hline
\end{tabular}

${ }^{12}$ OECD, PISA Latvija. (2015). Starptautiskajā skolēnu novērtēšanas programmā 2015 - pirmie rezultāti un secinājumi. A. Kangro redakcijā. Rīga, Latvijas Universitāte. 
Šāda veida analìtiskās rubrikas sauc arī par "progresējoša snieguma rubrikām" (advanced pathways perfomance assessment rubrics). Analīiskās rubrikas var izmantot mācību procesa laikā, lai skolotāji un skolēni saņemtu iespējami precīzu atgriezenisko saiti, ko mācoties darìt turpmāk.

Dažreiz rubrikas tiek veidotas tā, ka izmantotie vērtēšanas kritēriji ir saistīti tikai ar konkrētā uzdevuma izpildi, tā sauktās, rubrikas konkrēta uzdevuma vērtēšanai (task-specific rubrics). Dž. Popams skaidro, ka "rubrikas konkrēta uzdevuma vērtēšanai” nepalīdz skolotājam izdarìt secinājumus par to, kas viṇam jādara, lai turpinātu attīstīt skolēna prasmes. Tādējādi skolotājs nevis attīsta prasmi, bet gan māca paveikt konkrēto uzdevumu. Šis ir piemērs tam, cik nozīmīgi vērtēšanas instrumentu izvēle un to saturs var ietekmēt skolotāja lēmumu pieņemšanu par mācību procesu. Kā uzsver Dž. Popams un S. Brukhārta, lai arī "rubrikas konkrēta uzdevuma veikšanai” l̦auj vienkāršāk izvērtēt skolēnu sniegumu, tās mēdz izmantot arī tieši šādos atsevišķos gadījumos, lai izdarìtu precīzus spriedumus par konkrēto sniegumu, taču tām ir ierobežota vērtība mācību procesa uzlabošanā.

Skolēnam lietojot analītisko rubriku mācību gada laikā, skolēns kopā ar skolotāju vai patstāvīgi var sekot savai individuālajai izaugsmei attiecībā pret konkrētu prasmi, piemēram, secināt, ka 1. semestra laikā (septembrī, novembrī) tā vēl ir procesā, janvārī jau tuvojas vēlamajam un martā sasniedz gaidīto.

S. Brukhārta (Brookhart, 2013) labi raksturo potenciālo pievienoto vērtību rubriku izmantošanai formatīvajā vērtēšanā. Rubrikas palīdz skolēniem saprast pazīmes, kas raksturo labu darbu, tāpēc vieš skaidrību par mērḳi un veiksmes kritērijiem. Viṇa apgalvo, ka rubrikas palīdz skolotājiem mācìt, saskaņot mācīšanu ar vērtēšanu un palīdz skolēniem mācīties. Turklāt, lai izveidotu vai izvēlētos rubriku, skolotājam jāpievērš uzmanība kritērijiem, pēc kuriem vini izvērtēs skolēnu sniegumu, kas savukārt liek skolotājam pievērst uzmanību tam, ko skolēns iemācīsies, nevis tam, ko vinịi mācīs; un tādējādi uzlabojas mācību kvalitāte. Patiesi labas rubrikas palīdz skolotājiem nesajaukt uzdevumu skolēniem ar sasniedzamo rezultātu, līdz ar to nesajaukt uzdevuma izpildi ar mācǐšanos. Rubrikas palīdz skolotājam fokusēties uz kritērijiem, kas raksturo ilgtermiņa prasmi vai izpratni, nevis uz uzdevumu.

S. Brukhārta uzsver, ka vairums rubriku nepieciešams izstrādāt vairākkārtējai lietošanai, vairākiem uzdevumiem, ilgstošā laika periodā. Skolēni saṇem rubriku temata sākumā, veic uzdevumus, saṇem atgriezenisko saiti atbilstoši kritērijiem, veic nākamo uzdevumu un turpina vingrināties, līdz noslēgumā saṇem vērtējumu (atzīmi), balstoties uz šo pašu rubriku. Šāda mācišanās ir daudz iedarbīgāka nekā uzdevumu sērija ar saistītiem, bet atšķirīgiem kritērijiem. Labi veidotas rubrikas, ja tās izmanto formatīvās vērtēšanas kontekstā, palīdz skolēniem ne tikai saprast, kā viṇu sniegums atbilst kritērijiem, bet arī to, kas viņiem jādara, 
lai uzlabotu sniegumu. S. Brukhārta uzsver, ka pētijumi dažādās vecuma grupās un jomās liecina par rubriku izmantošanas pozitīvo ietekmi uz mācišanos, un apraksta vairāku pētījumu piemērus.

\section{Kāds ir labs snieguma līmeṇu apraksts}

Gan Dž. Popams (2008), gan S. Brukhārta (2013) uzsver, ka rubrikas var atšķirties pēc to noderīguma mācību procesā, sakot, ka daudz svarīgāk ir veidot rubrikas, kas mēra prasmes, - "prasmju rubrikas" (skill-focused rubrics) (Popham, 2008) vai vispārīgi snieguma līmeṇu apraksti (general rubrics) (Brookhart, 2013)), izmantojot konkrēto snieguma vērtēšanas uzdevumu kā vienu konkrētu gadījumu jeb ilustrāciju skolēna spējai šo prasmi izmantot līdzīgās situācijās. Lai rubrika būtu noderīga gan skolēnam, gan skolotājam mācību procesa uzlabošanā, jāveido "prasmju rubrikas", kas sastāv no attiecīgajām prasmēm raksturīgajām pazīmēm neatkarīgi no konkrētā uzdevuma. Tas nozìmē, ka uzdevums pārstāv tam radniecīgu uzdevumu kopu (task class). Jēdzienu "radniecīgu uzdevumu kopa" (task class) lieto arī citi autori, kas piedāvā mācību satura izstrādes modeḷus kompleksu prasmju mācišanai (Merril, 2012; van Merriënboer, \& Kirschner, 2007).

Dž. Popams (2008) arī atzīmē, ka pārāk vispārīgas rubrikas, kurās vērtēšanas kritēriji aprakstīit izplūdušā veidā, ko viņš sauc par hypergeneral rubrics, arī nav skolotājam noderīgas, jo nepiedāvā konkrētus snieguma līmeṇu aprakstus, kas l̦autu izvērtēt skolēnu izpildītā uzdevuma kvalitāti. Viņš uzsver, ka visvērtīgākās ir rubrikas, kas (a) apraksta prasmi, kuras izvērtēěanai konkrētais uzdevums veidots; (b) tā ir prasme, ko skolotājs plāno skolēniem mācìt, jo: "Uz prasmju izvērtēšanu vērstas rubrikas skaidri parāda, ko skolotājam vajadzētu akcentēt mācību nolūkā, kad skolotājs cenšas veicināt skolēnu meistarību, novērtējot prasmi. "Mana pārliecība ir tā, ka skolotāji, kuri pirms mācību plānošanas izveido uz prasmēm orientētu punktu skaitu, gandrīz vienmēr izplānos un veidos labāku mācību procesu nekā skolotāji, kuri to nedara." (Popham, 2008, p. 185).

Dž. Popams (2008) piedāvā šādus soļus rubriku izveidē vai izvēlē:

- 1. noteikums. Pārliecinieties, ka novērtējamā prasme ir nozīmīga. Prasmēm vajadzētu atbilst nevis maziem, bet nozīmīgiem skolēnu sasniegumiem.

- 2. noteikums. Pārliecinieties, vai visi rubrikas vērtēšanas kritēriji var tikt lietoti mācību nolūkā. Jābūt pārliecinātam, lai skolēns mācoties izmantotu katru vērtēšanas kritēriju, kas izmantots rubrikā.

- 3. noteikums. Izmantojiet pēc iespējas mazāk vērtēšanas kritēriju.

- 4. noteikums. Izveidojiet īsu aprakstu katram vērtēšanas kritērijam.

- 5. noteikums. Pielāgojiet rubrikas teksta garumu savām vajadzībām. 
Labas rubrikas tiek veidotas, fokusējoties uz kopīgo, vispārīgo (common not task specific), nevis uz konkrētam uzdevumam specifisko sniegumu. Piemēram, valodā - argumentu, skaidrojuma, stāsta rakstī̌sana; dabaszinātnēs - pētišana, veidošana, modelēšana; matemātikā - modelěšana un problēmrisināšana; vēsturē un sociālajās zinībās - dokumentos balstīta jautāšana, izpēte u. c.

Dž. Popams (2008) uzsver, ka visnozīmīgākais kritēriju izvēles procesā ir saprast, kas ir vissvarīgākie faktori jeb pazīmes, kas atškir apmierinošu sniegumu no neapmierinoša. Būtiski izvēlēties nelielu skaitu nozīmīgu kritēriju, par kuriem sniegumu iespējams uzlabot mācīšanās procesā. Vislielākā atdeve no labi izveidotas rubrikas ir apliecinājums, kādā mērā tās izmantošana dod ieguldījumu mācību procesa uzlabošanā. Viņš iesaka izvirzīt ne vairāk kā trīs vai četrus kritērijus jebkura snieguma izvērtēšanai un vārdiski aprakstìt katru snieguma līmeni, izvēloties tādu detalizācijas pakāpi aprakstam, kas noder vērtētājam, kas šo rubriku izmanto. Arī vērtētājiem, kas instrumentu izmantos, var būt dažādas pieredzes ar konkrēto saturu un vēlamo detalizācijas pakāpi, tāpēc viņš iesaka rubriku veidotājiem (ja instrumentam plānots plašs lietojums) piedāvāt divas rubriku versijas - garāku, detalizētāku un ìsāku, kompaktāku. Lietotājam draudzīgākas rubrikas ir tās, kas nav garākas par vienu vai divām lappusēm (izṇemot valsts līmeṇa pārbaudỉjumus, kur l̦oti svarīgas precīzas detaḷas lēmumiem ar lielu ietekmi uz individuālu skolēnu likteñiem (high -stakes).

Kā tiek aprakstìts L. Dārlingas-Hamondas un F. Adamsona piemērā, lietojot rubriku, var izvēēêties snieguma līmeṇu gradāciju (no 1 lìdz 4) pret standartos balstìtu snieguma kritēriju (Select standards based perfomance criteria), t. i., virzìtu uz skaidru, būtisku sasniedzamo rezultātu. Piemēram, pirmais līmenis "Mēgina standartu" rāda, ka darbïba attiecas uz nepieciešamo darbību, bet fokuss ir pazaudēts. Otrais līmenis “Tuvojas standartam” nozīmē, ka parādīta vispārēja nostāja, kas kopumā attiecas uz nepieciešamo darbību. Trešais līmenis "Sasniedz standartu” parāda precīzu un ticamu pozīciju, kas pamatojas pierādỉjumos un spriešanā. Ceturtais līmenis "Pārsniedz standartu" parāda precīzu, pārliecinošu pozīciju, kā arī ierobežojumus un kompleksumu tematā (Darling-Hammond, \& Adamson, 2010).

Balstīties kritērijos, ne normās, t. i., nesalīdzināt skolēnus savstarpēji:

\begin{tabular}{|l|l}
$\begin{array}{l}\text { Skolēns X ir labāks nekā 99\% citu } \\
\text { skolēnu }\end{array}$ & $\begin{array}{l}\text { Skolēna X uzrakstītais ir skaidrs, fokusēts un balstās } \\
\text { spriedumos un teksta detal̄ās, tāpēc tas ir ... }\end{array}$
\end{tabular}

Vērtējuma līmen̦i ir atbilstoši pieaugoši:

\begin{tabular}{|c|c|c|c|}
\hline 1 & 2 & 3 & 4 \\
\hline Veido nostāju & Vispārīgs & Precīzs un ticams & Pārliecinošs \\
\hline
\end{tabular}


Mērḳtiecīga struktūra - īsa, fokusēta; ir izcelti svarīgākie atslēgas vārdi; vienkārša, skaidra, skolēnam draudzīga; pozitīva (Daro, \& Kokka, 2016).

Labi izveidotas rubrikas ir izglïtojošas, sakārtotas, ar skaidri nodalīitem snieguma līmen̦iem, mērḳtiecīgi formatētas un strukturētas. Pārliecinies, vai tava izveidotā rubrika:

- mēra to, ko domāts, ka mēra,

- ir saskaņota ar standarta prasībām,

- fokuss ir uz būtiskākajām zināšanām, prasmēm, procesiem,

- dimensijas ir nodalītas un fokusētas,

- atspogul̨o attīstošu progresiju,

- ir pietiekams līmeñu skaits, lai parādītu progresu,

- indikatori ir parādìti paralēli visos līmeņos,

- valoda parāda novērojamu uzvedību, aprakstìtas kvalitatīvas prasmes (Darling-Hammond, \& Adamson, 2010).

Situācijas risināšanai rosinām mācību procesā ne tikai dažādot uzdevumus, teksta veidus un darbā ar tekstu iekḷaut daudzveidīgas stratēéijas, bet arī izmantot rubrikas, lai skolēns varētu sekot savam progresam, apzināti attīstot savas prasmes darbā ar tekstu. Skolotājiem mācību procesā svarīgi vienoties, kādas konkrētās prasmes tiek apgūtas, kādi tekstu veidi tiek izvēlēti, kādi paṇēmieni tiek izmantoti un kā to mācām novērtēt skolēniem pašiem.

\section{Secinājumi}

Mācību procesā vairāk uzsverot augstākā līmeņa kognitīvo prasmju apguvi un nostiprinot skolēnu spēju lietot zināšanas daudzveidīgā kontekstā, arvien lielāka nozīme jāpiešķir snieguma vērtēšanai. Kā atzīst vairāki autori, tas ir vienīgais veids, kā pārliecināties par skolēnu spēju lietot prasmi kontekstā.

Snieguma vērtēšana ir pieeja skolēnu darba vērtēšanai, kas pirmām kārtām, balstās uz skaidru izpratni par mērāmo prasmi vai kompetenci un būtiskām dimensijām, kas to raksturo. Šì izpratne ir kritiski svarīga gan kvalitātes kritēriju izvirziš̌anā, gan snieguma līmeņu aprakstu (indikatoru) izveidē.

Snieguma vērtēšanai un snieguma līmeņu aprakstu (rubriku) izmantošanai snieguma vērtēšanas kontekstā var būt liela pozitīva ietekme uz mācǐšanu un mācīšanos. Veidojot vai izvēloties skolēnu snieguma vērtēšanas instrumentus, skolotājam var rasties padziḷināta izpratne par sasniedzamo rezultātu, viņ̌̌ var sākt pievērst vairāk uzmanības augstākas domāšanas prasmēm. Skolēnam kḷūst skaidri kvalitatīva snieguma kritēriji, veidojas izpratne par darba aspektiem, kurus nepieciešams pilnveidot. 
Snieguma vērtēšanas pozitīiā ietekme uz mācībām atkarīga gan no kvalitatīiem vērtēšanas instrumentiem un snieguma līmeņu aprakstiem (piemēram, vai kritēriji apraksta prasmi, nevis tikai konkrētā uzdevuma izpildes prasības vai prasmes demonstrācijai nenozīmīgas, virspusējas pazìmes), gan no konteksta, kādā šie instrumenti tiek izmantoti. Šì pieeja īpaši piemērota formatīvās vērtēšanas situācijām gan skolēnu, gan pedagogu darba novērtēšanai situācijās, kurās prasme tiek apgūta ilgstošā laikposmā ar iespējām vairākkārt veikt līdzīgus uzdevumus un uzlabot sniegumu.

Attīstoties tehnolog̣ijām un procedūrām vērtējumu saskaņošanai vairāku vērtētāju vidū, snieguma vērtēšanu iespējams sekmīgi îstenot arī nacionāla mēroga kontekstā, ne tikai ikdienas vērtēšanā klasē. Vairākās pasaules valstīs (piemēram, Austrālijā) ir uzkrāta šāda pieredze.

Komplekss skolēna sniegums vērtējams ar kompleksa problēmuzdevuma izpildes palīdzību. Kompleksa snieguma mērīšanai izvēlēts uzdevums atbilst šādiem kritērijiem (pazīmēm): sasniedzamais rezultāts jeb kādu sniegumu mēs vēlamies, lai skolēns demonstrē, ir pirmais uzdevuma izvēles kritērijs. Nozīmīgs kritērijs uzdevumu atlasē ir arī kognitīvās darbības dziḷums. Izvēloties uzdevumus, iespēju robežās tie jāizvēlas dažāda dziḷuma kognitīvajā līmenī. Papildu kritēriji atbilstoša uzdevuma izvēlē ir kompleksums un tas, cik pazīstama vai nepazīstama skolēniem ir dotā situācija/uzdevums.

SOLO taksonomija ir izziņas rīks, ar kura palīdzību var atspoguḷot un izvērtēt kvalitatīvu virzību no virspusējas uz dziḷu mācišanos. Taksonomiju var izmantot, lai analizētu, cik dziḷi domā skolēns; lai skolēnam palīdzētu saprast, kā uzlabot savu rezultātu (pāriet uz nākamo līmeni), un spriestu par paša mācību uzdevuma kognitīvo līmeni.

Uzdevumu izvēlei kompleksa snieguma mērī̌sanā ir svarīgi šādi kritēriji: zināšanas un izpratne, pamatprasmes mācību priekšmetā (nozarē); to saskatīšana un apjēgšana dotajā kontekstā; reālās dzìves un citu nozaru konteksts (starpdisciplinaritāte), kognitīvās darbības dziḷums; dažādi paṇēmieni darbā ar tekstu; lai veiktu uzdevumu, jāprot kompleksi ieraudzìt tā jēgu.

Kvalitatīvu snieguma vērtēšanas instrumentu izveide ir darbietilpīgs process, kurā vērtīgi izmantot gan teorētiskus modeḷus, piemēram, par konkrētas kognitīvas prasmes struktūru, gan informāciju par tipisku prasmes attīstību un lielākajām grūtībām, ar kurām skolēni sastopas ikdienā klasē. Snieguma vērtēšana - kritēriju izvēle, rubriku izveide, snieguma novērtēšana - ir laikietilpīga, tāpēc instrumentiem un procedūrām jābūt pēc iespējas vienkāršiem, draudzīgiem lietotājiem, atkārtoti izmantojamiem un tādiem, kas sniedz noderīgu informāciju, lai uzlabotu mācǐšanu un mācīšanos.

Skolēna sniegumu, izmantojot rubrikas, var vērtēt veselumā (holistiski), t. i., piemērojot visus vērtēšanas kritērijus kopumā/vienotā veselumā, vai balstoties 
uz katru kritēriju atsevišķi, izmantojot analītisko vērtēšanas pieeju. Holistiskas rubrikas veiksmīgi var izmantot summatīvās vērtēšanas nolūkos.

Analìtiski vērtējot, rubriku veido atbilstoši izvirzìtajam sasniedzamajam rezultātam, ko plāno novērtēt, pakāpeniski atsedzot konkrētās prasmes dimensijas (piemēram, kāda informācija jāmeklē, kādā tekstā, situācija skolēnam mācìta vai jauna, lasišanas pan̄ēmiens) un izveidojot katram līmenim precīzu aprakstu, t. i., indikatoru. Analītiskās rubrikas ir noderīgi izmantot mācību procesāa, lai skolotāji un skolēni saṇemtu iespējami precīzu atgriezenisko saiti, kas mācoties darāms turpmāk.

Svarīgi izvēelêties tās rubrikas, kuras veidotas, ņemot par pamatu teorētisku modeli vai citu pierādījumos balstītu informāciju (piemēram, par efektīvas mācǐšanas aspektiem). Labas rubrikas pazīmes ir mācību priekšmetu satura būtībā balstīti snieguma kritēriji un skaidras to dimensijas; snieguma līmeņi ir atbilstoši augoši; tās ir īsas, fokusētas; ir izcelti svarīgākie atslēgas vārdi; vienkārša, skaidra, skolēnam draudzīga, pozitīva valoda.

Labi izveidotas rubrikas ir izglïtojošas, sakārtotas, ar skaidri nodalītiem snieguma līmen̦iem, mērḳtiecīgi strukturētas.

\section{IZMANTOTĀ LITERATŪRA}

Biggs, J., Collis, K. (1982). Evaluating the quality of learning: The SOLO taxonomy.

Biggs, J., Tang, C. (2007). Teaching for quality learning at university: What the student does.

Black, P., \& Wiliam, D. (2007). Large-scale assessment systems: Design principles drawn from international comparisons. Measurement: Interdisciplinary Research and Perspectives, 5(1), pp. 1-53.

Bleiler, S. K., \& Thompson, D. R. (2012/2013). Multi-dimensional assessment of the common core. Teaching Children Mathematics, 19(5), pp. 292-300.

Bloom, B., Englehart, M. Furst, E., Hill, W., \& Krathwohl, D. (1956). Taxonomy of educational objectives: The classification of educational goals. Handbook I: Cognitive domain. New York, Toronto: Longmans, Green.

Brookhart, S. M. (2013). How to Create and Use Rubrics for Formative Assessment and Grading. Ascd.

Brookhart, S. M. (2010). How to assess higher-order thinking skills in your classroom. ASCD. Product No: 109111. ISBN-13: 978-1-4166-1048-9

Darling-Hammond, L., \& Adamson F. (2010). Beyond basic skills: The role of performance assessment in achieving $21^{\text {st }}$ century standards of learning. Stanford, CA. Pieejams: https://scale.stanford.edu/system/files/beyond-basic-skills-role-performance-assessmentachieving-21st-century-standards-learning.pdf (aplūkots: 10.02.2018.).

Daro, V. E., Kokka, K. (2016). Evaluating Item Quality in Mathematics Assessments. In Evaluating Item Guality in Large-Scale Assessments. Understanding Language. Stanford Center for Assessment, Learning \& Equity. Stanford Graduate School of Education, pp. 48-82.

Halpern, D. F. (2014). Thought and Knowledge: An Introduction to Critical Thinking (5 ${ }^{\text {th }}$ ed). NY: Psychology Press. 
Kramarski, B., \& Mevarech, Z. R. (2003). Enhancing mathematical reasoning in the classroom: The effects of cooperative learning and metacognitive training. American Educational Research Journal, 40(1), pp. 281-310.

Kuhn, D. (2000). Metacognitive development. Current directions in psychological science, 9(5), pp. $178-181$.

Martin, D. (2016). Evaluating Item Guality in History Assessments. In Evaluating Item Guality in Large-Scale Assessments. Understanding Language. Stanford Center for Assessment, Learning \& Equity. Stanford Graduate School of Education, pp. 107-132

Merrill, D. (2012). First principles of instruction: Identifying and designing effective, efficient and engaging instruction, $1^{\text {st }}$ ed. John Wiley \& Sons.

Panizzon, D., Pegg J. (2003). Using a cognitive structural model to provide new insights into students' understandings of diffusion. International Journal of Science Education, 25(12), pp. 1427-1450.

Pecheone, R. L., \& Whittaker, A. (2016). Well-prepared teachers inspire student learning. Phi Delta Kappan V97 N7.

Popham, J. (2008). Classroom assessment: What teachers need to know. ( $5^{\text {th }}$ edition.) Boston: Allyn \& Bacon.

Schraw, G. (1998). Promoting general metacognitive awareness. Instructional science, 26(1-2), pp. 113-125.

Smith, T. W., \& Colby, S. A. (2007). Teaching for deep learning. The Clearing House: A Journal of Educational Strategies, Issues and Ideas.Stanford University, Stanford Center for Opportunity Policy in Education. Pieejams: https://scale.stanford.edu/system/files/ beyond-basic-skills-role-performance-assessment-achieving-21st-century-standardslearning.pdf (aplūkots 12.02.2018.).

Stiggins, R. J., Arter, J. A., Chappuis, J., \& Chappius, S. (2004). Classroom assessment for student learning: Doing it right - using it well. Portland, Oregon: Assessment Training Institute.

Thompson, D. R., \& Kaur, B. (2011). Using a multi-dimensional approach to understanding to assess students' mathematical knowledge. In Kaur, B., \& Wong K. Y. (eds.). Assessment in the mathematics classroom: Association of Mathematics Educators Yearbook (pp. 17-32). Singapore: World Scientific Publishing.

van Merriënboer, J. J. G., \& Kirschner, P. A. (2007). Ten steps to complex learning: A systematic approach to four-component instructional design. Routledge.

Wertheim, J., Holthuis, N., \& Schultz, S. (2016). Evaluating Item Quality in Science Assessments. In: Evaluating Item Guality in Large-Scale Assessments. Understanding Language. Stanford Center for Assessment, Learning \& Equity. Stanford Graduate School of Education, pp. 81-106

Wiggins, G., Grant, P., \& McTighe, J. (2005). Understanding by design. Expanded $2^{\text {nd }}$ ed. Alexandria, VA: Association for Supervision and Curriculum Development.

Стоунс, Е. (1984). Психопедагогика: Психологическая теория и практика обучения. Москва: Педагогика. 
4. nodala

\title{
Ko rāda makrolīmeṇa vērtēšanas darbu analīze eksaktajos mācību priekšmetos trīs gadu periodā
}

\author{
Līga Čakāne, Dace Namsone, Pāvels Pestovs, Dace Bērtule
}

Vērtēšanai makrolīmenī jeb valsts mēroga pārbaudes darbos mērḳis ir zināšanu un prasmju apguves līmeņa konstatēšana noteiktā izglïtîbas posmā. Pašlaik saskaņā ar Ministru kabineta noteikumiem Nr. 1510 "Valsts pārbaudījumu norises kārtība" valsts līmeņa pārbaudījumi (valsts pārbaudes darbi) ir diagnosticējošais darbs un eksāmens. MK noteikumos Nr. 468 "Noteikumi par valsts pamatizglìīibas standartu, pamatizglìtỉbas mācību priekšmetu standartiem un pamatizglìtîbas programmu paraugiem" nosaukti konkrētie valsts pārbaudījumi, beidzot 3., 6. un 9. klasi. ${ }^{1}$ Valsts izglítības satura centrs (VISC) veido arī citus makrolīmeņa diagnosticējošos darbus, kuriem nav valsts pārbaudījuma statuss, piemēram, diagnosticējošais darbs dabaszinātnēs 9. klasei, kura mērkis - "noskaidrot izglītojamo spējas dabaszinātņu mācību priekšmetos iegūtās kompetences izmantot praktisku dabaszinātṇu problēmu risināšanā ar nolūku tās pilnveidot".2.

Dabaszinātņu apguves mērķis pamatskolā ir dabaszinātniskā izpratība, kas spēkā esošajos šo mācību priekšmetu standartos ir strukturēta trīs blokos - izpratne par dabas sistēmām un procesiem; pētnieciskā darbība; vides, sabiedrības

1 Latvijas Republikas Ministru kabineta 2014. gada 12. augusta noteikumi Nr. 468 "Noteikumi par valsts pamatizglitīibas standartu, pamatizglìtïbas mācību priekšmetu standartiem un pamatizglitibas programmu paraugiem".

2 Valsts pārbaudes darbi, beidzot 3., 6. un 9. klasi. Pieejams: http://visc.gov.lv/vispizglitiba/eksameni/dokumenti/programmas/2016_2017/09_dabzin_diagdarbs.pdf

http://visc.gov.lv/vispizglitiba/eksameni/dokumenti/programmas/2016_2017/08_matematika_diagdarbs.pdf (aplūkots 12.02.2018.). 
un tehnologijiju vajadzības, kas veido reālo kontekstu. ${ }^{3}$ Atbilstoši tam skolēna dabaszinātṇu mācišanās rezultāts ir daudzdimensionāls, kas pilnībā var izpausties kompleksā sniegumā. Pretendējot mērīt šo rezultātu, kritiski svarīga kḷūst piemērota vērtēšanas instrumenta izstrāde, sākot ar konstrukta definēšanu, precìzu snieguma indikatoru formulēšanu, snieguma aprakstī̌sanu līmeņos, atbilstošo testelementu atlasi.

\section{Kā tas notiek citur pasaulē}

Vērtēšanas darbi makrolīmenī tiek veidoti ārpus skolas un pārsvarā tiek izmantoti starptautiskajā, nacionālajā vai pašvaldības līmenī. Tradicionāli šāda veida vērtēšana tiek izmantota starptautiskos salīdzinošos pētijumos (Programme for International Student Assessment (PISA), Progress in International Reading Literacy Study (PIRLS) ${ }^{4}$, Trends in International Mathematics and Science Study (TIMSS)), summatīvajai novērtēšanai un mācību programmu novērtēšanai. Līdz ar to vērtēšana makrolīmenī bieži atškiras pēc veida, mērķa un citiem parametriem. Svarīgi ir definēt, kā notiks vērtēšana konkrētajos apstākḷ̣os, lai nebūtu vispārinājuma, kas ir attiecināms uz visiem vērtēšanas darbiem makrolīmenī (Kifer, 2000).

Vairākās valstīs ir mēǵināts apvienot formatīvās un summatīvās vērtēěanas mērķus, kas joprojām ir diskutējams jautājums, lai skolotāja formatīvās vērtēšanas stratēégijas netiktu ierobežotas ar valsts līmeņa summatīviem vērtēšanas darbiem (Black, \& Wiliam, 2007).

Ja vērtēšanas mērḳis ir sertificēšana, t. i., apliecinājuma dokumenta izsniegšana par noteiktu snieguma līmeni, un tā notiek vienā skolā, būtiskais elements darba kvalitātes nodrošināšanai ir visu viena priekšmeta skolotāju iesaiste, vienojoties par pierādījumiem, kuri liecinās par skolēna sasniegumiem atbilstoši sasniedzamajiem rezultātiem mācību priekšmetu standartos. Pašvaldības vai valsts līmenī tas veicams, izmantojot ietvarstruktūru (framework), vērtēšanas darba programmu, kritērijus un kritēriju līmeņu aprakstus par to, ko nozīmē labs sniegums.

3 Latvijas Republikas Ministru kabineta 2014. gada 12. augusta noteikumi Nr. 468. Pieejams: Noteikumi par valsts pamatizglìtības standartu, pamatizglitības mācību priekšmetu standartiem un pamatizglìtības programmu paraugiem. (aplūkots 12.02.2018.).

4 Starptautiskā lasītprasmes novērtēšanas pētījuma IEA PIRLS 2016 pirmie rezultāti par 4. klašu skolēnu lasittprasmi Latvijā un pasaulē. Pieejams: https://www.ipi.lu.lv/fileadmin/user_upload/ lu_portal/projekti/ipi/Publikacijas/elektronisks_PIRLS2016_nacionalais_zinojums.pdf (aplūkots 12.02.2018.). 
Pētījumos (piemēram, Britton, 2007) parādās informācija, ka vērtēšanas darbos ir nepietiekams kompleksu, problēmu risināšanas uzdevumu skaits, bet ir liels zemākam izziņas līmenim atbilstošu uzdevumu īpatsvars.

Pieaug nepieciešamība pēc mērīšanas instrumentu saskaņotības dažādās dimensijās: starp dažādām mācību programmām, mācišanās praksēm un vērtěšanas formām, dažādu klašu grupās un starp dažādām organizācijām (klase, skola, pašvaldība, valsts), saturiski (izziņas, afektīvie u. c.). Jauni mērī̌sanas un datu apstrādes instrumenti l̦auj veikt mērījumus gan starp dažādām populācijām, gan ar vienu un to pašu populāciju dažādos laikposmos, kā arī salīdzināt iegūtos datus (Bond, \& Fox, 2007). Ar mērī̌sanas instrumentu tiek saprasts veids, kas ļauj pēc iespējas precīzāk saistìt skolēna snieguma novērojumus ar to, ko mēs gribam vērtēt, kas ir daḷa no teorētiskā mainīgā (latentais mainīgais, konstrukts) (Wilson, 2005).

Datu analīzei ar nolūku uzlabot vērtēšanas instrumentu un datu interpretāciju izmanto klasiskās testa teorijas - Classic Test Theory (KTT) un testelementaatbildes teorijas - Item Response Theory (TAT) modelus, kuri efektīvi papildina viens otru. KTT izvērtē testelementa grūtības pakāpi, testelementa izškirirtspēju (diskriminācijas indeksu), drošumu. Testelementos ar zemu izšķirtspēju vispirms nepieciešams analizēt formulējumus un testelementa izpildes nosacỉjumus, pēc tam pārliecināties, vai konkrētais testelements mēra definēto konstruktu. L,oti sarežğìti un ḷoti viegli testelementi noved pie zemas izšķirtspējas, bet to ietveršanu vai neietveršanu testā vērtē pret definēto mērḳi. Iekḷaujot testelementus ar zemu izškirtspēju, tiek samazināts testa drošums, palielinās mērījuma kḷūda. Tādējādi samazinās iespēja precīzi interpretēt iegūtos datus. TAT savukārt ḷauj veikt mērīšanas instrumentu pielīdzināšanu, mērot latento mainīgo dažādām grupām, veidot datorizētu adaptīvu testēšanu un interpretēt iegūtos datus. Mērīšanas instrumentam ir jābūt tādam, ka skolēna prasmju līmenis nav atkarīgs no konkrētiem testelementiem, ar kuriem mēra vienu un to pašu prasmi. TAT l̦auj veikt neapstrādāto datu transformāciju, lai iegūtie dati atspoguḷotu arī lineāru sakarību starp skolēnu sasniegumiem. Tas dod papildu iespējas iegūto datu interpretācijai. TAT modelī ir iespēja prognozēt skolēna varbūtību pareizi atrisināt konkrētu testelementu, izmantojot skolēna spēju līmeni un testelementa grūtības pakāpi (Wu, Tam, \& Jen, 2016).

Viens no centrālajiem mērišanas instrumenta komponentiem ir ticamība (validitāte). Ticamības pierādījumi ir nepieciešami vismaz par trim elementiem: mācību saturu, uzdevuma jeb testelementa indikatoru un konstrukta modeli. Lìdztekus ar faktoru analīzi ticamība tiek sasniegta, izmantojot ekspertu diskusijas metodi par satura ticamību un skolēnu intervijas (Liu, 2012). Mērī̌sanas instrumenta veidošanā uzmanība jāvērš uz to, lai atbalstīto iegūtajai datu 
interpretācijai būtu augsta ticamības pakāpe atbilstoši definētajam mērḳim. Mērǐšanas instrumenta veidotājiem izstrādes procesā svarīgi iegūt un dokumentēt pierādījumus drošumam, ticamībai, atbilstîbai plānotajai populācijai un indivīdam. ${ }^{5}$ Kvalitatīva mērī̌sanas instrumenta izveides process ietver:

- izstrādes plānošanu - ticamības izvērtēšanu, datu interpretācijas mērḳi un izmantošanu, mērī̌sanas instrumenta kvalitātes rādītājus;

- ietvara definēšanu - kas tiks mērīts (kādas zināšanas, prasmes, attieksmes), prasības snieguma līmeñiem;

- satura definēšanu - lai efektīvi izstrādātu testelementus;

- uzdevumu testelementu izstrādi un aprobāciju;

- mērīšanas instrumenta izstrādi - formas, satura atbilstību specifikācijai, testelementa formātus, vērtēšanas principus, pielīdzināšanas un izškirtspējas iespējas;

- mērī̌sanas instrumenta publicēšanu;

- mērišanas instrumenta administrēšanu;

- vērtējuma izlikšanu - procedūras testelementa novērtēšanai;

- robežu definēšanu - piemēram, minimāli iespējamo robežu, lai sasniegtu noteiktu lïmeni;

- datu paziņošanu - mērķauditorijai pārskatāmu mērišanas rezultātu apkopojumu;

- mērīšanas instrumenta drošību - procedūras izstrādes un administrēšanas laikā.

Sākot mērīšanas instrumenta veidošanu, būtiski ir izstrādāt mērīšanas instrumenta ietvaru, kurā tiek definēts mērī̌šnas mērḳis, mērḳauditorija, mērīšanas metodologijia, konstrukta modelis, kas būs pārklāts. Mērǐšanas instrumenta sagatavē definē uzdevumu testelementu formu, grūtības pakāpju sadalījumu, testelementu procentuālo sadalijumu katrā no konstrukta dimensijām un apakšdimensijām, kā arī to, kurus lielumus varēs novērot, mērīt tieši, kuri mainīgie būs latenti (Wu, Tam, \& Jen, 2016).

Saistībā ar testelementiem mērišanas instrumentos bieži tiek iekḷauti īso atbilžu uzdevumi, kuru izmantošanas iespējas var paplašināt, mainot formu vai saturu, piemēram, palielinot atbilžu variantu skaitu, prasot izvēlēties vairākas atbildes no piedāvātajām, pievienojot papildu jautājumus - aicinot skolēnu skaidrot, kāpēc tika izvēlēta atbilstošā atbilde u. c. Atbilžu izvēles uzdevumiem piemìt vairākas priekšrocỉbas, piemēram, to formāts l̦auj palielināt satura pārklājumu un iegūt augstu atkārtojamību, bet to izmantošanai ir tendence negatīvi ietekmēt mācỉbu procesu, padarot to virspusēju. Tie nedod iespēju iegūt

5 APA, AERA \& NCME. (2014). Standards for educational and psychological testing. Washington, DC: American Educational Research Association. 
datus par skolēna izvēles pamatojumu un domāšanas gaitu. Viens no virzieniem, kā palielināt šīs formas testelementu efektivitati, ir izmantot atbildes, kas ietver skolēnu nepareizos priekšstatus (Wylie, \& Wiliam, 2006). Otrs trūkums ir saistīts ar šauru un izolētu kontekstu (Black, \& Wiliam, 2007). Strukturētu atbilžu uzdevumi sniedz daudz vairāk informācijas par skolēna domāšanas veidu, bet atbilžu vērtēšanā samazinās drošums, daudz lielāks resurss jāiegulda skolotāju sagatavošanā un vērtētāju vērtēšanas prasmju attīstīšanā. Snieguma vērtēšanai ir izmantojami esejas tipa uzdevumi, bet šai formai piemīt būtiski trūkumi - skolēnam ir nepieciešams liels laika resurss, tādējādi šādu uzdevumu skaits vērtēšanas darbā ir limitēts, nereti darbā tiek iekḷauts tikai viens uzdevums. Šis fakts būtiski ietekmē darba drošumu, jo skolēns spēj uzrādīt augstu sniegumu tāpēc, ka tieši šis jautājums ir derīgs konkrētajam skolēnam. Otrs trūkums ir saistìts ar prasmēm radìt tekstu. Daļa snieguma veidojas no izpratnes konkrētajā nozarē, prasmes argumentēt, bet daļa nepārprotami veidojas no skolēna prasmes radīt tekstu, līdz ar to nevaram būt droši, kas tieši tiek izmērìts.

Saistībā ar makrolīmeṇa mērījumiem tieši dabaszinātṇu jomā skolēnu sasniegumi pārsvarā tiek mērìti multidimensionāli, piemēram, dabaszinātṇu joma sastāv vismaz no četriem saturiskajiem laukiem. Taču pat vienā nozarē skolēnam ir stiprās un vājās puses noteiktos tematos, dabaszinātniskā izpratība var būt atšķirīgos snieguma līmeņos. Metodolog̣ija, kādā veidā informācija tiek apkopota, tiešā veidā ietekmē datu interpretācijas iespējas par individuālo skolēnu vai skolu. Apvienojot individuālā skolēna datus līdz vienam kopìgam snieguma līmenim, netiek iegūti dati par to, ko skolēns patiesībā prot un var izdarìt, jo augsti sasniegumi vienā dạ̦ā var kompensēt zemus sasniegumus citā dạ̦ā. Sasniedzamie rezultāti skolēnam konkrētajā mācišnanās posmā ir ekspertu vienošanās jautājums, līdzīgi ir arī ar robežu starp snieguma līmeņiem. Dabaszinātniskajai izpratîbai ir iespējams definēt dimensijas, vadoties gan no satura, gan pētnieciskajām prasmēm. Definējot pētniecisko prasmju vērtēšanas dimensijas, tiek akcentēts vienojošais dabaszinātṇu jomā (Black, \& Wiliam, 2007).

Kā nozīmīgs pavērsiens atzīmējams tas, ka šobrīd pētnieciskā interese tiek virzìta arī uz mērišanas instrumentu izstrādi metakognitīvo prasmju mērīšanai (Liu, 2012).

Latvijas situācijā būtiski saprast, cik precīzi valsts līmeņa pārbaudes darbi mēra 2006. gada pamatizglìtỉbas mācību satura dokumentos moteiktās prioritātes, vai un kā tie mēra kompleksu sniegumu, kā tie atbilst labam makrolīmeņa mērišana/vērtēšana instrumentam. 


\section{Kā tika analizēti valsts līmeṇa pārbaudes darbi dabaszinātnēs un matemātikā}

Analīzei par trīs gadu periodu (2015-2017) dabaszinātnēs izvēlēti diagnosticējošie darbi 9. klasei. Lai spriestu par tendencēm visā pamatskolas posmā, analizēti arī 6. klases darbi dabaszinībās, un visi valsts līmeṇa darbi matemātikā diagnosticējošie darbi 3., 6. un 8. klasei un eksāmens 9. klasei.

Darbu analīzei izvēlēta trīsdimensionāla ietvarstruktūra (skat. 1. tabulu). Tas atbilst dabaszinātṇu mācību priekšmetu standartu struktūrai - izpratne par procesiem, parādībām dabā; pētnieciskā darbība; kā trešo aspektu izdalot kognitīvo darbību (2006. gadā kā būtisks mācību satura aspekts izcelta problēmrisināšana ar mērḳi veicināt dziḷu domāšanu), lai pārliecinātos, kā skolēni spēj rīkoties situācijās, uzdevumos, kas prasa augsta līmeņa kognitīvu darbību. Tas atbilst arī OECD (the Organisation for Economic Co-operation and Development (OECD)) PISA dabaszinātniskās izpratības mērỉjuma ietvarstruktūrai ${ }^{6}$ (skolēnu prasme zinātniski skaidrot parādības; prasme plānot un vērtēt dabaszinātnisku izpēti; prasme zinātniski interpretēt datus un pierādỉjumus). Skolēns var skaidrot uzdevumu, balstoties gan uz procesu, parādību izpratni, ko ieguvis mācīšanās procesā, gan uz tajā doto informāciju. Arī šādā griezumā svarīgi saprast, vai skolēns spēj darboties tikai atpazī̌anas līmenī vai spēj saskatīt kopsakarības, risināt kompleksu problēmu, cik vienkārši vai kompleksi ir interpretējamie dati, cik skaidrs vai atvērts ir veicamais pētījums; tātad kognitīvais aspekts.

1. tabula. Valsts līmeṇa darbu analīzei izvēlētā ietvarstruktūra

\begin{tabular}{|c|c|}
\hline letvarstruktūras elementi & Izvēlētie kritēriji, mācību satura lauki \\
\hline \multirow{4}{*}{$\begin{array}{l}\text { Izpratne par procesiem, parādībām } \\
\text { dabā, specifiskas prasmes }\end{array}$} & Bioloǵiskās sistēmas un procesi \\
\hline & Fizikālās sistēmas un procesi \\
\hline & Vielas un to pārvērtības \\
\hline & Zemes dabas sistēmas \\
\hline \multirow[b]{2}{*}{ Pētnieciskā darbība } & Ar eksperimenta veidošanu saistītās prasmes \\
\hline & $\begin{array}{l}\text { Prasmes darbā ar informāciju, tostarp grafisku } \\
\text { (tekstpratība) }\end{array}$ \\
\hline Kognitīvais līmenis & Kognitīvais dziḷums \\
\hline
\end{tabular}

6 OECD (2016). PISA 2015 Results (Volume I): Excellence and Equity in Education, PISA, OECD Publishing, Paris. Pieejams: http://dx.doi.org/10.1787/9789264266490-en (aplūkots 12.02.2018.). 
Fiksēts katram kritērijam atbilstošo uzdevumu skaits pārbaudes darbos trīs gadu periodā.

Diagnosticējošā darba analīzē iesaistītie eksperti formulēja katra testelementa indikatoru - zināšanas, prasmes, ko šis uzdevums mēra; noteica katra uzdevuma kognitīvās darbības dziḷumu atbilstoši SOLO (Structure of the Observed Learning Outcome (SOLO)) taksonomijai (Biggs, \& Collis, 1982), prognozējot nepieciešamo kognitīvās darbības līmeni, ko paredz uzdevums. Uzdevumu analīzi veica katrs eksperts individuāli, vērtējumi tika salīdzināti, atšķirību gadījumos diskusiju gaitā vienojoties.

Diagnosticējošā darba analīzē kognitīvās darbības raksturojumam izvēlēta SOLO taksonomija (Biggs, \& Collis, 1982), kur definēti četri snieguma līmeņi, jo šis instruments palīdz detalizētāk ieraudzìt atšķirību starp augstākajiem līmeņiem - ko tieši skolēns demonstrē katrā no tiem, kas ir l̦oti būtiski, ja domājam par nepieciešamību dot skolēniem pieredzi dziḷāk domāt un mērìt sniegumu.

Visiem izvēlētajiem darbiem analizēti gan paši uzdevumi, gan statistiskie dati par skolēnu sniegumu. Diagnosticējošo darbu padziḷinātai analīzei izmantoti arī atlasìti skolēnu darbi. Pieejamie dati (visi skolu iesniegtie skolēnu rezultāti pa uzdevumiem) apstrādāti atbilstoši klasiskajai testa teorijai (Classic Test Theory) un testelementa-atbildes teorijas (Item Response Theory) Raša modelim (Rasch model). Analizējot datus, izmantotas Iteman, Winsteps un $R$ programmas.

Noteikta katra uzdevuma grūtības pakāpe, uzdevuma izškirtspēja, kā uzdevuma izpilde veikusies skolēnu grupai ar augstiem un zemiem sasniegumiem darbā kopumā. Ja uzdevumu veido vairāki apakšuzdevumi (testelementi), grūtības pakāpe noteikta katram no tiem. Ja katrs testelements atbilst citam snieguma indikatoram, tas mēra atšķirīgas zināšanas vai prasmes.

Lai konstatētu pārbaudes darbos iekḷauto uzdevumu piemērotību kompleksa snieguma vērtēšanai, izmantoti kritēriji (skat. 2. tabulu).

2. tabula. Kritēriji uzdevuma piemērotībai kompleksa snieguma vērtēšanai

Izpratne disciplīnā ar fokusu uz būtisko

Starpdisciplinaritāte (pārnesums, integritāte, autentiskums)

Prasmes, tostarp prasmes darbā ar informāciju

Kognitīvās darbības dziḷums

Metakognitīvā darbība

Atbilžu, risināšanas stratēǵiju variativitāte

Vērtēšanas kritēriji 


\section{Kas tiek izmērīts valsts līmeṇa pārbaudes darbos dabaszinātnēs, un kāds ir skolēnu sniegums}

Vispirms atbilstoši izvēlētajam konstruktam noskaidrots, kā tiek mērīta izpratne par procesiem, parādībām dabā.

Satura pārklājums diagnosticējošajos darbos dabaszinātnēs 9. klasei trīs gadu laikposmā redzams 3. tabulā. Šeit aplūkoti tie testelementi, kuri pārbauda skolēnu izpratni par procesiem, parādībām vai nu tiešā veidā, vai kompleksā situācijā.

3. tabula. Testelementu īpatsvars mācību satura laukos (\% no visiem testelementiem) ${ }^{7}$

\begin{tabular}{lccc}
\hline Satura lauks & 2015 & 2016 & 2017 \\
\hline Bioloǵiskās sistēmas un procesi & 20 & 18 & 18 \\
\hline Fizikālās sistēmas un procesi & 18 & 18 & 27 \\
\hline Vielas un to pārvērtī̄bas & 20 & & 27 \\
\hline Zemes dabas sistēmas & 5 & 5 & 6 \\
\hline
\end{tabular}

Tradicionāli vismazāk pārbaudes darbos tiek iekḷauti geogrāfijas satura jautājumi, 2016. gada darbā ķīmijas satura uzdevumu nav vispār. 2017. gadā akcents bijis uz izpratnes mērī̌sanu par procesiem un parādībām dabā, 2016. gadā tam atvēlēts mazāk par pusi testelementu - akcents bijis uz prasmju mērišanu darbā ar informāciju.

Turpmāk analizēts satura lauku atsegums, kā piemērus aplūkojot divus no laukiem, kuri visvairāk pārstāvēti pārbaudes darbos (skat. 4. un 5. tabulu), uzdevuma raksturošanai izmantojot tā grūtỉbas pakāpi (vidējā rezultāta un maksimāli iespējamā punktu skaita attiecỉba) un snieguma indikatoru - ko mēra uzdevums.

Tā kā katrs testelements aplūkots no vairākiem aspektiem, sastopami starpdisciplināri uzdevumi, kompleksi uzdevumi, tad šeit un turpmāk summa var nebūt $100 \%$. 
4. tabula. Indikatori mācību satura laukā "Fizikālās sistēmas un procesi“

\begin{tabular}{|c|c|c|c|c|}
\hline Lauks & Gads & Uzd. & $\begin{array}{l}\text { Grūtības } \\
\text { pakāpe }\end{array}$ & Skolēna snieguma indikators \\
\hline \multirow[t]{4}{*}{ Optika } & 2015 & 6.3 & 0,46 & $\begin{array}{l}\text { Attēlo savācējlēcu, saprotot, ka tā } \\
\text { saistīta ar tālredzību. }\end{array}$ \\
\hline & & 6.4. & 0,43 & $\begin{array}{l}\text { Attēlo, kur fokusējas gaisma normālas } \\
\text { redzes gadījumā. }\end{array}$ \\
\hline & & 6.5. & 0,22 & Aprēkina lēcas fokusa attālumu. \\
\hline & 2017 & 11. & 0,27 & Zina savācējlēcas darbības principu. \\
\hline \multirow[t]{2}{*}{ Elektrība } & 2016 & 7.4 . & 0,64 & $\begin{array}{l}\text { Lieto zināšanas, ka strāva plūst tikai } \\
\text { noslēgtā k̦ēēē, nolasot informāciju no } \\
\text { dotās slēguma shēmas. }\end{array}$ \\
\hline & & 7.5. & 0,53 & $\begin{array}{l}\text { Lieto zināšanas, ka strāva plūst tikai } \\
\text { noslēgtā kēēdē, nolasot informāciju no } \\
\text { dotās slēguma shēmas. }\end{array}$ \\
\hline \multirow[t]{7}{*}{ Siltums } & 2015 & 5.3. & 0,37 & $\begin{array}{l}\text { Saprot, ka sildot pirmā iztvaiko tā } \\
\text { viela, kurai viršanas temperatūra } \\
\text { zemāka. }\end{array}$ \\
\hline & & 8.4. & 0,50 & $\begin{array}{l}\text { Zina, ka gaiss ir labs siltuma izolators, } \\
\text { novēršot siltumvadīšanu. }\end{array}$ \\
\hline & 2016 & 9.3. & 0,29 & $\begin{array}{l}\text { Nolasa informāciju no grafika } \\
\text { un saista ar zināšanām par } \\
\text { siltumizolācijas būtību. }\end{array}$ \\
\hline & & 9.4 & 0,37 & Atpazīst siltuma pārneses virzienu. \\
\hline & 2017 & 3.2. & 0,45 & $\begin{array}{l}\text { Zina, ka, palielinoties temperatūrai, } \\
\text { notiek iztvaikošana, veidojas burbuḷi - } \\
\text { ūdens gāzveida stāvoklī. }\end{array}$ \\
\hline & & 12.1. & 0,36 & $\begin{array}{l}\text { Skaidro konkrēto situāciju } \\
\text { (ledusskapja darbības principu), } \\
\text { izmantojot sakarību enerǵijas apritē. }\end{array}$ \\
\hline & & 12.2. & 0,46 & $\begin{array}{l}\text { Skaidrot konkrēto situāciju, } \\
\text { pamatojoties uz siltumapmainas } \\
\text { principu, ūdens siltumietilpību. }\end{array}$ \\
\hline
\end{tabular}




\begin{tabular}{|c|c|c|c|c|}
\hline Lauks & Gads & Uzd. & $\begin{array}{l}\text { Grūtības } \\
\text { pakāpe }\end{array}$ & Skolēna snieguma indikators \\
\hline \multirow[t]{10}{*}{$\begin{array}{l}\text { Spēki un } \\
\text { mijiedarbība }\end{array}$} & 2015. & 3.3. & 0,27 & $\begin{array}{l}\text { Zina, kas ir potenciālā un kinētiskā } \\
\text { enerǵija. Spriež, kā konkrētajā } \\
\text { situācijā pārvēršas kinētiskā enerǵija. }\end{array}$ \\
\hline & & 6.2 & 0,22 & $\begin{array}{l}\text { Saprot, ka lēcas biezums ir attālums } \\
\text { (celı̌s), ko noiet stars, lieto ātruma } \\
\text { formulu. }\end{array}$ \\
\hline & 2016 & 8.1 & 0,63 & $\begin{array}{l}\text { Lieto zināšanas par blīvumu, } \\
\text { peldēšanas nosacījumiem, analizējot } \\
\text { doto informāciju attēlos un tabulā. }\end{array}$ \\
\hline & & 8.3. & 0,42 & $\begin{array}{l}\text { Lieto zināšanas par peldēšanas } \\
\text { nosacījumiem, lai spriestu jaunā } \\
\text { situācijā, kontekstā. }\end{array}$ \\
\hline & & 8.2. & 0,16 & $\begin{array}{l}\text { Kompleksi lieto zināšanas (Arhimēda } \\
\text { likums, ledus blīvums ir mazāks nekā } \\
\text { izkusušā ledus gabala ūdens blīvums), } \\
\text { lai analizētu jaunu situāciju. }\end{array}$ \\
\hline & 2017 & 9.1 & 0,47 & $\begin{array}{l}\text { Zina, kā darbojas smaguma spēks un } \\
\text { gaisa pretestības spēks. }\end{array}$ \\
\hline & & 9.2 & 0,31 & $\begin{array}{l}\text { Prot aprēkināt smaguma spēku, } \\
\text { zinot brīvās krišanas paātrinājuma } \\
\text { konstanti. }\end{array}$ \\
\hline & & 9.3. & 0,29 & $\begin{array}{l}\text { Analizē kustības ātruma izmainas, } \\
\text { izmantojot tekstā, attēlā un grafikā } \\
\text { doto informāciju. }\end{array}$ \\
\hline & & 9.4 & 0,25 & $\begin{array}{l}\text { Secina par ātrumu, pārvietojumu, } \\
\text { salīdzinot divus atškirīgus viena } \\
\text { procesa grafiskos attēlojumus (no } \\
\text { kuriem viens ir netipisks shematisks } \\
\text { attēls). }\end{array}$ \\
\hline & & 10.1 & 0,14 & $\begin{array}{l}\text { Secina, saistot izpratni par blīvumu } \\
\text { kā materiālu raksturojošu lielumu } \\
\text { ar netipiskā grafiskā formā doto } \\
\text { informāciju. }\end{array}$ \\
\hline
\end{tabular}

Gan apjoma, gan izpratnes mērīšanas nozīmē uzsvars ir bijis uz jautājumiem par spēkiem un mijiedarbību. Šie uzdevumi prasa zināšanu un prasmju lietojumu kompleksās situācijās. Pārējie satura laukiem atbilstošie uzdevumi ir vairāk reproduktīivi. 
5. tabula. Indikatori mācību satura laukā "Bioloǵiskās sistēmas un procesi"

\begin{tabular}{|c|c|c|c|c|}
\hline Lauks & Gads & Uzd. & $\begin{array}{l}\text { Grūtības } \\
\text { pakāpe }\end{array}$ & Skolēna snieguma indikators \\
\hline \multirow{3}{*}{$\begin{array}{l}\text { Organismu } \\
\text { iedalījums }\end{array}$} & 2015 & 12.1 & 0,78 & Tekstā un attēlā atpazīst baktērijas. \\
\hline & & 4.1. & 0,37 & Zina augu/dzīvnieku atškirīgo pazīmi. \\
\hline & 2017 & 15.1 & 0,23 & Attēlā atpazīst sēṇu valsts pārstāvi. \\
\hline \multirow{14}{*}{$\begin{array}{l}\text { Organismu } \\
\text { uzbūve un } \\
\text { funkcijas }\end{array}$} & 2015 & 7.1. & 0,72 & $\begin{array}{l}\text { Starp attēliem atpazīst pareizo attēlu ar } \\
\text { orgānu sistēmu. }\end{array}$ \\
\hline & & 4.4. & 0,48 & $\begin{array}{l}\text { Zina, kura orgānu sistēma veic vielu transportu } \\
\text { organismā. }\end{array}$ \\
\hline & & 10.1 & 0,42 & Skaidro, kādē| izmanto fizioloǵisko šḳīdumu. \\
\hline & & 4.3. & 0,26 & $\begin{array}{l}\text { Zina, kuras vielas pārvietojas no auga lapām } \\
\text { uz saknēm. }\end{array}$ \\
\hline & 2016 & 1.1. & 0,75 & Atpazīst cilvēka orgānu attēlā. \\
\hline & & 1.2. & 0,53 & $\begin{array}{l}\text { Atpazīst cilvēka orgānus dažādi novietotos } \\
\text { attēlos (iepriekš nezināma situācija - } \\
\text { škēersgriezuma spogulattēls). }\end{array}$ \\
\hline & & 1.3. & 0,46 & $\begin{array}{l}\text { Atpazīst cilvēka orgānus dažādi novietotos } \\
\text { attēlos. }\end{array}$ \\
\hline & & 3.4. & 0,44 & $\begin{array}{l}\text { Zina par augu vairošanos, kā gēni var tikt } \\
\text { pārnesti. }\end{array}$ \\
\hline & & 2.3. & 0,18 & $\begin{array}{l}\text { Zina, pēc kuras ārējās pazīmes var spriest, ka } \\
\text { kukainis ir parazīts. }\end{array}$ \\
\hline & 2017 & 13.1 & 0,39 & Zina, ka augi gaismā izdala skābekli. \\
\hline & & 14.2 & 0,65 & $\begin{array}{l}\text { Zina, kāpēc uztura bagātinātāji neaizstāj } \\
\text { pilnvērtīgu uzturu. }\end{array}$ \\
\hline & & 14.3. & 0,54 & $\begin{array}{l}\text { Zina, kad lietot uztura bagātinātājus, izmanto } \\
\text { tekstā doto informāciju. }\end{array}$ \\
\hline & & 15.2 & 0,46 & $\begin{array}{l}\text { Zina, ka vicas un skropstas ir kustību } \\
\text { nodrošinātāji. }\end{array}$ \\
\hline & & 15.3. & 0,42 & $\begin{array}{l}\text { Zina, ka sēnes un monēras noārda organiskās } \\
\text { vielas. }\end{array}$ \\
\hline Šūnas & 2015 & 4.2 . & 0,37 & Zina, kas ir fotosintēze un hloroplasti. \\
\hline
\end{tabular}




\begin{tabular}{lcccc}
\hline \multicolumn{1}{c}{ Lauks } & Gads & Uzd. & $\begin{array}{c}\text { Grūtības } \\
\text { pakāpe }\end{array}$ & Skolēna snieguma indikators \\
\hline $\begin{array}{l}\text { Ekoloǵija, } \\
\text { biotehnolo- } \\
\text { ǵijas }\end{array}$ & 2015 & 9.3. & 0,57 & $\begin{array}{l}\text { Skaidro zooloǵisko dārzu darbinieku rīcību ar } \\
\text { reti sastopamiem abiniekiem. }\end{array}$ \\
\cline { 2 - 5 } & 2016 & 3.2. & 0,46 & Zina, kā var noskaidrot, vai izmantoti G̣MO. \\
\cline { 2 - 5 } & & 3.3. & 0,23 & Spriež, kā var izmantot G̣MO. \\
\hline
\end{tabular}

Analizējot bioloǵijas uzdevumu saturu trīs gadu posmā, redzams, ka no iespējamajiem satura laukiem jautājumi ir par organismu uzbūvi un to funkcijām, bet pārsvarā tiek pārbaudītas atsevišḳu faktu zināšanas, orgānu sistēmu atpazīšana attēlos.

Problēma ir ne tikai satura nevienmērīgs nosegums - katrā no četriem laukiem tiek mērīts kaut kas cits, būtiski atškiras kognitīvais dziļums, kāds tiek sagaidīts - biolog̣ijā specifisku faktu zināšanas (zina, atpazīst), fizikā zināšanu lietošana, tostarp jaunās situācijās; kīmijā dominē uzdevumi, kas pārbauda specifiskas prasmes.

Kādi ir skolēnu rezultāti dabaszinātṇu darbos uzdevumos, kas mēra izpratni par procesiem, parādībām dabā?

Datu analīze rāda, ka mazāk nekā $1 / 3$ skolēnu demonstrē labu sniegumu uzdevumos, kuros nepieciešama konkrēta dabaszinātṇu jomas satura izpratne kompleksā situācijā. Puse (vai nedaudz vairāk) skolēnu atpazīst faktus, lieto zināšanas pazīstamās situācijās.

Nākamais izpētes aspekts atbilstoši izvēlētajai ietvarstruktūrai - skolēnu pètnieciskā darbība kā viena no mācību satura prioritātēm.

Tās apguve nav mazāk būtiska kā izpratnes veidošanās par procesiem un parādībām dabā. Diagnosticējošajos darbos dabaszinātnēs 9. klasei trīs gadu laikā salīdzinoši neliela daḷa uzdevumu dod iespēju parādīt, ko skolēni apguvuši par pētijuma veidošanu vai procedūru (eksperimenta) veikšanu. Ar eksperimenta veidošanu saistīto prasmju mērišana iekḷauta 2015. gadā 10\%, 2016. gadā 13\%, 2017. gadā - 14\% no visiem testelementiem (skat. 6. tabulu).

Analizējot detalizētāk, akcents bijis uz prasmi saskatīt pētāmo problēmu, korekta eksperimenta apstākḷu nodrošināšanu, lielumu izvēli - pētijuma plānošanas prasmēm. Vairumā gadījumu šis prasmes skolēnam jādemonstrē, iegūstot nepieciešamo informāciju no teksta, piemēram, 2016. gada diagnosticējošajā darbā iekḷauti pieci testelementi, kas attiecas uz pētnieciskās darbības prasmēm, no tiem trīs uzdevumos bija jāizmanto dotā (teksts, attēls, grafiks) informācija. 2017. gada diagnosticējošā darba pieci testelementi pārbauda, kā skolēni apguvuši pētijjuma plānošanu, eksperimenta veidošanu, turklāt divos no tiem tekstā dotā informācija palīdz atbildēt uz jautājumu. Piemēram, 8. uzdevumā tekstā teikts: "Jānis pētīja, 
kā svārsta garums ietekmē vienas pilnas svārstības ilgumu. Kuri svārsti vinam jāizvēlas šim pētijumam?" Tālāk dots zīmējums un atbilžu varianti: "jāizvēlas pēc iespējas vairāk svārstu; jāizvēlas visgarākais svārsts; jāsalīdzina dažādu svārstu garums un dažādi atsvari; visam, izņemot svārstu garumu, jābūt vienādam."

6. tabula. Pētnieciskās darbības prasmju mērǐšana diagnosticējošajos darbos dabaszinātnēs 9. klasei

\begin{tabular}{|c|c|c|c|c|}
\hline $\begin{array}{l}\text { Pētnieciskās } \\
\text { prasmes }\end{array}$ & Gads & Uzd. & $\begin{array}{l}\text { Grūtības } \\
\text { pakāpe }\end{array}$ & Skolēna snieguma indikators \\
\hline \multirow{10}{*}{$\begin{array}{l}\text { Pētījuma } \\
\text { plānošana: } \\
\text { pētāmā } \\
\text { problēma, } \\
\text { hipotēze, } \\
\text { lielumi }\end{array}$} & 2015 & 8.2 & 0,42 & $\begin{array}{l}\text { Izvērtēt hipotēzes un rezultātu atbilstību, } \\
\text { izmantojot datus no teksta. }\end{array}$ \\
\hline & \multirow[t]{4}{*}{2016} & 4.1 & 0,76 & $\begin{array}{l}\text { Lieto zināšanas par pētāmo jautājumu, } \\
\text { atrodot informāciju tekstā. }\end{array}$ \\
\hline & & 4.2. & 0,55 & $\begin{array}{l}\text { Izvēlas visbūtiskāko lielumu vienādu } \\
\text { eksperimenta apstākḷ nodrošināšanai. }\end{array}$ \\
\hline & & 9.1 & 0,32 & $\begin{array}{l}\text { Nosaka nemainīgo lielumu, atrodot } \\
\text { informāciju (tekstā, attēlā, grafikā). }\end{array}$ \\
\hline & & 5.2 & 0,31 & $\begin{array}{l}\text { Spriež, analizē, ar kuriem eksperimentiem } \\
\text { varēs iegūt atbildi uz pētāmo jautājumu; } \\
\text { lieto vielu masas nezūdamības likumu jaunāā } \\
\text { situācijā. }\end{array}$ \\
\hline & \multirow[t]{5}{*}{2017} & 2. & 0,35 & $\begin{array}{l}\text { Salīdzina reālas situācijas (naftas noplūde) } \\
\text { un modelētas situācijas apstākḷs. }\end{array}$ \\
\hline & & 4.3. & 0,63 & $\begin{array}{l}\text { Skaidro pētnieciskā eksperimenta } \\
\text { nosacījumus konkrētā piemērā, pamato } \\
\text { kontroleksperimenta nepieciešamību. }\end{array}$ \\
\hline & & 8.1. & 0,37 & $\begin{array}{l}\text { Nosaka izvēlēto neatkarīgo mainīgo, zina, } \\
\text { ka nedrīkst mainīt vienlaikus divus lielumus, } \\
\text { atrod attēlā un atbilžu variantos atbilstošo } \\
\text { situāciju. }\end{array}$ \\
\hline & & 8.2. & 0,31 & $\begin{array}{l}\text { Izvēlas pamatojumu - zina, ka nedrīkst } \\
\text { mainīt vienlaikus divus lielumus, attiecina to } \\
\text { uz konkrēto situāciju. }\end{array}$ \\
\hline & & 13.2. & 0,54 & $\begin{array}{l}\text { Saskata (tekstā, attēlā) iespējamos } \\
\text { eksperimentā maināmos lielumus. }\end{array}$ \\
\hline \multirow{2}{*}{$\begin{array}{l}\text { Eksperimenta } \\
\text { veikšana }\end{array}$} & \multirow[t]{2}{*}{2015} & 5.1. & 0,63 & Atpazīst maisījuma sadalīšanas metodi. \\
\hline & & 10.3. & 0,44 & $\begin{array}{l}\text { Atpazīst, kuri piederumi ir, kuri jāpapildina, } \\
\text { kuru trūkst šk̦īduma pagatavošanai. }\end{array}$ \\
\hline
\end{tabular}




\begin{tabular}{lcccl}
\hline $\begin{array}{l}\text { Pētnieciskās } \\
\text { prasmes }\end{array}$ & Gads & Uzd. & $\begin{array}{c}\text { Grūtības } \\
\text { pakāpe }\end{array}$ & Skolēna snieguma indikators \\
\hline $\begin{array}{l}\text { Datu analīze, } \\
\text { apstrāde, } \\
\text { secināšana }\end{array}$ & 2016 & 4.3. & 0,41 & $\begin{array}{l}\text { Analizē iegūto datu atbilstību eksperimenta } \\
\text { aprakstam, lietojot tekstā (vienlaidus un } \\
\text { vizuālā) iegūto informāciju. }\end{array}$ \\
\cline { 2 - 5 } & 2015 & 8.3. & 0,42 & $\begin{array}{l}\text { Izvēlas pareizo secinājumu, izmantojot datus } \\
\text { no teksta. }\end{array}$ \\
\hline
\end{tabular}

Kādas ir skolēnu pētnieciskās darbības prasmes? Dati rāda, ka 34 skolēnu spēj atrast tekstā pētāmo jautājumu. Tikai nedaudz vairāk par $1 \frac{1}{2}$ spēj izvēlēties visbūtiskāko lielumu vienādu apstākḷu nodrošināšanai eksperimentam. Taču ar uzdevumiem, kas prasa spriešanu, iedziḷināšanos datos vai eksperimenta nosacījumos, tikuši galā tikai aptuveni $40 \%$ un attiecīgi $30 \%$ skolēnu.

Tā kā prasmes darbā ar datiem (informāciju) ir ne tikai pētniekam nepieciešama prasme un diagnosticējošajos darbos liela uzmanība ir pievērsta tekstpratỉbai - prasmēm darbā ar informāciju, tostarp grafisku, šo uzdevumu analīze tiek izdalìta atseviški.

Daudzu valsts līmeņa darbu uzdevumu izpildei izšķirošas ir tieši prasmes darbā ar tekstu. Uzdevumi, kuros nepieciešama prasme darbā ar informāciju, 2015. gadā veido $25 \%$ no visiem testelementiem, 2016. gadā - 38\%, 2017. gadā $42 \%$. Piemēram, 2017. gada diagnosticējošajā darbā 14 no 33 analizētajiem testelementiem skolēniem ir iespēja izmantot prasmi darbā ar informāciju dabaszinātniskā vai reālās dzīves kontekstā. Starp šiem 14 uzdevumiem ir tādi, kuros skolēnam līdztekus prasmei izmantot tekstā doto informāciju nepieciešamas arī priekšmeta specifiskās prasmes (7.1. prasme rakstìt reakcijas vienādojumu) vai atsevišķu jēdzienu izpratne (blīvums uzdevumā 10.1.), izpratne par eksperimenta veidošanu (8.1., 13.2.). Trijos no tiem (1.1., 1.3., 3.1.) mērīta tieši prasme darbā ar tekstu - uzdevums jau satur atbildes veidošanai nepieciešamo informāciju.

Skolēniem salīdzinoši labi veicas uzdevumos, kuru izpildei nepieciešams parādìt vienkāršu atsevišķu prasmi darbā ar informāciju, piemēram, atrast tekstā teikumu, nolasìt skaiț̣us (lielumus) no vienkārša grafika.

Piemēram, ja aplūko prasmi atrast nepieciešamo informāciju tekstā, 9. klašu skolēnu rezultāti ir šādi:

- jādemonstrē atsevišķa vienkārša prasme - atrast (atpazìt) viena veida tekstā (vienlaidus, vizuālā) konkrētu informāciju, piemēram, atrast datus tabulā - veic $60-75 \%$ skolēnu,

- teksts komplicētāks, satur lieku informāciju, jāinterpretē, jāsaista ar pieredzi - veic $20-45 \%$, 
- vienlaikus dažādu veidu informācija - vārdisks teksts, attēls, shēma, grafiks u. c. - veic 35-70\% (rezultātu izkliedi ietekmē katra teksta veida komplicētība un tas, kāda veida informācija jāmeklē).

9. klašu skolēnu sniegums izvēlētajos testelementos, kas pārbauda prasmes darbā ar grafisku informāciju vienā diagnosticējošajā darbā, redzams 7. tabulā. Lìdzīgu sniegumu skolēni uzrāda arī pārējos darbos - 1. attēlā redzams arī skolēnu sniegums dažāda kognitīvā līmeņa uzdevumos par darbu ar grafisku informāciju trīs gadu laikā.

7. tabula. Skolēnu snieguma indikatori testelementos ar grafiski dotu informāciju 2016. gadā

$$
\text { Uzd. }
$$

Skolēna snieguma indikators

Grūtības

pakāpe

\begin{tabular}{llc}
\hline 7.3. & Nolasa vienkāršu informāciju no grafika. & 0,80 \\
\hline 9.2. & $\begin{array}{l}\text { Nolasa vienkāršu informāciju no grafika, lietojot arī tekstā un attēlā } \\
\text { doto informāciju. }\end{array}$ & 0,72 \\
\hline 6.4. & $\begin{array}{l}\text { Nolasa kompleksu informāciju no teksta un grafika, lai spriestu, veidotu } \\
\text { secinājumu, analizējot situāciju (kā dziḷums ietekmē og!̣skābās gāzes } \\
\text { uzglabāšanas iespējas). }\end{array}$ & 0,49 \\
\hline
\end{tabular}

11.2. Analizē tekstā, grafikā un citā vizuālā veidā dotu informāciju par jaunu reālās dzīves situāciju.

11.1. Analizē tekstā un grafikā doto komplekso informāciju par jaunu reālās dzīves situāciju.

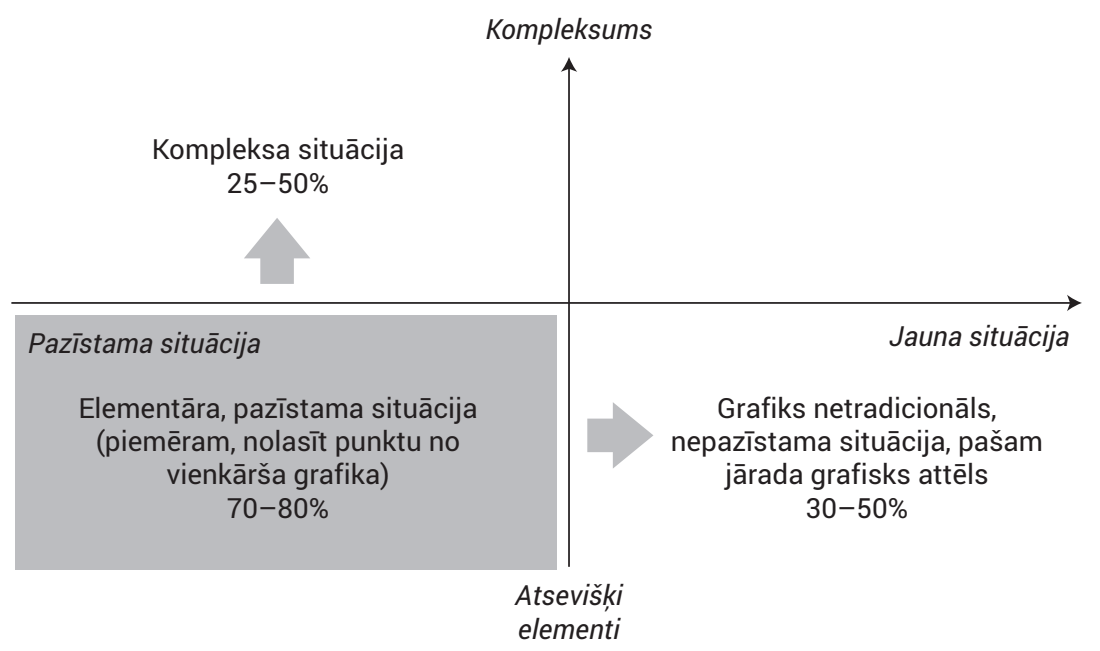

1.attēls. Skolēnu skaits \%, kas spēj veikt darbības ar grafisku informāciju, mainoties uzdevuma kognitīvajam līmenim (LU SIIC arhīvs) 
Turpmāk atbilstoši izvēlētajai ietvarstruktūrai un metodolog̣ijai analizēts valsts līmeņa darbos iekḷauto uzdevumu kognitīvās darbỉbas dziḷms kopumā.

8. tabulā apkopoti dati par valsts līmeṇa darbos iekḷauto uzdevumu kognitīvo līmeni atbilstoši analīzes ekspertu vērtējumam.

8. tabula. Valsts mēroga darbos dabaszinātnēs ieklauto uzdevumu kognitīvais līmenis (testelementu skaits \% katrā līmenī no visiem testelementiem)

\begin{tabular}{cccccc}
\hline \multirow{2}{*}{ 6. klase } & SOLO limenis & I & II & III & IV \\
\cline { 2 - 6 } & 2015 & 33 & 54 & 13 & 0 \\
\cline { 2 - 6 } & 2016 & 52 & 39 & 9 & 0 \\
\hline \multirow{2}{*}{ 9. klase } & 2017 & 41 & 41 & 18 & 0 \\
\cline { 2 - 6 } & 2015 & 20 & 60 & 20 & 0 \\
\cline { 2 - 6 } & 2016 & 32 & 60 & 8 & 0 \\
\hline
\end{tabular}

Konstatēts, ka darbi galvenokārt mēra skolēnu prasmi rīkoties tipveida situācijās. Piemēram, diagnosticējošajos darbos dabaszinātnēs 6. klasei vairāk nekā $80 \%$ no visiem testelementiem prasa zema līmeṇa kognitīvu darbību. Kopumā trīs gadu periodā $64-92 \%$ visu uzdevumu prasa reproduktīvu skolēna darbību faktu un procedūru atcerēšanos, zināšanu un prasmju lietošanu tipveida uzdevumos, vienkāršu datu kopumu interpretēšanu. Šie dati atsedz pretrunu starp 2006. gada satura dokumentos iestrādāto virzỉbu uz produktīvu skolēnu darbību un to, ko mēra valsts līmeña pārbaudes darbi.

N̦emot vērā, ka 2006. gadā kā būtisks mācību satura aspekts izcelta problēmrisināšana ar mērḳi attīstīt dziḷa līmeņa domāšanu, ir nepieciešams pārliecināties, kā skolēni spēj rīkoties situācijās un uzdevumos, kas prasa dažādu līmeṇu kognitīvu darbību.

Darbu statistiska analīze uzrāda, ka arī spējīgāko skolēnu sniegums nereti ir labāks uz reproduktīvu uzdevumu rēķina, piemēram, dabaszinātņu diagnosticējošajā darbā 9. klasei 2017. gadā no testelementiem ar augstu izšķirtspēju (1.1., 1.2., 2., 3.1., 4.2., 8.1., 8.2., 9.2., 13.1., 15.2.) visi, izņemot vienu, ir zema kognitīva lìmeña uzdevumi. Skolēni ar kopumā augstu sniegumu uzrāda lıtoti zemu rezultātu, piemēram, uzdevumā 1.3., kas prasa grafikā dotās informācijas interpretēšanu; 7.2., kur tiek sagaidīta reakcijas vienādojumā redzamās informācijas (koeficienta jēgas) izpratne un pārnešana uz konkrētu situāciju; 9.3. un 9.4. nepieciešama situācijas analīze, demonstrējot tekstā, attēlā, grafikā un netradicionālā shematiskā attēlā dotās daudzveidīgās informācijas interpretāciju, saistī̌sanu. 
Piemēram, 2017. gadā diagnosticējošajā darbā 9. klasei 6. uzdevumu (skat. 2. attēlu) spēja izpildīt tikai $15 \%$ visu skolēnu un tikai $29 \%$ skolēnu, kas darbā kopumā uzrāda samērā augstu rezultātu. Izteikti starpdisciplinārajā šì paša darba 10. uzdevumā rezultāti līdzīgi - to veikuši 14\% visu skolēnu un 30\% no augsta snieguma grupas.

\section{6. uzdevums (1 punkts)}

Anna ir ieplānojusi apstrādāt maurinu ar minerālmēslojumu šḳīdumu. Uz minerālmēslojuma pudeles etiketes ir rakstīts, ka vienu tilpuma dalu minerālmēslojuma nepieciešams sajaukt ar 15 tilpuma dalām ūdens un vienmērīgi izsmidzināt. Cik liels ir nepieciešams minerālmēslojuma tilpums, ja maurina apstrādei vajadzīgi 12 litri škīiduma?
A $750 \mathrm{ml}$
B $800 \mathrm{ml}$
C $1200 \mathrm{ml}$
D $1333 \mathrm{ml}$

2. attēls. Diagnosticējošajā darba uzdevums dabaszinātnēs 9. klasei (VISC, 2017)

Analizējot skolēnu sadalījumu atbilstoši sniegumam, kā piemērs 9. tabulā ir redzama situācija par rezultātiem diagnosticējošajā darbā dabaszinātnēs 9. klasei 2016. gadā.

9. tabula. Skolēnu grupas saskaṇā ar Raša modeli un atbilstošajam SOLO līmenim doto uzdevumu skaits \%

\begin{tabular}{|c|c|c|c|}
\hline $\begin{array}{c}\text { Statistiski } \\
\text { izveidotā } \\
\text { skolēnu grupa }\end{array}$ & Skolēnu snieguma raksturojums & $\begin{array}{c}\text { SOLO } \\
\text { līmenis }\end{array}$ & $\begin{array}{l}\text { Uzdevumu } \\
\text { skaits \% }\end{array}$ \\
\hline $\begin{array}{l}\text { III grupa } \\
\text { (ap } 15 \% \\
\text { no skolēnu } \\
\text { skaita) }\end{array}$ & $\begin{array}{l}\text { Skolēni spēj lietot zināšanas un algoritmus nepazīs- } \\
\text { tamās (jaunās) situācijās, citā kontekstā; analizēt } \\
\text { kompleksu informāciju; radīt risinājumus. }\end{array}$ & III, IV & 8 \\
\hline $\begin{array}{l}\text { Il grupa } \\
\text { (ap } 50 \% \\
\text { no skolēnu } \\
\text { skaita) }\end{array}$ & $\begin{array}{l}\text { Skolēni spēj skaidrot vai lietot zināšanas pazīsta- } \\
\text { mās standartsituācijās, izvēlas atbilstošus pan̄ēmie- } \\
\text { nus vai procedūras (ar diviem vai vairākiem soḷiem), } \\
\text { strukturē (organizē) un interpretē vienkāršus datus. }\end{array}$ & II & 60 \\
\hline \multirow{2}{*}{$\begin{array}{l}\text { I grupa un } \\
0 \text { grupa } \\
\text { (ap 35\% } \\
\text { no skolēnu } \\
\text { skaita) }\end{array}$} & $\begin{array}{l}\text { Skolēni spēj parādīt elementāras prasmes, atce- } \\
\text { rēties vai atpazīt vienkāršus faktus, jēdzienus vai } \\
\text { procedūras. }\end{array}$ & 1 & 32 \\
\hline & $\begin{array}{l}\text { Skolēni nespēj parādīt elementāras prasmes, atce- } \\
\text { rēties vai atpazīt vienkāršus faktus, jēdzienus vai } \\
\text { procedūras. }\end{array}$ & & \\
\hline
\end{tabular}


Dati rāda, ka skolēni prot veikt uzdevumus, kas prasa reproducēt apgūtās pamatprasmes, lietot tās standartsituācijās (lìdz 85\% skolēnu) un ka skolēnu potenciāls veikt augstāka līmeņa kognitīvas darbības ir lielāks nekā pārbaudes darbā dotās iespējas to demonstrēt.

Gan valsts mēroga pārbaudes darbu satura - uzdevumu kopuma, gan skolēnu snieguma analīze uzrāda problēmas, kam nepieciešams risinājums. Diskutējamie jautājumi ir divi - makrolīmeņa pārbaudes darbu veidošana un mācīšanās process skolā. Vispirms - par nepieciešamajiem risinājumiem pārbaudes darbu veidošanā.

\section{Kāds ir valsts mēroga pārbaudes darbos dabaszinātnēs un matemātikā iekḷauto uzdevumu potenciāls mērīt skolēnu kompleksu sniegumu?}

Saskatāma tendence valsts līmeṇa pārbaudes darbos iekḷaut uzdevumus ar potenciālu mērìt kompleksu sniegumu, bet uzdevumu potenciāls netiek izmantots. Tiek iegūta virspusēja informācija par skolēnu sniegumu.

Augstākā kognitīvā līmeņa uzdevumi prasa no skolēniem prasmi vispārināt, veidot hipotēzes, reflektēt, teoretizēt, radīt; skolēnam nepieciešams paskatīties uz zināmām idejām jaunā, atšksiinīgā veidā. Šie uzdevumi ir kompleksi, un to pamatā ir skolēniem iepriekš nezināma situācija. Kompleksumu veido vairāki nepieciešamo zināšanu un izpratnes elementi un prasmes (gan specifiskas zinātnu jomas, gan vispārējas, starpdisciplināras, piemēram, pan̄ēmieni darbā ar tekstu); konteksts, kas var būt gan konkrētās zinātnes, gan reālās dzìves, gan citu zinātnu konteksts. Parasti šie uzdevumi ir starpdisciplināri, jo tieši tas veido gan kompleksumu, gan situācijas novitāti. Kompleksa uzdevuma piemērs ir 10. uzdevums 2017. gada diagnosticējošajā darbā dabaszinātnēs 9. klasei (skat. 3. attēlu, 10. tabulu). 
10. tabula. Uzdevuma, kas mēra kompleksu sniegumu, padziḷināts raksturojums (VISC, 2017)

\begin{tabular}{|c|c|c|}
\hline Prasmju joma & $\begin{array}{l}\text { Zināšanas un prasmes, kas } \\
\text { nepieciešamas*, lai izpildītu uzdevumu }\end{array}$ & Konteksta radītā jaunā situācija \\
\hline \multirow[t]{2}{*}{$\begin{array}{l}\text { Fizika, kīimija } \\
\text { (jēdzienu izprat- } \\
\text { ne, uzdevuma } \\
\text { jēgas izpratne) }\end{array}$} & $\begin{array}{l}\text { Masa, tilpums, materiāls, blīvums. } \\
\text { Zina, ka dažādiem materiāliem ir da- } \\
\text { žāds blīvums, vienādiem vienāds - b/̄̄- } \\
\text { vums ir materiālu raksturojošs lielums. } \\
\text { Blīvuma jēdzienu var tiešā veidā ne- } \\
\text { lietot - ja materiāli ir vienādi, tad, pa- } \\
\text { lielinoties tilpumam tieši proporcionāli } \\
\text { (tikpat reižu), palielinās masa. }\end{array}$ & $\begin{array}{l}\text { "Kuri akmeṇi veidoti no viena } \\
\text { materiāla" - visticamāk, ka } \\
\text { šāds formulējums mācoties nav } \\
\text { lietots. Varētu būt priekšstats, ka } \\
\text { visi akmeṇi (ieži) ir no vieniem } \\
\text { un tiem pašiem materiāliem. } \\
\text { Uzdevuma tekstā nav norādes } \\
\text { par nepieciešamību izmantot blī- } \\
\text { vuma jēdzienu - to var noprast } \\
\text { no konteksta. }\end{array}$ \\
\hline & $\begin{array}{l}\text { Prasme aprēkināt blīvumu, ja zināma } \\
\text { masa un tilpums. }\end{array}$ & $\begin{array}{l}\text { Nav dotas/nav zināmas mērvie- } \\
\text { nības, kas nav raksturīgi mācību } \\
\text { uzdevumiem fizikā. }\end{array}$ \\
\hline \multirow[t]{3}{*}{$\begin{array}{l}\text { Matemātika } \\
\text { (sakarību un } \\
\text { tam atbilstošā } \\
\text { grafika izpratne } \\
\text { un izmantoša- } \\
\text { na, aprēḳinu } \\
\text { veikšana; } \\
\text { spriešana) }\end{array}$} & $\begin{array}{l}\text { Kā koordinātu plaknē novietoti pun- } \\
\text { kti, kuru koordinātas saista tiešās } \\
\text { proporcionalitātes sakarība - grafiks } \\
\text { ir taisne, kas iet caur (0; 0) un abi } \\
\text { punkti atradīsies uz šīs taisnes. Tiešāā } \\
\text { proporcionalitāte kā lineāras funkcijas } \\
\text { speciālgadījums. } \\
\text { Var nelietot minētos jēdzienus, bet } \\
\text { spriest, piemēram, - ja izvēlas vienu } \\
\text { punktu (akmeni), kur var atrasties tāda } \\
\text { paša materiāla akmeṇi (ja tilpumu } \\
\text { palielina ... reižu, arī masa palielinās } \\
\text { tikpat reižu). }\end{array}$ & $\begin{array}{l}\text { Uzdevuma formulējums nesatur } \\
\text { nekādas norādes par iespējām } \\
\text { izmantot konkrētas matemātikas } \\
\text { zināšanas un prasmes - mate- } \\
\text { mātiskās prasmes citas zināt- } \\
\text { nes/reālās dzīves kontekstā. }\end{array}$ \\
\hline & Prasme spriest induktīvi/deduktīvi. & \\
\hline & $\begin{array}{l}\text { Prasme izpildīt darbības ar skaitliem } \\
\text { (dalīt veselus skaițus un daḷskaițus), } \\
\text { salīdzināt daḷskaițus (ja izvēlas no- } \\
\text { teikt katra akmens blīvumu). }\end{array}$ & \\
\hline $\begin{array}{l}\text { Informācijas } \\
\text { iegūšana } \\
\text { (grafiskas } \\
\text { informācijas } \\
\text { lasīšana un } \\
\text { interpretēšana) }\end{array}$ & $\begin{array}{l}\text { Prasme nolasīt no grafika datus par } \\
\text { doto punktu, ja informācija nav pie- } \\
\text { tiekama/pilnīga - dotā informācija } \\
\text { nolasot jāinterpretē. }\end{array}$ & $\begin{array}{l}\text { Nav dotas mērvienības - jāiz- } \\
\text { manto nenosauktas (izmanto } \\
\text { tikai skaitlisko vērtī̄bu) vai jāde- } \\
\text { finē/jāpieṇem kāda vienība pat- } \\
\text { valīgi un jāizmanto kā piemērs. } \\
\text { Absolūti netipiska situācija, jo } \\
\text { mācoties tiek uzsvērta nepiecie- } \\
\text { šamība pie asīm norādīt mērvie- } \\
\text { nības un, grafikus lasot, primāri } \\
\text { pievērst uzmanību tam, kādas ir } \\
\text { dotās mērvienības. }\end{array}$ \\
\hline
\end{tabular}




\begin{tabular}{lll}
\hline \multirow{2}{*}{ Prasmju joma } & \multicolumn{1}{c}{$\begin{array}{c}\text { Zināšanas un prasmes, kas } \\
\text { nepieciešamas*, lai izpildītu uzdevumu }\end{array}$} & Konteksta radītā jaunā situācija \\
\hline Risināšanas & Izvēle sākt ar grafiski dotās infor- & Vai skolēnam ir pieredze, kā \\
stratēǵijas & mācijas vispusīgu apjēgšanu (ko & rīkoties, ja nav gatavs skaidrs \\
izvēle & te vispār var ieraudzīt); jautājumā & algoritms? Ko dara skolēns, ja \\
(iespējamo & minēto punktu pāru izpēte; doto un ar & nav metakognitīvo prasmju/ \\
stratēǵiju & tiem saistīto jēdzienu apzināšana un & stratēġiju? \\
apzināšana) & izmantošana. & \\
\hline
\end{tabular}

* Konkrētā nepieciešamība atkarīga no risinājuma stratēǵijas izvēles.

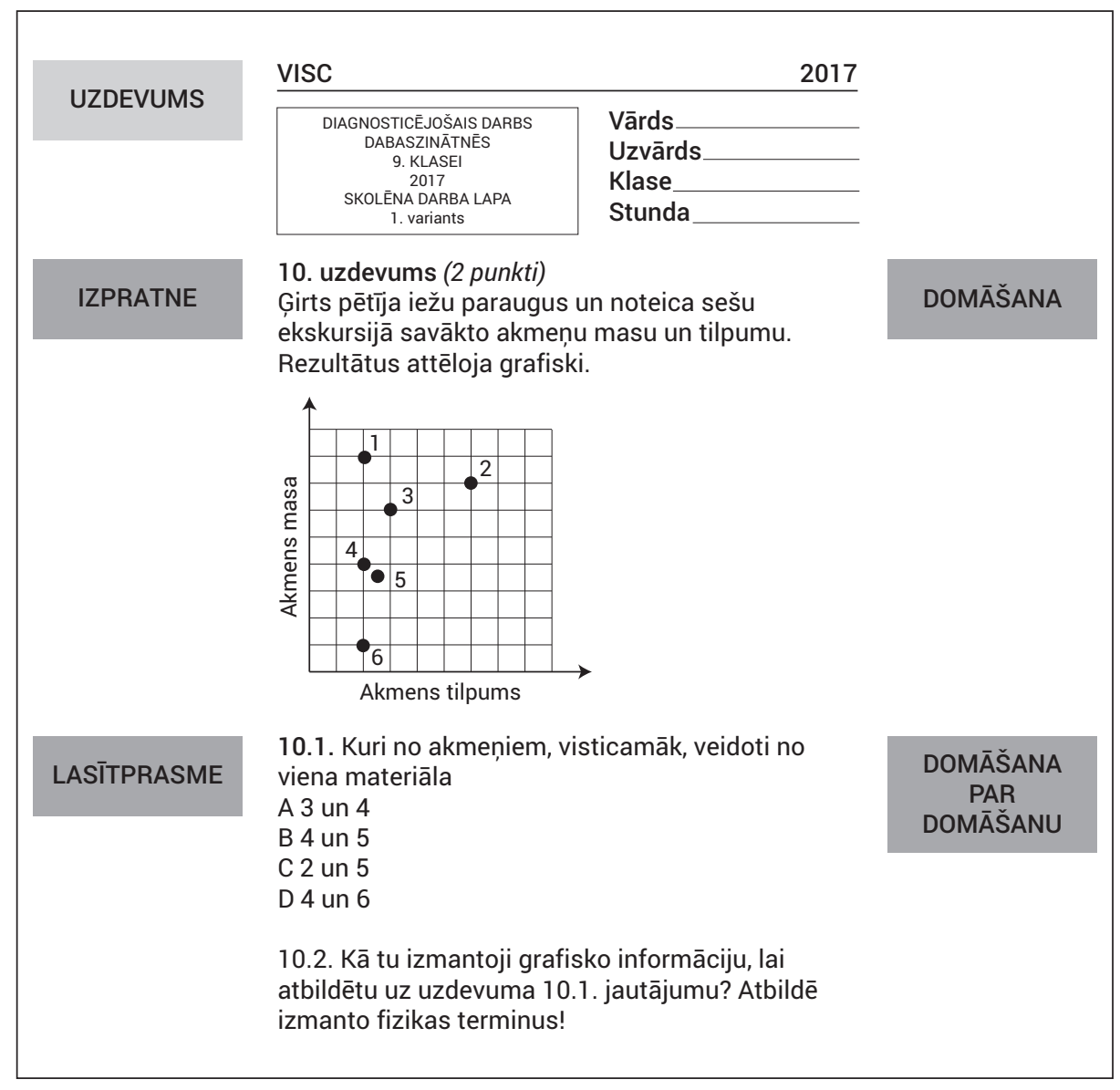

3. attēls. Diagnosticējošā darba uzdevums dabaszinātnēs 9. klasei (VISC, 2017) 
Analizējot katra atsevišḳa uzdevuma kvalitāti, mērḳis bija konstatēt uzdevumu atbilstỉbu, izmantojamību kompleksa snieguma vērtěšanai. Kāpēc tas ir būtiski? Kā norāda citi zinātnieki - mainoties prasmēm, kas skolēniem jāapgūst 21. gadsimtā, ir jāmainās arī pieejai vērtěšanai, jo svarīgas ir ne tikai zināšanas, bet arī tas, ko skolēns spēj ar tām paveikt (Darling-Hammond, \& Adamson, 2010).

Valsts līmeṇa darbos dabaszinātnēs un matemātikā trīs gadu periodā vērojama tendence, ka tiek iekḷauti uzdevumi ar potenciālu mērīt kompleksu sniegu$\mathrm{mu}$, bet šis uzdevuma potenciāls netiek izmantots, dodot iespēju iegūt salīdzinoši virspusēju informāciju par skolēna sniegumu. Darbos sastopami uzdevumi, kuru konteksts ir veiksmīgs un kuri, tos nedaudz pārveidojot - pārformulējot pašu uzdevumu, no kognitīi virspusējiem iegūtu iespēju mērìt daudz augstāka līmeņa kognitiviu skolēna darbību.

Konstatēts, ka ne tikai neprecīzi definēti snieguma indikatori uzdevumiem, bet arī vērtēšanas kritēriji ne vienmēr ir korekti. Tas ne tikai nesniedz iespēju precīzi konstatēt skolēnu prasmes - nekorekti formulēti snieguma indikatori un vērtēšanas kritēriji dot aplamu ziņu skolotājam un skolēniem par mācišanās mērḳiem un veidu. Ja tie precīzi aprakstītu sagaidāmo sniegumu, varētu palīdzēt veidot atbilstošu mācīšanos.

Precīzu vērtēšanas kritēriju formulēšana, aprakstǐšana, kā arī vērtējuma izlikšana ir viens no būtiskākajiem aspektiem kvalitatīvu vērtēěanas instrumentu izstrādē. Valsts pārbaudes darbos dabaszinātnēs un matemātikā joprojām pamatā tiek izmantota pieeja - pareiza/nepareiza atbilde, kas tiek fiksēta punktos 0/1. Šāda pieeja izmantojama, ja nepieciešams konstatēt faktu zināšanas, bet neḷauj spriest par prasmēm, domāšanas dziḷumu, ko darbi pretendē mērìt. Vērtējot vajadzētu skaidri zināt, ko vērtē - zināšanas vai prasmi. Prasmi var novērtēt kā sniegumu, bet ne kā formālu rezultātu (pareizi/nepareizi). Ja gribam ieviest dziḷu mācīšanu, tad vajadzētu mērīt arī prasmi, ko var izdarìt, veidojot snieguma līmeņu aprakstus.

Uzdevumu padzilināta analīze izvēlētajā ietvarā (skat. 11. tabulu) palīdz ne tikai konstatēt faktu, spriest par uzdevuma kvalitāti (kā to dara?), bet arī ieraudzīt, kā šo uzdevumu iespējams pilnveidot (kā darìt labāk?). Kā piemēru aplūkosim divu uzdevumu analīzi. 11. tabulā parādīta 3. klases uzdevuma (skat. 4. attēlu) salīdzinošã analīze. 


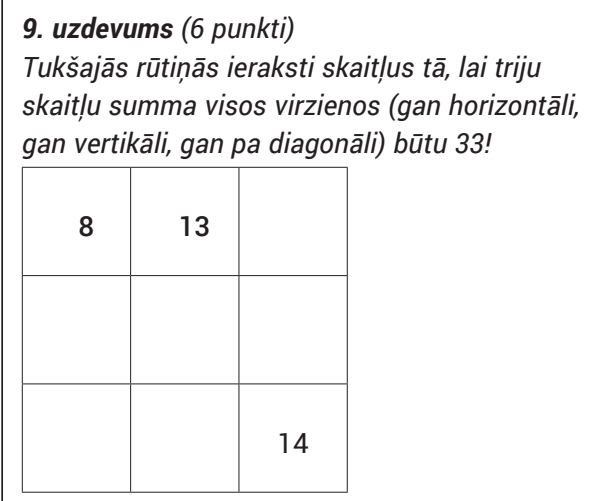

4. attēls. Diagnosticējošā darba uzdevums matemātikā 3. klasei (VISC, 2016)

Šì uzdevuma problēma ir vērtēšanas kritēriji. Dotajos vērtēšanas kritērijos paredzēts punkts par katru pareizi aprēḳinātu trūkstošo skaitli - par katru aizpildītu rūtiņu (turklāt tādā secībā, kādā tās ir izvietotas kvadrātā, nevis secībā, kā tās pakāpeniski iespējams aizpildīt). Tātad skolēnam iespējams iegūt 6 punktus par pilnīgi pareizu formālu atbildi, bet tā nesniedz nekādu informāciju par skolēna domāšanu, šajā uzdevumā nepieciešamo prasmju līmeni. Tā kā šis ir diagnosticējošais darbs, tad vērtēšanas procesā būtu jāsaṇem precīzas atbildes uz jautājumiem, ko tieši skolēns prot labi un kādas prasmes vēl nav pietiekamā līmen̄ī, jo uzdevums pārbauda skolēnu prasmi veikt saskaitīšanas darbības, atrast nezināmo saskaitāmo, ja summa dota (turklāt ne tiešā veidā - šo informāciju jāspēj nolasīt no teksta), un to visu lietot jaunā situācijā, izdomājot stratēgiju, kā rīkoties - kādā secība iespējams rūtiņas aizpildìt.

11. tabula. Uzdevuma matemātikā 3. klasei analīze

\begin{tabular}{ll}
\hline \multicolumn{1}{c}{ Kritērijs } & \multicolumn{1}{c}{ Uzdevuma raksturojums } \\
\hline Izpratne disciplīnā ar fokusu uz būtisko & Augsta. Nezināmais lielums vienādībā \\
\hline $\begin{array}{l}\text { Starpdisciplinaritāte (pārnesums, } \\
\text { integritāte, autentiskums) }\end{array}$ & $\begin{array}{l}\text { Pārnesuma nepieciešamība - matemātisko } \\
\text { pamatprasmju lietošana jaunā situācijā }\end{array}$ \\
\hline Prasmes, kas tiek mērītas & $\begin{array}{l}\text { Teksta izpratne, stratēḡijas izvēle nezināma } \\
\text { saskaitāmā aprēḳināšanai, ja summa zināma; } \\
\text { skaitlisku darbību izpilde }\end{array}$ \\
\hline Kognitīvās darbības dziḷums & Vidējs - SOLO III līmenis \\
\hline Metakognitīvā darbība. & Nav \\
\hline Atbilžu, risināšanas stratēǵiju variativitāte & Pareiza viena atbilde, vairāki risinājuma ceḷi \\
\hline Vērtēšanas kritēriji & $\begin{array}{l}\text { Neatbilstoši, iegūst informāciju tikai par to, vai } \\
\text { formālā atbilde ir pareiza }\end{array}$ \\
\hline
\end{tabular}


Uzdevumam ir pilnveidošanas iespējas. Ir potenciāls pārliecināties, kā skolēns apzinās nepieciešamās prasmes, kā pārvalda paškontroles iespējas. (Skat. piemēru.) Vērtēšanas kritēriji formulējami tā, lai pārbaudītu visas prasmes, tostarp prasmi izveidot stratēgiju, lietot prasmes jaunā situācijā. (Skat. iespējamo vērtēšanas kritēriju piemēru.)

lespējamo vērtēšanas kritēriju piemērs:

- skolēns izmanto tekstā un attēlā doto informāciju (faktu, ka summa ir 33, saskata, kā ši summa veidojas),

- izstrādā stratēgíiju, kā (kādā secībā) iespējams pakāpeniski aizpildīt kvadrātu,

- pareizi izpilda aritmētiskās darbības (saskaitīšanu, atñemšanu) ar skaițliem 20 apjomā.

Saglabājot kopīgo punktu skaitu, katram no šiem kritērijiem var atvēlēt 2 punktus, sīkāk definējot, kāds sniegums atbilst 2, kāds 1 un kāds 0 punktiem.

Lai vērtējot būtu iespējams konstatēt katra kritērija izpildi, nepieciešams arī nedaudz pārformulēt uzdevumu. Piemēram, lai saprastu, vai skolēnam bija stratēgija, kā atbilstoši uzdevuma nosacijumiem veikt prasìto, uzdevumu vajadzētu papildināt: "Iekrāso to rūtiņu, kuru aizpildīji vispirms! Uzraksti, kāpēc tieši to!"

Pārbaudes darbos šobrīd neierasta prakse ir sekot skolēnu metakognitīvajām prasmēm. Aplūkotajam uzdevumam ir arī šāds potenciāls. Piemēram:

- papildinot uzdevumu ar jautājumu: "Kā tu vari pārliecināties, ka kvadrāts aizpildīts pareizi?", skolēns tiek rosināts domāt par paškontroles iespējām; skolotājs var pārliecināties, vai skolēnam ir kāda atbilstoša stratēǵija,

- uzdevumā var būt jautājums: "Kādas prasmes tev bija nepieciešamas, lai veiktu šo uzdevumu?", tādējādi konstatējot, vai skolēns atpazīst, apzinātā līmenī saista uzdevuma izpildes gaitā veiktās darbības,

- var veidot uzdevumu virkni, piemēram, jautājot, kā iepriekšèjā uzdevuma risinājums var palīdzēt izpildīt nākamo:

$8+11+14=\ldots$

$8+13+\ldots=33$

Tātad ir vairākas iespējas pilnveidot uzdevumu, lai tas dotu lielāku, precīzāku informāciju par skolēna sniegumu (skat. piemēru 5. attēlā). 
Tukšajās rūtināās ieraksti skaițus tā, lai triju skaițu summa visos virzienos (gan horizontāli, gan vertikāli, gan pa diagonāli) būtu 33.

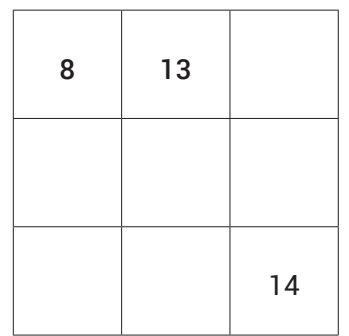

lekrāso to rūtinu, kuru aizpildīji vispirms! Uzraksti, kāpēc tieši to! Kādas prasmes Tev bija nepieciešamas, lai veiktu šo uzdevumu?

5. attēls. Matemātikas uzdevuma jaunā redakcija

Otrs piemērs, kura potenciāls analizēts 12. tabulā, ir uzdevums no piloteksāmena k̦īmijā 2016. gadā (skat. 6. attēlu). Šì uzdevuma autoru formulētais vērtēšanas kritērijs: Izmantojot tabulā doto informāciju, uzraksta vienu iemeslu, kāpēc aprikozēs, kuras tiek konservētas pēc "sēra dedzināšanas" metodes, bieži tiek pārsniegta sēra (IV) oksīda pielaujamā norma.

\section{6. uzdevums (4 punkti)}

Pēdējos gados ir veikti vairāki nozīmīgi pētījumi par aprikozēm. Aprikozes satur lielu daudzumu $\beta$-karotīnus. Aprikozēm ir īss uzglabāšanas laiks. Lai to pagaronātu, izmanto daudzveidīgas konservēšanas metodes: saldēšanu, fasēšanu hermētiski noslēgtos iepakojumos, žāvēšanu ar un bez sēra(IV) oksīda. Sēra(IV) oksīds saglabā aprikožu dabisko dzelteno krāsu un pasargā no pūšanas. Izlasi trīs aprikožu konservēšanas metolzu aprakstus!

Tabula

Aprikožu konservēšanas metožu apraksti

\begin{tabular}{|c|c|c|}
\hline Sēra dedzināšana & $\begin{array}{c}\text { Sašḳidrināta sēra(IV) oksīda } \\
\text { izmantošana }\end{array}$ & $\begin{array}{c}\text { Nātrija disulfīta } \mathrm{Na}_{2} \mathrm{~S}_{2} \mathrm{O}_{5} \\
\text { šḳīduma izmantošana }\end{array}$ \\
\hline $\begin{array}{l}\text { Telpā aprikozes izvieto vienā } \\
\text { slānī. Telpā sadedzina sēru. } \\
\text { Pēc sēra sadegšanas telpa tiek } \\
\text { slēgta un aprikozes tiek izturētas } \\
12 \text { stundas sēra(IV) oksīda gāzē. } \\
\text { Izmantojot šo metodi, bieži tiek } \\
\text { pārsniegta sēra(IV) oksīda pie-- } \\
\text { l̦aujamā norma } 2000 \text { mg/kg. }\end{array}$ & $\begin{array}{l}\text { Telpā aprikozes izvieto vienā } \\
\text { slānī. Aprikozes iztur } 3,5 \\
\text { stundas telpā, kurā ir precīza } \\
\text { sēra(IV) oksīda koncentrācija. } \\
\text { To nodrošina, iztvaicējot } \\
\text { precīzu sašk̦idrināta sēra(IV) } \\
\text { oksīda masu. Telpā izmanto } \\
\text { ventilatorus un silda gaisu. }\end{array}$ & $\begin{array}{l}\text { Pagatavo precīzas } \\
\text { koncentrācijas } \\
\text { nātrija škīīumu, kurā } \\
35 \text { minūtes mērcē } \\
\text { aprikozes. }\end{array}$ \\
\hline
\end{tabular}

6.1. Izmantojot tabulā doto informāciju, uzraksti vienu iemeslu, kāpēc aprikozēs, kuras konservē pēc "Sēra dedzināšanas" metodes, bieži tiek pārsniegta sēra(IV) oksīda pielaujamā norma!

6. attēls. Piloteksāmena uzdevums k̦īmijā 12. klasei (VISC, 2016) 
12. tabula. Uzdevuma k̦īmijā analīze

\begin{tabular}{ll}
\hline \multicolumn{1}{c}{ Kritērijs } & \multicolumn{1}{c}{ Uzdevuma raksturojums } \\
\hline Izpratne disciplīnā ar fokusu uz būtisko & Zema \\
\hline $\begin{array}{l}\text { Starpdisciplinaritāte (pārnesums, integritāte, } \\
\text { autentiskums) }\end{array}$ & Autentisks konteksts \\
\hline Prasmes, kas tiek mērītas & Viena atbilstoša fakta atrašana tekstā \\
\hline Kognitīvās darbības dziḷums & Zems \\
\hline Metakognitīvā darbība & Nav \\
\hline Atbilžu, risināšanas stratēḡiju variativitāte & lespējamas dažādas atbildes \\
\hline Vērtēšanas kritēriji & Formāli - pareizi/nepareizi \\
\hline
\end{tabular}

Pilnveidojot uzdevumu, nepieciešams padziḷināt izpratni par ķīmisko reakciju norises apstākḷiem un faktoriem, kas to ietekmē; pārveidot uzdevumu tā, lai būtu iespējams mērìt prasmi argumentēt un atbilstoši pārveidot vērtēšanas kritērijus kompleksa snieguma mērī̌sanai.

Analizējot uzdevumu un skolēnu darbus, rodas jautājums - kas īsti tiek vērtēts? Kādas zināšanas, prasmes parāda skolēns, rakstot šo vienu iemeslu, izmantojot uzdevuma tekstu gandrīz pus lapas (A4) apjomā? Analīze rāda, ka tiek sagaidītas un akceptētas visai primitīvas skolēnu atbildes:

- viss $\mathrm{SO}_{2}$ nosēžas uz aprikozēm, jo tas ir smagāks par gaisu,

- aprikožu uzglabāšana 12 stundas slēgtā telpā liecina par to, ka sēra (IV) piel̦aujamā norma nav kontrolējama, tāpēc tā tiek pārsniegta,

- šajā konservēšanas metodè grūti kontrolēt sēra degšanas temperatūru, skābekḷa koncentrāciju gaisā, sēra (IV) oksīda vienmērīgu koncentrāciju visā telpā; grūti kontrolèt, vai sērs ir pilnīgi sadedzis,

- jo telpa pēc sēra sadegšanas tiek slēgta,

- tāpēc, ka tās ilgu laiku pavada sēra ietekmē.

Ja uzskatām, ka mācīšanās rezultāts ir prasmes, tad šis uzdevums ir kā neizmantotā iespēja. Pārformulējot uzdevumu, tekstā iekḷautā informācija dotu iespēju iegūt pilnīgi citu ainu par skolēna sniegumu. Skolēnam būtu jāprasa pamatot, kāpēc ar šo metodi tiek pārsniegta piel̦aujamā norma, jeb izveidot apgalvojumu, kas ietver to faktoru analīzi, no kā ir atkarīgs rezultāts. Faktori atrodami esošajā tekstā, tie tiek pamatoti ar datiem. Pamatošanas prasmes vērtēšanas līmeņi aprakstīti 13. tabulā. 
Lai skolēns tiktu pie atbildes:

- jāizlasa trīs nelieli, vienkārši teksti, kas doti uzdevuma tabulā "Aprikožu konservēšanas metožu apraksti”, kuros ir aprakstītas procedūras, atrodami faktori,

- jāsaprot teksta jēga, jāatrod faktori - cik biezi saliktas, cik stundu turētas, kaitīgo vielu koncentrācija, kas vēl papildus tiek darīts,

- jāveic salīdzināšana, spriežot pēc būtiskām pazīmēm,

- jāuzraksta pamatojums.

13. tabula. Līmeṇu apraksts pamatošanas prasmes vērtēšanai

\begin{tabular}{ll}
\hline 0 & Nav apgalvojuma formā, nesatur faktus no dotās informācijas. \\
\hline 1 & $\begin{array}{l}\text { Pamatojumam ir ar būtiskas nepilnības, t. i., tekstā atrasti fakti; tekstā atrasts viens } \\
\text { faktors no vairākiem (cik bieži saliktas; cik stundu turētas - laiks; koncentrācija - } \\
\text { ir/nav kontrolējama; kas vēl papildus tiek darīts...). Pamatojums nav izveidots. }\end{array}$ \\
\hline 2 & Ir pamatojums, tas satur 1-2 tekstā atrastus ietekmējošos faktorus. \\
\hline 3 & $\begin{array}{l}\text { Pamatojums ir pilnīgs un argumentēts, tas satur 1-2 tekstā atrastus faktorus, kas } \\
\text { balstīti faktos (virsmas laukums - cik biezi saliktas; laiks - cik stundu turētas); } \\
\text { koncentrācija; kas vēl papildus tiek darīts, t. i., katram faktoram nosaukts atbilstošs } \\
\text { fakts no teksta. }\end{array}$ \\
\hline 4 & $\begin{array}{l}\text { Apgalvojums ir pilnīgs un pamatots - ietverti visi tekstā atrodamie faktori, tas ir } \\
\text { sasaistīts ar zināšanām par } \mathrm{SO}_{2} \text { relatīvo blīvumu pret gaisu u. c. }\end{array}$ \\
\hline
\end{tabular}

Ietverot minētās uzdevuma pilnveidošanas iespējas, 7. attēlā redzama uzdevuma jaunā redakcija.

Būtu nepieciešams precīzāk diagnosticēt tieši kompleksu prasmju apguvi, salīdzinot rezultātus ar datiem par mācību procesā notiekošo, lai varētu precizēt iespējamos situācijas uzlabošanas risinājumus. Ieteikums sekot kritērijiem, kas raksturo labu kompleksu uzdevumu, gan to izstrādājot, gan atlasot, gan pilnveidojot uzdevumus, kuri tiek iekḷauti valsts līmeņa pārbaudes darbos.

Turpinot diskusiju, analīzē konstatēts, ka zināšanu un izpratnes par procesiem, parādībām dabā, specifisku prasmju apguves mērījumi nedod iespēju iegūt drošu atbildi par skolēna sniegumu katrā no mācỉbu satura laukiem, jo tas notiek fragmentāri - darbā iekḷautie testelementi aptver nelielu dalı no satura kopumā. Diskutējams ir darbos ietverto jautājumu būtiskums. Tas pats attiecas uz skolēnu pētnieciskās darbības prasmēm. Šobrīd tiek radīti diagnosticējošie un pārbaudes darbi ar milzīgu apjomu, bet iegūtā informācija par skolēnu sniegumu, kas ir ticama un droša, ir neliela. Vienā darbā kvalitatīvi nav iespējams izmērìt visu - aptvert gan priekšmetu specifisko saturu, gan vispārēju būtisku prasmju diagnosticēšanu. 


\section{6. uzdevums (4 punkti)}

Pēdējos gados ir veikti vairāki nozīmīgi pētījumi par aprikozēm. Aprikozes satur lielu daudzumu bēta-karotīna. Aprikozēm ir īss uzglabāšanas ilgums. Lai to pagarinātu, izmanto daudzveidīgas konservēšanas metodes: saldēšanu, fasēšanu hermētiski noslēgtos iepakojumos, žāvēšanu ar un bez sēra (IV) oksīda. Sēra (IV) oksīds saglabā aprikožu dabisko dzelteno krāsu un pasargā no pūšanas. Izlasi trīs aprikožu konservēšanas metožu aprakstus!

Tabula

Aprikožu konservēšanas metožu apraksti

\begin{tabular}{|c|c|c|}
\hline Sēra dedzināšana & $\begin{array}{c}\text { Sašḳidrināta sēra (IV) oksīda } \\
\text { izmantošana }\end{array}$ & $\begin{array}{c}\text { Nātrija disulfīta } \mathrm{Na}_{2} \mathrm{~S}_{2} \mathrm{O}_{5} \\
\text { šḳīduma izmantošana }\end{array}$ \\
\hline $\begin{array}{l}\text { Telpā aprikozes izvieto vienā } \\
\text { slānī. Telpā sadedzina sēru. } \\
\text { Pēc sēra sadegšanas telpa tiek } \\
\text { slēgta un aprikozes tiek izturētas } \\
12 \text { stundas sēra (IV) oksīda } \\
\text { gāzē. Izmantojot šo metodi, bieži } \\
\text { tiek pārsniegta sēra (IV) oksīda } \\
\text { pieḷaujamā norma } 2000 \text { mg/kg. }\end{array}$ & $\begin{array}{l}\text { Telpā aprikozes izvieto vienā } \\
\text { slānī. Aprikozes iztur } 3,5 \\
\text { stundas telpā, kurā ir precīza } \\
\text { sēra (IV) oksīda koncentrācija. } \\
\text { To nodrošina, iztvaicējot } \\
\text { precīzu sašk̦idrināta sēra (IV) } \\
\text { oksīda masu. Telpā izmanto } \\
\text { ventilatorus un silda gaisu. }\end{array}$ & $\begin{array}{l}\text { Pagatavo precīzas } \\
\text { koncentrācijas } \\
\text { nātrija škīldumu, kurā } \\
35 \text { minūtes mērcē } \\
\text { aprikozes. }\end{array}$ \\
\hline
\end{tabular}

Pamato, kāpēc, izmantojot aprikožu konservēšanai sēra dedzināšanas metodi, bieži tiek pārsniegta pielaujamā sēra (IV) oksīda norma! Izmanto tekstā un tabulā doto informāciju, nosakot un analizējot faktorus, kas ietekmē rezultātu. (Snieguma aprakstu skat. iepriekš.)

7. attēls. Uzdevuma kīimijā jaunā redakcija

Darbu kopējais apjoms diagnosticējošajos un pārbaudes darbos ir liels, piemēram, dabaszinībās 6. klasei 2017. gada darba apjoms ir 7 lpp., 9. klasei - 8 lpp.; 9. klasei 2016. gadā - pat 12 lappuses. Darba izpildes laiks ir 80 minūtes. Darba lielais apjoms skolēniem ar sliktāku lasītprasmi varētu radīt ierobežojumus dabaszinātniskās izpratības un prasmju demonstrēšanā.

Ne vienmēr tekstuālā un vizuālā informācija ir noderīga, lai veiktu uzdevumu. Ir gadijjumi, kad autori uzdevuma formulējumā norāda uz nepieciešamību izmantot doto informāciju, bet tā nepalīdz veidot skolēnam atbildi - faktiski tiek pārbaudìtas skolēna zināšanas, piemēram, 13. un 14. uzdevumā 2017. gadā diagnosticējošā darbā dabaszinībās 6. klasei. Kā labu piemēru, kur tekstuālā un vizuālā informācija ir būtiska - nepieciešama, izmantojama uzdevuma veikšanai, var minēt 1.3., 8. un 10. uzdevumu 2017. gada diagnosticējošajā darbā dabaszinātnēs 9. klasei. 2017. gadā diagnosticējošajā darbā atškirīibā no iepriekšējā gada vērojama pozitīva virzība: izmantotie teksti nav ḷoti apjomīgi, bet dotā informācija ir ietilpìga. Piemēram, 9. uzdevumā šķietami vienkāršajā attēlā jānolasa informācija gan par to, ka tas ir lēciena sākums, gan tas, ka abi attēlotie spēki ir vienādi, kaut arī šiem abiem aspektiem vārdiskajā tekstā netiek pievērsta îpaša uzmanība. 
Analīzes veicēju formulētie uzdevumu indikatori daudzos gadījumos nesakrìt ar uzdevumu autoru dotajiem vērtēšanas kritērijiem ${ }^{8}$ (skat. piemērus 14. tabulā). Iemesls varētu būt formāla pieeja - nepieciešamajiem/izvēlētajiem indikatoriem, iespējams, piekārtoti uzdevumi, kas indikatoram atbilst nepilnīgi. Uzdevums nav izvērtēts pēc būtības, precīzi aprakstot konkrētā uzdevuma izpildei nepieciešamās zināšanas un prasmes.

14. tabula. Atškirīibas indikatoru formulējumos 2017. gada diagnosticējošajam darbam dabaszinātnēs 9 . klasei

\begin{tabular}{lll}
\hline Uzd. & \multicolumn{1}{c}{ Autoru formulētais indikators } & Analīzes ekspertu formulētais indikators \\
\hline 3.2. & $\begin{array}{l}\text { Skaidro novērojumu, izmantojot } \\
\text { informāciju un pieredzi }\end{array}$ & $\begin{array}{l}\text { Zina, ka, temperatūrai palielinoties, notiek } \\
\text { iztvaikošana, veidojas burbuḷi - ūdens } \\
\text { gāzveida stāvoklī }\end{array}$ \\
\hline 8.1. & Izvēlas darba piederumus & $\begin{array}{l}\text { No teksta nosaka izvēlēto neatkarīgo } \\
\text { main̄̄go; zina, ka vienlaikus nedrīkst mainīt } \\
\text { divus lielumus; attēlā un atbilžu variantos } \\
\text { atrod atbilstošo situāciju }\end{array}$ \\
& & $\begin{array}{l}\text { Zina, ka sēnes un monēras noārda } \\
\text { organiskās vielas }\end{array}$ \\
\hline 15.3. & $\begin{array}{l}\text { Izspriež, kuras valsts pārstāvji } \\
\text { nodrošina vielu noārdīšanu } \\
\text { ekosistēmā }\end{array}$ & \\
\hline
\end{tabular}

Ir daudz uzdevumu, kuros nepieciešama prasme strādāt ar informāciju. Rodas jautājums, vai tas darīts apzināti. Turpmāk, izvēloties indikatoram atbilstošu uzdevumu un/vai otrādi - nosakot indikatoru (ko mēra konkrētais uzdevums), detalizēti jāizvērtē šì atbilstība, kas palīdzēs saprast uzdevuma izmantošanas mērḳi - vai primārais ir mērìt izpratni par procesiem, parādībām, pētniecību vai tekstpratību.

Konstatējama neatbilstība arī starp ekspertu noteikto un pārbaudes darbu autoru definēto uzdevumu kognitīvo dziḷumu, kam pamatā ir atškirīga metodologiija. Valsts mēroga pārbaudes un diagnosticējošos darbos tradicionāli tiek piedāvāts skolēnu izziņas darbības sniegumu aplūkot trīs līmeņos: 1. līmenis iegaumēšana un izpratne; 2. līmenis - zināšanu un prasmju lietošana; 3. līmenis - analīze un produktīvā darbība. ${ }^{9}$

Teorijā šim nolūkam tiek izmantotas dažādas taksonomijas (Blūma, Stouna, SOLO u. c.), OECD PISA testu ietvaram definēti līmen̦i - zems, vidējs un augsts,

8 Pārbaudes un diagnosticējošie darbi. Pieejams: http://visc.gov.lv/vispizglitiba/eksameni/ uzdevumi.shtml (aplūkots 13.02.2018.).

9 VISC piedāvātie pārbaudes un diagnosticējošie darbi. Pieejams: http://visc.gov.lv/vispizglitiba/ eksameni/uzdevumi.shtml (aplūkots 13.02.2018.). 
kas tālāk iedalīti sešos līmeņos, pirmo iedalot vēl la un $1 b$, kā arī paredzot, ka sniegums var būt zem 1. lìmeņa. Lai būtu iespējams salīdzināt kognitīvās darbības dziļumu dažādos pārbaudes darbos, kā arī mācību stundās, iespējama dažādo instrumentu pielīdzināšana, nosakot to samērojamību.

Analīzi veicot, izmantota SOLO taksonomija, kas palīdz konstatēt atšķirību starp augstākajiem līmen̦iem.

Turpmāk apsverama vēl precīzākas (Pannzion, \& Pegg, 2003) aprakstītās pilnveidotās SOLO taksonomijas izmantošana, skolēna sniegumu aplūkojot divos lokos. Katrs loks ietver trīs līmeņus atbilstoši klasiskajai SOLO taksonomijai. Tādējādi detalizētāk tiktu izzināta citu valstu pieredze makrolīmeņa darbu veidošanā un vērtēšanā.

Aplūkojams vēl ir viens aspekts, kas saistìts ar kognitīvās darbïbas līmeni valsts mēroga pārbaudes darbos. Visu pārbaudes darbu programmās norādīts katram izziņas darbības līmenim atbilstošo uzdevumu ìpatsvars darbā procentos (skat. 15. tabulu).

15. tabula. VISC norādītais 2017. gada darbos iekḷauto testelementu sadalījums pa izziṇas līmen,iem \%

\begin{tabular}{cccccc}
\hline & $\begin{array}{c}\text { Matemātika } \\
\text { 3. kl. }\end{array}$ & $\begin{array}{c}\text { Matemātika } \\
\text { 6. kl. }\end{array}$ & $\begin{array}{c}\text { Matemātika } \\
\text { 9. kl. }\end{array}$ & $\begin{array}{c}\text { Dabaszin̄ibas } \\
\text { 6. kl. }\end{array}$ & $\begin{array}{c}\text { Dabaszinātnes } \\
\text { 9. kl. }\end{array}$ \\
\hline I & $28-29$ & $16-17$ & $22-24$ & $40-45$ & $15-20$ \\
\hline II & $45-46$ & $67-68$ & $64-66$ & $45-50$ & $55-60$ \\
\hline III & $24-25$ & $15-16$ & $9-11$ & $13-18$ & $20-25$ \\
\hline
\end{tabular}

Rodas jautājums, kādi apsvērumi ir šādas pieejas pamatā - būtiskām atšḳirībām katram kognitīvās darbības līmenim atbilstošo uzdevumu īpatsvarā gan starp mācību priekšmetiem, gan starp klasēm jau pārbaudes darbu programmu līmenì.

Kā iepriekš minēts (skat. 15. tabulu), augsta līmeņa uzdevumu darbos faktiski nav. Šì pretruna skolotājiem var radìt maldīgu priekšstatu par uzdevumu kognitīvo dziḷumu. OECD PISA testā 2015 zema kognitīva līmeņa uzdevumu kategorijā ietilpa $30 \%$ uzdevumu, vidēja $-62 \%$, augsta $-8 \% .^{10}$

LU SIIC iepriekš veiktie pētījumi (France, Namsone, Čakāne, Dzērve, \& Vilciņš, 2016) rāda, ka mācību procesā ir zema kognitīvā aktivitāte. Viens no iemesliem varētu būt valsts mēroga pārbaudes darbi, jo vairāki pētỉjumi (piemēram,

${ }^{10}$ OECD (2016). PISA 2015 Results (Volume I): Excellence and Equity in Education, PISA, OECD Publishing, Paris. Pieejams: http://dx.doi.org/10.1787/9789264266490-en (aplūkots 12.02.2018.). 
Millar, 2013) liecina, ka skolotāji, izvēloties mācību procesā izmantojamos uzdevumus, lielā mērā orientējas uz to, kas tiek sagaidīts valsts līmeņa pārbaudes darbos. Tik liels zema kognitīvā līmeņa uzdevumu pārsvars valsts pārbaudes darbos, kāds tas ir šobrīd, neveicina produktīvu mācību aktivitāšu skaita palielināšanos mācību stundās. Vienlaikus jāatzīmē pozitīva tendence - darbos tiek iekḷauti atsevišḳi uzdevumi, kuros jādemonstrē augsta līmeṇa kognitīvā darbïba. Taču joprojām augstam kognitīvajam līmenim atbilstošu uzdevumu vispār nav dabaszinībās 6. klasei, matemātikā 6. un 9. klasei. Otrs iemesls, kāpēc jāpalielinās to uzdevumu skaitam, kas sagaida skolēna darbību dziḷākā kognitīvajā līmenī (SOLO taksonomijas 3. un 4. līmenis), - lai būtu iespējams precīzāk noteikt skolēnu spēju spektru.

Iekḷautie uzdevumi vērtēšanas darbos var padarìt mācǐšanos efektīvāku, bet ir arī riski. Piemēram, dabaszinātņu jomā atkarībā no tā, kādi uzdevumi tiek iekḷauti, dabaszinātniskās izpratības veidošanās var tikt attīstīta vai bremzēta. Citi (Britton, 2007) atzīmē, ka, iekḷaujot obligātos pārbaudījumus tekstpratībā un matemātikā, novērota tendence, ka skolās tiek samazināta uzmanība dabaszinātṇu jomai. Ir pierādijjumi, ka skolotāji veic izmaiņas mācību saturā un metodēs, vadoties tieši no uzdevumiem makrolīmeņa vērtēšanas darbos. Ja vērtēšanas darbā dominē atbilžu izvēḷu uzdevumi, tad arī mācišsanas procesā parādās liels skaits tieši šāda tipa uzdevumu. Un otrādi - pieaugot atvērto, strukturēto atbilžu skaitam, kuru vērtēšanai izmanto rubrikas, pieaug arī līdzīgu darbu skaits mācīšanās procesā (Britton, 2007; Millar, 2013). Vērtēšanas darbos makrolīmenī ir liels skaits atbilžu izvēḷ uzdevumu un îso atbilžu uzdevumu, jo tādi testelementi ir vienkāršāk un lētāk pārbaudāmi un vieglāk administrējami nekā atvērti, "esejas" tipa uzdevumi.

Šobrīd Latvijā summatīiā vērtēšana matemātikā un dabaszinātnēs tiek veikta, izmantojot rakstisku pārbaudes darbu, kas neḷauj pilnībā novērtēt skolēnu prasmes. Jāapsver iespēja summatīvajai vērtēšanai izmantot dažādas formas, kombinētus vērtēšanas rīkus, ne tikai rakstiskos pārbaudes darbus. Vērtēšanu vēlams îstenot, kombinējot skolotāju vērtējumus ar centralizētajām procedūrām un ārējiem vērtētājiem (Darling-Hammond, \& Adamson, 2010), vienlaikus paredzot atbalstu skolotājiem, lai panāktu vērtētāju vienādu izpratni par snieguma kvalitāti (Stiggins, Arter, Chappuis, \& Chappius, 2004). Izmantojot IT, iespējams precīzāk konstatēt būtisku pamatprasmju līmeni un piedāvāt skolēnam nākamo uzdevumu atbilstoši iepriekšèjā uzdevumā parādītajam prasmju snieguma limenim.

Sabalansēta uzdevumu grūtības pakāpe ir viens no kvalitatīva pārbaudes/ vērtēšanas darba kritērijiem. Tā vistiešākajā veidā var ietekmēt skolēnu rezultātus, tāpēc jāskata kontekstā ar šiem uzdevumu raksturojošiem rādìtajiem. Piemēram, 2017. gadā diagnosticējošajā darbā dabaszinātnēs 9. klasei ir 6 testelementi, kuru grūtības pakāpe mazāka par 0,25 (tie izrādījušies par grūtu konkrētajai 
skolēnu grupai). Nav neviena uzdevuma, kurš (atbilstoši pārbaudes darbu izveides teorijai) būtu šai skolēnu grupai par vieglu. Arī pašu vieglāko testelementu pareizi izpildījuši tikai 75\% skolēnu. Savukārt 6. klases darbs uzrāda pretēju ainu - liela daļa uzdevumu atbilstoši IRT Raša modelim ir par vieglu. Tas nozīmē, ka tas, cik labi vai slikti izrādījušies skolēnu rezultāti darbā kopumā un/ vai atsevišķos uzdevumos, nav drošs pamats, lai spriestu par skolēnu patiesajam prasmēm, iespējamo sniegumu. Nepieciešama ne tikai rūpīga uzdevumu izstrāde, bet arī uzdevumu raksturojošo parametru definēšana. Līdztekus pārbaudes darbu izstrādei jāapsver iespējas pilnveidot arī ekspertēšanas un aprobācijas procesu, detalizēti analizējot iegūto informāciju par uzdevumiem.

Šobrīd esošajiem diagnosticējošajiem darbiem ir neskaidrs fokuss (ko tie pretendē mērìt), bet vērtěšanas kritēriji nepalīdz veikt diagnosticējošo funkciju - tie nedod atbildi, ko tieši skolēns prot, ko neprot, kāds ir kḷūdu cēlonis. Izņēmums ir diagnosticējošais darbs matemātikā 8. klasei, kas pretendē mērìt skolēnu specifiskās matemātiskās prasmes konkrēta satura temata ietvaros. Šajos darbos savukārt pietrūkst apjomīgāku problēmuzdevumu, kas mēra kompleksu sniegumu, prasmju lietojumu praktiskās situācijās. Darbs jāveido precīzā atbilstībā tā mērḳim, skolai un skolotājiem jāsaņem turpmākās darbības plānošanai izmantojama informācija par rezultātiem. Izvirzot prioritāro mērḳi - sekmēt skolas atbildību, skolēnu rezultātiem vērtēšanās darbā nevajadzētu kalpot par vienīgajiem datiem, kuri tiek interpretēti, lai izdarītu secinājumus par skolas līmeni. Nepieciešams arī pārskatìt tradicionālo pien̦ēmumu, ka par izglìības sistēmu ir iespējams iegūt datus, piedaloties visiem skolēniem (Black, 1990). Vērtējot skolēnu reprezentatīvo kopu sasniegumus, pietiek ar daudz mazāku skolēnu skaitu, toties ir iespēja veikt padziḷinātu analīzi.

\section{Kāda saistība ir makrolīmeṇa darbiem ar nepieciešamajiem uzlabojumiem mācīšanās procesā skolā}

Kā skolēniem izdodas vienā priekšmetā apgūto lietot citos mācību priekšmetos, un kas būtu darāms, lai skolēnu sniegums būtu labāks? Viens no 21. gadsimta atbilstošas mācišanās rezultātiem ir prasme lietot apgūtās zināšanas un prasmes dažādā kontekstā. Tie var būt gan jauni konkrētās zinātnes, gan sadzīviski, ar reālo dzīvi saitīti konteksti, gan no citām zinātnēm, jomām, starpdisciplināri. Visos analizētajos dabaszinātņu darbos iekḷauti uzdevumi, kuru izpildei nepieciešamas prasmes, kuras sākotnēji tiek mācìtas matemātikā. (Pārbaudes darbos matemātikā nav uzdevumu, kuru veikšanai būtisks būtu citos mācību 
priekšmetos apgūtais.) Visos šajos uzdevumos trīs gadu laikā skolēnu rezultāti ir lıoti zemi. Problēma par iepriekš apgūto prasmju lietojumu citos mācību priekšmetos analizēta arī Latvijā (France, et al. 2016).

Uz matemātikas lietojumu dabaszinātṇu kontekstā, piemēram, 2015. gadā attiecināmi trīs testelementi - 5.2., 6.2. un 10.4. To grūtības pakāpes atbilstoši ir 0,36; 0,22 un 0,17 . Salīdzinot ar kopējiem rezultātiem (darba grūtības pakāpe $0,43)$, redzams, ka šie trīs uzdevumi skolēniem ir izrādījušies pārāk grūti, viṇu prasmes atrisināt šos uzdevumus vērtējamas kā kritiskas. Neraugoties uz to, ka šo uzdevumu grūtības pakāpe izrādijusies ḷoti augsta, uzdevumi ir tieši par to, ko vēlamies, - lai vairums skolēnu spētu lietot matemātiskās pamatprasmes dažādās, ne tikai tipveida situācijās, tostarp reālās dzīves situācijās.

Piemērs 10.4. Aprēķini vajadzīgo kristāliskā nātrija hlorìda masu, lai pagatavotu $500 \mathrm{~g}$ fiziologiiskā šķiduma - 0,9\% NaCl šķìdumu. Parādi risinājumu!

Veiksmīgai uzdevuma izpildei, lasot tekstu (reālās dzīves kontekstu), jāsaprot jēga, ka nepieciešamā vielas masa ir daḷa no veselā - no šḳīduma masas; jāsaprot, kas ir \%, kas ir daļa no veselā un kas ir procenta daļa; jāprot aprēķināt daļas vērtību, lietojot algoritmu, spriežot; jāprot izpildìt darbïbas ar skaitḷiem.

Šì uzdevuma rezultāti ir vissliktākie, kaut gan konkrētā satura mācǐšana matemātikā sākas ar izpratnes par dạ̦ām veidošanu 3. un 4. klasē, turpinās 5. un 6. klasē, kad apgūst visu veidu daḷu un procentu aprēkinus; procentu aprēḳināšana tiek mācìta arī kịmijā 8. klasē. Dati rāda - no skolēnu grupas ar augstiem sasniegumiem darbā kopumā šo uzdevumu veikuši tikai $46 \%$, no grupas ar zemiem sasniegumiem - 6\%. Tā kā uzdevums gan no matemātikas, gan ķìmijas mācīšanās aspekta nav tipveida situācija, iespējams, ka dạ̣a skolēnu to nemègina risināt.

Uz šo problēmu norādīts metodiskajos materiālos "Diagnosticējošais darbs dabaszinātnēs 9. klasei 2014./2015. mācību gadā: rezultātu analīze un ieteikumi” un "Diagnosticējošais darbs dabaszinātnēs 9. klasei 2015./2016. mācību gadā: rezultātu analīze un ieteikumi” ${ }^{11}$, taču nākamajos divos mācību gados nav izdevies panākt situācijas uzlabošanos.

Tajā pašā laikā vērojams, ka atseviškiiem skolēniem ir potenciāls šādu uzdevumu veikšanai: vinịi spēj veidot pārnesumu - izmantot citos mācību priekšmetos iepriekš mācìto. Iepazisstoties ar skolēnu darbiem, kuri šo uzdevumu ir risinājuši, redzams, ka tikai daži skolēni ir risinājuši uzdevumu, izmantojot ķīmijā

${ }^{11}$ Diagnosticējošais darbs dabaszinātnēs 9. klasei 2014./2015. mācību gadā: rezultātu analīze un ieteikumi. Pieejams: http://visc.gov.lv/vispizglitiba/eksameni/dokumenti/metmat/2014_2015_ ddarbs_dabzin_9kl_analize.pdf (aplūkots 13.02.2018.).

Diagnosticējošais darbs dabaszinātnēs 9. klasei 2015./2016. mācību gadā: rezultātu analīze un ieteikumi. Pieejams: http://visc.gov.lv/vispizglitiba/eksameni/dokumenti/metmat/2015_2016_ ddarbs_dabzin_9kl_analize.pdf (aplūkots 13.02.2018.). 
piedāvāto formulu un atbilstošu risinājuma pierakstu. Skolēni izmanto pārsvarā matemātikā apgūto, izmantojot dažādus paņēmienus:

- atrisinājuma gaitā tiek aprēķināta un tālāk izmantota $1 \%$ vērtỉba,

- skolēni uzreiz aprēķina $0,9 \%$ no šķīduma masas, pārejot uz reizinājumu $(0,9 \%$ no $500=0,009 \cdot 500)$,

- tiek izmantota proporcionalitāte spriežot,

- lieto formulu proporcijas nezināmā locekḷa aprēḳināšanai.

Konstatējot, ka skolēni nespēj izmantot uzdevumā daudzus gadus mācību procesā lietotu algoritmu, iezīmējas nepieciešamība mācību procesā konsekventi noskaidrot skolēnu iepriekšējo pieredzi un balstîties uz to, dažādot uzdevumu kontekstu gan dabaszinātṇu, gan matemātikas stundās, apzināti mācìt skolēniem pārnesuma veidošanu - atpazìt situācijas, paṇēmienus, vairāk izmantot uzdevumus ar atbilžu un risināšanas pañēmienu/stratēgiju variativitāti. Ja mācību stundās apzinātā līmenī tiek mācīts šo pārnesumu veidot, to skolēnu skaits, kas spēj rīkoties jaunā situācijā, varētu kḷūt lielāks, jo kopumā skolēnu sniegums šāda veida uzdevumos ir loti zems. Nepieciešams skaidri apzināties, kuri uzdevumi darbā pārbauda skolēnu prasmi rīkoties jaunā situācijā, lai nepārvērstu tos par vēl vienu tipveida uzdevumu, ko nepieciešams apgūt.

Aktualizējas dažādu mācību priekšmetu/jomu skolotāju sadarbības nozīme, lai palīdzētu skolēnam veidot pārnesumu, vingrināties dažādā kontekstā.

Par skolēnu prasmēm darbā ar informāciju ir vēl kāda iespējama problēma. Skolēni pietiekami labi veic uzdevumus, ja visa nepieciešamā informācija ir vienkopus konkrētā uzdevuma formulējumā. Ja uzdevums ir strukturēts (satur vairākus testelementus) un informācija atbildes veidošanai ir meklējama uzdevuma sākuma tekstā vai iepriekšējos testelementos, rezultāti ir daudz sliktāki. Piemēram, 2016. gada dabaszinātņu diagnosticējošajā darbā 9. klasei uzdevumā 5.3. (skat. 8. attēlu) pareizi atbildējuši tikai $20 \%$ skolēnu, lai gan pareizā atbilde atrodama tekstā uzdevuma sākumā.

\section{5. uzdevums (4 punkti)}

Lai izgatavotu maizes mīklu, pavārs samaisa miltus, ūdeni, sāli un raugu. Pēc samaisišsanas maizes mīklu atstāj uz vairākām stundām, lai uzbriest. Rauga sēnes klātbūtnē notiek kịmiskas pārvērtības, kuru laikā miltos esošās organiskās vielas pārvēršas par oglskābo gāzi un spirtu.

5.3. Kura mīklas satāvdaḷ dod oglekla atomus oglskābās gāzes un spirta molekulu veidošanai? Atzīmē vienu atbildi!

A milti

B sāls

C ūdens

D raugs

8. attēls. Diagnosticējošā darba uzdevums dabaszinātnēs 9. klasei (VISC, 2016) 
Atbilstoši lasītprasmes snieguma aprakstam (skat. 9. attēlu) tiek sagaidìts 2. līmeņa sniegums ar prognozējami labāku rezultātu, nekā tas reāli sasniegts. Iespējamais šādas situācijas cēlonis varētu būt tas, ka skolēni mācību procesā katru uzdevumu pieraduši uztvert kā autonomu, viņiem nav pietiekamas pieredzes saistīt un izmantot informāciju, apzināti meklēt saistību starp uzdevumiem un to risinājumiem.

\begin{tabular}{|c|c|c|c|}
\hline \multicolumn{4}{|c|}{ Rubrika: prasme atrast tekstā informāciju } \\
\hline 1 & 2 & 3 & 4 \\
\hline $\begin{array}{l}\text { Atrod/nolasa } \\
\text { tieši izlasāmu } \\
\text { (burtisku) } \\
\text { informāciju } \\
\text { (konkrēta tekstā } \\
\text { atrodama atbilde uz } \\
\text { konkrētu jautājumu; } \\
\text { termins; ...) }\end{array}$ & $\begin{array}{l}\text { Atrod/nolasa } \\
\text { pazīstamu, bet ne } \\
\text { burtiski izlasāmu } \\
\text { informāciju (tekstā } \\
\text { tas pateikts citiem } \\
\text { vārdiem; formulu, } \\
\text { kas atbilst konkrētai } \\
\text { situācijai; ...) }\end{array}$ & $\begin{array}{l}\text { Atrod/nolasa } \\
\text { daḹjii pazīstamu } \\
\text { situāciju (netieši? } \\
\text { formulētu, piemēram, } \\
\text { atslēgas vārdus, kad } \\
\text { jāpien,em lēmums - } \\
\text { ir vai nav atslēgas } \\
\text { vārds) }\end{array}$ & $\begin{array}{l}\text { Atrod/nolasa } \\
\text { meklējamā } \\
\text { informācija } \\
\text { kompleksa (atslēgas } \\
\text { vārdi }+\ldots \text {...) }\end{array}$ \\
\hline $\begin{array}{l}\text { Vienkāršā (pazīstami } \\
\text { vārdi, pazīstams } \\
\text { saturs) neliela } \\
\text { apjoma viena veida } \\
\text { tekstā }\end{array}$ & $\begin{array}{l}\text { Vienkāršā viena } \\
\text { veida tekstā; var } \\
\text { būt vairāki teksti } \\
\text { (fragmenti) }\end{array}$ & $\begin{array}{l}\text { Teksts dots } \\
2 \text { veidos (vienlaikus } \\
\text { teksts, tabula, } \\
\text { shēma, grafiks, } \\
\text { diagramma, ...) } \\
\text { teksts var saturēt } \\
\text { nezināmus } \\
\text { terminus, ... }\end{array}$ & $\begin{array}{l}\text { Kompleksi (vismaz } \\
3 \text { veidos) dotā jaunā } \\
\text { tekstā (konteksts } \\
\text { nezināms), } \\
\text { nepieciešams } \\
\text { izmantot informāciju } \\
\text { no visiem tekstiem }\end{array}$ \\
\hline $\begin{array}{l}\text { Ja lasīšanas } \\
\text { stratēǵija dota }\end{array}$ & $\begin{array}{l}\text { Ja lasīšanasa } \\
\text { stratēǵijija dota }\end{array}$ & $\begin{array}{l}\text { Lietojot viena veida } \\
\text { lasīšanas stratēǵiju }\end{array}$ & $\begin{array}{l}\text { Lietojot dažādas } \\
\text { lasīšanas stratēǵgijas }\end{array}$ \\
\hline
\end{tabular}

9. attēls. Snieguma līmeṇu apraksts par prasmi atrast tekstā informāciju (LU SIIC arhīvs)

Tas, ka arī skolēniem ar augstu akadēmisko sniegumu ir nepietiekami attīstīta tekstpratība, vedina domāt, ka tās ir sekas mācīšanas procesam stundās, kad skolēni neiegūst nepieciešamo pieredzi. Rezultāti trīs gadu posmā uzrāda skolēnu grūtîbas atrast un izmantot dažādā veidā dotu informāciju un aktualizē gan nepieciešamību ar to apzinātāk strādāt mācību stundās, gan skolotāju sadarbības nepieciešamību, lai, plānojot mācību saturu un procesu, atbalstītu skolēnu vajadzības tekstpratības un citu starpdisciplināru prasmju apguvei un pilnveidošanai.

Gan valsts lïmeña darbos, gan PISA pārbaudijumos l,oti mazs ir to skolēnu skaits, kuri uzrāda labu sniegumu uzdevumos, kas prasa dzil̦u domāšanu. Tas vedina domāt par nepietiekamu problēmuzdevumu risināšanas pieredzi. Par saikni starp rezultātu/skolēnu sniegumu vērtēšanas darbos un procesā 
notiekošo - kā notiek mācišana klasē, skat. 2.1. nodạ̦ā, kur aplūkoti mācību stundu vērošanā iegūtie dati. Tie uzrāda, ka tikai aptuveni 1/3 stundu novērojama skolēnu produktīva darbība (Namsone, Čakāne, \& Cirulis, 2017; Volkinsteine, Namsone, \& Cakane 2015; Namsone, \& Cakane, 2015; France, \& Namsone, Čakāne, Dzērve, \& Vilciņš, 2017).

Interpretējot skolēnu rezultātus saistībā ar izziṇas darbības dzilumu, jāṇem vērā, ka atkarībā no tā, ko un kā skolēni ir mācījušies, kādus konkrētus piemērus pildījuši mācību procesa laikā klasē, viens un tas pats uzdevums kādam var izrādīties pazīstama, citam - jauna situācija, kurā ir nepieciešams pašam radīt pārnesumu no citos priekšmetos apgūtā, un tad kognitīvās darbības dziḷums šiem skolēniem var būt augsts.

Skolēnu sniegums uzdevumos, kas mēra pētnieciskās darbības prasmes, liek domāt par to, vai pietiekami liels ir bijis pētniecisku uzdevumu īpatsvars mācību procesa laikā.

Uzdevumi, kurus sāk iekḷaut pārbaudes darbos un atsevišķās mācību grāmatās, ir dzị̄āki, prasa citus kognitīvos rīkus. Jāpalīdz skolotājiem atpazìt šādus uzdevumus, pārveidot tradicionālos, panākot tajos lielāku kognitīvo dziḷumu. Atlasīto skolēnu darbu analīze atklāj problēmas skolēnu snieguma korektā vērtēšanā. Nepieciešams palīdzēt skolotājiem pilnveidot prasmi vērtēt uzdevumus, kuri izmantojami kompleksu prasmju mācǐšanai; prasmi analizēt statistisko informāciju, kas nonāk skolotāja un skolas rīcībā.

\section{Secinājumi}

Makrolīmeņa vērtēěanas darbi nepilnīgi mēra skolēnu izpratni par procesiem un parādībām dabā. Nepieciešams izstrādāt konkrētu, precīzu mērḳu un indikatoru sistēmu, ko tieši katrs darbs mērīs, pamatojot, kāpēc tas ir svarīgi.

Darbi pārsvarā paredz skolēnu darbỉbu zemā kognitīvā līmenī. Veidojot valsts lïmeņa darbu konstruktus, nepieciešams skaidri definēt paredzamos kognitīvos līmeņus un panākt, lai darbā iekḷautie uzdevumi mēra prasmes plānotajā kognitīvajā līmenī, tostarp augstākajā.

Veidojot valsts līmeņa pārbaudes darbus, jāseko mūsdienīga uzdevuma kritērijiem: uzdevumi pārbauda izpratni par atbilstošās zinātnes būtiskākajiem jautājumiem (lielajam idejām); pārbauda ikvienam nozīmīgas prasmes; uzdevumi ir iespējami starpdisciplināri, autentiski (ar reālo dzīvi saistìti), lai skolēni varētu demonstrēt prasmi veidot pārnesumu; ar iespēju demonstrēt dažādu līmeņu, tostarp visaugstākā, kognitīvu darbību; ar iespēju lietot dažādas stratēgeijas; jāsāk iekḷaut uzdevumus, kuri paredz arī metakognitīvu darbību. Vienlaikus pārskatot 
darba apjomu - samazinot uzdevumu skaitu, lai skolēniem pietiktu laika iedziḷināties šajos uzdevumos.

Ja tiek vērtēta uzdevuma izpildes pareizība, nav iespējams spriest par skolēnu prasmēm, prasmju apguves līmeni. Uzdevumos, ar kuriem tiek pārbaudītas prasmes, komplekss sniegums, jāveido snieguma limen,u apraksti, apsverot iespējas izmantot Austrālijas pieredzi (no SOLO taksonomijas atvasinātu pieeju). Tas būtiski, ne tikai lai adekvāti mērītu skolēnu sniegumu, bet arī tāpēc, ka vērtēšanas kritēriji arī ir viens no orientieriem skolotajiem, lai pārskatìtu savu praksi gan mācišanā, gan vērtēšanā skolas līmenī. Īpaši diagnosticējošo darbu gadỉjumā nepieciešams iegūt daudzpusīgāku informāciju par skolēnu stiprajām pusēm un snieguma dimensijām, lai skaidri saprastu, kādi uzlabojumi nepieciešami.

Ir pārskatīta diagnosticējošo darbu loma, statuss - tiem jābūt rīkiem, kas ir pilnībā skolotāja rīcībā. Skolām jāpiedāvā kvalitatīvi izstrādāti diagnosticējošo darbu paraugi noteiktu prasmju mērīšanai. Valsts līmenī diagnosticējot/monitorējot situāciju, jādomā par ticamu datu iegūšanu, veicot šos mērỉjumus korekti izvēelētās izlases kopās.

Daudz lielāka nozīme jāpiešķir aprobācijai un tajā iegūto datu analīzei, kas palīdzētu veidot kvalitatīvākus valsts mēroga pārbaudes darbus.

Skolēnu rezultāti uzrāda nepieciešamību pārskatīt, kā notiek prasmju mācīšana, vai tiek veidota stratēgija un ir strādāts, lai pārnestu no situācijas uz situāciju, no temata uz tematu, no priekšmeta uz priekšmetu, uz dzīvi. Jāpārskata, vai mācīšana nav pārprasti formalizējusies, jēgas izpratnes vietā veicot matemātiskus pārveidojumus, dažādos mācību priekšmetos katru faktu mācot nesaistīti ar kaut ko jaunu, nevis rādot, mācot saskatīt kopsakarības.

Skolēniem ir daudz labāki rezultāti uzdevumos, ar kuriem tiek pārbaudīta atsevišķa prasme, bet grūtības sagādā uzdevumi, kuros nepieciešams kombinēt vairākas prasmes. Mācību stundās būtisku prasmju vingrināšanai izmantojami dažādi konteksti. Jāpanāk lielāks kompleksu, kognitīvi dziḷu uzdevumu īpatsvars mācību procesā. Tas palīdzēs skolēniem veidot pārnesumu, dos pieredzi darboties jaunās situācijās.

Jāsekmē sadarbība starp matemātikas un dabaszinātṇu skolotājiem skolas un valsts līmenī. Nepaliekot tikai sarunu un plānošanas līmenī, bet skatoties stundās - kādas stratēǵijas katrs izmanto, kā māca tās atpazìt un pārnest. Tas sasaucas ar pašvadītas mācišanās prasmju nepieciešamu ienākšanu skolēna ikdienas pieredzē. Mācīt skolēnam veidot pārnesumu no zināmām uz svešām situācijām nav iespējams bez metakognitīvo stratēǵiju izmantošanas.

Skolēniem trīs gadu periodā ir nemainīgi pieticīgi rezultāti uzdevumos, kuros nepieciešamas prasmes darbā ar informāciju (tekstpratība). Skolotāju sadarbības loks vēl vairāk paplašināms, iesaistot savstarpējā pieredzes apmaiṇā un 
pilnveidē arī sākumskolas un citu mācību priekšmetu skolotājus, kas ir svarīgi, sekmējot skolēniem tik nepieciešamo lasišanas stratēǵiju, argumentēšanas un citu prasmju apguvi.

VISC jānodrošina skolas ar būtiskiem, mācišanas uzlabošanai izmantojamiem datiem par skolēnu rezultātiem valsts līmeṇa darbos.

\section{IZMANTOTĀ LITERATŪRA}

Biggs, J. B., \& Collis, K. F. (1982). Evaluating the Quality of Learning - the SOLO Taxonomy. New York: Academic Press.

Black, P. (1990). APU Science: The Past and the Future. School Science Review, 72(258), pp. 13-28.

Black, P., \& Wiliam, D. (2007). Large-scale assessment systems: Design principles drawn from international comparisons. Measurement: Interdisciplinary Research and Perspectives, 5(1), pp. 1-53. https://doi.org/10.1080/15366360701293386

Bond, T. G., \& Fox, C. M. (2007). Applying the Rasch model: Fundamental measurement in the human sciences ( $2^{\text {nd }}$ ed.). Mahwah, NJ: Lawrence Erlbaum.

Britton, E. D., \& Schneider, S. A. (2007). Large-scale assessments in science education. In Abell, S. K., \& Lederman, N. G. (eds.). Handbook of research on science education (pp. 1007-1040). Mahwah, NJ: Lawrence Erlbaum.

Darling-Hammond, L., \& Adamson, F. (2010). Beyond basic skills: The role of performance assessment in achieving $21^{\text {st }}$ century standards of learning. Stanford, CA: Stanford University, Stanford Center for Opportunity Policy in Education. Pieejams: https://scale. stanford.edu/system/files/beyond-basic-skills-role-performance-assessment-achieving21st-century-standards-learning.pdf (aplūkots 12.02.2018.).

France, I., Namsone, D., Čakāne, L., Dzērve, U., \& Vilciņš, J. (2016). Teaching to Use in Science and mathematics Previously Acquired Skills. SOCIETY. INTEGRATION. EDUCATION. Proceedings of the International Scientific Conference, 2016. Vol. II, (pp. 51-65). Rezekne: Rezeknes Academy of Technologies.

Kifer, E. (2000). Large-scale assessment: Dimensions, dilemmas, and policy. Thousand Oaks, CA: Corwin Press.

Liu, X. (2012). Developing Measurement Instruments for Science Education Research. No Fraser, B. J., Tobin, K., \& McRobbie, C. J. (red.). Second International Handbook of Science Education. Dordrecht: Springer Netherlands.

Millar, R. (2013). Improving svience education: Why assessment matters, Valuins assessment in science education. Pedagogy, curriculum, policy, Dordrexht Springer pp. 55-68.

Namsone, D., \& Cakane, L. (2015). How the absence of higher PISA scores is connected with Science Classroom? Paper presenter at the $5^{\text {th }}$ World Conference on Educational Technology Researsh, North Cyprus.

Namsone, D., Cakane, L., \& Cirulis, A. (2017). How does cognitive demand in observed lessons and national diagnostic testing compare to PISA science results in Latvia? $12^{\text {th }}$ Conference of the European Science Education Research Association (ESERA), 21-25.2017. Dublin, Ireland. 
Panizzon, D., Pegg, J. (2003). Using a cognitive structural model to provide new insights into students' understandings of diffusion. International Journal of Science Education, 25(12), pp. 1427-1450.

Stiggins, R. J., Arter, J. A., Chappuis, J., \& Chappius, S. (2004). Classroom assessment for student learning: Doing it right - using it well. Portland, Oregon: Assessment Training Institute.

Volkinsteine, J., Namsone, \& D., Cakane, L. (2015). What lesson observation data reveal about the changes in teaching science: Case study from Latvia, International Baltic Symposium on Science and Technology Education, BalticSTE 2015 (15.-18.06.2015., Šaul̦i, Lietuva).

Wilson, M. (2005). Constructing measures: an item response modeling approach. Mahwah, N. J: Lawrence Erlbaum Associates.

Wylie, E. C., \& Wiliam, D. (2006). Diagnostic questions: is there value in just one? Paper presented at the Annual Meeting of the National Council on Measurement in Education held at San Francisco, CA.

Wu, M., Tam, H. P., \& Jen, T. H. (2016). Educational Measurement for Applied Researchers. Springer, Singapore. 
5. nodala

\section{Formatīvās vērtēšanas lomas pastiprināšanās, īstenojot mācīšanos iedzilinoties}

Līga Čakāne

Domājot par izglītības mērḳiem 21. gadsimtā, vienlaikus jādomā, kā palīdzēt jauniešiem tos sasniegt. Šajā kontekstā aktuāla ir vērtēšana, kas atbalsta, regulē, sekmē mācīšanos - formatīvā vērtēšana un pašregulācija, skolēnu pašnovērtēšanas prasmju pilnveidošana.

\section{Kas ir formatīvā vērtēšana}

Vērtēšanas primārajam mērḳim jābūt: dot nepieciešamo informāciju, lai varētu uzlabot mācīšanu un mācīšanos, kas atbilst formatīvajai vērtēšanai - vērtēšanai, lai mācītos (assessment for learning). Tā nav jauna ideja vai pieeja. Literatūrā formatīvās vērtēšanas nozīmīgums un tās īstenošanas pieredze ir daudz aprakstīta. Zinātnieki raksturo formatīvās vērtēšanas būtību: iegūt pierādījumus par skolēna sniegumu, tos interpretēt un izmantot, lai pieņemtu lēmumu par turpmākajiem mācību procesa soḷiem, lai tie būtu piemērotāki, pamatotāki. Tas nebūtu iespējams bez vērtējošās darbības (Black, \& Wiliam, 1998a, 1998b, 2009; Black, 2004).

Terminu formatīvs, to attiecinot uz vērtēšanu, pirmo reizi lietoja 1967. gadā (Scriven, 1967). Lielbritānijā 1998. gadā veiktais pētījums apliecināja, ka profesionāli īstenota formatīvā vērtēšana uzlabo skolēnu sniegumu (summatīvajā vērtēšanā) par 30\% (Black et al., 2002).

Pēdējo 10-15 gadu laikā priekšstati par formativo vērtēšanu, tās lomu un ìstenošanu pasaulē ir strauji paplašinājušies. Ir veikti apjomīgi pieejamo avotu 
analīzes apkopojumi, piemēram, projektā $\operatorname{ASSISTME}^{1}$ (Bernholt, Ronnebeck, Ropohl, Koller, \& Parchmann, 2013).

Grants Vigins uzsver, ka nepieciešams pārskatīt, kādiem mērḳiem izmantojam vērtēěanu vispār, aicinot uz vērtēšanu raudzīties kā uz līdzekli, lai uzlabotu mācišanos, nevis tikai "auditēt faktu uzkrāšanu" un aizstāt jēdzienu "vērtēšana" ar jēdzienu "atgriezeniskā saite". Viṇš rosina domāt par vērtēšanu kā par informāciju, kas nepieciešama, lai uzlabotu sniegumu. Vigins aicina atgriezties pie vērtēšanas primārā mērķa - palīdzēt skolēniem labāk mācīties un skolotājiem labāk mācīt (Wiggins, 2006).

Vigins (2006) iesaka daudz lielākā mērā izmantot tā saukto autentisko vērtēšanu (authentic assessment) jeb tādu pieeju vērtēšanai, kas prasa skolēniem demonstrēt sniegumu un radìt produktus, kas līdzinās uzdevumiem un situācijām, ar kuriem viṇi saskarsies reālajā dzīvē ar atbilstošām prasībām, iespējām un ierobežojumiem. Autentiska vērtēšana, viņaprāt, nozīmē tādu pieeju vērtēšanai, kurā tiek vērtēta skolēnu spēja "rīkoties", izmantojot attiecīgās jomas prasmes kontekstā, lai nostiprinātu viņu spēju tās efektīvi pārnest jeb vispārināt. Viginsa aicinājumu tāpèc varētu attiecināt arī uz mācīšanās iedziḷinoties pieeju mācišanai.

Vigins ir pārliecināts, ka skolēniem ir tiesības uz viņiem noderīgāku un draudzīgāku vērtēšanas sistēmu, jo skolēni ir pelnījuši saņemt vairāk atgriezenisko saiti un iespējas to izmantot. Kad vērtēšana palīdz pareizi fokusēt mācišanu šādā veidā, skolēna pašnovērtējums un spēja pašiem uzlabot savu darbu (self-adjustment) kḹst par kritiski nozīmīgu mācǐšanas un mācī̌sanās procesa daļu (Wiggins, 2006). Viginsa redzējums par vērtēšanu, izvēloties autentiskus uzdevumus, ar kuru palīdzību pakāpeniski attīstìt skolēnu prasmes, īpaši akcentē nepieciešamību uztvert vērtēšanu kā sistēmu un daḷu no mācišanas un mācīšanās procesu, nevis lēmumu par vienas vai otras metodes vai instrumenta izvēli.

Vērtēšanas eksperti (Brownlie, Feniak, \& Schnellert, 2006; Pollard, Anderson, Maddock, Swaffield, Warin, \& Warwick, 2008) lieto arī terminus vērtēšana, lai mācītos (assessment for learning), un vērtēšana kā mācišanās (assessment as learning). Lai notiktu vērtēšana kā mācǐšanās, būtiskākais aspekts ir skolotāja dota aprakstošā atgriezeniskā saite skolēnam par viņa mācišanos, iesaistot skolēnu savu rezultātu analīzē, turpmāko mācīšanās mērķu definēšanā.

Tikai tad, ja skolotājs veic šādas darbības, viņš īsteno vērtēšanu, lai mācītos (Wiliam, \& Thompson, 2007):

- skaidro mācišsanās mērķus un snieguma kritērijus, panāk skolēnu izpratni par tiem,

Assess Inquiry in Science, Technology and Mathematics Education, 8 dalibvalstu kopprojekts, FP7 atbalsts. 
- veido efektīvas sarunas klasē, izmanto uzdevumus un aktivitātes, kas dod datus, faktus, pierādījumus par mācīšanos,

- nodrošina tādu atgriezenisko saiti, kas palīdz skolēniem virzìties uz priekšu,

- aktivizē skolēnu sadarbību mācoties un dodot savstarpēju atgriezenisko saiti, lai viņi palīdzētu cits citam,

- veicina skolēnu metakognīciju, motivāciju, pašvērtējumu, atbildīgumu par savu mācišanos.

Formatīvā vērtēšana prasa abu iesaistìto pušu - gan skolotāju, gan skolēnu ieinteresētību, aktīvu, mērkstiecīgu darbību. Skolēniem jābūt skaidrai formatīiās vērtēšanas būtỉbai - ka tā domāta, lai sniegtu viṇam atbalstu, ka tā nav ne atalgojums, ne sods (Kaftan, Buck, \& Haack, 2006). Citi uzsver, ka mācī̌anās būs efektīva, ja formatīva vērtēšana ietvers atgriezenisko saiti no skolēna uz skolotāju, atgriezenisko saiti no skolotāja uz skolēnu un informācijas apmaiņu starp skolēniem (Hodgen, \& William, 2006). Tieši skolotāja profesionāli īstenotai formatīvajai vērtēšanai ir liela motivējoša ietekme. Tiek uzsvērts, ka motivē vai demotivē veids, kādā skolēnam tiek dota atgriezeniskā saite (Reece, \& Walker, 2007).

Tiek aktualizēta nepieciešamība mainīt mācību vidi no kritizējošas (tādas, kur valda konkurence, svarīgi formālie rezultāti, notiek sociāla salīizināšana, skolēnu dalīšana grupās pēc spējām, mācǐšanā un vērtēšanā uzsvars uz pareizām atbildēm, ne tik daudz uz rūpēm par saprašanu) uz motivējošu, iesaistošu (kur dominē centieni, kam seko uzlabojumi, uzsvars uz ieguldīto darbu, pilnveidošanos, jauktu spēju grupām, skolēnu kḷūdu cieṇpilnu pieņemšanu, jo tās ir mācīšanās neatṇemama sastāvdaḷa) (Maday, 2008²). Uz skolēna mācišanos orientēta vide, mācǐšanās kā aktīvs zināšanu, prasmju un attieksmju veidošanās process, sadarbība mācoties, mācišanās kā pašregulējošs process, kas ietver plānošanu, vadīšanu, refleksiju, vistiešākajā veidā ir saistīts ar formatīvās vērtēšanas īstenošanu (De Corte, 2000).

Formatīvo vērtēšanu mācību stundā (Harlen, 2013) raksturo:

- skolēnu iesaistišana, gan komunicējot stundas mērķus, gan veidojot vienotu izpratni par snieguma vērtēšanas kritērijiem,

- procesa cikliskums - skolēna darbība, ar mērķa sasniegšanu saistītu pierādījumu iegūšana, lēmums par nepieciešamajiem nākamajiem soḷiem, lēmums par to, kā tos veikt, un atbilstošas skolēna darbības.

2 Maday, T. (2008). Stuck in the Middle. Strategies to Engage Middle-Level Learners. The Center for Comprehensive School Reform and Improvement. Learning Point Associates. 
Laba formatīvā vērtēšana (Nicol, \& Draper, 2008):

- palīdz skaidrāk saprast, kāds ir labs sniegums (mērḳi, kritēriji), dod pieredzi saistīt domas ar mērķiem un kritērijiem pirms uzdevuma, tā veikšanas laikā un pēc veikšanas,

- sekmē ieguldīt laiku un pūles mācību uzdevumu veikšanā, veicina regulāru mācīšanos,

- dod augstas kvalitātes atgriezenisko informāciju, kas palīdz skolēniem pašiem uzlabot sniegumu,

- sniedz pieredzi izmantot atgriezenisko saiti, lai samazinātu plaisu starp esošo un vēlamo izpildījumu,

- pārliecina, ka vērtēšana pozitīvi ietekmē mācīšanos,

- veicina sadarbību un sarunas par mācīšanos (skolēns - skolotājs, starp skolēniem),

- rosina pilnveidot pašnovērtējuma un refleksijas prasmes,

- dod skolēnam izvēles iespējas par tematu, metodēm, kritērijiem, laiku vērtēšanai, iesaista skolēnus lēmumu pieņemšanā par vērtēšanu,

- atbalsta mācīšanos sadarbojoties,

- veicina pozitīvu motivāciju, pašapziṇu,

- dod skolotājam informāciju, ko var izmantot, lai pilnveidotu mācīšanu.

\section{Formatīvās vērtēšanas īstenošana}

Literatūrā pieejami formatīvās vērtēšanas konkrētu metožu, paṇēmienu un instrumentu apraksti, taču jāuzsver būtiskākais - formatīvā vērtēšana ir integrēta mācǐšanas un mācīšanās procesā. Tā ir nepārtraukta, tā panāk aktīvu skolēnu iesaisti savstarpējā un pašnovērtējumā, ietver atgriezenisko saiti ar ieteikumiem, kā uzlabot mācīšanos, fokusējoties tieši uz procesu, saistīta ar mācī̌sanās mērḳu precīzu definēšanu, kas palīdz mācīšanos labāk pārraudzīt (Looney, 2011³). Skolotājs nepārtraukti monitorē savu skolēnu progresu, izmantojot efektīvu jautāšanu, sarunas stundā, atsevišksu skolēnu intervēšanu un vērojumus, skolēnu pierakstus, piezīmes, skolēnu atbildes elektroniskā formā, rakstveida uzdevumu risinājumus un citas metodes. Pieejams plašs paṇēmienu klāsts, ko skolotāji var iekḷaut savā praksē (Black, \& Wiliam, 1998; Keeley, \& Tobey, 2011). Izvērtējot konkrētā paṇēmiena izmantošanu, jāṇem vērā, ka dažs no tiem fokusējas uz to, kā skolotājs var iegūt datus par skolēna mācīšanos, cits uz to, kā dot atgriezenisko saiti skolēnam, vēl citi paredz skolēnu savstarpēju vērtējumu, akcentē skolēna pašrefleksiju utt.

3 Looney, J. W. (2011). Integrating Formative and Summative Assessment: Progress Toward a Seamless Sustem? OECD Education Working Papers, No. 58. 
Formatīvā vērtēšana var būt vairāk vai mazāk formāla/neformāla. Tas atkarīgs gan no vērtēšanas procesā iegūto datu dabas un kvalitātes, gan no atgriezeniskās saites. Tā var būt īpaši plānota vai interaktīva, uz situāciju reageējoša (Shavelson Young, Ayala, Brandon, Furtak, Ruiz-Primo, \& Yin, 2008).

Detalizēti katru no formatīvās vērtēšanas paṇēmieniem raksturojuši pētnieki, vērtēšanas eksperti, piemēram, tūlītēju vērtēšanu brīdī, kad tas vajadzīgs (on the fly) (Ruiz-Primo, \& Furtak, 2006), skolotāja rakstiskus komentārus, pašnovērtējumu un savstarpējo vērtēšanu (Black, \& Harrison 2004).

Veicot formatīivo vērtěšanu, tāpat kā summatīvās vērtēšanas gadījumā jābūt skaidriem vērtēěanas kritērijiem, jo tas pilnībā nosaka, kādi skolēna snieguma aspekti tiks izvērtēti un kādus secinājumus izdarīsim. Snieguma kritēriju un to lìmen,u apraksti, mācišanās progresa apraksti ir tie instrumenti, kas skolotajam un pašiem skolēniem mācišanās procesā palīdz konstatēt esošo situāciju un plānot turpmākās darbības, lai uzlabotu sniegumu.

\section{Atgriezeniskās saites kvalitāte}

Formatīvās vērtēšanas būtiska daḷa ir atgriezeniskā saite, kas nosaka formatīiās vērtēšanas ietekmi uz mācǐšanos. Šì ietekme ir pozitīvi nozīmīga, ja atgriezeniskā saite dod noderīgu, izmantojamu informāciju, lai varētu mācī̌̌anos uzlabot.

Vērtēt, lai mācītos, nozīmē saprast, cik tālu skolēns ir ticis mācišanās procesā; saprast, kur jānokḷūst; izdomāt, kā tur nokḷūt. Tātad formatīvajai vērtēšanai jāsniedz atbildes uz jautājumiem: kas jāiemācās? kas izdodas, kas vēl ne? ko darīt turpmāk? (feed up, feed back, feed forward). Kā redzams, formatīvā vērtēšana nenotiek procesa beigās, faktiski tā sākas ar mērķu un snieguma kritēriju komunicēšanu (Wiliam, 2008; Hattie, \& Timperley, 2007; Nicol, \& Draper, 2008).

Lai uzlabotu turpmāko mācišsanos, atbildes nepieciešamas skolēnam par savu darbību un skolotajam - par viņa skolēniem. Svarīgi, lai atbildes uz šiem jautājumiem būtu pamatotas, datos un faktos balstītas. Citiem vārdiem sakot jāplāno, kā skolotājs un kā skolēni iegūs atbildes uz iepriekš minētajiem jautājumiem (skat. 1. tabulu). 
1. tabula. Jautājumu piemēri atgriezeniskās saites saṇemšanai un tās plānošanai

\begin{tabular}{ll}
\hline $\begin{array}{c}\text { Jautājumi, uz kuriem tiek saṇemtas } \\
\text { atbildes, ja notiek formatīvā vērtēšana }\end{array}$ & \multicolumn{1}{c}{$\begin{array}{c}\text { Jautājumi, kuri ir būtiski, plānojot } \\
\text { atgriezeniskās saites došanu }\end{array}$} \\
\hline Kas jāiemācās? & Kā skolotājs iegūst informāciju par to, kā veicas? \\
Kā veicas? & Kā skolēni uzzina, saprot, saṇem atbildes uz \\
Ko zinu, protu, cik labi? & jautājumiem par savu mācīšnos? \\
Ko vēl nezinu, neprotu? Kāpēc? & Kā tiek mācīta atgriezeniskās saites izmantošana? \\
Ko un kā darīt turpmāk? & Kā panākt skolēna iesaistǐšanos, jo atgriezeniskā \\
& saite ir mijiedarbīgs process. \\
\hline
\end{tabular}

Atgriezeniskā saite tiek īstenota starp abām mācību procesā iesaistītajām pusēm - skolotāju un skolēnu. Skolēns, kurš sapratis atgriezeniskās saites nozīmi, ir ieinteresēts, lai skolotājs iegūtu pēc iespējas precīzu informāciju par to, kā viņam veicas, kas izdodas un kas pagaidām ne (skolēns dod atgriezenisko saiti skolotājam). Skolotājs, saṇemot šo informāciju, plāno savu turpmāko darbību (kas un kā jāmāca), dod izmantojamu atgriezenisko saiti skolēnam par to, kas viņam jādara turpmāk un paredz iespēju skolēnam saṇemto atgriezeniskās saites informāciju tūlìt izmantot.

Atgriezeniskā saite izmantojama 4 dimensijās:

- uzdevuma dimensija - cik labi ir saprasts, izpildīts konkrētais uzdevums,

- procesa dimensija - kas ir nepieciešams, kas jādara, lai saprastu, izpildītu uzdevumu,

- pašregulācijas dimensija - kā skolēns var labāk sevi kontrolēt, virzìt un regulèt savu darbỉbu,

- personas dimensija - skolēna kā personas vērtējums (Hattie, \& Timperley, 2007).

Procesa un pašregulācijas dimensijas ir ḷoti būtiskas, domājot par mācīšanās uzlabošanu. Skolotāju praksē vērtējums bieži vien paliek uzdevuma līmenī, taču šāda informācija vairumam skolēnu nav pietiekama. Dodot skolēnam atgriezenisko saiti un ieteikumus par to, kā uzlabojams pats mācǐšanās process un ko skolēns var darīt, lai turpmāk pats varētu labāk vadìt savu mācišsanos, skolotājs ne tikai tieši palīdz skolēnam konkrētajā situācijā, bet arī dod iespēju veidot pieredzi par to, kam mācoties jāpievērš uzmanība. Tas var palīdzēt skolēnam prasìt un pieñemt viņam noderīgu atgriezenisko saiti un māca tādu dot citiem skolēniem. Savstarpējas vērtēšanas nosacijums: klasē ir pozitīva, uz mācišanos vērsta gaisotne, savstarpējas uzticēšanās attiecības starp skolēniem, kas arī kḷūst par vienu no skolotāja darbības virzieniem.

Dot un pieņemt atgriezenisko saiti ir jāmācās, un ir pieejami labi piemēri, kā skolotāji Latvijā to dara. 1. attēlā redzams, kā tas tiek mācīts sākumskolas 


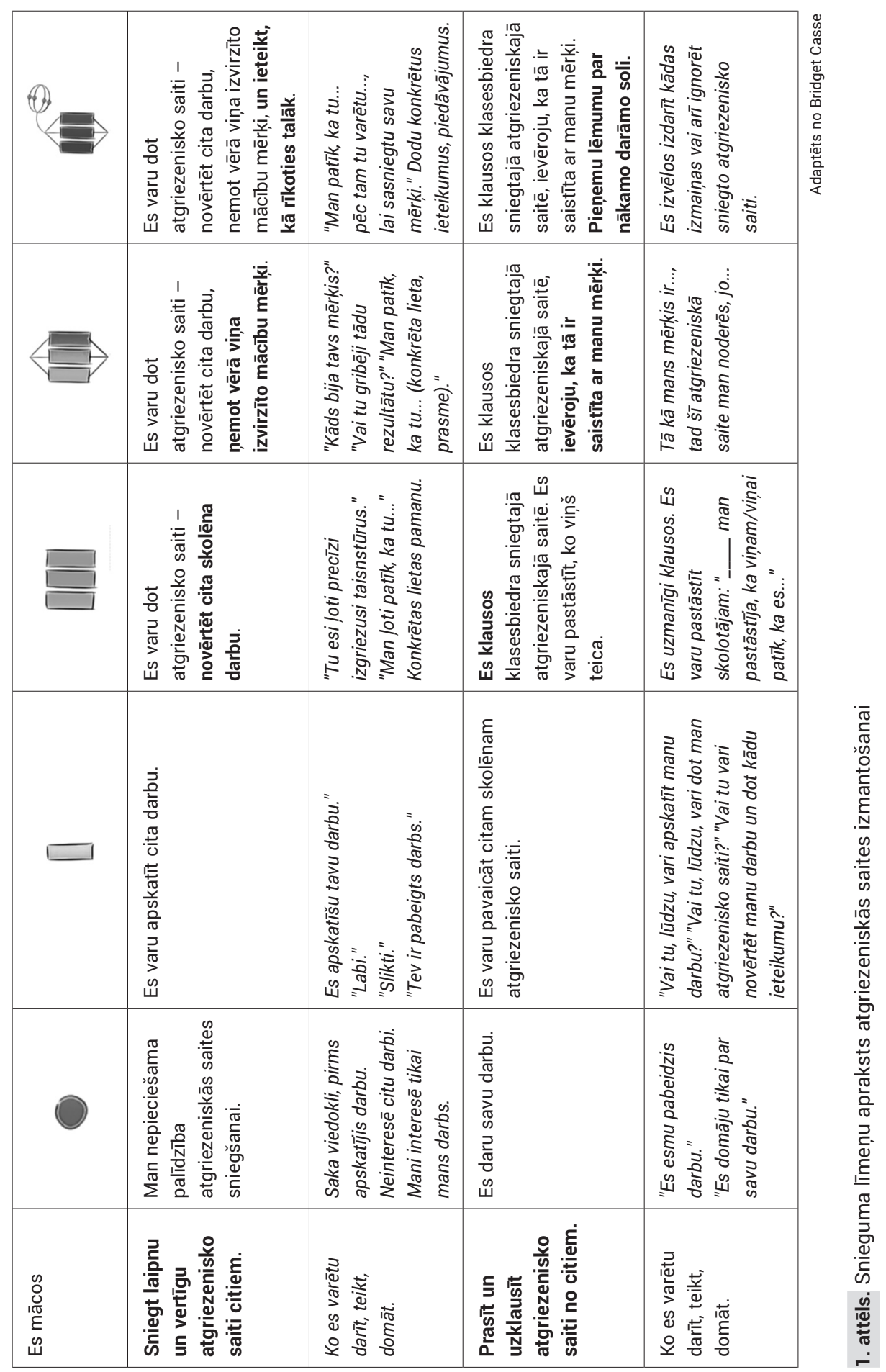


$\mathrm{X}$ skolēniem, izmantojot snieguma līmeṇu aprakstu (rubriku), kas adaptēta no Jaunzēlandes skolotājas Bridget Casse.

Viens no efektīvas atgriezeniskās saites nosacījumiem - tai jābūt maksimāli ātrai laikā. Šajā ziṇā papildu iespējas dod IT rīku izmantošana formatīvajā vērtēšanā. Tas ir būtiski, domājot arī par iespējami personalizētu atgriezenisko saiti klasē ar lielu skolēnu skaitu.

Runājot par formatīvās vērtēšanas ietekmi uz mācišanos, svarīgs aspekts ir atgriezeniskās saites izmantojamība (ne katra atgriezeniska saite ir noderīga skolēnam) un iespējas to tūlīt izmantot, lai sniegumu uzlabotu. Atgriezeniskās saites izmantojamību nosaka tas, vai skolēns saprot viņam dotās informācijas saturu, jēgu. Savukārt pat kvalitatīva atgriezeniskā saite pati par sevi nav efektīva, ja tai neseko skolēna darbība, kurā viņš iegūto informāciju izmanto, ja neturpinās mācǐšanās process (Halperna, 2014).

\section{Formatīvā vērtēšana un pašregulācija}

Skolēna prasme izmantot formatīvajā vērtēšanā iegūto informāciju ir cieši saistìta ar skolēna prasmi vadīt savu mācīšanos. Tieši noderīga atgriezeniskā saite un skolotāja veicināta atgriezeniskās saites izmantošana savas turpmākās darbības plānošanā, objektīvu mērḳu izvirzī̌sanā ir pašvadītas mācīšanās elementi.

Pašnovērtējums nenozīmē fiksēšanu, vai un cik pareizas atbildes ir bijušas, veicot uzdevumu. Skolēns vada savu mācišanos, ja viņš saista savu šì brīža sniegumu ar plānotajiem mācīšanās mērḳiem un atgriezenisko saiti ar to, kā tikt tuvāk mērḳim. Pirmais solis, ko skolotājs var veikt, ir dot skolēnam šādu pieredzi stundās - lai skolēns redz, kā skolotājs definē mācišsanās mērḳus un snieguma kritērijus, vērtē sniegumu atbilstoši šiem kritērijiem un palīdz konstatēt, kādas turpmākās darbības nepieciešamas, korigee plānus, formulē jaunus mērḳus.

Mēginot panākt objektīvāku snieguma vērtēšanu, vienlaikus arvien vairāk sava darba novērtēšanā tiek iesaistīti paši skolēni (Stiggins, Arter, Chappuis, \& Chappius, 2004). Prasmīgi izmantojot snieguma vērtēšanu, skolēniem ir iespēja skaidrāk saredzēt sava snieguma līmeņus un izprast kvalitatīva darba kritērijus. Faktiski viens no formatīvās vērtēšanas nolūkiem ir padarìt skolēnus par efektīviem pašnovērtētājiem, kuri spēj savā sniegumā saskatīt gan stiprās puses, gan trūkumus un plānot savu turpmāko darbību. Ir būtiski, lai skolēni praktizējas vērtēšanā, redzot gan kvalitatīva, gan mazāk kvalitatīva snieguma piemērus, izmanto gan dotus, gan paša izstrādātus snieguma kritērijus.

Savas mācī̌sanās vadīšanai noderīgi rìki ir snieguma līmeņu apraksti - rubrikas. Tiek norādīts, ka rubrikas palīdz skolēniem saprast pazīmes, kas raksturo labu darbu, dod skaidrību par mērḳi un snieguma kritērijiem. Tādējādi rubrikas 
palīdz skolotājiem mācìt, saskaņot māciššnu ar vērtēšanu un palīdz skolēniem mācīties. Skolēni saṇem rubriku temata sākumā, veic uzdevumus, saṇem atgriezenisko saiti atbilstoši kritērijiem, veic nākamo uzdevumu un turpina vingrināties, līdz noslēgumā saṇem vērtējumu (atzīmi), balstoties uz šo pašu rubriku. Šāda mācišanās ir daudz iedarbīgāka nekā uzdevumu sērija ar saistītiem, bet atšḳirīgiem kritērijiem (Brookhart, 2013).

Liels potenciāls mācību kvalitātes uzlabošanā ir mācišanās progresa aprakstiem - progresējoša snieguma rubrikām (learning progression), kurās līmeṇu apraksti nevis vienkārši diferencē vājāku vai pārliecinošāku sniegumu, bet gan raksturo tipisku secību, kādā konkrētā prasme attīstās (skat. 1. attēlu). Šādas rubrikas varētu būt īpaši noderīgas gan skolēniem, gan skolotājiem, lai viṇi precīzāk varētu noteikt, kur viṇi "atrodas" ceḷā uz mērḳi un kāds atbalsts viņiem nepieciešams. Šādas rubrikas palīdzētu pievērst uzmanību arī domāšanas modeliem par attiecīgo jautājumu, ne tikai gatavām atbildēm. Formatīvajā vērtēšanā izmantojami dažādi paņēmieni un instrumenti. Tie, kas atsedz, palīdz saprast domāšanu, skolēnam varētu dot ìpaši lielu labumu.

\section{Formatīvā vērtēšana un skolotāja prasmes un uzskati}

Ar ESF atbalstu Valsts izglîtības satura centra îstenotajos projektos "Mācību satura izstrāde un skolotāju tālākizglīîiba dabaszinātṇu, matemātikas un tehnologiju priekšmetos" un "Dabaszinātnes un matemātika" vēroto stundu dati saistībā ar formatīvo vērtěšanu uzrāda pozitīvas tendences: vērtēšana notiek daudzveidīgi, skolēniem tiek skaidroti mācīšanās mērḳi un snieguma kritēriji, vērojama efektīva sadarbība, vērtējums tiek izmantots turpmākās mācišanās plānošanā, tiek attīstītas skolēnu pašnovērtēšanas prasmes. Tajā pašā laikā ir daudz nepilnību, veicot formatīvo vērtēšanu: stundās redzama formatīiās vērtēšanas būtības neizpratne, neskaidri stundas mērḳi, pilnvērtīga mācību dialoga trūkums, vērtējot akcents tiek likts uz reproduktīva līmeņa prasmju vērtēšanu, tiek izdarīti nepārliecinoši secinājumi.

Latvijas Universitātes Starpnozaru izglìtības inovācijas centra (LU SIIC) veiktie stundu vērojumi rāda atsevišķas veiksmīgas aktivitātes mācību stundās, kad skolotāji māca skolēnus dot un pieṇemt atgriezenisko saiti par mācīšanos. Piemēram, epizode no matemātikas stundā 10. klasei skolā A, kur skolēni veica pētỉjumu par šaurā leṇķa trigonometrisko funkciju vērtỉbu saskatāmību vienības riṇ̂īi.

Skolotāja: "Iedošu instrumentu, kas var palīdzēt katram saprast, kur viņš ir cel̦ā uz labu problēmrisinātāju. Lūdzu, iezīmējiet katrs vietu, kur tu domā, ka esi šobrīd. Un uzrakstiet apakšà - kāpēc tu domā, ka tu tur esi, kā tu to zini. Tas 
paliks pie jums. Šajā rubrikā jūs varat arī redzēt, kā tikt tālāk uz nākamo soli.” Skolēni saṇem rubriku:

2. tabula. Progresējoša snieguma līmen,u apraksts problēmas risināšanai

\begin{tabular}{|c|c|c|c|c|}
\hline$\rightarrow$ & $\rightarrow$ & $\rightarrow$ & $\rightarrow$ & $\rightarrow$ \\
\hline $\begin{array}{c}\text { Atrisinu } \\
\text { problēmu, } \\
\text { izmantojot } \\
\text { dotu plānu, } \\
\text { bet neprotu } \\
\text { pārliecināties, } \\
\text { vai risinājums ir } \\
\text { derīgs. }\end{array}$ & $\begin{array}{c}\text { Atrisinu } \\
\text { problēmu, } \\
\text { izmantojot dotu } \\
\text { plānu, protu } \\
\text { pārliecināties, } \\
\text { vai risinājums ir } \\
\text { derīgs. }\end{array}$ & $\begin{array}{c}\text { Atrisinu problēmu } \\
\text { pats, bet neprotu } \\
\text { pārliecināties, } \\
\text { vai risinājums ir } \\
\text { derīgs. }\end{array}$ & $\begin{array}{c}\text { Atrisinu } \\
\text { problēmu } \\
\text { pats un protu } \\
\text { pārliecināties, } \\
\text { vai risinājums ir } \\
\text { derīgs. }\end{array}$ & $\begin{array}{c}\text { Atrisinu problēmu } \\
\text { pats, varu to } \\
\text { izdarīt vairākos } \\
\text { veidos un protu } \\
\text { pārliecināties, } \\
\text { vai risinājumi ir } \\
\text { derīgi. }\end{array}$ \\
\hline
\end{tabular}

LU SIIC veiktajos pētījumos (France, Namsone, \& Čakāne, 2015), vērojot mācību stundas 10 skolās laika periodā no 2013. līdz 2015. gadam (kopumā iegūstot un analizējot datus par 368 stundām 1.-12. klašu dažādos mācību priekšmetos), analizēta arī formatīvas vērtēšanās izmantošana stundās. Dati rāda, ka tikai $49 \%$ visu pētījumā vēroto stundu skolēniem stundā ir skaidrs plānotais sasniedzamais rezultāts, 54\% gadījumu skolotājs konstatē stundā sasniegto. Vērojama tendence skolotājam konstatēt, vai stundā sasniegts plānotais rezultāts, bet tas nepietiekami tiek izmantots tūlītējai atgriezeniskās saites došanai skolēniem. Stundās pēc konkrētu uzdevumu veikšanas skolēniem ir iespēja pārliecināties, vai viṇu iegūtās atbildes ir pareizas, bet viṇi nesaṇem skolotāja konstruktīvus ieteikumus par to, kas un kā būtu jādara, lai mācīšanās rezultāts būtu labāks. Stundas beigās veiktais pašnovērtējums bieži ir vairāk emocionālā līmenī, trūkst skaidru kritēriju, lai pārliecinātos par rezultāta un mācīšanās procesa kvalitāti.

Arī citur pasaulē profesionāli īstenota formatīvā vērtēšana nebūt vēl nav ikviena skolotāja ikdienas prakse. Analizējot šḳēršlus formatīvas vērtēšanas ìstenošanā, pētnieki uzsver, ka traucē skolotāju dziļie pedagoǵiskie uzskati par vērtēšanu kā skolotāja rīku un atbildību, nevis kā par iespēju iesaistīt skolēnus, veidojot konstruktīvu vērtējošu vidi (Bernholt et al., 2013). Viṇi atsaucas uz American Association for the Advancement of Science, ka vērtēšana lielākās daḷas skolotāju un skolēnu prātos tiek nošķirta no mācīšanās. Skolotāji nav droši par to, ka sabiedrība kopumā šādu vērtēšanu akceptē, un viņiem ir nepieciešams atbalsts, lai mainītu savus priekšstatus par skolotāja lomu. Projekta ASSISTME $^{4}$ pieredze kā šḳēršlıus formatīvās vērtēšanas īstenošanā uzrāda lielas

4 Assess Inquiry in Science, Technology and Mathematics Education, 8 dalibvalstu kopprojekts, FP7 atbalsts. 
klases, skolotāju grūtības, sastopot atšķirīgus skolēnus, viņu dažādās vajadzības, bažas, ka formatīva vērtēšana ir resursu un laika ietilpīga, nepietiekamā saskaņotība starp vērtēšanu klases, skolas un valsts līmenī, dažādie izglitības politikas veidotāju un skolu vadìtāju uzskati. Līdzīgi arī Latvijā - starp problēmām, kas ietekmē vērtēšanu, atzīmējama skolēna, skolotāja, skolas, vecāku dažādā izpratne un ar to saistìtās vajadzības. Skolu izstrādātajos Vērtēšanas nolikumos (kārtībās) akcentēti formālie rādītāji, stingri reglamentēts nepieciešamais vērtējumu skaits ballēs, arī valsts līmeņa dokumentos akcentēta summatīvā vērtēšana.

Par vērtēšanu tiek runāts kā par atseviškiem paņēmieniem, tehnikām, procedūrām nošķirti no citām mācǐšanas un mācǐšanās aktivitātēm (Coffey, Hammer, Levin, \& Grant (2011). Formatīvā vērtēšana pārāk maz tiek iestrādāta mācību programmās. Būtiska ir ciešāka sasaiste starp pētniekiem, politikiem, vērtēšanas ekspertiem un skolotājiem, kā arī starp pašiem skolotājiem (Shavelson et al., 2008).

Attiecībā uz skolotājam nepieciešamajām prasmēm, lai īstenotu efektīvu formatīvo vērtēšanu, specifiska ir prasme diagnosticēt (Turner, 2014). Savukārt saistībā ar formatīvo vērtēšanu jādomā nevis par to, kā skolotājam apgūt jaunas zināšanas, bet gan par ieradumu mainu (William, 2006). 2008. gada OECD $\mathrm{CERI}^{5}$ 40. gadadienas konferencē prezentācijā, runājot par vērtēšanas, lai mācìtos ieviešanas problēmām, Viljams uzsver: "Skolotāji lielāko dạ̧u no tā jau zina problēma nav zināšanu trūkums. Tas ir izpratnes trūkums par to, ko nozīmē vērtēšana, lai mācītos - tāpēc stāstīšana skolotājam, ko darìt, nestrādā." ${ }^{\prime 0}$ Šie pirms vairāk nekā 10 gadiem izteiktie secinājumi Latvijas kontekstā ir aktuāli joprojām. Jēgpilnai formatīvajai vērtēšanai nepieciešama dziḷa izpratne, pieredze un pārliecība, jo formatīvā vērtěšana nav ikdienas prakse Latvijas vidusskolās, kā savā promocijas darbā secina Anžela Jurāne-Brēmane (2018).

Vērtēšanu skolotāju praksē ietekmē skolotāju uzskati, kurus Amerikas matemātikas skolotāju padome ${ }^{6}$ piedāvā pretstatīt kā neproduktīvus un produktīvus, uzsverot, ka tie nav labi vai slikti. Produktīvi uzskati atbalsta efektīvu mācišsanu un mācǐšanos, neproduktīvi ierobežo skolēnu būtiskas praktizēšanas iespējas (skat. 3. tabulu).

5 OECD CERI. (2008). 21st Century Learning: Research, Innovation and Policy. Directions from recent OECD analyses. OECD Center for Educational Research and Innovation. Pieejams: http:// www.oecd.org/site/educeri21st/40554299.pdf (aplūkots 20.10.2017.).

6 National council of teachers of mathematics. Principlesto Actions. Ensuring MathematicalSuccess for ALL (2017). Pieejams: https://www.nctm.org/uploadedFiles/Standards_and_Positions/PtA ExecutiveSummary.pdf (aplūkots 14.02.2018.). 
3. tabula. Skolotāju uzskati par vērtēšanu

\begin{tabular}{|c|c|}
\hline Neproduktīvi uzskati & Produktīvi uzskati \\
\hline $\begin{array}{l}\text { Vērtēšana primāri ir atbildība informēt } \\
\text { skolēnus par atzīmēm. }\end{array}$ & $\begin{array}{l}\text { Vērtēšanas primārais mērḳis ir informēt par } \\
\text { mācīšanos, uzlabot mācīšanu un mācǐšanos. }\end{array}$ \\
\hline $\begin{array}{l}\text { Vērtēšana notiek, mācīšanās procesu } \\
\text { pārtraucot. }\end{array}$ & $\begin{array}{l}\text { Vērtēšana ir nepārtraukts process, kas ir } \\
\text { iestrādāts mācīšanā, lai atbalstītu skolēnu } \\
\text { mācīšanos un veiktu korekcijas mācǐšanā. }\end{array}$ \\
\hline $\begin{array}{l}\text { Tikai testi un citi “objektīvi” rakstiski } \\
\text { pārbaudes darbi mēra matemātikas } \\
\text { zināšanas droši un precīzi. }\end{array}$ & $\begin{array}{l}\text { Matemātiskā izpratne un process var } \\
\text { tikt mērīts, lietojot dažādus vērtēšanas } \\
\text { paṇēmienus un uzdevumus. }\end{array}$ \\
\hline $\begin{array}{l}\text { Atsevišḳs vērtējums var tikt izmantots, lai } \\
\text { pieṇemtu svarīgus lēmumus par skolēniem } \\
\text { un skolotājiem. }\end{array}$ & $\begin{array}{l}\text { Nepieciešami daudzveidīgi datu avoti, lai } \\
\text { veidotu precīzu ainu par skolēnu un skolotāju } \\
\text { sniegumu. }\end{array}$ \\
\hline Vērtējums informē skolēnus. & $\begin{array}{l}\text { Vērtēšana ir process, kam jāpalīdz, lai skolēni } \\
\text { kḷūtu labāki sava darba vērtētāji, kas palīdz } \\
\text { saskatīt augstas kvalitātes darbu, kas sniedz } \\
\text { atbalstu, izmantojot iegūtos pierādījumus, lai } \\
\text { uzlabotu savu mācīšanos. }\end{array}$ \\
\hline $\begin{array}{l}\text { Mācīšanas pārtraukšana, lai pārbaudītu, } \\
\text { veiktu testus, uzlabo skolēnu sniegumu } \\
\text { augstas likmes pārbaudījumos. }\end{array}$ & $\begin{array}{l}\text { Nepārtraukta pārskatīšana, praktizēšanās } \\
\text { iekḷaušana efektīvā mācību procesā ir } \\
\text { produktīva stratēǵija, kā sagatavoties } \\
\text { pārbaudījumiem. }\end{array}$ \\
\hline
\end{tabular}

Arī Latvijas pieredze rāda, ka efektīvas formatīvās vērtēšanas iedzīvināšana saistās ar skolotāja personību. Tiek aicināts skatît vērtējošās darbības autoritārās un humānās pedagog̣ijas kontekstā. Formatīvā vērtēšanā ir humānās izglìtības paradigmas elements, to nekad pilnvērtīgi neizmantos autoritārs skolotājs. Aktuāla ir neuzticēšanās skolēnam kā godprātīgam un ieinteresētam pēc iespējas labāk mācīties (Hahele, 2006).

Viens no iemesliem, kāpēc formatīvā vērtēšana nav ierasta skolotāja ikdienas prakse un tā netiek atbilstošā veidā īstenota, ir tas, ka skolotājam pašam nav personīgas pieredzes, kā laba atgriezeniskā saite palīdz uzlabot sniegumu - viņš nav izjutis formatīvās vērtēšanas, noderīgas atgriezeniskās saites pozitīvo ietekmi gan tad, kad pats mācỉjās kā skolēns, gan attiecībā uz sevi kā darbinieku. Arī skolotājam nepieciešama profesionāla, izmantojama atgriezeniskā saite.

7 National council of teachers of mathematics. Principles to Actions. Ensuring Mathematical Successfor ALL (2017).Pieejams:https://www.nctm.org/uploadedFiles/Standards_and_Positions/ PtAExecutiveSummary.pdf (aplūkots 14.02.2018.). 


\section{Secinājumi}

Lìdz šim valsts līmeņa izglîtîbu reglamentējošos dokumentos nav nostiprināta formatīvās vērtēšanas nozīme. Izglìīibas standartos nepieciešams skaidri parādīt formatīvās vērtēšanas vietu un lomu mācību procesā, uzsverot tās nozīmīgumu gan konkrētā satura mācǐšanas aspektā, īstenojot mācǐšanos iedziḷinoties, gan kā būtisku pašvadītas mācišanās elementu.

Formatīiās vērtēšanas efektivitāte atkarīga no skolotāju prasmēm. Nepieciešams pilnveidot skolotāju izpratni par formatīvo vērtēšanu, prasmi izmantot dažādus vērtēšanas instrumentus, izmantot iegūtos datus, lai veiktu uzlabojumus gan mācišanā stundas līmenī, gan nodrošinot, ka skolēni saṇem noderīgu atgriezenisko saiti un uzlabo savu mācīšanos, mācās to vadīt.

Jāizplata labās prakses piemēri, nepieciešams sekmēt skolotāju profesionālu sadarbību, ieviešot un pārbaudot formatīiās vērtēšanas paṇēmienus, veicot savas darbības izpēti, lai iegūtu pierādījumus, kas apliecina vērtēšanas efektivitāti.

Jāturpina pētījumi par formatīvās vērtēšanas īstenošanu mācību procesā un tās ietekmi uz skolēnu sniegumu un motivāciju, lai skolu prakse vairāk balstītos pētījumu datos un būtu lielāka pārliecība par pieejas efektivitāti.

\section{IZMANTOTĀ LITERATŪRA}

Bernholt, S., Ronnebeck, S., Ropohl, M., Koller, O., \& Parchmann, I. (2013). ASSIST ME. Report on current state of the art in formative and summative assessment in IBE in STM. ASSIST-ME Report Series Number 1-2.

Black P., Broadfoot, P., Daugherty, R., Gardner J., Harlen, W., James, M., Stobart, G., \& Wiliam, D. (2002). Testing, Motivation and Learning. Nuffield Foundation and University of Cambridge.

Black P., \& William, D. (2009). Developing the theory of formative assessment. Educational Assesment, Evaluation and Accountabillity, 21(1), p. 53.

Black, P. (2004). The Nature and Value of Formative Assessment for Learning. London.

Black, P., \& Harrison, C. (2004). Science Inside the Black Box. London: NferNelson.

Black, P., \& Wiliam, D. (1998a). Inside the black box: Raising standards through classroom assessment. Phi Delta Kappan, 80(2), pp. 139-148.

Black, P., \& Wiliam, D. (1998b). Assessment and Classroom Learning. A review of 25 years of World Wide Research on Formative Assessment. London.

Brookhart, S. M. (2013). How to Create and Use Rubrics for Formative Assessment and Grading, Chapter 1. Pieejams: http://www.ascd.org/publications/books/112001/chapters/ What-Are-Rubrics-and-Why-Are-They-Important\%C2\%A2.aspx (aplūkots 14.02.2018.).

Brownlie, F., Feniak, C., \& Schnellert, L. (2006). Student Diversity (2 ${ }^{\text {nd }}$ ed.) Markham, ON: Pembroke Publishers.

Coffey, J. E., Hammer, D., Levin, D. M., \& Grant, T. (2011). The missing disciplinary substance of formative assessment. Journal of research in science teaching 48(10), pp. 1109-1136. 
De Corte, E. (2004). High-powered learning communities: a european perspective. CIP\&T, University of Leuven, Belgium.Council's Research Programme on Teaching and Learning, Leicester, England, November 9-10.

France, I., Namsone, D., \& Cakane, L. (2015). What Research Shows about Mathematics Teachers' Learning Needs: Experience from Latvia. In SOCIETY, INTEGRATION, EDUCATION (Vol. 2, pp. 45-55). http://dx.doi.org/10.17770/sie2015vol2.457

Hahele, R. (2006). Pašnovērtējums mācību procesā. Rīga: RaKa.

Halpern, D. F. (2014). Thought and Knowledge: An Introduction to Critical Thinking (5 $5^{\text {th }}$ ed). NY: Psychology Press.

Harlen, W. (2013). Assessment and inquiry-based science education: issues in policy and practice. Global Network od Science Academies (IAP) Science Education Programme (SEP).

Hattie, J., \& Timperley, H. (2007). The Power of Feedback. Review of Educational Research, 77(1), pp. 81-112.

Hodgen, J., \& Wiliam, D. (2006). Mathematics inside the Black Box. Assessment for learning in the mathematics classroom. Department of Education \& Professional Studies King's College London. NferNelson.

Jurāne-Brēmane, A. (2018). Formatīvā vērtēšana studiju procesā. Promocijas darbs doktora zinātniskā grāda iegūšanai pedagoǵijā. Latvijas Universitāte.

Kaftan, J. M., Buck, \& G. A., Haack, A. (2006). Using Formative Assessments to Instruction and Promote Learning. Middle School Journal. National Middle School Individualize Association.

Keeley, P., \& Tobey, C. R. (2011). Mathematics Formative Assessment. 75 Practical Strategies for Linking Assessment, Instruction and Learning. - NCTM, Corwin.

Nicol, D., \& Draper, S. (2008). Redesigning written feedback to students when class sizes are large. Paper presented at the Improving University Teachers Conference, Glasgow, UK.

Pollard, A., Anderson, J., Maddock, M., Swaffield, S., Warin, J., \& Warwick, P. (2008). Reflective teaching: evidence-informed professional practice. ( $3^{\text {rd }}$ ed.) London: Continuum International Publishing Group.

Reece, I., \& Walker, S. (2007). Teaching, training \& learning. A.practical guide. 6 Rev Ed. Business Education Publishers Ltd (United Kingdom).

Ruiz-Primo, M. A., \& Furtak, E. M. (2006). Informal formative assessment and scientific inquiry: Exploring teachers' practices and student learning. Educational Assessment, 11(3-4), pp. 237-263.

Scriven, M. (1967). The methodology of evaluation. In Perspectives on curriculum evaluation, ed. R. Tyler, R. Gagne, and M. Scriven. AERA monograph series - curriculum evaluation Chicago: Rand McNally.

Shavelson, R. J., Young, D. B., Ayala, C. C., Brandon, P. R., Furtak, E. M., Ruiz-Primo, M. A., \& Yin, Y. (2008). On the impact of curriculum-embedded formative assessment on learning: A collaboration between curriculum and assessment developers. Applied Measurement in Education, 21(4), pp. 295-314.

Stiggins, R. J., Arter, J. A., Chappuis, J. \& Chappius, S. (2004). Classroom assessment for student learning: Doing it right - using it well. Portland, Oregon: Assessment Training Institute.

Turner, S. L. (2014). Creating an assessment-centered classroom: Five essential assessment strategies to support middle grades student learning and achievement. Middle School Journal, 45(5), pp. 3-16. 
Wiggins, G., \& McTighe, J. (2006). Understanding by Design. $2^{\text {nd }}$ ed. Association for Supervision and Curriculum Development: Alexandria, VA.

William, D. (2006). Assessment: learning communities can use it to engineer a bridge connecting teaching and learning. Journal of Staff Development, 27(1), pp. 16-20.

William, D., \& Thompson, M. (2007). Integrating assessment with instruction: what will it take to make it work? In Dwyer, C. A. (ed.). The future of assessment: shaping teaching and learning (pp. 53-82). Mahwah, NJ: Lawrence Erlbaum Associates. 


\title{
6. nodala
}

\section{Skolotājam nepieciešamās kompetences}

\author{
Dace Namsone, Jeḷena Volkinšteine, Gunta Lāce
}

Skolotāja profesionālo kompetenci veido zināšanas, prasmes un uzskati, kas rezultējas darbībā. No vienas puses, skolotāja kompetenci veido spējas, specifiskās zināšanas un prasmes, no otras - skolotāja personības zīmes pārliecỉba, vērtības, motivācija. Skolotāja kompetence izpaužas viņa darbībā. Skolotāja darbība ietekmē skolēnu darbību, kas savukārt ir viṇu topošās kompetences pamatā.

Lai vadītu mācǐšanos iedziḷinoties, aktualitāti iegūst skolēnu mācǐšanās vadīšana, skolotāju refleksijas un pašanalīzes prasmes, kā arī sadarbība.

\section{Kas veido skolotāja profesionālās kompetences struktūru}

Šobrīd pasaulē diskusija par skolotāju profesionālo kompetenci - tās dimensijām un struktūru - norit pa dažādiem ceḷiem, kuri gandrīz nesaskaras. Tāpēc, protams, dažādi ir arī rezultāti un secinājumi par to, kādam jābūt ideālam skolotājam un kādai jābūt skolotāju izglìtîbai.

Ir autori, piemēram Ulriks Overmans (Ulrich Oevermann) un Verners Helspers (Werner Helsper), kuri skolotāja darbību cenšas strukturēt kā kvaziterapeitisku: skolotājs kā "ārsts", kurš ir blakus skolēna augšanas grūtỉbās un vada viņu no vienas nelielas attīstības krīzes pie nākamās (Baumert, \& Kunter, 2006). Šì pieeja nepietiekami uztver skolotāja profesiju kā tādu, kuru var apgūt un iemācīties. Tà vairāk atbilst mītam, ka "par skolotāju jāpiedzimst". Jāṇem vērā, ka mācỉbas ir valstiski noteiktas gan saturiski, gan organizatoriski. Izglitiibas standarts un skola kā institūcija, kurā mācības notiek, "uzliek rāmjus" skolotāja profesionālajai darbībai un definē pamatstruktūru skolotāja un skolēna attiecībām. Šìs attiecības ir specifiski mācību priekšmetā orientētas, tāpēc tām noteikti nav tikai 
psihoterapeitiska daba. Tiek atzīts, ka šajās teorijās ir ḷoti daudz pretrunu (Baumert, \& Kunter, 2006), tāpēc tās sīkāk neaplūkosim.

Ir autori, kuri, ietekmējoties no savstarpējām diskusijām, meklē skolotāja profesijas standartu, t. i., tādu skolotājam piemìtošo kompetenču komplektu, kas l̦auj nodrošināt skolēna mācišanos atbilstoši izglîtības standartu prasībām. Šie autori pievērš uzmanību tam, kā uzlabot skolotāju izglītību, jo skolotāja profesijas standarts apraksta, kādas kompetences jāattīsta topošajiem skolotājiem. Viṇi ir izveidojuši dažādus kompetences modeḷus, kuru spektrs variē no standartiem, kuros primārais ir mācāmais saturs (Terhart, 2000, 2002), līdz standartiem, kuros galvenās ir pedagogiskās un psiholog̣iskās kompetences (Ozers, 2001).

Džese Vilkinsa (Jesse Wilkins) (Wilkins, 2008) modelis apstiprina domu, ka skolotāju profesionālā kompetence, kas izpaužas mācǐšanas praksē, summējas gan no skolotāju daudzveidīgajām zināšanām un prasmēm, kas ir kompetences kodols, gan no viņu attieksmes un uzskatiem par mācỉbu procesu (skat. 1. attēlu). Būtiski ir saskatìt, kā tas aplūko mācišanas praksi. Tas sakrìt ar Jana van Driela (Jan van Driel) atziṇu par skolotāja praktisko jeb darbības prakses laikā iegūto zināšanu lomu. Praktiskās teorijas, kas virza skolotājus un mācǐšanu, ir balstītas praktiskās zināšanās. Skolotāju praktiskās zināšanas ir pašu skolotāju konstruētas viṇu darbību kontekstā, kurā tiek integrētas eksperimentālās un formālās zināšanas un personīgie uzskati (van Driel, Beijaard, \& Verloop, 2001).

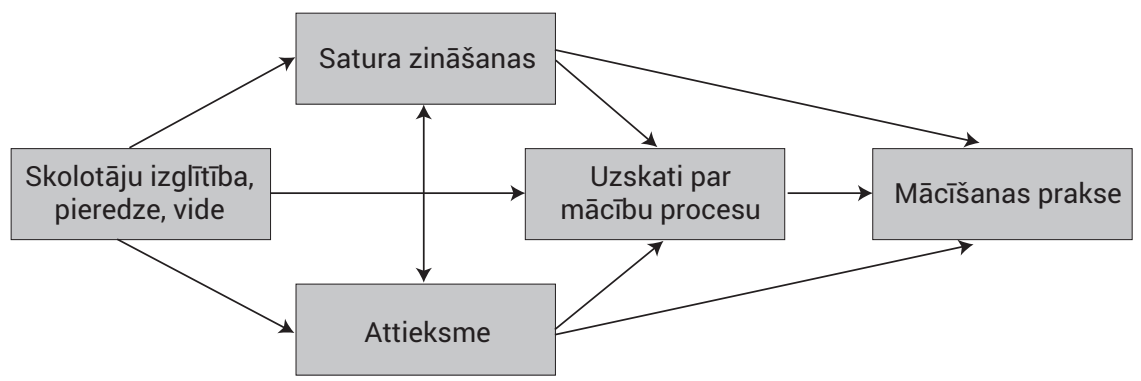

1. attēls. Teorētiskais modelis (adaptēts pēc Wilkins, 2008)

Ir radīti modeḷi, kas ietver mācīšanās teoriju par skolēnu zināšanām un prasmēm, par izglìtības mērķiem un vīzijām, priekšmeta zināšanām, par vērtēšanu un klasvadibu u. c. (Reynolds, 1989; Murray, 1996; Darling-Hammond, \& Bransford, 2005).

Ir vienprātība, ka zināšanas un prasmes ir kompetences daļa, bet atšķiras pētnieku viedokḷi, kuras zināšanas un prasmes to veido. Aplūkojot dažādus literatūrā sastopamus skolotāja kompetenču modelıus, jāṇem vērā, ka, laikam ejot, attīstās pētnieciskā doma un konkrētu terminu lietojums. Pašreizējā izpratnē uz 
terminu "zināšanas" lietojumu, aprakstot skolotāju kompetences, vajadzētu raudzìties tā plašākā izpratnē.

Lì Šulmans (Lee Shulman) (Shulman, 1987) izdala mācìbu satura zināšanas (content knowlwdge), pedagogijas zināšanas (general pedagogical knowledge) un zināšanas par to, kā šo saturu iemācìt otram (pedagogical content knowledge, $P C K)$. Aplūkojot detalizēti, redzams, ka Šulmans uzskata: lai mācītu priekšmetu, skolotājam nepieciešamas vispārīgās pedagogíiskās zināšanas ar īpašu atsauci uz mācību procesa vadības un organizācijas pamatprincipiem un mācību priekšmetam raksturīgiem pañēmieniem, zināšanas par skolēniem un viṇu īpatnībām, zināšanas par izglīīibas kontekstu, sākot ar darbu grupā vai klasē, zināšanas par izglītības mērḳiem un vērtībām, satura zināšanas, mācību satura (curriculum, programmas) zināšanas, īpaši par materiāliem, kas kalpotu kā skolotāju "instrumenti”, zināšanas par to, kā saturu otram iemācīt (PCK). Šīs zināšanas Šulmans sauc par amalgamu, kas sakausē mācību satura zināšanas ar pedagoğiskajām zināšanām. Tieši šĩs zināšanas atškịir fizikas skolotāju no fizikas eksperta un fizikas skolotāju no sociālo zinību skolotāja.

Šo zināšanu nozīmīgumu uzsver arī citi autori (Magnusson, Krajcik, \& Borko, 1999); Loughran, et al., 2001; Shallcross et al., 2002; skat. Park, \& Oliver, 2008; Schneider, \& Plasman, 2011; Van Driel, \& Berry, 2012, p. 26). Pamela Grosmane (Pamela Grossman) piedāvā modeli, kurā L. Šulmana konceptam pievieno zināšanas par kontekstu un aplūko tās mijiedarbībā (Grossman, 1990).

Šajā klasifikācijā balstās arī Rainers Bromme (Rainer Bromme) (1992, 1997), Jurgens Baumerts (Jürgen Baumert) un Mareike Kuntere (Mareike Kunter) (2006). Savā pētījumā par topošo matemātikas skolotāju kompetenci vēl izškirtas zināšanas par mācāmā priekšmeta standartu un programmu uzbūves logiiku, kā arī izpratni par mācāmā priekšmeta filozofiju (Blömeke, Kaiser, \& Lehmann, 2008). R. Bromme īpaši pētijis mācību priekšmeta satura zināšanas, jo paši elegantākie mācǐšanas/mācǐšanās scenāriji neko nedos, ja skolotājiem trūks priekšmeta zināšanu. R. Bromme argumentē: kaut arī nav tiešas sakarības starp skolotāja priekšmeta zināšanām un klases mācību sasniegumiem, jo skolotāji savu zināšanu trūkumu var dažādi kompensēt, tomēr zināšanu trūkums netieši ietekmē mācību procesa vadī̌sanu. Taču nepietiek tikai ar to, ka skolotājs pārvalda priekšmeta saturu, ja tajā pašā laikā detaḷās nezina, kā šo saturu mācìt dažādu vecumu skolēniem, dažādu spēju skolēniem un skolēniem ar dažādām priekšzināšanām.

Pētnieku ilggadējās diskusijās ir radīts Konsensus dabaszinātṇu skolotāju PCK (zināšanu par to, kā saturu iemācīt otram) modelis (skat. 2. attēlu). Tas parāda saikni starp skolotājam nepieciešamajiem zināšanu pamatiem, praksē iegūtajām zināšanām un praksi saistībā ar skolēnu rezultātiem. 


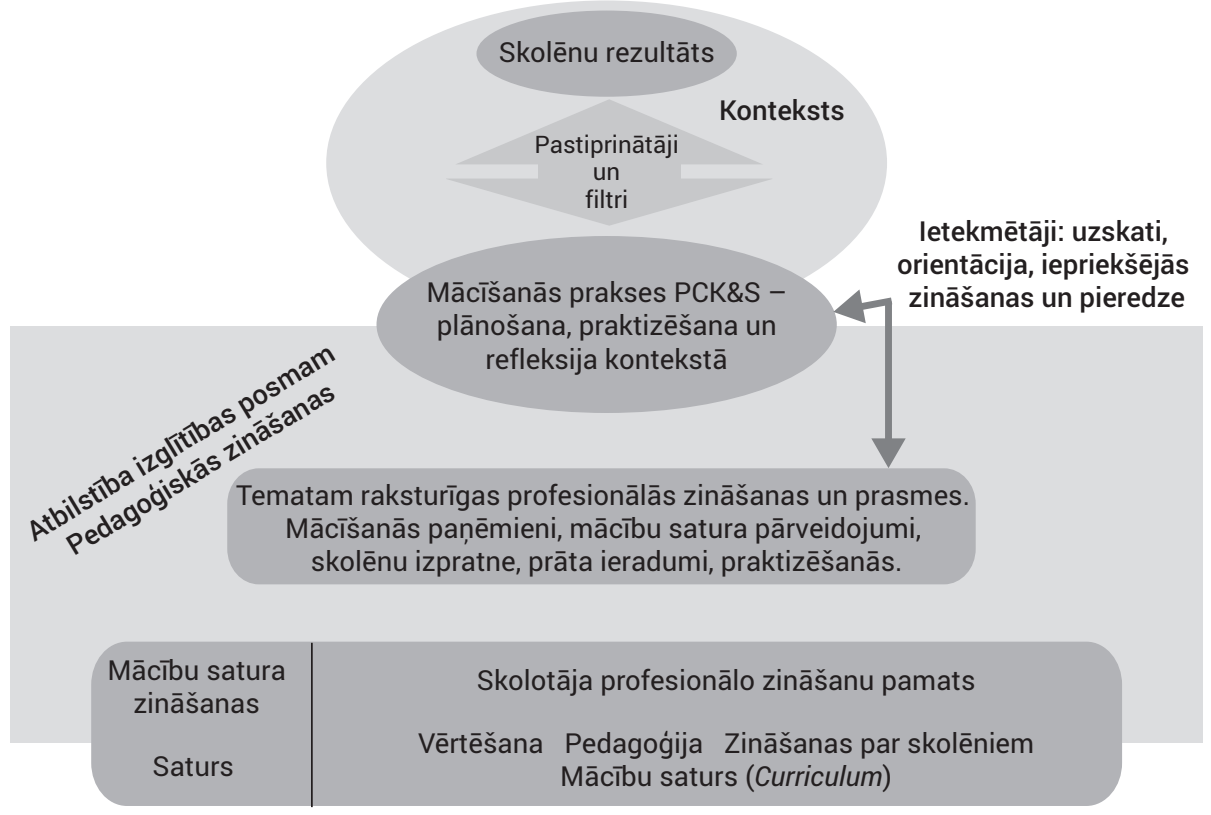

2. attēls. Konsensus modelis dabaszinātṇu skolotāju PCK (adaptēts pēc Berry, Nilsson, Van Driel, \& Carlson, 2017)

Pētījumi aplūko arī skolotāju uzskatu, motivācijas un citu līdzīgu faktoru ietekmi. Daudzi pētnieki raksta par uzskatiem kā par kritisku faktoru pārmain̄ām. Piemēram, Sallija Hovarda (Sally Howard) citē Donnu Kaganu (Dona Kagan), ka skolotāju uzskati (beliefs) ir noklusēti un nereti zemapziṇā mìtoši uzskati par skolēniem, mācišanos, mācību darbu klasē un mācību saturu, kuru viṇi māca. Skolotāja mācīšanas stilu ir ietekmējuši viņu uzskati. Tomēr ne vienmēr var veikt secinājumus par skolotāja pārliecību, novērojot viṇa uzvedību (behaviour), jo skolotāji var arī veikt tādas darbības mācību stundā, kas neatspoguḷo viṇu uzskatus par mācišanos. Skolotāji nereti neapzinās paši savus uzskatus par viņu amatu, vai arī viņiem trūkst valodas, lai to aprakstìtu (Kagan, 1992). Tiek uzskatìts, ka skolotāja profesionālo kompetenci būtiski ietekmē viṇa subjektīvās teorijas un pārliecība par savu mācību priekšmetu un to, kā skolēni to apgūst (Keiser, \& Vollstedt, 2007; Helmke, 2009). Subjektīvās teorijas ir būvētas un strukturētas līdzīgi kā zinātniskās teorijas, tomēr tām trūkst rūpīga izvērtējuma. Tās balstìtas lielākoties vien̄igi personiskajā pieredzē, t. i., tās skaidro skolotāja mācīšanas un mācīšanās pieredzi. Subjektīvās teorijas ietekmē skolotāja darbību vairāk nekā zinātniskās teorijas. Galvenie subjektīvo teoriju virzieni ir skolēnu agresija, mācỉbu grūtības, grupu darba organizēšana (Bromme et al., 2006). 


\section{Kas tiek iekḷauts skolotāju profesionālajos standartos}

Lai analizētu skolotāja profesionālo kompetenci mācīšanās iedzilinoties vadǐšanai, balstisimies uz to, kādi ir skolotāju galvenie profesionālie uzdevumi, t. i., analizēsim tā saukto "skolotāja profilu", aplūkojot gatavību plānot, sagatavot un vadìt mācību procesu. Šāda pieeja ir pamatā tā saukto "skolotāju standartu" izveidei.

Aplūkosim dažus profesionālās kompetences modelı un "skolotāju standartu" struktūru piemērus.

Vāciski runājošajā Eiropas dạ̦ā pazīstams ir Evalda Terharta (Ewald Terhart) 2002. gadā izstrādātais skolotāja profesionālo kompetenču modelis (Terhart, 2002). Tajā ir trīs dimensijas - konkrētās zināšanas un prasmes, to taksonomija un laiks jeb kompetences attīstība profesionālās biogrāfijas aspektā. Galvenās šî modeḷa priekšrocības ir precīza mācību priekšmeta didaktikas aprakstī̌̌ana un biogrāfiskās perspektīvas ieviešana. Balstoties uz šo modeli, uzskata, ka prasmes nav skolotāju akadēmiskās izglīīibas mērḳis. Tās tiek attīstītas praksē un tad pilnveidotas turpmākajos izglìtības posmos.

ASV, kur standartiem ir senāka vēsture nekā Eiropā, un angliski runājošajā Eiropas dạ̣ā atsaucas uz Nacionālo profesionālās mācǐšanas pārvaldi (NBPTS, National Board for Professional Teaching Standards ${ }^{1}$ ), kas l̦oti sīki strukturē, kas skolotājam jāzina, jāprot, jādara. Vispārējās standarta sadaḷas ir formulētas apgalvojumu veidā:

- skolotājiem ir uzticēti (un skolotāji labprātīgi to ir uzṇèmušies) skolēni un vinu mācīšana;

- skolotājs pārzina savu mācību priekšmetu un to, kā to iemācìt skolēniem;

- skolotāji atbild par skolēnu mācību procesa vadību un pārraudzību;

- skolotāji sistemātiski domā par savu praksi un mācās no pieredzes;

- skolotāji ir mācību kopienas dalībnieki, t. i., regulāri mācās un apmainās ar pieredzi kopā ar saviem kolēgiem.

Katra sadal̦a sīki aprakstìta gan attiecībā uz konkrēto mācību priekšmetu, gan mācāmo skolēnu vecumposmu.

İpašu vietu ieṇem Fritza Ozera (Fritz Oser) 2001. gadā izstrādātais skolotāju kompetenču profils (Oser, 2001). Ozers pats arī formulējis četrus kritērijus, kuriem jāistenojas, pirms kompetenču profilu var izmantot standarta veidošanai: teorētiskais pamatojums, empīriska pārbaude, vērtēšanas skalas iespējamība, praktiska lietojamība, t. i., kompetences ir tādas, ka skolotājs tās var apgūt. Lai paskaidrotu, ko nozīmē skolotāja profesijas standarts, F. Ozers pats esot

1 NBPTS. (2008). National Board for Professional Teaching Standards. Pieejams: www.nbpts. org (aplūkots 13.02.2018.). 
izmantojis metaforu par lidmašīnas pilotu - lidotāju izglīîbas standarts nodrošina pasažierim to, ka viņš droši tiks nogādāts tur, kur vajag (Oser 2001, citēts no Helmke 2009).

Aptaujājot ekspertus, F. Ozers izstrādājis skolotāja kompetenču profilu, kurā ietilpst 88 rādītāji, kas apvienoti divpadsmit grupās (skat. 1. tabulu).

1. tabula. Skolotāja kompetenču profila sadalījums grupās (pēc Oser, 2001)

\begin{tabular}{|c|c|c|}
\hline Nr. & Grupa & Apraksts \\
\hline 1. & $\begin{array}{l}\text { Skolotāja - skolēna } \\
\text { attiecības un atbalstoša } \\
\text { atgriezeniskā saite }\end{array}$ & $\begin{array}{l}\text { Spēja veidot pozitīvas attiecības ar bērniem un nodrošināt klasē } \\
\text { cilvēcīgu, no bailēm brīvu gaisotni. Skolotājam, no vienas puses, } \\
\text { rūpīgi un uzmanīgi jāpārrauga klasē notiekošais kopumā, no } \\
\text { otras puses - "jāpatur acīs" atseviški skolēni. }\end{array}$ \\
\hline 2. & $\begin{array}{l}\text { Skolēnus atbalstoša } \\
\text { rīcība un diagnostika }\end{array}$ & $\begin{array}{l}\text { Lai varētu iejaukties un pareizi rīkoties attīstībai kritiskos brī̌zos } \\
\text { un problēmu situācijās, skolotājam tie ir jādiagnosticē un } \\
\text { atbilstoši jāreaǵēe. }\end{array}$ \\
\hline 3. & $\begin{array}{l}\text { Disciplīnas problēmu } \\
\text { pārvarēšana }\end{array}$ & $\begin{array}{l}\text { Prasmes, kas nepieciešamas situācijās, kad klasē radušies } \\
\text { konflikti vai citas grūtības. }\end{array}$ \\
\hline 4. & $\begin{array}{l}\text { Sociālas uzvedības } \\
\text { izveidošana un } \\
\text { veicināšana }\end{array}$ & $\begin{array}{l}\text { Prasmes, ar kuru palīdzību skolotājs veicina savu skolēnu } \\
\text { sociālu uzvedību un heterogēnā klasē izveido tādu cilvēku } \\
\text { kopienu, kurā cits citu abpusēji akceptē un atbalsta. }\end{array}$ \\
\hline 5. & $\begin{array}{l}\text { Dalīšanās ar mācīšanās } \\
\text { paṇēmieniem un mācību } \\
\text { procesa uzraudzǐšana } \\
\text { (monitorēšana) }\end{array}$ & $\begin{array}{l}\text { Prasmes, kas skolēniem dod iespēju patstāvīgi un efektīvi } \\
\text { mācīties. }\end{array}$ \\
\hline 6. & $\begin{array}{l}\text { Mācību organizēšana un } \\
\text { metodes }\end{array}$ & $\begin{array}{l}\text { Skolotāja spēja nodrošināt daudzveidīgas mācību metodes un } \\
\text { aktivitātes. }\end{array}$ \\
\hline 7. & Sasniegumu vērtēšana & $\begin{array}{l}\text { Prasmes, kas nepieciešamas, lai skolēnu sasniegumus } \\
\text { daudzpusīgi, uzreiz un efektīvi pārbaudītu un novērtētu. }\end{array}$ \\
\hline 8. & Mediji & Skolotāja prasmes jēgpilni iesaistīt mācību procesā medijus. \\
\hline 9. & Sadarbība skolā & $\begin{array}{l}\text { Spēja sadarboties ar kolēǵiem, pārraugiem, skolas vadību un } \\
\text { vecākiem, sadarboties ar jebkuru personu, kas iesaistīta skolas } \\
\text { darbā. }\end{array}$ \\
\hline 10. & $\begin{array}{l}\text { Skola un sabiedrība } \\
\text { (kopiena) }\end{array}$ & $\begin{array}{l}\text { Skolotāja spēja nodibināt kontaktus ar sabiedrību (kopienu) un } \\
\text { pārstāvēt skolu ārpus tās. }\end{array}$ \\
\hline 11. & $\begin{array}{l}\text { Skolotāja } \\
\text { pašorganizēšanās }\end{array}$ & $\begin{array}{l}\text { Zināšanas, spējas un personiskie resursi, kas skolotājam } \\
\text { nepieciešami, lai rezultatīvi pavadītu skolas ikdienu bez } \\
\text { nevajadzīgas spēku izšk̦ērdēšanas. }\end{array}$ \\
\hline 12. & $\begin{array}{l}\text { Vispārējie un mācību } \\
\text { priekšmeta didaktikas } \\
\text { standarti }\end{array}$ & $\begin{array}{l}\text { Prasmes, kas izglïtībā relatīvi bieži tiek sauktas par mācišanas } \\
\text { tehnikām. }\end{array}$ \\
\hline
\end{tabular}


2. tabulā detalizēti apkopoti rādìtāii par tām konkrētajām prasmēm, kas vajadzīgas, lai dotu iespēju skolēniem patstāvīgi un efektīvi mācīties (5. grupa, skat. iepriekš) un plānot mācību procesu (6. grupa, skat. iepriekš) (Oser, 2001). Ozera veidotajā modelī katra mācību priekšmeta īpatnībām nav pievērsta uzmanība.

2. tabula. Rādītāji skolotāja prasmēm skolēna mācīšanās vadīšanai un plānošanai (adaptēts pēc Oser, 2001)

\begin{tabular}{|c|c|}
\hline $\begin{array}{c}\text { Skolēniem dod iespēju patstāvīgi un efektīvi } \\
\text { mācīties }\end{array}$ & $\begin{array}{c}\text { Nosaka mācību procesa plānošanu un } \\
\text { metožu izvēli }\end{array}$ \\
\hline 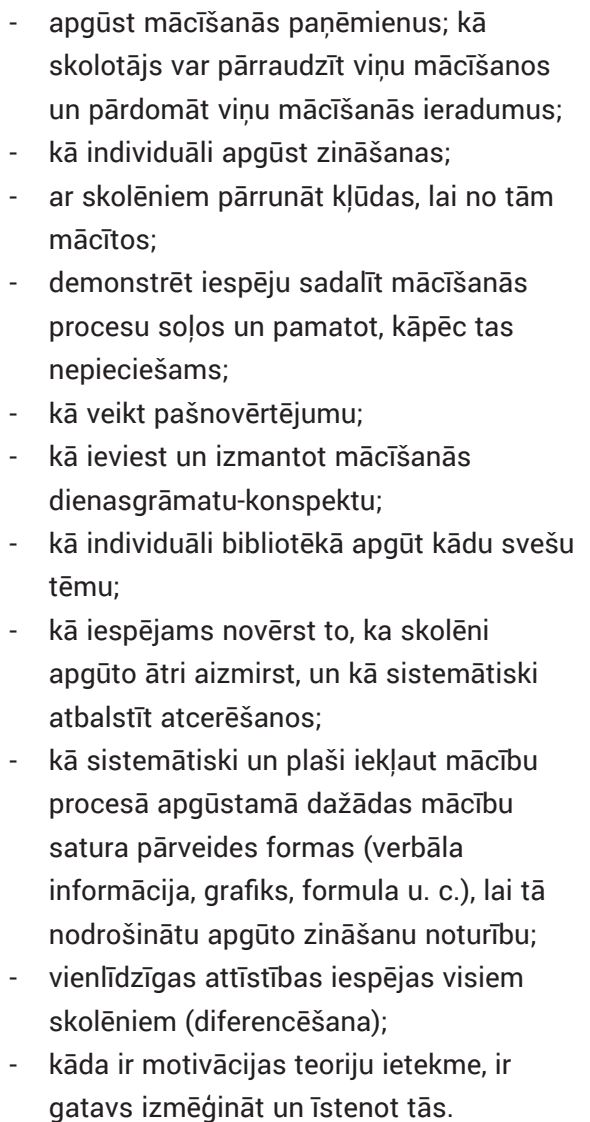 & $\begin{array}{l}\text { - } \quad \text { iespēja darboties daudzveidīgi - rakstīt, } \\
\text { lasīt, runāt utt.; } \\
\text { - } \text { skaidri un viennozīmīgi noteikt/nodalīt } \\
\text { mācību fāzes, kurās skolēni apgūst } \\
\text { jaunas zināšanas un prasmes, nostiprina } \\
\text { tās un kurās tiek vērtēti; } \\
\text { - } \quad \text { novērtēt projektorientētas mācīšanās } \\
\text { iespējas un ierobežojumus; } \\
\text { - } \quad \text { īstenot individuālu un patstāvīgu } \\
\text { mācīšanos dažādās formās; } \\
\text { - } \quad \text { dalīt klasi grupās, ievērojot dažādus } \\
\text { principus un kritērijus; organizēt dažādu } \\
\text { veidu grupu darbus; } \\
\text { - } \text { mācīt ilgtermin̄ā, t. i., neievērojot mācību } \\
\text { gada robežas; } \\
\text { - } \quad \text { sagatavot un vadīt jēgpilnu kooperatīvo } \\
\text { mācīšanos; } \\
\text { - } \quad \text { auglīgi vadīt un rezultatīvi pabeigt } \\
\text { spontāni izraisījušos diskusiju ar } \\
\text { skolēniem; } \\
\text { variēt mācību metodes un pamatot } \\
\text { konkrētas metodes lietojumu. }\end{array}$ \\
\hline
\end{tabular}

Helmke (Helmke, 2009) par ḷoti būtisku skolotāja profesionālās kompetences sastāvdaļu atzīst skolotāja gatavību pašrefleksijai un pašrefleksijas prasmes. Viena no svarīgākajām skolotāja prasmēm ir reflektēt par savu mācǐšanas sniegumu un pieeju, kas notiek gan individuāli, gan sadarbībā ar citiem skolotājiem (Taconis et al., 2004). 
Skolotāja prasme sadarboties ar citiem skolotājiem un skolas vadỉbu ietekmē skolēnu mācību rezultātus; skolotājs tiecas pēc atgriezeniskās saites no kolēgiem, kas palīdz viņam izvērtēt savu sniegumu (Leana, \& Pil, 2006; UK Standard, $2016^{2}$ ). Uz skolēnu mācīšanās uzlabošanu fokusēta skolotāju savstarpējā sadarbība un sadarbība starp skolotājiem un skolas vadību dod lielu un izmērāmu skolēnu sasniegumu pieaugumu un to uzlabošanās noturību (Leana, 2011).

\section{Kas kḷūst svarīgi skolotājam, mācot skolēnu iedziḷināties?}

Akcentējot mācǐšanas pieeju, kuras rezultāts ir kompetence, mainās skolotāja loma: no skolotāja, kurš nodod zināšanas skolēnam, uz skolotāju, kurš vada skolēna mācī̌šnos (Biemans et al., 2004). Papildus 20. gadsimta 90. gados akcentētajām skolotājam nepieciešamajām zināšanām arvien lielāku nozīmi pētnieki pieškir skolotāja prasmei sadarboties ar citiem, analizēt un izvērtēt savu darbību un reflektēt par to. Tādējādi kā vienlīdz svarīgas skolotāja profesionālās kompetences daļas ir izdalāmas kategorijas - prasmes, kas skolotājam vajadzīgas, lai plānotu un vadītu skolēnu mācišsanos, skolotāja analīzes un refleksijas prasmes un skolotāja prasmes sadarboties. Katrā kategorijā ietilpst skolotāju zināšanas, prasmes, uzskati, pieredze. Detalizēts piemērs parādīts 3. tabulā, aplūkojot Jeḷenas Volkinšteines (2018) izstrādāto ḳimijas skolotāja profesionālās kompetences struktūru. Tabulā nav iekḷauti uzskati, mācību satura zināšanas, izpratne par mācību satura dokumentiem, zināšanas par skolēnu u. c., kas iepriekš minēti.

2 UK Standard for teachers' professional development. Implementation guidance for school leaders, teachers, and organisations that offer professional development for teachers. Department for education. (2016). Pieejams: https://www.gov.uk/government/uploads/system/ uploads/attachment_data/file/537031/160712_-_PD_Expert_Group_Guidance.pdf (aplūkots 21.03.2018.). 
3. tabula. Skolotāja profesionālās kompetences mācību procesa īstenošanai mācīšanās iedziḷinoties aspekti

\section{Kategorija Apakškategorija}

\begin{tabular}{|c|c|c|}
\hline \multirow{6}{*}{$\begin{array}{l}\text { Mācību } \\
\text { procesa } \\
\text { plānošana }\end{array}$} & \multirow{6}{*}{$\begin{array}{l}\text { Mācību darbības } \\
\text { plānošana }\end{array}$} & Prot izvirzīt stundas mērḳus un sasniedzamos rezultātus \\
\hline & & Prot plānot atbilstoši sasniedzamajam rezultātam \\
\hline & & Prot izvēlēties efektīvu mācību metodi \\
\hline & & Prot izvēlēties efektīvu skolēnu sadarbības modeli \\
\hline & & Prot atlasīt vai izstrādāt uzdevumus atbilstoši mērḳim \\
\hline & & $\begin{array}{l}\text { Prot izvēlēties formatīvās vērtēšanas un atgriezeniskās } \\
\text { saites nodošanās paṇēmienus }\end{array}$ \\
\hline \multirow{20}{*}{$\begin{array}{l}\text { Mācīšanās } \\
\text { vadīšana }\end{array}$} & \multirow{6}{*}{$\begin{array}{l}\text { Mācību metožu } \\
\text { un paṇēmienu } \\
\text { izmantošana }\end{array}$} & Prot realizēt mācību metodes (tehnika) \\
\hline & & Prot organizēt sarunu \\
\hline & & Prot iesaistīt skolēnus aktīvā mācīšanās procesā \\
\hline & & Prot izmantot uzdevumus atbilstoši mērḳim \\
\hline & & Prot izmantot mācību līdzekḷus (arī IT) efektīvi \\
\hline & & Prot menedžēt laiku \\
\hline & \multirow{5}{*}{$\begin{array}{l}\text { Skolēnu } \\
\text { sadarbības } \\
\text { organizēšana }\end{array}$} & Prot efektīvi sadalīt skolēnus grupās \\
\hline & & Prot precīzi un saprotami uzdot uzdevumu grupu darbam \\
\hline & & Prot organizēt laiku uzdevuma izpildei grupā \\
\hline & & Prot izmantot paṇēmienus skolēnu sadarbības veicināšanai \\
\hline & & Prot veicināt pozitīvas sadarbības attiecības \\
\hline & \multirow{5}{*}{$\begin{array}{l}\text { Skolēnu } \\
\text { sasniegumu } \\
\text { vērtēšana }\end{array}$} & Prot konstatēt stundas sasniedzamo rezultātu \\
\hline & & Prot izmantot uzdevumus, paṇēmienus, kritērijus vērtēšanai \\
\hline & & Prot sniegt atgriezenisko saiti \\
\hline & & Prot organizēt skolēnu pašnovērtēšanu \\
\hline & & Prot organizēt skolēnu savstarpēju vērtēšanu \\
\hline & \multirow{4}{*}{$\begin{array}{l}\text { Skolēnu } \\
\text { motivācijas } \\
\text { paaugstināšana }\end{array}$} & Prot veidot labvēlīgu mācību vidi \\
\hline & & Prot nostiprināt skolēnos drošības izjūtu \\
\hline & & $\begin{array}{l}\text { Prot izmantot atbalsta paṇēmienus mācību rezultāta } \\
\text { sasniegšanai }\end{array}$ \\
\hline & & Prot izmantot paṇēmienus intereses veicināšanai \\
\hline
\end{tabular}




\begin{tabular}{|c|c|c|}
\hline Kategorija & Apakškategorija & Rādītāji \\
\hline \multirow{6}{*}{$\begin{array}{l}\text { Refleksija } \\
\text { un analīze }\end{array}$} & \multirow{3}{*}{ Reflektēšana } & Prot analizēt savu un kolēǵu profesionālo darbību \\
\hline & & Prot reflektēt par savu profesionālo darbību kopā ar citiem \\
\hline & & Prot sniegt un pienemt atgriezenisko saiti \\
\hline & \multirow{3}{*}{$\begin{array}{l}\text { Problēmu } \\
\text { risināšana }\end{array}$} & Prot veikt profesionālās darbības pētījumu \\
\hline & & Prot iegūt pierādījumus, kas liecina par uzlabojumiem \\
\hline & & Prot risināt mācīšanas un mācīšanās procesa problēmas \\
\hline \multirow{3}{*}{ Sadarbība } & \multirow{3}{*}{ Sadarbība } & Prot sadarboties kopienā, ar kolēǵiem, vecākiem u. c. \\
\hline & & Prot dalīties savā pieredzē ar kolēǵiem, mācās sadarbojoties \\
\hline & & Veido partnerattiecības ar skolēniem, vecākiem \\
\hline
\end{tabular}

\section{Secinājumi}

Skolotāja kompetenci veido zināšanas, prasmes un uzskati, kas rezultējas darbībā. Skolotāja darbība ietekmē skolēnu darbību, kas savukārt ir viṇu topošās kompetences pamatā.

Lai skolēnu mācīšanās rezultāts būtu kompetence, aktualizējas skolotāja prasmes vadīt atbilstošu mācǐšanos, analizēt un reflektēt, sadarboties.

Skolotājs prot:

- izvirzìt skolēnam aktuālus mācību mērḳus un dot noderīgu atgriezenisko saiti par to sasniegšanu, prot mācìt skolēnu pašu formulēt mērḳi, sekot virzỉbai uz to, dot un pieņemt atgriezenisko saiti - veicināt pašvadìtu mācǐšanos;

- izvēlēties un prasmīgi lietot mācību paṇēmienus, metodes, kas panāk skolēnu iedziļināšanos un iesaistišanos, izmantot produktīvus uzdevumus, veidot sasaisti ar reālo dzīvi;

- mācīt jēgpilni izmantot IKT rīkus.

Skolotājs izmanto atbilstošus instrumentus (snieguma līmeņu aprakstus), lai sekotu skolēnu izaugsmei, analizē datus, lai plānotu turpmāko darbību. Skolotājs iesaistās profesionālās sarunās ar kolēǵiem, mācību darbỉbu plānošanā un analīzē, rezultātu izvērtēšanā; dalās pieredzēe (savstarpēja stundu vērošana un analīze), reflektē par savu un kolēgu profesionālo darbību. Skolotājs izmanto snieguma līmeņu aprakstus, vadības un kolēgu komentārus, lai spriestu par stundu kvalitāti, formulē mācišsanās vajadzības atbilstoši savām prasmēm un skolas mērķiem. Plāno savu individuālo izaugsmi. 


\section{IZMANTOTĀ LITERATŪRA}

Baumert, J., \& Kunter, M. (2006). Stichwort: Professionelle Kompetenz von Lehrkräften. Zeitschrift für Erziehungswissenschaft, 9, pp. 469-520.

Berry, A., Nilsson, P., van Driel, J., \& Carlson, J. (2017). Analysing Science Teachers' Pedagogical Content Knowledge: a Report on the Second PCK Summit. Paper presented at the ESERA2017 Conference, 21. -25.08.2017, Dublin, Ireland. Retrieved from: https:// keynote.conference-services.net/resources/444/5233/pdf/ESERA2017_0784_paper.pdf

Biemans, H., Nieuwenhuis, L., Poell, R., Mulder, M., \& Wesselink, R. (2004.) Competencebased VET in the Netherlands: background and pitfalls. Journal of vocational education and training, 56(4), pp. 523-538.

Blömeke, S., Kaiser, G., \& Lehmann, R. (eds.). (2010). TEDS-M 2008. Professionelle Kompetenz und Lerngelegenheiten angehender Mathematiklehrkräfte für die Sekundarstufe I im internationalen Vergleich. Waxmann Verlag.

Bromme, R. (1992). Der Lehrer als Experte: Zur Psychologie des professionellen Wissens. Bern: Huber.

Bromme, R. (1997). Kompetenzen, Funktionen und unterrichtliches Handeln des Lehrers. In Weinert, F. E. (Hrsg.): Enzyklopädie der Psychologie. Pädagogische Psychologie. Bd. 3: Psychologie des Unterrichts und der Schule. Göttingen, pp. 177-212.

Bromme, R., Rheinberg, F., Minsel, B., Winteler, A., \& Weidenmann, B. (2006). Die Erziehenden und Lehrenden. In Krapp, A., \& Weidenmann, B. (Hrsg.). Pädagogische Psychologie (5., vollst. überarb. Aufl.). Weinheim: Beltz PVU, pp. 269-355.

Darling-Hammond, L., \& Bransford, J. (eds.). (2005). Preparing teachers for a changing world: Report of the Committee on Teacher Education of the National Academy of Education. San Francisco: Jossey-Bass.

Grossman, P. L. (1990). The making of a teacher: Teacher knowledge and teacher education. Teachers College Press.

Helmke, A. (2009). Unterrichtsqualität und Lehrerprofessionalität - Diagnose, Evaluation und Verbesserung des Unterrichts. Seelze: Klett - Kallmeyer in.

Kagan, D. M. (1992). Implication of research on teacher belief. Educational psychologist, 27(1), pp. 65-90.

Keiser, G., \& Vollstedt, M. (2007). Teachers' views on effective mathematics teaching: commentaries from a European perspective: ZDM mathematics Education, 39, pp. 341-348.

Leana, C. R. (2011). The missing link in school reform. Stanford Social Innovation Review, 9(4), pp. 30-35.

Leana, C. R., \& Pil, F. K. (2006). Social capital and organizational performance: Evidence from urban public schools. Organization Science, 17(3), pp. 353-366.

Loughran, J., Milroy, P., Berry, A., Gunstone, R., \& Mulhall, P. (2001). Documenting science teachers' pedagogical content knowledge through PaP-eRs. Research in Science Education, 31(2), pp. 289-307.

Magnusson, S., Krajcik, J., \& Borko, H. (1999). Nature, sources, and development of pedagogical content knowledge for science teaching. In Examining pedagogical content knowledge (pp. 95-132). Springer, Dordrecht.

Murray, F. B. (1996). The Teacher Educator's Handbook: Building a Knowledge Base for the Preparation of Teachers. The Jossey-Bass Education Series.

Oser, F. (2001). Modelle der Wirksamkeit in der Lehrer- und Lehrerinnenausbildung. In Oser, F. Oelkers, J. (Hrsg.). Die Wirksamkeit der Lehrerbildungssysteme. Chur, pp. 67-96. 
Park, S., \& Oliver, J. S. (2008). Revisiting the conceptualisation of pedagogical content knowledge (PCK): PCK as a conceptual tool to understand teachers as professionals. Research in science Education, 38(3), pp. 261-284.

Reynolds, M. C. (1989). Knowledge base for the beginning teacher. Pergamon Press Inc.

Schneider, R. M., \& Plasman, K. (2011). Science teacher learning progressions: A review of science teachers' pedagogical content knowledge development. Review of Educational Research, 81(4), pp. 530-565.

Shallcross, T., Spink, E., Stephenson, P., \& Warwick, P. (2002). How primary trainee teachers perceive the development of their own scientific knowledge: Links between confidence, content and competence?. International Journal of Science Education, 24(12), pp. $1293-1312$.

Shulman, L. (1987). Knowledge and teaching: Foundations of the new reform. Harvard Educational Review, 57(1), pp. 1-22.

Taconis, R., van der Plas, P., \& van der Sanden, J. (2004). The development of professional competencies by educational assistants in school-based teacher education. European Journal of Teacher Education, 27(2), pp. 215-240.

Terhart, E. (2002). Standards für die Lehrerbildung. Eine Expertise für die Kultusministerkonferenz. Münster.

Terhart, E. (Hrsg.) (2000). Perspektiven der Lehrerbildung in Deutschland. Abschlussbericht der von der Kultusministerkonferenz eingesetzten Kommission. Weinheim.

Van Driel, J. H., \& Berry, A. (2012). Teacher professional development focusing on pedagogical content knowledge. Educational researcher, 41(1), pp. 26-28.

Van Driel, J. H., Beijaard, D., \& Verloop, N. (2001). Professional development and reform in science education: The role of teachers' practical knowledge. Journal of research in science teaching, 38(2), pp. 137-158.

Volkinšteine, J. (2018). Skolotāja kompetence organizēt skolēnu pētniecisko darbību k̦īmijā. Nepublicēta disertācija pedagogijas doktora zinātniskā grāda iegūšanai, Daugavpils Universitāte.

Wilkins, J. M. (2008). The relationship among elementary teachers' content knowledge, attitude, belief, and practices. Journal of Math Teacher Education, 11, pp. 139-164. 


\title{
7. nodala
}

\section{Kā novērtēt skolotāju sniegumu un mērḳtiecīgi pilnveidot skolotāju prasmes}

\author{
Dace Namsone, Līga Čakāne, Jeḷena Volkinšteine, Anete Butkēviča
}

Izglìtības sistēmas kvalitāte nevar pārsniegt skolotāju darba kvalitāti. Vienīgais veids, kā uzlabot skolēnu rezultātus, ir uzlabot mācǐšanu (Barber, \& Mourshed, 2007). Profesionāla mācīšana kā profesija nozīmē sevis attīstību, komandas snieguma veicināšanu un kopējās kvalitātes uzlabošanu profesijā (Hargreaves, \& Fullan, 2012).

Skolēnu mācību procesu un rezultātu vistiešāk ietekmē skolotāja prasmes un darbība stundā, nevis, piemēram, skolēnu spējas, attieksme, uzvedība vai sociālais stāvoklis. Džons Hatijs (John Hattie), analizējot ietekmes faktorus (effect size; salïdzinoši vidēja ietekme ir 0,4; Hattie J., 2012), izdala divas grupas - mācīšana un skolotāja "spēks" jeb skolotāja personības un citu profesionālās darbības aspektu ietekme. Saskaņā ar Dž. Hatija (2012) pētījumiem nozīmīga pozitīva ietekme uz skolēnu mācīšanos ir: skolotāja stratēgiskajai skaidrībai (teachers clarity; ietekmes faktors ir 0,75 ) un izaicinošu sasniedzamo rezultātu skolēniem izvirzišanai $(0,56)$; izziṇas stratēgiiju $(0,74)$ un metakognitīivo stratēgiiju $(0,67)$ mācīšanai; atgriezeniskās saites sniegšanai skolēniem $(0,72)$; skolotāja un skolēnu sadarbības attiecibu veidošanai $(0,72)$ u. c.

Vairums skolotāju savu ietekmi uz skolēnu mācišsanos un viṇu sasniegumu dinamiku novērtē pārāk zemu (Helmke, 2009). Būtisks priekšnoteikums, lai notiktu sekmīga, novērojama mācišanās, ir skolotājs, kurš zina un apzinās savu ietekmi un spēj skatīties uz mācību procesu "ar skolēna acīm". Lai uzlabotos skolēnu sniegums, skolotājam jāapzinās sava ietekme un jācenšas uzlabot savu sniegumu (Hattie, \& Yates 2014).

Skolotājs pats atbild par savu profesionālo kompetenci un tās pilnveidošanu. Ja skolotājs mācās, domā un runā par to, ko un kāpēc viņš apgūst, tad viņš demonstrē skolēniem atdarināšanas vērtu paraugu (Helmke, 2009). 


\section{Kā var novērtēt skolotāja sniegumu}

OECD (the Organisation for Economic Co-operation and Development) zinojumā tiek ieteikts attīstìt skolotāju vērtēšanas sistēmu un skolotāju profesionālo pilnveidi ${ }^{1}$. Kāda ir pieredze skolotāju darba vērtēšanā? Snieguma vērtēšana tiek izmantota arī skolotāju darba vērtēšanai un profesionālajai pilnveidei dažādos veidos, piemēram, jauno vai topošo skolotāju snieguma vērtēšanai, ikgadējai skolotāju snieguma izvērtēšanai skolas vai izglìtības pārvaldes līmenī, profesionālās pilnveides vajadzību apzināšanai, pētniecības un citos nolūkos.

Vērtēšanai var izmantot arī tos skolotāja profesijas standartus, kas detalizēti apraksta skolotāja ieteicamo darbību, var izmantot kādu no efektīvas mācīšanas teorētiskajiem modeḷiem. Lai novērtētu skolotāja sniegumu, t. i., to, kā viņa kompetence izpaužas darbībā, vajadzīgi kritēriji, pēc kuriem vērtēt. Lai precīzāk novērtētu sniegumu, apraksta procedūru, kritērijus, veido snieguma aprakstu līmeņos (līdzīgi kā vērtējot skolēnu sniegumu).

1. attēlā redzams piemērs, kā Austrālijas skolotāja standarts apraksta skolotāju sniegumu četros līmeņos - iesācējs (beidzis augstskolu), pamata, profesionālais un skolotājs līderis (eksperts). Piemērā aplūkota snieguma dimensija - izpratne par skolēniem un viṇu mācišanos.

\section{Profesionālās zināšanas}

1. Standarts - saprot skolēnus un to, kā viṇi mācās

Joma 1.1. Skolēnu fiziskā, sociālā un intelektuālā attīstība un īpašības

\begin{tabular}{|c|c|c|c|}
\hline IESĀCĒJS & PAMATA & PROFESIONĀLIS & SKOLOTĀJS-LITDERIS \\
\hline $\begin{array}{l}\text { Skolotājs demonstrē } \\
\text { zināšanas un } \\
\text { izpratni par skolēnu } \\
\text { fizisko, sociālo un } \\
\text { intelektuālo attīstību } \\
\text { un īpašībām; to, } \\
\text { kā tās ietekmē } \\
\text { māciš̌anos }\end{array}$ & $\begin{array}{l}\text { Skolotājs lieto } \\
\text { mācību pieejas, kas } \\
\text { balstītas zināšanās } \\
\text { par skolēnu } \\
\text { fizisko, sociālo } \\
\text { un intelektuālo } \\
\text { attīstību, īpašībām, } \\
\text { lai uzlabotu } \\
\text { skolēnu mācīšanos }\end{array}$ & $\begin{array}{l}\text { Skolotājs atrod } \\
\text { mācību pieejas, kas } \\
\text { piemērotas skolēnu } \\
\text { fiziskajai, sociālajai } \\
\text { un intelektuālajai } \\
\text { attīstībai un } \\
\text { ipašīinām }\end{array}$ & $\begin{array}{l}\text { Vada citus skolotājus, lai } \\
\text { viṇiem palīdzētu atrast } \\
\text { un radīt mācību pieejas } \\
\text { skolēnu mācīšanās } \\
\text { uzlabošanai, lietojot } \\
\text { zināšanas par skolēnu } \\
\text { fizisko, sociālo un } \\
\text { intelektuālo attīstību un } \\
\text { īpašībām }\end{array}$ \\
\hline
\end{tabular}

1. attēls. Piemērs no skolotāja standarta Austrālijā

1 OECD. (2016). Education in Latvia, Reviews of National Policies for Education, OECD Publishing, Paris. http://dx.doi.org/10.1787/9789264250628-en

2 AITSL. (2011). Australian Professional Standards for Teachers. Pieejams: https://www.aitsl. edu.au/docs/default-source/apst-resources/australian_professional_standard_for_teachers_ final.pdf (aplūkots 10.02.2018.). 


\begin{tabular}{|c|c|c|}
\hline & 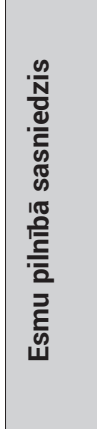 & 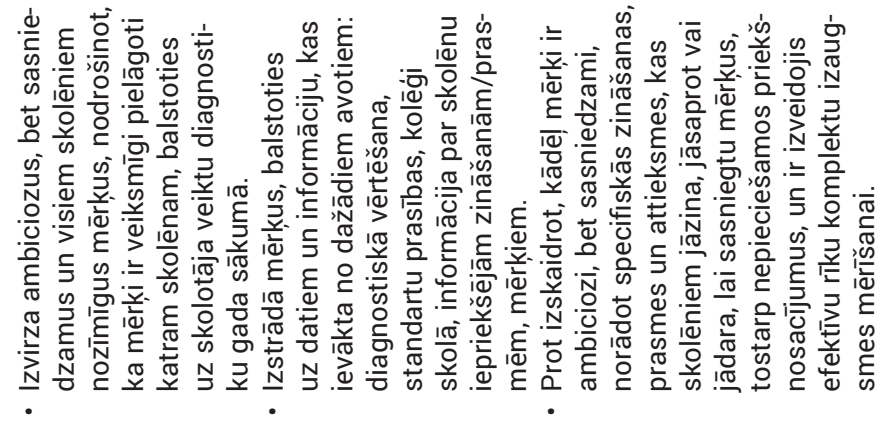 \\
\hline & 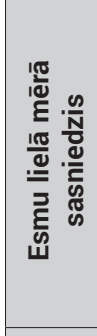 & 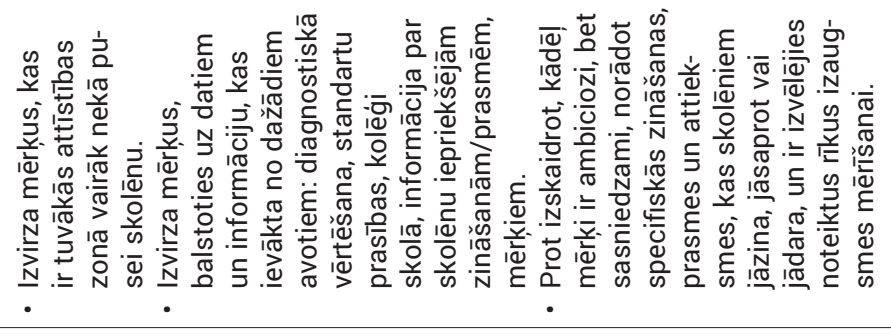 \\
\hline 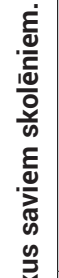 & 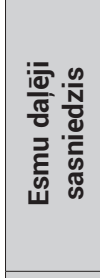 & 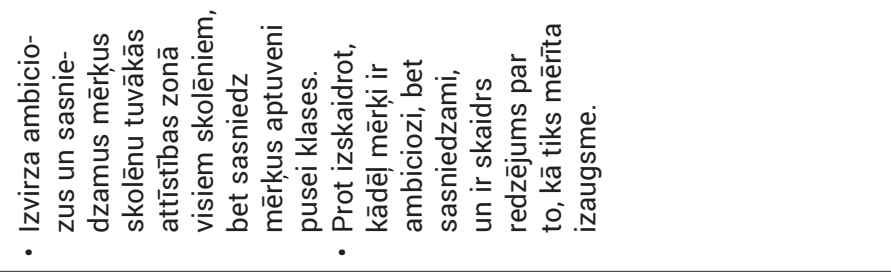 \\
\hline 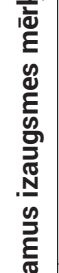 & 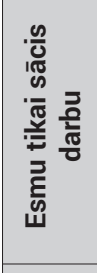 & 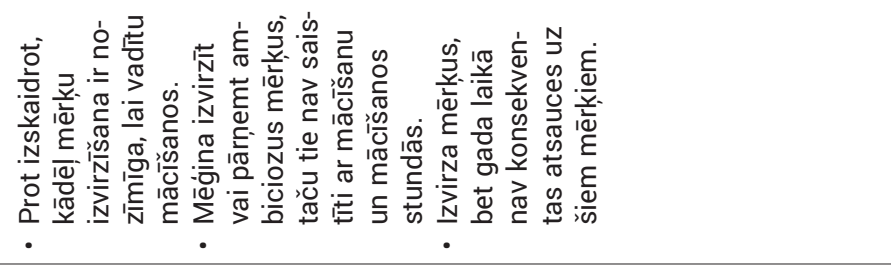 \\
\hline 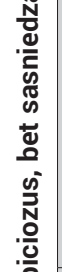 & 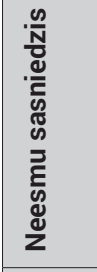 & 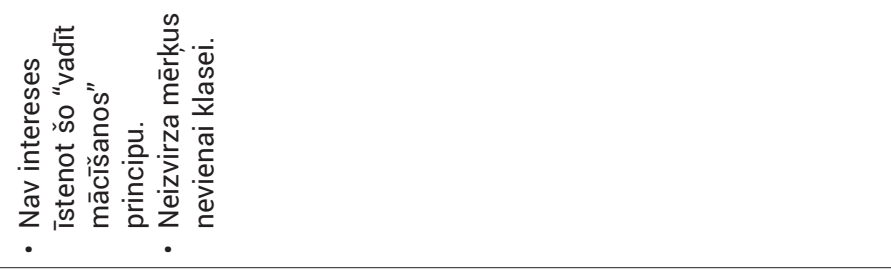 \\
\hline 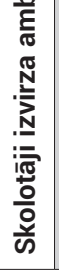 & 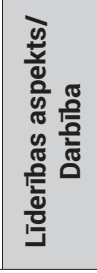 & 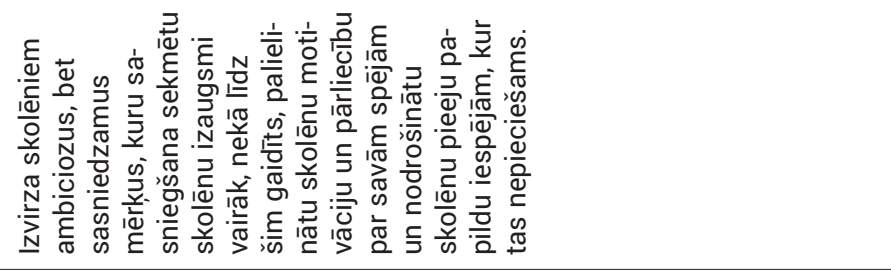 \\
\hline
\end{tabular}


Latvijā līdzīga prakse ir aprobēta kustībā "Iespējamā misija", kas snieguma aprakstu līmeņos (rubriku) "Vadìt mācǐšanos" izmanto jauno skolotāju sagatavošanas procesā kā refleksijas instrumentu dalībnieku pašvērtējumam un profesionālās izaugsmes plānošanai, arī kā konceptuālo modeli mācību programmas satura izstrādē (skat. 2. attēlu). Tā adaptēta no līdzịgiem instrumentiem, ko izmanto "Iespējamās misijas" partnerorganizācijas Teach for America (ASV) un Teach First (Lielbritānijā). Rubrikas dimensijas tiek identificētas apjomīgā pētījumā, pētot to Teach for America izcilāko skolotāju rīcību, kuriem ir vislielākā ietekme uz skolēniem (Farr, 2010).

Ir sastopama arī pieeja aprakstìt līmeņos skolotāju sniegumu konkrētos mācību priekšmetos. Piemēram, Japānā izšḳiir trīs ekspertīzes līmeņus matemātikas mācīšanā. Pirmajā līmenī skolotājs var skolēniem pastāstìt (parādît) matemātikas pamatidejas - faktus, jēdzienus, procedūras un vingrinājumus. Otrajā līmenī skolotājs var paskaidrot galvenā mācību satura jēgu, spriešanu, praktizēšanos tādā veidā, kā skolēni spēj saprast. Trešajā līmenī skolotājs nodrošina skolēniem iespēju saprast šo matemātikas saturu un praktizēšanos un atbalsta mācišanos (Takahashi, $2011^{3}$ u. c.).

Skolotāji tiek vērtēti atbilstoši specifiskām kompetencēm, kas savukārt atbilst kopējai vīzijai par efektīvu mācǐšanu (Jayaram, Moffit, \& Scott, 2012).Vīziju kodē ar aptverošiem snieguma aprakstiem līmen,os (rubrikām), kurās tiek atsegti šādi aspekti: klasvadības un pedagoǵiskās darbības efektivitāte, skaidrība par stundas mērkiiem un sasniedzamajiem rezultātiem, spēja ieinteresēt skolēnus neatkarīgi no viņu mācīšanās stila, spēja diferencēt mācību procesu atbilstoši dažādām skolēnu spējām. Šādas rubrikas piedāvā, piemēram, Centrālšveices pedagogiskās augstskolas (PHZ Schwyz) izstrādātā sistēma, kas vienlaikus piedāvā gan kompetenču aprakstu, gan aprakstošu instrumentu to mērī̌sanai trīs līmeņos (Jayaram, Moffit, \& Scott, 2012; Helmke, 2009).

Arī efektīvai mācišsanai tiek piemēroti snieguma apraksti līmeņos. Piemēram, "Piecas dimensijas par efektīva skolotāja rīcību (5D+)" autori norāda, ka modelis balstìts uz apjomīgu pētniecisko darbu ${ }^{4}$ un šis piecas dimensijas ir: mērḳis, skolēnu iesaistišana, mācību saturs un pedagoǵija, formatīvā vērtēšana, klases vide un kultūra. Tās ir sīkāk sadalītas 13 apakšdimensijās. "5D+" rubrika iekḷauj profesionālo sadarbību un komunikāciju, kas ir balstīta uz skolotāja veidotajām aktivitātēm un attiecībām gan klasēe, gan ārpus tās. 3. attēlā redzamajā piemērā

3 Takahashi, A. (2011). Helping teachers work together to improve teaching \& learning. Pieejams: http://www.LSAlliance.org (aplūkots 14.02.2018.).

4 Center for Educational Leadership. (2017). Dimensions of the 5D+ Teacher Evaluation Rubric. University of Washington. Pieejams: https://www.k-12leadership.org/ (aplūkots 10.02.2018.). 
tiek apskatīta mērķa dimensija, apakšdimensija ir standarta izmantošana un indikators ir savienošana ar standartu, plašāks mērḳis un pārnesama prasme.

\section{MĒRKIS}

Saikne ar standartiem, plašāko mērḳi un caurviju prasmēm

\begin{tabular}{|c|c|c|c|}
\hline NEAPMIERINOŠS & PAMATA & LIETPRATẼJS & IZCILS \\
\hline $\begin{array}{l}\text { Mācību stunda nav } \\
\text { balstīta standartos } \\
\text { noteiktajā līmen̄̄. } \\
\text { Nav sasniedzamā } \\
\text { rezultāta, kas } \\
\text { saskaṇots ar } \\
\text { standartu. Mācību } \\
\text { stunda nesaistās ar } \\
\text { plašāku mērḳi vai } \\
\text { caurviju prasmju } \\
\text { apguvi }\end{array}$ & $\begin{array}{l}\text { Mācību stunda } \\
\text { balstīta standartos } \\
\text { noteiktajā līmenī, } \\
\text { sasniedzamais } \\
\text { rezultāts saskaṇots } \\
\text { ar standartu. Mācību } \\
\text { stunda ir dalēeji } \\
\text { saplānota tā, lai } \\
\text { saistītos ar plašāku } \\
\text { mērḳi vai caurviju } \\
\text { prasmju apguvi }\end{array}$ & $\begin{array}{l}\text { Mācību stunda } \\
\text { balstīta standartos } \\
\text { noteiktajā līmenī, } \\
\text { un sasniedzamais } \\
\text { rezultāts saskaṇots } \\
\text { ar to. Mācību stunda } \\
\text { ir bieži saplānota } \\
\text { tā, lai saistītos ar } \\
\text { plašāku mērḳi vai } \\
\text { caurviju prasmju } \\
\text { apguvi }\end{array}$ & $\begin{array}{l}\text { Mācību stunda } \\
\text { balstīta standartos } \\
\text { noteiktajā līmen̄ī, } \\
\text { un sasniedzamais } \\
\text { rezultāts saskaṇots } \\
\text { ar to. Mācību stunda } \\
\text { ir vienmēr saplānota } \\
\text { tā, lai saistītos ar } \\
\text { plašāku mērki vai } \\
\text { caurviju prasmju } \\
\text { apguvi }\end{array}$ \\
\hline \multicolumn{4}{|c|}{ SKOLOTĀJA RĪCĪBA, NOVĒROJAMA MĀCĪBU STUNDAS GAITĀ: } \\
\hline $\begin{array}{l}\text { - Skolotājs vada mā- } \\
\text { cību stundu 6. klasei } \\
\text { par revolūciju. } \\
\text { Saturs, prasmes } \\
\text { atbilst 5. klases } \\
\text { standartam } \\
\text { • Skolotājs vada } \\
\text { 6. klases mācību } \\
\text { stundu par Āfrikas } \\
\text { ǵeogrāfiju, saturs } \\
\text { un prasmes atbilst } \\
\text { 6. klases standar- } \\
\text { tam. Saturs netiek } \\
\text { saistīts ar plašāku } \\
\text { mērkịi, piemēram, kāa } \\
\text { Āfrikas ǵeogrāfija } \\
\text { ietekmē tās ekono- } \\
\text { miku; vai to, kā iegū- } \\
\text { tās prasmes tiks } \\
\text { lietotas nākamajās } \\
\text { mācību stundās. } \\
\text { Nav sasniedzamā } \\
\text { rezultāta }\end{array}$ & $\begin{array}{l}\text { • Skolotājs vada } \\
\text { 6. klases mācību } \\
\text { stundu par revo- } \\
\text { lūcijām Āfrikā, kur } \\
\text { saturs un prasmes } \\
\text { atbilst } 6 . \text { klases } \\
\text { standartam } \\
\text { • Tikai mācību stun- } \\
\text { das sākumā sko- } \\
\text { lotājs paskaidro, } \\
\text { kā lietot prasmes. } \\
\text { Sasniedzamais } \\
\text { rezultāts ṇemts no } \\
\text { skolotāja rokasgrā- } \\
\text { matas un atbilst } \\
\text { standartam }\end{array}$ & $\begin{array}{l}\text { Papildinot "Pamata" } \\
\text { līmeni: } \\
\text { • Sākot katru mā- } \\
\text { cību stundu, sko- } \\
\text { lotājs paskaidro, } \\
\text { kā, mācoties par } \\
\text { Āfrikas ǵeogrāfiju, } \\
\text { skolēni varēs labāk } \\
\text { izprast esošos } \\
\text { notikumus šajā } \\
\text { kontinentā. Sko- } \\
\text { lotājs, pārskatot } \\
\text { nedēlas saturu, } \\
\text { paskaidro skolē- } \\
\text { niem, kā iegūtas } \\
\text { prasmes skolēni } \\
\text { lietos nākamajās } \\
\text { mācību stundās }\end{array}$ & $\begin{array}{l}\text { Papildinot } \\
\text { "'Lietpratēja" līmeni: } \\
\text { • Mācību stundas } \\
\text { sākumā, tās gaitā } \\
\text { un noslēgumā sko- } \\
\text { lotājs paskaidro, } \\
\text { kā, mācoties par } \\
\text { Āfrikas ǵeogrāfiju, } \\
\text { skolēni varēs } \\
\text { izprast Āfrikas } \\
\text { notikumu ietekmi } \\
\text { uz valsti, kurā viṇi } \\
\text { dzīvo } \\
\text { • Skolotājs, pasnie- } \\
\text { dzot mācību satu- } \\
\text { ru par Āfriku, at- } \\
\text { gādina skolēniem, } \\
\text { ka viṇi lietos tās } \\
\text { pašas prasmes, } \\
\text { kas tika apgūtas, } \\
\text { mācoties par Āziju }\end{array}$ \\
\hline
\end{tabular}

3. attēls. " $5 \mathrm{D}+$ " rubrika efektīva skolotāja snieguma vērtēšanai 
Skolotāju snieguma efektivitātes vērtēšanas sistēma TEPES (Stronge Teacher Effectiveness Performance Evaluation System ${ }^{5}$ ) ir diezgan tipiska sistēma, kas lielākā vai mazākā detalizācijas pakāpē ilustrē veidu, kā ASV N̦ūdžersijas pavalsts vietējās skolu pārvaldes cenšas novērtēt skolotāju sniegumu. Šìs sistēmas parasti balstītas uz kādu skolotāju profesijas standartu, kas apraksta efektīva skolotāja kompetences dimensijas. Piemēram, TEPES gadijumā šīs dimensijas ir profesionālās zināšanas, mācišanas plānošana, mācišana, formatīvā vērtēšana, mācišanās vide, profesionalitāte, skolēnu progress. Katram kritērijam ir atbilstoši kvalitātes līmeņu apraksti, citi instrumenti dažādu mācību darba aspektu izvērtēěanai, piemēram, stundu vērošanas rubrikas, skolēnu aptaujas, u. tml. vajadzībām ASV.

Līdzīga rubrika kopā ar sistēmu ir skolotāju snieguma izvērtēěanai ASV Konektikutas pavalstî. ${ }^{6}$ Tà balstìta uz skolotāju profesijas standarta modeli, sistēmā piedāvāti dažādi instrumenti katras standarta dimensijas izvērtēšanai. Modelis sastāv no šādām dimensijām: mācību saturs un pamatprasmes, klases vide, skolēnu iesaistīšana un atdeve, aktīvas mācǐšanās plānošana, formatīvā vērtēšana, profesionāla atbildība un skolotāja līderība.

Redzams, ka aplūkotajos piemēros snieguma apraksti līmeņos veidoti pēc kopīgiem principiem, izvēloties kompetenču dimensijas un tās atsedzošos indikatorus un aprakstot skolotāju sniegumu vairākos (3-5) līmeṇos. Lìmeṇu aprakstīšanai izvēelēti gan profesionālajos standartos sastopamie līmeņu nosaukumi iesācēja, pamata, profesionālais un eksperta, gan jau vērtējumu tieši ietveroši nosaukumi, piemēram, neefektīvs, daḷēji efektīvs un efektīvs. Atšķiras nolūks, kādam rubrika tiek izmantota (ir holistikas un analītiskas rubrikas) un kurš tieši šo rubriku izmanto. Atškịiras veids, kā informācija tiek iegūta, - tieši vērojot mācību procesā notiekošo vai pastarpināti.

Efektīivi būtu, ja skolotājs pats kopā ar kolēgiem, skolas vadību un pašvaldỉbu, kas bieži finansē tālākizglîtību, vienotos par to, kāda ir efektīva mācǐšanās, gan balstoties teorētiskos pētijumos, gan salīdzinot savu un kolēgu sniegumu un sasniegtos rezultātus. Pat tad, ja skolotājs ir gatavs pārdomāt un analizēt savu darbību tehniski vienatnē, bez stundas gaitas ierakstī̌sanas, to nav viegli izdarìt. Darbības laikā, piemēram, stundā, skolotājam ir maz iespēju pārdomāt savas rīcības efektivitāti, jo tam neatliek laika, bet pēc stundas jau ir grūti atcerēties notikušā detalizētās nianses. Tāpēc bieži vien skolotājiem ir problēmas ar to, lai konstatētu nepiln̄ibas savā darbā, piemēram, pārāk ìss laiks skolēna atbildes

5 Stronge, J. H. (2012). Teacher Performance Evaluation Program Handbook 2012-2013.Stronge \& Associates. Pieejams: http://mnprek-3.wdfiles.com/local--files/teacher-effectiveness/TEPES\%20\%20Stronge.pdf (aplūkots 10.02.2018.).

6 Connecticut State Department of Education (2014). The Connecticut Common Core of Teaching Rubric for Effective Teaching. Pieejams: http://www.connecticutseed.org/wp-content/ uploads/2014/05/CCT_Rubric_for_Effective_Teaching-May_2014.pdf (aplūkots 10.02.2018.). 
gaidīšanai, skolotāja runas laiks stundā, skolotāja uzdoto jautājumu skaits. Piemēram, pētījumā, kas izmantoja angḷu valodas stundu videoierakstus paralēli skolotāju pašrefleksijai, tika noskaidrots, ka tikai $27 \%$ skolotāju atzīst, ka viņu runas laiks stundā pārsniedzis $60 \%$ no stundas laika, kaut patiesībā $77 \%$ skolotāju runāja vairāk nekā $60 \%$ stundas laika (Helmke, 2009). Tātad, lai iegūtu reālu vērtējumu par niansēm, ieteicams stundu ierakstitt, izmantojot tehnologijas, vai vismaz veikt novērotāja pierakstus.

Katrai profesionālās pilnveides iespējai jābūt skaidri sasaistāmai ar vienoto vīziju par efektīvu mācīšanu un mērāmām izmaiņām skolotāja praktiskajā darbībā. Ja skolotājs atrod aspektu, kas viṇam jāuzlabo, viṇš ar to strādā, izvēloties atbilstošu profesionālās pilnveides saturu un formu. Tālāk tiek mērīts, kā šîs kompetences uzlabojas. Lai būtu progress, nozìmīgs ir skolas vadības atbalsts. Skolas līmenī, kā norāda turpmāk tekstā minētie McKinsey (ASV) pētnieki, bieži galvenais izaicinājums ir nobalansēt starp "viens izmērs der visiem" un "katrs skolotājs ir citādāks" pieejām. Ierobežotie resursi liek skolu pārvaldēm jautāt: kur ieguldot, investīcijas dos vislielāko uzlabojumu skolotāju mācīšanas praksē un skolēnu sasniegumos? Skolotāju sadalǐšana pēc definētiem principiem ir rīks, kas palīdz atbildēt uz šo jautājumu. Skolotāji lielākoties tiek iedalīit pēc pieredzes ilguma (darba stāža) un viṇu snieguma. Svarīgi nodrošināt labu pamatu jaunajiem skolotājiem. Skolotājus, kuru darba stāžs ir līdz diviem gadiem, nevajadzētu iedalìt pēc snieguma, jo visiem lielākoties ir līdzịgas problēmas. Pēc otrā gada sniegums ir svarīgs diferencētājs. Skolotājiem, kuru pieredze ir virs trīs gadiem un ir augsts sniegums, jāpiedāvā speciālas tālākizglìtîbas iespējas atkarībā no tā, vai viṇus vairāk interesē mācīšana vai administratīvs darbs (Jayaram, Moffit, \& Scott, 2012).

\section{Kāda ir efektīva un neefektīva mācīšana}

Mērḳis ir panākt efektīvu mācību procesu, kurā skolotāji un skolēni ir partnerībā un mācās kopā; tiek izvirzīts skaidrs mācību mērḳis un ir skaidrs mācīšanās progresa mērỉjums; ir nepārtraukta atgriezeniskās saites sniegšana skolēniem par viṇu mācỉbu progresu; tiek analizēti dati par skolēnu mācību progresu un, ņemot vērā datus, ieviestas nepieciešamās izmaiñas (Fullan, \& Langworthy, 2014). Efektīvs skolotājs veido stundu, kurā notiek patiesa mācišanās, skolotājs seko katra skolēna mācišanās progresam un prot virzīt katru skolēnu pretī izvirzìtajam mērķim, nepārtraukti meklē atbildes uz jautājumiem: "Kurp doties? Kā tur nokḷūt? Kur doties turpmāk?” (Hattie, 2012). Pilnīgi visiem mācību procesā iesaistītajiem - no izglîtības pārvaldes vadītāja līdz skolotāja asistentiem - jābūt vienotai vīzijai, kura konkretizē, kā izskatās efektīva mācīšana. Tà ir pamats 
produktīvai sarunai par katra stiprajām pusēm un uzlabojamajām jomām (Jayaram, Moffit, \& Scott, 2012).

OECD TALIS (Teaching and Learning International Survey) (Schleicher, $2015^{7}$ ) pētijumā konstatēts, ka skolotāji novērtē 21. gadsimta pedagogiiju, bet mācību prakses ne vienmēr to atspoguḷo. Lìdztekus efektīvai mācīšanai skolu praksē pētnieki runā par neefektīvu mācīšanu. Kā neefektīivas mācīšanas pazīmes pētnieki min pārāk lielu skolēnu autonomiju, istermiņa uzdevumus, kas tiek doti vienā mācību priekšmetā, skolēniem nav skaidri mācīšanās mērḳi un snieguma kritēriji, ir pārāk liela skolotāja kontrole, neefektīva atgriezeniskā saite vai nobeiguma vērtēšana, informācijas tehnolog̣ijas (IT) tiek lietotas informēšanai (Fullan, \& Langworthy, 2014). Šāds salīdzinājums parādīts 4. attēlā.

\begin{tabular}{|l|l|l|}
\hline \multicolumn{1}{|c|}{ Kritēriji } & \multicolumn{1}{|c|}{ Neefektīva mācišana } & \multicolumn{1}{c|}{ Efektīva mācīšana } \\
\hline $\begin{array}{l}\text { Skolēnu un skolotāju } \\
\text { attiecības }\end{array}$ & $\begin{array}{l}\text { Pārāk liela skolēnu } \\
\text { autonomija }\end{array}$ & Partnerība \\
\hline Mācību uzdevumi & $\begin{array}{l}\text { İstermiṇa uzdevumi } \\
\text { vienā mācību priekšmetāā }\end{array}$ & $\begin{array}{l}\text { Kompleksi, integrēti, ilgtermiña dziḷas } \\
\text { mācǐsanās uzdevumi }\end{array}$ \\
\hline Mācīšanās mērḳi & $\begin{array}{l}\text { Nav skaidri mācīšanās } \\
\text { mērḳi un snieguma } \\
\text { kritēriji }\end{array}$ & $\begin{array}{l}\text { Dzilas mācīšanās uzdevumi ar } \\
\text { skaidriem mērḳiem un skaidri definētiem } \\
\text { instrumentiem, kā mērīt sasniegto }\end{array}$ \\
\hline $\begin{array}{l}\text { Skolotāja kontrole/ } \\
\text { partnerība }\end{array}$ & $\begin{array}{l}\text { Pārāk liela skolotāja } \\
\text { kontrole }\end{array}$ & $\begin{array}{l}\text { Pakāpeniski tiek būvēta skolēna } \\
\text { kapacitāte vadīt savu mācīšanos; ir } \\
\text { izvēles iespēja }\end{array}$ \\
\hline Atgriezeniskā saite & $\begin{array}{l}\text { Neefektīva atgriezeniskā } \\
\text { saite vai nobeiguma } \\
\text { vērtēšana }\end{array}$ & $\begin{array}{l}\text { Pastāvīga, efektīva atgriezeniskā saite, } \\
\text { formatīvā vērtēšana pret izvirzītajiem } \\
\text { mērkịiem }\end{array}$ \\
\hline
\end{tabular}

/Adaptēts No NPDL/

4. attēls. Efektīvas un neefektīvas mācīšanas salīdzinājums (adaptēts pēc Fullan, \& Langworthy, 2014)

Marks Prenskis (Marc Prensky) (Prensky, 2001) atškirības starp efektīvu un neefektīvu mācīšanu saskata partnerībā; parāda tās skalā, uzdodot it kā jautājumu skolotājiem, vai viṇi zina, kur šajā skalā atrodas.

7 Schleicher, A. (2015). How do we foster innovation that has a positive impact on student learning. Report presented at the 2015 International Summit of the Teaching Profession (30.03.2015). Pieejams: http://istp2015.org/Documents/PC\%20Summit\%20Session\%201_Schleicher_EN.pdf (aplūkots 10.02.2018.). 
Latvijas Universitātes Starpnozaru izglìtỉbas inovācijas centra (LU SIIC) veiktajos pētijumos, vērojot mācību stundas ilgākā laika periodā (France et al., 2015; Dudareva et al., 2015; Volkinšteine, \& Namsone, 2014; u. c.), vērtēšanai tiek izmantoti kritēriji skolotāju sniegumam stundā, aprakstot sniegumu līmeños. Ilglaicīgi vērotas mācību stundas 10 skolās laika periodā no 2013. līdz 2015. gadam, kopumā iegūstot un analizējot datus par 368 stundām 1.-12. klasēs dažāà mācību priekšmetos. Viena līmeṇu apraksta piemērs parādīts 1. tabulā. ${ }^{8}$

1. tabula. Snieguma līmeṇu apraksts kritērijam par uzdevumu sadarbības organizēšanai grupā

\begin{tabular}{|c|c|c|c|c|}
\hline & 0 & 1 & 2 & 3 \\
\hline $\begin{array}{l}\text { Uzdevumu } \\
\text { piemērotība, lai } \\
\text { skolēni mācītos } \\
\text { sadarbojoties }\end{array}$ & $\begin{array}{l}\text { Uzdevums ir } \\
\text { nepiemērots } \\
\text { darbam grupā, } \\
\text { nav nodrošināti } \\
\text { nepieciešamie } \\
\text { apstākli, } \\
\text { lai veiktu } \\
\text { uzdevumu. }\end{array}$ & $\begin{array}{l}\text { Uzdevumu } \\
\text { var veikt gan } \\
\text { individuāli, gan } \\
\text { grupā; sadarbība, } \\
\text { lai iegūtu } \\
\text { rezultātu, nav } \\
\text { nepieciešams } \\
\text { nosacījums, lai } \\
\text { veiktu uzdevumu. }\end{array}$ & $\begin{array}{l}\text { Uzdevuma } \\
\text { veikšana prasa } \\
\text { skolēnu dalītu } \\
\text { atbildību, bet } \\
\text { viṇiem nav } \\
\text { nepieciešams } \\
\text { kopā pieṇemt } \\
\text { lēmumus. }\end{array}$ & $\begin{array}{l}\text { Uzdevums } \\
\text { prasa, lai } \\
\text { skolēniem jādala } \\
\text { atbildība, viṇiem } \\
\text { jāpieñem kopīgs } \\
\text { lēmums par } \\
\text { saturu, procesu } \\
\text { vai produktu. }\end{array}$ \\
\hline
\end{tabular}

Mācǐšanās efektivitātes vērtēšanai tiek darbināti šādi kritēriji: mācīšanās mērḳu (sasniedzamā rezultāta) skaidrība skolēnam, noderīgas atgriezeniskās saites nodrošināšana skolēnam, produktīvu mācību aktivitāšu veidošana, skolēnu iesaistišana, sadarbības veidošana, informācijas un komunikāciju tehnologiiju (IKT) jēgpilna izmantošana u. c., kas sasaucas ar mācišanās iedziḷinoties pazīmēm (skat. iepriekš). Tiek vērota arī skolotāja darbība, veidojot strukturētu mācību stundu, kā arī skolotāja tehnika un izvēètēà mācību satura skaidrība skolēniem. Katram kritērijam izveidots līmeņu apraksts konkrētā skalā. Piemēram, 5. attēlā parādīti dati izvēles kopai par četriem kritērijiem - sadarbỉbas veidošana, produktīvu mācību aktivitāšu veidošana, skolotāja izvēlēto metožu tehnika un metožu efektivitāte.

8 Microsoft Partners in Learning. (2012). 21 CLD Learning Activity Rubrics. Pieejams: http://www. kasc.net/2010/21CLD\%20Learning\%20Activity\%20Rubrics\%202012.pdf (aplūkots 16.02.2018.). 
104 stundas 2013. II, III vidējais vētējums pa kritērijiem

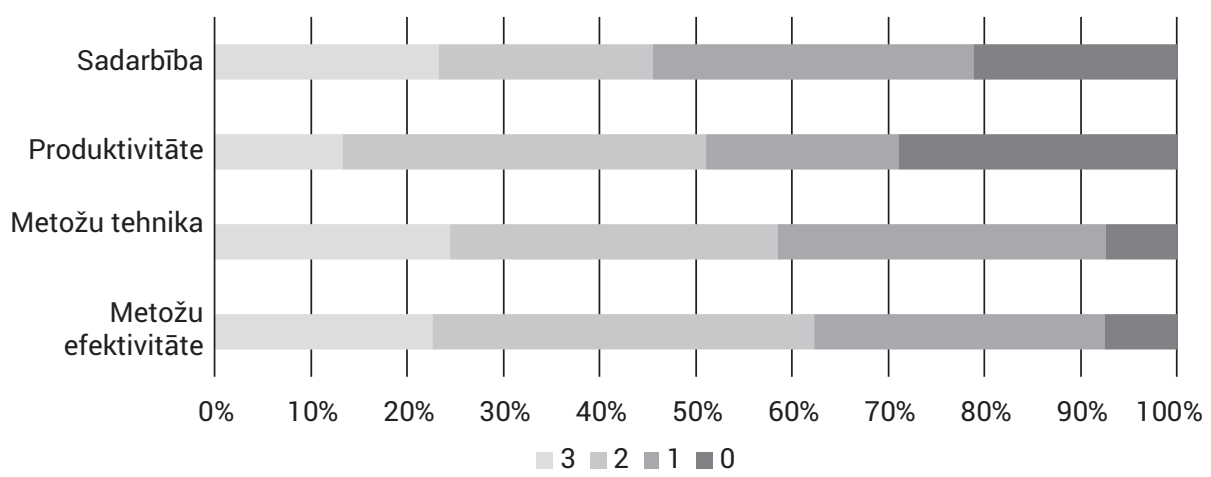

5. attēls. Skolotāju snieguma salīdzinošs vērtējums (skala 0-3)

Redzams, ka skolotāju sniegumā ir konstatētas lielas atšḳirības. Mācību stundu vērojumi uzrāda tendenci, ka mācību process iedzị̣ināšanās pieredzi skolēniem dod ierobežoti, apstiprinot plānoto reformu nepieciešamību. Vērotajās stundās dominē frontāla darbība un uzdevumi, kas rosina reproducēt. Vērojama tendence, ka tikai $10 \%$ stundu skolēniem veicamie uzdevumi prasa dzilu domāšanu, 55\% stundu skolēnu mācīšanās mērḳis ir skaidrs un saprotams, $45 \%$ stundu tiek organizēta skolēnu sadarbība (Namsone, \& Čakāne, 2015).

Analizējot sniegumu pret mācǐšanās iedziḷinoties kritērijiem kopumā, ir vairākas skolotāju grupas atbilstoši to sniegumam. Piemērā aplūkosim šo snieguma grupu ìsu salīdzinājumu. Katrs kritērijs analizēts, izmantojot snieguma līmeṇu aprakstu.

I grupas sniegums skalā vērtēts 2-3. Šajās stundās skolotāju sniegums kopumā ir efektīvs, atbilst mācišanās iedziḷinoties kritērijiem: skolēniem ir skaidri mācišanās mērḳi un snieguma kritēriji, ir iespēja saṇemt konstruktīvus ieteikumus turpmākai darbībai gan par plānoto sasniedzamo rezultātu, gan mācišanās procesu un atgriezenisko saiti tūlìt izmantot; risināt kompleksus uzdevumus, pašiem konstruēt (radīt) zināšanas vai lietot tās jaunā situācijā (kontekstā); ir bijusi iespēja sadarboties kopīga uzdevuma veikšanā, pien,emot kopīgus lēmumus, dalot atbildību par rezultātu; mācību metodes un paṇēmieni tiek izmantoti atbilstoši to pedagogiskajam nolūkam, to efektivitāte ir augsta.

II grupas sniegums skalā vērtēts 0. Faktiski šādām stundām nav rezultāta skolēnam. Šajās stundās skolēniem nav skaidri māciššnās mērḳi, stundā nepārliecinās par stundā sasniegto, skolēni atgriezenisko saiti nesaņem; uzdevumi ir tikai reproduktīvā līmenī - nepieciešams atcerēties faktus, lietot zināmas procedūras pazīstamās situācijās; skolēniem nav jāstrādā kopā. Nav skaidru uzdevumu, 
skolotājs nepārvalda metožu un pañēmienu tehniku, metodes netiek izmantotas efektīivi.

III grupas sniegums būtiski atšķiras kritēriju ziṇā pret skolēna mācišanos iedziḷinoties (vērtējums 0-1) un skolotāja tehniku un metožu efektivitāti (vērtējums 1-3). Tas vedina domāt: ja skolotāji labi tiek galā ar reproduktīvu mācību procesu, tad atbilde, kāpēc skolēnam nav iespēju stundās veikt produktīvus mācỉbu uzdevumus un sadarboties, var būt meklējama skolotāju uzskatos par mācīšanu un mācǐšanos. Tas ir turpmākas izpētes uzdevums.

IV grupas sniegums atrodas skalā starp 1 un 2; vērojamas arī lielākas konkrēta vērtējuma atšķirības starp kritērijiem. Šajā grupā ir tās stundas, kurās skolotāji mēgeina lietot mācīšanās iedzị̣inoties paṇēmienus, bet pagaidām vēl tas neizdodas efektīvi. Pozitīvi vērtējama skolotāju apṇemšanās atbilstošos mācību paņēmienus mēgeināt lietot. Piemēram, tiek formāli pateikts stundas mērḳis, nepārliecinoties, vai skolēni to saprot; skolotājs pārliecinās par rezultātu, bet skolēniem tiek tikai jautāts, kā viņiem patika stunda, t. i., skolēni nesaņem atbildi, ko darìt turpmāk; ir kāds atseviškss radošs uzdevums nelielā stundas daḷā, bet pamatā tiek vingrinātas zema kognitīva līmeņa prasmes; skolotājs uzdod jautājumus, bet gaida uz tiem vēlamās atbildes, faktiski veic atprasǐšanu, neveido sarunu; skolēni sēž grupā, bet uzdevums nav piemērots darbam grupā u. c.

Domājams, ka vērotais ir uzlūkojams kā objektīvs ilgtermiņa pārejas process, kurā saskatāma paradigmas maiņa klasē, mācību stundas līmenī. Ātrāki risinājumi iespējami, sniedzot individuālu atbalstu konkrētam skolotājam mācīšanās iedziḷinoties pieejas ieviešanā vai veidojot profesionālu skolotāju mācī̌sanos iedzilinoties.

Veidojot pēcstundu sarunas ar skolotāju, konstatēts, ka nereti atšķiras skolotāju pašu domas par stundā notikušo un ekspertu vērtējumi. Kā piemēru aplūkosim, kā skolotājiem izdodas vadīt skolēnu pētniecisko darbību ķīmijas stundās. Pētnieciskā mācīšanās dabaszinātnēs un matemātikā mācību saturā ir iekḷauta kopš 2006. gada; pētnieciskās darbības profesionālā organizācijā kompleksi izpaužas mācišanās iedzị̣inoties. Jel̦ena Volkinšteine (2018): Pēc skolotāju domām, viṇi prot efektīvi vadīt skolēnu pētniecisko darbību. Savukārt eksperti, kas vēroja stundas konstatēja, ka tikai vienā trešajā dal̦ā gadījumu skolotāji efektīvi realizēja izvēlēto mācību metodi stundā un lielākajā daļā vēroto stundu, kad, pēc skolotāju domām, notika pētnieciskā mācī̌sanās, stundā bija saskatāmi tikai atsevišḳi pētnieciskās darbības elementi. Lielākajai dal̦ai skolotāju prasmes skolēnu sadarbības organizēšanā pētnieciskajā darbībā pašnovērtējums ir augsts, tomēr stundu vērošanas un analīzes dati liecina, ka gandrīz divas trešdaļas skolotāju organizē skolēnu sadarbỉbu neefektīvi (Volkinšteine, 2018). 
Stundu vērojumi rāda tendenci, ka skolotāji jaunas metodes, paṇēmienus, idejas mēdz iekḷaut tradicionālajā praksē ("gatavu” zināšanu nodošanas modelī) kā atsevišķus elementus, bet skolotāja darbības nepalīdz skolēnam apgūt jaunas prasmes. Piemēram, mācību procesā iekḷaujot pētnieciskus problēmuzdevumus, vērojamas divas galējibas - skolēniem tiek dots uzdevums, ar kuru vini nespēj tikt galā, jo pietrūkst prasmju un tās netiek mācìtas, un skolēni nesaṇem atbilstošu skolotāja atbalstu, vai arī skolēnam nav iespēju pašam risināt problēmu viss process ir skolotāja virzīts, kontrolēts. Abos gadījumos pētniecisko prasmju apguve ir ierobežota, mācǐšanās nav efektīva (Volkinšteine, \& Namsone, 2014; Namsone, \& Čakāne, 2015; u. c.).

\section{Kā padarīt mācīšanu efektīvāku, skolotājiem mērḳtiecīgi mācoties pētīt mācību stundā notiekošo}

Skolotāju mācǐšanās iedziḷinoties norisinās, ja skolotāji mācās tādā pašā veidā, kā gribam, lai strādā ar skolēniem; tiek ṇemtas vērā dalībnieku vajadzības; virzìta, organizēta sadarbība; praktisku situāciju analīze; mācǐšanās formu dažādība; organizēta refleksija (Barzel, \& Selter, 2014). Iepriekš aplūkotā skolotāju snieguma vērtēšana, lietojot snieguma aprakstus līmen,os (rubrikas), vienlaikus kalpo, arī lai apzinātu skolotāju mācīšanās vajadzības.

Izvēloties profesionālās pilnveides veidu, nepieciešama skaidra atbilde, kādā līmenī vēlamies panākt profesionālās pilnveides (skolotāju profesionālas mācīšanās) ietekmi. Profesionālās pilnveides ietekmi aplūko četros līmeņos: pirmajā lìmenī - dalībnieku apmierinātîba un laime (happiness), otrajā līmeñ - skolotāju zināšanas, prasmes, uzskati, trešajā līmenī - mācišanas prakse klasē, ceturtajā ietekme skolēnu līmenī (Lipowsky, \& Rzejak, 2012). Iespējams un nepieciešams izvēlēties skolotāju konkrētajām mācǐšanās vajadzībām atbilstošāko profesionālās pilnveides veidu. Piemēram, skolotājiem, kuriem nepieciešams apgūt jaunu mācišanas pieredzi, ir lietderīgi piedalīties darbnīcā ar mācību stundu vērošanu un analīzi; skolotājiem, kuru praksē vērojama inovatīvu elementu (vairāk formas) iekḷaušana informācijas nodošanas modelī, uzdodot to par mācǐšanos iedziḷināties, būtu lietderīgs refleksijas prasmju treniņš u. c.

Veidojot skolotāju profesionālu mācišanos, jāizvirza skaidri kritēriji:

- nepieciešams, lai tiktu sasniegts mērḳis ieviest jaunas idejas (praksi);

- balstīties reālā skolu praksē, kur skolotāji var mācīties cits no cita;

- mācišanās notiek sadarbojoties, apmainoties idejām un daloties pieredzē;

- skolotāji gūst kolēgu atbalstu;

- katrs saņem atbalstošu atgriezenisko saiti par savu praksi; 
- mācās reflektēt;

- mācǐšanās ir koordinēta, bet nav hierarhiska;

- tā ir regulāra un ilgtermiṇa.

Skolotāju ilgtermiṇa profesionāla mācīšanās sadarbojoties ir balstīta atzinā, ka pārmaiṇas notiek, skolotājam iedziḷinoties savā praksē. To sekmē regulārs refleksijas prasmju treniņš, neskaitāmas reizes katras mācību darbnīcas vai semināra laikā ejot cauri ciklam, kas līdzinās rīcībpētījuma spirālei "vēro - reflektē - raksti - apspried” (Kemmis, \& McTaggart, 2000). Sadarbība, skolotājiem mērḳtiecīgi kopīgi vērojot un analizējot stundas, ir šì modeḷa pamatā. Sadarbība izpaužas, daloties ar idejām un materiāliem, darot kopīgu darbu: kopīgi mācot, plānojot un analizējot; vērojot mācību stundas; kopīgi analizējot un reflektējot par tām (Namsone, \& Čakāne, 2018).

\section{Kas ir zināms par mācību stundu izpēti literatūrā?}

Mācību stundu izpēte ir skolotāju profesionālās mācīšanās veids sadarbojoties, kas notiek klasē, fokusējoties uz mācību stundu, kas Japānā un Ḳīnā tiek praktizēts gadu desmitiem (Fernandez, \& Yoshida, 2004; Lewis, 2002; Lewis, \& Tsuchida, 1997, 1998). Fokuss ir uz kopīgu plānošanu un mācīšanās procesa vērošanu, kur skolotāji salīdzina klasē notiekošo ar to, ko viṇi domā, kam vajadzētu notikt, skolotājam lietojot mācīšanas paṇēmienus (Dudley, 2014, p. 10). Primārais fokuss ir nevis uz to, ko skolēni mācās, bet kā notiek mācīšanās. Tas ir atškirīịi no centieniem vērtēt mācību stundu efektivitāti ar skolēnu mācīšanās vērtējumu pirms un pēc stundas (Cerbin, \& Kopp, 2006). To arī dēvē par sistēmisku un skaidri formulētu prakses pārbaudi (Fernandez, 2002, p. 393). Mācību stundu izpēte ir drīzāk sistemātiska iedziḷināšanās (systematic inquiry) mācīšanas praksē. Piemēram, matemātikas mācīšana Japānā, pateicoties tieši mācību stundu izpētei, tika pārveidota no skolotājcentrēta skolēncentrētā procesā (Lewis, \& Tsuchida, 1998). Pētījumi rāda, ka mācību stundu izpētes teorētiskais modelis ietver pētīšanu, plānošanu, stundas izpēti, refleksiju un trīs ceḷus mācīšanas uzlabojumiem iejaucoties - pārmaiṇas skolotāju zināšanās un uzskatos, pārmaiṇas profesionālajā kopienā un pārmaiņas mācību resursos (Lewis, Perry, \& Hurd, 2009). Mācību stundas izpētes laikā individuāli skolotāji kḷūst par reflektējošiem profesionāliem pētniekiem un var novērot savu rīcību daudz objektīvāk (Roberts, 2010). Kā mācību stundu izpētes dimensijas tiek aplūkotas: klasē balstīta, skolotāju virzīta, stundai raksturīga, sadarbība, refleksija, problēmrisināšana, dalīšanās ar prakses pieredzi, mācīšanās vienam no otra (Puchner, \& Taylor, 2006; Pollard et al., 2014; Dudley, 2014). Pētījumi rāda, ka šāda mācīšanās palīdz skolotājiem pilnveidot profesionālās zināšanas, profesionālo praksi un paaugstina 
profesionālisma sajūtu (sense of professionalism) (Lee, 2008, Marble, 2007; Ono et al., 2011; Rock, \& Wilson, 2005). Tā palīdz mainìt skolotāju attieksmi un uzskatus par mācīšanu kā profesiju (Pella, 2011; Sibbald, 2009). Tiek uzsvērta jaunas kultūras veidošanās skolā kā mācǐšanās kopiena, kas šādi tiek attīstīta (Saito, Murase, Ttsukui, \& Yeo, 2014, p. 1).

Autori uzsver, ka mācību stundu izpēte, kopīgi plānojot un vadot, ir auglīga pieeja, lai samazinātu skolotāju izolētību (Hird, Larson, Okubo, \& Uchino, 2014). Sadarbība kā koleǵiāls atbalsts paaugstina skolotāju uzticēšanos jaunu mācī̌anas ideju izmēgināšanai (Meng, \& Sam, 2011).

Ketrīna Luisa (Catherin Lewis) (2009) paplašina stundu izpētes fokusu, parādot, ka tā ir skolotāju profesionāla mācī̌sanās, kuras laikā skolotāji attīsta jaunas zināšanas par to, kā šo saturu iemācìt otram (pedagogical content knowledge, $P C K)$, iegūst savā īpašumā mācīšanas metodes, jūtas vairāk atbildīgi par to, kā māca paši un kolēgi.

Mācību stundu izpēte: Japānā un Ķīnā ilgstoši un plaši izmantots profesionālās pilnveides veids, kas, piemēram, ASV iedzīvojas grūti (Gersten, Taylor, Keys, Rolfhus, \& Newman-Gonchar, 2014; Lewis, Perry, Hurd, \& O'Connell, 2006). Autori to skaidro ar to, ka mācību stundu izpētei nevar būt sākums un beigas, tas ir nepārtraukts process konkrētu mācību mērḳu sasniegšanai. Pētījums aplūko arī citus modelıus, kurus īstenojot faktiski tiek veikta mācību stundu izpēte, piemēram, mācību stundu izpēte sadarbojoties (Collaborative Lesson Research), mācīšanās izpēte (learning study) (Ling Lo, 2012, Marton, 2015), educational design research (McKenney, \& Reeves, 2013) u. c.

Pētnieki aplūko arī profesionālās pilnveides saistību ar mācīšanās fāzi, kurā skolotājs atrodas (skat. iepriekš par trīs fāzēm matemātikas mācǐšanā). Pirmajā fāzē tiek apgūtas zināšanas par matemātikas mācǐšanu, klausoties lekcijas, vērojot video u. c.; otrajā tiek veidota ekspertīze - skolotājiem uzmanīgi jāplāno stunda, jānovada tā, pamatojoties uz plānu, un jāreflektē par to, pamatojoties uz uzmanīgi novēroto u. c. Skolotāiiem mācoties katrā no fāzēm, Japānā tiek izmantota mācību stundu izpēte (Takahashi, 201199). Tā padara mācišsanos apzinātāku, praktiskāku, mērḳtiecīgāku. To sākts izmantot, veidojot skolotāju mācišanās programmas Latvijā.

9 Takahashi, A. (2011). Helping teachers work together to improve teaching \& learning. Pieejams: http://www.LSAlliance.org (aplūkots 14.02.2018.). 


\section{Kāda pieredze ir uzkrāta Latvijā}

Skolotāju ilgtermiṇa profesionālu mācīšanos sadarbojoties, kopīgi vērojot un analizējot mācību stundas eksperta (nodarbību vadìtāja) vadībā, Latvijā, Starpnozaru izglīīibas inovāciju centrā, praktizē kopš 2006. gada. Modelis tiek praktizēts, iesaistot skolu komandas (3-5 skolotājus un skolas vadības pārstāvi). To var izmantot arī individuālu skolotāju mācībām, veidojot ilgtermiṇa grupas, kas strādā regulāri. Modelis aprobēts dažādās skolotāju grupās, gan veidojot to starp skolām, gan vienā atsevišksā skolā. Iegūtā pieredze apkopota un publicēta (Namsone, \& Čakāne, 2018 u. c.).

Skolotāju mācīšanās norisinās, skolotājiem gūstot jaunu mācīšanas pieredzi, vērojot stundas, kopīgi analizējot un reflektējot par to (skat. 6 attēlu). Vienlaikus jāṇem vērā, ka modelis ir ilgtermiņa, tā veiksmīgai īstenošanai nepieciešams vismaz viens, vēlams vairāki mācību gadi. Viena darbnīca ar stundu vērošanu ir tikai viens atsevišks model̦a elements.

\section{SKOLOTĀJU MĀCĪŠANĀS MODELIS SKOLAS VIDĒ}

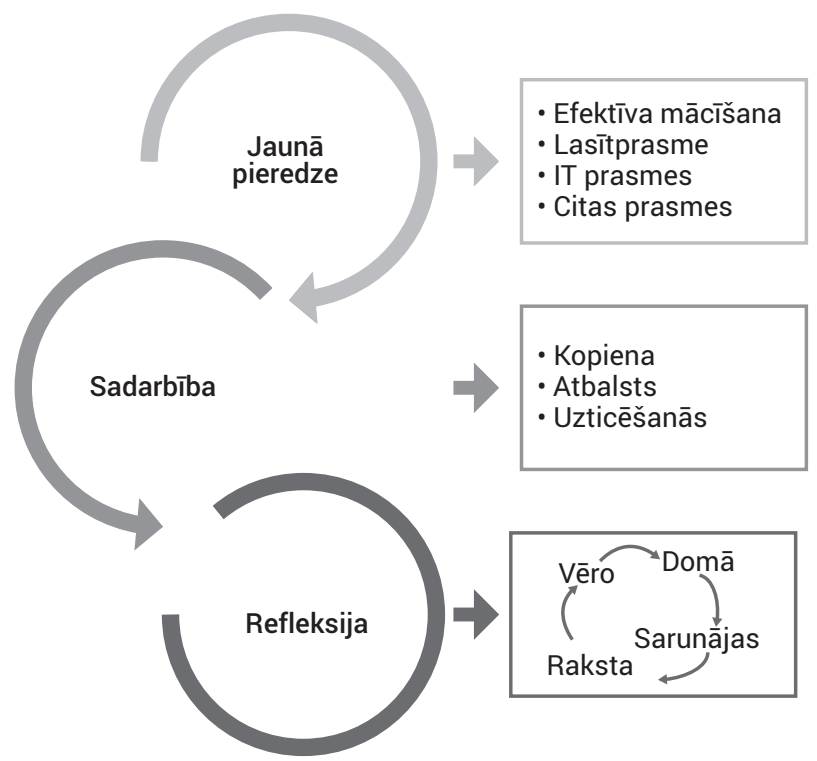

6. attēls. Skolotāju profesionālas mācīšanās modeḷu, sadarbojoties skolas vidē, kopīgā struktūra (adaptēts pēc Namsone, \& Čakāne, 2018) 


\section{Mācīšanās izpēte plānojot, veidojot un izmēǵinot}

Sadarbība ir ḷoti nozīmīga šādas skolotāju mācīšanās sastāvdaḷa, bet svarīga ir katra paša individuālā iedziḷināšanās. Lietojot šādu modeli izmēginājuma pētỉjuma vajadzībām, tika kombinēta mācīšanās, jaunu piemēru radīšana un skolotāju prakses pētišana. Šādas māciššnās pieredze tika aprobēta, veidojot regulāru skolotāju mācišanos sadarbojoties divu mācību gadu garumā, lai skolotājiem palīdzētu apgūt veidu, kā labāk plānot un vadīt klasē mācīšanos iedziḷinoties. 7. attēlā parādītas modeḷa trīs daļas - skolotāju patstāvīga mācišanās izpēte, sadarbība skolas komandā un mācǐšanās starp skolu komandām, savstarpēji vērojot un analizējot stundas.

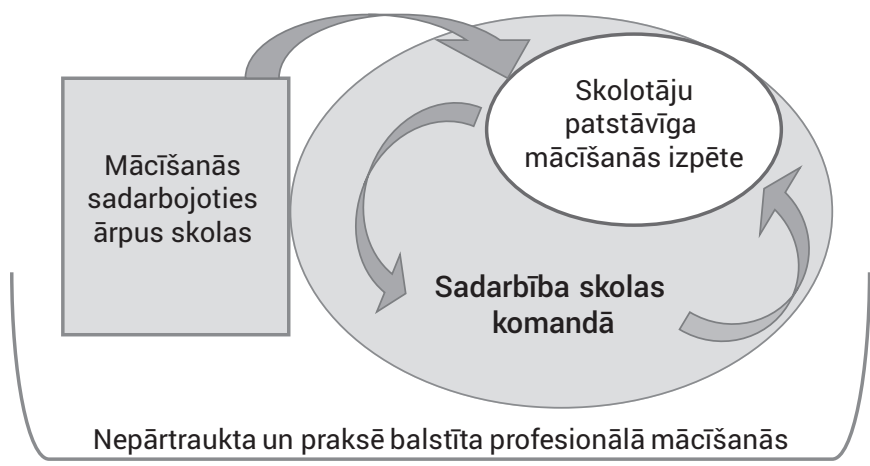

7. attēls. Skolotāju profesionālās mācīšanās modeḷ struktūra (adaptēts pēc Namsone, Čakāne, France, \& Butkēviča, 2016)

Pētījumā bija iesaistītas skolotāju komandas no 13 skolām. Katru komandu veidoja divi sākumskolas posma skolotāji un skolas vadības pārstāvis. Komandai bija uzdevums plānot un vadīt mācību stundas konkrētu (starp skolām atšḳirīgu) kognitīvu un metakognitīvu prasmju apguvei. Konsultanti vadija darbnīcas ar stundu vērošanu un analīzi, kas pētījuma laikā notika katrā no skolām; strādāja ar skolas komandu, dodot atgriezenisko saiti par mācību stundu plānošanas procesu. Pētijuma vajadzībām veidotās stundas un radītie stundu plāni tika vērtēti, izmantojot snieguma lìmeņu aprakstus (skat. 2. tabulu). Izmantojot rubrikas, tika pētìts, kā skolotājs progresē pētījuma laikā, analizējot radìtos mācību stundu plānus un vadītās mācību stundas. 
2. tabula. Skolotāju snieguma līmeṇu apraksts metakognitīvo prasmju mācīšanai

\begin{tabular}{ll}
\hline 0 & Nav priekšnoteikumu, lai notiktu mācīšanās apzināšanās \\
\hline 1 & $\begin{array}{l}\text { Skolēniem pirms darba izpildes ir zināms mācību mērkis un ar to saistītie snieguma } \\
\text { kritēriji; ir refleksija (İstenojas vismaz 1) }\end{array}$ \\
\hline 2 & $\begin{array}{l}\text { Pēc mācību aktivitātes notiek refleksija par tās jēgu; zināšanas un prasmes tiek skaidri } \\
\text { nosauktas, notiek saruna par to izmantošanas iespējām }\end{array}$ \\
\hline 3 & Skolēnam jādomā, kādā veidā mācās, kā domā, kā atceras \\
\hline 4 & $\begin{array}{l}\text { Skolēnam jāizvērtē dažādas stratēǵijas, to efektivitāte (kādā veidā mācās, kā domā, kā } \\
\text { atceras), jāizvēlas sev un situācijai atbilstošākā }\end{array}$ \\
\hline
\end{tabular}

Pētijuma dati uzrādīja lielu progresu kognitīvo prasmju, mazāku - metakognitīvo prasmju mācišanā. Skolotāji pētījuma noslēgumā veiktajā aptaujā uzsvēra, ka sākuši vairāk iedzilināties savā praksē, skolu vadības komandu pārstāvji akcentēja skolotāju profesionālo izaugsmi. Kā svarīgākos veicinošos faktorus skolotāji minēja kopīgu stundu vērošanu un analīzi ar kolēgiem (85\%); ilglaicīgu sadarbību ar nodarbību vadītāju; individuālu atgriezenisko saiti no kolẹgiem (75\%) un no nodarbību vadītāja (65\%) u. c. Skolotāji uzsvēra labās prakses piemēru lielo lomu un to, ka praktizēšanās ir izšḳiroša.

Modeḷa aprobācija apstiprina skolas komandas un vadỉbas lielo ietekmi uz individuāla skolotāja profesionālo izaugsmi (Namsone, Čakāne, France, \& Butkēviča, 2016).

\section{Mācīšanās grupa savas profesionālās darbības izpētei (rīcībpētījumam)}

Kāda no skolotājām raksta: "Mācīšanās izvēršas nepiespiesta... Ir noteikts gala punkts, mērkikis, kas ir manis pašas izvirzìts. Grupa rosina uz darbïbu, bet nepasaka priekšā." Ideja pētīt savu profesionālo darbību (action research; rīcībpētỉjums) izglītỉbā nav jauna. Pašreizējie priekšstati ir veidojušies visa 20. gadsimta laikā. Kurts Levins (Kurt Lewin) (Lewin, 1951) rakstija, ka "nekas nav tik praktisks kā laba teorija”; ir zināmas vairākas skolotāju - pētnieku kustības. Darbības pētǐšanu ietver rīcỉbpētijums (action research, Elliot, 1991); mācišanas pētijumu grupas (teaching research groups, Paine, \& Fang, 2007; Salleh, \& Tan, 2013 u. c.).

Mūsdienu uzskati par savas darbības pētī̌sanu pamatojas pieņēmumos, ka šai darbībai raksturīgi vairāki spirālveida cikli: problēmas (pētāmā jautājuma) identifikācija, datu ieguve, pārdomas, analīze un problēmas pārdefinēšana jeb 
vienkāršojot - plāno - dari - vēro - reflektē (Kemmis, \& McTaggart, 1988). Darbïbas pètijums ir skolotāja rīks savas prakses un refleksijas prasmju uzlabošanai ar mērḳi atrisināt vai uzlabot problemātisku situāciju (Taber, 2007).

Savas darbïbas pētījumam ir ietekme uz skolotāju praksi un izpratni par šo praksi, tiek pētìta situācija, kurā skolotājs atrodas. Šis pētijuma veids nekad nebūs perfekts, sākotnējais plāns mainīsies, spirāles posmi pārklāsies, tajā nav striktas soḷu secỉbas, uzmanība tiek pievērsta profesionālajai izaugsmei (Kemmis, \& McTaggart, 2005).

Pētījums tas ir tāpēc, ka tā laikā skolotāji uzkrāj datus par savu praksi. Skolotāji analizē šo praksi, veido izpratni par notiekošo; interpretē savus secinājumus un pieņem lēmumus turpmākai darbībai, akadēmiski pētnieki iesaistās kā palīgi. Ja skolotājs maina savu praksi, tam būs ietekme arī uz citiem skolotājiem. Pētījumā uzsvars likts uz konkrētas prakses pētišanu skolā.

Profesionālas darbības izpēte var būt izmantota, lai aizpildìtu plaisu starp teoriju un praksi (Johnson, 2012) un palīdzētu praktikiem attīstìt jaunas zināšanas tieši saistībā ar viņu darbu klasē (Hensen, 1996). Tā paplašina skolotāja pilnvaras un iespējas (Fueyo, \& Koorland, 1997). Vācot datus par savu darbību, viṇi var pieņemt lēmumus par savu skolu, klasi (Hensen, 1996). Ja skolotājiem aț̣auts uzņemties riskus un veikt atbilstošas izmaiņas mācību procesā, tad arī skolēnu sasniegumi uzlabosies (Marks, \& Louis, 1997). Darbïbas izpēte ir efektīvs un noderīgs līdzeklis profesionālajai izaugsmei (Osterman, \& Kottkamp, 1993), tas sniedz iespēju skolotājiem kritiski pārdomāt savu praksi, mainīt savu domāšanu un praksi (Cain, \& Harris, 2013; Hodgson, Benson, \& Brack, 2013) (Volkinšteine, 2018).

Rīcỉbpētijums ir individuāls process, kas balstās uz pašrefleksiju. Tā galvenā ideja ir, ka savas darbības pētnieks ir centrālā persona savas darbības pētǐšnā. "Es uzdodu jautājumu par reālu problēmu un ceru panākt risinājumu. Es sāku no vietas, kur es esmu. Es cenšos panākt stāvokḷa uzlabošanos." (McNiff, Lomax, \& Whitehead, 1996) Skolotājs reflektē par to, ko viṇš darīs, kā viṇam veicas, kā darìt citādāk u. c. Ir ieteicams pievērst uzmanību sadarbībai starp visiem dalībniekiem. Pētijuma laikā skolotāji izveido kopịgu sadarbības un komunikācijas platformu (Kemmis, \& Taggart, 2005). Tas ir vērsts uz skolotāja apzinātu darbību, kuras pamatā ir refleksīaa domāšana (Hodgson, Benson, \& Brack, 2013).

21. gadsimta sākumā dabaszinātṇu skolotāju profesionālā pilnveide pievēršas darbïbas pètijumiem, ne tikai lai uzlabotu konkrētu skolotāju praksi, bet arī lai gūtu empīirskus datus par to, kā norisinās mācǐšana un mācišanās, ieviešot jaunus jēdzienus, strādātu pie prasmju uzlabošanas, dokumentētu labo praksi u. c. (Eilks, \& Ralle, 2002; Eilks, \& Markic, 2011; Mamlok-Namman, \& Eilks, 2012, u. c.). 


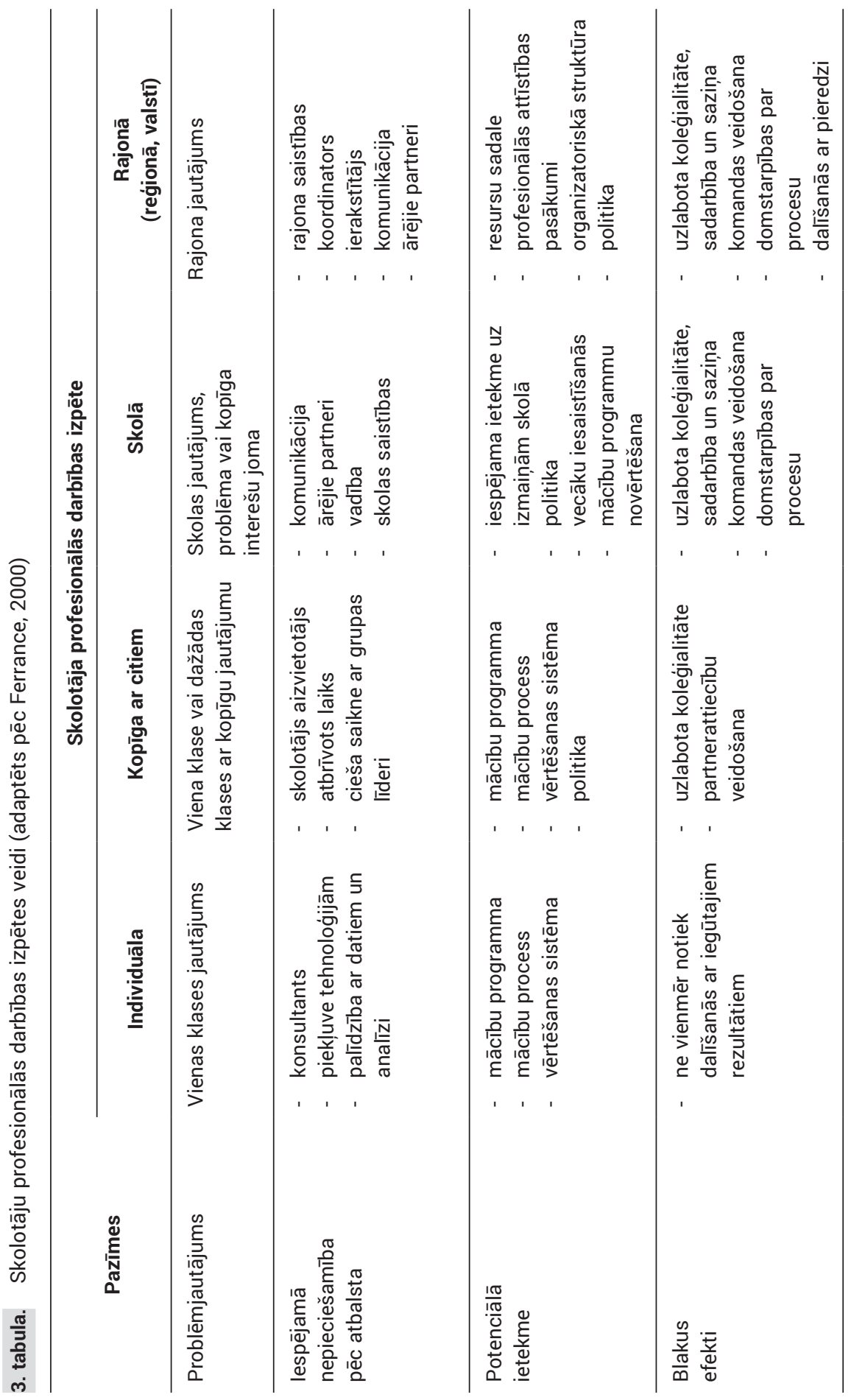


Prakse Latvijā, veidojot mācǐšanās grupu darbu, ir iegūta laikā kopš 2011. gada, kad tās tika īstenotas PROFILES ${ }^{10}$ projektā Latvijas Universitātes Dabaszinātņu un matemātikas izglìtības centrā (kopš 2016. gada LU SIIC) (Volkinšteine, Namsone, \& Logins, 2014), kā arī vēlāk vairākās skolās. Mūsu aplūkotajā modelī šis platformas funkciju veic mācišanās grupa, tāpēc aplūkoto profesionālās pilnveides modeli saucam par "mācīšanās grupu savas profesionālās prakses izpētei". Šădas grupas darbam ir it kā divas puses - individuāli norisinās savas darbības pētī̌sana, satiekoties grupā notiek sadarbība, komunikācija. Mācī̌sanās līdz ar to norisinās gan individuāli, gan sadarbojoties grupā.

Grupas darbs sākas ar dalībnieku mācīšanās vajadzību identificēěanu. İstenotā prakse rāda, ka ne katrā grupā ir iespējams pilnībā organizēt darbu kā savas darbības pētišanu. Ir pieredze, ka sākuma stadijā grupa strādā kā mācišanās grupa, kas regulāri satiekas, lai gūtu atbalstu, apmainītos pieredzē par mācī̌sanas praksi un uzskatiem par mācišanos, pārrunātu dažādas mācību situācijas, bet grupas dalībnieki vēl nespēj noformulēt individuālu pētāmo jautājumu. Sākot ieviest šādu mācīšanos skolā, ieteicams iet cauri posmiem: Mācāmies kopā! (Mācāmies ciešā līdera vadībā); Sadarbojamies! (Mācāmies, daloties pieredzē ar kolēgiem.) Grupā gūstam atbalstu. Izpētām! Mācāmies, pētot savu praksi un iedzị̣inoties paša izvirzìtos jautājumos (LU SIIC, PROFILES projekta materiāls, 2014). 8. attēlā parādīts, ka mācǐšanās grupas darba laikā darba mērḳis ir panākt izmaiņas ne tikai skolotāju praksē, bet arī skolēnu sniegumā. Darbības izpēte ir ilgtermiņa process. Mācǐšanās norisinās ilgtermiņā (viena vai vairāku mācību gadu garumā), tiekoties vienu reizi mēnesī grupā (ne vairāk par 10-12 dalībniekiem) klātienē un kā individuālais darbs, ko veic katrs dalībnieks patstāvīgi. 11. attēlā augšèjā dal̦ā parādīta darba norise klātienē; otrajā līmenī - katram grupas dalïbniekam individuāli veicot savas darbības pētijumu starplaikos starp tikšanās reizēm.

${ }^{10}$ Professional Reflection Oriented Focus on Inquiry-based Learning and Education through Science. Pieejams: http://www.profiles-project.eu/ (aplūkots 14.02.2018.). 


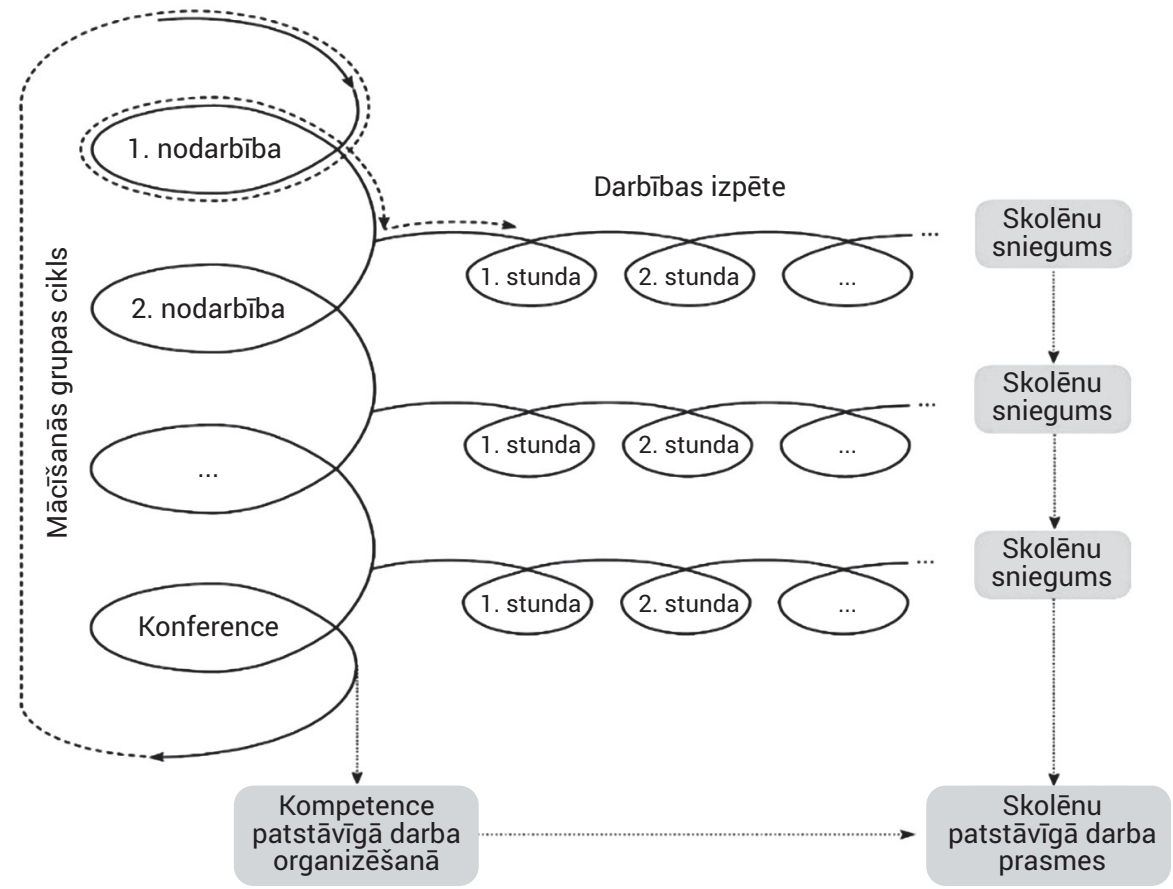

8. attēls. Mācīšanās grupas darba struktūra (Volkinšteine, \& Namsone, 2016)

Katrs grupas dalībnieks izvirza pētāmo jautājumu (problēmu), ko vēlas risināt, piemēram, "Kā uzlabot 10. klases skolēnu prasmi saskatìt pētāmo problēmu, formulēt atbilstošu hipotēzi, iekḷaujot tajā lielumus?”; "Rezultātu analīzes un izvērtējuma prasmju pilnveidošana skolēnu pētnieciskajā darbībā"; "Ja es došu skolēniem uzdevumu veikt īsu pētījumu ik pēc divām nedẹlām, vai vini iemācīsies formulēt pētāmo problēmu un hipotēzi?"; "Ja es katru otro nedẹlu piedāvāšu skolēniem izpildīt teorētisku uzdevumu, kurā pēc situācijas apraksta un formulētā problēmas jautājuma ir jāizvirza hipotēze, jāizvēlas atbilstoši darba piederumi un vielas un jāsastāda darba gaita, tad tas palīdzēs skolēniem pilnveidot prasmes šajā jomā", un plāno veidu, kā to iespējams izdarìt un kādi dati būs vajadzīgi, lai pārliecinātos par klasē notiekošo (Volkinšteine, 2018).

Grupas var apgūt vienu kopīgu tematu, piemēram "Skolēnu pētnieciskā darbïba", "Formatīvā vērtēšana" u. c., vai arī tajās var satikties dalïbnieki, kuri katrs izvirza individuāli pētāmo jautājumu. Ir prakse veidot mācīšanās grupas arī skolu vadītājiem un viṇu vietniekiem.

Mācīšanās grupas darbā tiek ievērota noteikta procedūra, kas tiek ievērota katrā nodarbībā, veicot noteiktus soḷus: refleksija (individuālā un grupā) par padarīto starplaikā; teorētisks materiāls par pētāmo saturu vai profesionālās 

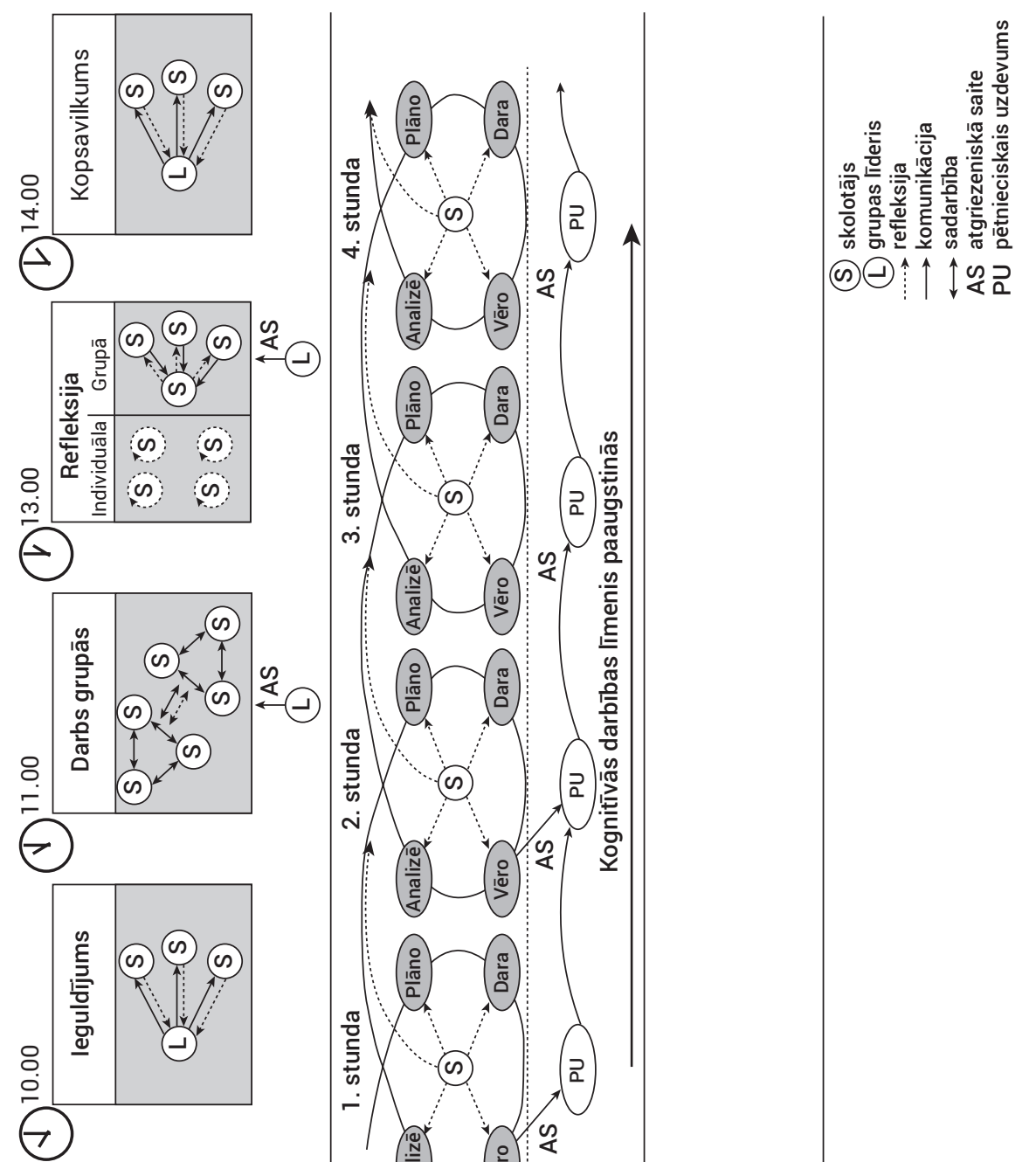

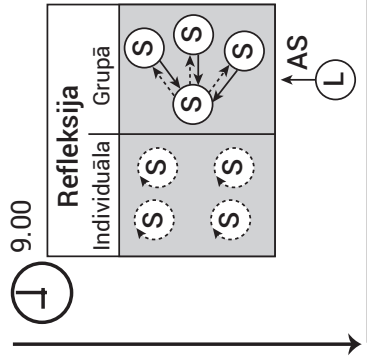

(ч s-†) eqıquepou

səuə!!’e|사

\section{लं}

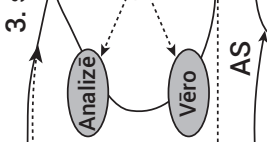

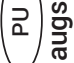

1)
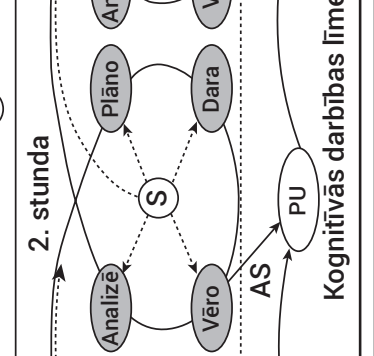

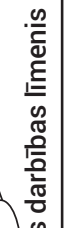

党

오
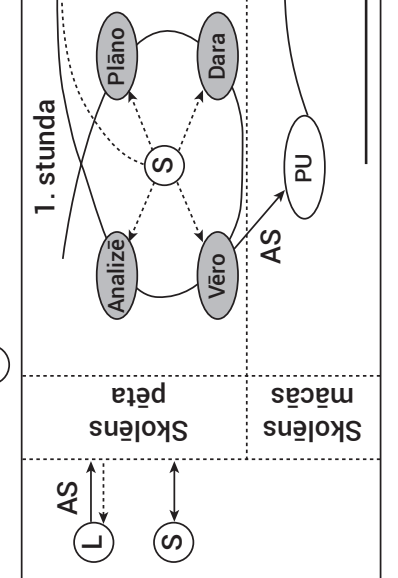

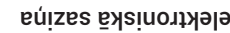

('ü̈ · l) sy!epdıets

(ч s-t) eqıquepou

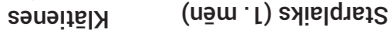

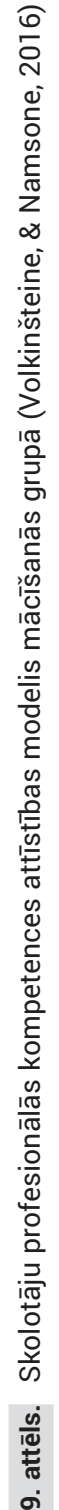


darbības izpēti; darbs grupās, refleksija (individuāla un grupā); grupas līdera kopsavilkums par dienā paveikto un mājas darbiem (skat. 9. attēlu). Mācīšanās grupas dalībnieku sadarbība notiek, skolotājiem kopīgi izstrādājot uzdevumus, kurus plānots dot skolēniem. Komunikācija norisinās kā brīva domu apmaiņa ar iespēju saņemt atgriezenisko saiti pēc vajadzïbas. Grupas līderis sniedz atgriezenisko saiti dalïbniekiem, vada refleksiju, sadarbïbu u. c.

Mācīšanās grupas darbību ietekmē vairāki faktori. Vēlams, lai mācīšanās grupā notiktu neformālā vidē. Svarīgi, lai saruna notiktu aplī, vajadzības gadījumā varētu strādāt arī mazās grupās. Valdot uzticēšanās attiecībām, draudzīgā, atvērtā vidē dalībnieks var gūt kolēgu un grupas līdera atbalstu. Viena no līdera funkcijām ir izcelt labās prakses piemērus jeb "skolotāju veiksmes stāstus", vairojot pozitīvu gaisotni grupas darbā, radot drošỉbas izjūtu un pārliecību par savu paveikto skolotājos.

Šì prakse rāda, ka uzmanība jāpievērš dalïbnieku atlasei grupas darbā. Ir svarīgi, lai skolotāji paši vēlētos piedalīties grupas darbā. Pēc skolas administrācijas rīkojuma skolotāju mācību process nav veiksmīgs.

\section{Skolotāju mācīšanās atbalsta personu loma}

Visiem aplūkotajiem skolotāju profesionālās pilnveides modeḷiem ir kopīga iespēja atšķirīgā veidā saṇemt dažādos veidos personalizētu, individualizētu atgriezenisko saiti par savu praksi, kas palidz to uzlabot (Kas izdodas? Kas ne? Ko darìt turpmāk?), faktiski norisinās skolotāju formatīvā vērtēšana. Vērtēšana, lai mācītos, tiek pārnesta uz skolotāju mācišanos. Kā norāda J. Hattie (effect size, vidēja ietekme 0,$4 ; 2012$ ) - ietekmes faktors tam ir 0,9 , kas ir vairāk nekā divas reizes augstāks par ikdienas mācību procesa ietekmi.

Atgriezenisko saiti dalībnieki saņem gan no nodarbïbu vadītāja, gan no kolēgiem. Tā kalpo kā atbalsts, iedrošinot mēginināt, darīt, kḷūdīties un vēlreiz mēǵināt praksē jaunus paņēmienus utt.

Mainoties profesionālās pilnveides mērkiem un līdz ar to tās norises veidam, mainās funkcijas, kuras veic persona, kas vada profesionālās pilnveides nodarbības. Arī terminolog̣ijā latviešu valodā līdztekus vārdam lektors kā nodarbību vadītājs ienāk vārdi - treneris, koučs, konsultants, eksperts, supervīzors (supervisory), mentors (mentor, tutor) un citi, kas apskata līdzīgu savstarpējā atbalsta formātu augstskolu vidē, tiek minēti arī jēdzieni atbalsta kolēgis (support collegue) un izglìitibas attīstītājs (educational developer) u. c. Šajā rakstā tiks lietota atbalsta persona vai nodarbību vadītājs darbam grupā. 
Iepriekš aplūkojām skolotāju mācǐšanos, kas norisinās grupā. Profesionālās pilnveides formām var pievienot arī individuālu mācīšanos, ja atbalsta persona (mentors, konsultants, eksperts) atrodas klasē.

Mentors var būt kā persona, kas specifiski apmācìta veikt atbalsta funkciju jaunajiem skolotājiem (Kačkere, Odiņa, \& Rieksta, 2005). Mentors ir viens no profesionālā atbalsta personu veidiem Latvijā, kura funkcijas un darbība, kā arī apmācība ir skaidri definēta. Mentora jēdziens ārvalstu prakses kontekstā tiek lietots līdzīgi, norādot, ka mentors ir atbalsta kolēgis ar lielāku pieredzi, kas atbalsta skolotāju-praktikantu (internu) pedagogiiskās prakses laikā vai pirmo darba gadu laikā. Nereti kā sinonīmi mentora jēdzienam anglu valodā tiek lietoti jēdzieni associate teacher, supervisory teacher (Le, \& Vásquez, 2011). Mentora darbībai pēcstundas diskusijā tiek piešķirta būtiska loma - pamatā mentors ir sarunas vadītājs un virzītājs, kas palīdz gan atbalstāmajam skolotājam objektīvi analizēt savu pieredzi, gan izvirzìt turpmākās darbības soḷus, kas saskan ar soḷiem refleksijas prasmju pilnveidei. Tādējādi secināms, ka mentora darbība ir vērsta uz refleksijas prasmju pilnveidi un ka mentors sarunā ieņem eksperta lomu un virza skolotāju uz refleksiju par savu darbību (Choy, \& Oo, 2012).

Strādājot ar pieredzējušiem kolẹgiem un īstenojot profesionālās pilnveides nodarbības (parasti grupā), kas ietver gan jaunas pieredzes (arī informācijas) apguvi, gan mācī̌sanos no prakses, analizējot un reflektējot par to, atbalsta persona veic vairāk funkciju nekā mentors. Strādājot grupā, atbalsta persona ir kā nodarbïbu vadītājs, kas veic arī lektora funkciju, gan daloties ar savu pieredzi, gan dodot nepieciešamo jauno saturu brīžos grupas darbā, kad rodas šāda vajadzība. Tas nozīmē, ka vadītājam ir arī funkcija diagnosticēt konkrētās dalībnieku mācīšanās vajadzības grupā (iepriekš sagatavojoties vai procesā) un uzreiz spēt uz tām reagèt, dodot īstajā brīdī tieši to informāciju, kas ir vajadzīga. Nodarbību vadītājam (atbalsta personai) sākot grupas darbu, ir jāspēj ieraudzìt, kurā refleksijas līmenī ir grupā iesaistīto dalībnieku refleksijas prasmes, lai izvēlētos atbilstošo procedūru.

Atbalsta personas loma (funkcijas) ir organizēt procesu (veidot procedūru) tā, lai grupas dalībnieki sadarbotos; lai ar katru nākamo reizi analīzes un refleksijas process notiktu dziḷāk (ne tikai parunāšanās, kas ir viens no riskiem šāda veida mācībās). Ir vairāki veidi, kā to iespējams darìt. Būtiskais ir tas, ka neviena aplūkotā metode nebūs efektīva, ja šì atbalsta persona nebūs ilgstoši trenēta profesionāli vadīt grupas darbu, analizēt un reflektēt, trenējusies vadìt un reflektêt šāda veida procesu, pieṇemt un sniegt atgriezenisko saiti individuāli un grupā.

Padomdevēji mācību stundu izpētes grupām tiek izvēlēti tāpēc, ka viniiem ir stipras mācību satura, pedagogiskās un mācību programmas zināšanas, ko viṇi 
var ienest grupā. Šie eksperti var palīdzēt grupai ar informāciju, tostarp jaunākajiem teorētiskajiem pētỉjumiem, kas var būt laikietilpīgi vai grūti katram skolotājam (Fernandez, 2002, p. 396). Atbalsta persona ar lielāku pieredzi var efektīvāk virzìt skolotāju uz apzinātu lēmumu pieņemšanu par turpmāko profesionālo darbību, balstoties uz autentiskām situācijām skolotāja pedagogiskajā pieredzē (Griffin, 2003). Analizējot pēcstundas diskusijas vadītāja funkcijas, veiktās darbības un tām būtiskās prasmes un īpašìbas, redzams, ka pētỉjuma rezultāti apstiprina būtiskus tādus refleksiju veicinošu faktoru - regulāru praktizēšanu (Rodgers, 2002; Bell, 2001). Atbalsta personai ir svarīgi ar vienu grupu strādāt ilgtermiņā (piemēram, viens vai labāk divi mācību gadi), izveidojot uzticēšanās attiecības, lai iesaistītie kolēǵi nebaidītos runāt ne vien par to, kas izdodas labi, bet arī par savām neveiksmēm - kur un kādi uzlabojumi nepieciešami.

Ja iesaistītajiem dalībniekiem vēl nav uzkrāta pieredze iedziḷināties savā un kolēgu praksē (piemēram, sākot savstarpējo stundu vērošanu vai mācīšanās grupu darbu skolā), nepieciešams, lai atbalsta persona būtu no ārpuses vai apguvusi šāda veida nodarbību vadīšanas treniņu programmu.

Līdzšinējie pētījumu dati rāda, ka lielu pievienoto vērtību skolotājiem, kuri vēlas mainīt savu praksi, bet pagaidām to dara nedroši, neefektīvi (IV grupa), var gūt, veicot savstarpējo stundu vērošanu pieredzējuša eksperta vadībā. Tas salīdzinoši īsā termiņā panāk izmaiņas praksē, notiek refleksijas prasmju pilnveide. II grupas skolotājiem var palīdzēt eksperts klasē, kas sniedz individuālu atbalstu. III grupas skolotājiem piemērotākās būtu profesionālās pilnveides formas, kas fokusējas uz skolotāju uzskatu maiņu. Rīcībpētijumu vajadzētu izvēlēties skolotājiem, kuru profesionālais sniegums jau ir salīdzinoši augsts (I grupa) un kuri vēlas sevi profesionāli pilnveidot.

\section{Secinājumi}

Skolēna mācǐšanās rezultāts būs dziḷa izpratne un kompetence, ja skolotāja īstenotās darbības - mācīšana - būs efektīva:

- tiek nodrošināta skolēna iespēja sekot mācišanās progresam - skolēnam ir skaidri mācišanās mērḳi un laba snieguma kritēriji gan ilgtermiņā, gan katrā mācību stundā; skolotājs īsteno efektīvu formatīvo vērtēšanu - skolēns saņem noderīgu atgriezenisko saiti par mērḳa sasniegšanu, viņam ir iespēja tūlìt korigêet savu sniegumu;

- skolotājs izmanto ilgtermiņa, integrētus mācību uzdevumus skolēniem, kas prasa gan iedziḷināšanos saturā, gan savas darbības plānošanu, monitorēšanu, koriǵēšanu; 
- skolotājs veido sadarbības attiecības ar skolēniem, kur pretstatā neefektīviem model̦iem (kur skolēnam ir vai nu pārāk liela autonomija, vai gluži otrādi - visu nosaka skolotājs), tiek īstenota partnerība, kas prasa izdarìt izvēles un uzṇemties atbildību.

Skolotāja sniegumu iespējams mērīt, izmantojot snieguma kritērijus un atsedzot sniegumu pa līmeniem. Snieguma apraksti līmeņos tiek veiksmīgi izmantoti skolotāju snieguma mērišanā pētnieciskām vajadzībām. Tos var izmantot pašnovērtējumā skolotāju personīgai izaugsmei un profesionālās pilnveides vajadzībām.

Vēroto stundu dati uzrāda četras snieguma grupas attiecībā pret mācīšanas efektivitāti.

LU SIIC veiktie pētijumi (Čakāne et al., 2015; France et al., 2015; Dudareva et al., 2015; Volkinšteine, Logins, \& Švirksts, 2014; Volkinšteine, \& Namsone, 2014; Volkinšteine, Namsone, \& Cakane, 2014, u. c.) par skolotāju prasmēm, savu prasmju un mācǐšanās vajadzību vērtējumu, skolotāju darbībām mācību stundā un skolotāju mācību aktivitātēs liecina, ka skolotājiem nepieciešamas atbalsts, lai veidotu mācǐšanos, darbinot dzị̣u domāšanu, stundās palielinātos produktīvu uzdevumu īpatsvars, uzlabotos skolotāju prasme veidot sarunu, nevis "atprasī̌sanu", būtu jēgpilns IKT lietojums.

Novērotais ir uzlūkojams kā objektīvs ilgtermiṇa pārejas process, kurā saskatāma paradigmas maiṇa klasē, mācību stundas līmenī.

Aktualizējas jautājums par skolotāju uzskatiem, kas ir mācǐšanās un kā skolēnam palīdzēt šo prasmi apgūt (piemēram, mērḳu izvirzišana, kvalitatīva atgriezeniskā saite). Saskatāma plaisa starp skolotāja prasmju pašnovērtējumu un ekspertu konstatēto vērotajās mācību stundās.

Katrā no šìm metodēm citā veidā ir iespēja saṇemt dažādos veidos personalizētu, individualizētu atgriezenisko saiti par savu praksi, kas palīdz to uzlabot (Kas izdodas? Kas ne? Ko darīt turpmāk?), jeb skolēnu formatīvā vērtēšana (atgriezeniskās saites process) tiek pārnesta uz skolotāju mācišanos, panākot būtisku ietekmi uz praksi.

Profesionālās pilnveides modelim jāatbilst šādiem kritērijiem: iespēja ieviest inovatīvu praksi; balstās skolu praksē, kur dalībnieki var mācīties cits no cita; dalībnieki mācās, sadarbojoties un daloties pieredzē; skolotāji jūt kolēǵu atbalstu un saṇem atgriezenisko saiti; mācās reflektēt nevis hierarhiski, bet koordinēti; aktivitātes notiek ilgtermiņā un regulāri.

Plānojot profesionālo pilnveidi, svarīgi paredzēt, kādā līmenī vēlamies panākt profesionālās pilnveides ietekmi: dalībnieku apmierinātība; uzlabojumi skolotāju zināšanās, prasmēs, uzskatos; izmaiņas skolotāju praksē vai skolēnu sniegumā. Uz katru līmeni ietekme var būt atškịīgām profesionālās pilnveides 
formām. Ietekmi uz praksi (trešajā līmenī), panāk, profesionāli veidojot mācību stundu izpēti (savstarpējo stundu vērošanu), radot un izmēginot stundu piemērus kopā ar kolēgiem, veicot savas darbības izpēti. Izšķirošas ir nevis profesionālās pilnveides nodarbības, bet gan veiksmīga praktiskās ieviešanas pieredze, kuru skolotājs gūst, izmēgiinot iemantotās idejas savā praksē; tā maina skolotāju attieksmi un uzskatus.

Mācību stundu izpētes procesa fokusā ir mācišana un mācǐšanās, prioritāri - nevis ko mācās, bet kā tas notiek. Tā ir sistemātiska, ilgtermiņa skolotāju iedziļināšanās mācǐšanas praksē. Mūsu pētìtais sakrīt ar citvalstu pētnieku atziņu, ka tam nav beigu, tam jānorisinās visu laiku, lai sasniegtu konkrētus mācīšanās un mācišanas mērḳus.

LU SIIC izstrādāts un istenots modelis savstarpējai stundu vērošanai ietver trīs dimensijas: jaunas pieredzes apguvi, refleksiju un sadarbību. Tas tiek realizēts, ilgtermiṇā īstenojot regulāras aktivitātes skolas vidē. Uzlabotais modelis ir kombinēts, tas ietver trīs nozīmīgus struktūrelementus: ilgtermiṇa, regulāras kopīgas darbnīcas savstarpējai stundu vērošanai un analīzei; mācišsanas pētīšana starp darbnīcām, radot un izmēginot stundu piemērus; sadarbība skolas komandā. Modelis ir aprobēts praksē izmēginājumskolu grupā un veiksmīgi izmantojams caurviju prasmju (21. gadsimta prasmju) mācīšanas pieredzes uzkrāšanā. Izmēǵinājuma pētījums parāda, ka ir vajadzīgs laiks, lai skolotāji saskatītu atšķirību un iekḷautu savā praksē ne tikai zinātnes mācību satura, bet arī šo prasmju mācǐšanas elementus.

Darbs mācišanās grupā savas profesionālās darbības izpētei ir mācišanās, pētot savu praksi, kas norisinās individuāli un sadarbojoties grupā. Skolotāji veic pētijumu, uzkrājot datus par savu praksi, analizējot šo praksi, pilnveidojot izpratni par notiekošo; interpretē savus secinājumus un pieṇem lēmumus turpmākai darbībai; sadarbojas grupā. Latvijā gūtā pieredze apstiprina, ka darbs mācīšanās grupā savas profesionālās darbības izpētei palīdz skolotājiem uzlabot viņu prasmes, kā arī uzlabot skolotāju praksi. Vērojama tendence skolēnu sasniegumiem uzlaboties, mainās skolēnu attieksme pret mācību priekšmetu, palielinās skolēnu interese un vēlme mācìties.

Atbalsta personas funkcijas aplūkotajos skolotāju mācīšanās modelı ir sarunas vadītājs un virzìtājs, kura darbība ir vērsta uz refleksijas prasmju pilnveidi; būt lektoram, daloties ar informāciju un pieredzi, ja nepieciešams, diagnosticēt konkrētās dalībnieku mācišanās vajadzības grupā (iepriekš sagatavojoties vai procesā) un nekavējoties spēt uz tām reageêt; organizēt procesu (veidot procedūru) tā, lai grupas dalībnieki sadarbotos lai ar katru nākamo reizi analīzes un refleksijas process notiktu dziḷāk. 


\section{IZMANTOTĀ LITERATŪRA}

Barber, M., \& Mourshed, M. (2007). How the world's best-performing schools systems come out on top. McKinsey \& Company.

Barzel, B., \& Selter, C. (2015). Die DZLM-Gestaltungsprinzipien für Fortbildungen. Journal für Mathematik-Didaktik, 36(2), pp. 259-284.

Bell, M. (2001). Supported reflective practice: a programme of peer observation and feedback for academic teaching development. International Journal for Academic Development, 6(1), pp. 29-39. http://doi.org/10.1080/13601440110033643

Cain, T., \& Harris, R. (2013). Teachers' action research in a culture of performativity. Educational Action Research, 21(3), pp. 343-358.

Čakāne, L., Volkinšteine, J., Namsone. D., \& France, I. (2015). What lesson observation data reveal about the changes in teaching science: a case study from Latvia. In Lamanauskas, V., Šlekiene, V., Raguliene, L. (eds.). State-of-Art and Future Perspectives. Proceedings of the

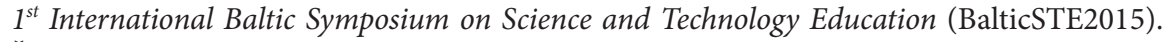
Šiauliai: The Scientia Socialis Press, pp. 30-32.

Cerbin, W., \& Kopp, B. (2006). Lesson study as a model for building pedagogical knowledge and improving teaching. International journal of teaching and learning in higher education, 18(3), pp. 250-257.

Choy, S., \& Oo, P. (2012). Reflective thinking and teaching practices: A precursor for incorporating critical thinking into the classroom. International Journal of Instruction, 5(1), pp. 167-182. http://doi.org/e-ISSN:1308-1470

Dudareva, I., Namsone, D., \& Čakāne, L. (2015). The development of students` digital competence and physics teacher's professional development needs. Conference of International Research Group on Physics Teaching (GIREP EPEC) 06-10.07.2015. Wroclaw, Poland.

Dudley, P. (2014). Lesson Study: Professional learning for our time. Routledge.

Eilks, I., \& Markic, S. (2011). Effects of a long-term Participatory Action Research project on science teachers' professional development. Eurasia Journal of Mathematics, Science and Technology Education, 7(3), pp. 149-160.

Eilks, I., \& Ralle, B. (2002). Participatory Action Research in chemical education. In Ralle, B., \& Eilks, I. (eds.). Research in chemical education - what does this mean? (pp. 87-98). Aachen: Shaker.

Elliot, J. (1991). Action research for educational change. McGraw-Hill Education (UK).

Farr, S. (2010). Teaching as Leadership: the Highly Effectice Teacher's Guide to Closing the Achievement Gap. Jossey-Bass.

Fernandez, C. (2002). Learning from Japanese approaches to professional development the case of lesson study. Journal of teacher education, 53(5), pp. 393-405.

Fernandez, C., \& M. Yoshida. (2004). Lesson study: A case of a Japanese approach to improving instruction through school-based teacher development. Mahwah, NJ: Lawrence Erlbaum Associates.

Ferrance, E. (2000). Action Research. Northeast and Islands Regional Educational Laboratory At Brown Universtiy. Pieejams: https://www.brown.edu/academics/education-alliance/ publications/action-research (aplūkots 14.02.2018.).

France, I., Namsone, D., \& Cakane, L. (2015). What Research Shows about Mathematics Teachers' Learning Needs: Experience from Latvia. In SOCIETY, INTEGRATION, EDUCATION (Vol. 2, pp. 45-55). http://dx.doi.org/10.17770/sie2015vol2.457 
Fueyo, V., \& Koorland, M. A. (1997). Teacher as researcher: A synonym for professionalism. Journal of Teacher Education, 48(5), pp. 336-344.

Fullan, M., \& Langworthy, M. (2014). A rich seam: How new pedagogies find deep learning. London: Pearson. Pieejams: http://www.michaelfullan.ca/wp-content/uploads/ 2014/01/3897.Rich_Seam_web.pdf (aplūkots 10.02.2018.).

Gersten, R., Taylor, M. J., Keys, T. D., Rolfhus, E., \& Newman-Gonchar, R. (2014). Summary of research on the effectiveness of math professional development approaches. (REL 2014-010). Washington, DC: U.S. Department of Education, Institute of Education Sciences, National Center for Education Evaluation and Regional Assistance, Regional Educational Laboratory Southeast.

Griffin, M. L. (2003). Using Critical Incidents to Promote and Assess Reflective Thinking in Preservice Teachers. Reflective Practice, 4(2), pp. 207-220. http://doi.org/10.1080/ 14623940308274

Hargreaves, A., \& Fullan, M. (2012). Professional capital. Transforming teaching in every school. Nueva York, NY: Teachers College Press of Columbia University.

Hattie, J. (2012). Visible learning for teachers: Maximizing impact on learning. Routledge.

Hattie, J., \& Yates, G. (2014). Visible Learning and the Science of How We Learn. London, New York: Routledge.

Helmke, A. (2009). Unterrichtsqualität und Lehrerprofessionalität - Diagnose, Evaluation und Verbesserung des Unterrichts. Seelze: Klett-Kallmeyer in.

Hensen, K. T. (1996). Teachers as researchers. In J. Sikula (ed.). Handbook of research on teacher education ( $4^{\text {th }}$ ed., pp. 53-66). New York: Macmillan Library Reference USA.

Hird, M., Larson, R., Okubo, Y., \& Uchino, K. (2014). Lesson study and lesson sharing: an appealing marriage. Scientific Research Publishing, Inc.

Hodgson, Y., Benson, R., \& Brack, C. (2013). Using action research to improve student engagement in a peer-assisted learning programme. Educational Action Research, 21(3), pp. 359-375.

Jayaram, K., Moffit, A., \& Scott, D. (2012). Breaking the habit of ineffective professional development for teachers. McKinsey on Society, McKinsey \& Company.

Johnson, A. P. (2012). A short guide to action research ( $4^{\text {th }}$ ed.). New Jersey: Pearson Education.

Kačkere A., Odiṇa I., Rieksta S. (2005). Mentorings Eiropā. Latvijas perspektīva. Rīga: Latvijas Universitāte. Pieejams: http://www.menttime.tsn.at/cms/upload/pdf/00_druk_mentors_latviski.pdf (aplūkots 14.02.2018.).

Kemmis, S., \& McTaggart, R. (1988). The action research planner ( $3^{\text {rd }}$ ed.). Victoria, Australia: Deakin University Press.

Kemmis, S., \& McTaggart, R. (2005). Participatory Action Research: Communicative Action and the Public Sphere. Sage Publications Ltd.

Le, P. T. A., \& Vásquez, C. (2011). Feedback in teacher education: mentor discourse and intern perceptions. Teacher Development, 15(4), 453-470. http://doi.org/10.1080/13664530.2011. 635264

Lee, J. F. K. (2008). A Hong Kong case of Lesson Study - benefits and concerns. Teaching and Teacher Education, 24, pp. 1115-1124.

Lewin, K. (1951). Field Theory in Social Science; Selected Theoretical Papers, edited by D. Cartwright, New York: Harper and Row.

Lewis, C. (2009). What is the nature of knowledge development in lesson study? Educational action research, 17(1), pp. 95-110. 
Lewis, C. (2002). Lesson Study: A handbook of teacher-led instructional change. Philadelphia, PA: Research for Better Schools.

Lewis, C. C., Perry, R. R., \& Hurd, J. (2009). Improving mathematics instruction through lesson study A theoretical model and North American case. Journal of Mathematics Teacher Education, 12(4), pp. 285-304.

Lewis, C., \& Tsuchida, I. (1997). Planned educational change in Japan: The case of elementary science instruction. Journal of Educational Policy12(5) pp. 313-331.

Lewis, C., \& Tsuchida, I. (1998). A lesson is like a swiftly flowing river: Research lessons and the improvement of Japanese education. American Educator, 14(17), 50-2.

Lewis, C., Perry, R., Hurd, J., \& O'Connell, M. P. (2006). Lesson Study Comes of Age in North America. Phi Delta Kappan, 88(04), pp. 273-281.

Ling Lo, M. (2012). Variation theory and the improvement of teaching and learning. Göteborg: Acta Universitatis Gothoburgensis.

Lipowsky, F., \& Rzejak, D. (2012). Lehrerinnen und Lehrer als Lerner - Wann gelingt der Rollentausch? Merkmale und Wirkungen effektiver Lehrerfortbildungen. Schulpädagogik heute, 5(3), pp. 1-17.

Mamlok-Namman, R., \& Eilks, I. (2012). Different Types of Action Research to Promote Chemistry Teachers' Professional Development - A Joint Theoretical Reflection on Two Cases from Israel and Germany. International Journal of Science and Mathematics Education, 10, pp. 581-610.

Marble, S. (2007). Inquiring into teaching: lesson study in elementary science method. Journal of Science Teacher Education, 18, pp. 935-953.

Marks, H. M., \& Louis, K. S. (1997). Does teacher empowerment affect the classroom? The implication of teacher empowerment for instruction, practice and student performance. Educational Evaluation and Policy Analysis, 19(3), pp. 245-275.

Marton, F., \& Runesson, U. (2015). The idea and practice of learning study. Realising Learning. Teachers' Professional Development through Lesson and Learning Study, pp. 103-121.

McKenney, S., \& Reeves, T. C. (2013). Conducting educational design research. Routledge.

McNiff, J., Lomax, P., \& Whitehead, J. (1996). You and your action research project. London: Hyde Publications.

Meng, C. C. \& Sam, L. C. (2011). Encouraging the Innovative Use of Geometer's Sketchpad through Lesson Study. Creative Education, 2(03),236. DOI:10.4236/ce.2011.230

Namsone D., \& Čakāne L. (2015.) What lesson observation data reveal about the changes in teaching science and mathematics?. $11^{\text {th }}$ biannual Conference ESERA 2015. Helsinki, Finland, 31.08.-04.09.2015.

Namsone D., \& Čakāne L. (2018). A Collaborative Classroom-Based Teacher Professional Learning Model. In Yeo J., Teo T., \& Tang KS. (eds). Science Education Research and Practice in Asia-Pacific and Beyond (pp. 177-195). Springer, Singapore. DOI: https://doi. org/10.1007/978-981-10-5149-4_13

Namsone, D., Čakāne, France, I., \& Butkēviča A. (2016). Lesson-based Professional Development as a Way to Help Primary Teachers Teach $21^{\text {st }}$ Century Skills. Proceedings of the ICERI2016, Seville, Spain, 14.-16.11.2016.

Ono, Y., Chikamori, K., Shongwe, Z. F., \& Rogan, J. M. (2011). Reflections on a mutual journey of discovery and growth based on a Japanese-South African collaboration. Professional Development in Education, 37(3), pp. 335-352.

Osterman, K. F., \& Kottkamp R. B. (1993). Reflective practice for educators: Improving schooling through professional development. Newbury Park, CA: Corwin. 
Paine, L. W., \& Fang, Y. (2006). Reform as hybrid model of teaching and teacher development in China. International Journal of Educational Research, 45(4), pp. 279-289.

Pella, S. (2011). A situative perspective on developing writing pedagogy in a teacher professional learning community. Teacher Education Quarterly, winter: pp. 107-125.

Pollard, A., Black-Hawkins, C., Cliff-Hodges, G., Dudley, P., James, M., Linklater, H., Swaffield, S., Swann, M., Turner, F., Warwick, P., Winterbottom, M., \& Wolpert, A. (2014). Reflective Teaching in Schools. London. Bloomsbury.

Prensky, M. (2001). Digital Natives, Digital Imigrants. From On the Horizon (MCB University Press, Vol. 9, No. 5, October 2001).

Puchner, L. D., \& Taylor, A. R. (2006). Lesson study, collaboration and teacher efficacy: Stories from two school-based math lesson study groups. Teaching and teacher education, 22(7), pp. 922-934.

Roberts, M. (2010). Lesson Study: Professional Development and Its Impact on Science Teacher Self-Efficacy. Ph. D. Dissertation, New York: Columbia University.

Rock, T. C., \& Wilson, C. (2005). Improving teaching through lesson study. Teacher Education Quarterly, 32(1), pp. 77-92.

Rodgers, C. (2002). Defining Reflection: Another Look at John Dewey and Reflective Thinking. Teachers College Record, 104(4), pp. 842-866.

Saito, E., Murase, M., Tsukui, A., \& Yeo, J. (2014). Lesson Study for Learning Community: A Guide to Sustainable School Reform. Routledge.

Salleh, H., \& Tan, C. H. P. (2013). Novice teachers learning from others: Mentoring in Shanghai schools. Australian Journal of Teacher Education, 38(3), 152-165.

Sibbald, T. (2009). The relationship between lesson study and self-efficacy. School Science and Mathematics, 109(8), pp. 450-460.

Taber, K. S. (2007) Classroom-based research and evidence-based practice. Los Angeles: Sage

Volkinšteine J., \& Namsone D. (2014). What lesson observation data reveal about the skills of Latvian chemistry teachers to organize students' scientific inquiry? $19^{\text {th }}$ International conference "EcoBalt 2014". Riga, October 8-10, 2014.

Volkinšteine, J. (2018). Skolotāja kompetence organizēt skolēnu pētniecisko darbību kịimijā. Nepublicēta disertācija pedagogijas doktora zinātniskā grāda iegūšanai, Daugavpils Universitāte.

Volkinšteine, J., Logins, J., Švirksts, J. (2014). Skolotāju prasme organizēt skolēnu sadarbību ķīmijas mācību procesā Latvijā. In Proceeding of the $55^{\text {th }}$ International Scientific Conference of Daugavpils University/sast. Inese Zugicka, Daugavpils Universitāte. Daugavpils: Saule, pp. 760-768.

Volkinšteine, J., Namsone, D., \& Logins, J. (2014). Teachers' Learning Team as a tool to Improve Scientific Inquiry Teaching. In Bolte, C., Holbrook, J., Mamlok-Naaman, R., \& Rauch, F. (eds.). Science teachers Continuous Professional Development in Europe. Case Studies from the PROFILES Project (pp. 157-161). Berlin: Freie Universitat Berlin; Klagenfurt: Alpen- Adria- Universitat Klagenfurt.

Volkinšteine, \& J., Namsone, D. (2016). Science Teachers' learning team for the action research as a way of improving inquiry teaching practice. $9^{\text {th }}$ annual International Conference of Education, Research and Innovation ICERI2016, Spain, Seville, IATED, pp. 3911-3920.

Volkinšteine, J., Namsone, \& D., Čakāne, L. (2014). Latvian chemistry teachers' skills to organize student scientific inquiry. Problems of Education in the 21 $1^{\text {st }}$ Century, Vol. 59, pp. 86-98. 
8. nodala

\section{Informācijas tehnoloǵijas mācīšanās iedzilinoties atbalstam}

Inese Dudareva

Šobrīd reti kura darbības joma ir iedomājama bez informācijas tehnolog̣iju (IT) lietojuma. Izglìitibas joma nav izṇēmums. IT ierīces un rỉki tiek lietoti informācijas meklēšanai, apkopošanai, prezentēšanai, savstarpējai saziņai, datu ieguvei un apstrādei, procesu simulēšanai, jaunu zināšanu un produktu radīšanai u. tml.

Zinātniskajā literatūrā tiek lietots jēdziens Leveraging digital kā viens no četriem elementiem, kas paātrina piekḷuvi globālām zināšanām un veicina mācīšanos iedzilinoties. ${ }^{1}$

Ar šo jēdzienu saprot digitālo tehnologiju pieejamību un tehnologiju potenciālu nodrošināt personalizētās mācīšanās iespējas, komunikācijas un sadarbības iespējas, iespējas veikt vērtēšanu reālā laikā, sniegt tūlītēju atgriezenisko saiti, iespējas atrast, apkopot, apstrādāt un prezentēt informāciju, piekḷūt autentiskiem mācību kontekstiem (Fullan, \& Langworthy, 2013).

\section{Kas ir digitālā kompetence}

Digitālā kompetence ir viena no astoṇām Eiropas Komisijas definētām mūžizglìīibas pamatprasmēm jeb kompetencēm. Digitālā kompetence tiek definēta kā spēja izmantot tehnolog̣ijas, lai iegūtu, uzkrātu, veidotu, novērtētu un apmainìtos ar informāciju, lai droši komunicētu un līdzdarbotos sadarbības/sociālajos

1 New Pedagogies for Deep Learning. A global partnership. Pieejams: http://npdl.global/makingit-happen/new-pedagogies/ (aplūkots 16.02.2018.). 
tîklos, izmantojot interneta un tehnolog̣iju iespējas; spēja pārliecinoši un kritiski izmantot informācijas tehnoloǵijas mācībās darbā un brīvajā laikā. ${ }^{2}$

Digitālo kompetenci veidojo šādi faktori:

- IT lietošanas pamatprasmes - izpratne par to, kā darbojas IT rīki, un spēja izvērtēt šo rīku iespējas un ierobežojumus;

- mediju pratība - nepieciešamo zināšanu, prasmju un domāšanas apguve, lai apzināti, kritiski un aktīvi spētu izmantot komplekso un mainīgo mediju informāciju;

- informācijas pratība - spēja formulēt jautājumus, analizēt avotus, veikt sistemātisku informācijas meklēšanu, atlasīt un apstrādāt lielu datu apjomu, izvērtēt informācijas izmantojamību un uzticamību;

- digitālā problēmrisināšana (computational thinking) - spēja pārfrāzēt problēmas un organizēt datus tā, lai tos varētu analizēt un problēmas atrisināt, izmantojot datortehnologijas. ${ }^{3}$

Mācoties skolā, skolēniem jāapgūst zināšanas, prasmes un attieksmes, kas viniem ļautu iesaistìties un attīstìties arī digitālajā vidē. Tas aptver ne tikai tehniskas prasmes lietot IT rīkus, bet arī mediju un informācijas pratību, sadarbības un komunikācijas prasmes, zināšanu radīšanu un problēmu risināšanu, izmantojot IT rīku piedāvātās iespējas.

ISTE (International Society for Technology in Education) ${ }^{4}$ 2016. gadā ir izstrādājusi standartus, kas jārealizē mācību procesā skolēniem dažādos vecuma posmos un visos mācību priekšmetos, lai skolēni attīstìtu un pilnveidotu digitālo kompetenci. Šie standarti nosaka, ka skolēnam ir:

- jāattīsta pašvadītas mācišanās prasmes (Empowered learner), t. i., skolēns, izmantojot informācijas tehnologiijas, spēj iesaistīties savu mācīšanās mērḳu izvēlē, to sasniegšanā, sasniegtā demonstrēšanā, kā arī refleksijā par savu mācỉbu procesu;

- jākḷūst par digitālu pilsoni (Digital Citizen), t. i., skolēns zina un atpazīst tiesības, pienākumus un iespējas, kā droši, legāli un ētiski darboties digitālajā pasaulē, gan meklējot informāciju un izmantojot tiešsaistē esošos resursus, gan komunicējot sociālajos tìklos;

2 Eiropas Komisija. (2007). Mūžizglìtības galvenās pamatprasmes. Eiropas pamatprincipu kopums. Pieejams: http://jaunatne.gov.lv/sites/default/files/web/Jaunatne_darbiba/Info_materiali/ Brosuras/2012/kompetences.pdf (aplūkots 16.02.2018.).

3 Kennisnet Trend Report. (2016/2017). Technology Compass for Education. How smart ICT prepeares our students for future. Pieejams: https://www.kennisnet.nl/fileadmin/kennisnet/ corporate/algemeen/Kennisnet_Trendreport_2016_2017.pdf (aplūkots 16.02.2018.).

4 ISTE Standards for Students. (2016). Pieejams: https://www.iste.org/standards (aplūkots 16.02.2018.). 
- jāattīsta zināšanu konstruēšanas prasmes (Knowledge Constructor), t. i., skolēni izmanto informācijas tehnolog̣ijas un digitālos resursus, lai konstruētu zināšanas, radītu jaunus produktus un veidotu jēgpilnu mācīšanās procesu un pieredzi sev un citiem;

- jākḷūst par inovatīvu radītāju (Innovative Designer), t. i., skolēni izmanto dažādas informācijas tehnoloğijas, lai identificētu, risinātu un atrisinātu problēmas, radot jaunus, noderīgus vai teorētiskus risinājumus;

- jāattīsta digitālās problēmrisināšanas prasmes (Computional Thinker), t. i., skolēni izstrādā un lieto problēmu izpratnes un risināšanas stratēǵijas - izmanto informācijas tehnologiju piedāvātās iespējas - datu ieguvi, apstrādi un analīzi, kā arī programmēšanu;

- jāattīsta komunikācijas un prezentācijas prasmes (Creative Communicator), t. i., skolēni, izmantojot dažādus IT rīkus, platformas un digitālos medijus, atbilstoši izvirzītajiem mērḳiem komunicē un prezentē sava mācību darba rezultātus;

- jākḷūst par sadarbības partneri (Global Collaborator), t. i., skolēni, izmantojot IT rīku iespējas, sadarbojas ar citiem ne tikai lokālā, bet arī globālā mērogā.

2017. gadā ISTE ir izstrādājusi arī standartus, kas skolotājiem ir jārealizē savā profesionālajā darbībā, lai viṇi attīstītu un pilnveidotu savu digitālo kompetenci un būtu gatavi organizēt mācību procesu tā, lai skolēni varētu attīstīt un pilnveidot digitālo kompetenci.

Piemēram, İrijas National Council for Curriculum and Assessment (NCCA) jau 2007. gadā izstrādāja IT ietvaru, kas aptver 15 specifiskus ar IT saistītus skolēniem sasniedzamos rezultātus. ${ }^{5}$ Materiāls tika veidots kā rokasgrāmata, lai palīdzētu skolotājiem mērḳtiecīgi un ar atbilstošiem resursiem integrēt IT izmantošanu mācību procesā dažādos vecuma posmos un dažādos mācību priekšmetos.

Piedāvātais ietvars tiek balstīts uz pamatpieṇēmumu, ka IT var dot pievienoto vērtību mācību procesā, ja to izmanto mērkstiecīgi un ar atbilstošiem resursiem.

Ietvara mērḳi, lai l̦autu skolotājiem atbalstīt skolēnus:

- atklāt IT potenciālu - radīt, komunicēt un sadarboties, organizējot un radot informāciju (joma C);

- saprast un lietot zināšanas par IT funkcijām, tostarp drošu IT lietošanu, uzturēšanu un ergonomiku (joma F);

- lietot IT domāšanas prasmju attīstīšanai mācību procesā, iekḷaujot pētniecību, informācijas izvērtēšanu, problēmu risināšanu un ideju radīšanu dažādās priekšmetu jomās (joma T);

5 NCCA (2007). ICT Framework. A structured approached to ICT in Curriculum and Assessment. 
- attīstīt kritisku skatu uz IT lomu sabiedrībā un paradumiem, kas atspogulo ètisku un atbildīgu IT lietošanu (joma S).

Kā piemēru, kā tas izpaužas dažādos vecuma posmos, apskatīsim vienu sasniedzamo rezultātu jomā "Kritiski un radoši domāt" (skat. 1. tabulu).

1. tabula. Sasniedzamais rezultāts jomā "Kritiski un radoši domāt" (ICT Framework, National Council for Curriculum and Assessment, 2007)

\begin{tabular}{|c|c|}
\hline T2 & Izvērtēt, organizēt un sintezēt informāciju, lietojot IT \\
\hline $\begin{array}{l}\text { I līmenis } \\
\text { Sākumskola } \\
\text { (1.-3. klase) }\end{array}$ & $\begin{array}{l}\text { grupēt informāciju, attēlus vai tekstu atbilstoši dotajiem kritērijiem - } \\
\text { vienādi, atšḳirīgi izmēri, forma u. c.; } \\
\text { diskutēt ar skolotāju un konsultantiem par informācijas meklēšanas } \\
\text { rezultātu lietderību; } \\
\text { sākt atšḳirt faktus no stāstiem skolotāja izvēlētās mājaslapās; } \\
\text { saskatīt jēgu uz ekrāna attēlotā tekstā un attēlos }\end{array}$ \\
\hline $\begin{array}{l}\text { Il līmenis } \\
\text { Pamatskola } \\
\text { (4. -6. klase) }\end{array}$ & $\begin{array}{l}\text { diskutēt un attīstīt pañēmienus, lai izvērtētu informācijas ticamību, } \\
\text { derīgumu un piemērotību elektroniskajiem resursiem un mājaslapām; } \\
\text { organizēt un grupēt informāciju, lietojot diagrammas, grafikus, domu } \\
\text { kartes un mapes }\end{array}$ \\
\hline $\begin{array}{l}\text { III līmenis } \\
\text { Pamatskola } \\
\text { (7.-9. klase) }\end{array}$ & $\begin{array}{l}\text { izvērtēt informācijas un datu atbilstību un ticamību, kas iegūti no } \\
\text { elektroniskajiem avotiem, ṇemot vērā iespējamās neprecizitātes, } \\
\text { motivāciju un viedokḷus; } \\
\text { izvilkt būtiskāko informāciju no vairākiem informācijas avotiem, lietojot } \\
\text { IT informācijas sagrupēšanai (t. i., domu karte, teksta apstrādes } \\
\text { programmas u. c.); } \\
\text { radīt jaunu informāciju, sintezējot un integrējot ar IT atrasto informāciju. }\end{array}$ \\
\hline
\end{tabular}

Sasniedzamo rezultātu - izvērtēt, organizēt un sintezēt informāciju, lietojot IT - skolēns apgūst pakāpeniski un secīgi dažādos vecuma posmos. Tādējādi, beidzot pamatskolu, viņš ir apguvis un pilnveidojis prasmi.

Jāņem arī vērā, ka vairums skolēnu mūsdienās lieto digitālo vidi - sociālos medijus, tūlītējos ziṇu apmaiñas servisus (WhatsApp, SnapChat u. c.), sociālos tìklus (Facebook, draugiem.lv u. c.), izmanto lietotnes, kas mobilajās ierīcēs ir pieejamas nepārtraukti. Liela daḷa skolēnu dzīves notiek un attīstās digitālajā vidē. Marks Prenskis (Mark Prensky) (2001) apgalvo, ka digitālās pasaules "iedzimtie" domā un mācās fundamentāli citādāk, pateicoties viṇu pieredzei digitālajā pasaulē. Jaunā paaudze dod priekšroku ātrai informācijas ieguvei un apmainai, izmantojot IT, bieži darbojas ar daudziem uzdevumiem (multitasking) vienlaikus, viņiem piemìt zema tolerance attiecībā pret lekcijām, viṇi dod priekšroku aktīvai, nevis pasīvai darbïbai. 
Kriss Džones (Chris Jones) un kolēgi (Jones, \& Shao, 2011) veica padziḷinātu dažādu visā pasaulē veiktu pētījumu literatūras apskatu par digitālas vides “iedzimtajiem”, kas būtu jāṇem vērā izglītībā. Daži secinājumi:

- topošajiem un esošajiem studentiem ir l̦oti atšḳirīgs digitālo mediju zināšanu un prasmju līmenis;

- digitālās pratības pārrāvums starp skolēniem un skolotajiem nav tik milzīgs, ka nebūtu pārvarams;

- skolēni un studenti pozitīvi novērtē tehnoloǵiju integrāciju mācību priekšmetos un studiju kursos, ja tās tiek jēgpilni izmantotas.

Tehnoloğijas un mediji ir tikai rīki mācību procesā. Līdz ar to uzsvars ir jāliek nevis uz kādu konkrētu rīku vai mediju, bet uz tehnolog̣iju lietojumu atbilstoši plānotajam mērķim (Bates, 2015). Tā kā medijos izmanto dažādas simbolu sistēmas, formātus, kultūras vērtības, tas nodrošina to pieejamību un atbalstu, lai skolēniem palīdzētu mācīties dažādos veidos, savā tempā un sasniegt arī atšķirīgus rezultātus. Skolotājam jāizvērtē, kuri IT rīki būs piemēroti, kādās situācijās tie palīdz sasniegt plānoto mērḳi, atbalstot skolēnu - konstruējot zināšanas, sadarbojoties, komunicējot, mācoties iedziḷinoties u. tml.

Kādas iespējas sniedz IT lietošana mācību procesā ${ }^{6}$, detalizētāk aplūkosim priekšrocības e-mācību vidē:

- palielinās interese darboties ar tehnologiijām neatkarīgi no mācību priekšmeta;

- iespēja mācīties jebkurā vietā un jebkurā laikā;

- pieejami strukturēti mācību materiāli arī skolēniem, kuri nav bijuši skolā;

- pieejami daudzveidīgi informācijas pasniegšanas formāti: dokumenti, prezentācijas, video, animācijas, u. c.;

- piekḷuve globālajiem resursiem, kas atbilst dažādiem sagatavotības līmeņiem un interesēm;

- iespēja mācīties sev atbilstošā tempā un plānot savu laiku mācībām;

- iespēja mācīties atbilstoši dažādiem mācīšanās stiliem;

- iespēja sekot saviem mācību sasniegumiem;

- iespēja sadarboties ar citiem;

- vairāk atbildības par mācīšanās procesu;

- vairāk laika, lai diskutētu kopā un iedziḷinātos mācību saturā klātienē;

- vairāk iespēju komunicēt ar individuāliem skolēniem, izmantojot e-mācību vidē pieejamo tērzētavu, forumu, e-pastu u. c., sniedzot individuālu atgriezenisko saiti un diskutējot par aktuāliem jautājumiem;

6 Teach-Thought. The Benefits of Blended Learning. Pieejams: https://www.teachthought.com/ technology/the-benefits-of-blended-learning/ (aplūkots 16.02.2018.) 
- atbalsts individuāli katram skolēnam, lai radītu iespējas mācīties iedzilinoties, jo nav ierobežojuma, cik reižu skatīties video, cik reižu izpildīt testus, cik reižu lasìt piedāvāto informāciju;

- sagatavo skolēnus tam, kā mācǐšanās notiks nākotnē, kad darba vajadzībām būs nepieciešams apgūt jauno patstāvīgi - saprast, kur un kā meklēt informāciju, kur un kā saņemt atbalstu.

\section{Pasaulē veiktie pētījumi par IT lietojumu mācību procesā}

Nav viennozīmīgi apstiprinošu pētījumu, ka IT lietošana mācību procesā uzlabo akadēmiskos mācỉbu sasniegumus, jo ir veikti dažādi gadijuma nevis visaptveroši pētījumi. Gadījuma pētijumos faktori, kas nav salīdzināmi: iesaistīto skolotāju un skolēnu digitālā kompetence, kā arī IT pieejamība aplūkotajā situācijā (Livingstone, 2012). Tas, kādu ietekmi uz skolēnu mācību sasniegumiem atstāj IT, nosaka atbilde uz jautājumiem - vai IT tiek lietotas kā rīks, kas palīdz ātrāk veikt darbības? Vai IT izmantošana pilnībā maina mācīšanās veidu? Ar digitālo rīku palīdzību var attīstīt gan mijiedarbības, gan sadarbības prasmes, kritisko domāšanu, kā arī līdera prasmes, kas ir nozīmīgas darba tirgū. Integrēta tehnolog̣iju lietošana mācību procesā palielina skolēna darbības efektivitāti un snieguma kvalitāti, nodrošina skolēnu iesaistî̌šnos mācību aktivitātēs, panāk skolēnu pozitīvāku attieksmi pret mācību procesu (Underwood, 2009).

IT lietojums mācību procesā palielina skolēnu motivāciju iesaistîties mācību procesā, attīsta digitālās prasmes, nodrošina patstāvīgu mācīšanos un veicina savstarpējo sadarbību. Skolēni uzņemas lielāku atbildību par mācišanos, jo, izmantojot IT, viṇi var mācīties savā tempā, atbilstoši viṇu vēlmēm un vajadzībām (Rodrigues, 2010). Skolotājiem ir vieglāk diferencēt mācību procesu, strādājot gan ar talantīgiem skolēniem, gan skolēniem ar mācǐšanās grūtībām, kā arī ar skolēniem ar speciālām vajadzībām (Diass, 1999).

IT lietojums mācību procesā ietekmē skolēnu sasniegumus ${ }^{7}$, ja:

- skolotājs pārvalda IT rīkus un viņam ir izpratne par IT izmantošanu, kas virzìta atbilstoši plānotajiem mērḳiem;

- skolēns arī ārpus klases lieto IT rīkus mācībām, veltot vairāk laika konkrētā jautājuma apgūšanai;

- skolotājs ar IT rīku palīdzību sniedz atbalstu skolēniem, kuriem nepieciešama papildu palīdzība;

7 ICF Consulting Services Ltd. (2015). Literature Review on the Impact of Digital Technology on Learning and Teaching. Pieejams: http://dera.ioe.ac.uk/24843/1/00489224.pdf (aplükots 16.02.2018). 
- IT rīkus lieto kā papildinājumu, nevis kā aizstājēju tradicionālam mācību procesam klasē;

- skolotājs mērḳtiecīgi lieto tehnologijas mācību procesā.

IT rīku un digitālo resursu jēgpilnai lietošanai ir potenciāls atbalstìt un organizēt skolēnu mācīšanos iedziḷinoties, kā arī iespējas skolēniem pašiem pieņemt lēmumus, konstruēt zināšanas, modelēt situācijas, risināt problēmas, sadarboties un komunicēt ar kolēgiem, radīt jaunas lietas, kā arī sekot savai izaugsmei.

IT rìku un digitālo resursu jēgpilna lietošana palīdz:

- mācīties efektīvāk, ko nodrošina iespēja saṇemt atgriezenisko saiti uzreiz procesā;

- veidot daudzpusīgu skatu uz apskatāmo problēmu, ko nodrošina digitālie resursi: teksti, video, attēli, animācijas, simulācijas, modelēšanas programmatūras, kā arī iespējas forumos un sociālajās platformās uzdot jautājumus un pamatot savu viedokli;

- radìt izcilus darbus, ko nodrošina iespēja saglabāt, pārskatīt un pilnveidot radito;

- konstruēt zināšanas vidē, kas rada iespējas aktīvi iesaistīties procesā, iegūt nepastarpinātu pieredzi, mācīties no labās prakses piemēriem;

- mācīties jebkurā vietā un jebkurā laikā, ko nodrošina digitālo resursu pieejamība (Abbott, Townsend, Johnston-Wilder, \& Reynolds, 2009).

\section{Skolotāju digitālās kompetences pilnveide}

Kā liecina Eiropas Komisijas salīdzinošā pētījuma dati par IT izglìtîbā Eiropas skolās, divas trešdal̦as no Eiropas savienības skolotājiem pilnveido savu digitālo kompetenci brīvajā laikā. Tomēr, neskatoties uz pilnveidei veltīto laiku, daudzi skolotāji IT rīkus mācību procesā pamatā lieto, lai sniegtu un patērētu informāciju, nevis lai būtiski pārveidotu mācišsanās pieredzi. ${ }^{8}$

Arī skolotāji Latvijā ir apguvuši prasmes IT rīku un digitālo resursu lietošanā. Skolotājiem ir zināšanas par jēgpilnu IT rīku lietošanu mācību procesā, bet izpildījums praksē ne vienmēr par to liecina. Lai IT lietojums sāktu reāli ietekmēt skolēnu sasniegumus, nepieciešams laiks: no IT ieviešanas skolā, skolotāju

8 European Union. (2013). Survey of Schools: ICT in Education.Benchmarking Access, Use and ttitudes to Technology in Europe's Schools. Pieejams: https://ec.europa.eu/digital-singlemarket/sites/digital-agenda/files/KK-31-13-401-EN-N.pdf (aplūkots 16.02.2018.). 


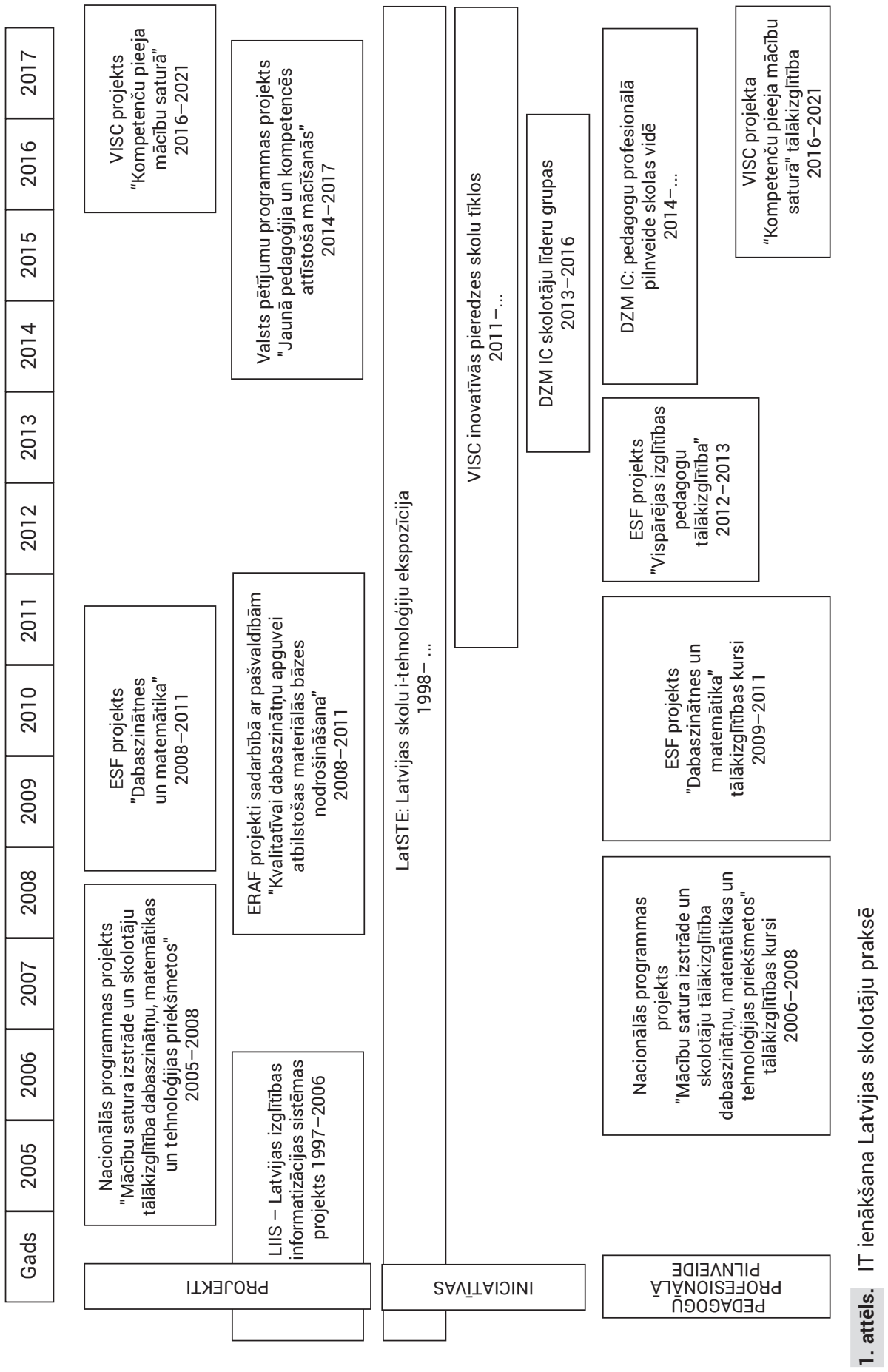


profesionālās kompetences paaugstināšanas līdz reālai ietekmei uz skolēnu sasniegumiem (Ramboll Management, 2006 ; European Schoolnet, 2006 ${ }^{10}$ ).

Kopš 1998. gada skolotāji, kuriem bija interese par IT lietojumu mācību procesā, varēja apmainīties ar pieredzi un gūt jaunas idejas Latvijas skolu i-tehnologiiju ekspozīcijā. ESF dabaszinātņu projektos: 1) skolas tika apgādātas ar mūsdienīgu laboratorijas aprīkojumu, demonstrāciju ierīcēm, IT ierīcēm; 2) tika izveidoti skolotāju atbalsta materiāli un skolēnu darba lapas; 3) tika organizēta arī skolotāju profesionālā pilnveide (skat. 1. attēlu).

\section{Kā mērīt - kādas ir iespējas skolēniem darbināt IT, lai mācītos iedziḷinoties}

2014 -2016. gadā Latvijas Universitātes Dabaszinātṇu un matemātikas izglìtîbas centra eksperti vienas pašvaldības 10 skolu 7.-12. klasē vēroja 64 dabaszinātņu priekšmetu mācību stundas. Pētījumā iesaistītās skolas aptvēra dažādu skolu tipus: mazas lauku skolas, lielas pilsētas skolas, kā arī gimnāzijas. Viens no pētījuma jautājumiem bija noskaidrot, cik mērkstiecīgs ir IT rỉku lietojums dabaszinātṇu mācību procesā. Vērojot stundu, eksperts veica mācỉbu procesa transkripciju: aprakstīja, kas notiek stundā, ko dara skolotājs un ko dara skolēni, lai pēc stundas norises apraksta varētu analizēt stundu atbilstoši šādiem kritērijiem:

- kā par plānoto sasniedzamo rezultātu tiek informēti skolēni;

- kā skolotājs un skolēni pārliecinās par plānotā rezultāta sasniegšanu;

- cik efektîvas ir stundā realizētās mācību metodes;

- cik lielā mērā skolēni iesaistās mācību procesā;

- kā tiek realizēta sadarbība starp skolēniem un skolotāju;

- vai un cik jēgpilni mācību stundā tiek izmantots IT.

Lai noskaidrotu, kā skolēni lieto IT mācību procesā - cik aktīvi vai pasīvi IT lietotāji ir skolēni; vai skolēniem ir iespējas izmantot IT rīkus aktīvai zināšanu konstruēšanai vai jaunu produktu radīšanai -, stundu vērošanā iegūto datu analīzē tika izmantota adaptēta rubrika Use of ICT for Learning (Microsoft Partners in Learning, 2012) (skat. 2. tabulu). Šajā rubrikā ar IT saprot gan digitālās ierīces (datori, planšetes, viedtelefoni, datu uzkrājēji, sensori, interaktīvās tāfeles u. c.), gan programmatūru (tostarp interneta pārlūkprogrammas, sociālie tīkli, animācijas, simulācijas, projektēšanas programmas u. c.). Rubrikā ir fokuss uz IT

9 Ramboll Management. (2006). E-learning Nordic 2006: Impact ICT on Education. Denmark.

${ }^{10}$ European Schoolnet. (2006). The ICT Impact Report. A review of studies of ICT impact on schools in Europe. Pieejams: http://unpan1.un.org/intradoc/groups/public/documents/unpan/ unpan037334.pdf (aplūkots 16.02.2018.). 
lietošanu zināšanu konstruēšanai, problēmu risināšanai un inovāciju radī̌̌anai. Šie nav vien̄igie IT lietojumi mācību procesā, bet šādi var pārveidot mācīšanās pieredzi, izmantojot IT rīku piedāvāto potenciālu.

2. tabula. Rubrika: IT lietošana mācību procesā

\begin{tabular}{ll}
\hline Līmenis & \multicolumn{1}{c}{ Kritēriji } \\
\hline 1 & Skolēniem nav iespējas izmantot IT aktivitātes veikšanai \\
\hline 2 & $\begin{array}{l}\text { Skolēni lieto IT, lai apgūtu vai pilnveidotu pamatprasmes vai reproducētu } \\
\text { informāciju. Skolēni nekonstruē zināšanas }\end{array}$ \\
\hline 3 & $\begin{array}{l}\text { Skolēni lieto IT zināšanu konstruēšanai, bet šīs pašas zināšanas var konstruēt } \\
\text { arī bez IT rīkiem }\end{array}$ \\
\hline 5 & $\begin{array}{l}\text { Skolēni lieto IT zināšanu konstruēšanai, un IT ir nepieciešams, lai konstruētu } \\
\text { šis zināšanas, bet skolēni nerada IT produktu }\end{array}$ \\
\hline 5 & $\begin{array}{l}\text { Skolēni lieto IT zināšanu konstruēšanai, un IT ir nepieciešams, lai konstruētu } \\
\text { šis zināšanas, skolēni rada IT produktu }\end{array}$ \\
\hline
\end{tabular}

3. tabulā minēti piemēri, kad skolēni lieto IT zināšanu konstruēšanai dažādos līmeṇos atbilstoši rubrikai - IT lietošana mācību procesā.

3. tabula. Rubrika: zināšanu konstruēšanas līmeṇi, lietojot IT

\begin{tabular}{|c|c|}
\hline Lìmenis & Piemēri \\
\hline 1 & $\begin{array}{l}\text { Skolēniem nav iespēju izmantot IT aktivitātes veikšanai. } \\
\text { Skolēns mācās par elektrostaciju veidiem, skatoties skolotāja demonstrēto } \\
\text { animāciju/prezentāciju/video. } \\
\text { Skolēns mācās par atškirīīām starp kristāliskām un amorfām vielām, veicot } \\
\text { uzdevumus skolotāja izdrukātā darba lapā. }\end{array}$ \\
\hline 2 & $\begin{array}{l}\text { Skolēni lieto IT, lai apgūtu vai pilnveidotu pamatprasmes vai reproducētu } \\
\text { informāciju. Skolēni nekonstruē zināšanas. } \\
\text { Skolēns mācās lietot temperatūras sensoru un datu uzkrājēju, veicot mērījumus, } \\
\text { kā atdziest ūdens. } \\
\text { Skolēns veido kopsavilkumu par sēṇu daudzveidību, izmantojot kādu no } \\
\text { prezentācijas programmām (MS PowerPoint, prezi.com u. c.). }\end{array}$ \\
\hline 3 & $\begin{array}{l}\text { Skolēni lieto IT zināšanu konstruēšanai, bet šīs pašas zināšanas var konstruēt } \\
\text { arī bez IT rīkiem. } \\
\text { Skolēns konstruē grafiku, kā mainās apgaismojums atkarībā no attāluma, } \\
\text { izmantojot datu uzkrājēja programmatūru vai MS Excel. } \\
\text { Skolēns pēta dažādu škīìumu pH līmeni, lietojot datorsimulāciju. }\end{array}$ \\
\hline
\end{tabular}




\begin{tabular}{|c|c|}
\hline Līmenis & Piemēri \\
\hline 4 & $\begin{array}{l}\text { Skolēni lieto IT zināšanu konstruēšanai, un IT ir nepieciešams, lai konstruētu } \\
\text { šīs zināšanas, bet skolēni nerada IT produktu. } \\
\text { Skolēns mācās, kā veidojas zvaigznes, kā notiek kodolreakcijas, kā veidojas } \\
\text { molekulas, lietojot datorsimulāciju. } \\
\text { Skolēns meklē internetā informāciju par kādu notikumu no dažādu valstu } \\
\text { informācijas avotiem un analizē kopīgo un atškirīgo atrastajā informācijā. }\end{array}$ \\
\hline 5 & 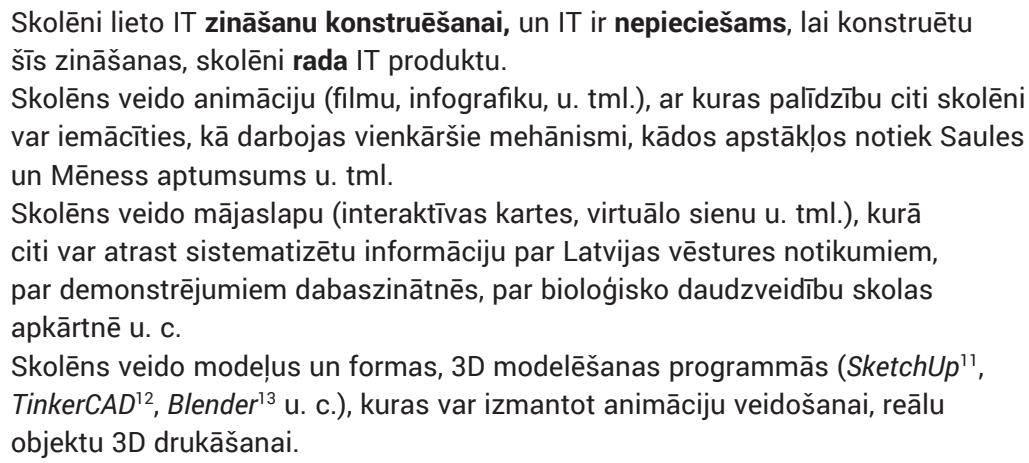 \\
\hline
\end{tabular}

Analizējot pētījuma rezultātus, tika konstatēts, ka IT rīki un digitālie resursi tika lietoti 78\% no vērotajām 64 stundām. Stundās, kurās tika lietotas IT, $94 \%$ gadījumu IT rīkus lietoja skolotāji, bet tikai $22 \%$ gadījumu to darīja arī skolēni (skat. 2. attēlu).

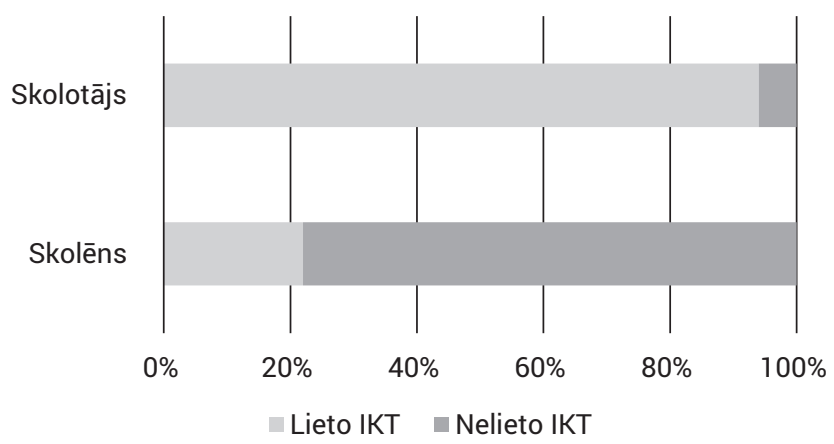

2. attēls. IT rīku un digitālo resursu lietošana (\%) vērotajās dabaszinātṇu stundās ( $N=64$ vērotas mācību stundas)

${ }_{11}$ SketchUp programma. Pieejams: https://www.sketchup.com/ (aplūkots 16.02.2018.).

12 TinkerCAD programma. Pieejams: https://www.tinkercad.com/ (aplūkots 16.02.2018.).

${ }^{13}$ Blender programma. Pieejams: https://www.blender.org/ (aplūkots 16.02.2018.). 
Skolotāji lietoja datoru kopā ar projektoru, interaktīvo tāfeli, veb kameru, dokumentu kameru, lai demonstrētu un vizualizētu attēlus, prezentācijas, uzdevumu nosacījumus un risinājumus, kā arī eksperimentu iekārtas un mērierīces. Skolēni lietoja datu uzkrājējus, sensorus un mobilos telefonus laboratorijas darbos datu ieguvei, reǵistrěšanai un apstrādei, veica uzdevumus pie interaktīvās tāfeles, lietoja simulācijas, meklēja informāciju internetā un veidoja prezentācijas. Iegūtie rezultāti sasaucas ar OECD PISA pētỉjuma secinājumiem: ja mācību process ir uz skolēnu centrēts, tad skolotājs mācību procesā piedāvā skolēnam iespējas darboties ar IT; ja uz skolotāju centrēts - tad reti. ${ }^{14}$

Analizējot vērotās stundas, izmantojot rubrikas par IT lietošanu mācību procesā 64 dabaszinātṇu stundās, redzam, ka skolēniem ir maz iespēju lietot IT (2., 3. un 4. līmenis), kā arī tikai $2 \%$ gadījumu, t. i., vienā no vērotajām stundām, IT ir nepieciešamas, lai konstruētu zināšanas (skat. 3. attēlu).

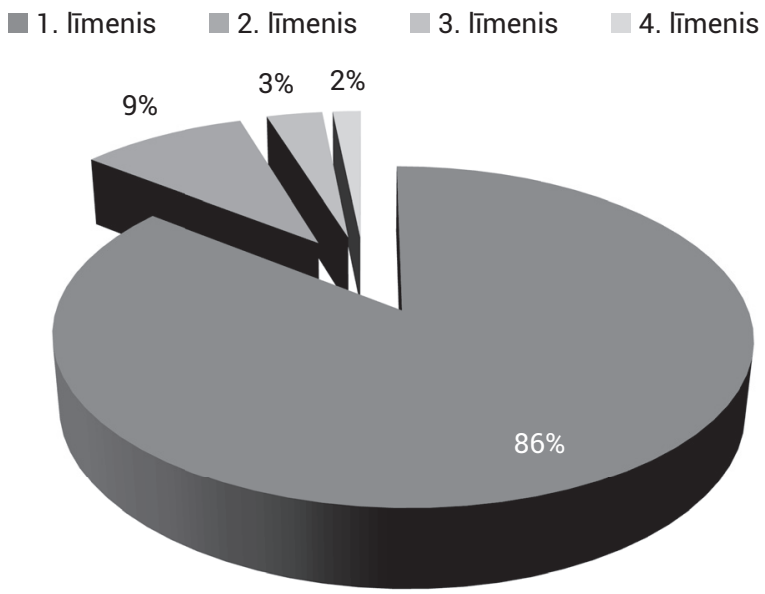

3. attēls. Vēroto stundu izvērtējums atbilstoši rubrikai: kā skolēni lieto IT stundā zināšanu konstruēšanai

Tas, protams, nenozīmē, ka visās mācỉbu stundās skolēniem ir jāizmanto IT tikai zināšanu konstruēšanai. Skolotājs var izmantot IT, piemēram, tikai vizualizēšanai īstajā brīdī, lai mācību stundā notiktu skolēnu jēgpilna mācīšanās. Eksperti analizēja vērotās stundas, izmantojot Likerta skalu, lai novērtētu, cik mērḳtiecīgs IT lietojums ir atbilstoši plānotajam stundas mērḳim ( 0 - nav atbilstošs, 1 - var veikt aktivitāti bez IT, 2 - nevar veikt aktivitāti bez IT, 3 - mērḳtiecīgs IT lietojums) (skat. 4. attēlu).

14 OECD. (2015). Students, Computers and Learning: Making the Connection. PISA, OECD Publishing. Pieejams: http://dx.doi.org/10.1787/9789264239555-en (aplūkots 16.02.2018). 


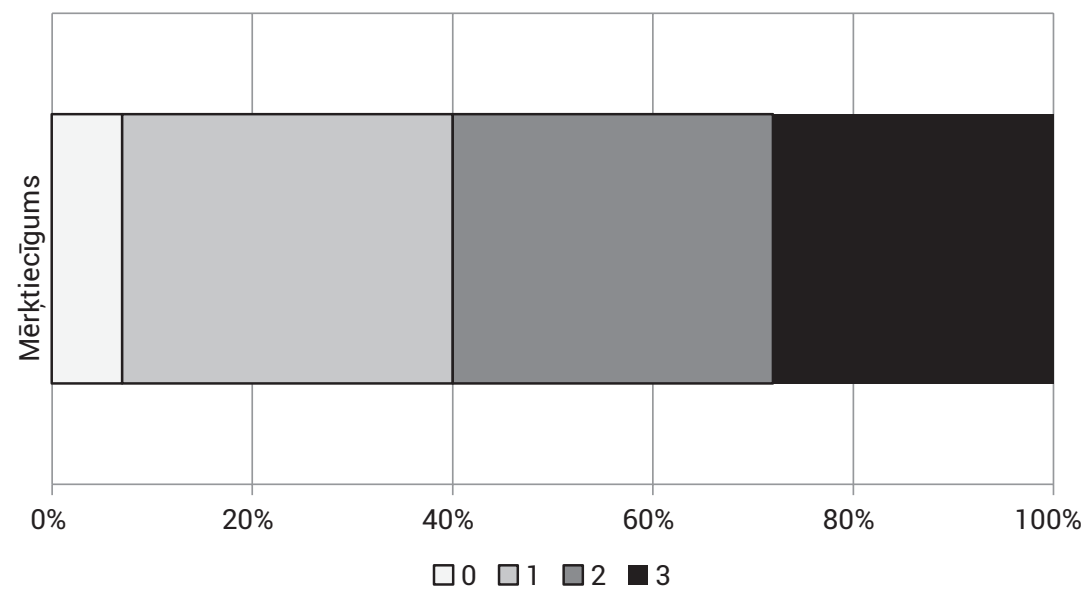

4. attēls. IT lietojuma mērḳtiecīgums atbilstoši plānotajam stundas mērḳim

$40 \%$ no vērotajam stundām liecina, ka skolotāji lieto zemas kvalitātes digitālos materiālus vai organizē skolēniem aktivitātes, kuras var jēgpilni organizēt arī bez IT lietošanas ( 0,1 pēc Likerta skalas). Ekspertu komentāri par šādām stundām ir šādi: prezentācijai vairāk nekā 30 slaidi; skolotāja izmanto pašas veidotu prezentāciju, tajā izmantotie attēli ir neskaidri; prezentācija stundā ir nepieciešama, bet problēma, kā tā tiek izmantota; uzdevumi netiek formulēti skaidri, tāpēc ir zema procesa efektivitāte.

Iegūtie dati tika analizēti, vērtējot IT lietojuma korelāciju atbilstoši stundā izvēlētajām mācību metodēm, skolotāja prasmi realizēt izvēlēto metodi praksē jeb metodes "tehniku", kā arī sniegtajai atgriezeniskajai saitei (skat. 5. attēlu). IT lietojums ir mērḳtiecīgs, ja skolotājam ir atbilstošas prasmes izvēlēties piemērotu metodi plānoto rezultātu sasniegšanā un prasmes realizēt šo metodi praksē. Kopš 2006. gada, realizējot dabaszinātṇu skolotāju profesionālo pilnveidi, viens no jautājumiem, uz kuru tika likts uzsvars, - kā skolotājs iepazīstina skolēnus ar stundā plānoto mērḳi un sniedz atgriezenisko saiti par skolēnu sasniegumiem, lai skolēni varētu sekot mācību norisei. Vērotajās stundās ir redzams, ka skolotāji pievērš lielu uzmanību tam, lai skolēniem būtu skaidrs plānotais mērḳis. Pat ja skolotājs neizvēlas vispiemērotāko un efektīvāko metodi mērḳa sasniegšanai vai pilnībā nepārvalda metodes realizēšanas tehniku, skolotājs neaizmirst sniegt skolēniem atgriezenisko saiti par mācību procesā sasniegto progresu. 


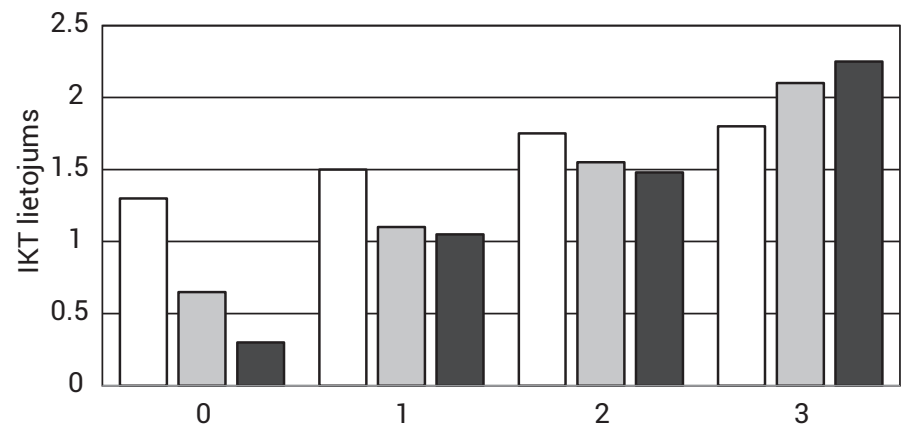

$\square$ Atgriezeniskā saite $\square$ Metožu realizācijas tehnika

Atbilstošas metodes izvēle

5. attēls. Korelācija starp IT lietojumu un stundā realizētām metodēm

Faktori, kas nosaka IT rīku un digitālo resursu jēgpilnu lietošanu: 1) IT rīki mācību procesā jālieto vienīgi tad, ja tie ir piemērotākie rīki plānotā mērķa sasniegšanā; 2) skolēniem jāpiedāvā iespēja patstāvīgi atklāt un pārbaudīt savas idejas; 3) skolotājam jāveicina skolēnu savstarpējā sadarbība un diskusijas; 4) jābūt pieejamiem atbilstošiem IT rīkiem plānotā mērḳa sasniegšanā.

Iespējamie situācijas cēloṇi var atbilst iepriekšminētajiem citu autoru uzskatiem, ka mērkstiecīgai IT rīku lietošanai vajadzīgi apmācīti skolotāji, kuri ir ieguvuši nepieciešamās prasmes un zināšanas skolotāju apmācības programmās augstskolās, profesionālās pilnveides kursos un skolās balstītos labās prakses apmaiņas pasākumos (Horn, \& Little, 2010). Profesionālajā pilnveidē 12 stundu modulis IT apgūšanai ir nepietiekams.

\section{Kā attīstījusies skolotāju profesionālā pilnveide darbam ar IT mācību procesā}

Tehnologiju pieejamība automātiski nenodrošina skolotāju pedagogiskās pieejas izmainas (Campbell, \& Martin, 2010). Mūsdienu straujajā IT attīstības laikmetā digitālo prasmju apgūšana ir nepieciešama, lai sagatavotu gan universitātes studentus, gan nākamos skolotājus un pieredzējušus skolotājus. Turklāt IT izmantošana veicina skolēnu mācīšanās sasniegumu uzlabošanos tikai tad, ja skolotājiem ir zināšanas par efektīvu un lietderīgu IT lietojumu mācību procesā (Ertmer, \& Ottenbreit-Leftwitch, 2010). Skolotāji var attīstīt savas profesionālās kompetences tehnologiju lietošanai, nevis par to mācoties no grāmatām, bet gan ar praktisku tehnoloǵiju izmantošanu sava mācību priekšmeta kontekstā (Duran, Brunvand, \& Fossum, 2009). Šai atbalsta sistēmai jābūt visaptverošai: iespēja iepazìties un dalīties pieredzē ar labās prakses piemēriem mācību procesā, skolas 
administrācijas atbalsts, profesionālās pilnveides kursi, piemēroti mācīšanas un mācišanās materiāli (Betcher, \& Lee, 2009).

Lai skolotāji varētu attīstīt un pilnveidot skolēnu digitālo kompetenci, skolotājiem ir pastāvīgi jāpilnveido sava profesionālā kompetence:

- digitālajā pedagogiijā - plānot un realizēt mācību procesu, izmantojot IT, veidot un vadìt uz tehnolog̣ijām balstìtu mācību vidi, sniegt atgriezenisko saiti, izmantojot IT;

- digitālo resursu lietošanā un radīšanā - izvēlēties un lietot digitālos resursus, radīt digitālos resursus, pārzināt autortiesību un licenču nosacỉjumus, gūt priekšstatu par programmēšanas principiem un/vai programmēt;

- digitālā komunikācijā un sadarbībā - komunicēt ar tehnologiju palīdzību sociālajos medijos, dalīties ar informāciju un resursiem gan ar kolēgiem, gan ar skolēniem, darboties tiešsaistē, sadarboties ar tehnologiju palīdzību;

- digitālajā sabiedrībā - atbildīgi uzvesties tiešsaistē, pārvaldīt savu digitālo identitāti, nodrošināt IT ierī̌cu drošību, rīkoties ar tehnologijām videi un veselïbai draudzīgi.

Latvijā tika īstenota pedagogu profesionālā pilnveide ar mērķi mainīt pedagog̣isko pieeju un attīstītu skolotāju digitālās kompetences. Tika organizēti skolas administrācijas darbinieku semināri par IT ieviešanas nozīmi. Šie pasākumi radỉja priekšnosacijumus IT jēgpilnai izmantošanai dabaszinātṇu un matemātikas mācību procesā.

Skolotāju profesionālā pilnveide dabaszinātṇu un matemātikas skolotājiem Latvijā tika organizēta pakāpeniski, īstenojot ESF projektus (2005-2011). Pirmais posms - vidusskolas skolotājiem profesionālās pilnveides nodarbības 72 stundu apjomā, no kurām 15 stundu nodarbïbas par informācijas tehnoloǵiju lietošanu mācību procesā. IT nodarbību mērḳi: 1) iepazīstināt ar informācijas tehnolog̣iju izmantošanas daudzveidīgajām iespējām dabaszinātṇu mācību procesā; 2) pilnveidot prasmi izmantot IT priekšrocības (kvalitāte, ātrums, precizitāte, efektīva resursu izmantošana) dabaszinātņu mācību procesā.

Pirmajā posmā: 1) skolotāji apgūst tehniskās prasmes, lai lietotu dažādus IT rīkus: datu uzkrājējus, sensorus, interaktīvo tāfeli, tīmekḷa kameru, datu kameru utt.; 2) skolotāji identificē resursus, kas viņiem ir pieejami mācišanas un mācīšanās organizēšanai matemātikā un dabaszinātnēs: video, virtuālās laboratorijas, animācijas utt. Ja fokuss tiek likts uz mācǐšanos un mācišanu, pirmajā posmā skolotāji uzlabo prasmes lietot IT vizualizēšanai, lai demonstrētu saturu, lai pasniegtu informāciju skolēniem.

Otrais posms - pamatskolas skolotājiem profesionālās pilnveides nodarbības 36 stundu apjomā skolotājiem, kuri izgājuši pirmā posma nodarbības, un 54 stundu apjomā pārējiem skolotājiem, to skaitā 6-8 stundas IT nodarbībām. 
Nodarbību mērkị: 1) pilnveidot izpratni par IT rīku un resursu mērḳtiecīgu lietojumu dabaszinātnu un matemātikas mācỉbu procesā pamatskolā, organizējot daudzveidīgu mācību procesu; 2) pilnveidot prasmi izmantot IT rīkus un elektroniskos mācību līdzekḷus mācību stundās pamatskolā.

Otrajā posmā: 1) skolotāji mēgina plānot, kā lietot mācību materiālus, IT rìkus un resursus mācību procesā: stundu plānus, darbalapas virtuālām laboratorijām, izstrādātas animācijas; 2) skolotāji mācās no citu kolẹǵu labās prakses piemēriem; 3) skolotāji organizē skolēnus, lai identificētu pieejamos resursu mācišanās procesam (dabaszinātnēs un matemātikā): video, virtuālās laboratorijas, animācijas.

Profesionālās pilnveides otrajā fāzē galvenā uzmanība tika pievērsta stundu fragmentu modelēšanai, lai apgūtu iemaņas, lai plānotu jēgpilnu IT izmantošanu klasē, kur bez IT lietošanas prasmju apguves skolēni var apgūt problēmu risināšanas prasmes, modelēt procesus, atrast un piekḷūt informācijai, attīstìt un uzlabot vinu sadarbỉbas prasmes.

Skolotāji vispirms sistemātiski apgūst tehniskās prasmes IT izmantošanā, tad uzmanība tiek pievērsta mācìbu procesam - kā organizèt procesu ar IT jēgpilnu izmantošanu, vairāk koncentrējoties uz skolēniem (skat. 4. tabulu).

Lai skolotājs varētu atbalstīt un organizēt skolēniem mācīšanos iedziḷinoties, izmantojot IT rīkus, viņam pašam pakāpeniski ir jāapgūst IT lietošanas pamatprasmes, ir jābūt izpratnei par to, kur meklēt un saņemt atbalstu gan resursu, gan metodikas jomā. 


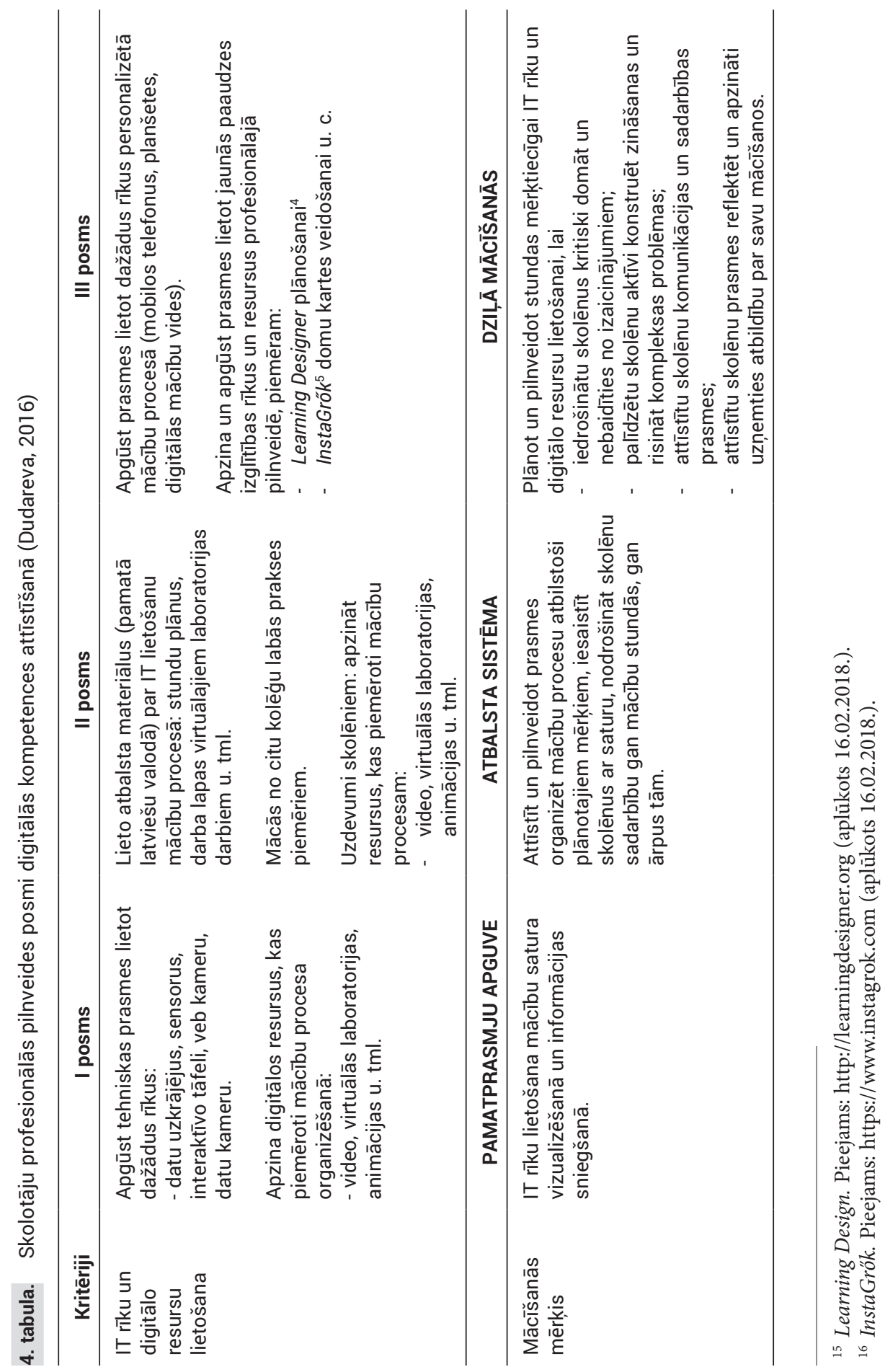




\section{Kā profesionāli pilnveidoties turpmāk, ja skolotājs ir apguvis IT lietošanas pamatprasmes}

Lai ieviestu nepieciešamās pārmaiņas, skolotāji analizēja pašu un kolēǵu darbību stundu laikā un reflektēja par to. Skolotāji dalījās ar savu pieredzi plānošanā un stundu vadīšanā, kur viṇi demonstrē savas jaunās pieejas. Mācīšanās filozofija - iegūt jaunu pieredzi, tad kopīgi ar kolēgiem radīt jaunas mācīšanās situācijas un reflektēt par to saturu (skat. 7. nodaḷas 9. attēlu).

Latvijas Universitātes Starpnozaru izglītības inovāciju centrs (LU SIIC) organizēja darbnīcas dabaszinātṇu un matemātikas skolotājiem līderiem viena mācību gada laikā (kopā 35 skolotāji). Šajā grupā piedalījās skolotāji, kas bija apguvuši abu ESF dabaszinātṇu projektu tālakizglītības programmas. Darbnīcas (6 x 6 stundas vienā mācību gadā) sastāvēja no ievadsemināriem par kādu konkrētu problēmu (zināšanu konstruēšana, jēgpilna IT rīku lietošana, atgriezeniskā saite utt.), kopīgu stundu plānošanu, adaptēšanās pašu klasēs un refleksiju.

Darbnīcu mērkịis bija radīt mācī̌sanās situācijas, kurās skolotāji var iegūt jaunu pieredzi, piedalīties diskusijās, dalīties ar domām, lai izstrādātu stundas, kas koncentrējas uz kompetencēs balstītu izglītību, un vadīt šīs stundas savās skolās.

Skolotāju atsauksmes liecina, ka kopīga plānošana un stundu analīze ir palīdzējusi skolotājiem kḷūt kompetentākiem profesionāḷiem, kā arī kḷūt par skolotājiem līderiem (sava procesa vadības uzṇemšanās jeb ownership, analīze un refleksija par paša sniegumu, atvērtība, komandas darbs, sevis apzināšanās).

Šādā veidā skolotāi kḷūst par līderiem, jo viena no būtiskajām skolotāju līderības lomām ir mācīties nepārtraukti. Viṇi demonstrē mācīšanos mūža garumā un lieto to, ko ir iemācījušies, lai palīdzētu skolēniem sasniegt dziḷāka līmeṇa mācīšanās procesu.

Pēc darbnīcām skolotāji saṇem individuālus uzdevumus. Darbnīcu laikā katrs skolotājs dalās ar savu stundu idejām, tad šīs idejas tiek attīstītas kopīgās diskusijās ar citiem skolotājiem. Pēc tam skolotāji pilotē izstrādātās stundas savās skolās, reflektē par mācīšanu un mācīšanās procesu.

Skolotāja praktiskās zināšanas interpretē viṇu darba kontekstā, integrējot eksperimentālās zināšanas, formālās zināšanas un personīgos uzskatus (van Driel, Beijard, \& Verloop, 2001). Piedāvātais modelis ir nepārtraukta profesionālā pilnveide (skat. 7. nodalıas 10. attēlu).

Tika izstrādāti 23 stundu plāni par IT lietošanu mācību procesā (skat. 5. tabulu). Darbojoties, plānojot un reflektējot klātienē, stundās skolēnu darbošanās, lietojot IT, notiek dziḷākā līmenī. 
5. tabula. Snieguma līmeṇu apraksts IT izmantošanai (Microsoft Partners in Learning, $2012^{17}$ ).

\begin{tabular}{llc}
\hline Līmenis & \multicolumn{1}{c}{ Kritēriji } & $\begin{array}{c}\text { Nodarbību } \\
\text { skaits, \% }\end{array}$ \\
\hline 1 & Skolēniem nav iespēju izmantot IT mācību aktivitātei & 35 \\
\hline 2 & $\begin{array}{l}\text { Skolēni izmanto IT, lai apgūtu vai praktizētu pamatprasmes vai } \\
\text { reproducētu informāciju, bet viṇi nekonstruē zināšanas }\end{array}$ & 26 \\
\hline 3 & $\begin{array}{l}\text { Skolēni izmanto IT, lai atbalstītu zināšanu veidošanu, taču viṇi } \\
\text { varētu konstruēt tādas pašas zināšanas, neizmantojot IT }\end{array}$ & 13 \\
\hline 4 & $\begin{array}{l}\text { Skolēni izmanto IT, lai veicinātu zināšanu konstruēšanu, un IT ir } \\
\text { nepieciešams, lai veidotu šĩs zināšanas }\end{array}$ & 9 \\
\hline 5 & Skolēni izveido IT produktu autentiskiem lietotājiem & 17 \\
\hline
\end{tabular}

Izstrādātie stundu plāni un pētījumu rezultāti tiek izplatīti skolotāju vidū, mēgeinot atspoguḷot faktus un minimizējot akadēmisko valodu. Darbnīcu laikā tika analizēti empīriskie mācību procesa norises pieraksti, skolotāju atgriezeniskā saite pēc darbnīcām un fokusgrupu rezultāti; tika aprobēts nākamais tālākizglītības modeḷa līmenis. Uzmanība būtu jāvērš uz: 1) IT rīkiem, kas veicina personalizētu mācǐšanos un tūlìtēju atgriezenisko saiti. Piemēram, ievadsesijas laikā mēs izmantojam Learning Designer nodarbību plānošanai, skolotāiji var saņemt tūlìtēju atgriezenisko saiti, lai skolēniem plānotās aktivitātes ir daudzveidīgas; 2) tādu uzdevumu un problēmu izstrādi, kuru risināšana prasa IT izmantošanu (ne tikai vizualizēšanai un demonstrēšanai), tādējādi veicinot zināšanu un/vai jaunu produktu izstrādi, ko veic paši skolēni. Šāds tālākizglīî̄bas modelis atbilst ieteikumiem, kas atrodami literatūras avotos. Pastāvīga profesionālā pilnveide ir jāveido, balstoties uz to, ka skolotāju individuālās vajadzības ir prioritāras, un uz sadarbību vērstām pieejām jākḷūst par būtiskiem punktiem, veidojot nepārtrauktu profesionālo tālākizglìtību (Daly, Pachler, \& Pelletier, 2009).

\section{Kā skolotājs var saprast, kādā līmenī ir viṇa IT prasmes, un ko darīt turpmāk}

Kopš IT rīkus sāka lietot mācību procesā, ir veikti dažādi projekti un pētījumi par to, kā skolotājs var saprast, kādas ir viṇa prasmes lietot IT; cik mērḳtiecīgi

\footnotetext{
${ }^{17}$ Microsoft Partners in Learning. (2012). 21 CLD Learning Activity Rubrics. Pieejams: http:// www.kasc.net/2010/21CLD\%20Learning\%20Activity\%20Rubrics\%202012.pdf (aplūkots 16.02.2018.).
} 
pats plāno mācību procesu, kurā skolēni lieto IT; kādas ir zināšanas par IT lietošanas drošỉbu un ètiku, darbojoties internetā - sociālajos tìklos, lietojot bankas pakalpojumus, izvēloties saviem kontiem paroles u. tml. ACOT (The Ten-Year Apple Classrooms of Tomorrow) pētijumā jau pirms divdesmit gadiem tika secināts, ka profesionālajā pilnveidē skolotājs, secīgi mācoties, apgūst vairākus posmus, līdz vinšs jūtas kompetents, plānojot mācību procesu ar IT, un jūtas droši klasē, to realizējot ${ }^{18}$ (skat. 6. tabulu).

6. tabula. IT lietošanas apgūšanas secīgie posmi

\begin{tabular}{ll}
\hline \multicolumn{1}{c}{ Posms } & \multicolumn{1}{c}{ Skolotāja darbība } \\
\hline Sākums & Mācās jauno tehnoloǵiju lietošanas pamatprasmes \\
\hline Pieṇemšana & Lieto jaunās tehnoloǵijas, realizējot tradicionālās darbības \\
\hline Adaptācija & $\begin{array}{l}\text { Integrē jaunās tehnoloǵijas tradicionālā mācību procesā. Bieži fokusējas } \\
\text { uz skolēnu produktīvām darbībām un iesaisti, lietojot teksta redaktorus, } \\
\text { elektroniskās tabulas un grafiskos IT rīkus }\end{array}$ \\
\hline Pārṇemšana & $\begin{array}{l}\text { Tehnoloǵiju iekḷaušana mācību procesā, kur tās nepieciešamas kā viens no } \\
\text { daudziem rīkiem. Fokusējas uz skolēnu sadarbību, starpdisciplināru darbu } \\
\text { un projektu realizāciju, izmantojot informācijas tehnoloǵijas }\end{array}$ \\
\hline Radīšana & $\begin{array}{l}\text { Atklāj jaunas IT rīku izmantošanas iespējas, piemēram, mācot algebru, } \\
\text { elektroniskajās tabulās veido automatizētas aprēḳinu funkcijas, vai veido } \\
\text { projektus, kuros skolēniem jāizmanto vairākas kombinētas tehnoloǵijas }\end{array}$ \\
\hline
\end{tabular}

IT mācību procesā ir viens no izmaiņu katalizatoriem. Tā kā skolēni tehnologijas plaši lieto arī sadzīvē, darbā un izklaidēs, tad nereti viṇi pazīst un pārvalda vairāk dažādu atšķirīigiem IT mērķiem izmantojamu IT rīku nekā skolotāji. Ja skolotājs ir atvērts pārmaiṇām, gatavs mācīties un nebaidās mègināt kaut ko jaunu, tad automātiski mainās arī mācību process klasē. Tas pakāpeniski mainās no skolotāju centrēta un didaktiska uz skolēnu centrētu un interaktīvu, kas ir viens no nosacỉjumiem, lai klasē varētu notikt mācǐšanās iedziḷinoties (skat. 7. nodaḷas 6. attēlu).

Eiropas Komisija, apkopojot pētījumos iegūtos rezultātus, ir izveidojusi Eiropas Izglītotāju digitālās kompetences ietvaru (European Framework for the Digital Competence of Educators - DigCompEdu), kurā apkopots dažādu

${ }^{18}$ Apple Computer, Inc. (1995). Changing the Conversation About Teaching, Learning \& Technology. A Report on 10 Years of ACOT Research. Pieejams: http://gse.buffalo.edu/ fas/yerrick/UBScience/UB_Science_Education_Goes_to_School/Technology_Reform_ files/10yrs\%20of\%20ACOT.pdf (aplūkots 16.02.2018). 
līmeṇu - sākot no pirmsskolas un beidzot ar pieaugušo izglîtības - nepieciešamo kompetenču/prasmju kopums, lai varētu attīstìt un pilnveidot izglìtojamo digitālo kompetenci. ${ }^{19}$

Ietvarā aptvertas sešas jomas: profesionālā iesaistišanās, digitālo resursu pārvaldība, digitālā pedagoǵija, vērtēšana, atbalsts izglītojamajiem un viṇu digitālās kompetences attīstī̌sana. Šis jomas ir savstarpēji saistîtas. Katra joma tiek aprakstìta detalizētāk, aptverot prasmes/kompetences, kuras skolotājam nepieciešams attīstìt, lai apgūtu un pilnveidotu efektīvas IT rīku lietošanas stratēgijas. Kā piemēru apskatīsim jomu par skolēnu digitālās kompetences attīstǐšanu - kādām prasmēm/kompetencēm ir jāpiemìt skolotājam.

MENTEP ${ }^{20}$ (MENtoring Technology Enhanced Pedagogy) projektā ir izveidots interaktīvs tiešsaistes pašvērtējuma rīks TET-SAT ${ }^{21}$, kas l̦auj skolotājam izvērtēt pašam savu prasmju līmeni šādās jomās: digitālā pedagog̣ija, digitālo resursu lietošana un radīšana, digitālā komunikācija un sadarbība, kā arī izvērtēt, cik atbildīgs skolotājs ir digitālajā vidē. Rỉks pašlaik ir pieejams angḷu valodā un to 11 valstu valodās, kuras piedalijjās kā partneri projektā (tostarp lietuviešu un igauņu valodā). Skolotājs izvērtē savu prasmju līmeni katrā no 30 rīkā iekḷautajiem IT rīku lietošanas aspektiem, izvēloties no rubrikas viņa darbỉbai atbilstošo līmeni.

Kad skolotājs atbildējis uz visiem 30 jautājumiem, viņš saņem atgriezenisko saiti dažādos griezumos gan kopumā, gan atseviški katrā no apskatītajiem aspektiem. Tā ir iespēja arì ieraudzìt, kā skolotāja prasmes izskatās uz kopējā fona, un iegūt informāciju, kuru aspektu pilnveidei jāpievērš uzmanība.

\section{Secinājumi}

Lai skolotājs varētu mērḳtiecīgi attīstìt un pilnveidot skolēnu digitālo kompetenci dažādos mācību priekšmetos, viņam pašam ir jāattīsta un jāpilnveido arī sava digitālā kompetence.

Jau plānojot mācỉbu procesu, ir jāparedz iespēja skolēnam veikt IT uzdevumus ar IT rīkiem. Lai saprastu, vai mācību procesā IT rīku potenciāls tiek izmantots mērḳtiecīgi, skolotājs var izvērtēt plānotās un realizētās aktivitātes, izmantojot rubrikas, piemēram, Microsoft Partners in Learning rubriku par IT lietošanu mācību procesā. Rubriku skolotājs var izmantot gan pašvērtējumam, gan vērojot kolēgu stundas ar mērḳi uzlabot savu praksi.

\footnotetext{
${ }^{19}$ European Commision. (2017). European Framework for the Digital Competence of Educators (DigCompEdu. Pieejams: https://ec.europa.eu/jrc/en/digcompedu

${ }^{20}$ MENTEP mājaslapa. Pieejams: http://mentep.eun.org/ (aplūkots 16.02.2018.).

${ }^{21}$ TET-SAT mājaslapa. Pieejams: http://mentep-sat-runner.eun.org/ (aplūkots 16.02.2018.).
} 
IT potenciāls Latvijā mācību procesā netiek pilnībā izmantots. Ir vērojama plaisa starp IT rīku jēgpilnas lietošanas potenciālu un to, kā IT rīki reāli tiek izmantoti mācību procesā. Stundās, kurās tiek izmantoti IT rīki un resursi, skolēni bieži ir pasīvā lomā. IT rīki tiek izmantoti pamatā konkrētu uzdevumu veikšanai, nevis zināšanu konstruēšanai.

Skolotājiem plānojot un realizējot mācību stundas, ir jāmaina akcenti no IT rīku un resursu lietošanas mācību satura vizualizēšanai uz IT rīku un resursu lietošanu zināšanu konstruēěanai, procesu modelēšanai, problēmu risināšanai, jaunu produktu radīšanai, sadarbībai, personalizēta mācību procesa organizācijai.

Tiešsaistē ir atrodami dažādi IT rīki un resursu vietnes, kuras skolotājs var izmantot mācỉbu procesa plānošanā un organizēšanā, kā arī resursu vietnes, kurās skolotāji var profesionāli pilnveidoties. Labās prakses piemēri un sadarbība ar kolẹgiem ir motivatori, kas iedrošina skolotāju sākt mēgināt izmantot dažādus jaunus IT rìkus.

Lai efektīvi varētu ieviest un izmantot digitālās tehnologijas mācību procesā $\bar{a}^{22}$ : profesionālai pilnveidei un atbalstam ir jābūt vērstam ne tikai uz IT lietošanas prasmēm, bet arī uz IT rīku un digitālo resursu lietošanu mācību procesā; skolotājiem jāpārvar neticība par IT lietošanas efektivitāti mācību procesā, viņiem jāpalīdz, ne tikai iepazīstinot ar labās prakses piemēriem, kā IT lietot mācỉbu procesā, bet arī izmantojot dažādas uz skolēnu centrētas mācību metodes; jālauj skolotājiem eksperimentēt ar tehnologiju lietojumu mācỉbu procesā; jābūt iespējai skolotājiem profesionāli sadarboties savā starpā - gan skolas, gan valsts līmenī; jāizmanto, jāuztur un jāatjauno IT ierīces, kas ir savietojamas ar dažādām sistēmām, ejot līdzi IT rīku attīstības tendencēm.

Lai skolotāju profesionālajai pilnveidei IT lietošanā būtu paliekošs efekts, tā ir jāveido, balstoties uz skolotāju vajadzībām, organizējot mācīšanās grupas, sadarbojoties ar kolẹgiem. Skolotājam ir jābūt savas mācǐšanās centrā, lai viṇš varētu mainìt savus IT rīku lietošanas paradumus (Daly, Pachler, \& Pelletier, 2009).

Lai skolotājs saprastu, kādā līmenī ir viņa IT prasmes un ko darìt turpmāk, ir jāreflektē par savu darbu un darbošanos ar IT mācību procesā. Te noderīgas ir dažādas rubrikas, ar kuru palīdzību skolotājam ir iespēja izvērtēt savu prasmju līmeni un iepazīties ar nākamajiem pakāpieniem attiecīgajā aspektā, lai varētu saprast, kurā virzienā profesionālā pilnveide īstenojama (piemēram, Eiropas Izglītotāju digitālās kompetences ietvars, $\left(2017^{23}\right)$, interaktīvs tiešsaistes pašvērtējuma rīks TET-SAT u. c.).

${ }^{22}$ ICF Consulting Services Ltd. (2015). Literature Review on the Impact of Digital Technology on Learning and Teaching. Pieejams: http://dera.ioe.ac.uk/24843/1/00489224.pdf (aplūkots 16.02.2018).

${ }^{23}$ European Commision.(2017). European Framework for the Digital Competence of Educators (DigCompEdu. Pieejams: https://ec.europa.eu/jrc/en/digcompedu 


\section{IZMANTOTĀ LITERATŪRA}

Abbott, I., Townsend, A., Johnston-Wilder, S., \& Reynolds, L. (2009). Literature Review: Deep learning with technology in 14 to 19-year-old learners. Coventry (UK): British Educational Communications and Technology Agency (Becta).

Bates, T. A. W. (2015). Teaching in a Digital Age. Guidelines for designing and teaching and learning. Glokalde, 1(3).

Betcher, C., \& Lee, M. (2009). The Interactive Whiteboard Revolution. Teaching with IWBs. Australia: ACER Press, p. 154.

Campbell, C., \& Martin, D. (2010). Interactive whiteboards and the first year experience: Integrating IWBs into pre-service teacher education. Australian Journal of Teacher Education, 35(6), pp. 68-75.

Daly, C., Pachler, N., \& Pelletier, C. (2009). Continuing Professional Development in ICT for Teachers: A literature review. BECTA. Pieejams: http://eprints.ioe.ac.uk/3183/1/ Daly2009CPDandICTforteachersprojectreport1.pdf (aplūkots 16.02.2018.).

Diass, B. L. (1999). Integrating Technology some things you should know. ISTE - L\&L 27(3).

Duran, M., Brunvand, S., \& Fossum, P. (2009). Preparing science teachers to teach with technology: Exploring K-16 networked learning community approach. The Turkish Online Journal of Educational Technology, 8(4), pp. 21-42.

Ertmer, P. A., \& Ottenbreit-Leftwich, A. T. (2010). Teacher technology change: How knowledge, confidence, beliefs, and culture intersect. Journal of Research on Technology in Education, 42(3), pp. 255-284.

Fullan, M., Langworthy, M. (2013). Towards a New End: New Pedagogies for Deep Learning. Pieejams: http://npdl.thumbtack.co.nz/wp-content/uploads/2015/08/Towards-a-New-EndNew-Pedagogies-for-Deep-Learning-Invitation.pdf (aplūkots 16.02.2018.).

Horn, I. S., \& Little, J. W. (2010). Attending to problems of practice: Routines and resources for professional learning in teachers' workplace interactions. American educational research journal, 47(1), pp. 181-217.

Jones, C., \& Shao, B. (2011). The net generation and digital natives: implications for higher education. Higher Education Academy, York.

Livingstone, S. (2012). Critical reflections on the benefits of ICT in education. Oxford Review of Education, 38(1), pp. 9-24.

Prensky, M. (2001). Digital Natives, Digital Imigrants. From On the Horizon (MCB University Press, Vol. 9, No. 5, October 2001)

Rodrigues, S. (2010). Multiple literacy and science education: ICT's in formal and informal learning environments. Hershey: IGI Global.

Underwood, J. (2009). The impact of digital technology. A review of the evidence of the impact of digital technologies on formal education. Becta.

Van Driel, J. H., Beijaard, D., \& Verloop, N. (2001). Professional development and reform in science education: The role of teachers' practical knowledge. Journal of research in science teaching, 38(2), pp. 137-158. 


\title{
9. nodala
}

\section{Informācijas tehnoloǵijas formatīvajā vērtēšanā}

\author{
Jāzeps Logins
}

Skolotājam interneta vidē pieejamo formatīvās vērtēšanas informācijas tehnologiiju (IT) rīku klāsts sniedzas vairākos simtos. Ievērojama ir arī šo IT rīku iespēju dažādība. Par tām plaši tiek ziṇots metodiskajos rakstos skolotāja darbam un izglìīibai veltìtos portālos, piemēram, Edutopia, GettingSmart, Educational Technologie and Mobile Learning, metodiskās norādes sniedz arī paši šo IT rīku veidotāji. Skolotāji savu darba pieredzi plaši publicē sociālajos tîklos.

Līdztekus digitālajā vidē publicētajai plašajai skolotāju personīgajā praksē balstìtajai pieredzei svarīgi ir noskaidrot zinātniskajos pètijumos iegūto informāciju par formatīvās vērtēšanas, lietojot IT, izmantošanas iespējām prasmju apguvē. JISC (The Joint Information Systems Committee ${ }^{1}$ ) definē digitālo vērtēšanu jeb e-vērtēšanu kā aktivitāšu kopu, kur vērtēšanas procesā izmanto digitālās tehnologijas. Digitālo vērtēšanu veido tās izstrādes, nosūtišanas un veikšanas, kā arī vērtējuma atskaites sagatavošanas, glabāšanas un pārsūtišanas procesi. Savukārt citi zinātnieki (Broadfoot, Timmis, Payton, Oldfield, \& Sutherland, 2013) norāda, ka e-vērtēšana ir process, kurā IT var daudzveidīgi izmantot vērtēšanas uzlabošanai, turklāt atgriezeniskā saite ir skatāma uz displeja.

Šì raksta nolūks ir apkopot galvenokārt Google Schoolar 2014.-2017. gadā pieejamo informāciju par formatīvās vērtēšanas digitāli izmantošanu mācību procesā.

Literatūra tiek analizēta, lai noskaidrotu digitāli veiktas formatīvās vērtēšanas iespējas konkrētu mācību situāciju kontekstā. Analizētas formatīvās vērtēšanas digitāli izmantošana mūsdienīga mācību procesa pilnveidē, îpaši,

1 JISC. (2007). Effective Practice with e-Assessment: An overview of technologies, policies and practice in further and highereducation. Pieejams: http://www.jisc.ac.uk/media/documents/ themes/elearning/effpraceassess.pdf. (aplūkots 13.02.2018.). 
problēmrisināšanas prasmju, sadarbỉbas prasmju un pašvadītas mācīšanās prasmju apguvē.

Formatīvās vērtēšanas digitāli iespējas plaši analizētas un informācija apkopota gan pètniecības projektu atskaitēs (Hughes, Green, \& Green, 2013), gan apskatos (DiCarlo \& Cooper, 2014; Gikandi, Morrow, \& Davis, 2011; Shute, \& Rahimi, 2017; Luckin, Clark, Avramides, Hunter, \& Oliver, 2017).

Formatīvā vērtēšana digitāli ietver vairākus posmus, līdzīgi kā papīra formāta gadijumā (Hughes, Green, \& Green, 2013; DigCompEdu, 2017²).

- Formatīvās vērtēšanas uzdevumu veida un atbildes iegūšanas veida izvēle. Uzdevumi var būt, piemēram, reālās dzìves situācijas, simulācijas, interaktīvi uzdevumi, uzdevums ar piemēru. Par mācišsanos iespējams iegūt pierādījumus no vairākizvēḷ jautājumu atbildēm, paplašinātajām atbildēm, e-portfolio, e-piezīmēm.

- Iegūto datu analīze. Formatīivās vērtēšanas IT rīki sniedz skolotājam informāciju par mācǐšanas un mācišanās efektivitāti, piemēram, par skolēnu aktivitāti, sniegumu un tā progresu.

- Atgriezeniskās saites sniegšana un turpmākās rīcības plānošana. Iegūtā informācija ḷauj sniegt skolēnam nepieciešamo palīdzību un norādes par turpmāk apgūstamo.

Formatīvā vērtēšana digitāli ir nozīmīgs palīgs mācību procesā gan skolotājam, gan skolēnam, ja tajā tiek rastas atbildes uz atgriezeniskās saites pamatjautājumiem (Hattie, \& Timperley, 2007). Publikācijā tiek izmantoti līdzīgi, ar formatīvo vērtēšanu saistīti, jautājumi:

1. Kas vēl nav apgūts?

2. Kas ir jādara, lai veiksmīgi mācītos turpmāk?

Minētie formatīvās vērtēšanas posmi ir savstarpēji saistīti, turklāt uz tiem atbildes ir jāiegūst gan skolotājam, gan skolēniem. Tāpēc ir svarīgi noskaidrot IT rīku izmantošanas iespējas, t. i., uz kuriem no nosauktajiem formatīvās vērtēšanas pamatjautājumiem ar tiem ir iespējams iegūt atbildes konkrētās mācību situācijās.

Šajā rakstā īpaša uzmanība veltìta formatīivās vērtēšanas IT rīkiem, kas mācību procesā nodrošina skolēnu mācišsanos iedziḷinoties. Tas skolēniem l̦auj attīstìt prasmes, kas būs noderīgas viņu profesionālajā dzìvē (Fulan, \& Langworthy, 2013). Analizēti ir zinātniskās informācijas avoti, kuros atrodami tieši pierādījumi par IT rīku izmantošanas ietekmi uz formatīvo vērtēšanu. Ar mācišanos

2 DigCompEdu (2017). Digital Competence Framework for Educators. Assessing Educators' Digital Competence. European Komission. Pieejams: https:/ec.europa.eu/jrc/sites/jrcsh/files/ digcompedu_leaflet_en-2017-10-09.pdf (aplūkots 13.02.2018.). 
iedzil̦inoties saistīto prasmju kontekstā īpaša vērība ir veltīta formatīvajai vērtēšanai digitāli, ko izmanto:

- problēmrisināšanas prasmju pilnveidē, mācību procesā izmantojot spēles un simulācijas;

- pašvadītās mācīšanās prasmju pilnveidē, mācību procesā izmantojot jēdzienu kartes;

- personalizēto mācǐšanos un e-portfolio.

IT strauji attīstoties un apzinoties formatīvās vērtēšanas nozīmīgumu, digitālo formatīvās vērtēšanas rīku klāsts pēdējos gados ir būtiski pieaudzis. Lai gūtu kopainu par IT rīku daudzveidību un to izmantošanas iespējām formatīvajā vērtēšanā, pārskata tabulā līdztekus zinātniskajai informācijai ir izmantotas arī skolotāju empīriskajā pieredzē gūtās atziṇas.

\section{Formatīvā vērtēšana digitāli problēmrisināšanas prasmju pilnveidē}

Spēles. Tiek norādīts, ka videospēles ir noderīgs problēmrisināšanas rīks. Tās piedāvā virtuālu pasauli, kur iespējams risināt reālās dzives problēmu simulācijas, tādējādi mācoties reālās dzīves prasmes, zināšanas un vērtības. Problēmrisināšanas gaitā tiek apliecināta spēja mācīties un apgūt jaunas zināšanas un prasmes. Spēle ir izaicinājums, un spēlētājs to spēlē maksimāli. Spēlē iekḷautā vērtēšana spēlētāju motivē gūt panākumus, lai veiktu nākamo, grūtāku uzdevumu (Gee, \& Schaffer, 2010).

Spēlēšanas laikā formatīvā vērtēšana sniedz informāciju par domāšanas prasmēm problēmrisināšanas procesā - ir iespējams iegūt informāciju, lai pielāgotu katra spēlētāja efektīvu mācīšanos. Ja spēles izstrādātāji prasmīgi tajā ir ieḳ̣āvuši vērtēšanu digitāli, iespējams iegūt drošu informāciju gan par rezultātu, gan par problēmrisināšanas procesu. Tas l̦auj adaptēt spēli, personalizēt to (Hughes, Green, \& Green, 2013). Šādu e-vidi, kurā ir integrēta gan vērtēšanas sistēma, gan spēlēšanas iespēja un kas l̦auj iegūt plašu informāciju par rezultātu un problēmrisināšanas procesu, piedāvā spāṇu zinātnieki (Gañán, Caballé, Clarisó, \& Bañeres, 2017). Apskatīta arī adaptētas atgriezeniskās saites sniegšana (Kickmeier-Rust, \& Albert, 2013).

Alfs Vangs (Alf Wang) un līdzautori piedāvā pašiem spēlētājiem veidot spēles jautājumus un tos nodarbībā kopīgi izspēlēt, izmantojot savās mobilajās ierīcēs instalētu IT rīku Kahoot. Skolotājs spēj sekot spēles norisei un sniegt atgriezenisko saiti, kad tas nepieciešams. Pētījums liecina par nozīmīgu motivācijas, iesaistes, labsajūtas un koncentrēšanās pieaugumu spēles laikā (Wang, Zhu, \& Sætre, 
2016). Par līdzīgiem rezultātiem, kas iegūti, izmantojot digitālos spēḷu rīkus, raksta arī citi autori (Iwamoto, Hargis, \& Vuonk, 2017; Tsai, F. H., Tsai, C. H., \& Lin, 2015; Schlegel, \& Selfridge, 2014).

Spēḷ izmantošana liecina, ka tajās var sekmīgi iekḷaut gan formatīvās, gan summatīvās vērtēšanas elementus, kas l̦auj attīstìt prasmes (Hughes, Green, \& Green, 2013).

Simulācijas. Simulācijās skolēns izvēlas un maina lielumus, izmantojot tehnolog̣ijas. Simulācijas var atkārtot, izmainīt mainīgos, rīkoties ar struktūrām un modeḷiem, kas citādi nebūtu pieejami. Tās mudina skolēnus izpētìt šo sistēmu veidojošo dalı mijiedarbïbu (Quellmalz, Timms, Buckley, Davenport, Loveland, \& Silberglitt, 2012a; Quellmalz, Timms, Silberglitt, \& Buckley, 2012b; Srisawasdi, \& Kroothkeaw, 2014). Tiek uzsvērta simulāciju interaktivitātes nozīmība, kā arī tas, ka simulācijas var izmantot kā neatkarīgu rīku, ar ko darbojas simulācijas veicējs, vai arī tajā var integrēt vērtēšanu (Neumann, 2010).

Citi autori (Kowalski, \& Kowalski, 2013) fizikas kursā ir izmantojuši interaktīvu simulāciju, ko veic kopā ar formatīvo vērtēšanu, un norāda, ka skolēni bija vairāk iesaistîti, stundā strādāja ar lielāku interesi un atdevi arī bez ārējās stimulēšanas.

Līdzīga dabaszinātṇu simulācija ir izmantota kā formatīvās vērtēšanas rīks, lai vērtētu dabaszinātnisko izpratību un apgūto zināšanu un prasmju atbilstîbu mācību priekšmeta standarta prasībām (Quellmalz et al., 2012a; Quellmalz et al., 2012b). Apstiprinoši rezultāti par formatīvās vērtēšanas izmantošanas lietderību ir iegūti arī citā pētijumā (Srisawasdi, \& Kroothkeaw, 2014; Srisawasdi, \& Sornkhatha, 2014). Tajā atgriezeniskās saites iegūšanai tika izmantota 2-4 jautājumu kopa par simulācijā apgūto mācību saturu. Skolēniem pārrunu laikā bija nepieciešams reflektēt savu mācǐšanās procesu.

Cita pētījuma autori ķermeṇu peldspējas jēdziena apguvei izvēlējās divas skolēnu grupas. Viena skolēnu grupa to veica ar simulācijas palīdzību, kurā tika integrēta formatīvā vērtēšana (Srisawasdi, \& Panjaburee, 2015). Šî grupa, kurā izmantoja formatīvo vērtēšanu, uzrādīja nozīmīgi labāku rezultātu zinātniskā eksperimenta izpratnē, savukārt otra grupa - jēdziena izpratnē.

\section{Formatīvā vērtēšana digitāli izpratnes veidošanai un pašvadītas mācīšanās prasmju pilnveidei}

Jēdzienu kartes mācišanās procesā. Jēdzienu kartes (concept maps) l̦auj demonstrēt kompleksu domāšanu un parāda, kā skolēns strukturē savu domāšanu un saprot mācību saturu (Weinerth, Koenig, Brunner, \& Martin, 2014). 
Jēdzienu kartes veidošanai un vērtēšanai nav jābūt nodalītiem posmiem. Daudzi rīki pieḷauj vērtēšanu izstrādes gaitā. Iespējams izmantot dažādus rīkus ar atšḳirīgām funkcijām (Bruillard, \& Baron, 2000).

Citi zinātnieki apraksta pusautomātisku jēdzienu karšu analīzes sistēmu, kas ḷauj saṇemt sistēmas veidotu atgriezenisko saiti. To saņem abi - skolēns un skolotājs. Autors norāda, ka ne vienmēr tā ir korekta. Taču to var izmantot kā argumentēšanas pamatu, un šādi tā noder snieguma uzlabošanai (Conlon, 2006).

Deivids Trumpovers (David Trumpower) ar kolēgiem analizē efektīvas formatīiās vērtēěanas kritērijus, kas l̦auj noskaidrot, vai ir apgūtas augstākā kognitīvā līmeņa prasmes, un attiecina tos uz jēdzienu karšu vērtēšanu. Tiek konstatēts, ka vērtēšanas kritērijus jēdzienu kartēm var piemērot, ja tās ir pietiekami detalizētas. Kaut arī e-vidē automātiski tiek iegūti summatīvās vērtēšanas rezultāti, tiek norādīts, ka tos var izmantot arī formatīvajā vērtēšanā. Tiek iegūti dati, kas l̦auj skaidri diskutēt par jēdzienu kartes stiprajām un vājajām pusēm (Trumpower, Filiz, \& Sarwar, 2014).

Jēdzienu karšu formatīivajā vērtēšanā var izmantot kā paṇēmienu, kurā e-vidē izstrādāto jēdzienu karti salīdzina ar iepriekš sagatavotu references karti (Berlanga, Rosmalen, Boshuizen, \& Sloep, 2012; Wu, Hwang, Milrad, Ke, \& Huang, 2011). Pēc salīdzināšanas automātiski tiek norādītas trūkstošās saites un sniegti komentāri. Darba autors var veikt izmaiņas un salīdzināšanu veikt atkārtoti, piemēram, CmapTool vidē. Pētijumi liecina, ka jēdzienu kartes izstrādes rezultātus ietekmē nodarbības laikā sniegto atgriezenisko saišu skaits. Pieaugot atgriezenisko saišu sniegšanas skaitam, mācī̌sanās rezultāti būtiski uzlabojas (Hsieh, \& O’Neil, 2002).

Po-hans Vu (Po-han Wu) un līdzautori (Wu et al., 2011) izveidojuši digitālās formatīvās vērtēšanas sistēmu, kurā jēdzienu kartes tiek vērtētas un atgriezeniskā saite tiek sniegta izstrādātāja kartē norāžu vai saišu veidā. Savukārt Marija Kordaki (Maria Kordaki) (Kordaki, 2015) izveidojusi jēdzienu karšu viedo analizēšanas rīku, kas l̦auj diagnosticēt un palīdz novērst kartē iekḷautos skolēnu nepareizos priekšstatus. Iegūtie rezultāti ļauj diferencēt mācību procesu atkarībā no skolēnu zināšanām. Autori arī norāda, ka atgriezeniskās saites jāveido tā, lai tās būtu noderīgas ikvienam kartes veidotājam (Kordaki, 2015).

Raksta "Paturi prātā! Automatizētai jēdzienu kartes atgriezeniskajai saitei jāveicina skolēnu viegli saprotamu skaidrojumu rakstǐšana" autori ir izpētījuši, ka saskaņots un nepārprotami saprotams savas jēdzienu kartes tekstuāls skaidrojums ir lıti noderīgs izpratnes veidošanai par mācību saturu. Skaidrojums tiek rakstīts vairākos posmos - vispirms melnraksts, tad tīrraksts. Pierādīts, ka skaidrojuma kvalitāte ir būtiski labāka, ja rakstītājs pirms tam ir veidojis jēdzienu karti. Atgriezeniskā saite var būt personalizēta vai ǵgenerēta e-vidē, taču tai jāveicina noturīgu prasmju izveide (Lachner, Burkhart, \& Nückles, 2017). 
Dotie piemēri parāda jēdzienu karšu digitāli veiktās formatīvās vērtēšanas dažādību. Iegūtie rezultāti tiek raksturoti kā daudzsološi, tās var novērtēt ar IT rīkiem, tādējādi noraidot bažas par laika trūkumu vai spēju nodrošināt vērtēšanu, kas sekmē mācīšanos (Trumpower et al., 2014). Arī autori norāda, ka jēdzienu kartēm kā IT rïkiem piemīt plašas to lietošanas iespējas, un tās nodrošina vizuālu un interaktīvu satura izmantošanu, kā arī spēj sniegt atbildes uz trim formatīvās vērtēšanas pamatjautājumiem - "Kas izdodas? Kas vēl ne? Ko darīt turpmāk?” (Kingston \& Broaddus, 2017). Taču jāṇem vērā, ka jēdzienu kartes ir komplekss rīks, to veidošanai un vērtēšanai arī skolotājam nepieciešama pieredze (Weinerth, Koenig, Brunner, \& Martin, 2014).

\section{Personalizēta mācīšanās}

Personalizēta mācǐšanās l̦auj mācību stundās apgūt mācību saturu katram skolēnam piemērotā, optimālā veidā. Personalizētu mācišanos var nodrošināt adaptīvi testi, kuros izmantoti dažāda kognitīvā lìmeņa uzdevumi. Tos papildina ar diferencētām dažādu veidu atgriezeniskajām saitēm (Maier, Wolf, \& Randler, 2016). Citi autori norāda, ka personalizētie atgriezeniskās saites sniegšanas rīki optimizē lielu skolēnu grupu mācišanos. Izmantojot mobilās ierīces, viṇi atgriežas pie nesekmīgi veiktiem uzdevumiem un tos izlabo. Savukārt IT rỉks skolotājam nodrošina pieeju reālajā laikā skolēnu sniegumam. To ieviešanas izmaksas ir zemas (Rodriguez-Sanchez, Torrado-Carvajal, Vaquero, Borromeo, \& Hernandez-Tamames, 2015).

Vērtēšanu reālajā laikā, kas l̦auj sniegt atgriezenisko saiti, nodrošina arī vairāki IT rìki, piemēram, Nearpod. Šādi apvērstās (flipped) mācī̌anās laikā, kad skolēni mācību pamatsaturu apgūst patstāvīgi pirms klātienes nodarbības, iespējams iegūt informāciju par katra studenta sniegumu (Mattei, \& Ennis, 2014). Tehnologiju attīstîba paver jaunas iespējas efektīvas un personalizētas atgriezeniskās saites sniegšanā. Piemēram, to var nodrošināt audio vai video ieraksta veidā, kas īpaši svarīgi ir valodu apguvē (Koç, Liu, \& Wachira, 2015).

Arvien plašāk tiek izmantotas arī jauktās (blended) mācīšanās forma, kad mācību saturu skolēni apgūst patstāvīgi digitālā vidē mācību stundas laikā. Operatīva atgriezeniskā saite un formatīvā vērtēšana reālajā laikā palielina skolēnu iesaistišanos kursa satura apguvē, paver sadarbïbas iespējas ar vienaudžiem, mācỉbspēkiem un ārējiem ekspertiem, tādējādi palielinot skolēnu panākumus un apmierinātību (Vaughan, 2014). Jauktās mācīšanās efektivitāti var paaugstināt, ja izmanto vērtēšanā centrētu mācību procesu, kurā îsas mācību aktivitātes mācīšanas menedžmenta sistēmā apvienotas ar e-vērtēšanas rīkiem (Nguyen, 2017). 


\section{e-portfolio}

Refleksija par savu mācīšanās procesu ir metakognitīvā prasme, kuras attīstîšana būtiski palīdz uzlabot pašam savu māciššnās procesu. Viena no šìs prasmes nozīmīgām pilnveidošanas mācību metodēm ir e-portfolio izstrāde.

Mācību procesā izstrādātu e-portfolio (digitālo portfolio) var definēt kā mācīšanās pierādījumu (artefaktu) elektronisku krājumu, kas var saturēt ievadītu tekstu, datnes, attēlus, multimediju materiālus, emuāru (blogu) ierakstus un hipersaišu apkopojumus. Mācǐšanās pierādījumi kādā noteiktā laika periodā tiek apkopoti, atjaunoti un pārvaldīti. Šādi mācību process tiek dokumentēts, reflektêts un prezentēts, un tas apliecina darba veicēja sniegumu (Zimmerman, 2012).

Citi zinātnieki akcentē formatīvās vērtēšanas nozīmi e-portfolio izstrādes gaitā. Skolotāja vai grupas biedru sniegtajai atgriezeniskajai saitei ir svarīga loma (Barrett, 2007):

- tā padzilịina skolēna iesaistišanās pakāpi;

- padara skolēnam vieglāk saprotamu savu paša mācišanos;

- skolotājam un vecākiem rodas skaidrāks priekšstats, ko skolēns zina un ko spēj paveikt;

- veicina skolēna izaugsmi. Vācot, atlasot un pievienojot e-portfolio mācīšanās pierādījumus, skolēns "stāsta par savu mācīšanos".

Tas atbilst arī citu (Bernhardt, \& Kirchner, 2007) atziņām par e-portfolio izstrādi kā ļoti nozīmīgu metakognitīvo prasmju apguves mācību metodi: autoram nepieciešama augsta patstāvīguma pakāpe sava mācīšanās procesa vadīšanā. Tas ietver daudzus elementus - līdztekus situācijas analīzei un e-portfolio satura plānošanai arī pierādījumu vākšanu, atlasi un apvienošanu, refleksiju par pievienotajiem materiāliem un darba procesu un komunikāciju, prezentāciju, kā arī vērtēšanu un novērtěšanu vai refleksiju par produktu. Šādi darba autors pats veido e-portfolio saskaņā ar savu motivāciju - pats izvirza sev uzdevumus, kurus sasniedz, un pats veic refleksiju par sasniegto (Moon, 2014).

Pašvadītā mācišanās un izaugsme tiek sekmēta, ja regulāra pašrefleksija (pašnovērtējums) un iespēja saņemt atgriezenisko saikni no darba vadītāja un/ vai grupas biedriem ir visā darba izstrādes laikā. Prakse liecina, ka komunikācijas kvalitāti starp skolēnu un skolotāju (pašrefleksijas un atgriezeniskās saites sniegšanu) iespējams uzlabot, ja e-portfolio tiek saglabāts un ir pieejams dažādās tā pabeigtïbas pakāpēs (Baumgartner, Himpsl, \& Zauchner, 2006).

Lìdzīgi kā tradicionālo portfolio gadījumā, pateicoties darba izstrādes laikā gūtajai pieredzei un pašrefleksijai, e-portfolio veicina darba autoru izpratni par paša mācǐšanos, l̦auj apzināt savu prasmju attīstības procesu (mācǐšanās cel̦u/izaugsmi), tādējādi vairāk vērības tiek veltīts mācǐšanās stratēǵijai un vajadzībām (Moon, 2014; Salzburg Research, 2007). 
Atgriezenisko saiti par e-portfolio izstrādi ir vieglāk sniegt e-vidē, nevis tradicionālajā papīra formātā. Tas, iespējams, ir iemesls, kāpēc vienu un to pašu nosacījumu gadījumā e-portfolio ir labāks veids mācību snieguma uzlabošanai (van Wesel, \& Prop, 2008). Grupas biedru dotā atgriezeniskā saite - draudzīga, tieša, profesionāla - l̦auj uzlabot portfolio, pirms tās gala versija tiek iesniegta vērtēšanai. Tas māca būt atbildīgiem (Wakimoto, \& Lewis, 2014).

Izstrādājot e-portfolio īpaši šim nolūkam paredzētā tīmekḷa mācību vidē, sasniedzamie rezultāti ir augstāki, nekā izmantojot paša skolēna izvēlētu e-vidi, kurā darbu veic patstāvīgi (Chang, Tseng, Liang, \& Liao, 2013). Autori to skaidro ar atškirīịām iespējām abos gadījumos sekot līdzi skolēnu sniegumam.

Mācību e-portfolio izstrāde, ko pavada atgriezeniskās saites sniegšana par paveikto darbu, veicina neatkarīgu un autonomu domāšanu. E-portfolio veidotājs pats izvēlas pierādījumus un tos organizē saistībā ar mācību mērḳi. Autors pats pilnībā seko, kur, kad un cik daudz portfolio informācijas tiek publicēts (Salzburg Research, 2007). Laikā, kad cilvēki koncentrējas uz kolektīvo darbu, svarīgi atcerēties, ka darbā katrs ir nozīmīgs kā indivīds. Katrs indivīds ir atbildīgs par savu mācīšanos un izvēlēm, kas apliecina prasmes. Katram ir jāsaprot, ko viņš jau ir apguvis, un jāsaprot, ko vēlas apgūt, veido plānus nākotnei. Veidojot e-portfolio, skolēns ir kritisks domātājs, kas pilnveido sevi (Strivens, 2007; Lorenzo, \& Ittelson, 2005).

Skolēnu pašrefleksijas prasmes var pilnveidot, ne tikai pievēršot tam īpašu uzmanību e-portfolio izstrādes gaitā un sniedzot regulāru atgriezenisko saiti, bet arī mērḳtiecīgi izvēloties e-portfolio tematu - aicinot sniegt tajā atbildes uz diviem vai trim būtiskiem jautājumiem, piemēram:

- kādām rakstura īpašībām ir jāpiemīt labam problēmu risinātājam?

- kādas citas rakstura īpašības man vēl būtu nepieciešamas (Holand, 2017³)?

Līdztekus skolotājam, kurš veic formatīvo vērtēšanu, uzmanība jāpievērš tam, ka skolēni mūsdienās plaši izmanto sociālos tīklus, multimedijus, teksta ievadi, taču to dara galvenokārt neformālos nolūkos. E-portfolio izstrādē skolēniem tas jāizmanto daudz formālākā veidā. Skolēnu vēlme justies ierasti ērti, strādājot tīmeklī, var izrādīties šḳērslis, un e-portfolio netiek korekti veidoti (Lane, 2007).

3 Holand, B. (2017). The Art of Reflection. Edutopia. Pieejams: https://www.edutopia.org/blog/ digital-portfolios-art-of-reflection-beth-holland (aplūkots 13.02.2018.). 


\section{Formatīvā vērtēšana digitāli - skolotāju pieredze}

Zinātniskā literatūra sniedz secību, kādā formatīvā vērtēšana organizējama digitāli, un bagātina skolas praksi ar vērtīgiem piemēriem. Tomēr tajā nav atrodami apkopoti dati par skolotājiem interneta vidē pieejamiem digitālajiem formatīvās vērtēěanas rīkiem. Noderīgāka ir skolotāju praktiķu publicētā informācija. 1. tabulā veikts apkopojums - formatīvās vērtēšanas IT rìku grupas, dots gan grupas, gan atsevišķu rīku îss raksturojums, kā arī novērtēts šo rīku noderīgums gan skolotājam (SK), gan skolēnam (SN), lai gūtu atbildes uz formatīvās vērtēšanas pirmo (v), pirmo un otro (vv) vai visiem trim (vvv) pamatjautājumiem. 


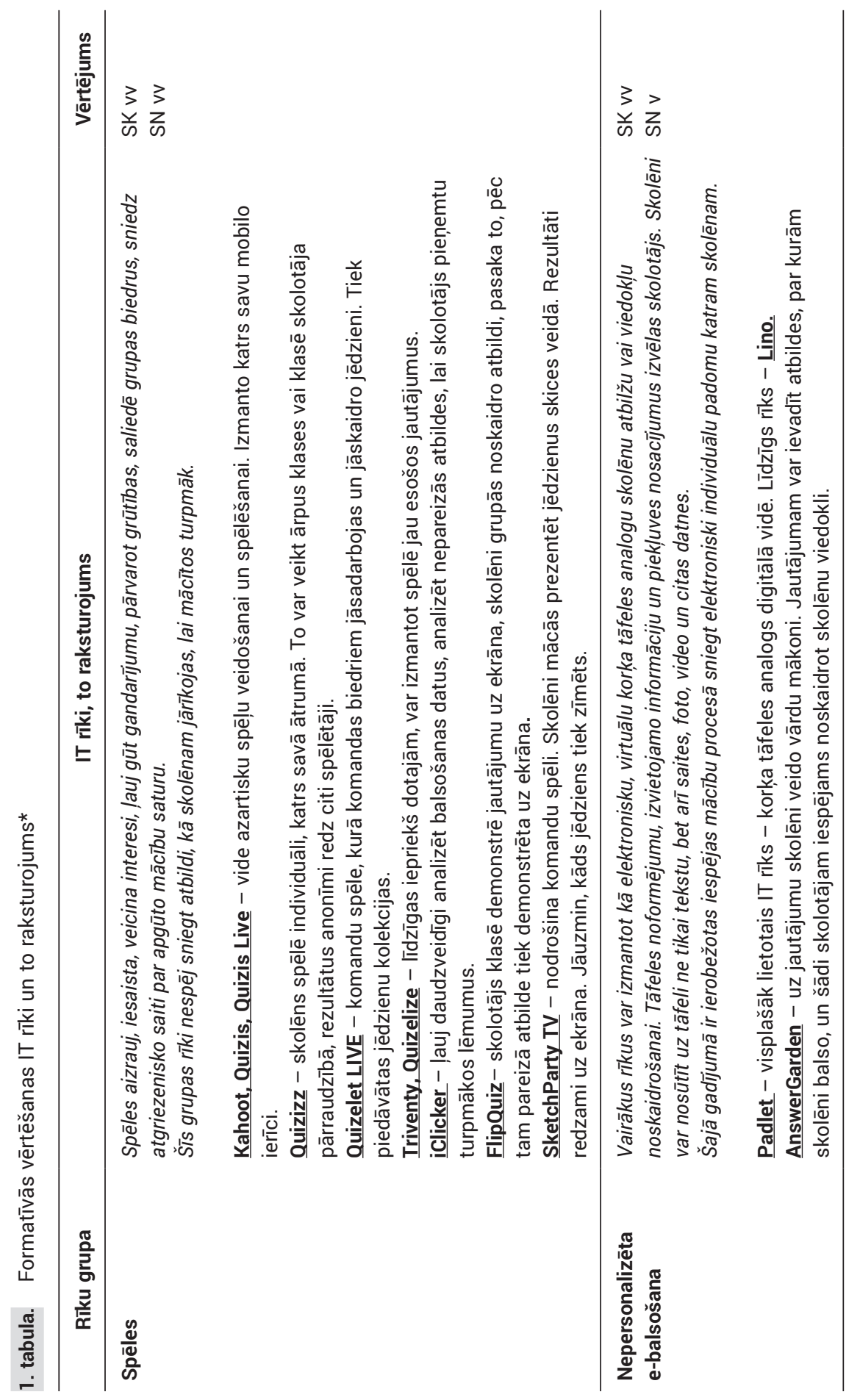


3
乩
¿

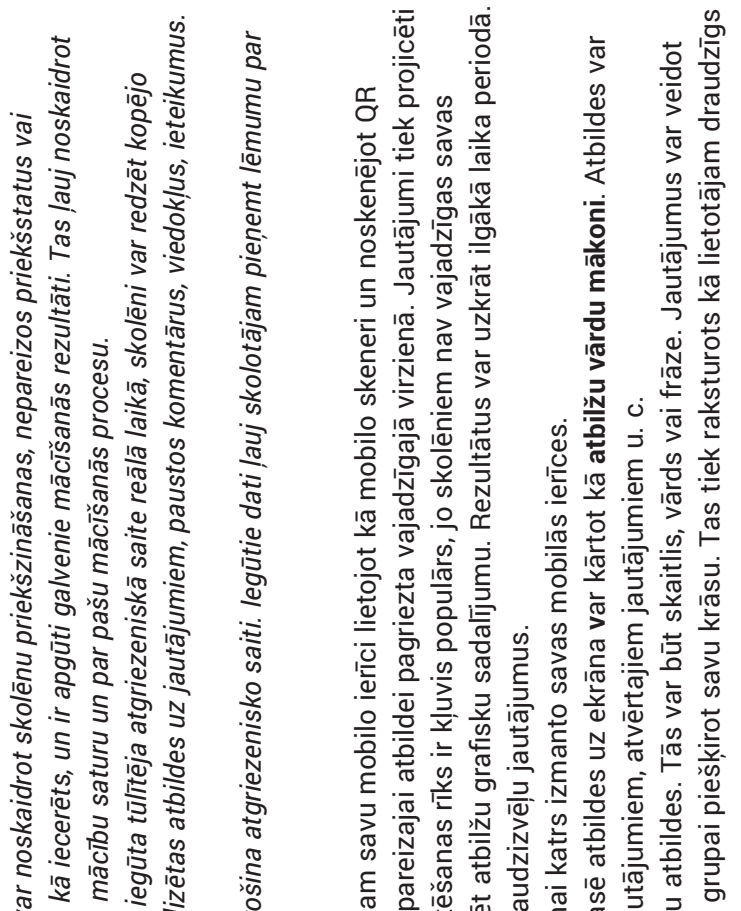

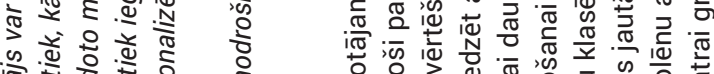
ป⿱宀⿻三丨口 के.

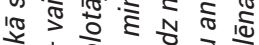
की 1 के

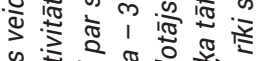

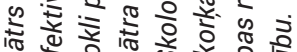
$=$ क

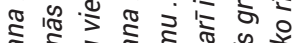
त्र

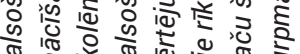

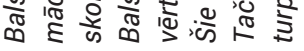

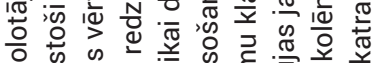

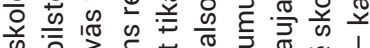

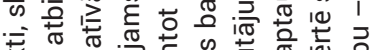

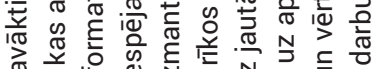

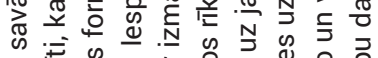

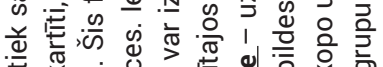

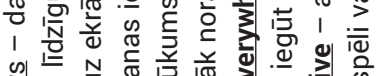

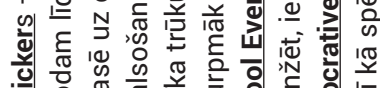

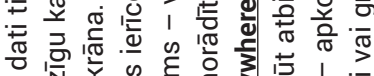

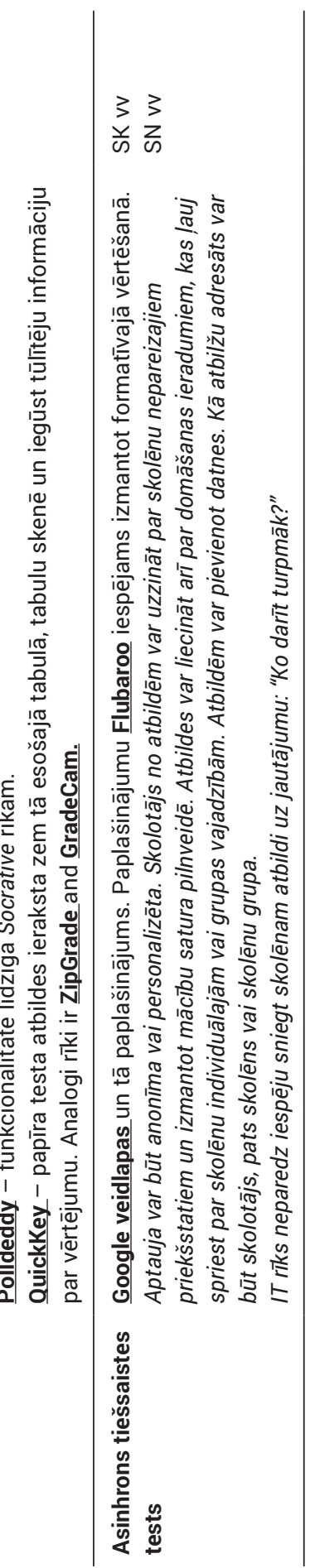

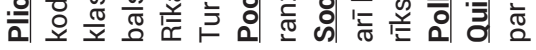

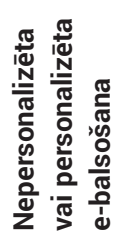


3
3
y
0

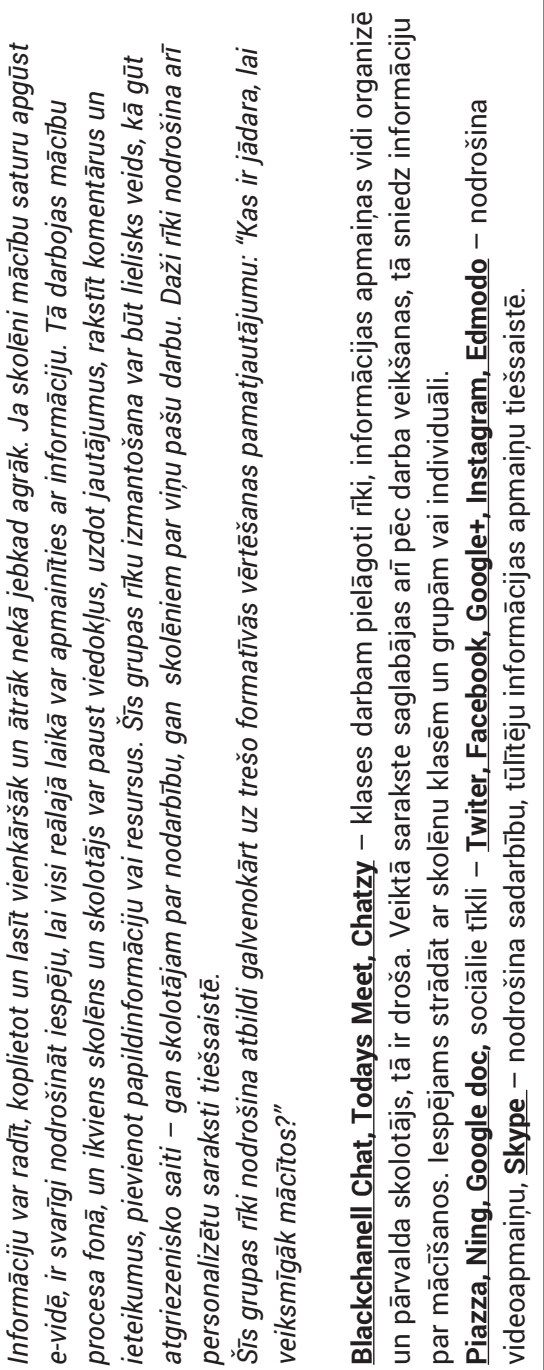


3
के क

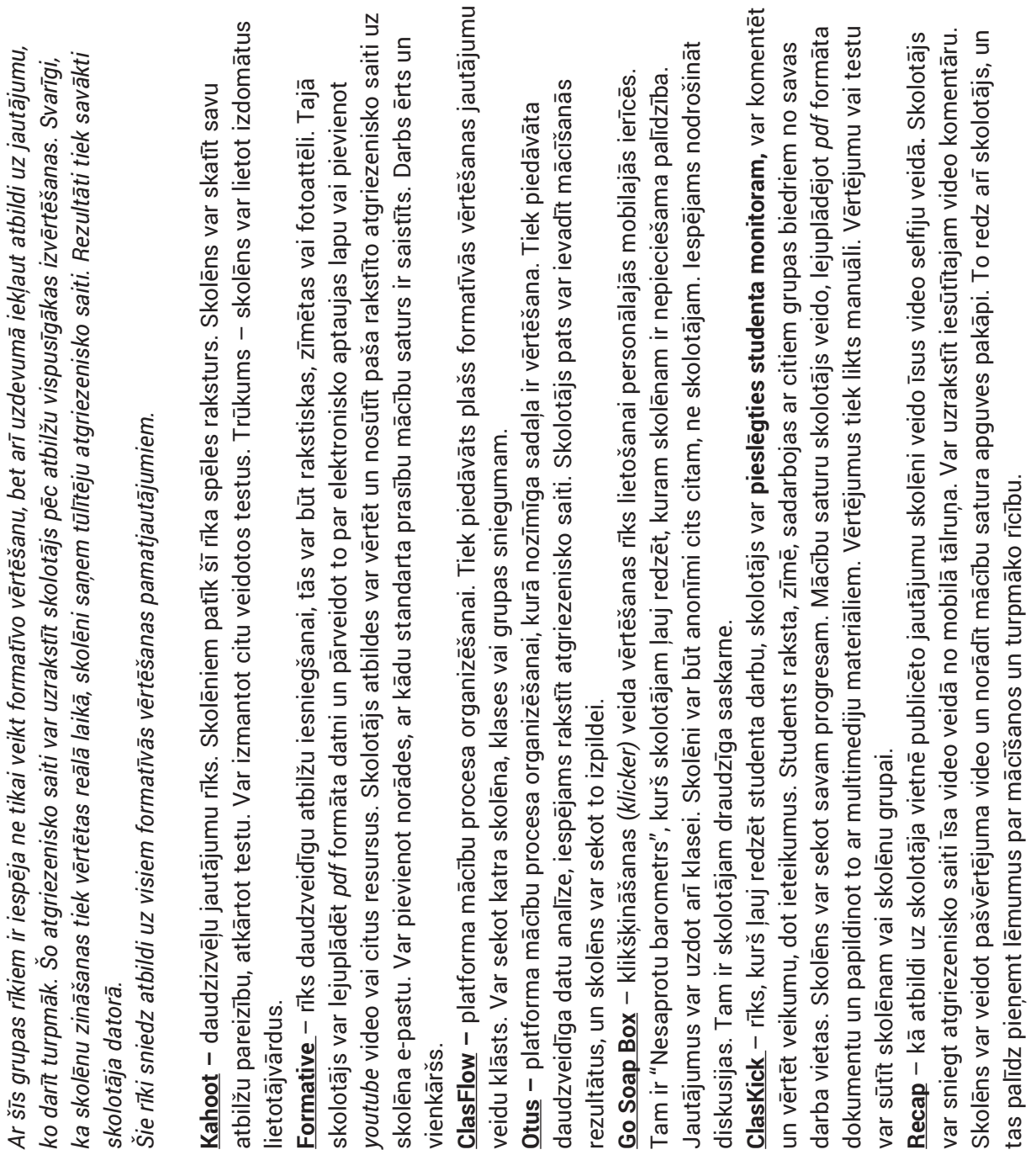

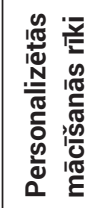




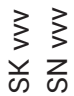

$\stackrel{2}{2}$

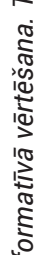

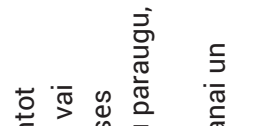

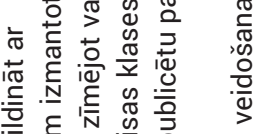

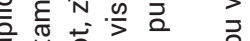

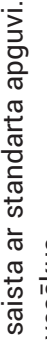

$\frac{\overline{\frac{\pi}{\sigma}}}{\overline{\frac{\pi}{d}}}$

氶

10.0

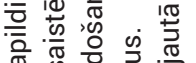

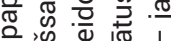

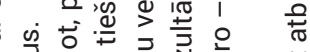

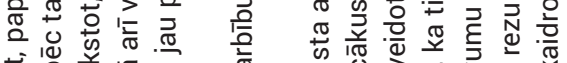

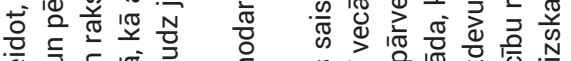

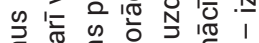

ह

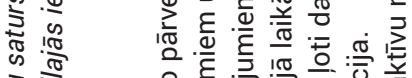

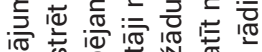

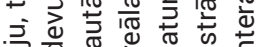

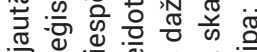

O)

.

孚

बٓं

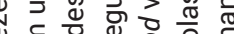

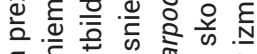

$\pi$ 西

需

论

$\varepsilon>$ 뉴

荡㴆 N

की है ह

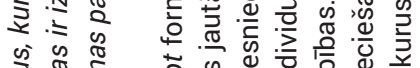

$>$ है

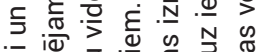

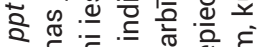

元宁

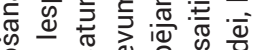

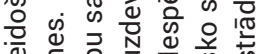

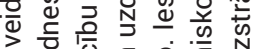

כ

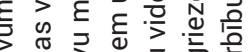

$\stackrel{\infty}{10}$

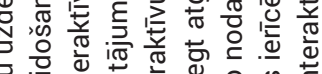

舟

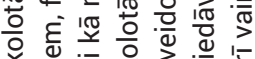

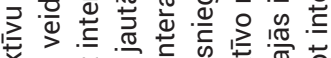

点

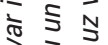

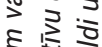

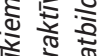

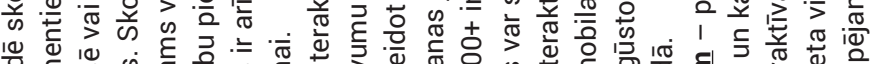

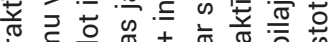

蕞

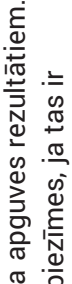

뜬

空

范䨌

ญ

宁

10

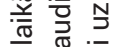

$10 \frac{\pi}{10} \pi$

西

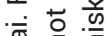

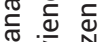

is

응 $\frac{0}{2} \cdot \frac{0}{2}$

ग एक

की

잉

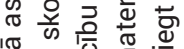

10

类 $ह$ क क

흥 क्ष

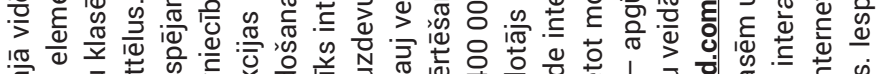

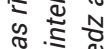

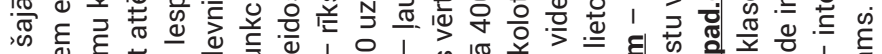

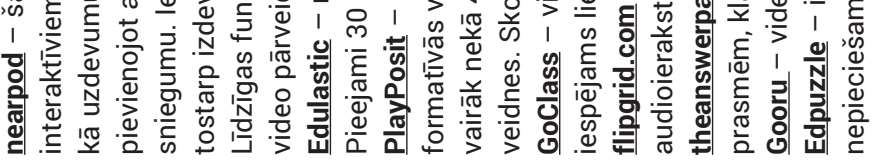

का

文疍此

는

1 


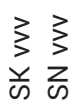

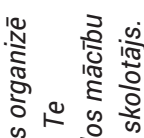

窐:

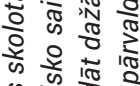

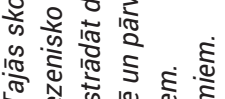

ब.

c.

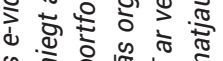

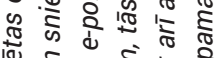

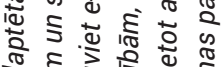

ช.

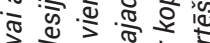

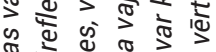

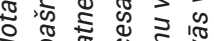

政

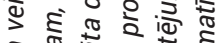

हิ

空空高是 5

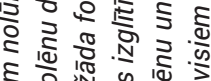

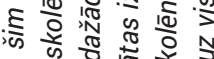

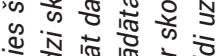

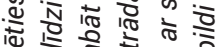

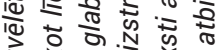

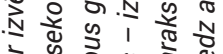

๘

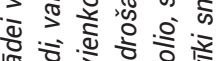

总袋

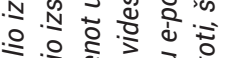

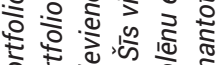

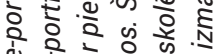

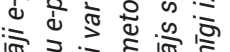

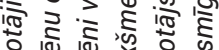

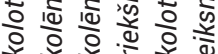
के के के के

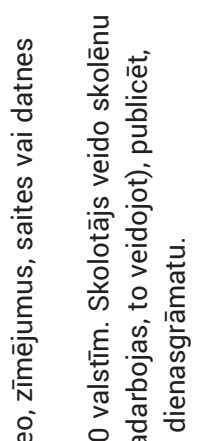

范

웡

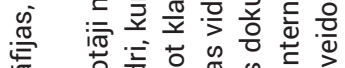

袋 to is is 80 on 10 .

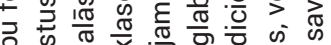

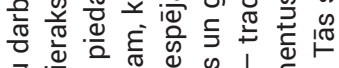
ว. क స

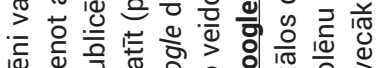

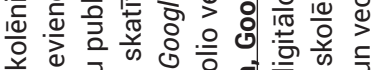

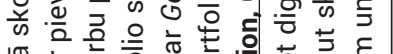

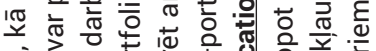

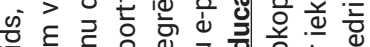

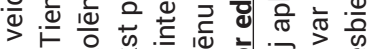
क 空

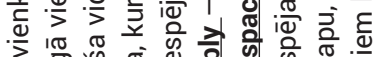

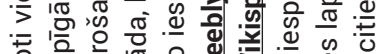
흐 흥 흔

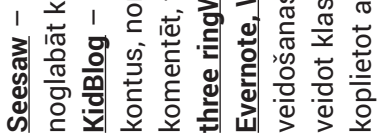

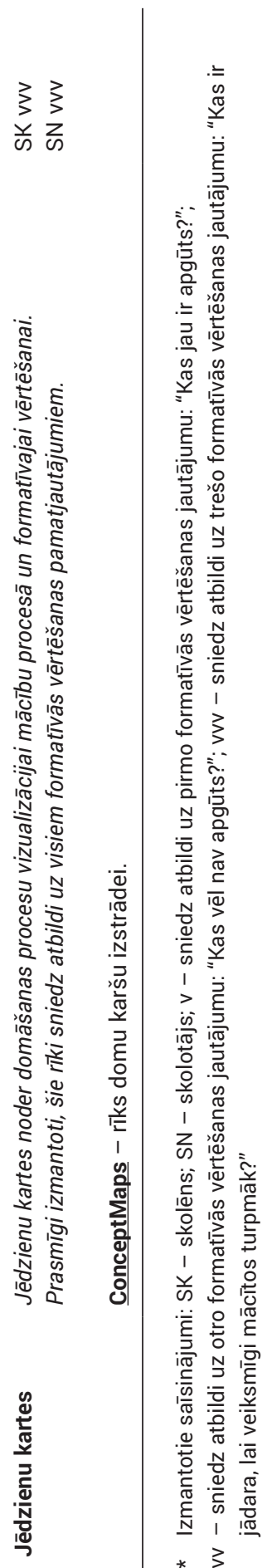




\section{Secinājumi}

Jo kompleksāks ir mācību mērḳis, jo grūtāk ir to novērtēt. Tas attiecināms arī uz kompetences apguves vērtēšanu (Hughes, Green, \& Green, 2013). Taču tiek arī norādīts, ka inteliǵentās un interaktīvās mācību e-vides ḷauj skolēniem attīstīt un demonstrēt atbilstošas prasmes, kurās tiek izmantota formatīvā vērtēšana digitāli.

Tās izmantošanu var balstīt uz veiktajiem zinātniskajiem pētijumiem. Šim nolūkam skolotājs noskaidro nepieciešamību veikt formatīvo vērtēšanu digitāli; literatūrā noskaidro vērtēšanas teorijas un modeḷus; noskaidro stratēgijas, kuru izmantošana atbilst labās prakses pieredzei; īsteno formatīvo vērtēšanu un atgriezenisko saiti izmanto skolēnu mācīšanās uzlabošanai (Hughes, Green, \& Green, 2013).

Prasmīgi izmantota formatīvā vērtēšana digitāli var būt tradicionālās vērtēšanas nozīmīgs papildinājums. Tās veids, saturs un funkcionalitāte spēj nodrošināt nozīmīgu un ticamu datu ieguvi, savukārt sniegtā atgriezeniskā saite ir personalizēta, motivējoša un saistīta ar kognitīvo procesu. Tā ir operatīva un individualizēta - atbilst katra skolēna sniegumam un mācǐšanās stilam.

Veikti pētījumi par daudzu veidu digitālo formatīvās vērtēšanas rīku izmantošanu mācỉbu procesā, kuriem ir atšķirīgs izmantošanas nolūks un iespējas, kā arī lietošanas ērtums. Izvēloties piemērotus digitālos formatīvās vērtēšanas rīkus, tos sekmīgi var integrēt dažādu formu mācību procesā - tradicionālajās, apvērstajās un jauktajās nodarbībās.

IT rīkiem ir l̦oti atšḳirīgas to izmantošanas iespējas, lai nodrošinātu atbildes uz formatīvās vērtēšanas pamatjautājumiem: "Kas izdodas? Kas vēl ne? Ko darīt turpmāk?” To izmantošanas efektivitāti nosaka gan paša IT rīka funkcijas, gan skolotāja darba pieredze.

Īpaši strauju attīstību pēdējos gados gūst digitālie formatīvās vērtēěanas rīki ar šādām iespējām:

- tie darbojas personīgajās mobilajās ierīcēs,

- veic tūlìtēju vērtēšanu "reālā laikā",

- skolēniem un skolotājiem (arī skolas administrācijai) pieejama vērtēšanas analīze,

- skolēniem pieejama anonīma savas darba grupas un klases vērtēšanas analize,

- skolēniem pieejama atgriezeniskā saite reālā laikā,

- iespējams sekot mācīšanās rezultātu (mācību priekšmeta standarta) apguvei,

- to izmantošana veicina ieinteresētîbu mācību satura apguvē, 
- formatīvo vērtēšanu ir iespējams daudzveidīgi integrēt e-vidē publicētā mācību saturā.

\section{IZMANTOTĀ LITERATŪRA}

Baumgartner, P., Himpsl, K., \& Zauchner, S. (2006). Einsatz von E-Portfolios an (österreichischen) Hochschulen: Zusammenfassung, p. 20.

Barrett, H. C. (2007). Researching electronic portfolios and learner engagement: The REFLECT initiative. Journal of Adolescent and Adult Literacy, 50, pp. 436-449.

Berlanga, A. J., van Rosmalen, P., Boshuizen, H. P. A., \& Sloep, P. B. (2012). Exploring formative feedback on textual assignments with the help of automatically created visual representations. Journal of Computer Assisted Learning, 28, pp. 146-160.

Bernhardt, T., \& Kirchner, M. (2007). E-Learning 2.0 im Einsatz. Du bist der Autor! Vom Nutzer zum WikiBlog-Caster. Boizenburg: Verlag Werner Hülsbusch, p. 83.

Broadfoot, P., Timmis, S., Payton, S., Oldfield, A. \& Sutherland, R. (2013). Rethinking Assessment, series of discussion papers. Paper 1 Transforming education through technology enhanced assessment. Graduate School of Education, University of Bristol.

Bruillard, E., \& Baron, G.-L. (2000). Computer-based concept mapping: a review of a cognitive tool for students. In Benzie, D., \& Passey, D. (eds.). Proceedings of conference on educational uses of information and communication technologies: IFIP, $16^{\text {th }}$ World Computer Congress 2000, Beijing, China, 21e25 August 2000 (pp. 331e338). Pekin: PHEI. Pieejams: http:// tecfa.unige.ch/tecfa/teaching/bachelor_74111/Cours_2010_2011/semestre1/cartes_ conceptuelles/Bruillard.pdf (aplūkots 13.02.2018.)

Chang, C.-C., Tseng, K.-H., Liang, C., \& Liao, Y.-M. (2013). Computers \& Education, 69, pp. 237-249.

Conlon, T. (2006). Formative Assessment of Classroom Concept Maps: the Reasonable Fallible Analyser. Journal of Interactive Learning Research, 17.

DiCarlo, K., \& Cooper, L. (2014). Classroom Assessment Techniques: A Literature Review. Journal of Instructional Research, 3, pp. 15-20.

Fullan M., \& Langworthy, M. (2014). How New Pedagogies Find Deep Learning. Pieejams: http://www.michaelfullan.ca/wp-content/uploads/2014/01/3897.Rich_Seam_web.pdf (aplūkots 15.02.2018.).

Gañán, D., Caballé, S., Clarisó, R., \& Bañeres, D. (2017). ICT-FLAG: a web-based e-assessment platform featuring learning analytics and gamification. International Journal of Web Information Systems, 13(1), pp. 25-54.

Gee, J. P., \& Shaffer, D. W. (2010). Looking where the light is bad: Video games and the future of assessment. Phi Delta Kappa International EDge, 6(1), pp. 3-19.

Gikandi, J. W., Morrow, D., \& Davis, N. E. (2011). Online formative assessment in higher education: A review of the literature. Computers \& Education, 57(4), pp. 2333-2351.

Hsieh, I.-L. G., \& O’Neil, H. F., Jr. (2002). Types of feedback in a computer-based collaborative problem-solving group task. Computers in Human Behavior, 18, pp. 699-715.

Hughes, S., Green. C., \& Green, V. (2013). Report on current state of the art in formative and summative assessment in IBE in STM. Part II. Contribution from Pearson Education International. A literature review to inform the development of digital assessments which are relevant to the aims of the ASSIST-ME project, p. 72. Pieejams: http://assistme.ku.dk/ pdf-uploads/D2.4.pdf (aplūkots 13.02.2018.). 
Hattie, J., \& Timperley, H. (2007). The power of feedback. Rev. Educ. Res. 2007, 77, pp. 81-112. Iwamoto, D. H., Hargis, J., Taitano, E. J., \& Vuonk, K. (2017). Analyzing the efficacy of the testing effect using Kahoot ${ }^{\mathrm{tm}}$ on student performance. Turkish Online Journal of Distance Education (TOJDE), 18(2). Pieejams: http://tojde.anadolu.edu.tr/yonetim/icerik/makaleler/ 1379-published.pdf (aplūkots 13.02.2018.).

Kickmeier-Rust, M., \& Albert, D. (2013). Gamification and intelligent feedback mechanisms for a division learning tool. In European Conference on Games Based Learning (p. 290). Academic Conferences International Limited. Pieejams: http://search.proquest.com/open view/8bc5951059a9cb2d5d3ea44fe3033bc2/1?pq-origsite=gscholar\&cbl=396495 (aplūkots 13.02.2018.).

Kingston, N. M., \& Broaddus, A. (2017). The Use of Learning Map Systems to Support the Formative Assessment in Mathematics. Education Sciences, 7(1), p. 41. https://doi. org/10.3390/educsci7010041

Koç, S., Liu, X., \& Wachira, P. (2015). Assessment in online and blended learning environments. IAP.

Kordaki, M. (2015). Diagnosis and Treatment of Students' Misconceptions with an Intelligent Concept Mapping Tool. Procedia: Social \& Behavioral Sciences, 191, pp. 838-842. https:// doi.org/10.1016/j.sbspro.2015.04.478

Kowalski, F. V., \& Kowalski, S. E. (2013). Enhancing curiosity using interactive simulations combined with real-time formative assessment facilitated by open-format questions on tablet computers. Paper presented at Proceedings of Frontiers in Education Conference, Seattle, WA. Pieejams: https://arxiv.org/pdf/1308.1110v1.pdf (aplūkots 13.02.2018.).

Lachner, A., Burkhart, C., \& Nückles, M. (2017). Mind the gap! Automated concept map feedback supports students in writing cohesive explanations. Journal of Experimental Psychology: Applied, 23(1), p. 29.

Lane, C. (2007). The Power of 'e': Using e-Portfolios to Build Online Presentation Skills. Innovate, 3(3), p. 5.

Lorenzo, G., \& Ittelson, J. (2005). An Overview of E-Portfolios. Educause. (online). Pieejams: https://web.archive.org/web/20131102080117/https://net.educause.edu/ir/library/pdf/ ELI3001.pdf (aplūkots 13.02.2018.).

Luckin, R., Clark, W., Avramides, K., Hunter, J., \& Oliver, M. (2017). Using teacher inquiry to support technology-enhanced formative assessment: a review of the literature to inform a new method. Interactive Learning Environments, 25(1), pp. 85-97.

Maier, U., Wolf, N., \& Randler, C. (2016). Effects of a computer-assisted formative assessment intervention based on multiple-tier diagnostic items and different feedback types. Computers \& Education, 95, pp. 85-98. Pieejams: https://doi.org/10.1016/j.compedu.2015.12.002 (aplūkots 13.02.2018.).

Mattei, M. D., \& Ennis, E. (2014). Continuous, Real-Time Assessment of Every Student's Progress in the Flipped Higher Education Classroom Using Nearpod. Journal of Learning in Higher Education, 10(1), pp. 1-7.

Moon, J. (2014). Guide for Busy Academics No. 4: Learning through reflection. The Higher Education Academy.

Neumann, D. L. (2010). Using Interactive Simulations in Assessment: The Use of ComputerBased Interactive Simulations In The Assessment Of Statistical Concepts. International Journal for Technology in Mathematics Education, 17(1), pp. 43-51.

Nguyen, V. A., (2017). Towards the implementation of an assessment-centred blended learning framework at the course level: A case study in a Vietnamese national university. The International Journal of Information and Learning Technology, 34(1), pp. 20-30. 
Quellmalz, E., Timms, M., Buckley, B., Davenport, J., Loveland, M., \& Silberglitt, M. (2012a). $21^{\text {st }}$ century dynamic assessment. In Mayrath, M., Clarke-Midura, J., \& Robinson, D. (eds.). Technologybased assessments for $21^{\text {st }}$ century skills: Theoretical and practical implications from modern research (pp. 55-90). Charlotte, NC: Information Age Publishers.

Quellmalz, E. S., Timms, M. J., Silberglitt, M. D., \& Buckley, B. C. (2012b). Science assessments for all: Integrating science simulations into balanced state science assessment systems. Journal of Research in Science Teaching, 49(3), pp. 363-393.

Rodriguez-Sanchez, M. C., Torrado-Carvajal, Á., Vaquero, J., Borromeo, S., \& HernandezTamames, J. A. (2015). A new open-source technological system for real-time assessment in the classroom. Computer Applications in Engineering Education, 23(3), pp. 412-421.

Salzburg Research (2007). Didaktische, organisatorische und technologische Grundlagen von E-Portfolios und Analyse internationaler Beispiele und Erfahrungen mit E-PortfolioImplementierungen an Hochschulen. Studie der Salzburg Research Forschungsgesellschaft im Auftrag des "Forum Neue Medien in der Lehre Austria" (fnm-austria), p. 36.

Schlegel, E. F., \& Selfridge, N. J. (2014). Fun, collaboration and formative assessment: Skinquizition, a class wide gaming competition in a medical school with a large class. Medical Teacher, 36(5), pp. 447-449.

Shute, V. J., \& Rahimi, S. (2017). Review of computer-based assessment for learning in elementary and secondary education. Journal of Computer Assisted Learning, 33(1), pp. 1-19.

Srisawasdi, N., \& Kroothkeaw, S. (2014). Supporting students' conceptual learning and retention of light refraction concepts by simulation-based inquiry with dual-situated learning model. Journal of Computers in Education, 1(1), pp. 49-79.

Srisawasdi, N., \& Panjaburee, P. (2015). Exploring effectiveness of simulation-based inquiry learning in science with integration of formative assessment. Journal of Computers in Education, 2(3), pp. 323-352.

Srisawasdi, N., \& Sornkhatha, P. (2014). The effect of simulation-based inquiry on students' conceptual learning and its potential applications in mobile learning. International Journal of Mobile Learning and Organisation, 8(1), pp. 24-49.

Strivens, J. (2007). A survey of e-pdp and e-portfolio practice in UK Higher Education. Higher Education Academy.

Trumpower, D. L., Filiz, M., \& Sarwar, G. S. (2014). Assessment for learning using digital knowledge maps. In Digital Knowledge Maps in Education (pp. 221-237). Springer.

Tsai, F.-H., Tsai, C.-C., \& Lin, K.-Y. (2015). The evaluation of different gaming modes and feedback types on game-based formative assessment in an online learning environment. Computers \& Education, 81, pp. 259-269.

Vaughan, N. (2014). Student engagement and blended learning: Making the assessment connection. Education Sciences, 4(4), pp. 247-264.

Wakimoto, D. K., \& Lewis, R. E. (2014). Graduate student perceptions of eportfolios: Uses for reflection, development, and assessment. The Internet and Higher Education, 21, pp. 53-58.

Wang, A. I., Zhu, M., \& Sætre R. (2016). The Effect of Digitizing and Gamifying Quizzing in Classrooms. In European Conference on Games Based Learning (p. 729). Academic Conferences International Limited. Pieejams: https://search.proquest.com/openview/578f b19b8d97af209baad905e968f56a/1?pq-origsite=gscholar\&cbl=396495 (aplūkots 13.02.2018.).

Weinerth, K., Koenig, V., Brunner, M., \& Martin, R. (2014). Concept maps: A useful and usable tool for computer-based knowledge assessment? A literature review with a focus on usability. Computers \& Education, 78, pp. 201-209. 
Van Wesel, M., \& Prop, A. (2008). The influence of Portfolio media on student perceptions and learning outcomes. Maastricht University. Archived from the original. Pieejams: https:// web.archive.org/web/20120229121030/http://www.fdewb.unimaas.nl/EDUC/MASTER/ Documents/Proceedings_S_ICT2008_Final.pdf (aplūkots 13.02.2018.).

Wu, P. H., Hwang, G. J., Milrad, M., Ke, H. R., \& Huang, Y. M. (2011). An innovative concept map approach for improving students' learning performance with an instant feedback mechanism. British Journal of Educational Technology, pp. 1-16.

Zimmerman, E. (2012). Career couch: Showcasing Your Work, in an Online Portfolio. New York Times. 
10. nodala

\title{
Inovāciju pārnese skolā un starp skolām
}

\author{
Līga Čakāne, Anete Butkēviča
}

Lai arī katrai skolai ir savas iekšèjās kultūras īpatnības, skolotāju un vadības sagatavotība, prioritātes, problēmas un atškirīgā vide, lielākajā daḷā skolu, kad tajās tiek ieviestas pārmaiņas, notiek viens un tas pats ietekmes cikls. Ietekmes ciklam ir piecas komponentes: 1) kas ir sasniedzamais rezultāts, kā tas izskatās, ko tas nozīmē; 2) kādas ir skolotāju profesionālās pilnveides vajadzības saistībā ar šo sasniedzamo rezultātu; 3) kas ir nepieciešamās darbības un uzvedība, lai ieviestu vēlamās izmaiņas; 4) kā var gūt pierādījumus tam, ka pašreizējā mācīšana ietekmē skolēnu mācīšanās rezultātus; 5) pirmo četru soḷu izskatīšana - kur esam savā attīstībā, un kā rīkoties turpmāk (Hattie, Masters, \& Birch, 2015). Šìs sastāvdaḷas tiek papildinātas ar attiecīgajām skolas procesu pārvaldes jomām un

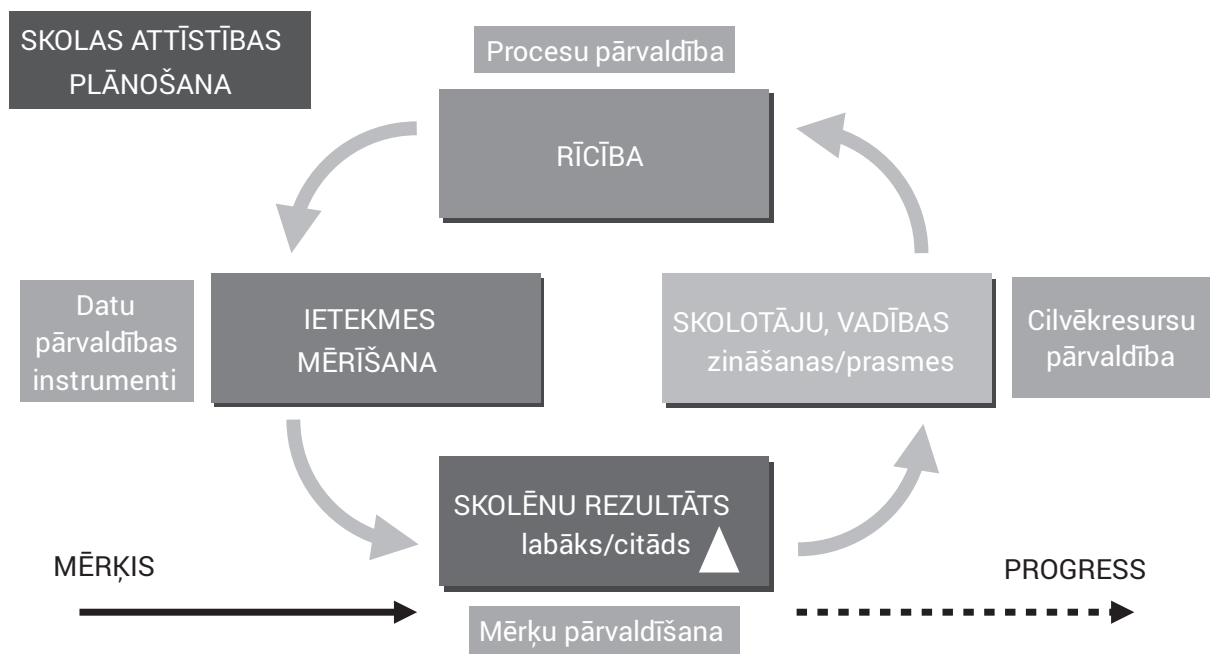

1. attēls. letekmes cikls izvirzīto mērḳu sasniegšanā skolā 
skolas attīstîbu, kas notiek, izvirzot mērkịi, piedzīvojot ietekmes ciklu tā sasniegšanā (skat. 1. attēlu).

Šajā nodaļā tiks apskatìts, kāda loma ir dažādiem izglìtības sistēmas līmeņiem un to dalïbnieku darbībām, lai skolā ieviestu skolotāju profesionālai pilnveidei nepieciešamas inovācijas un lai tās tiktu pārnestas starp citām skolām.

\section{Inovācijas jēdziens skolu izglītības kontekstā}

Inovācija ir jauna ideja, sociāla prakse vai objekts. Inovāciju pieņemšana saistās ar augstu sarežgìitibas līmeni, neziṇu, diskomfortu un riskiem, tāpēc nepieciešamas mērḳtiecīgas darbības, kas vērstas uz inovāciju izzināšanu (Rogers, 2003). Atbilstoša atbalsta trūkums ir visbūtiskākais iemesls, kāpēc kāda inovācija netiek pieñemta un ieviesta (Mulgan, 2006).

Jauns mācību saturs, jaunas pieejas skolēnu rezultātu vērtēšanā un pedagogisko uzskatu maiņa ir daži inovāciju piemēri skolu kontekstā. Izmaiņas skolas kopienas dalībnieku uzskatos un izpratnē ir pamats, lai sasniegtu ilgstošas pārmaiņas izglìtībā. Ar pašu ieviestām un pārvaldītām inovācijām saistās lielāka apñēmība un lielākas iespējas, ka šìs inovācijas nostiprināsies ilgtermiṇā (Huberman, 1983; Fullan, 2007). Šì brīža inovācija izglìitỉā Latvijā ir tādas mācišanas un mācīšanās iedibināšana skolu ikdienas praksē, kas atbilst 21 . gadsimta vajadzībām, kas rezultējas ar skolēna kompetenci.

Inovācijas var tikt definētas kā nepārtraukts process, kas vērsts uz attīstību (Nicholls, Simon, Gabriel, \& Whelan, 2015). Arī šì brǐža inovācija izglìīibā Latvijā uzskatāma par pakāpenisku, jo tā turpina virzību, kas iezīmējās jau 1998. un 2006. gadā ar pārmain̄ām izglìtibas saturā.

\section{Inovāciju ieviešana un pārnese skolotāja darbību līmenī}

Skolu attīstības literatūrā nostiprinājusies tēze, ka skolotāji ir svarīgākais ķēdes posms, lai realizētu inovatīvas pārmaiņas izglìtībā, un ka viṇi ir pārmaiņu aǵenti. Pirmais, kas ieviesa jēdzienu "pārmainu aǵenti" sakarā ar pārmaiņām skolu izglìtībā, bija Maikls Fulans (1993). Pēc viņa domām, skolotājiem jāveic tādas darbības, kas ieviestu vispārējus uzlabojumus izglītībā. Tieši skolotāji ir inovāciju radītāji, ieviesēji, tas aktualizē skolotāju līderu lomu.

Skolotāji līderi uztver sevi kā aktīvus zināšanu radītājus, nevis tikai informācijas saṇēmējus, kā arī kā nozīmes radītājus, identificējot un pastiprinot savu profesionālo balsi (Taylor et al., 2011). Tiek uzskatīts, ka viena no skolotāju līderu lomām ir būt par inovāciju ieviesējiem (Lieberman, \& Miller, 2004). Skolotāji 
līderi kā inovāciju ieviesēji ir aktīvi darītāji, nevis tikai domātāji. Skolu kontekstā skolotāji līderi ir lietas kursā par inovatīvām mācību pieejām, kuras tie, piemēram, ir iemācījušies no pētijumiem, kas var būt viens no vinu kā līderu uzdevumiem (Frost, 2012).

Skolotāju līderu darbība ir process, kurā skolotāji individuāli vai kolektīvi ietekmē citus kolēgus, skolas vadỉbu un citus skolas kopienas locekḷus, lai uzlabotu mācišanas un mācišanās praksi ar mērḳi uzlabot skolēnu mācīšanos un sasniegumus (York-Barr, \& Duke, 2004). Skolotāju līderība tiek definēta kā cilvēku mobilizācija, lai pieņemtu jaunas skolas prakses un pārliecības tā vārdā, lai katra skolēna mācīšanās un izaugsme tiktu optimizēta (Donaldson, 2006). Skolotāju līderībā ir jāuzsver koleg̣iālā dimensija, kas norāda uz sadarbību un abpusēju atbildību vienam pret otru (Frost, \& Durrant, 2003). Ja skolā ir tikai viens vai daži aktīvi skolotāji līderi, ar to nepietiek, lai visā skolā ieviestu inovācijas ilgstošām pārmaiņām. Skolai nepieciešama kopiena ar skolotājiem, kas vēlas sadarboties, ieviest un reflektēt par inovatīvām pārmaiņām (Hargreaves, \& Fullan, 2012).

Kā izpaužas skolotāju līderu darbība:

- skolotāji līderi pēta savu mācību praksi, radot dzilāāku izpratni par mācīšanu, mācišanos un mūžizglìtỉbas veidošanu;

- skolotāji ir atvērti dalīties ar savu izpratni par skolēniem, mācīšanos un mācišanu, tādējādi ietekmējot citus skolotājus un savas skolas sociālo vidi;

- skolotāji līderi atrod un rada iespējas vadìt citus un tajā pašā laikā uzturēt saikni ar mācību stundās notiekošo;

- skolotāji līderi mācās vadīt praktizējošu skolotāju kopienas, kas sekmē un atbalsta risku uzņemšanos un eksperimentēšanu. Tas rada drošu vidi profesionālai pilnveidei gan skolotājiem, kas ir iesācēji, gan pieredzējušiem skolotājiem;

- kad skolotāji ieņem līdera lomu, viṇi palīdz radīt piemērotu mācīšanās vidi, kura ietekmē visu skolas kopienu - gan skolotājus, gan skolēnus (Lieberman, \& Miller, 2005).

Skolotāju līderību Latvijā savā maǵistra darbā pētījusi Anete Butkeviča (2016). Viņa secina, ka Latvijas skolotāju līderu darbība ir cieši saistīta ar jaunu attiecību veidošanu, kuras mērḳis ir mācīties sadarbojoties un pilnveidot skolotāju profesionālo praksi. Skolotāji līderi apzinās nepieciešamību pēc uzlabojumiem viṇu un citu skolotāju mācību procesā. Intervijās atklājās skolotāju līderu motivācija un izpratne par nepieciešamību dalīties ar savu inovatīvo pieredzi savā skolā un ārpus tās. Efektīvākai inovāciju pārnesei nepieciešama pašiniciatīva. Skolotāju līderu izpratne par nepieciešamību pēc inovācijām un pārmaiņām veicina vinus iegūt daudzveidīgu un praktisku pieredzi, viņi izmēginina jaunus mācỉbu pañēmienus un uzlabo savu mācību darbu klasē. Intervētajiem skolotājiem 
līderiem ir divas būtiskas kopīgas īpašìbas - spēja radīt praksē balstītu pieredzi un radìt koleǵiālu vidi skolā.

Galvenais secinājums - mācišsanās kopiena skolā un ārpus tās rodas tikai tad, ja ir vairāki tādi skolotāji, jo dalīšanās ar pieredzi skolā veicina vidi, kas raksturīga mācišanās kopienai. Mācīšanās kopienā skolotāji var iegūt izpratni un atgriezenisko saiti par inovatīiām mācību metodēm, mācoties no savas un citu pieredzes, kas var veicināt uz uzlabojumiem virzîtu darbïbu. Tomēr ir nepieciešami vairāki šādi skolotāji, lai veidotu šādu vidi. Butkēviča (2016) analizē veidu, kā skolotāii līderi Latvijā sekmē inovāciju ieviešanu un pārnesi (skat. 2. attēlu).

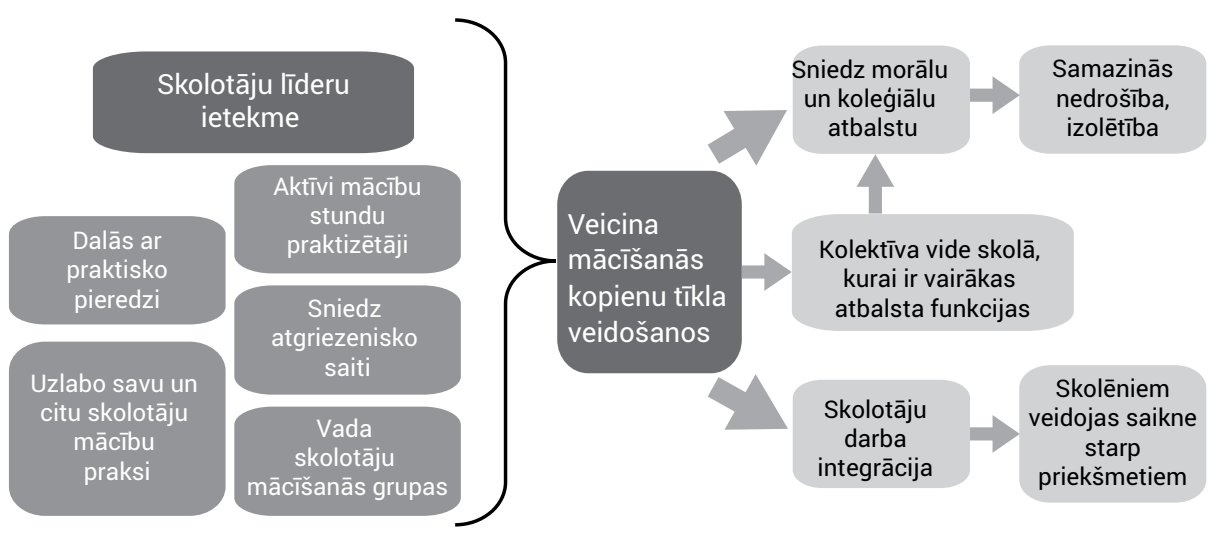

2. attēls. Skolotāju līderu darbība Latvijā (adaptēts pēc Butkēviča, 2016)

Skolotāju līderu darbības pieprasa attiecīgu atbalstu no skolas vadības. Skolas vadībai jāpamana un jāatbalsta skolotāji līderi; jāveicina pašvaldības atbalsts; jāpiesaista izglìtības eksperti vajadzību diagnosticēšanai, darbību plānošanai, skolotāju sadarbības modeḷu sākotnējai ieviešanai; jāplāno laiks un finansiālais atbalsts skolotāju sadarbības nodrošināšanai (Butkēviča, 2016).

Papildus skolotāju līderu lomai un dažādajām darbībām, kas veicina inovāciju rašanos un pārnesi skolās, atbilstošas profesionālās pilnveides un mācī̌nanās modeḷu ieviešana skolā arī tiek uzskatīta par svarīgu inovāciju ieviešanas aspektu skolā. Inovāciju ieviešanas mērḳis ir panākt pārmaiņu būtībai atbilstošas izmaiņas skolotāja darbībā. Tam var būt nepieciešama jaunu prasmju apguve. Skolotāja prasmes un attieksmi būtiski ietekmē tas, kāda veida profesionālās pilnveides iespējas ir pieejamas, kurās var regulāri iesaistìties. Ietekme panākama, iedzīvinot skolotāju mācišanās modeḷus, kuri balstìti reālā klases vidē un reāli, tūlìtēji ietekmē praksi (skat. arī 2. nodalı). 
Izmainas skolotāja praksē ir paliekošas, ja tās ir jau uzskatu līmenī - skolotājs ir pārliecinājies praksē par pieejas maiņas efektivitāti. Tāpēc nepieciešams izmantot tādas profesionālās pilnveides formas, kas panāk jaunas pieredzes izplatīšanu, aktīvu jaunā lietošanu ikdienas praksēe, refleksiju, kolēgu atbalstu. Pārmainas skolotāju uzskatos notiek primāri, kad tiek iegūti pierādījumi par skolēnu mācīšanās uzlabošanos. Ši uzlabošanās ir rezultāts skolotāja profesionālās mācīšanas pieeju izmaiņām, jaunam mācību saturam vai materiāliem vai atsevišķu darbību maiņām klasē (Guskey, 2002). Tieši veiksmīga pārmaiņu ieviešanas pieredze ir izšķirošais (skat. 3. attēlu).

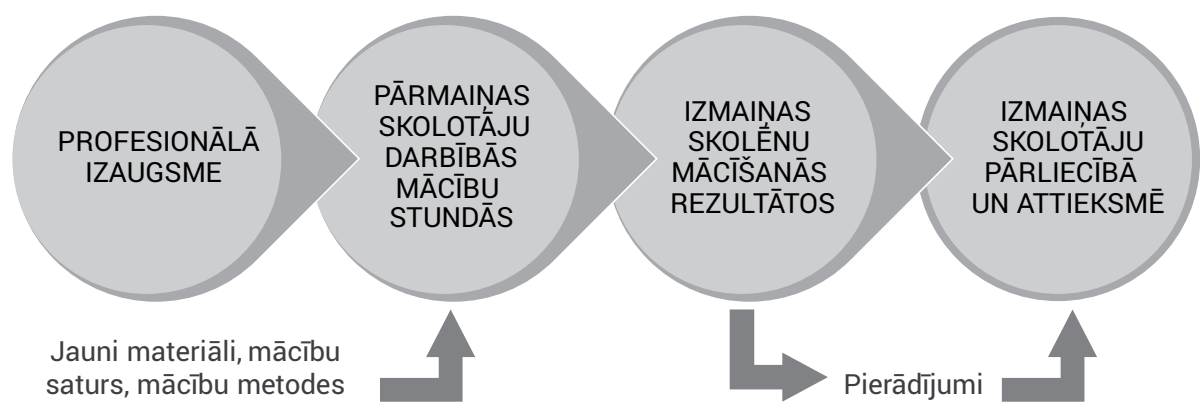

3. attēls. Izmainu saistība ar profesionālo izaugsmi (adaptēts pēc Guskey, 2002)

Vērojot skolotāju darbību un par to reflektējot, viena skolotāja pieredze var tikt pārnesta no klases uz klasi, redzot gan atsevišķus paņēmienus, kā to darìt, gan apliecinot konkrētas mācǐšanas pieejas iespējamību. Ja tam vēl pievienojas liecības par efektivitāti un ietekmi uz skolēna mācišanās rezultātiem ilgtermiņā, tad tas var sekmēt arī sākotnēji skeptisko, atturīgo skolotāju uzskatu maiṇu. Pārmaiņas mācību praksēs ir saistītas ar pārmaiņām attiecỉbā uz to, kādi ir skolēnu mācīšanās rezultāti, kāda ir skolotāju attieksme un uzskati (Guskey, 2002). Ne mazāk svarīgs aspekts ir skolotāju savstarpējās sadarbības treniņš - apzinoties, ka skolotāju cieša sadarbība ir viens no mūsdienu skolas kultūras neatṇemamiem elementiem. Sadarbība nepieciešama ne starp viena mācību priekšmeta skolotājiem, bet starp dažādu priekšmetu un jomu skolotājiem, kā arī starp skolotājiem konkrētā klasē, lai varētu efektīvi plānot un īstenot skolēnu dažādu, tostarp caurviju prasmju mācišanu, palīdzētu vinịiem veidot pārnesumu no viena mācību priekšmeta uz citu, uz reālās dzīves situācijām. Tas šobrīd ir ìpaši aktuāli, sekmējot kompetenci kā skolēna mācīšanās rezultātu.

Inovāciju izglìīibas jomā pētnieki norāda, ka skolās ir nepieciešama koleǵiāla vide (Saito, Murase, Ttsukui, \& Yeo, 2014). Skolotāju līderība veicina šādas vides rašanos (Crowther, 1997; Frost, \& Durrant, 2003; Fairman, \& Mackenzie, 2012). 
Mācīšanās kopienu tīkls un koleg̣iālā vide skolotājiem sniedz nepieciešamo atbalstu un drošības sajūtu eksperimentēt ar inovācijām. Pretstats šādai radošai un inovāciju pārneses veicinošai videi ir izolēts un atsvešināts skolotāja darbs, kas ir diezgan izplatīta parādība mūsdienu skolās. Skolotāju līderības darbības veicināšana varētu būt viens no veidiem, kā samazināt skolotāju profesijas izolētību (Shirley, \& Miller, 2016). Minētie profesionālās pilnveides pieeju piemēri arī saistās ar augsta līmeṇa skolotāju sadarbību. Stundu vērošana var veicināt arī skolas mācīšanās kopienas attīstību (Saito, Murase, Ttsukui, \& Yeo, 2014). Mācǐšanās kopiena var veidoties, ja vēroto stundu plāni tiek izplatīti ar citiem skolotājiem un ja tie tiek papildināti ar pašu skolotāju pierakstiem un refleksiju par stundā veiktajām un vērotajām darbībām. Papildus tam ieteicams pievienot arī skolēnu darba lapas un citus materiālus, kas ilustrē stundā veikto (Takahashi, \& Yoshida, 2004).

Ir vairāki veiksmīgi profesionālās pilnveides pieeju piemēri, kurus skolotāji var praktizēt. Stundu vērošana var veicināt lēmumu pieņemšanu, lai sāktu inovatīvu mācību pieeju praktizēšanu, kas kopīgas mācišanās cẹ̦ā izriet no racionālas empīisku pierādījumu izvērtēšanas (Young, 2009). Mācǐšanās no skolotājulīderu (kā inovāciju agrīno adaptētāju) reālās prakses ir empīiski pierādīta kā viens no faktoriem, kas paātrina inovāciju izplatišsanos (Young, \& Brown, 2016). Kopiga pierādījumu analīze - stundu vērošana un stundu video ierakstu vērošana un analīze, kas notiek starp vairāku skolu skolotājiem un vadību, liek kritiski pārvērtēt esošo zināšanu un uzskatu derīgumu. Tādējādi rodas jaunas darbības un tiek veicināts radošums (Ainscow et al., 2012). 2013. gadā Latvijā izveidotais "Inovatīvās pieredzes skolu tīkls" ir piemērs tam, kā var notikt inovāciju pārnese gan vienā skolā, gan starp skolām, un kurā aktīvi sadarbojas un mācās skolotāji līderi. Raksturīgākās skolotāju sadarbības formas skolās, kas veicina pārmaiṇu ieviešanu (skat. 4. attēlu), ir dažādu līmen̦u skolotāju sadarbības grupas, tostarp rīcỉbpētijumu grupas; savstarpēja stundu vērošana ar sekojošu stundas analīzi un atgriezenisko saiti kolēgim par viṇa profesionālo darbību stundā; sadarbība starp skolotājiem, plānojot un ìstenojot prasmju mācišanu konkrētas klases skolēniem. Ir daudz piemēru, kā skolas vadība vada, aprobē, līderē skolotāju savstarpējo mācǐšanos skolā, kā strādā skolotāji līderi, pulcējot ap sevi citus kolēgus.

Latvijā skolās pakāpeniski ienāk daudzveidīga, mērḳtiecīga skolotāju sadarbïba. Lai arī tā nav ikvienas skolas ikdiena, pozitīvie piemēri liecina, ka tas ir iespējams. Skolotāji ir gatavi iesaistìties un iedzị̣ināties, lai uzlabotu mācǐšanu un tādējādi arī mācišanos un skolēnu rezultātus. Praksē pārbaudīta arī ìpaša programma tieši skolotāju līderu grupas prasmju pilnveidei. Skolotāju līderības veicināšanas programmā skolotājiem bija jāsadarbojas ar citu skolu skolotājiem un jāielaiž viṇi savās mācību stundās, lai demonstrētu savas mācību pieejas. Šāda profesionālās pilnveides pieeja pierādījās kā efektīvs veids, kā skolotājos attīstīt 
līderības prasmes. Vēroto stundu analīze ir strukturēta veidā, lai uzsvērtu pozitīvo un ļautu skolotājam, kas vadījis stundu, izjust gandarījumu par sasniegto, kā arī lai paaugstinātu skolotāja efektivitāti un pārliecinātību. Pozitīvi iespaidi un sava snieguma apzināšanās ir labs veids, kā kḷūt par skolotāju lỉderi. Pētijumā veikto aptauju rezultāti rāda, ka arvien lielāks skaits skolotāju izsaka vēlmi kḷūt par līderiem (Namsone, Čakāne, \& Sarceviča-Kalviške, 2016).

Šādu un līdzīgu uz līderību vērstu profesionālās pilnveides modeḷu ieviešanai skolās nepieciešami vairāki faktori. Pirmais - ir nepieciešami entuziastiski skolotāji, kas vēlas iedziḷināties savā praksē un kuri sevi vēlas uzlūkot kā savas profesijas ekspertus. Otrs faktors ir uzticēšanās starp visām iesaistìtajām pusēm: starp skolotājiem savā skolā, no citām skolām, skolotāju un no ārpuses piesaistīto ekspertu savstarpējā uzticēšanās. Trešais faktors ir skolas vadības iesaiste. Skolotāji Latvijā ir norādījuši uz skolas vadības svarīgo lomu, nodrošinot iespējas skolotāju sadarbībai un praktisko problēmu risinājumam. Skolotāju mācīšanās rezultāti ir augstāki, ja skolas vadība darbojas kā mācību līderi, atbalsta skolotājus un veicina sadarbību (Namsone, Čakāne, \& Sarceviča-Kalviške, 2016, p. 219). Kopumā skolā jātiecas ieviest tādu sociālā kapitāla attīstību, kas vērsta uz līderību, uzticēšanos, kopīgo atbildību un sadarbību (Namsone, Čakāne, \& France, 2015, p. 234).

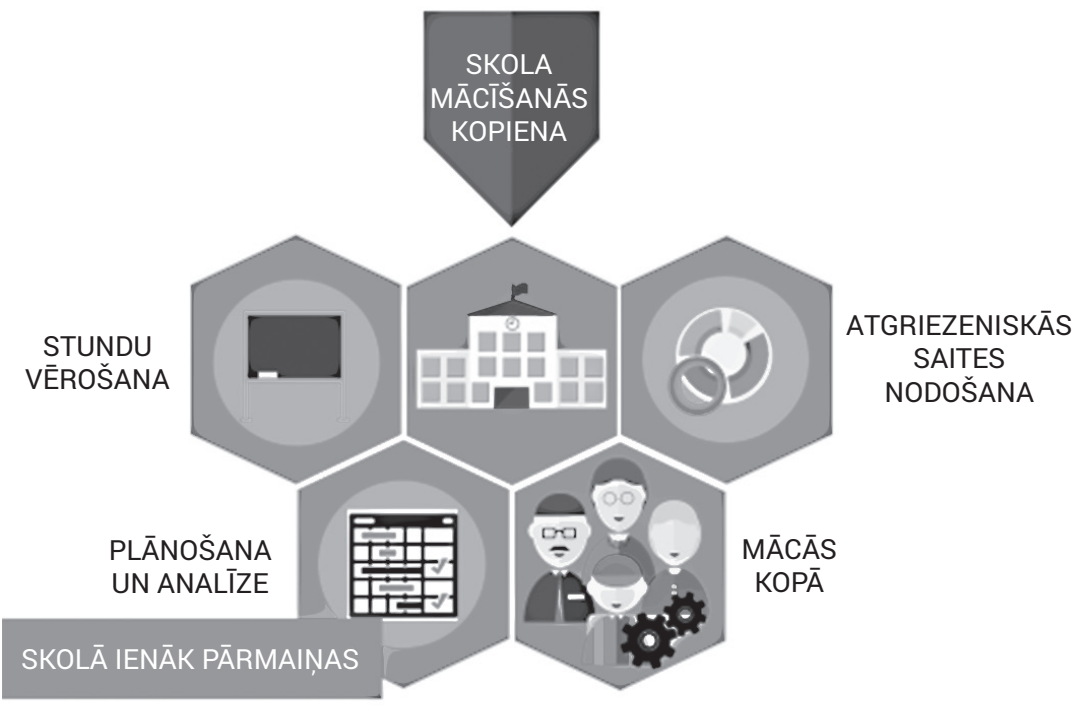

4. attēls. Pārmaiṇu ieviešana skolā: centrālie elementi (LU SIIC arhīvs) 
Daudzās skolās Latvijā ne tikai vārdos jau tiek atbalstīts uzskats, ka skolai ir jākḷūst par vietu, kur mācās arī skolotāji, ne tikai skolēni, kur skolotāji kopā strādā, lai uzlabotu mācīšanu un mācīšanos (Stigler, \& Hiebert, 2009).

\section{Skola kā mācīšanās kopiena: jēdziena apraksts un analīze}

Pārmaiņu mērḳis skolā ir sagaidāmā skolēnu snieguma uzlabošanās. Tiek izšķirti seši vienlīdz nozīmīgi pamatprincipi ceḷā uz rezultātu: skolas vadỉba ir mācīšanās līderi; skolotāji iesaista efektīvās mācībās katru skolēnu; skolotāju mācīšanās ir visefektīvākais cel̦šs, kā uzlabot skolēnu sniegumu; katram skolotājam un skolas vadībai pienākas mērḳtiecīga un regulāra atgriezeniskā saite; spēks ir sadarbībā. Dati ir kā informēts atspogul,ojums skolēniem, skolotājiem, skolas vadībai par situāciju, tie palīdz uzlabot skolotāju praksi (Hargreaves, \& Fullan, 2012).

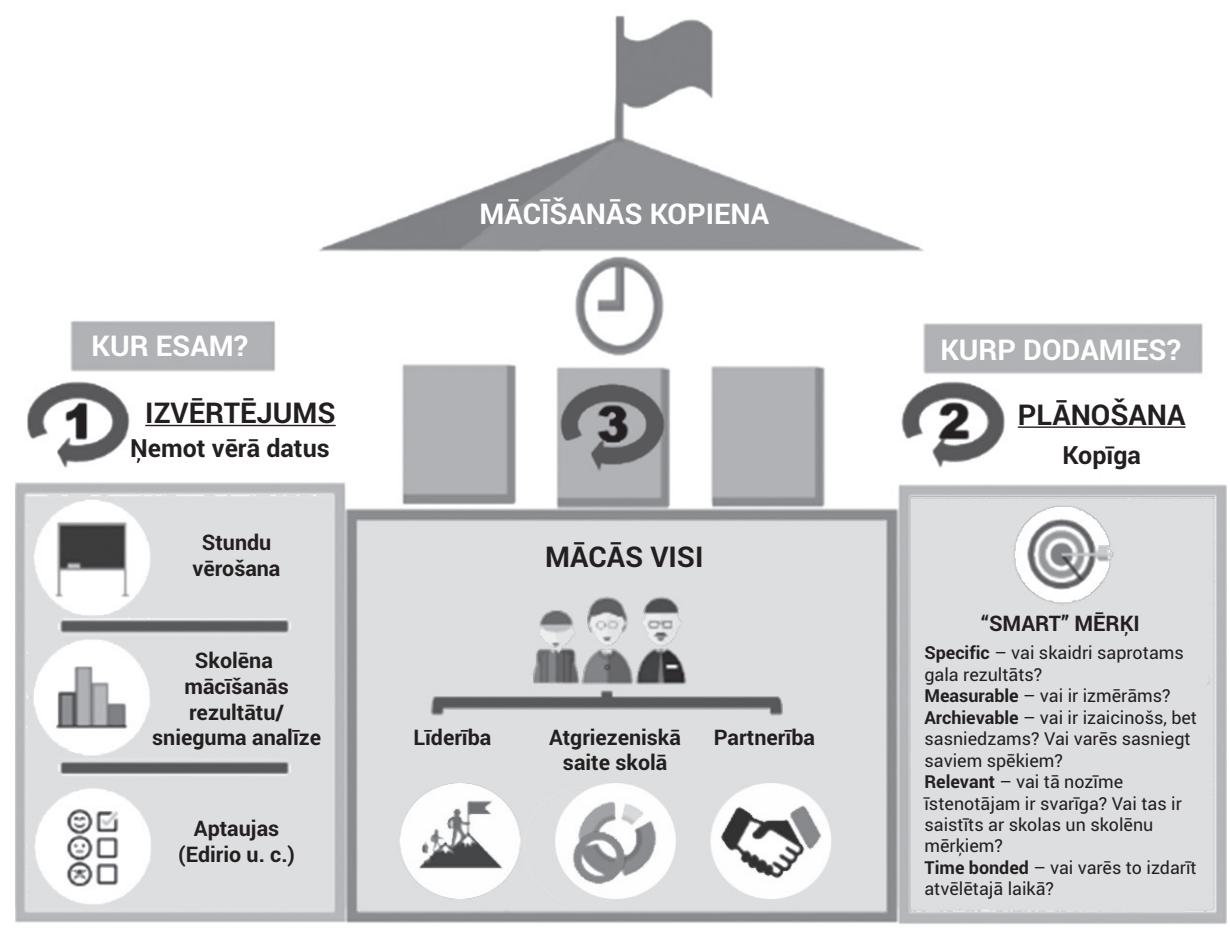

5. attēls. Skola kā mācīšanās kopiena (LU SIIC arhīvs) 
Tātad pārmaiņu ieviešanā skolā izšķiroša ir datos balstīta pārvaldība un plānošana un skolotāju un skolas vadības prasmes, profesionalitāte, kas pastāvīgi jāpilnveido. Tas atbilst priekšstatiem par skolu kā organizāciju, kurā visi mācās un nodrošina savstarpēju atgriezenisko saiti, lai sasniegtu maksimāli labu rezultātu. Lai pārmaiṇas notiktu, ir jābūt iniciatoriem. Tā var būt skolotāju grupa, kas analizē situāciju un ātri uztver nepieciešamo pārmainu būtību, ja skolas vadība ir pārmaiṇu līderi (skat. 4. un 5. attēlu).

\section{Datos balstītas izglītības pārvaldības loma}

Sākta pētniecība, kurā analizēti Latvijas skolu dokumenti (pašvērtējuma ziņojumi u. c.). Vērojama tendence, ka skolu dokumentos formulētie mērķi nereti ir nekonkrēti, grūti izmērāmi (Butkēviča, Zandbergs, Namsone, \& Briķe, 2018). Skolu (arī pašvaldību) veiktā rezultātu analīze bieži balstās tikai datos par skolēnu vidējiem rezultātiem summatīvajā vērtēšanā. Vairumā gadījumu iesaistītās puses nesaṇem noderīgu atgriezenisko saiti par viṇu rezultātiem un darbību kontekstā ar mērķu îstenošanu un turpmākās darbības koriḡěšanu.

Saistībā ar datu ieguvi un lietošanu skolas attīstībai tiek nošķirta divu veidu vērtēšana - skolēnu mācišanās rezultātu vērtēšana un skolotāju profesionalitātes vērtēšana. Skolas līmeņa attīstība tiek saistīta ar spēju objektīivi veikt šāda veida vērtēšanu, bet Latvijā tā diemžēl nav sistemātiski pilnveidota. OECD (the Organisation for Economic Co-operation and Development) uzsver, ka Latvijā ir nepieciešamība pēc jaunām stratēgiskām pieejām izglîtîbas procesu vērtēšanas ietvaram, kas aptver izglìīibas mērķus un skolēnu mācišanās uzlabošanu. Pašreizējā situācija nodrošina izglìtības vērtēšanu, kas ir fragmentāra. OECD norāda, ka drošu un ticamu datu un kontekstuālās informācijas pieeju vajadzētu uzlabot, un šajā nozīmē ir jācel̦ Izglīîibas un zinātnes ministrijas kapacitāte lietot datus un pētijjumus skolu attīstībai. N̦emot vērā pašreizējās reformas ieviestās konceptuālās izmaiņas, ir l̦oti aktuāli atbalstìt skolotāju spēju izvērtēt jaunā satura mācību mērḳus. Ministrijai nevajadzētu novērtēt par zemu šāda uzdevuma kompleksumu, ņemot vērā, ka Latvijas skolotājiem darba pieredze ir tikai ar zināšanās balstītu mācību saturu. Pašreizējā skolotāju vērtēšanas sistēma jāattīsta tālāk un jāvirza uz skolotāju profesionālās attīstības atbalstî̌šnu, tajā jāiesaista skolu līderi un vadība. Šo profesiju standartu aprakstā vajadzētu iekļaut to, kā precīzi izpaužas efektīvu skolotāju un skolas vadības attīstība. Šāda standarta saturs kalpo kā vadlīnijas vai uzziṇu palīglīdzeklis skolotājiem 
un skolas vadỉbai, kā dažādos karjeras posmos mācīties par savu profesionālo attīstîbu (OECD, 2016¹).

Skolu vadības prakse plaša spektra lēmumu pieṇemšanā balstìties uz datiem un šādas pieejas nozīmīgums skolas attīstībai uzsvērts pētījumos (Park, \& Datnow, 2009; Halverson, Grigg, Prichett, \& Thomas, 2007; Kowalski, Lasley, \& Mahoney, 2017). Uz izzināšanu/izpēti balstīta līderība atbalsta sistemātiskus pētỉjumus skolā, lai iegūtu datus par to, kā notiek mācišana un kādi ir rezultāti; reflektēt par tiem, kā uzlabot skolu (Stoll, Bolam, \& Collarbone, 2002; citēts Stoll et al., 2006). Mērījumu dati par skolas sniegumu un to publiskošana ievieš skaidrību, notiek jaunu zināšanu radīšana. Skolā pastāv sadarbības kultūra, skolas locekḷi kopā analizē rezultātus un plāno, kā tos uzlabot. Šādi rodas skaidrība par vērtībām, mērḳiem, turpmāko darbību virzību (Fullan, 1999).

Latvijā skolās pastiprinās interese par datiem, tos aizvien vairāk izmanto, lai iegūtu vispusīgu informāciju par rezultātiem. Tiek analizēti ne tikai valsts līmeņa pārbaudes darbu rezultāti. Skolu praksē ienāk skolotāju, skolēnu un vecāku viedokḷu noskaidrošana par skolai aktuāliem, ar mācibu procesa uzlabošanu saistītiem jautājumiem. ${ }^{2}$ Pieaugot dažādu skolas rīcībā esošo datu apjomam, aktualizējas jautājums par skolu vadības un skolotāju prasmēm kopā interpretēt, reflektēt un izmantot šo informāciju turpmākiem skolas attīstības mērḳiem (Halverson, Grigg, Prichett, \& Thomas, 2007).

Kombinēta dažādu datu analīze palīdz identificēt efektīvu skolu stratēgeiju. Dati par skolēnu rezultātiem būtu jāanalizē saistỉbā ar citiem datiem: skolotāju mācīšanas pañēmieniem, skolas vadības darbības rādītājiem. Dati jāorganizē tā, lai tie palīdzētu skolotājiem uzlabot savu praksi, skolā jāparedz speciāls laiks datu analīzei un lēmumu pieņemšanai (Shen, \& Cooley, 2008, Berhardt, 2013; u. c.) Lai skolā veidotos mācīšanās kopiena un inovāciju ieviešana, nepieciešams aktīvs un mērḳtiecīgs skolas vadības atbalsts.

\section{Skolas vadības loma}

Kolegiaāās vides veicināšana ir svarīga arī starp skolotājiem un skolas vadību. Tā tiek atzìta par skolas vides faktoru, kas var ietekmēt inovāciju ieviešanu skolās (Hargreaves, 2000). Skolotāji līderi ir labs atbalsts skolu vadībai. Skolās, kur vadība ien̦em nogaidošu pozīciju, viṇi var veicināt pārmaiṇu ieviešanu "no

1 OECD. (2016). Education in Latvia, Reviews of National Policies for Education, OECD Publishing, Paris. http://dx.doi.org/10.1787/9789264250628-en

2 Skat. piemēram, EDURIO piedāvātās darbības EDURIO. (2018). Quality monitoring for school systems. Pieejams: https://edurio.com/ (aplūkots 10.02.2018.). 
apakšas". Kā aptaujās norāda paši skolotāji, tas gan var būt l̦oti apgrūtinoši, jo kā skolotāju sadarbības priekšnosacijums tiek minēts tieši skolas vadības atbalsts (Namsone, Čakāne, \& Sarceviča-Kalviške, 2016).

Tas, kā skolā tiek analizēti dati, plānota attīstība, sekots progresam, sniedzot nepieciešamo atbalstu skolēniem un skolotājiem, ir atkarīgs no skolas vadības komandas, pirmām kārtām, no skolas direktora, viṇa prasmēm un uzskatiem. Kopīgas vērtïbas un vienota mērḳtiecība tiek atzītas par svarīgiem faktoriem (Andrews, \& Lewis, 2007). Skolas pārstāvji ar vecākiem vienojas, kādi skolēnu mācīšanās mērḳi ir jāizvirza un kā izpaužas kvalitatīvs skolotāju darbs, kā kopumā skolas darbība var tikt strukturēta, lai uzlabotu skolēnu mācǐšanos. Stratēgijas fokuss ir pievērsties izglītības instrumentiem, nevis tiešām regulām (Bryk et al., 1998; citēts Fullan, 1999).

Skolu vadības lomas būtiskums izkristalizējas vairākos Latvijas Universitātes Starpnozaru izglìtības inovāciju centra (LU SIIC) pētỉjumos. Ir pamats domāt, ka rezultātu atškirīibas starp skolām nevar tikt skaidrotas, balstoties tikai uz skolotāju profesionalitāti. Skolu vadībai un līerībai arī ir ietekme uz skolotāju komandu sniegumu (Namsone, \& Čakāne, 2017). Problēma liek meklēt risinājumus skolu vadības izglìtošanā, jo skolas līmenī inovāciju ieviešana primāri būs atkarīga tieši no skolu vadības izpratnes par pārmainu būtību un prasmēm motivēt un atbalstīt savus skolotājus.

Aktuāls jautājums Latvijas izglìtības sistēmā ir - kas kḷūst par skolas vadību? Kā norādìts (ETUCE, 2012³), nav valsts līmeņa regulējuma, kas to noteiktu. Tā ir pašvaldības kā skolas dibinātāja atbildība. L̦oti bieži skolas direktors uzṇēmies prioritāri saimnieciska rakstura problēmu risināšanu, atstājot mācību procesa vadību vietnieku ziṇā. Tas varētu būt daḷejji skaidrojams ar to, ka skolas vadībai nav formālu prasību tālākizglîtībai saistībā ar līderību un vadības zinībām (Daiktere, 2012). Arī vēsturiski Latvijas skolu vadības loma tika vairāk izprasta kā administratīva: resursu un procesu pārvaldība, neiesaistoties skolotāju profesionālās pilnveides jautājumos (Blūma, \& Daiktere, 2016, p. 157).

Skolu vadība atkarībā no savām darbībām var atainot dažādus līderības tipus (Brauckmann, \& Pashiardis, 2011). Katrs tips atspoguḷo daļu no iespējamajām darbībām, ko vadība var veikt, lai veicinātu inovāciju ieviešanu skolā un pārnesi starp skolām.

3 ETUCE. (2012). ETUCE School Leadership Survey Report: School Leadership in Europe: Issues, Challenges and Opportunities, European Trade Union Committee for Education, Brussels. Pieejams: www.csee-etuce.org/images/attachments/SchoolleadershipsurveyEn.pdf (aplūkots 01.12.2017.). 
Uzṇēmējdarbības stilam (Entrepreneurial style) raksturīgs, ka šie līderi radoši lieto ārējos tīklus un to piedāvātos resursus, lai sasniegtu skolas izvirzìto misiju. Notiek pozitīvu partnerību veidošana ar vecākiem, plašāku kopienu. Skolēniem to pamanot, uzlabojas viņu uzvedība. Ārējās vides apzināšanās un sadarbošanās ar apkārtējām skolām, sistēmām, kopienām, sabiedrību, uzṇēmumiem un valdības institūcijām. Pamatelementi: ārējo kontaktu iesaistī̌̌ana; stratēǵiska resursu piesaiste; attiecību veicināšana ar vecākiem un sabiedrību; sadarbība ar uzņēmumiem, organizācijām; nepieciešamo paņēmienu lietošana, lai iesaistītu minētās puses; skolas mērḳu pārrunāšana ar iesaistìtajām pusēm (stakeholders); skolas vīzijas komunicēšana sabiedrībai; abpusējas komunikācijas nodrošināšana; laba iespaida sniegšana par skolu kopienas acīs; uzticības būvēšana kopienā.

Mācību līderība (instructional style) izteikti fokusējas uz mācišanas un mācīšanās kvalitātes uzlabošanu un būvē skolas misiju un mērķus, kas saistīti ar mācišanu. Tie rada klimatu, kurā ir augstas prasības tam, kā notiek mācīšana un mācǐšanās, veic pārraudzību un izvērtēšanu. Nepārtraukti stimulē mācību inovācijas. Pamatelementi: mācību resursu nodrošināšana; augstāka līmeņa mācỉbu prakšu nodrošināšana; praktisku zināšanu lietošana; mācību pārraudzība; atgriezeniskās saites sniegšana skolotājiem; izvērtējumos iegūto datu lietošana, lai uzlabojumus ieviestu.

Partnerības līderība (participative style) norāda uz to, ka līderi organizē vadības aktivitātes caur citiem skolas darbiniekiem dažādos veidos atkarībā no vadības ieskatiem un atkarībā no skolas organizācijas kultūras. Viṇu līderības iespaidā notiek skolas darbinieku aktīva iesaistišanās lēmumu pieņemšanā un komandas nostiprināšanā. Šo līderu efektivitāte izpaužas, atbalstot skolotājus līderus, veicinot administratīivās komandas līderību, kas savukārt pozitīivi ietekmē skolas kā organizācijas mācīšanos (organizational learning) un skolotāju darbību. Skolas darbinieki izjūt izteiktāku apņemšanos sasniegt skolas organizatoriskos mērķus. Pamatelementi: sadarbības, apñēmības, atvērtas komunikācijas veicināšana; kopējas skolas misijas radīšana; aktīva skolas darbinieku iesaiste plānošanā, lēmumu pieṇemšanā, problēmu risināšanā; skolotāju mācību autonomija.

Personāla vadības un attīstības līderība (personnel development) raksturīga skolas līderiem, kuru pārliecība un darbība saistās ar skolotāju profesionālo izaugsmi un kas ietekmē skolotāju mācību praksi. Atbilstošu modelı,u, individuāla atbalsta un intelektuāla stimula nodrošināšana skolotājiem. Šādi skolas līderi veicina skolotāju profesionālo izaugsmi ar šādām darbībām: sniegšana, skolotāju profesionālās pilnveides vai kvalifikācijas celšanas (in-service training) nodrošināšana, profesionāla satura žurnālu nodrošināšana, ar mācībām saistītu inovāciju pārrunāšana kopīgās sanāksmēs. Pamatelementi: profesionālās pilnveides iedrošināšana; skolotāju apbalvošana, komplimentu un atzinības izteikšana par sasniegumiem; 
skolotāju panākumu atzīmēšana; informētu ieteikumu sniegšana personāla vadības attīstībai; informēšana par iespējām uzlabot zināšanas un prasmes.

Strukturējošā līderība (structuring style) saistās ar virzības un koordinēšanas nodrošināšanu skolā. Šie līderi uzṇemas atbildību par standartizētu procedūru un rutīnas uzturēšanu. Skolas objektu tehniskā apkope un uzturēšana, drošỉba. Skaidrības nodrošināšana par lomām, aktivitātēm, prioritātēm, skolēnu uzvedības normām, šo normu uzraudzīšana; kārtīguma nodrošināšana. Pamatelementi: skaidru likumu, noteikumu, procedūru konsekventa iedibināšana; disciplīna, kārtība.

Skolas vadības pamatdarbības inovāciju ieviešanā un pārnesē ir konkrētu mērḳu definēšana gan skolai kopumā, gan katram skolotājam; atbalsta nodrošināšana šo mērḳu sasniegšanā; sadarbības veicināšana, nodrošinot atbilstošas iespējas, aktivizējot pieredzes apmainu un cita veida mācišanās aktivitātes skolā. Vadībai jāiesaistās kopīgajās mācībās un jāseko līdzi jaunapgūtā ieviešanai reālā darbībā mācību stundās.

\section{Kā notiek inovāciju pārnese starp skolām Latvijā - līderības un motivācijas perspektīva}

Inovāciju pārnesei ārpus vienas skolas izšķiroša ir pašvaldības - skolu dibinātāja - loma un skolotāji līderi (pārmaiṇu ağenti), kuri spēj iedvesmot un dot reālu atbalstu ne tikai savas skolas skolotājiem, bet arī kolẹgiem citās skolās.

Pētijums par Latvijas skolotājiem līderiem parāda, ka skolotājs līderis iesaistās nepārtrauktā profesionālajā izaugsmē, analizē un reflektē, iedzịlinās, izrāda vēlmi mācìties kopā un vērot stundas. Skolotāji līderi nereti uzṇemas iniciatīvu vadīt darbnīcas, sniegt prezentācijas ārpus savas skolas un kopā plānot, analizēt, organizēt un izvērtēt aktivitātes savā skolā un novadā (Namsone, Čakāne, \& Sarceviča-Kalviške, 2016). Skolotāju līderu kustības veicināšanā izšḳiroša loma ir šo skolotāju pašu sākotnējai profesionālajai pilnveidei un turpmākajām pašu mācībām. Izveidotais vairāklīmeṇu skolu un skolotāju sadarbības tīkls un nacionālajā tîklā îstenotā skolotāju nepārtrauktās profesionālās pilnveides modelis paredz, ka reǵionālā tîklā skolotāji mācās paši (tostarp apgūst līderības prasmes), bet novada līmenī jau īsteno sevi kā līderi darbībā.

Skolas un skolotāju līderības pierādījums - skolas komanda pārnes un darbina savā novadā apgūtās idejas, daloties pieredzē ar novada skolām, kā arī pārnesot skolas komandas nacionālajā tỉklā iegūto pieredzi uz skolu kopumā. Skolotāju komandas skolās kopīgi plāno, ievieš un vērtē dažādas aktivitātes turpmākaji attīstībai un izplata idejas citu skolotāju vidū. Tīkla dalībnieku vidū ir 
savstarpēja uzticēšanās un atbalsts. Mācǐšanās notiek, vadot un piedaloties darbnīcās, semināros, apmainoties ar atbalsta materiāliem, vadot un vērojot mācību stundas. Tīklā iesaistītie skolotāji mācās cits no cita pieredzes reālā darba situācijās skolās ar fokusu uz darbībām mācību stundās. Galvenie faktori, kas ietekmē šo procesu, ir nepārtrauktas profesionālās pilnveides modeḷa darbināšana, pašas skolas organizēto pasākumu kvalitāte, skolas komandas saliedētība, skolas vadības atbalsts, laiks darbību un rezultātu ilgtspējai, skolotāja personiskās īpašības, pieredze (Namsone, Čakāne \& Sarceviča-Kalviške, 2016).

Par līderiem var kḷūt ne tikai atsevišksi skolotāji. Arī vienas skolas skolotāju grupa vai skola kopumā var kḷūt par līderskolu. Šādas skolas atbilstošās kvalitātes formulētas 1. tabulā (Namsone, Čakāne \& Sarceviča-Kalviške, 2016). Skola, kas iesaistījusies tīklā, var kḷūt par mācī̌anās klāstera centru citām skolām atbilstoši tam, kā to literatūrā par skolu kā mācišsanās kopienu klāsteriem apraksta citi autori (Hargreaves, \& Fullan, 2012). Daloties pieredzē novados, novada skolu skolotājiem ir radīta jaunas mācī̌sanās pieredzes iegūšanas iespējas, iesaistoties semināros ar mācību stundu vērošanu vai skolotāju sadarbības grupās. Skola uzskatāma par līderskolu, ja notiek mērḳtiecīgas, efektīvas, ilgtermiṇa skolotāju nepārtrauktas profesionālās pilnveides aktivitātes, kurās iesaistās lielākā dalıa skolotāju; notiek regulāra skolotāju sadarbība pārmaiṇu ieviešanā; notiek regulāra dalīšanās pieredzē ar citu skolu skolotājiem.

1. tabula. Kategorijas, kas raksturo līderskolu

\begin{tabular}{|c|c|c|}
\hline Kategorijas & Rādītāji & Piemēri, pierādījumi (skola x) \\
\hline \multirow[t]{4}{*}{ Mācīšanās kopiena } & Mērḳtiecīga & $\begin{array}{l}\text { Skolā organizēts mācību cikls visiem skolas } \\
\text { skolotājiem "Efektīva mācību stunda" u. c. }\end{array}$ \\
\hline & Efektīva & $\begin{array}{l}\text { Skolā ir rīcībpētījuma grupas, notiek savstarpēja } \\
\text { stundu vērošana un analīze }\end{array}$ \\
\hline & $\begin{array}{l}\text { Regulāra, } \\
\text { ilgtermin,a }\end{array}$ & $\begin{array}{l}\text { Mācīšanās grupas notiek katru mēnesi, noslēgumā } \\
\text { tiek organizēta konference; mācību semināri visiem } \\
\text { skolotājiem reizi semestrī }\end{array}$ \\
\hline & $\begin{array}{l}\text { lesaistās lielākā } \\
\text { dala skolotāju }\end{array}$ & $\begin{array}{l}26 \text { skolotāji iesaistījušies rīcībpētījuma grupās, } \\
\text { mācību semināros skolā piedalās visi skolotāji }\end{array}$ \\
\hline \multirow[t]{2}{*}{$\begin{array}{l}\text { Skola, kurā } \\
\text { sadarbojas }\end{array}$} & Mērḳtiecīga. & $\begin{array}{l}\text { Sadarbība starp kolēǵiem, kas fokusēta uz } \\
\text { uzlabojumiem, inovācijām, izmaiṇu ieviešanu }\end{array}$ \\
\hline & $\begin{array}{l}\text { Aptveroša, } \\
\text { ar tendenci } \\
\text { paplašināties }\end{array}$ & $\begin{array}{l}\text { Sadarbība tika sākta } 5 \text { kolēǵu komandā, tagad } \\
\text { aptver } 26 \text { kolēǵus }\end{array}$ \\
\hline
\end{tabular}




\begin{tabular}{|c|c|c|}
\hline Kategorijas & Rādītāji & Piemēri, pierādījumi (skola $x$ ) \\
\hline \multirow[t]{2}{*}{$\begin{array}{l}\text { Notiek pārnese } \\
\text { (apliecina gatavību } \\
\text { dalīties pieredzē) }\end{array}$} & $\begin{array}{l}\text { Uzṇem kolēǵu } \\
\text { vizītes, organizēe } \\
\text { pasākumus }\end{array}$ & $\begin{array}{l}\text { Skolas x vietējā līmeña tīklā iesaistās vēl } \\
\text { septiṇas skolas; skola x dalās pieredzē kopš } \\
\text { 2011. gada }\end{array}$ \\
\hline & $\begin{array}{l}\text { Organizē } \\
\text { mācību } \\
\text { seminārus ar } \\
\text { stundu vērošanu } \\
\text { un analīzi citās } \\
\text { skolās }\end{array}$ & $\begin{array}{l}\text { Laikposmā no } 2011 \text {. līdz 2013. gadam organizēja } \\
\text { vienu starptautisku, } 11 \text { nacionāla līmeña un } \\
24 \text { novadu līmeṇa darbnīcas un trīs skolas } \\
\text { lìmeña darbnīcas. }\end{array}$ \\
\hline
\end{tabular}

Mācīšanās līderi skolas kontekstā ir tie, kuriem izdodas uzlabot savu mācību praksi un palīdzēt citiem darìt to pašu (Fullan, 2011). Tìklošanās, lai sazinātos un sadarbotos ar kolēgiem, mācītos cits no cita un dalīšanās pieredzē vairāku skolu līmenī ir viena no skolotāju profesionālās pilnveides dimensijām (Zehetmeier, 2015; Craft, 2002).

Ir daudz labu piemēru, kā tiek īstenota skolotāju sadarbība ar mērķi sekmēt skolotāju profesionalitāti un inovāciju ieviešanu klasēs un skolās. Vairāk šādu piemēru ir par pārmaiņām atseviškāa skolā, mazāk - pašvaldību iniciētu un vadìtu starpskolu model̦u. Pārņemamas prakses piemērs ir izglìtības politika pašvaldībā X, kur jau piecus gadus tiek īstenotas mērḳtiecīgas aktivitātes skolu un skolotāju profesionālai pilnveidei. Ir izveidojusies produktīva sadarbība gan skolā, gan starp skolām, ir izveidots metodiskais dienests, kurā iekḷauti skolotāji līderi, kuri spēj sniegt atbalstu mācišanas pilnveidošanā skolotajiem neatkarīgi no tā, kura mācību priekšmeta skolotāji viṇi ir. Lai gūtu drošus pierādījumus, apstiprinājumu šādu sadarbības modeḷu efektivitātei, ietekmei uz skolēnu mācīšanos ilgtermiņā, nepieciešams papildu pētijums - padzilināàta situācijas (procesu un rezultātu) analīze.

\section{Secinājumi}

Inovāciju ieviešana skolā un veiksmīga pārnese starp skolām ir dažādos līmeņos iesaistīto dalībnieku kopīga atbildība. Nepieciešamo pārmaiņu ieviešanu ikvienā skolā ietekmē skolotāju izpratne par inovāciju izraisīto pārmaiņu būtību. Skolotājiem ir būtiski izmēgeināt inovācijas praktiski un pārliecināties par izmaiņu efektivitāti jeb gūt pozitīvu pieredzi. Šādu pieredzi var gūt, iesaistoties profesionālās pilnveides darbībās, kas mērḳētas uz regulāru sadarbību un refleksiju, kā dēl mainās attieksme un uzskati. Šāda profesionālās pilnveides model̦a piemērs ir kopīgā stundu vērošana un analīze, kas var notikt ne tikai vienā skolā, bet arī 
starp vairāku skolu skolotāju komandām. Tas aktualizē jautājumu par spēju sadarboties un uzticēties kopīgā mācǐšanās procesā.

Skolotāju līderu darbība var kalpot kā pieeja skolām izmantot savus iekšējos cilvēkresursus skolotāju profesionālajā pilnveidē. Skolotāju līderu darbībā inovācijas tiek ieviestas skolā un tiek veicināta to pārnese starp skolotājiem un skolām. Tomēr jāṇem vērā, ka šādiem skolotājiem nepieciešama attiecīga koleg̣iāla vide jeb motivēti domubiedri, kas vēlas mācìties sadarbojoties, kā arī vadības atbalsts.

Skolas vadības līmenī inovāciju ieviešanu un pārnesi ietekmē vadības komandas un direktora izpratne un prasmes plānot inovāciju ieviešanu un vadīt šo procesu. Skolu vadībai jāfokusējas ne tikai uz saimnieciski organizatoriskām skolas pārvaldības funkcijām, bet arī uz mācību procesa uzlabošanas funkcijām.

Pārmaiņu ieviešana skolā lielā mērā ir atkarīga arī no datos balstìtas pārvaldības. Ietekmes cikls skolā sākas ar izvērtējumu, kādi skolā ir pierādījumi un dati par pašreizējo situāciju. No tā izriet plānošana un mērķu izvirziššna turpmākajai attīstībai. Nākamajā posmā atkal tiek veikts izvērtējums, vai ir notikušas vēlamās izmaiņas. Šāda ietekmes cikla uzturēšanai skolas vadībai ir nepieciešama datu pārvaldības un analīzes pratība, kā arī spēja iesaistìt visus skolas kopienas locekḷus mācǐšanās vajadzību identificēšanā. Tas atbilst koncepcijai par skolu kā mācīšanās kopienu, aktualizējot jautājumu, kā skolu veidot par organizāciju un kopienu, kurā visi mācās sadarbojoties un skolas vadība ir pārmaiņu līderis.

\section{Kā darbojas skola, kura izmanto pārmaiṇu dotās iespējas, lai rezultāti uzlabotos:}

- skolā radīta vienota izpratne par pārmaiņu būtỉbu, visu iesaiste mērḳu definēšanā un sasniegtā izvērtēšanā;

- mērķu izvirzišanai seko esošās situācijas analīze, izmantojot datus par mācību stundu kvalitāti un skolēnu sniegumu;

- skolas darba izvērtējums vienmēr ir samērots ar skolas konkrētajiem mērkiem. Tiek plānots, kādi dati ir skolā, vai tie ir pietiekami daudzpusīgi (mācību procesa vērojumi, aptaujas, skolēnu sniegums), kādus vēl nepieciešams iegūt, kā notiks analīze;

- ir nodrošināti nepieciešamie apstākḷi inovāciju ieviešanai, tostarp skolotāju sadarbībai plānot un analizēt mācišanu un mācišsanos, savstarpējai mācību stundu vērošanai un analīzei (vide, resursi, mācību procesa organizācija);

- skolas vadība strādā kā komanda, kas vienoti iet uz mērḳiem, spēj motivēt skolotājus, plāno skolotāju mācišanos. Skolas vadībai ir pilnīga izpratne (kas balstās datu analīzē) par katra skolotāja prasmēm un skolotājiem nepieciešamo atbalstu prasmju pilnveidē. Tiek izvirzīti individuālie mērksi katram skolotājam, notiek regulāras progresa sarunas. Tiek sniegts atbalsts individuālam skolotājam, palīdzot apgūt nepieciešamās prasmes. 


\section{IZMANTOTĀ LITERATŪRA}

Ainscow, M., Dyson, A., Goldrick, S., \& West, M. (2012). Making schools effective for all: rethinking the task. School Leadership \& Management, 32(3), pp. 197-213.

Andrews, D., \& Lewis, M. (2007). Transforming practice from within: The power of the professional learning community. In L. Stoll \& K.S. Louis (eds). Professional learning communities: Divergence, depth and dilemmas. Maidenhead: Open University Press.

Bluma, D., \& Daiktere, I. (2016). Latvia: School Principals and Leadership Research in Latvia. In A Decade of Research on School Principals (pp. 137-160). Springer International Publishing.

Brauckmann, S., \& Pashiardis, P. (2011). A validation study of the leadership styles of a holistic leadership theoretical framework. International Journal of Educational Management, 25(1), pp. 11-32.

Bryk, A., Sebring, P., Kerbow, D., Rollow, S., \& Easton, J. (1998) Charting Chicago School Reform, Boulder, CO, Westview Press.

Butkēviča, A. (2016). Dabaszinātņu un matemātikas skolotāji līderi kā sociālo inovāciju difūzijas aǵenti (Maǵistra darbs). Rīga: Latvijas Universitātes Sociālo zinātṇu fakultātes Sociologijas studiju nodaļa.

Butkēviča, A., Zandbergs, U., Namsone, D., \& Briķe, S. (2018). Exploring the input of competence assessment to goal-setting in various types of organizations. SOCIETY, INTEGRATION, EDUCATION 2018.

Craft, A. (2002). Continuing professional development: A practical guide for teachers and schools. Routledge.

Crowther, F. (1997). Teachers as leaders-an exploratory framework. International Journal of Educational Management, 11(1), pp. 6-13. http://dx.doi.org/10.1108/09513549710155410

Daiktere, I. (2012). Vispārizglītojošās skolas direktora loma skolas kultūras pilnveidē. Disertācija doktora grāda iegūšanai. Latvijas Universitāte.

Donaldson Jr, G. A. (2006). Cultivating leadership in schools: Connecting people, purpose, and practice ( $2^{\text {nd }}$ ed.). Teachers College Press.

Fairman, J. C., \& Mackenzie, S. V. (2012). Spheres of teacher leadership action for learning. Professional development in education, 38(2), pp. 229-246. DOI: 10.1080/19415257.2012. 657865

Frost, D. (2012). From professional development to system change: teacher leadership and innovation. Professional development in education, 38(2), pp. 205-227. DOI: 10.1080/ 19415257.2012.657861

Frost, D., \& Durrant, J. (2003). Teacher leadership: Rationale, strategy and impact. School Leadership \& Management, 23(2), pp. 173-186. DOI:10.1080/1363243032000091940

Fullan, M. (1993). Why teachers must become change agents. Educational leadership, 50, pp. $1-13$.

Fullan, M. (1999). Change forces: The sequel. Psychology Press.

Fullan, M. (2007). The new meaning of educational change ( $4^{\text {th }}$ ed.). Routledge.

Fullan, M. (2011). Change leader: Learning to do what matters most. John Wiley \& Sons.

Guskey, T. R. (2002). Professional development and teacher change. Teachers and teaching, 8(3), pp. 381-391. 
Halverson, R., Grigg, J., Prichett, R., \& Thomas, C. (2007). The new instructional leadership: Creating data-driven instructional systems in school. Journal of School Leadership, 17(2), p. 159.

Hargreaves, A. (2000). Contrived collegiality: The micropolitics of teacher collaboration. In Sociology of education: Major themes, 3. Taylor \& Francis Group.

Hargreaves, A., Fullan, M. (2012). Professional capital: Transforming teaching in every school. Teachers College Press.

Hattie, J., Masters, D., \& Birch, K. (2015). Visible learning into action: International case studies of impact. Routledge.

Huberman, M. (1983). The role of teacher education in the improvement of educational practice: A linkage model. European Journal of Teacher Education, 6(1), pp. 17-29.

Kowalski, T. J., Lasley II, T. J., \& Mahoney, J. W. (2017). Data-driven decisions and school leadership: Best practices for school improvement. Pearson.

Lieberman, A., \& Miller, L. (2004). Teacher leadership. San Francisco: Jossey-Bass.

Lieberman, A., \& Miller, L. (2005). Teachers as leaders. In The Educational Forum 69(2), (pp. 151-162). Taylor \& Francis Group.

Mulgan, G. (2006). The process of social innovation. Innovations, 1(2), pp. 145-162. doi:10.1162/itgg.2006.1.2.145

Namsone, D., Čakāne, L. (2017). How primary school teachers succeed in designing lessons to teach students $21^{\text {st }}$ century skills. $12^{\text {th }}$ Conference of the European Science Education Research Association (ESERA), 21-25.08.2017. Dublin, Ireland.

Namsone, D., Čakāne, L., \& France, I. (2015). How science teachers learn to reflect by analyzing jointly observed lessons. LUMAT, 3(2), pp. 223-236. Pieejams: http://www. luma.fi/lumat-en/385 (aplūkots 01.12.2017.).

Namsone, D., Čakāne, L., \& Sarceviča-Kalviške, D. (2016). Teacher Teams and Schools Become Leaders to Disseminate Innovative Practice. SOCIETY. INTEGRATION. EDUCATION. Proceedings of the International Scientific Conference, 2016. Volume II, (pp. 208-222). Rezekne: Rezeknes Academy of Technologies. DOI: http://dx.doi.org/10.17770/sie2016 vol2.1393.

Nicholls, A., Simon, J., Gabriel, M., \& Whelan, C. (eds.). (2015). New frontiers in social innovation research. Springer.

Park, V., \& Datnow, A. (2009). Co-constructing distributed leadership: District and school connections in data-driven decision-making. School leadership and Management, 29(5), pp. 477-494.

Rogers, E. M. (2003). Diffusion of innovations ( $5^{\text {th }}$ ed.). New York: Free Press.

Saito, E., Murase, M., Tsukui, A., \& Yeo, J. (2014). Lesson Study for Learning Community: A Guide to Sustainable School Reform. Routledge.

Shen, J., \& Cooley, V. E. (2008.) Critical issues in using data for decision-making. International Journal of Leadership in Education.

Shirley, D., \& Miller, A. F. (2016). The labyrinth of teacher leadership. Journal of Educational Change, 17(1), pp. 1-5.

Stigler, J. W., \& Hiebert, J. (2009). Closing the teaching gap. Phi Delta Kappan, 91(3), pp. 32-37.

Stoll, L., Bolam, R. \& Collarbone, P. (2002). Leading for change: Building capacity for learning. In Leithwood, K., \& Hallinger, P. (eds). Second international handbook of educational leadership and administration, Dordrecht: Kluwer. 
Stoll, L., Bolam, R., McMahon, A., Wallace, M., \& Thomas, S. (2006). Professional learning communities: A review of the literature. Journal of educational change, 7(4), pp. 221-258.

Takahashi, A., \& Yoshida, M. (2004). Lesson-study communities. Teaching children mathematics, 10(9), pp. 436-437.

Taylor, M., Goeke, J., Klein, E., Onore, C., \& Geist, K. (2011). Changing leadership: Teachers lead the way for schools that learn. Teaching and teacher education, 27(5), pp. 920-929. doi:10.1016/j.tate.2011.03.003

York-Barr, J., \& Duke, K. (2004). What do we know about teacher leadership? Findings fromtwo decades of scholarship. Review of educational research, 74(3), pp. 255-316. doi:10.3102/00346543074003255

Young, H. P. (2009). Innovation diffusion in heterogeneous populations: Contagion, socialinfluence, and social learning. The American economic review, pp. 1899-1924.

Young, H. P., \& Brown, L. M. (2016). The Diffusion of a Social Innovation: Executive Stock Options from 1936-2005 (777).

Zehetmeier, S., Andreitz, I., Erlacher, W., \& Rauch, F. (2015). Researching the impact of teacher professional development programmes based on action research, constructivism, and systems theory. Educational action research, 23(2), pp. 162-177. 


\section{Introduction}

Theoreticians, researchers, practitioners, and politicians have expressed their need for new skills, knowledge, values, and habits at the school curriculum, suggesting usage of the so called $21^{\text {st }}$ century competency-based education models to achieve different goals of education which are closely related to significant changes in economics and development of society.

Competency is a person's ability to use one's knowledge, skills, and express one's attitude solving issues in changing situations of real life that complies with the definition included in the OECD "Education 2030". Competency is complex, its development is related to creation of a transition necessary for action in a new situation, and new contexts. Competency cannot be reduced to a specific skill or isolated set of knowledge.

In the last decades, the scientific literature has suggested different structures of competencies. The viewed modelsin different combinations interchange competences in the key human working areas (reading literacy, mathematical literacy, scientific literacy, etc.) with the transversal skills (problem solving, critical and creative thinking, self-directed learning, communication, cooperation, digital literacy, etc.) related to every area and to which sufficient focus has not been given in the curriculum until now. Shaping of habits based on values is highlighted.

Analysing the global experience and future (different frames of competencies) and developing the previous Latvian educational contents, a framework curriculum was created going further to the direction that was taken when creating the current documents of curriculum. Although, the documents regulating curriculum of 2006, learning aspects have been defined that generally comply with the transversal competences, their development is provided by the state education standards, however, observations at lessons and pupils' performance show that it is not a daily practice at all schools.

Competency as a result of learning cannot be achieved without changing the approach to learning and school organisation radically, because teaching,

1 National Centre for Education. (2016). Towards Competency-Based Approach. Available: http:// www.izm.gov.lv/images/izglitiba_visp/Konferences_Tagad/VISC_-_Ce\%C4\%BC\%C4\%81_ uz_kompeten\%C4\%8Du_pieeju_m\%C4\%81c\%C4\%ABb\%C4\%81m.pdf 
rather than redefining of results in the curriculum documents, will serve as the decisive aspect in regard to whether pupils would develop a competency or not. According to analysis of situation analysis, competency as a result of learning can be achieved by applying the deep learning approach in the classroom.

A report by the National Research Council of the USA (National Research Council, 2012 2 ) where the most prominent models of competencies of the 21 st century were evaluated, the necessity to achieve deeper learning has been emphasised. The features of deeper learning are common with the learning process viewed by other authors (deep learning, visible learning) (Fullan, \& Langworthy 2014³; Hattie, 2012 ${ }^{4}$; etc.).

Deep learning is a process during which pupils develop their ability to generalise or transfer their new knowledge and skills to new and unknown situations. The possibility that a transfer will happen if pupils would have understanding of general principles and approach to problem solving, if pupils have knowledge of facts and concepts in the respective area, as well as appropriate problem solving strategies, if pupils are able to recognise how, when, and why to use the knowledge and skills of facts, concepts, and procedures (National Research Council, 2012).

According to the authors of the report, that is the goal of integration of the transversal skills in the $21^{\text {st }}$ century, to facilitate the processes of deep learning and, as the development of the 21 st century skills fosters deepened acquisition of curriculum, such an approach might reduce the inequality of learning goals among pupils, therefore preparing a larger number of youngsters for a successful life in society and professional work. Implementation of such learning approach has several reasons, the above-mentioned objective changes in social development, when the current skills are not sufficient anymore and the graduates have to consider that learning will continue all their lives, as well as new understanding of efficient learning process and factors facilitating a transfer or ability to use the knowledges in complicated and unknown situations.

In a learning process during which a pupil develops ability to generalise, transfer new knowledge and skills to unknown situations (including real life situations), which processes that provide as knowledge (how to we know?), rather than just accumulate a specific amount of contents (what do we know?). On the

2 NRC. (2012). Education for Life and Work: Developing transferable knowledge and skills in the $21^{\text {st }}$ century. In Pellegrino, J. W., Hilton, M. L. (eds.). Committee on Defining Deeper Learning and $21^{\text {st }}$ Century Skills, National Research Council (NRC). Pieejams: http://www. nap.edu/catalog.php?record_id=13398 (aplūkots 20.10.2017.).

3 Fullan, M., \& Langworthy, M. (2014). A rich seam: How new pedagogies find deep learning. MaRS Discovery District.

4 Hattie, J. (2012). Visible learning for teachers: Maximizing impact on learning. Routledge. 
level of a lesson, this, first, means setting goals, receipt of feedback from pupils, implementation of pupils' experience, intentional application of cognitive and metacognitive strategies to construct a thought (essence) in different contexts and situations, as well as cooperation. Using the approach that facilitates a deeper learning, a teacher provides pupils an opportunity to involve high level cognitive skills (to analyse, synthesise, assess, solve problems), to develop the metacognitive skills to ensure that a pupil would be able to construct the essence of the acquired matters and apply experience in solving complicated matters in new situations and contexts. This is paradigmaticly different from the traditional teaching, i.e. the model of information transfer.

With this approach to learning, the process has a direct impact on the learning goal or it is actually equal to the goal. The idea that acquisition of competencies of the $21^{\text {st }}$ century or doing is closely related to the learning goals has been also emphasised by Michael Fullan in his essay "Education Plus" (Fullan, \& Scott, 20145). Fullan suggests strengthening an unprecedented idea in education that an educated person is a doer, a doing thinker or thinking doer, who learns to do and does to learn.

A competency (the outcome of deeper learning) or complex performance is formed based on different individual elements, demonstrating those in action. The outcome of complex is measured by selecting tasks, setting performance criteria, and describing their levels. Stiggins and authors $\left(2004^{6}\right)$ emphasise that performance assessment is an approach to assessment that is based on observations on pupil's action or created product and expression of opinion on the observed. According to several authors, it is the only way how to verify the pupils' ability to use the skill in a context.

With clear and specific criteria it is possible to provide a description of a good performance that can serve as a signal to further development direction and help to identify specific areas where improvements are necessary. Development of qualitative performance assessment tools is a labour-intensive process within the framework of which it is valuable to use theoretical models, for example, structure of a specific cognitive skill and information on a typical development of a skill and difficulties that pupils face and that teachers can observe in daily life in the classroom. Performance assessment, selection of criteria, creation of rubrics, performance assessment is time-consuming, therefore tools and procedures need

5 Fullan, M., \& Scott, G. (July 2014). New Pedagogies for Deep Learning Whitepaper: Education PLUS. Collaborative Impact SPC, Seattle, Washington. Pieejams: http://www.academia. edu/7999210/Education_Plus (aplūkots 20.10.2017.).

6 Stiggins, R. J., Arter, J. A., Chappuis, J., \& Chappius, S. (2004). Classroom assessment for student learning: Doing it right - using it well. Portland, Oregon: Assessment Training Institute. 
to be as simple, user-friendly, repeatedly usable as possible, as well as provide useful information to improve teaching and learning.

Performance assessment planning includes selection of suitable tasks by completing which pupils will be able to demonstrate the respective skills and selection of appropriate criteria to assess this performance. A significant criteria on the basis of selection of tasks is the learning outcome for a pupil that is measured. With a complex learning goal, it is analysed what it consists of, knowledge and understanding of an area, inter-disciplinary matters, skills of working with a text, research skills, etc., context of real life and other areas (interdisciplinary nature), deepness of cognitive action, opportunities of metacognitive action. The form of a task is also of importance, considering what the various actions and diversified solutions and answers are a pupil need to perform to obtain an answer. In the $21^{\text {st }}$ century, the opportunities of technology use and technical quality of a task is significant.

To analyse the deepness of thought of a pupil, to help a pupil to understand how to improve one's outcome (to move to another level), and to judge the cognitive level of the task, different taxonomies can be used. SOLO (Structure of the Observed Learning Outcome) taxonomy (Biggs, \& Collis, 19827) is a cognition tool that helps to reflect and assess a qualitative movement from superficial to deep learning.

Applying rubrics, pupil's performance can be assessed in whole, i.e. applying all assessment criteria as a whole or performance can be assessed based on each criteria separately applying analytical assessment approach. Wholistic rubrics can be used successfully for the purposes of summative assessment.

Along with the development of technologies and procedures ensuring alignment of evaluations given by several valuers, performance assessment can be implemented successfully in a nation-wide examinations, rather than in just daily assessment in the classroom. Assessment on macro level are mainly used on the international, national, or municipal level. Traditionally such assessment is used in the international comparative research (PISA (Programme for International Student Assessment), PIRLS (Progress in International Reading Literacy Study), TIMSS (Trends in International Mathematics and Science Stud)), for the purposes of summative assessment, and assessment of learning programmes.

7 Biggs, J. B., \& Collis, K. F. (1982). Evaluating the quality of learning: The SOLO taxonomy. New York: Academic. 
According to Darling-Hammond and Adamson (Darling-Hammond, \& Adamson, $2010^{8}$ ), along with changing skills that pupils need to acquire in the 21 st century, the assessment approach needs to change as well, because not only knowledge is important, but also things a pupil can do with the knowledge. In Latvia, it is important to understand how accurately the state examinations measure the priorities set in the applicable curriculum documents (since 2006) for the natural sciences and whether and how those measure a complex performance and comply with a good macrolevel assessment tool. The conducted analysis includes state examinations from 2015 to 2017.

It has been detected that measurements of knowledge and understanding of processes, natural phenomena, acquisition of specific skills do not provide an opportunity to obtain a safe answer in regard to a pupil's performance in each field of curriculum, as measurements are conducted fragmentary. Examinations mainly measure pupils' ability to act in typical situations. All in all, over a three year period, $64-92 \%$ of all tasks require a reproductive action, remembering of facts and procedures, use of knowledge and skills in a standard tasks, interpreting simple data sets. These data reveal a discrepancy between the movement towards efficient action of pupils included in the curriculum documents of 2016 and the aspects measured by the state examinations.

However, a positive trend has been noticed that state examinations include tasks that potentially would measure a complex performance, the potential, however, is not used, and only superficial information is obtained on the performance of pupils. The exams include tasks with a successful context and with a slight adjustment those could be changed from a cognitively superficial to such providing an opportunity to measure a higher level cognitive actions of a pupil.

Providing an evaluation for state examinations in natural sciences and maths still mainly uses the approach correct/incorrect answer. Such an approach can be used if it is necessary to detect knowledge of facts, it does not, however, allow to make conclusions on skills, and depth of thinking that the examinations should measure. If deep learning approach is a goal, the state examinations should also measure skills that can be accomplished by creating rubrics.

It is proven that teachers change the curriculum and methods on the basis of tasks in the examinations of macrolevel evaluation. The dominance of low cognitive level tasks in the state examinations, as can be detected now, does not facilitate increase of efficient learning activities during lessons.

8 Darling-Hammond, L., \& Adamson, F. (2010). Beyond basic skills: The role of performance assessment in achieving 21st century standards of learning. Stanford, CA. 
It has been noted that pupils are not able to use an algorithm applied during several years' long learning process in a task and this marks the necessity to clarify the previous experience of pupils during learning process and rely on that, as well as to diversify the contexts of tasks, to teach pupils to create a transition, to recognise situations, and strategies, and use tasks that allow a variety of answers and solving strategies. Results of pupils show the necessity to review the process of teaching skills, whether a strategy is created and a transition from one situation to another, from one topic to another, from one subject to another, and to real life is developed.

The conclusions of macrolevel examinations demonstrate the necessity to facilitate cooperation between teachers on the school level, not remaining on the conversation and planning level, but observing the lessons and noting what strategies teachers use, how each teacher teaches to recognise and transfer those. This is related to implementation of self-directed learning skills in the daily life of a pupil that is impossible without the use of metacognitive strategies.

Formative assessment is an approach not used in practice often which can help pupils to improve their results. Formative assessment if implemented on microlevel, i.e. during a lesson. The essence of formative assessment is to obtain evidence of a pupil's performance, interpret and use it to take a decision on further learning steps to make those more reasonable (Black, \& Wiliam, 2007'; Black, 2004 ${ }^{10}$ ). Assessment experts (Brownlie et al., 2006 ${ }^{11}$; Pollard et al. 2008 ${ }^{12}$, etc.) use terms assessment for learning - assessment for purposes of learning and assessment as learning. To apply assessment as learning, the most significant aspect is a descriptive feedback provided by a teacher to a pupil on the learning process, involving a pupil in analysis of one's outcomes, and defining further learning goals.

During formative assessment, the same as in the case of summative assessment, assessment criteria need to be clear, as that defines what aspects of a pupil's performance would be assessed and what conclusions would be drawn. Formative assessment, in line with Harlen (Harlen, 2013 ${ }^{13}$ ), during a lesson

9 Black, P., \& Wiliam, D. (2007). Large-scale assessment systems: Design principles drawn from international comparisons. Measurement: Interdisciplinary Research and Perspectives, 5(1), pp. 1-53.

${ }^{10}$ Black, P. (2004), The Nature and Value of Formative Assessment for Learning. London.

${ }^{11}$ Brownlie, F., Feniak, C., \& Schnellert, L. (2006). Student Diversity (2 ${ }^{\text {nd }}$ ed.) Markham, ON: Pembroke Publishers.

${ }^{12}$ Pollard, A., Anderson, J., Maddock, M., Swaffield, S., Warin, J., \& Warwick, P. (2008). Reflective teaching: evidence-informed professional practice. ( $3^{\text {rd }}$ ed.) London: Continuum International Publishing Group.

${ }^{13}$ Harlen, W. (2013). Assessment and inquiry-based science education: issues in policy and practice. Global Network od Science Academies (IAP) Science Education Programme (SEP). 
can be characterised by involvement of pupils communicating goals of a lesson and shaping a unified understanding of criteria for performance assessment; cyclicality of the process, action of a pupil, obtaining evidence related to achievement of a goal, decision on the necessary next steps, decision on how to take these steps and appropriate actions of a pupil.

For the purposes of formative assessment and useful, qualitative feedback needs to provide answers to the following questions: what should I learn?, what am I good at and what I have to improve?, what to do to improve further learning process? Answers to these questions are necessary for a pupil about one's action and for a teacher about one's pupils. It is important that answers to these questions are justified and based on data and facts.

The regulatory documents governing education need to reveal clearly the role of formative assessment in the learning process, emphasising its significance from the point of view of teaching the specific curriculum, implementing deeper learning, and as a significant self-directed learning element.

Efficiency of formative assessment depends on teachers' skills, teachers' and managers' of schools understanding of formative assessment, ability to use different assessment tools and use the obtained data. It is necessary to facilitate professional cooperation between teachers, implementing and verifying formative assessment strategies, and studying one's actions to obtain evidence of assessment efficiency. A teacher needs a professional and usable feedback. We invite teachers to cooperate to broaden their experience and to obtain support in implementing formative assessment as a daily practice, to reflect and plan improvement of learning, in line with the data obtained during the assessment, to achieve a better understanding of the meaning of formative assessment and to teach pupils to give and accept feedback, to shape their experience of benefits from a teacher's feedback and mutual feedback.

Many internationally recognised authors (Barber, \& Mourshed, 2007 ${ }^{14}$; Hargreaves, \& Fullan, 2012 ${ }^{15}$; Hattie, 2012 ${ }^{16}$, etc.) are of the same opinion about the immense impact of a teacher's personality on the learning outcomes of a pupil. However, majority of teachers underestimate their influence on pupils' learning process and dynamics of their learning outcome (Helmke, 2009 ${ }^{17}$ ).

${ }^{14}$ Barber, M., \& Mourshed, M. (2007). How the world's best-performing schools systems come out on top. McKinsey \& Company.

${ }^{15}$ Hargreaves, A., \& Fullan, M. (2012.) Professional capital: Transforming teaching in every school. Teachers College Press.

${ }^{16}$ Hattie, J. (2012). Visible learning for teachers: Maximizing impact on learning. Routledge.

${ }^{17}$ Helmke, A. (2009). Unterrichtsqualität und Lehrerprofessionalität - Diagnose, Evaluation und Verbesserung des Unterrichts. Seelze: Klett-Kallmeyer in. 
To ensure that the learning outcome would be a competency, teacher's ability to manage learning, to analyse and reflect, and to cooperate are of importance.It is important that in the learning process a teacher would be able to set topical learning goals and provide a useful feedback in regard to their achievement, as well as a teach needs to be able to teach a pupil to define the goal, to follow the progress, to provide and accept feedback, to facilitate self-directed learning, to select and use skilfully the learning strategies, and methods fostering pupils' delving into the topic and involvement, to use efficient tasks, to create a link with the real life, to teach smart use of information and communication technology (ICT) tools, to use appropriate tools (rubrics) in order to follow growth of pupils, to analyse data in order to plan further actions.

The learning outcome would be a deep understanding and competency, if the actions implemented by a teacher and teaching would be efficient.It is possible to measure efficiency of teacher's actions, using rubrics. Rubrics are available in literature, and used for research needs, those can be used for selfassessment for teachers' personal growth and professional improvement.

Research by the Interdisciplinary Centre for Educational Innovation of the University of Latvia (France et al., 2015 ${ }^{18}$; Dudareva et al., 2015 ${ }^{19}$; Volkinšteine et al, $2014^{20}$, etc.) on teachers' skills, assessment of their skills and learning needs, teachers' actions during a lesson and teachers' learning activities reveal that teachers require a professional support to shape learning with deep thinking, therefore, the proportion of efficient tasks during lessons would increase, the ability of teachers to create a conversation, rather than "examining", would be a reasonable use of the ICT. There is a gab between the self-assessment of teachers and observations of experts during lessons. To manage deeper learning, management of learning, teachers' reflection and self-analysis skills, as well as cooperation become topical.

Continuous professional learning via cooperation are the key words that characterise the professional improvement of teachers in the $21^{\text {st }}$ century. In the beginning of the teacher's career a pre-service training is held, further growth and learning is a continuous long-term process that depends on each

${ }^{18}$ France, I., Namsone, D., \& Cakane, L. (2015). What Research Shows about Mathematics Teachers' Learning Needs: Experience from Latvia. In SOCIETY, INTEGRATION, EDUCATION (Vol. 2, pp. 45-55). Pieejams: http://dx.doi.org/10.17770/sie2015vol2.457 (aplūkots 14.02.2018.).

${ }^{19}$ Dudareva, I., Namsone, D., \& Čakāne, L. (2015). The development of students' digital competence and physics teacher's professional development needs. Conference of International Research Group on Physics Teaching (GIREP EPEC) 6-10.07.2015. Wroclaw, Poland.

${ }^{20}$ Volkinšteine, J., Namsone, D., Čakāne, L. (2014). Latvianchemistryteachers' skills to organize student scientificinquiry. ProblemsofEducationinthe $21^{\text {st }}$ Century, Vol. 59, pp. 86-98. 
other. Professional learning as an organised process, learning via cooperation as a process that includes exchange of experience between colleagues, and feedback and other support mechanism.

Facilitating professional improvement, it is necessary to plan on what level we would like to achieve the impact of professional improvement, satisfaction of participants, improvement of teachers' knowledge, skills, opinions, changes in the practical aspects or performance of pupils. Different professional improvement forms can have a impact on each of the rubrics.

The model of professional improvement has to comply with the following criteria: ability to implement an innovative practice, it is based on the school practice where participants can learn from each other, participants learn via cooperation and sharing of experience, teachers have the support of colleagues and receive feedback that is not hierarchical but rather coordinated where the activities are long-term and regular, and teachers learn to reflect. Model $^{21}$ for mutual observation of lessons developed and implemented by the Research by the Interdisciplinary Centre for Educational Innovation of the University of Latvia includes three dimensions, acquisition of new experience, observing and analysing lessons, reflection, and cooperation. This is implemented in long run by implementing regular activities in the school environment. The improved morel is combined, it includes three significant structural elements: long-term, regular and joint workshops for observation and analysis of lessons, research of learning between the workshops, creating and trying out examples of lessons, cooperation in the school team. The model has been approbated in practice, in a group of trial schools and can be successfully used to accumulate learning practice of transversal skills $\left(21^{\text {st }}\right.$ century skills). The trial research shows that time is required for the teachers to be able to view the difference and include not only science curriculum, but also teaching of skills in the teaching practice.

A work in a learning group for the purposes of research of one's own professional activities is learning via studying one's own practice that is individual and cooperative process. Teachers conduce a small research, obtaining data on their practice, analysing the practice and improving understanding, interpret their conclusions, and take decisions in regard to further activities, and cooperate in a group. Experience obtained in Latvia shows that work in a learning group for the purposes of research of one's own professional activities helps teachers

${ }^{21}$ Namsone D., \& Čakāne L. (2018). A Collaborative Classroom-Based Teacher Professional Learning Model. In Yeo J., Teo T., \& Tang K. S. (eds.). Science Education Research and Practice in Asia-Pacific and Beyond (pp. 177-195). Springer, Singapore. DOI: https://doi. org/10.1007/978-981-10-5149-4_13 
to improve their skills and improve teachers' practical work. A trend has been observed that along with improving learning outcomes of pupils the attitude of pupils towards the subject changes, their interest and learning desire increases.

At school, pupils need to acquire knowledge, skills, and attitudes that would allow them to get involved and develop in digital environment.

Meaningful use of IT tools and digital resources has a potential to support and organise pupils' deeper learning. ISTE (International Society for Technology in Education, 2016 22 ) standards for acquisition of digital competency provide that a pupils should use information technologies to develop self-directed learning skills, to become a digital citizen, to construct knowledge, to use different information technologies in order to identify, deal with, and solve issues, creating new, useful, or theoretical solutions, to acquire algorithmic reasoning skills, communication, and presentation skills, to become a cooperation partner, i.e., those are an integral part of acquisition of all transversal skills. This relates to the term used in literature leveraging digital (New Pedagogy for Deep Learning). This term is used to describe availability of digital technologies and their potential to ensure personalised learning opportunities, communication and cooperation opportunities, as well as opportunities to conduct assessment in real time, to provide immediate feedback, abilities to find, summarise, process, and present information, and to access original learning contexts (Fullan, \& Langworthy, $\left.2013^{23}\right)$.

Meaningful use of IT tools and digital resources would help to learn more efficiently that is provided by the ability to receive feedback immediately in the learning process, to create a comprehensive view of the issue under inspection that is ensured by digital resources, video, images, animations, simulations, modelling software, as well as opportunities to ask questions in forums and social platforms, and justify one's opinion; to create excellent work that is provided by the ability to save, review, and improve the creation; to construct knowledge in environment that provides opportunities to get involved in the process actively, to obtain direct experience, to learn from the best practice examples, to learn at any place and any time that is ensured by the availability of digital resources (Abbott et al., 200924).

${ }^{22}$ ISTE Standards for Students. (2016). Available: https://www.iste.org/standards

${ }^{23}$ Fullan, M., \& Langworthy, M. (2013). Towards a New End: New Pedagogies for Deep Learning. Available: http://npdl.thumbtack.co.nz/wp-content/uploads/2015/08/Towards-a-New-End-NewPedagogies-for-Deep-Learning-Invitation.pdf

${ }^{24}$ Abbott, I., Townsend, A., Johnston-Wilder, S., \& Reynolds, L. (2009). Literature Review: Deep learning with technology in 14 to 19-year-old learners. Coventry (UK): British Educational Communications and Technology Agency (Becta). 
Digital formative assessment in a learning process can serve as a significant supplement to traditional assessment. The type, contents, and functionality of the digital formative assessment has to ensure obtaining significant and reliable data. The provided feedback has to be personalised, motivating, and related to cognitive process. It has to be as fast and individualised as possible and compliant with the performance of each pupil.

Research has been conducted as to the use of different digital formative assessment tools in the learning process, with different purpose of use and opportunities, as well as the convenience of use. When selecting the most suitable digital formative assessment tool, it can be successfully integrated in different learning processes, the traditional, overturned, and mixed lessons.

Pupils have to be able to assess the advantages and deficiencies of the available IT tools not only at the lessons of informatics, but also at other subjects, to be able to act efficiently and safely in the digital environment.

To develop and improve the digital competency of pupils, during the planning of learning process, the opportunity to complete IT tasks with IT tools should be provided to a pupil. To understand whether the potential of IT tools is used purposefully in a learning process, a teacher can assess the planned and implemented activities, applying the rubrics.

Analysing situation in Latvia, it can be noted that slightly more than in ten years, IT has become an integral tool of many teachers during lessons. Observations of lessons show a gap between a meaningful use potential of IT tools and the way how IT tools are actually used during the learning process. During lessons where IT tools and resources are used, pupils often have a passive role. IT tools are used mainly to complete certain tasks, rather than to create knowledge. The new challenge is to make the use of IT meaningful and useful to develop pupils' competencies. To overcome this gap, teachers, when planning and implementing lessons, need to change the emphasis from using IT tools and resources to visualise the curriculum to management of learning process, where IT tools and resources are used to construct the knowledge, model processes, solve problems, create new products, facilitate cooperation, and ensure personalised learning process organisation.

To ensure that a teacher would be able to develop and improve the digital competency of pupils in different subjects, a teacher oneself needs to develop and improve one's own digital competence. Professional improvement of teachers will have a long-term impact if it will be created based on the needs of teachers, organising learning groups and cooperating with colleagues. A teacher has to be 
in the centre of one's learning to be able to change one's habits of using IT tools (Daly, Pachler, \& Pelletier, 200925).

Implementation of deep learning, and complex performance assessment and other aspects are paradigmaticly different from the traditional teaching model, i.e., provision of information. To implement it in the school practice, all the stakeholders need to cooperate to implement and transfer innovations. Changes, and innovations entering schools is the responsibility of stakeholders of different levels. At every school, it is impacted by each teacher's understanding of the sense of changes, motivation, and skills; school's management understanding and skills to plan and manage the process; and founder of school explaining the necessary changes and supporting their implementation.

It is the responsibility of the management of a school and teachers to collaborate in order to bring in innovations and to disseminate them among teachers and among schools. A school that uses the opportunities provided by changes to improve the learning outcome of pupils complies with the following principles: sets and communicates clear, specific, real, and measurable, definite goals for each person involved in implementation of changes; a structure has been created at school that helps to detect the result and serves as a regular feedback to everyone involved. Analysis of current situation, data on the quality of lessons, and pupils performance are followed by goal setting. Obtained data are comprehensive (observations of learning process, surveys, pupils' performance). There is a common understanding of the essence of changes at school and everybody is involved in defining goals and performance assessment.

The school is like a learning community ${ }^{26}$ where all the necessary conditions have been ensured for implementation of changes, including cooperation between teachers during planning and analysing teaching and learning, mutual observing and analysis of lessons. The management of school works as a team that goes towards achievement of goals, is able to motivate teachers, and plan learning of teachers. Support is provided to individual teachers on the basis of data analysis on each teacher's skills and support necessary for teachers.

${ }^{25}$ Daly, C., Pachler, N., \& Pelletier, C. (2009). Continuing Professional Developmentin ICT forTeachers: A literaturereview. BECTA. Pieejams: http://eprints.ioe.ac.uk/3183/1/ Daly2009CPDandICTforteachersprojectreport1.pdf

${ }^{26}$ Andrews, D., \& Lewis, M. (2007). Transforming practice from within: The power of the professional learning community. In L. Stoll \& K.S. Louis (eds.) Professional learning communities: Divergence, depth and dilemmas. Maidenhead: Open University Press. 
Teacher-leaders play an important role in implementing and disseminating innovations ${ }^{2728}$ but they need appropriate support from the management of the school. Activity of the management of school would be necessary to identify potential teachers-leaders and support them; involving education experts to diagnose the necessities and plan actions, to implement the teacher cooperation models, to plan time and financial support to ensure teach cooperation.

${ }^{27}$ Lieberman, A., \& Miller, L. (2004). Teacher leadership. San Francisco: Jossey-Bass.

${ }^{28}$ Namsone, D., Čakāne, L., \& Sarceviča-Kalviške, D. (2016). Teacher Teams and Schools Become Leaders to Disseminate Innovative Practice. SOCIETY. INTEGRATION. EDUCATION. Proceedings of the International Scientific Conference, 2016. Volume II, (pp. 208-222). Rezekne: Rezeknes Academy of Technologies. DOI: http://dx.doi.org/10.17770/sie2016vol2.1393 



\section{LATVIJAS UNIVERSITATE}

ANNO 1919

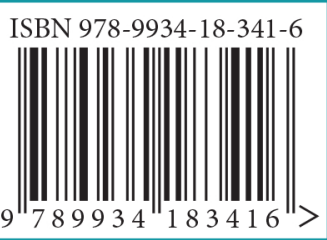

